Universidade de São Paulo

Faculdade de Filosofia, Letras e Ciências Humanas

Departamento de História

\title{
Sob o império das leis: \\ Constituição e unidade nacional na formação do Brasil (1822-1834)
}

\author{
Andréa Slemian \\ Orientador: Prof. Dr. István Jancsó \\ Tese apresentada ao Programa de Pós- \\ Graduação em História Social para \\ obtenção do título de Doutor.
}

São Paulo

2006 


\section{RESUMO}

A presente tese trata do advento de uma ordem constitucional moderna no Brasil que, surgida a partir da crise e desagregação do Império português na América, viabilizaria a Independência e sustentaria a construção de uma nova unidade política. $O$ foco de análise está no embate pela normatização de um arranjo político-institucional que vinculasse o “todo" e as "partes" do que, até 1822, reconhecera-se como português, com ênfase na definição de uma esfera provincial de poder. Defende-se que, num ambiente marcado por violentos conflitos em torno de diferentes projetos de unidade ao longo do Primeiro Reinado (1822-1831) e começo da Regência (1831-1834), a consecução de um pacto político mimetizado pela idéia de Constituição teve papel fundamental, reconhecido na prioridade conferida pelos nossos primeiros legisladores à implementação de reformas jurídicas para funcionamento da máquina pública. A experiência constitucional nesses anos iniciais do Brasil independente é entendida em conjunto com seus desdobramentos na Administração, tendo em vista que a criação das leis esteve intrinsecamente ligada à sua prática positiva, e que ambas, como partes constitutivas do que se denomina como Direito Público, forneceram os pilares de sustentação do novo Império. A partir daí, sustenta-se que a Carta Constitucional de 1824, ao contrário do que se pode imaginar, teve uma extraordinária eficácia na viabilização da estrutura de um novo Estado, como fica claro nos debates em torno de sua Reforma de 1831 a 1834. O espaço da produção legislativa revelou-se como campo central para compreensão do problema, pois que ele nascia sob um novo ideal de representação política - alicerçado na concepção revolucionária de que a "lei" criaria "Direito" e não o contrário - que adquiriu a legitimidade necessária para falar em nome da "nação". 


\section{ABSTRACT}

In the present thesis I deal with the development of a modern constitutional order in Brazil. An order that was cradled by the crises and desegregation of the American Portuguese Empire and also responsible for the movement of Independence and the formation of a new political entity. I focus on the struggle for the enforcement of an arrangement, both institutional and political, that enabled the development of a tie between the totality and its parts, with an emphasis on the definition of a provincial sphere of power; a totality that, until 1822, recognized itself as Portuguese. During the First Reign (18221831) and the beginning of the Regency period (1831-1834), in an environment scared by violent conflicts between those who fought for different political projects, a pact mirrored on the idea of a Constitution had a primary role. To such a degree, that our first legislators considered fundamental to put in motion judicial reforms that enabled the governmental apparatuses to work. I analyze the constitutional experience, in those first years after the Brazilian independence, together with its influence on the administration of the country. It is mandatory to do so because the making of laws was closely connected to their observance. And both, as parts of what is called Public Law, were the pillars of the new Empire. By taking that into account, I uphold that the Constitution of 1824 , differently of what is usually imagined, was extremely effective on grounding the new State's structure, as it can be seen by the debates concerning its reform. The legislative scenario revealed itself central to the understanding of the problem. That scenario evolved under a new ideal of political representation, grounded on the revolutionary concept that "laws" were the bearer of the "Law"; and to such an extent that it had the legitimacy needed for legislators to speak for the "nation". 


\section{AGRADECIMENTOS}

No longo percurso de elaboração desse doutorado, reconheço que não teria chegado ao fim sem os apoios/auxílios que felizmente recebi, alguns dos quais menciono a seguir.

Em primeiro lugar, o financiamento fornecido pela FAPESP foi fundamental para o andamento e aprofundamento da pesquisa.

O convívio acadêmico com o Prof. Dr. István Jancsó e a sua extraordinária capacidade de, para além de pensar História, investir na produção do conhecimento como algo que necessita ser partilhado coletivamente. Devo a ele, também, o respeito às minhas escolhas para que eu ousasse, em algum momento, "andar com as próprias pernas".

A leitura atenta e crítica, além da generosidade intelectual, de minha Banca de Qualificação, composta pelos professores José Reinaldo de Lima Lopes e Wilma Peres Costa. Ao primeiro, agradeço também a gentileza com que leu meu projeto inicial de pesquisa; à segunda, igualmente a disposição com que comentou algumas das páginas que aqui se seguem, cuja aproximação com temáticas que lhe são caras foi uma das melhores "surpresas" do meu percurso.

A convivência no âmbito do Projeto Temático Fundação do Estado e da nação: Brasil c.1780-1850, financiado pela FAPESP, do qual destaco a importância que Márcia Regina Berbel, Miriam Dolhnikoff, Ana Rosa Cloclet, Rafael Marquese, Mônica Dantas, Marco Morel, André Machado, Maria Aparecida Silva de Souza e Argemiro Ribeiro de Souza Filho tiveram, cada qual a seu modo, na minha trajetória de doutoranda. Não posso deixar de citar a paciência da incansável e sempre simpática Maria Inês Bento quando na secretaria do Projeto.

A participação na rotina acadêmica do Instituto Ravignani da Universidade de Buenos Aires, propiciado pelos professores José Carlos Chiaramonte e Noemí Goldman que, junto com vários de seus gabaritados pesquisadores, discutiram meu trabalho no segundo semestre de 2002.

Em Portugal, a simpática acolhida e apoio acadêmico que o Prof. António Manuel Hespanha e Ana Cristina Nogueira da Silva, da Universidade Nova de Lisboa, me propiciaram. Em Coimbra, à Profa. Ana Cristina Araújo. Ainda no ultramar, Miguel e Eduardo fizeram eu me "sentir em casa", mesmo tão longe da minha. 
O auxílio da equipe do Centro de Documentação do Arquivo da Câmara dos Deputados, em Brasília, em especial Rosamaria Schertel e Lígia Cristina Pinheiro da Silva, que se desdobram para me ajudar no curto período em que lá estive. Neste, contei com a amizade de Roberta Stumpf que, além de me hospedar, sempre me incentivou com seus comentários.

As críticas que gentilmente me fez Geneviève Verdo depois da alegria de conhecêla. O esforço de Madalena Marques Dias em me apontar como melhorar o texto, além do imenso auxílio, junto com Eduardo Natalino, na impressão final. A documentação que Dainis Karepovs me emprestou de sua biblioteca pessoal.

O trabalho de Veronica Aparecida Silveira Aguiar e Anelise Rahmeier só poderia ser comparado ao dos "anjos da guarda", se estes realmente existissem.

Deixo de citar - apenas aqui! - o mundo dos outros afetos, sendo imprescindível mencionar o apoio incondicional da minha família: minha mãe, meu pai, meus irmãos, minha sogra Selma, e a alegria pelo Viní existir.

Por tudo, passado futuro, a João Paulo Garrido Pimenta. 


\section{SUMÁRIO}

Introdução

09

Capítulo 1: Do Império português ao Império do Brasil

1.1. Do Reformismo à Revolução: poderes políticos na América portuguesa e ideário constitucional

1.2. O impacto da Revolução do Porto no Brasil, a Independência e a instalação da Assembléia Constituinte de 1823

1.2.1. A construção de um novo pacto político e a legitimidade da Assembléia 80

1.2.2. A criação dos Governos Provisórios das Províncias 102

1.3. A Carta Constitucional de 1824

Capítulo 2: Desenhando as instituições para um novo Império

2.1. Os Governos das Províncias

2.2. Um panorama das "reformas liberais"

2.3. A prática legislativa e a execução das leis na esfera da administração

3.1. A caminho da reforma constitucional

3.2. A tentativa de radicalização e a aprovação final do projeto de reforma da Constituição

3.3. A votação da reforma constitucional 262

3.4. O Ato Adicional 
Para Ana, minha mãe 
"Lei é a norma das ações humanas, segundo a justiça natural; ela se encaminha a fazer a felicidade particular e pública; e sempre é feita pela vontade geral dos Representantes que são o competente órgão do povo: $\log$ o sendo a Lei a norma das ações humanas, para a felicidade social, segue-se que ela deve ser acomodada aos fins da Sociedade, e que por isso deve ser razoável, clara, e justa; e por uma infalível consequiência aquela que não cumprir com os fins, não é verdadeira Lei, e por isso não se lhe deve obedecer cegamente" (Cipriano Barata, Sentinella da Liberdade na guarita de Pernambuco, 27/10/1823)

"Fazer amar as leis é um dos maiores segredos e cuidados de uma legislação sábia. A veneração religiosa com que o povo inclina sua fronte perante a autoridade da lei, essa veneração identifica-se com o amor à pátria e de suas instituições, e gera um nobre orgulho, virtudes e dedicações" (Marquês de São Vicente, Direito Público brasileiro e análise da Constituição do Império, 1857) 


\section{Introdução}

Em longo discurso feito às Cortes de Lisboa em abril de 1822, Diogo Antônio Feijó, então deputado por São Paulo, expressava em poucas palavras alguns dos significados que o vocábulo Constituição tinha adquirido à época:

"Soberano Congresso, O Brasil já sabe que a Constituição é o estabelecimento da ordem, da maneira por que um povo é governado; que é a expressão da livre convenção; a base fundamental da sociedade entre homens livres"1.

Seu pronunciamento respondia a uma crescente pressão que naquele ano se instaurara na Casa legislativa entre representantes de Portugal e os das Províncias americanas que se afinavam com a proposta, encabeçada pela bancada paulista, de defesa de uma condição política diferenciada para o Reino do Brasil na unidade portuguesa que se pretendia reformar ${ }^{2}$. O momento era delicadíssimo, e expressava um dos maiores impasses vividos pelo Reino Unido após a Revolução do Porto de 1820: o da construção de uma ordem constitucional com a derrocada do absolutismo, cuja principal tarefa recaía na redefinição dos papéis políticos que caberiam às diversas partes componentes da unidade portuguesa. Nesse momento, o próprio Feijó propunha uma indicação para que cada uma das Províncias fosse reconhecida como "independente" enquanto não se organizasse e ratificasse a Constituição, no intuito que essa autonomia fosse levada em consideração quando se tratasse do arranjo político imperial. Solicitava também que seus governos tivessem autoridade sobre os destacamentos militares provenientes de Portugal como forma de manter sua integridade.

Como hoje se sabe, seria no mesmo ano, 1822, que se mostraria viável um projeto de Independência do Brasil que, mesmo sem ser unanimidade, propôs a incorporação do

\footnotetext{
${ }^{1}$ Diário das Cortes Gerais e Extraordinárias da Nação Portuguesa, sessão de 25 de abril de 1822, tomo V, p. 951; disponível na Internet: www.debates.parlamento.pt

${ }^{2}$ Márcia Regina Berbel, A nação como artefato. Deputados do Brasil nas Cortes portuguesas 1821-1822, São Paulo, Hucitec/Fapesp, 1999.
} 
conjunto das Províncias portuguesas ${ }^{3}$. Seu aparecimento era a prova mais cabal do esgotamento da possibilidade de consenso entre os interesses dos diversos grupos surgidos de um e outro lado do hemisfério, e do qual resultaria a desagregação da estrutura imperial lusitana na América. Desde então, o pretendido Império independente encontrar-se-ia diante do nevrálgico, e idêntico, problema da criação de um regime sob a égide constitucional, com o agravante da inexistência prévia de uma articulação interna entre suas partes que lhe assegurasse a unidade "Brasil". Essa, como também se sabe, demoraria anos para se concretizar.

O presente trabalho nasceu de questionamentos acerca das bases de construção desse Império que, aparentemente frágil em seus primeiros anos, revelaria na verdade um surpreendente poder de estabilidade interna em longo prazo. Tais questionamentos evoluíram para uma análise de como, após a Independência do Brasil, foi possível a consecução de um novo "pacto político" mimetizado pela idéia de Constituição, o qual teria um papel fundamental na criação do aparato político-institucional imperial, tanto no plano do discurso como de sua prática efetiva. Um dos seus desdobramentos imediatos foi a urgente necessidade de soluções para integração dos antigos domínios portugueses o que, da mesma forma que nas Cortes lisboetas, não se tratava apenas de conceber uma nova unidade, mas de estabelecer que unidade poderia ser viável. Isso ficaria claro quando da instalação da Assembléia Constituinte em 1823, no Rio de Janeiro, cujos debates nos permitem perceber o nível de tensão que marcou a formação de um Estado independente. Feijó, que depois de sua volta ao Brasil seria novamente deputado por São Paulo em 1826, posteriormente Ministro da Justiça e Regente do Império, demonstrava estar profundamente consciente da resolução dessa agenda.

A criação e legitimação de um regime que se pretendia representativo da "nação" e defensor de seus direitos, inseria o Império do Brasil num amplo movimento que, desde

\footnotetext{
${ }^{3}$ A historiografia já tem demonstrado há anos que, apesar da oficialização da Independência em 1822, não estavam definidas nem a forma que o novo Império teria, nem mesmo consumada uma unidade política, vide o ambiente de profundas disputas de opiniões e projetos que então imperava nas várias províncias. Sobre isso ver, dentre outros: Sérgio Buarque de Holanda, "A herança colonial - sua desagregação", História geral da Civilização brasileira, $3^{\mathrm{a} e d}$., São Paulo, Difel, 1970, t. II, v. 1; Maria de Lourdes Viana Lyra, A utopia do poderoso império - Portugal e Brasil: bastidores da política 1798-1822, Rio de Janeiro, Sette Letras, 1994; Cecília Helena de Salles Oliveira, A astúcia liberal. Relações de mercado e projetos políticos no Rio de Janeiro (1820-1824), Bragança Paulista, Edusp/Ícone, 1999; Andréa Slemian e João Paulo Pimenta, $O$ "nascimento político" do Brasil: origens do Estado e da nação (1808-1825), Rio de Janeiro, DP\&A Editora, 2003; István Jancsó (org.), Independência: história e historiografia, São Paulo, Fapesp/Hucitec, 2005.
} 
meados dos setecentos, no bojo da decadência das bases ideológicas das monarquias vigentes, atingira todo o mundo atlântico de maneira tormentosa e fecunda ${ }^{4}$. A emergência de um espaço de crítica pública ${ }^{5}$ e de práticas de tipo revolucionário nunca antes vistas, alavancadas de modo difuso nas mais diversas localidades desse universo, colocariam na ordem do dia a expectativa de mudança nas formas políticas pela sensação de se viverem "novos tempos" ". Nesse momento de profunda transformação no modus vivendi das sociedades ocidentais, que se convencionou tratar por crise do Antigo Regime, a imagem da Constituição aparecia como de verdadeira pedra de toque, ao fornecer materialidade a anseios de normalização do futuro a partir das experiências vividas de ruptura/continuidade com o passado. Em meio a esse binômio, os revolucionários franceses de 1789 agiram de modo a romperem definitivamente com a tradição política monárquica e rapidamente convocaram uma Assembléia Constituinte para consolidar sua obra (anos mais tarde teriam que se haver com essa herança num momento de contenção conservadora). À sua maneira, os anglo-americanos que realizaram a Independência das Treze Colônias a fizeram em nome dos direitos históricos da tradição inglesa, mas era evidente o caráter de novidade da obra política que então iniciaram, pautada pela Constituição de $1787^{7}$.

Desde então, a ânsia por um ordenamento jurídico das sociedades passaria a conjugar duas premissas básicas: a reivindicação geral por um sistema de leis que ampliasse a visibilidade das ações dos governos, com controle e separação dos poderes

\footnotetext{
${ }^{4}$ Reinhart Koselleck, Crítica e crise. Uma contribuição à patogênese do mundo burguês, Rio de Janeiro, Ed. Uerj/Contraponto, 1999.

${ }^{5}$ Jürgen Habermas, Mudança estrutural da esfera pública, Rio de Janeiro, Tempo Brasileiro, 1984.

${ }^{6}$ De acordo com Reinhart Koselleck, Futuro Passado. Para uma semántica de los tiempos históricos, Barcelona, Paidós, 1993 (ver capítulo 13, "Modernidad"), a busca de soluções para a construção de uma nova ordem política liberal, na rasteira da crítica ao absolutismo, exigiu dos coevos um esforço inédito e esteve intrinsecamente ligada à uma profunda transformação da sua percepção em relação ao futuro, processo que chama de "aceleração do tempo histórico". Isso significa dizer que os acontecimentos revolucionários romperam definitivamente com a idéia predominante de um tempo cíclico e inauguraram uma noção de progresso em que, cada vez menos, o porvir era dotado de previsibilidade. Como decorrência deste processo, que o mesmo autor define por "modernidade", vivenciou-se a sensação de entrada em "novos tempos", cuja novidade não estava apenas na emergência de valores constitucionais liberais, mas, sobretudo, na percepção de transição e provisoriedade das formas políticas que, conjugada à rapidez de gestação de alternativas, informava agora um amplo espaço de possibilidades e expectativas. Ver também como Hannah Arendt, $D a$ Revolução, São Paulo/Brasília, Ática/UnB, 1990, explica o surgimento do conceito moderno de revolução a partir da concepção de ruptura com o passado e da idéia de um "novo rumo" para a História.

${ }^{7}$ Bernard Bailyn, Los orígenes ideológicos de la Revolución Norteamericana. Buenos Aires, Paidós, 1972; Os artigos federalistas (1787-1788) (edição integral), Rio de Janeiro, Nova Fronteira, 1993. Veja-se como foi evidente o imenso esforço de persuasão feito por Alexander Hamilton e James Madison para convencer os vários estados da confederação de que a presente Constituição, para conformação da "unidade nacional", não alteraria em quase nada as leis antigas das localidades, o que ela indubitavelmente o fazia.
} 
políticos, e a garantia dos direitos dos indivíduos, a partir de então tidos como invioláveis ${ }^{8}$. Mesmo com a retração do movimento revolucionário na Europa, sobretudo a partir do biênio 1814-1815, e o fortalecimento de soluções políticas corporificadas pelas monarquias restauradas, a ebulição ainda recente de paradigmas constitucionais continuaria a informar a clivagem entre alternativas mais ou menos radicais de mudança política. Tradicionalmente, embora o termo esteja longe de ter significado consensual entre os especialistas ${ }^{9}$, fala-se em "constitucionalismo moderno" para se definir tais paradigmas, diante dos quais o caso da Inglaterra representaria notória exceção.

Os Impérios ibéricos estiveram no epicentro da crise em condições semelhantes, mas viveriam experiências constitucionais em tempos e modos distintos. Se o ambiente conjuntural das reformas ilustradas nos setecentos aproximava-os ${ }^{10}$, os desdobramentos imediatos causados pelo avanço napoleônico na Europa do início do século XIX marcariam uma separação entre seus caminhos: de um lado, a prisão do monarca e acefalia do poder nos territórios espanhóis; de outro, a vinda da Família Real para o Rio de Janeiro e a

\footnotetext{
${ }^{8}$ Maurizio Fioravanti, Constitucion. De la Antiguedad a nuestros días, Madri, Ed. Trotta, 2001.

${ }^{9}$ Aqueles que, como Horst Dippel, "Constitucionalismo moderno. Introducción a una Historia que necesita ser escrita", Revista Eletrónica de Historia Constitucional, Espanha, Universidad de Oviedo, número 6, set./2005, (disponível no site: hc.rediris.es/06/articulos/html/08.html), adotam o termo, marcam algumas de suas características como: governo representativo para ampliar a legitimidade e prevenir um governo aristocrático; a separação de poderes para evitar sua concentração; a exigência de responsabilidade política para controlar o poder; a independência judicial; e um procedimento ordenado de reforma da Constituição para corrigir seus erros e omissões. Maurizio Fioravanti, op. cit., ao partir da definição de "constitucionalismos", no plural, como formas de "ordenamento geral da sociedade e seus poderes" que sempre existiram desde a Antiguidade, evita utilizar o termo. Isso lhe permite sintetizar a novidade trazida pelos movimentos revolucionários desde fins do século XVIII, sem perder de vista a experiência inglesa existente desde o século XVII. R.V. Van Caenegem, An historical introduction to western constitucional law, Cambrigde, Cambrigde University Press, 1995, prefere falar em três modelos modernos de lei constitucional: o da continuidade da monarquia, nos moldes da inglesa; o da conservação da legitimidade monárquica, como no caso da Prússia e da Áustria; e o da República, do qual os EUA seriam o exemplo mais "bem-sucedido". Assim, trata de "Estado-nação burgueses" (em referência ao termo Rechtsstaad, ou "Estado de direito") as novas unidades políticas que se formaram no seu desdobramento baseadas no "Parlamento" e na Constituição. Para o caso do Império português, Jorge Miranda, O constitucionalismo liberal luso-brasileiro. Lisboa, Comissão Nacional para as Comemorações dos Descobrimentos Portugueses, 2001; e Manual de Direito Constitucional, Coimbra, Coimbra Ed., 1982., prefere falar em "constitucionalismo liberal", também pontuando a especificidade do caso inglês. Já José Gomes Canotilho, Direito Constitucional e teoria da Constituição. Coimbra, Almedina, 1997, é mais cuidadoso no uso desta definição, ao marcar a existência de "vários constitucionalismos" ao longo da história os quais estariam vinculados entre si pela construção diferenciada de "teorias normativas da política". No entanto, para o caso português, ambos concordam em se falar em "constitucionalismo" apenas no século XIX, quando nasceria uma necessidade de disciplinar os governantes e suas relações com os governados, bem como de submeter à lei todas as manifestações de soberania e direitos dos cidadãos.

${ }^{10}$ Tulio Halperín Donghi, Reforma y disolución de los impérios ibéricos 1750-1850, Madrid, Alianza Ed., 1985.
} 
preservação imediata da dinastia bragantina e do próprio regime português ${ }^{11}$. O ambiente de guerra vivido na Espanha fez que a busca de soluções para a situação desembocasse na formação de Juntas de Governo, sendo que aquela considerada Central, em nome da "nação", trabalharia para a instalação das Cortes Constituintes em Cádiz, iniciando um movimento de radical ruptura em relação à própria monarquia bourbônica ${ }^{12}$. A mesma radicalidade também se desdobraria nas suas possessões americanas na década de 1810, quando o exemplo da Península tornou viável a formação de governos locais autônomos que passariam a reivindicar sua soberania e organização constitucional, iniciando um processo irreversível de Independência ${ }^{13}$.

Dessa forma, enquanto houve continuidade no processo espanhol desde 1810, do lado português a estratégia de migração da Corte forneceu a ele uma outra temporalidade. O legitimismo só se tornaria incontornável em 1820 com a eclosão de uma revolução liberal em terras portuguesas, a despeito da existência de fissuras internas nas bases políticas de sustentação da monarquia bragantina desde há muito ${ }^{14}$, e de movimentos que diretamente afrontaram o regime quando da Corte no Brasil ${ }^{15}$. Foi quando seus idealizadores proclamaram a convocação de Cortes para elaboração de uma Constituição como marco fundador de uma nova ordem, na qual o sentimento de "novos tempos" se fez presente na forma de "regeneração" 16 . Logo que a notícia chegou ao Brasil, ela encontrou

\footnotetext{
${ }^{11}$ István Jancsó, “A construção dos Estados nacionais na América Latina - apontamentos para o estudo do Império como projeto”, Tamás Szmrecsányi e José Roberto do Amaral Lapa (orgs.), História econômica da Independência e do império, São Paulo, Hucitec, 1996. Sobre as singularidades e dessemelhanças entre os processos americanos portugueses e hispânicos, ver João Paulo Pimenta, O Brasil e a América espanhola (1808-1822), São Paulo, FFLCH-USP, Tese de Doutorado, 2003.

12 Josep Fontana, La crisis del antiguo régimen (1808-1833), $4^{\mathrm{a}}$ ed., Barcelona, Grijalbo, 1992; Miguel Artola, Antiguo Régimen y revolución liberal, 2 ed., Barcelona, Ariel, 1983.

13 Observa-se, por exemplo, uma tendência dos textos e projetos constitucionais gestados em várias localidades ao longo dessa década serem dotados de propostas políticas radicais, espelhadas tanto no ideário revolucionário francês, como em princípios do federalismo norte-americano. Grande parte deles para toda a América Latina podem ser encontrados no site: www.cervantesvirtual.com/portal/constituciones. Ver a análise de François-Xavier Guerra, Modernidad e independencias. Ensayos sobre las revoluciones hispánicas, $2^{\mathrm{a}}$ ed. México, FCE, 1993.

${ }^{14}$ Refiro-me aqui ao movimento de crítica e descontentamento com o regime que, sobretudo na colônia, gerara respostas contundentes desde fins do século XVIII, como pode ser visto na materialização dos projetos de sedição então intentados. István Jancsó, "A sedução da liberdade: cotidiano e contestação política no final do século XVIII”, Fernando Novais (dir.). História da vida privada no Brasil. São Paulo, Cia. das Letras, 1997.

${ }^{15}$ Tratam-se especialmente dos episódios de 1817 em Pernambuco, com a tentativa de instauração de um governo "republicano" independente da Corte joanina, e em Lisboa, no mesmo ano, com a tentativa abortada de rebelião contra a Regência, liderada por Gomes Freire. Voltaremos a elas mais adiante.

${ }^{16}$ Sobre o tema ver: Zília Osório de Castro, Constitucionalismo vintista: antecedentes e pressupostos, Lisboa, Univ. Nova de Lisboa, 1986; Valentim Alexandre, Os sentidos do império. Questão nacional e questão
} 
terreno fértil e também mobilizou esforços na formação de Juntas de Governo que se diziam diretamente submissas à nova Casa legislativa, a despeito da presença da Corte no Rio de Janeiro ${ }^{17}$. Isso contribuiu decisivamente para a forçada aceitação que D. João VI fez ao movimento, em fevereiro de 1821. A resposta favorável e quase imediata dos portugueses de além-mar era, sem dúvida, reflexo de expectativas de transformação na situação política vigente, por meio do "soberano Congresso", que assumia para si a tarefa de reforma da nação portuguesa.

Alicerçada na valorização de um "pacto constitucional" que garantisse o controle das ações dos governos por parte dos cidadãos, bem como a afirmação de seus direitos, e em franca oposição ao que cada vez mais se caracterizava como "absolutista", as Cortes falavam em nome da consolidação da legitimidade daquele que seria um dos palcos mais importantes da vida política moderna ao longo dos oitocentos: o Parlamento. A centralidade que a instituição passava a ocupar no cenário político derivava de sua construção ideológica e discursiva como esfera responsável pelo equilíbrio entre os poderes da "nação" que, agora, rivalizavam com os dos antigos monarcas na elaboração das leis que deveriam reger as sociedades. Nesse sentido, seu papel seria alvo permanente de discussão, tanto em regimes politicamente mais conservadores como nos mais radicais. Mesmo no mundo anglo-saxão, onde o funcionamento dessa instituição remontava há séculos, uma reformulação jurídica vinha ocorrendo desde o século XVIII, em função da ruína dos paradigmas corporativos que alicerçavam o mundo ocidental ${ }^{18}$.

O papel do Parlamento como lugar dos "representantes da nação", que hoje tende a ser desprezado em consequiência da crise vivida pelos Estados nacionais e seu paradigma de

colonial na crise do antigo regime português. Porto, Afrontamento, 1993; Miriam Halpern Pereira (et alli.), $O$ liberalismo na península ibérica na primeira metade do século XIX. Lisboa, Sá da Costa, 1982, 2 vols.

${ }^{17}$ Márcia Regina Berbel, op. cit.; Andréa Slemian e João Paulo Pimenta; op. cit..

${ }^{18}$ Noelia González Adánez, "La monarquia inglesa en la crisis del Antiguo Régimen: polêmicas e identidades políticas en la segunda mitad del siglo XVIII", Revista Eletrónica de Historia Constitucional, Espanha, Universidade de Oviedo, número 5, jun/2004 (disponível no site: hc.rediris.es/05/articulos/), critica uma versão já consagrada pela historiografia mundial, que apresenta o sistema político inglês do século XVIII como completamente distinto do resto da Europa, sobretudo por causa da atuação do Parlamento. Defende a existência de uma ordem "Antigo Regime" inglesa, que não dependia tanto do sistema de governo, mas do modelo de conformação das relações de poder entre as elites. A expressão de sua crise seria visível na aspiração de uma nova concepção de monarquia que se traduzirá em um conjunto de reformas realizadas nas primeiras décadas do século XIX no sentido de convertê-la numa "monarquia parlamentária". Uma expressão dessas mudanças estava na defesa moderada da centralidade do Parlamento inglês feita por W. Blackstone, Commentaires on the Laws of England, Nova York, 1966, em 1765-1769, como resposta ao temor de que "outra soberania", a da "vontade popular", pudesse se sobrepor a ela. Maurizio Fioravanti, op. cit., p. 98-99. 
democracia, era, à época, um dos pilares de uma verdadeira crença liberal de que a racionalização das formas de funcionamento dos governos poderia atender aos interesses dos indivíduos na composição de uma sociedade que igualasse os homens perante a lei ${ }^{19}$. No caso do constitucionalismo vintista português, o ambiente parlamentar revelar-se-ia um dos espaços mais importantes de ação política e uma das poucas tribunas de discussão

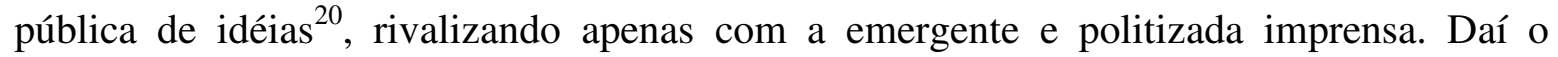
sentimento partilhado pelos parlamentares, imbuídos do espírito revolucionário do início dos anos 20, de que estariam "vocacionados para a tarefa de restaurar a Pátria, que se traduziu, na maior parte dos casos, num empenhamento político interventor e afirmativo enquanto cidadãos",21.

$\mathrm{Na}$ bagagem dos deputados que das mais longínquas províncias do Brasil se dirigiram às Cortes de Lisboa, esse empenho foi levado ao limite quando se viram malogradas as tentativas de manutenção da união com a ex-metrópole, e alguns de seus representantes, entre eles Feijó, abandonaram a $\mathrm{Casa}^{22}$. Muitas das demandas de grupos regionais americanos voltaram-se então para a promessa feita por D. Pedro, como Regente do Brasil, de abertura de Cortes no Rio de Janeiro para tratamento das questões específicas da América portuguesa. Essa era a prova de que o Vintismo significou, para o Brasil, uma clivagem a partir da qual qualquer alternativa política deveria passar pela convocação de uma instituição representativa similar. E o herdeiro legítimo do trono bragantino mostrava reconhecer o valor, tanto real como simbólico, que essa esfera de representação tinha adquirido nos últimos tempos, para onde convergiam as expectativas em torno da Constituição.

\footnotetext{
${ }^{19}$ Pierre Rosanvallon, em O liberalismo econômico: história da idéia de mercado, Bauru, EDUSC, 2002, discute como o liberalismo nasceu sem dissociação entre economia e política, tendo como substrato filosófico (no caso de Adam Smith) uma utopia de que todos os homens pudessem ser igualados na esfera do "mercado".

${ }^{20}$ Fernanda Paula Sousa Maia, O discurso parlamentar português e as relações Portugal-Brasil. A Câmara dos Deputados (1826-1852), Lisboa, Fundação Calouste Gulbenkian/Min. da Ciência e Tecn., 2002.

${ }^{21}$ Idem, p.25.

${ }^{22}$ Os deputados que assim fizeram escreveram um texto justificando seu ato que ficou conhecido por "Manifesto de Falmouth", transcrito em Diogo Antônio Feijó, São Paulo, Editora 34, 1999; ver análise instigante de István Jancsó e João Paulo Pimenta, "Peças de um mosaico (ou apontamentos para o estudo da emergência da identidade nacional brasileira)", in Viagem incompleta. A experiência brasileira (1500-2000). Formação: histórias, São Paulo, Editora SENAC, 2000, pp. 129-131.
} 
Nestes termos, o baiano Cipriano Barata, de volta ao Brasil depois de também ocupar uma cadeira nas Cortes lisboetas, cobrava a palavra do Príncipe, logo Imperador, para que um pacto favorável fosse realmente consumado, já que, em suas palavras:

“os Povos do Brasil rejeitaram a união com Portugal só porque a Constituição lhes não convém, e que se desejam fazer corpo com o Rio de Janeiro é porque esperam Constituição livre, que lhes agrada. Constituição feita sobre princípios liberais, que destrua Ordens, Privilégios, Isenções, Classes, Morgados, Comendas, etc." ${ }^{23}$.

O mesmo Barata, como periodista ferozmente crítico que se tornou, antenadíssimo com os trabalhos da Constituinte Brasileira que se instalou após a Independência, gostava de falar na "santidade da nossa Augusta Assembléia" e do "divinal Sistema Constitucional". O que significava dizer que, além da tradicional legitimidade monárquica herdada da tradição portuguesa, encarnada por D. Pedro, existia uma rival, caracterizada pela valorização de uma nova esfera de representação política, e evocada tanto por aqueles que defendiam uma maior participação política dos "cidadãos" ou "povos", como pelos adeptos de projetos mais autonomistas de governo. Posteriormente, constituir-se-ia uma outra leitura extremamente moderada de divinização da esfera da lei que, a despeito de qualquer discordância, deveria ser seguida como igualmente sagrada.

Sem perder de vista a diversidade das lutas políticas que se travavam nessas esferas de representação, vale notar que elas também foram - e são até hoje - palco permanente de consensos e acordos políticos, os quais adentrando os oitocentos vão tender à moderação e acomodação das divergências à medida que o próprio liberalismo abandona sua dimensão revolucionária e passa a ser entendido como burguês. No Império do Brasil, seu funcionamento não se constituiria em exceção ${ }^{24}$. Na sua base, estariam também presentes uma série de elementos condicionantes da ação discursiva dos deputados, que faziam que suas práticas fossem mediadas por instrumentos de controle, internos e externos,

\footnotetext{
${ }^{23}$ Análise do Decreto de $1^{o}$. de dezembro de 1822 apud Marco Morel, Cipriano Barata na Sentinela da Liberdade. Salvador, Academia de Letras da Bahia/ Assembléia Legislativa do Estado da Bahia, 2001, p. 104.

${ }^{24}$ Nesse sentido, destaco a análise que faz Miriam Dolnikhoff, O pacto imperial. Origens do federalismo no Brasil, São Paulo, Globo, 2005, ao analisar a Câmara Geral dos Deputados e o trabalho das Assembléias Legislativas Provinciais, após 1834, sem simplificá-las em esferas "monolíticas" de dominação e controle político, mas, sobretudo, como espaços em que muitos dos acordos eram então tecidos.
} 
responsáveis em grande medida pela consagração da imagem de sua eficácia ${ }^{25}$. Estes iam desde a normalização da ordem dos trabalhos (escolhas do presidente e de secretários, comissões, padrão das intervenções, regimento da Casa) aos julgamentos públicos das "galerias" e da imprensa. Não era à toa que a publicação do Diário das sessões fosse assunto de permanente preocupação e discussão, entendido até mesmo como "remédio" a acusações como a de que, em certa ocasião, "a Assembléia te[ria] sancionado os maiores disparates" 26 .

No seu limite, a construção de um regime de Monarquia Constitucional no Brasil significou a conflituosa consolidação do espaço do Parlamento como canal de representação dos cidadãos diante do poder do Imperador como tradicional defensor dos seus "súditos".

Em pronunciamento à Assembléia Constituinte de 1823, o deputado da Paraíba Joaquim Manoel Carneiro da Cunha afirmava em relação ao "pacto constitucional" que se pretendia compor:

"O que posso dizer, falando com a minha costumada franqueza, é que nas Províncias existem receios de se não seguir o Rio de Janeiro o verdadeiro sistema Constitucional; teme-se que a Constituição não seja feita segundo os princípios que por lá prevalecem, e que, portanto, lhe queiram dar aquilo de que elas não gostam; mas vontade de união com Portugal não se acha em nenhuma delas. Demais, os Povos esperam desta Assembléia leis pacíficas e sábias"27.

Além de querer pressionar seus companheiros para que se atendessem as demandas por maior autonomia vindas de algumas Províncias, o paraibano deixava claramente entrever que a Constituição tratava-se de uma necessidade. Desta forma, utilizava o termo no

\footnotetext{
${ }^{25}$ Fernanda Paula Sousa Maia, op. cit..

${ }^{26}$ Discurso de Manoel Ferreira de Araújo Guimarães, sessão de 04/outubro/1823, Diário da Assembléia Geral, Constituinte e Legislativa do Império do Brasil - 1823 [DAG] (edição fac-similar), Brasília, Senado Federal, 1973, v. 2, p. 166.

${ }^{27}$ Idem, v.1, Sessão de 10/julho, p.387.
} 
sentido em que caminhava sua transformação desde meados do século XVIII, quando deixava de significar uma idéia descritiva, ligada a normas que regulamentavam o "exercício do domínio", para tornar-se um "conceito-objetivo" prescritivo que passava a transportar expectativas definidas na construção de um novo ordenamento político ${ }^{28}$. Inserido no momento de passagem do direito como um "campo" doutrinário - ligado ao ensino e à dogmática - para o da legislação positiva e da codificação vividos na modernidade ${ }^{29}$, o vocábulo adquiria um substrato jurídico cada vez mais ligado a uma idéia de formação de um governo e de um Estado.

A partir desse movimento geral de transformação do conceito no mundo ocidental, os usos que se fizeram de Constituição foram expressão das condições políticas existentes em cada contexto específico ${ }^{30}$. Nesse sentido, as distintas formas com que foi apropriado em especial na Inglaterra, na América do Norte e na França - revelam modelos distintos de ordenamento jurídico que acabariam por ser influentes em outras regiões, tanto em função da importância do modelo da monarquia inglesa nos setecentos como pelos acontecimentos revolucionários protagonizados pelos outros dois.

Na língua anglo-saxônica, o vocábulo dizia respeito às "regras fundamentais da organização do Estado", como “instrumento" principal da manutenção dos direitos individuais - baseados especialmente nas liberdades civis, ou "negativas", de defesa de propriedade e segurança - que seriam herdados da tradição inglesa ${ }^{31}$. Por essa razão, a infração à Constituição deveria ser punida, pois atos arbitrários ou irracionais não poderiam lesionar os direitos adquiridos pelos Englishmen. Foi em nome desses direitos que os colonos anglo-americanos de 1776, ao construírem seu discurso pela Independência contra as medidas tomadas pelo Parlamento londrino, utilizaram a definição inglesa de

${ }^{28}$ Dieter Grimm, verbete "Verfassung (II)", Otto Brunner (et. alli.), Geschichtliche Grundbegriffe. Historisches Lexikon zur politisch-sozialen Sprache in Deutschland. Stuttgart, Klett-Cotta, 1984, v.6, p. 863; Dieter Grimm e Heinz Mohnhaupt, Verfassung. Zur Geschichte des Begriffs von der Antike bis zur Gegenwart. Berlin, Duncker \& Humblot, 1995, p. 100 em diante. Agradeço a José Reinaldo de Lima Lopes por uma cópia do segundo.

${ }^{29}$ José Reinaldo de Lima Lopes, As palavras e a lei. Direito, ordem e justiça na história do pensamento jurídico moderno, São Paulo, Edusp/Editora 34, 2004, p. 22.

${ }_{30}$ A base para essa discussão são as reflexões feitas por Dieter Grimm, op.cit.

${ }^{31}$ Maurizio Fioravanti, em Los derechos fundamentales. Apuntes de Historia de las constituciones, Madri, Trotta, 1998, p. 26 seg., a partir do caso da monarquia inglesa, apresenta um modelo jurídico de governo que chama de "historicista", o qual se expressava pela valorização de uma estrutura corporativa medieval na defesa dos direitos e "liberdades" individuais na organização política-constitucional. Essa era a base de legitimação da idéia de uma composição moderada da Monarquia por meio do equilíbrio de poderes entre o rei e o Parlamento. 
Constituição de forma específica. Valorizando-a como um documento que deveria ser apresentado por escrito, por ter uma "existência real", a idéia era que ela seria o produto de elaboração do "povo" na formação de seu governo; logo passou a ser entendida como um "sistema de princípios" para assegurar os direitos dos cidadãos perante qualquer intervenção arbitrária por parte do governo $^{32}$. Desta forma, reforçava-se o sentido de Constituição como instrumento de garantia contra a própria "onipotência parlamentária", e também se levava às últimas conseqüências uma perspectiva individualista, claramente antiestatista, que reconhecia a anterioridade dos direitos inalienáveis em relação à sua forma de ordenamento jurídico ${ }^{33}$.

Não à toa, o grande dilema constitucional vivido pelos construtores do novo Estado norte-americano passava pela questão da representação política, ou seja, de quais seriam os mais adequados mecanismos institucionais tanto para o controle do governo como para manifestação das "necessidades do povo"34. E o problema não se colocou apenas no plano dos indivíduos, mas também dos antigos "estados" ou "colônias" que para adentrarem a uma unidade política muito se debateram sobre a organização interna de poderes e jurisdições de cada uma de suas partes. As soluções encontradas acabariam por se diferenciar em muito do caso inglês, com a invenção de uma opção republicana e federativa que, por se esmerar na garantia dos direitos, permitiria inclusive a própria manutenção da escravidão.

Na França, uma outra tradição moderna de direitos foi inaugurada após 1789. No esforço empreendido pelos revolucionários em negar o passado, a necessidade de reconstrução jurídica do Estado definiu um conteúdo específico de Constituição, tomada

\footnotetext{
${ }^{32}$ Observe-se que o próprio preâmbulo das Constituições norte-americanas (refiro-me também a dos Estados) seguia forma semelhante à adotada pela Pensilvânia (1776): "We, the people, do ordain, declare and establish the following Declaration of Rights and Frame of Government, to be the constitution of this commonwealth", apud Dieter Grimm, op.cit., p. 867.

${ }^{33}$ Maurizio Fioravanti, Los derechos fundamentales..., p. 77 seg., analisa como na América do Norte se criou um modelo de liberdades constitucionais que conjugava a cultura "historicista" da tradição inglesa com um "jusnaturalismo individualista", o que fez que a proclamação dos "direitos naturais e individuais" se confundisse definitivamente com a contínua reclamação dos seus precedentes históricos.

${ }_{34}$ Bruce Ackerman, We, the people. Foundations, Cambridge, Harvard University Press, 1995, ao analisar a Constituição americana e suas correntes de interpretação, propõe um modelo para sua compreensão que chama de "dualist democracy". Este residiria em enxergar duas vias na formação das decisões políticas feitas em uma democracia: uma primeira, feita pelo "povo da América", e uma segunda, pelo governo instituído. Acredita que a tensão permanente entre essas forças foi central desde a construção dos mecanismos que dariam ao "segundo" o direito para falar em nome do "primeiro", colocando o problema da democracia como primordial até hoje para os norte-americanos.
} 
como "forma de governo" no sentido de normas legais claramente estabelecidas. Uma das novidades dessa opção estava na sua perspectiva "legicentrista", ou seja, na concepção da lei como um valor em si mesma (e não como mero instrumento), como limite no exercício das liberdades, atribuindo-se ao legislador a capacidade de interpretar a vontade geral. Isso fornecia um papel central ao próprio Estado na expressão de garantia dos "direitos inalienáveis dos homens" 35 . Desta forma, a ruptura promovida pela Revolução foi radical numa dupla e oposta direção: ao afirmar a prioridade do corpo soberano de cidadãos politicamente ativos contra os poderes constituídos; e ao conceber a primazia do Legislativo na encarnação da "nação". Para alguns, isso pôde se constituir numa dualidade quase insolúvel, pois a "nação" perderia sua capacidade de intervenção à medida que delegava aos órgãos públicos representativos o direito de agir em seu nome, devendo assim, obedecê- $\operatorname{los}^{36}$. Aí residia, sem dúvida, um dos maiores dilemas normativos legados pela Revolução à posteridade.

No mundo português, a transformação do conceito também se verifica, e pode ser observada nos seus significados lexicografados no dicionário de Antônio Moraes Silva. No ano de 1789, o verbete "Constituição" aparecia como "estatuto, lei, regra civil ou eclesiástica", sendo a palavra "constituinte" entendida como "ouvinte, pedinte" 37 . Ambos os sentidos seriam repetidos nos léxicos editados em 1813 e 1823. Já na edição de 1831, o termo é definido como "Lei que determina a forma de governo do Reino ou República; os direitos ou deveres e relações dos súditos e regentes ou governantes", ou seja, um claro conteúdo programático e jurídico. O vocábulo "constituinte" passava então a ser identificado como "pessoa que constitui a outrem seu procurador ou advogado"38. Além disso, no mesmo ano, são também inseridos outros verbetes correlatos, como

\footnotetext{
35 Segundo Maurizio Fioravanti, Los derechos fundamentales..., seu modelo combinava uma perspectiva individualista de garantia dos direitos individuais, com outro, que chama de "estatista", o qual legitimaria os poderes constituídos para falarem em nome da "nação".

${ }^{36}$ Seu principal problema residia no fato de a Revolução ter concebido idealmente o legislador como "virtuoso", essencialmente respeitoso com os direitos dos indivíduos como expressão da "vontade geral". Por essa razão, a forma de garantir os direitos seria o ponto mais controvertido desse esquema construído pelos franceses.

${ }^{37}$ Diccionario da Lingua Portugueza composto pelo Padre D. Rafael Bluteau, reformado, e accrescentado por Antonio de Moraes Silva natural do Rio de Janeiro, Lisboa, Officina de Simão Thaddeo Ferreira, 1789.

${ }^{38}$ Diccionario da Lingua Portugueza, 4ed., Lisboa, Impressão Régia, 1831.
} 
constitucional, "conforme a Constituição e segundo ela, legítimo, legal”; e constitucionar, "assentar por base constitutiva do Estado ou Governo"39.

Desse modo, e seguindo o movimento da época, Constituição, que em fins do século XVIII era sinônimo de "Leis Fundamentais", relacionada com o "exercício do domínio do rei”, teria que ser explicada à luz da consideração de uma nova força política que ganhava espaço em todo mundo ocidental: a nação. Em Portugal, essa tarefa caberia especialmente aos intelectuais vinculados à monarquia absolutista, que promoveram uma atualização dos saberes jurídicos à vista das teorias racionalistas do direito natural e pátrio (veja análise feita no $1^{\circ}$. Capítulo). Assim, quando do movimento liberal de 1820, o vocábulo adquiriu um caráter programático central no discurso da "regeneração" portuguesa, tornando-se palavra de ordem do "pacto" que deveria se conceber entre as partes do Reino Unido português, aos moldes do uso feito pelos revolucionários franceses.

Com a Independência, o Brasil herdaria não apenas conflitos deflagrados nas Cortes lisboetas, mas igualmente seus enunciados políticos. Grande parte dos discursos proferidos pelos deputados à Assembléia de 1823 apresentava Constituição, para além de instrumento de garantia dos direitos individuais e de formação de um governo com normas legais instituídas e poderes limitados para "salvação pública", como tábua de união dos territórios da América portuguesa. Isso daria margem à existência de, ao menos, dois usos distintos do termo, nem sempre incompatíveis: um que a definia como elemento de coesão do novo Império, "arraigada em nossas leis, estabelecimentos e costumes", pressupondo que a união já estaria estabelecida pela tradição e "espírito comum", ou seja, pelo passado; e outro que afirmava que sua existência real deveria se dar em função dos interesses da "nação" ou mesmo das localidades específicas que, na formação de um mesmo pacto, apontaria para um programa de futuro.

Em um debate sobre como se deveria discutir o projeto de Constituição, no discurso dos deputados Antônio Carlos de Andrada Machado, representante por São Paulo, e do já citado Joaquim Manoel Carneiro da Cunha, as duas utilizações do conceito se confrontam. O primeiro, sendo contrário à consulta direta da "opinião pública" acerca do seu conteúdo, contrapunha-se à idéia de que a Constituição deveria ser da "maior perfeição possível", evocando o exemplo da Inglaterra, onde ela recebeu "essa perfeição do decurso dos tempos

\footnotetext{
${ }^{39}$ Idem.
} 
e da experiência, [...] à medida que se foram reconhecendo as alterações de que precisava". O paraibano, defendendo a consulta, afirmava ser indispensável que a Constituição fosse "baseada na opinião geral de um povo livre como o do Brasil", e não apenas na "opinião" do Rio de Janeiro. Citava o fato de se ter "muitos desejos de ver ultimado" o texto constitucional por compreendê-lo como estabelecimento da forma política que, em construção, deveria reger o Império daí para diante ${ }^{40}$.

Por se tratar de um momento entendido como fundador, o substrato comum entre as duas concepções era pensar a Constituição como fundamental para composição de uma unidade política, mas a divergência era de fundo: a possibilidade de as províncias terem ou não o direito de negar o "pacto" que se pretendia estabelecer. Nesse sentido, estava-se diante de uma tensão vinda à tona quando da necessidade de reconstrução ideológica dos Estados sob a égide liberal, sintetizada pela passagem de uma fundamentação "contratual" dos governos para outra, de base "legalista". Se, por um lado, a perspectiva do contrato deixava aos indivíduos o poder da escolha sobre sua realização (a idéia de uma Constituição pactuada), por outro, era marcada pela necessidade de subordinação dos indivíduos à ordem estabelecida ${ }^{41}$. E se a segunda ganhava crescente legitimidade no mundo pós-revolucionário, especialmente após 1815, a primeira consubstanciava-se, mesmo que sob a evocação de pacto, em potencial reação contra a aceitação indiscriminada das leis.

A outorga da Carta brasileira de 1824 fez que o vocábulo e seus derivados fossem também utilizados, a partir do círculo dos poderes constituídos, como instrumento central da garantia de estabilidade (e constitucionalidade) do regime. Logo se transformou em adjetivo poderoso para simbolizar os atributos de uma monarquia cuja legitimidade era construída, senão pela participação direta do "povo", pela sua "aceitação", o que servia de justificativa para o "pacto legalista" 42 . Configurava-se um uso "defensivo" da Constituição como "código dos códigos", mais do que como estatuto dos cidadãos, segundo expressão

\footnotetext{
${ }^{40} D A G$, sessão de $12 /$ setembro, v.2, pp. 766-7.

${ }^{41}$ Essa questão remonta a toda tradição jusnaturalista moderna desde, pelo menos, Thomas Hobbes, que foi o primeiro a estabelecer a não existência de societas antes da decisiva submissão de todos à força imperativa e autoritária do Estado, como resultado do "ato de subordinação" dos indivíduos a essa autoridade. Trata-se de um pactum subiectionis que, diferentemente de uma idéia de contrato de garantia entre as partes, não partilhava da concepção de pré-existência de bens e direitos antes da formação do Estado. Maurizio Fioravanti, Constituición.
} 
de José Reinaldo Lopes ${ }^{43}$. Daí ser comum sua referência como ponto de salvação da união e prosperidade do Brasil, por vezes até mesmo revestida de sacralidade, conforme discurso proferido por um periódico mineiro às vésperas de seu juramento:

"Já tínhamos Pátria, tínhamos Monarca; faltava-nos, porém, a Lei Fundamental, a Constituição Política, que garantisse o direito individual do Cidadão, que marcasse a linha de seus deveres, numa palavra, que consolidasse as bases do Edifício Social Brasílico [...] o juramento da liberal Constituição do Império deve operar este milagre político" 44 .

Assim, explica-se o consenso em torno da utilização de Constituição após a Abdicação de D. Pedro I em 1831, quando, segundo Ilmar Rohloff de Mattos, liberais da estirpe de Evaristo da Veiga e Bernardo Pereira de Vasconcellos viram nela "um instrumento privilegiado para deter a revolução"45. Como moderados que eram, transformaram-na na "essência" das leis cuja principal qualidade residiria na sua capacidade de abrir a possibilidade de reforma e de manter a estabilidade da ordem. Mas radicais (ou, se quisermos, exaltados) e conservadores (caramurus) também seriam responsáveis pela valorização e amplitude dos significados que o conceito comportaria no período: os primeiros, utilizando-o como uma forma de constrangimento à "ação dos absolutistas" - pela sua dimensão de "pacto social" - e os segundos, em nome das instituições governamentais fundadas na tradição e no costume ${ }^{46}$. A polissemia era, portanto, expressão de sua força no ambiente da luta política.

\footnotetext{
${ }^{42}$ Essa era a justificativa das monarquias moderadas na Europa que pretendiam, acima de tudo, resguardar a legitimidade dinástica.

43 "Iluminismo e jusnaturalismo no ideário dos juristas da primeira metade do século XIX", Brasil: formação do Estado e da nação, São Paulo/Ijuí, Fapesp/Hucitec/Unijuí, 2003, p. 205.

${ }^{44}$ Abelha do Itacolomy, 31/03/1824, número 35, p.140.

45 Ilmar Rohloff de Mattos, "La experiencia del Imperio del Brasil", Antonio Annino (et. alli), De los imperios a las naciones: Iberoamerica, Ibercaja/Obra Cultural, 1994.

${ }^{46}$ Veja-se como o jornal "caramuru" pernambucano O Amigo do Povo $\left(\mathrm{n}^{\circ} 4,20 / \mathrm{julho} / 1829\right)$ criticava os ditos "republicanos" por usarem "o nome de Constitucionais para atacarem todos os dias a Constituição do Império". Afirmava que eles seriam os verdadeiros "constitucionais" por se ligarem às instituições governamentais. Apud Silvia Carla Brito Fonseca, A idéia de República no Império do Brasil: Rio de Janeiro e Pernambuco (1824-1834). Rio de Janeiro, Tese de Doutorado, IFCS/UFRJ, 2004, p.342. Sobre os usos do vocábulo na imprensa ver Lúcia Maria Bastos Pereira das Neves, Corcundas e constitucionais: a cultura política da independência, 1820-1822, Rio de Janeiro, FAPERJ/Revan, 2003; sobre a imprensa "caramuru" e "exaltada", ver Marco Morel, As transformações dos espaços públicos. Imprensa, atores políticos e
} 
Quando em 1831 se iniciaram, na Câmara dos Deputados, as discussões sobre a necessidade de uma reforma constitucional, tanto os deputados favoráveis como aqueles contrários a ela tomaram a Carta como inviolável. Ambos argumentaram ser inadmissível uma mudança que não fosse de acordo com ela. No entanto, os que atacavam a proposta de reforma eram incisivos na defesa da Constituição do Império, tratando-a como um "espírito", um "símbolo da união do Brasil" que "cumpria que se conservasse o maior respeito"47, "mais como obra da Providência do que dos homens" "48. Alguns dentre os representantes que apoiavam o projeto de reformulação falavam em torná-la "perfeita" para atender as novas demandas existentes, pois que sua inviolabilidade viria do reconhecimento de que servia como programa para "prosperidade" do Brasil. Nestes termos, pronunciava-se o mineiro Bernardo Belisário Soares de Souza:

"A Constituição que nos rege tem sido o elemento de toda a nossa prosperidade; ela por si só é bastante a se obter tudo quanto é mister para fazer o Brasil venturoso: e basta notar que ela tem em si mesma o gérmen das reformas e melhoramentos, sem os perigos que tais reformas e melhoramentos costumam trazer consigo (apoiados)" ${ }^{, 49}$.

De fato, quando da saída de D. Pedro I de cena em 1831, e em face da pressão social para a transformação de bases políticas do regime, seria a Carta Constitucional que delimitaria a possibilidade de mudança. Essa eficácia comprovava-se na utilização discursiva que dela foi feita por uma ampla gama de projetos políticos dos mais distintos calibres, o que reforçou sua centralidade e inseriu definitivamente o Império do Brasil no rol de problemas enunciados na formação dos novos Estados liberais.

sociabilidades na Cidade Imperial (1820-1840), São Paulo, Hucitec, 2005; e Marcello Campos Basile, $O$ Império em construção: projetos de Brasil e ação política na Corte Regencial, Rio de Janeiro, Tese de Doutorado, IFCS/UFRJ, 2004.

${ }^{47}$ Annaes do Parlamento Brasileiro. Segundo ano da segunda legislatura. Câmara dos Deputados. Sessão de 1831 (coligidos por Antonio Pereira Pinto), Rio de Janeiro, Typographia H. J. Pinto, Tomo Primeiro, 1878, sessão de 06/maio, discurso de Luiz Cavalcanti, p. 14.

${ }^{48}$ Idem, sessão de 09/julho, discurso de Antonio Francisco de Paula e Hollanda Cavalcanti de Albuquerque, deputado por Pernambuco, p.222. 
Na mesma época em que o conceito de Constituição tomava a cena política no mundo ocidental, fundamentava-se uma distinção no campo do direito que regularia as ações do Estado em contraposição à dos indivíduos. De forma clara, e citando "todos os autores clássicos desta matéria”, o deputado Antonio Luis Pereira da Cunha a apresentava em 1823, quando na abertura dos trabalhos constituintes no Rio de Janeiro definia que o espaço privativo da "Política" teria por objeto:

“as Leis particulares de uma Nação, e que formam o seu Direito público interno, que é relativo aos deveres que ela tem para consigo mesma, ou seja para determinar a forma de seu Governo, e de que maneira a Soberania deve ser exercitada, ou seja, sobre as bases em que são firmadas suas Leis fundamentais, que formam sua Constituição, e Pacto Social em contraposição do Direito Civil que regula os pactos, e convenções, contraídas [os] entre os indivíduos da Sociedade" ${ }^{\natural 0}$.

O que aqui aparece claramente como contraposição entre Direito Público e Direito Civil não existia anteriormente ${ }^{51}$. Foi, na verdade, no bojo das chamadas monarquias absolutas que, na Europa, tomaram forma tanto uma "lei pública" (ligada à idéia de "razão do Estado") como sua primazia na ordem das questões do governo. Elas foram resultado do fortalecimento da imagem do monarca como legislador, e do nascimento da concepção de políticas "públicas" que criassem uma ingerência da Coroa na administração dos seus domínios por meio da ação de órgãos e funcionários régios. Sua definição como um Direito suscitou uma luta pela autonomia de uma "lei privada" como uma esfera que poderia ser imune à imagem da onipotência dos Estados ${ }^{52}$.

\footnotetext{
${ }^{49}$ Idem, sessão de 14/maio, p.38.

${ }^{50} D A G$, sessão de 16/julho, p. 416.

${ }^{51}$ Sobre o sentido de administração no mundo moderno ver António Manuel Hespanha, "Un autre paradigme d'administration: la Cour en Europe du Sud à l'époque moderne", Die Anfänge der Verwaltung der Europäischen Gemeinschaft (Les débuts de l'administration de la Communauté européene), Baden Baden, Nomos Verlagsgesellschaft, 1992, pp. 271-292.

52 R.C. Van Caenegem, op. cit., p. 2-4. O autor mostra como o caso da Inglaterra é distinto pelo funcionamento da "common law" (ou seja, da unidade da lei como "paladino da liberdade e igualdade") a qual suscitou tanto uma resistência ao absolutismo como à separação entre Direito público e privado, sendo o primeiro até hoje de pouca familiaridade com o pensamento jurídico inglês.
} 
Em Portugal, nos anos 70 dos setecentos, o jurista Pascoal José de Mello Freire dos Reis, lente da Universidade de Coimbra e divulgador oficial da doutrina jurídica do pombalismo, foi um dos responsáveis pela atribuição de importância ao Direito Público. Na feitura de um compêndio para a matéria, utilizado nas aulas da disciplina, escrevia que duas coisas tinham de ser observadas na sua estruturação interna à "nação": "1". em poder de quem está o Sumo Império, isto é, se ele foi cometido a uma só pessoa, se a um Senado, se ao Povo, ou se a sua forma é mista de alguma das fórmulas símplices; $2^{\mathrm{a}}$. de que modo exercita o Sumo Império aquele, em cuja mão ele se acha depositado, quero dizer, qual é a organização da República, e como põe o Soberano em exercício os direitos Majestáticos" ${ }^{\text {,53. }}$ Nas palavras do próprio autor, eram elas a "constituição do Império Português" e o "sistema da sua administração, estrutura interna, e organização deste corpo", o que afirma ser o cerne de funcionamento do Estado. Em 1786, o mesmo Mello Freire seria escolhido para elaboração de um Projeto de Novo Código de Direito para Portugal, o qual, sendo iniciativa surgida no afã reformista ilustrado, manteria os valores de "poder soberano" e "majestade" do monarca, mas não sairia do papel. Dois anos depois, publicaria uma história do Direito Civil Lusitano, atendendo à demanda de uma sistematização desse campo sob os auspícios do absolutismo ${ }^{54}$.

Conforme vimos, o processo revolucionário em curso em fins do século XVIII colocaria na agenda política ocidental a valorização dos direitos inalienáveis dos homens como garantia de controle dos governos, alterando a balança da separação entre os citados campos jurídicos. Na França, onde a pretensão de negação radical com o passado se faria por meio dos poderes instituídos em nome da "nação", seus desdobramentos seriam mais paradigmáticos. Daí o embate entre as jurisdições do Direito Público e do Direito Privado ter sido marcado entre os franceses por uma tensa equação, presente ao longo de toda primeira metade dos oitocentos quando de tentativas de construção de unidades constitucionais estáveis: a da necessidade da preservação de um regime de liberdades e direitos conquistados pela Revolução num sistema político-administrativo que, mesmo

\footnotetext{
${ }^{53}$ BN, Seção de Reservados, Pascoal José de Mello Freire dos Reis, Direito Público de Portugal, Códice 8527, Parte Primeira, p. 5, parágrafo 9.

${ }^{54}$ Historia Iuris Civilis Lusitani (1788), traduzida para o português no Boletim do Ministério da Justiça, Lisboa, 173, 1968.
} 
centralizado, os garantisse politicamente ${ }^{55}$. Em outras palavras, reconstruir um Estado em que se pudesse transferir o poder para o "povo soberano".

Disso resultou, na França, num primeiro momento, a institucionalização da soberania popular na Assembléia Legislativa, cujo espaço expressava um permanente problema a ser resolvido no plano do equilíbrio dos poderes, mesmo depois do fortalecimento do Executivo com a restauração em 1814. Um outro problema colocava-se em relação à administração que, como um dos braços centrais do Direito público já desde antes, passava a ser vista como um espaço "simples e transparente" de poder, meramente executivo das leis as quais, sendo feitas pela representação nacional, reduziriam imensamente as ocasiões de litígio com os particulares ${ }^{56}$. Essa crença garantiu uma certa autonomia no gerenciamento e julgamento de suas questões independentemente, em princípio, de qualquer ação judicial $^{57}$.

É importante notar que, com a experiência francesa, inaugurava-se uma nova concepção jurídica, caracterizada por um caráter legalista e que viria a ser consolidada a partir da experiência codificadora napoleônica ${ }^{58}$. Tal concepção seria responsável por uma identificação entre "Lei e direito", com a consumação de especial poder normativo para o espaço do Parlamento que, mesmo no caso de divisão de suas atribuições legislativas com outros poderes, seria a partir de então entendido como o locus central da representação política garantida pelas Constituições. Vale notar que isso rompia tanto com a centralidade do monarca na produção das leis, perseguida pelas reformas ilustradas do século XVIII, quanto com a tradição anglo-saxônica dos direitos concebidos como pré-existentes a

\footnotetext{
${ }^{55}$ Pierre Rosanvallon, L'État en France de 1789 à nous jours, Paris, Éditions du Seuil, 1992.

${ }^{56}$ Idem, capítulo V.

${ }^{57}$ Nos Estados Unidos, isso foi concebido de forma muito distinta desde a Constituição Federal de 1787, na qual o regime de "checks and balances" - que previa separação, mas também uma certa intersecção entre os poderes políticos, para que eles pudessem se controlar mutuamente - relegou ao Judiciário um papel privilegiado como "supremo intérprete da Constituição" e de árbitro nas querelas entre Legislativo e Executivo (Congresso e Presidente). Ver Os artigos federalistas (1787-1788), op. cit.; Pedro Carlos da Silva Vasconcellos, A separação de poderes na Constituição americana, Coimbra, Dissertação de Mestrado, 1989. Para uma avaliação crítica da ação judicial nos Estados Unidos, Robert Burt, Constitución y conflicto, Buenos Aires, Eudeba, 2000. Na França, ao contrário, desde a Revolução se olhou com desconfiança para a jurisprudência. Foi assim que o princípio democrático de 1789 a acusaria de tornar o Direito um saber hermético, legitimado pela competência técnica dos juízes, cujos resultados seriam imprevisíveis e incontroláveis por parte dos cidadãos. António Manuel Hespanha, Panorama histórico da cultura jurídica européia, Mem Martins, Publicações Europa-América, 1998.

${ }^{58}$ Bartolomé Clavero, Happy Constitution. Cultura y lengua constitucionales. Madri, Trotta, 1997, e Razon de Estado, Razon de individuo, Razon de História. Madri, Centro de Estudios Constitucionales, 199. Como
} 
qualquer ordem política instituída (o direito como anterior à lei, e não o contrário) ${ }^{59}$. Os novos Códigos, por sua vez, forneceriam materialidade para a aplicação cotidiana do direito por meio de uma lógica que mesclava sistematicidade e generalidade suficientes de forma a serem controladas pelas novas práticas e instituições políticas ${ }^{60}$.

Essa foi a base jurídica que subsidiou a formação dos novos Estados liberais que, por meio da concepção da "lei positiva", paulatinamente monopolizaram a tutela dos direitos garantidos pela Constituição, subvertendo alguns dos princípios democráticos franceses de 1789. Isso significou conceber a idéia de Código (sobretudo o civil) e de "administração pública" como partes constitutivas dos mesmos Estados, que apostaram na autonomia e fortalecimento das suas instituições políticas como baluartes da "nação" que começava a ganhar sentido como uma realidade histórico-natural, perdendo sua conformação pactuante revolucionária ${ }^{61}$. Era, mais do que tudo, a estabilidade interna dos regimes o ponto crucial dessa conformação constitucional conservadora que adentrava o século XIX, num processo longo e violento, permeado de conflitos e especificidades de parte a parte.

Assim também o foi na América de colonização ibérica. Nela, onde a desagregação dos Impérios iniciou tortuosos processos de Independências, dos quais resultariam novos Estados e novas nações, a construção de unidades políticas estáveis que amalgamassem interesses e territórios tão distintos, como eram tanto os hispânicos como os portugueses, valeu-se da "lei" como fonte de emanação dos direitos, e também como instrumento de controle da ordem pública. Nesse sentido, a emergência de alternativas antagônicas quanto aos limites e formas de organização que os novos Estados deveriam ter instituiu, desde seu início, um panorama de conflitos intestinos cuja resolução passaria invariavelmente pela construção de esferas de legalidade para funcionamento de governos e respeito a suas "soberanias" "62. Nesse sentido, e no contexto brasileiro, é paradigmática a afirmação de José Mariano de Albuquerque Cavalcante feita em outubro de 1831, quando pedia demissão do

um dos juristas contemporâneos mais críticos a essa tradição, Clavero analisa como ela está presente até hoje em grande parte do mundo ocidental.

59 Conforme discutimos acima, a referência para a questão é Maurizio Fioravanti, Los derechos fundamentales.

${ }^{60}$ António Manuel Hespanha, op.cit.

${ }^{61}$ Idem; Maurizio Fioravanti, op.cit.

${ }^{62} \mathrm{Um}$ ótimo panorama sobre esse processo nas suas diversas partes, pode ser visto em Antonio Anino (et. alli.), De los Imperios a las Naciones: Iberoamerica, Ibercaja/Obra Cultural, Zaragoza, 1994. 
cargo de Presidente da Província do Ceará em face do clima de guerra civil vivido na localidade:

"Para sufocar as revoluções, que formigam em diferentes partes do Império são precisas Leis fortes, que, impondo terror aos revolucionários, possam assegurar estabilidade ao Governo, e mais garantias à vida, e propriedade dos Cidadãos amigos da ordem [e] da legalidade" ${ }^{\text {, }}$.

A criação de uma nova ordem jurídica nacional e, consequentemente, a negação à herança normativa colonial, era, portanto, um dos desafios impostos aos americanos. No Brasil, essa ruptura iniciou-se logo no Primeiro Reinado. À outorga da Carta Constitucional, seguiu-se a instalação do Parlamento em $1826^{64}$ que, composto de Câmara dos Deputados e dos Senadores, colocou em prática uma série de reformas na ordenação jurídica que se pretendia para a nação independente. Isso fez parte de uma atitude consciente e bem dirigida da parte de nossos primeiro legisladores que usaram a "faculdade de legislar como primeira fonte de todo o direito"65 na consolidação de um ideário de Estado, ou seja, valendo-se da apropriação do sentido mais moderno então existente para a "lei". Esta fora adotada já desde a abertura dos trabalhos da Assembléia de 1823, quando sequer era possível prever quais seriam as Províncias que fariam parte da nova unidade. Nesse espaço, que além de Constituinte era Legislativo, o posicionamento do deputado Manuel José de Sousa França permite entrever a clareza com que se tratava a necessidade da confecção de "leis positivas":

“a Constituição nada mais é do que um sistema de princípios gerais de Direito convencional, que não podem ser observados senão mediante as Leis regulamentares que são a norma de se aplicarem aos casos práticos: e não

\footnotetext{
${ }^{63}$ Arquivo Nacional (ANRJ), Negócios de Províncias, IJJ ${ }^{9} 173$.

${ }^{64}$ Sanchez Agesta, La democracia en Hispanoamérica. Um balance histórico, Madri, Rialp, 1987, aponta que no Brasil o Parlamento funcionou sem nenhuma interrupção desde sua instalação até 1889, sendo uma exceção diante dos exemplos dos seus vizinhos americanos, salvo o Chile, onde a instituição teve funcionamento muito irregular ao longo de todo o século XIX.

${ }^{65}$ José Reinaldo de Lima Lopes, "Iluminismo e jusnaturalismo no ideário dos juristas da primeira metade do século XIX”, p.196. Em outro momento, O Direito na História. Lições introdutórias. São Paulo, Max
} 
poderíamos ser comissionados de fazer uma Constituição, sendo, aliás, inibidos de lhes fazer as leis, de que depende a sua conveniente prática"66.

Esse caráter legalista frutificaria nos trabalhos das primeiras legislaturas, numa clara ênfase na organização do Estado sob um perfil eminentemente liberal que, em ambiente de profunda luta política, colocava-se como primeira necessidade. Isso significaria a prioridade dada por esses legisladores, desde o início, ao Direito Público ${ }^{67}$ no que tocava aos seus dois principais ramos: o Constitucional, entendido como "direito fundamental" (ou "sistema de princípios gerais", conforme descrito acima pelo deputado França); e o Administrativo, considerado como um complexo de "leis positivas" que demarcariam o papel ativo do governo na vida política ${ }^{68}$.

No que cabe a este último, deve-se notar que, desde a Independência, ele foi o campo privilegiado de resolução de questões de "interesse geral", numa linha de continuidade com a tradição do reformismo ilustrado que o tomara como interesse superior. O fim da administração - definida pela relação do Estado com os cidadãos, e não desses com seus iguais - era, portanto, "prover as necessidades coletivas"69 . Era assim que Bernardo Pereira de Vasconcellos afirmava, no início da Regência, ser a "administração central $[. .$.$] a expressão mais pura, a mais completa da representação nacional" { }^{, 70}$. E, da mesma forma que na concepção francesa, que se pretendeu segregar a discussão das matérias públicas das decisões dos tribunais, no Brasil tais questões ficariam

Limonad, 2000, o mesmo autor fala em uma "concepção do papel do direito, como instrumento de poder e de reforma".

${ }^{66} D A G$, sessão de 29/julho, p. 477.

${ }^{67}$ Note-se que, durante o Império, seriam aprovados, primeiramente, o Código Criminal (1830), seguido do Código do Processo Penal (1832), e anos depois do Código do Comércio (1850). Não foi aprovado nenhum Código Civil, cujo primeiro só veio à luz em 1916, após a proclamação da República.

${ }^{68}$ Como prova disso, ver a análise que José Antônio Pimenta Bueno (Marquês de São Vicente), Direito público brasileiro e análise da Constituição do Império (1857), Brasília, Senado Federal, 1978, que mesmo posteriormente ao período aqui abordado, deixa entrever como o direito público era central na conformação jurídica que se desenhara para o Império do Brasil.

${ }^{69}$ José Reinaldo Lopes, As palavras e a lei, p. 230s. O autor utiliza a obra de Pimenta Bueno para demonstrar como no Brasil a concepção é que o "direito público" protegia o "interesse coletivo", ou seja, uma concepção "estatalista" de ação do governo constituído.

${ }^{70}$ Annaes do Parlamento Brasileiro. Câmara dos Deputados. Primeiro Ano da Terceira Legislatura. Sessão de 1834, Rio de Janeiro, Typographia de Hypollito José Pinto e \& Cia, 1879, tomo primeiro, sessão de 23/06, p.170. 
eminentemente relegadas a uma "jurisdição administrativa", o que significava dizer que seus conflitos tendiam a ser resolvidos sem a intervenção dos órgãos do Judiciário ${ }^{71}$.

A outra face dessa organização jurídica era o permanente uso da violência que, também em nome de "interesses coletivos", seria utilizada pelo governo como forma de controlar os focos de dissidência e garantir a estabilidade do Império. O fato é que, em meio ao conturbado ambiente que marcava as primeiras décadas do Brasil independente, o funcionamento das instituições políticas reforçaria a crença coeva de que o ordenamento geral da sociedade poderia, de fato, ser mediado pelo poder público. Os artífices legisladores foram responsáveis diretos por isso, ao sobrevalorizarem a via institucional como um dos caminhos que pudesse servir à transformação da ordem vigente, trabalhando na criação de medidas que colocassem em prática uma nova máquina administrativa.

A organização dos governos das Províncias seria uma das dimensões mais visíveis desse processo. Logo após a Independência, três projetos que propunham sua regulamentação foram apresentados na Assembléia Constituinte, onde ao menos uma lei sobre o assunto seria aprovada antes de seu fechamento em novembro de 1823. Em nome do "direito dos cidadãos de participarem dos negócios de sua província”, implementar-seiam os Conselhos, tanto do Presidente como Geral da Província, que junto com uma série de outras medidas, entre as quais se incluíam uma nova jurisdição das Câmaras Municipais de 1828, a reformulação da Justiça - desde a criação dos cargos de Juízes de Paz, como do Supremo Tribunal no mesmo ano -, do Tesouro Público e das forças militares tocariam fundo nas bases jurídicas do novo Estado independente. No seu conjunto, eram inspiradas por uma diretriz liberal e, em meio a esse espírito, sua administração competia à alçada do próprio governo auxiliado pelo Legislativo no tocante à feitura das leis.

Tratava-se, portanto, dos primórdios da construção do espaço provincial como uma esfera efetiva de poder político, num movimento que incluiria a submissão das Câmaras à sua autoridade. Foi assim que as reivindicações por autonomia local e por uma organização institucional que fornecesse à Corte do Rio de Janeiro um verdadeiro papel de centro configuraram lutas cotidianamente travadas não apenas no Parlamento, mas nos mais variados círculos da vida pública brasileira. É notável como os clamores pela Reforma,

\footnotetext{
${ }^{71}$ Em última instância, de acordo com o esquema normativo estabelecido no Império do Brasil, quem decidia as questões ligadas ao "contencioso administrativo" era o Conselho de Estado como auxiliar institucional do Poder Moderador. José Reinaldo Lopes, As palavras e a lei.
} 
surgidos desde 1831, a partir de um projeto inicialmente radical quanto aos poderes do Estado e à federalização da monarquia, e que encontraria amplo respaldo na imprensa exaltada da época, acabariam por se concentrar em soluções efetivas para a administração do Império: a definição dos poderes das Províncias e a extinção do Conselho de Estado (órgão fundamental no trato de questões da jurisdição administrativa).

Desse modo, sustenta-se, neste trabalho, que quando da criação dos alicerces jurídicos para o novo Estado independente no Brasil, antes mesmo da sua existência efetiva como unidade estável, a apropriação da lei como fonte primeira do direito desdobrou-se na valorização do Direito Público (na sua expressão constitucional e administrativa) por meio do fortalecimento das instituições políticas como "pedra de toque" da sua ordem interna. Como uma delas, a Carta Constitucional de 1824 desempenharia um papel, simbólico e real, no forjar das alternativas que se constituiriam no tocante ao arranjo políticoinstitucional pelo Império adentro. No mesmo sentido, o Ato Adicional de 1834 tanto confirmaria sua importância como introduziria soluções na sua estrutura que, mesmo marcadas pela moderação em meio a um ambiente político que desde 1831 se mostrava aberto a radicalismos ${ }^{72}$, seriam herdadas como base de sustentação de um regime que vinha sendo posto em funcionamento desde o Primeiro Reinado.

Sendo essa tese factível, estamos diante de uma das explicações do porquê de, mesmo após a Abdicação de D. Pedro I e a instauração da Regência, ter sido possível a manutenção das bases de um Império monárquico que não tinha nada de menos liberal do que muitas das Repúblicas suas vizinhas. Ao contrário, sob a égide dos novos tempos, seus primeiros legisladores permitiriam que reformas fossem aprovadas e colocadas em prática, fundamentando a possibilidade de sua estabilidade, por mais tênue que ela se apresentasse, e concentrando nas instituições políticas as formas de representação dos cidadãos em nome dos "interesses coletivos".

No entanto, se isso foi uma solução encontrada do ponto de vista do ordenamento estatal, foi também um problema, num momento em que ainda se vivia a profunda transformação nas formas de se fazer política, sentidas no Brasil e no mundo desde finais

\footnotetext{
${ }^{72}$ Marco Morel, La monarchie de Juillet et la fin du Premier Regne bresilien: metamorphoses du liberalisme, Paris, Université de Paris I, 1992 (D.E.A.), analisou como a queda do monarca francês Carlos X teve implicações diretas no Brasil como reforço aos que defendiam a transformação do regime após a Abdicação.
} 
do século $\mathrm{XVIII}^{73}$. Isso porque a implosão do ideal de sociedade corporativa trazia na sua rasteira a noção de indivíduo, que tinha por direito primordial conhecer e interceder no governo de acordo com seus interesses, e derrubar, se preciso fosse, aqueles que os oprimissem. Mesmo nas regiões aonde não se chegou ao grau de radicalismo contido nesta última alternativa, as condições de sua possibilidade alimentariam sociabilidades e práticas objetivas de luta política, as quais fariam que a construção dos novos Estados liberais ocidentais fosse parte de um longo e conflituoso processo ainda em curso por boa parte do século XIX. No caso do Brasil, a profunda desigualdade que permeava as relações sociais, endógenas à sua reprodução escravista, reforçaria sua inerente violência e criaria tensões específicas no que dizia respeito à participação da população na vida política e no controle de suas instituições formais.

Com isso, e retomando as palavras das epígrafes deste trabalho, o sentido de lei como uma encarnação da "justiça natural", expresso por Cipriano Barata, e que dava margem à idéia de que "não se lhe deve obedecer cegamente" caso não se cumprissem seus fins, estaria permanentemente em choque com um outro, afirmado posteriormente pelo Marquês de São Vicente, segundo o qual "amar as leis" deveria ser uma verdadeira "veneração religiosa". A valorização de um ou de outro sentido dependeria da ordem dos conflitos que, no plano político, envolveriam a ação dos mais variados agentes.

Ainda que para a consecução do presente trabalho tenha sido necessário inseri-lo numa perspectiva cronológica mais ampla, a pesquisa concentrou-se num período de tempo limitado. Seu início, em 1822, justifica-se pela Independência e abertura dos trabalhos legislativos da Assembléia Constituinte instalada no ano seguinte, a qual tinha por função primordial a criação de um "novo pacto" para o nascente Império; seu término em 1834

\footnotetext{
${ }^{73}$ Sobre as transformações que estavam em curso no plano político é fundamental a leitura de István Jancsó, "A sedução da liberdade: cotidiano e contestação política no final do século XVIII", Fernando A. Novais (dir.). História da vida privada no Brasil, São Paulo, Cia. das Letras, 1997. Denis Antônio de M. Bernardes, O patriotismo constitucional: Pernambuco, 1820-1822, São Paulo, Universidade de São Paulo/ FFLCH, Tese de Doutoramento, 2002; Andréa Slemian, Vida política em tempo de crise: Rio de Janeiro (1808-1824), São Paulo, Hucitec, 2006; e André Roberto de A. Machado, A quebra da mola real das sociedades. A crise política do Antigo Regime português na Província do Grão-Pará (1821-25), São Paulo, Tese de Doutorado,
} 
corresponde ao momento de aprovação da Reforma Constitucional, e encerra pouco mais de uma década em que é perceptível a criação de uma estrutura normativa e institucional moderna cujas bases mostrariam, no decorrer do século, vida longa.

A análise dos trabalhos e discursos da Câmara dos Deputados norteou toda a argumentação e demonstração da tese, na condição de ponto privilegiado para observação da relação entre a produção da norma constitucional e a criação do direito positivo efetivo, num ambiente marcado por disputas políticas que contaminavam o espaço parlamentar. Tal ênfase também se justifica pela importância que a Assembléia adquiriu no cenário político brasileiro pós-Independência, aumentada sobremaneira a partir da Abdicação e início da Regência quando, da forma como estava prescrita na Constituição, ela procuraria "tomar as rédeas da nação". Mais especificamente, procurou-se apreender a concepção dos governos das Províncias, sobretudo as suas relações político-institucionais com a capital do Império; em outras palavras, o papel das partes com o todo na conformação de uma nova unidade.

A despeito do destaque aqui conferido à construção da norma jurídica e de sua prática administrativa na esfera provincial, vale dizer que se refutou tanto uma postura que a identificasse apenas e estritamente com o texto da lei, quanto uma outra mecânica que a considerasse como simples e imediata reprodução dos interesses na ordem da "luta de classes". Procurou-se ampliar seu significado, analisando-as como ação, inclusive discursiva, para o estabelecimento de um ordenamento material da realidade, que é de onde provém toda a especificidade da criação normativa ${ }^{74}$. Do ponto de vista da História, isso significa uma atenção para a permanente, mas não mecânica, intersecção entre uma lógica intrínseca de construção dos discursos e as disputas e transformações no plano político.

As fontes documentais aqui utilizadas foram: os Diários e Anais da Câmara dos Deputados para os anos aqui delimitados, incluindo aqueles produzidos pela Assembléia Constituinte e Legislativa de 1823; a Coleção de Leis do Império do Brasil; a Carta Constitucional de 1824 e o Ato Adicional - bem como seus Projetos - além de outras Constituições que ganharam forma e relevância no mundo atlântico após as revoluções liberais; textos político-constitucionais que, desde fins do século XVIII, foram

FFLCH-USP, 2006, tratam das novas condições políticas que forneceram possibilidade de radicalização da ordem vigente a partir da aceitação de um novo paradigma constitucional no Império português.

${ }^{74}$ Toma-se aqui as premissas enunciadas por José Joaquim Gomes Canotilho, Direito Constitucional, $4{ }^{\mathrm{a}}$ ed., Coimbra, Almedina, 1986, pp.31-34, como base para a análise da produção constitucional. 
fundamentais na conformação do ideário da época, com ênfase para os manuais portugueses de Direito; as Atas dos Conselhos Gerais das Províncias (de 1829-1834) e dos Conselhos da Presidência (1824-1834); a correspondência das Províncias com o governo, algumas encaminhadas pelo Executivo para a Câmara dos Deputados; e, ainda que em menor medida, alguns periódicos representativos para a época.

Optou-se por uma divisão do trabalho em três grandes capítulos que também expressam três momentos distintos do ponto de vista da criação das bases do ordenamento jurídico no Brasil. No primeiro, o objeto central é a experiência da Assembléia Constituinte de 1823 e seus desdobramentos legislativos, incluindo a Carta de 1824. Para tanto, analisase o ideário constitucional português desde fins do século XVIII, bem como o funcionamento geral dos poderes políticos na América portuguesa. A Revolução do Porto e seu impacto no Brasil também mereceu atenção por conta da inédita instalação de uma Assembléia Constituinte no então Reino Unido português, e que definiu as condições de sua implosão como unidade política da qual resultou a Independência do Brasil e a instalação, neste, de um Parlamento próprio.

O segundo capítulo é dedicado aos trabalhos legislativos da Câmara dos Deputados do Império do Brasil, com ênfase nas discussões e nas medidas relativas à implantação e funcionamento dos governos das Províncias. São analisadas as várias ordens de conflitos decorrentes da instalação dos Conselhos Gerais e da ação dos seus Presidentes, em meio à paulatina construção de um arranjo institucional que se fazia numa conjuntura nacional de profunda instabilidade política. Também é feita uma retomada das chamadas "reformas liberais", basicamente naquilo que elas diretamente interferiram no ordenamento institucional da unidade.

O terceiro e último capítulo centra-se na discussão da reforma da "Lei Fundamental", após a Abdicação de D. Pedro I e a instalação da Regência. Concebida num primeiro momento como possibilidade de uma mudança mais radical, ao longo de seu debate (1831-1834) e em meio a conflitos, deputados e senadores construíram um consenso para torná-la mais moderada. Um dos pontos privilegiados da análise está na regulamentação do governo das Províncias perante a Corte que desembocou na conformação das Assembléias Legislativas pari passu à consolidação dos seus Presidentes 
- regulado por um Regimento em 1834 - como duas autoridades centrais no funcionamento institucional do que daria forma à unidade nacional. 


\section{Capítulo 1}

\section{Do Império português ao Império do Brasil}

Em ofício de 07 de agosto de 1822, o Senado do Rio de Janeiro solicitou às Câmaras da Província que enviassem, de acordo com instruções aprovadas anteriormente, "informação individual, circunstanciada e clara, das necessidades e melhoramentos do distrito de sua jurisdição"1 a serem remetidas aos deputados que deveriam compor a Assembléia Constituinte aprovada pelo Príncipe Regente D. Pedro dois meses antes, em 03 de junho. A medida, ainda pensada no contexto da unidade portuguesa como resposta às ações das Cortes lisboetas, contribuiu decisivamente para a adesão que Províncias e Câmaras então fizeram à política do herdeiro legítimo do trono, animadas com a perspectiva de garantia de representação de seus interesses numa nova ordem constitucional $^{2}$. A Independência já aparecia, portanto, como uma alternativa viável.

Ao ofício supracitado, algumas Câmaras encaminharam respostas que no ano seguinte seriam endereçadas à Assembléia, efetivamente instalada. No geral, as necessidades elencadas, sempre a partir da "convocação" ou "aprovação" do "povo" da localidade, versavam sobre a urgente construção de estradas e o melhoramento da instrução pública, sobre problemas de escassez de rendimentos e da extrema penúria de que padeciam, da falta de medidas que regularizassem os limites das terras e doação de sesmarias, da deficiência nos impostos com críticas aos contratadores, e também das várias formas de incentivo aos lavradores e à sua produção.

Entre essas respostas, a da Vila de São Pedro de Cantagalo merece destaque ${ }^{3}$. Antes de esmiuçar quais seriam os principais pontos para melhoramento público, presidente e vereadores, dizendo-se "lisonjeados" com o pedido, criticavam a possibilidade aberta pelas Instruções de que os deputados eleitos tivessem "faculdades ilimitadas", mesmo sem o tema estar em questão. Sob o argumento de que consideravam ser "seus essenciais e

\footnotetext{
${ }^{1}$ Centro de Documentação e Informação, Arquivo da Assembléia Constituinte de 1823, Câmara dos Deputados/Seção de Documentos Históricos, (CEDI - AC 1823), localização: 27, 2.8.

${ }^{2}$ Roderick Barman, Brazil. The forging of a nation 1798-1852. Stanford, Stanford University Press, 1988.

${ }^{3}$ CEDI - AC 1823, 27, 2.8, documento 02.
} 
inamovíveis direitos" os de "instruir, advertir, e reclamar" seus representantes para que estes não "transcend[esse]m" a "linha de marcação, aquém da qual a natureza nós lhes prescrevemos que marchem", deixavam explícita a importância que a matéria possuía. Reforçavam que a Casa legislativa que se iria instalar não poderia propor uma Constituição sem que "vulgarizado e bem discutido" seu projeto pelo envio de "Atas às Províncias do Brasil, e a todas as Câmaras, cuja pluralidade absoluta balanceará a final decisão da Assembléia pela decidida manifestação da vontade e comprazimento dos povos"4. A idéia era, portanto, que a representação funcionasse sob a guarda dos mandatos imperativos das localidades ${ }^{5}$.

Os vereadores de Cantagalo marcavam também uma posição explícita no tocante à monarquia. Defendiam as "Bases da Constituição Lisboense" elaboradas pelas Cortes em Portugal $^{6}$ que, como "obra-prima, resultado do mais acrisolado liberalismo [...] consolida[va]m no povo a soberania", deveriam ser seguidas no Brasil como forma de "estreitar os vínculos e indissolúveis laços entre todas e cada uma das partes da Monarquia Portuguesa". Aceitando ter sido "a nossa vontade universal uníssona" a responsável pela escolha do Príncipe para manejar o Executivo, a Câmara afirmava ser "do dever da Assembléia Constituinte marcar a proporção que deve[ria] haver entre as bases já firmadas no Ápice da nossa Coluna social; isto é, delinear com sabedoria o como S.A.R. deve[ria] governar o Brasil, sem deslizar dos deveres de filho e súdito do Senhor D. João VI" 7 . Ao mesmo tempo, juravam fidelidade aos monarcas e reconheciam que também era preciso cercear "os direitos dos povos" como condição "indispensável para a boa harmonia administrativa", evitando-se os paroxismos vividos pela França, por um lado, e as "tramas" da Santa Aliança, por outro.

\footnotetext{
${ }^{4}$ Idem, fl. 2.

${ }^{5}$ Os chamados mandatos "imperativos" estavam ligados às formas de representação de tipo Antigo Regime em que se concebia o indivíduo como defensor dos interesses de cada "estado" ou corporação. Nesse caso, como as Câmaras ainda funcionavam, do ponto de vista institucional, como "corpos", é próprio de sua lógica que tal reivindicação assim apareça no discurso dos vereadores. No entanto, por se tratar de um momento de profunda ruptura nas formas de representação até então predominantes, seu conteúdo aponta na direção de uma mudança e não na reiteração de valores antigos.

${ }^{6}$ Aprovadas em 10 de março de 1821, tinham como objetivo balizar os trabalhos constituintes das Cortes de Lisboa e substituir a Constituição Espanhola de 1812 que, quando da eclosão do movimento constitucional português, havia sido jurada provisoriamente. Como documento que lançava as premissas do novo regime, as Bases encampavam os preceitos revolucionários da soberania como residente "essencialmente na nação", separação de poderes com fortalecimento do Legislativo por meio de seus representantes, e garantia de direitos invioláveis. (Disponíveis na Internet: www.arqnet.pt/portal/portugal/liberalismo/bases821.html )

${ }^{7}$ CEDI - AC 1823, 27, 2.8, documento 02, f1.4.
} 
Nestes termos, o que aparece de forma lapidar no ofício de Cantagalo é o anseio pela adequação dos canais de representação política para atendimento das necessidades locais num regime que equilibrasse, com moderação, monarquia e participação do "povo" (por eles citado sempre em maiúscula) nas decisões políticas. Para qual dos lados a balança deveria pender era um dos maiores dilemas vividos na época por aqueles que tinham diante de si a tarefa de construção de um sistema de monarquia constitucional, haja vista as experiências dos franceses nos primeiros anos da Revolução e depois de 1814-5, da Espanha a partir dos movimentos de Cádiz de 1810 e 1820, e mesmo das Cortes de Lisboa desde 1821. A autoridade do monarca estava impossibilitada de alcançar legitimidade pela simples reprodução de suas formas tradicionais, a partir de então amplamente combatidas como "absolutistas". A resolução da questão para o Brasil, quando de sua transformação em Império independente, revelavar-se-ia um dos pontos nevrálgicos para a nascente nação.

O problema da representação política explicitado pela Câmara da Vila de Cantagalo fazia parte, na época, daquilo que Pierre Rosanvallon chamou de construção dos "mecanismos da formação política da vontade geral” após o advento revolucionário 8 . Tratava-se da urgência em se criar um sistema constitucional que permitisse fundar um modo de governo dos homens e de administração das coisas em meio a um contexto de transformação das relações entre a sociedade e o Estado, em que se concebia cada vez mais o indivíduo com capacidade de intervir nos destinos da política. Cara ao liberalismo, essa premissa tinha um de seus desdobramentos na possibilidade de controle pelo "povo" dos cargos e órgãos que deveriam primar pela transparência no seu funcionamento e ação, que se desenvolvia pari passu à crescente racionalização das formas de governo. Mais do que nunca, a administração do "bem público" era vista como passível de ser, se não monitorada, ao menos concebida pelas esferas da política em comunhão com a sociedade 9 .

Mas o dilema dos citados vereadores não parava por aqui. Afinal, como controlar os poderes do monarca no equilíbrio dos pratos da citada balança? A matéria teve respostas diversas. A complexa equação política constitucional aqui esboçada, e que o nascente Império teria que resolver, ou seja, a da criação de um arranjo institucional que fornecesse

\footnotetext{
${ }^{8}$ Pierre Rosanvallon, L'Etat en France de 1789 à nous jours, Paris, Éditions du Seuil, 1992, 2ªrte, cap.III.

9 Annick Lemperière, "República y publicidad a finales del Antiguo Régimen (Nueva España)", FrançoisXaveir Guerra e Annick Lemperière (org.), Los espacios públicos en Iberoamérica, México, FCE/CEMCA, 1998, pp. 54-79.
} 
canais adequados de ligação do todo com as partes num regime monárquico, exigia soluções que contemplassem não apenas a concepção de uma autoridade Executiva em moldes modernos, mas também do papel que caberia à Corte do Rio de Janeiro nesse contexto. Se o Príncipe pôde aglutinar, pelas mais diversas razões, um arcabouço de expectativas que fizeram que a alternativa da Independência fosse factível - para o que vale a expressão "Imperador-contrato", cunhada por Iara Lis Souza ${ }^{10}-$, isso não foi sinônimo de consenso em ser a urbe carioca um centro efetivo para administração do novo Império.

Dessa forma, a busca de soluções por uma unidade estável foi marcada por tensões e conflitos de várias ordens, como se vê desde a instalação da Assembléia Constituinte de 1823, e nos episódios que deram forma à Carta Constitucional de 1824. Ambas experiências de ordenamento normativo estavam inseridas no processo de desagregação de um universo político mental, cuja diversidade de posições era refluxo de uma crise fecunda, em que o mundo português já revelava seus sinais de especificidade desde finais do século anterior.

\subsection{Do Reformismo à Revolução: poderes políticos na América portuguesa e ideário constitucional}

Nos setecentos, os sinais de desagregação dos padrões predominantes do Antigo Regime já podiam ser vistos em duas dimensões especialmente caras a este trabalho: na alteração do paradigma de organização da administração do Império e na construção discursiva de um ideário jusnaturalista de fundamentação da monarquia portuguesa. Quanto ao primeiro, há um certo consenso na historiografia de que o século XVIII, sobretudo a sua segunda metade, constitui um marco na concepção e funcionamento dos poderes políticos em Portugal e seus domínios, materializados por aquelas que ficaram conhecidas como "reformas ilustradas". Por mais controversa que seja a discussão acerca do nível e da eficácia das transformações operadas, as ações dos regimes josefino e mariano foram expressão de mudanças nas bases políticas de sustentação do regime. Nessas décadas, o poder do soberano foi reforçado dentro de uma lógica em que o governo assumia, cada vez

\footnotetext{
${ }^{10}$ Iara Lis Carvalho Souza, Pátria Coroada. O Brasil como corpo político autônomo 1780-1831. São Paulo, Unesp, 1999.
} 
mais, características de uma atividade regida por razões específicas (as "razões de Estado”) com o objetivo de organizar a sociedade e dotá-la de uma ordem ${ }^{11}$.

A concepção de que a administração deveria ser transformada num instrumento ativo, "racional e adequado", construiu-se por oposição ao ideal de sociedade corporativa vigente durante a Idade Moderna. Este era marcado pela imagem do rei como responsável por "fazer justiça", garantidor do equilíbrio social sem intervenção direta nas instituições que, com alguma imprecisão, poderiam ser chamadas de "estatais"12. O quadro de interpenetração das funções e a falta de homogeneidade com que essas instituições então operavam exigiu um grande esforço por parte da Coroa, responsável pela criação de novos instrumentos de mudança e pela elaboração de programas que pudessem racionalizar o funcionamento do governo.

Nestes termos, percebe-se uma ação política uniformizadora, em especial no período pombalino, que a seu modo também contribuiu para acirrar tensões sociais já existentes em cada recôndito do mundo português, em face da opção pela reformulação de práticas existentes sem alteração substantiva da estabilidade social e do status quo ${ }^{13}$. No que toca à América, é visível a tentativa metropolitana de aumentar os mecanismos de controle institucional, o que gerou respostas contundentes e violentas por parte dos colonos americanos $^{14}$. A própria condição de domínio do território fez que esse esforço empreendido pela coroa se desdobrasse, em parte, na criação de órgãos e cargos que passaram a manter ligação direta com seus congêneres europeus, o que acabou por acentuar a sobreposição de funções e jurisdições em relação ao que já existia ${ }^{15}$. Era a crítica feita

\footnotetext{
${ }^{11}$ José Subtil, "Os poderes do centro". In: José Mattoso (dir.). História de Portugal. O Antigo Regime. Rio de Mouro, Lexi Cultural, 2002, pp. 199-306.

${ }^{12}$ António Manuel Hespanha, "Para uma teoria da história institucional do Antigo Regime", António Manuel Hespanha, Poder e instituições na Europa do Antigo Regime, Lisboa, Fundação Calouste Gulbenkian, 1984, pp. 7-89.

${ }^{13}$ A bibliografia que discute a questão é muito ampla. Cabe citar o trabalho de Fernando A. Novais, Portugal e Brasil na crise do Antigo Sistema Colonial (1777-1808), $4^{\text {a }}$ ed., São Paulo, Hucitec, 1986, por ter sido um dos pioneiros a apontar a relação entre as "reformas" e o acirramento de tensões endógenas à América portuguesa, seara que vem sendo explorada até hoje pela historiografia. De como se deu um processo igualmente conflitivo em Angola, quando se tratou de reformular os dispositivos de justiça então existentes, ver Catarina Madeira dos Santos, Um governo 'polido' para Angola. Reconfigurar dispositivos de domínio (175 - c.1800), Lisboa/Paris, Tese de Doutorado, 2005.

${ }^{14}$ Kenneth Maxwell, A devassa da devassa. A Inconfidência Mineira: Brasil-Portugal 1750-1808, $2^{\mathrm{a}}$ ed., Rio de Janeiro, Paz e Terra, 1978; István Jancsó, Na Bahia contra o Império: história do ensaio de sedição de 1789. São Paulo, Hucitec/EdUFBA, 1996.

${ }^{15}$ Graça Salgado (coord.), Fiscais e meirinhos. A administração no Brasil colonial, $2^{a}$ ed., Rio de Janeiro, Nova Fronteira, 1985; ver também uma descrição do funcionamento da administração no período pombalino
} 
pelo vice-rei D. Fernando José de Portugal (nomeado para o cargo em 1801), ao comentar, anos depois, as atribuições que lhe cabiam no cargo, atestando a delegação da administração, em grande parte, aos funcionários régios ${ }^{16}$.

Como se sabe, o governo do Brasil em finais do século XVIII dividia-se em três principais níveis político-administrativos distintos: o do Vice-Reino, o das capitanias e o das vilas. Embora a princípio houvesse uma relação de hierarquia entre eles, ela não formava propriamente degraus inferiores e superiores na ação administrativa. Nestes termos, mesmo tendo os vice-reis ou governadores gerais um poder extraordinário no que se referia ao desenvolvimento de suas atribuições ${ }^{17}$, os donatários (extintos paulatinamente ao longo dos oitocentos) ou governadores locais também dispunham de grande autonomia de decisão em relação a eles ${ }^{18}$. Isso porque prestavam simultaneamente obediência direta aos secretários de Estado em Lisboa, o que lhes permitia consolidar espaços efetivos de atuação no que dizia respeito ao governo local (“econômico”), estando sujeitos ao vice-rei apenas no tocante à política geral e de defesa do Estado do Brasil ${ }^{19}$. Vale notar que ao longo do século XVIII se observa uma evidente tendência de exclusão dos "naturais da terra" dos principais cargos, a partir de então majoritariamente ocupados pelos egressos das

em Hélio de Alcântara Avellar, Administração pombalina, Brasília, UnB/Funcep, 1983 (Col. Hist. Administrativa do Brasil, v. 5), pp.51-81. Numa análise sobre a administração colonial, Maria de Fátima Gouvêa, "Poder político e administração na formação do complexo atlântico português (1645-1808)", João Fragoso, Maria Fernanda Bicalho e Maria de Fátima Gouvêa (org.), O Antigo Regime nos trópicos: a dinâmica imperial portuguesa (séculos XVI-XVIII), Rio de Janeiro, Civilização Brasileira, 2001, pp. 287-315, mostra como se assistiu à introdução de mudanças significativas nesse campo na América a partir de meados do século XVIII.

16 “Observações do Vice-Rei D. Fernando José de Portugal ao Regimento de Roque da Costa Barreto, de 23 de janeiro de 1677", publicado por Hélio de Alcântara Avellar, op.cit., pp. 287-336.

17 António Manuel Hespanha, "A constituição do Império português. Revisão de alguns enviesamentos correntes", João Fragoso, Maria Fernanda Bicalho e Maria de Fátima Gouvêa (org.), op.cit., pp. 163-189, ao tratar da questão afirma que nos vários regimentos que lhe foram outorgados "estava sempre inserida a cláusula de que poderiam desobedecer às instruções régias aí dadas sempre que uma avaliação pontual do serviço real o justificasse" (p.174-5). Essa autorização para criar, e mesmo dispensar "direito", desdobrava-se nas suas amplíssimas atribuições ligadas à religião, justiça e fazenda, somadas a permissão que tinha de "concessão da graça", o que lhes fornecia uma "dignidade quase real". Os regimentos de suas funções estão publicados por Graça Salgado, op.cit.

${ }^{18}$ Nesse sentido, a pressão dos donatários de Pernambuco fez que, em 1670, fosse criado um regimento especial que fornecia à Capitania autonomia em relação ao governo-geral, ficando devedora de ordens diretas do Conselho Ultramarino. Ver Graça Salgado, op.cit. .

${ }^{19}$ António Manuel Hespanha, “A constituição do Império português...”, pp. 177-9. 
linhagens de nobreza reinol ${ }^{20}$. Com isso a coroa fazia que as elites locais fossem, muitas vezes, preteridas nesses governos.

Situação semelhante à justaposição de funções experimentada entre os governos gerais e o das capitanias se passava, durante todo o período colonial, em relação às Câmaras. Por causa de sua função vital de base política para o desenvolvimento da ocupação portuguesa do vasto território da América, as municipalidades constituíam-se no principal espaço de "representação dos povos" e expressão de poder dos grupos abastados locais que, por meio delas, almejavam privilégios e mercês junto à $\operatorname{coroa}^{21}$. Como corporações, nos termos do Antigo Regime, elas também dispunham do privilégio de terem seus próprios estatutos legais. Desta forma, tradicionalmente possuíam amplo espectro de jurisdição nas suas regiões - expedição de posturas, julgamento de injúrias verbais, pequenos furtos e infrações (caso da Almotaceria), resolução de questões de terra, arrematação de seus réditos, nomeação de servidores, autorização de despesas, fiscalização do comércio, cuidados com a higiene pública, etc. - muitas vezes passando ao largo da aprovação do governo-geral e das capitanias; além disso, podiam acumular finanças e patrimônios que lhes permitiam desfrutar de condições para sua sobrevivência e manutenção ${ }^{22}$.

Na área da Fazenda e da Justiça, dois braços fundamentais da normalização de funções colocadas em prática pela Coroa desde a implantação do Governo Geral no Brasil em 1549, medidas de grande monta foram tomadas nos setecentos. Quanto ao primeiro, após a instalação do Erário Régio em Portugal (1761), criaram-se nas capitanias as Juntas de Fazenda que, ao longo da mesma década, substituiriam e aprimorariam a atuação das antigas provedorias, vigorando até depois da Independência. As Juntas foram encarregadas de administrar e arrecadar todas as rendas régias auferidas, além de formalizar as folhas de pagamento dos funcionários civis, eclesiásticos e militares, sob ordens diretas do Erário.

\footnotetext{
${ }^{20}$ Nuno Gonçalo Monteiro, "Governadores e capitães-mores do Império Atlântico português no século XVIII”, em Maria Fernanda Bicalho e Vera Ferlini (orgs.), Modos de governar: idéias e práticas políticas no Império português. Séculos XVI-XIX, São Paulo, Alameda, 2005, pp. 93-115.

21 A importância do município como espaço de poder político durante o período colonial é amplamente destacada na historiografia. Um dos primeiros a analisá-la foi Caio Prado Jr., Formação do Brasil contemporâneo, $21^{\mathrm{a}}$ ed., São Paulo, Brasiliense, 1989. Depois, dentre outros, Nestor Goulart Reis Filho, Contribuição ao estudo da evolução urbana do Brasil (1500-1720), São Paulo, Pioneira/EDUSP, 1968; C.R. Boxer, O Império marítimo português 1415-1825, Lisboa, Edições 70, 1969; e Maria Fernanda Bicalho, “As câmaras ultramarinas e o governo do Império”, em João Fragoso, Maria Fernanda Bicalho e Maria de Fátima Gouvêa (org.), op.cit., pp. 189-221.
} 
Eram presididas, nas capitanias, pelos governadores, e na capital pelo vice-rei ${ }^{23}$, sem interferirem diretamente nas municipalidades. No tocante às funções de Justiça, predominavam os muitos cargos a que o rei concedia a graça de exercer parte de sua jurisdição ${ }^{24}$. O estabelecimento do Tribunal da Relação no Rio de Janeiro (sob os moldes do existente na Bahia desde 1652) em $1751^{25}$, com um numeroso pessoal subalterno ao seu serviço, foi uma tentativa de solucionar as demandas crescentes da região, mesmo sem pôr fim à variedade de agentes existentes. Nessa seara do direito, foi, sobretudo, a reforma da prática jurídica e da formação de quadros habilitados para seu serviço, ocorridas no âmbito do ensino jurídico na Universidade de Coimbra, que tiveram papel fundamental no afã transformador do período.

No entanto, a proliferação das medidas reformistas esteve longe de criar uma estrutura homogênea de integração entre os níveis político-administrativos existentes, o que tampouco fora seu leitmotiv. Daí o problema do estabelecimento de uma sinonímia entre a proposta de racionalização setecentista e uma suposta centralização baseada na divisão das atribuições e poderes como a dos Estados liberais surgidos posteriormente. No entanto, o esforço pela difusão de um novo ideal de ação do governo, com o estabelecimento de laços de hierarquia funcional entre os vários níveis do aparelho administrativo, ao mesmo tempo em que colocou em voga um paradigma distinto ao dos poderes periféricos predominante no Antigo Regime, funcionou sobremaneira como reprodutor de uma lógica que tinha como centro o monarca. Nestes termos, e apenas neles, a ação unificadora promovida no século XVIII pela Coroa portuguesa possuiu aspectos centralizadores, ou seja, à medida que ela passou a interferir ativamente em vários setores da administração, sobrevalorizando o papel do soberano e dando forma àquilo que posteriormente seria criticado como "absolutista".

\footnotetext{
${ }^{22}$ Hélio de Alcântara Avellar, op. cit. .

${ }^{23}$ Graça Salgado, Op. cit. No que toca também às finanças, olhar especial delegou à coroa à implantação de uma reforma na política fiscal (sobretudo nas Minas) e também na criação de companhias monopolísticas régias; ver Kenneth Maxwell, op.cit:; Eulália Maria Lahmeyer Lobo, Processo administrativo IberoAmericano (aspectos sócio-econômicos), Rio de Janeiro, Biblioteca do Exército, 1962.

24 Além dos vice-reis e governadores gerais, que tinham permissão para agir nesse âmbito, havia nas Comarcas os corregedores, chanceleres, ouvidores e contadores, e nas municipalidades os juízes ordinários (eleitos com os vereadores), juízes de fora (nomeados pelo rei), almotáces e juízes de vintena. Ver Hélio Avellar, op.cit.

${ }^{25}$ Arno Wehling e Maria José Wehling, Direito e justiça no Brasil colonial. O Tribunal da Relação do Rio de Janeiro (1751-1808), Rio de Janeiro/São Paulo/Recife, Renovar, 2004.
} 
Soberano este, não se pode esquecer, que operava numa lógica política de doação de privilégios em função dos serviços prestados pelos seus súditos ${ }^{26}$.

A instalação da Corte de D. João no Rio de Janeiro em 1808, apesar de iniciar uma fase intensa do ponto de vista da ação legislativa e institucional da Coroa portuguesa no Novo Mundo ${ }^{27}$, não alterou a concepção dos poderes no âmbito da monarquia portuguesa reformulada nos setecentos. A novidade esteve, sobretudo, nos desdobramentos que couberam à cidade carioca que, já desempenhando um papel importante como "cabeça" da região Centro-Sul, transformou-se rapidamente no locus do poder real português ${ }^{28}$. Isso significa dizer que se alterava a forma como o Brasil estava inserido na dinâmica imperial, pois que as rotas políticas, econômicas e mesmo simbólicas que anteriormente ligavam as partes do Império a Lisboa passaram a convergir para a urbe carioca, onde entrou em funcionamento uma série de órgãos antes inexistentes. Novas sobreposições de funções e cargos, sobretudo na nova sede de poder, informariam a ação administrativa ainda carregada de marcas do Antigo Regime. Ação essa recorrentemente criticada por Hipólito José da Costa em seu Correio Braziliense que, como monarquista convicto, conclamava a Coroa a pôr em prática medidas para melhorá-la nas suas mais variadas esferas ${ }^{29}$. Nesse sentido, a crítica do periodista era um franco sinal de tempos em que a administração joanina podia ser tida como ineficaz a despeito dos persistentes empenhos reformistas.

No tocante à relação entre as partes do Império, a transformação do Rio em Corte fez que uma nova relação hierárquica se estabelecesse. Em Portugal, a perda da condição de

\footnotetext{
${ }^{26}$ Nuno Monteiro, O crepúsculo dos Grandes (1750-1832), Lisboa, Imprensa Nacional Casa da Moeda, 1998.

${ }^{27}$ No período joanino, o número de decretos, cartas régias e resoluções cresce muito, sobretudo nos primeiros anos; ver Francisco Luiz Teixeira Vinhosa, Brasil sede da Monarquia. Brasil Reino (2 parte), Brasília, Funcef, 1984 (Col. Hist. Administrativa do Brasil, v. 8). Para uma análise da ação política institucional de D. João no Brasil, ver Maria de Fátima Gouvêa, "As bases institucionais de construção da unidade. Dos poderes do Rio de Janeiro joanino: administração e governabilidade no Império luso-brasileiro", in: István Jancsó (org.), Independência: história e historiografia, São Paulo, Fapesp/Hucitec, 2005, pp. 707-752.

${ }^{28}$ Sobre os impactos que a transferência da monarquia promoveu no Brasil, ver: Maria Odila Dias, "A interiorização da metrópole", A interiorização da metrópole e outros estudos, São Paulo, Alameda, 2005, pp.7-37; Alcir Lenharo, As tropas da moderação. O abastecimento da Corte na formação política do Brasil: 1808-1842, $2^{a}$ ed., Secr. Mun. de Cultura/Dep. Geral de Doc. e Inf. Cultural, 1992; Kirsten Schultz, Tropical Versailles: empire, monarchy, and the portuguese royal court in Rio de Janeiro, 1808-1821. Nova York, Routledge, 2001; Andréa Slemian, Vida política em tempo de crise: Rio de Janeiro (1808-1824), São Paulo, Hucitec, 2006.

${ }^{29}$ Correio Braziliense ou Armazén Literário, jornal editado entre os anos de 1808 a 1822, em Londres (onde se exilara seu redator) que por ser crítico à política joanina, foi proibido no Brasil até 1821. Ver: István Jancsó e Andréa Slemian, "Um caso de patriotismo imperial". In: Correio Braziliense, ou, Armazém Literário, vol. XXX/ Hypólito José da Costa. São Paulo/Brasília, Imprensa Oficial do Estado/ Correio Braziliense, 2002, Tomo I, p.605-667.
} 
sede da monarquia, ainda que vislumbrada como temporária, foi sentida de forma intensa ${ }^{30}$. No Brasil, o fato de a Família Real se estabelecer e elevar seu território à condição de Reino em 1815 teve efeitos muito positivos para a região Centro-Sul, mas, em contrapartida, fez que as capitanias fossem profundamente oneradas com a criação de uma série de impostos para sustentação do governo na nova sede ${ }^{31}$. Ainda assim, a situação na Corte nunca fora confortável do ponto de vista das finanças. Em 1812, uma memória de Manoel Jacinto Nogueira da Gama, futuro Marquês de Baependi, quando escrivão da Mesa do Real Erário, apontava saídas para a falta de numerário e afirmava que não seria "deplorável o estado da real Fazenda" desde que se exigissem "impreterivelmente as sobras das capitanias" ${ }^{32}$, que muito provavelmente as Juntas de Fazenda não mandavam ao Rio de Janeiro.

O arranjo político-institucional herdado do Antigo Regime, reformulado a partir da segunda metade do século XVIII e incrementado em 1808 na América, só foi de fato colocado em xeque quando do movimento do Porto de 1820. Como no bojo das transformações advindas do processo de construção de uma nova ordem constitucional moderna estava a concepção da imperiosa necessidade de divisão dos poderes políticos, em razão da necessidade de racionalização e transparência das instituições e ações governamentais, e também à valorização dos "direitos inalienáveis do homem”, viver-se-ia em todo o mundo português um momento de radicalidade. As Cortes Gerais Constituintes instaladas em 1821, no mesmo ano aceitas como autoridade soberana, abririam espaço para o advento de um grande número de projetos e leis que pretendiam reformular a organização imperial, e que colocariam o rei a reboque de sua centralidade legislativa ${ }^{33}$.

Em relação aos poderes nas capitanias do Brasil - a partir de então definitivamente chamadas de "Províncias" - as Cortes conceberam uma organização provisória com a

\footnotetext{
${ }^{30}$ Valentim Alexandre, Os sentidos do Império - questão nacional e questão colonial na crise do Antigo Regime Português, Porto, Afrontamento, 1993; Ana Cristina Bartolomeu de Araújo, "O Reino Unido de Portugal, Brasil e Algarves - 1815/1822”, Revista de História das Idéias, n.14, Coimbra, 1992.

31 Wilma Peres Costa, "Do domínio à nação: os impasses da fiscalidade no processo de Independência", István Jancsó (org.), Brasil: formação do Estado e da nação, São Paulo/Ijuí, Fapesp/Hucitec/Unijuí, 2003, pp. 143-193.

${ }^{32}$ Apud Liberato Castro Carreira, História financeira e orçamentária do Império no Brasil, Brasília/Rio de Janeiro, Senado Federal/MEC, 1980, pp.91-2.

${ }_{33}$ Benedicta Maria Duque Vieira, O problema político português no tempo das primeiras cortes liberais, Lisboa, Edições João Sá da Costa, 1991.
} 
aprovação do decreto das Juntas de Governo, em setembro de $1821^{34}$. A lei, que tinha como objetivo regular o governo provincial e, sobretudo, controlar a atuação de D. Pedro que se encontrava no Rio de Janeiro como regente ${ }^{35}$, deve ser considerada como uma verdadeira ruptura com a prática vigente. Em substituição aos governadores ou capitães generais, criava-se um governo composto de cinco ou sete membros, todos elegíveis na própria localidade, sujeito à autoridade central em Portugal. $\mathrm{O}$ mesmo documento atribuía, no artigo $6^{\circ}$., à competência local "toda a autoridade e jurisdição na parte civil, econômica, administrativa, e de polícia, em conformidade das leis existentes, as quais serão religiosamente observadas, e de nenhum modo poderão ser revogadas, alteradas, suspensas, ou dispensadas pelas Juntas de Governo". Os magistrados e autoridades civis ficavam subordinados às Juntas (art. $7^{\circ}$.), as quais seriam responsáveis pela fiscalização dos empregados públicos, podendo também suspendê-los quando cometessem abusos de jurisdição $\left(\operatorname{art} .8^{\mathrm{o}}\right.$.).

Dois pontos do decreto foram motivos de permanente tensão. O primeiro, dizia respeito à instituição dos governadores de armas que, como nova autoridade militar, estariam sujeitos diretamente ao governo de Lisboa (art. $14^{\mathrm{o}}$.). O segundo referia-se à Fazenda pública que continuaria a ser administrada pelas respectivas Juntas criadas desde fins dos setecentos (com o membro mais antigo no lugar de presidente), sendo estas "coletiva e individualmente responsáveis ao Governo do Reino, e às Cortes por sua administração" (art. 9 ${ }^{\circ}$.). Em ambos os casos, as autoridades envolvidas permaneciam autônomas, ao menos no plano normativo, em relação ao governo local, o que posteriormente seria muito criticado em algumas localidades. Mesmo assim, o formato das Juntas provisórias atendia a muitas das expectativas das províncias na América no regime de seus interesses, sobretudo as do Norte, com a valorização política do seu espaço institucional perante o governo de D. Pedro no Rio de Janeiro. Nesse sentido, os deputados do Brasil que já se encontravam na Casa legislativa lisboeta praticamente não fizeram

\footnotetext{
34 Apesar da existência de um alvará, datado de 10 de setembro de 1811 , em que se determina a criação de Juntas que seriam eleitas regionalmente no âmbito das capitanias para auxiliar a Mesa do Desembargo do Paço no Rio de Janeiro, não se tem indícios da aplicação efetiva da medida; Maria de Fátima Gouvêa, "O Império das Províncias - Rio de Janeiro, 1822-1850”, texto apresentado no Seminário Internacional Brasil: de um Império ao outro (1750-1850), realizado entre 01 e 06 de setembro de 2005, São Paulo/USP. Diário das Cortes Gerais e Extraordinárias da Nação Portuguesa, disponíveis na internet: www.debates.parlamento.pt, Sessão de 29 de setembro de 1821. Decreto sobre as Juntas Provisórias do Governo.
} 
nenhuma objeção à medida da volta do Regente para a Europa em 1821, bem como à vinculação do governo das Províncias diretamente ao de Lisboa ${ }^{36}$.

Em virtude da tensão inerente à construção de uma unidade sob novas bases políticas para o Reino Unido português entre os idos de 1820 e 1822, a proposta de rearticulação dos poderes entre Portugal e a América naufragaria, e as Juntas de Governo, que continuariam a funcionar em todas as Províncias no Brasil, teriam de ser reformuladas para o projeto de um novo Império. De tudo isso ficava claro que, mesmo que no Rio de Janeiro a monarquia bragantina pudesse, após a Independência, amalgamar os vínculos entre os "portugueses da América" nos seus mais variados níveis ${ }^{37}$, o Brasil não possuía um centro político-administrativo moderno que articulasse institucionalmente suas partes, esfera em que a herança da administração antiga se tornava especialmente explícita. A emergência do constitucionalismo, mesmo tendo sido determinante nesse processo, também possuiu intrínseca relação com seu passado próximo.

Subjacente às reformas de meados do século XVIII estava em curso uma profunda mudança do imaginário político português no tocante a concepções de sociedade e poder que, até então interpretadas à luz de uma ordem objetiva providencialista, começavam a se aproximar cada vez mais do direito natural de vertente racionalista ${ }^{38}$. Tal mudança se inseria no panorama de transformação da concepção do que se convencionou chamar de jusnaturalismo. Entre os historiadores voltados ao período aqui estudado, o termo suscita diferentes leituras. Em linhas gerais, ele pode ser entendido como uma teoria política geral de que os governos se formavam a partir de um pacto fictício de vontades entre as partes, com obrigações estipuladas a cada qual, visando a conservação da ordem e felicidade das

\footnotetext{
${ }^{35}$ No mesmo dia fora aprovado o decreto que exigia que o Príncipe Real regresse quanto antes para Portugal, o qual teria repercussões de não pequena monta no Brasil.

${ }_{36}$ Márcia Regina Berbel, A nação como artefato. Deputados do Brasil nas Cortes portuguesas 1821-1822, São Paulo, Hucitec/Fapesp, 1999.

${ }^{37}$ Sobre as identidades nesse período, ver István Jancsó e João Paulo Pimenta, "Peças de um mosaico (ou apontamentos para o estudo da emergência da identidade nacional brasileira”, Carlos G. Mota (org.), Viagem incompleta. A experiência brasileira 1500-2000. São Paulo, SENAC, 2000, pp. 156-161.

38 António Manuel Hespanha e Ângela Barreto Xavier, "A representação da sociedade e do Poder", in: José Mattoso, op.cit., pp. 145-172; ver também de António Manuel Hespanha, Panorama histórico da cultura jurídica européia, Mem Martins, Publicações Europa-América, 1998.
} 
mesmas que o estado de natureza não garantia. José Carlos Chiaramonte ${ }^{39}$, partindo de uma definição ampla do direito natural (em sinonímia com o "direito das gentes"), sustenta que ele foi o fundamento da ciência política nos séculos XVII e XVIII, havendo grande diversidade no tocante as suas formas, desde as mais moderadas - como a afirmação deísta de aceitação do "pacto de sujeição" ao monarca - até as mais radicais - como a que concebia aos "povos" a possibilidade de alterarem o pacto de governo estabelecido. De forma genérica, esse teria sido o substrato teórico comum aos movimentos de independência na América ibero-americana em inícios do século XIX, em especial para o caso espanhol, em que o cativeiro do rei suscitou um movimento de fragmentação e confecção de "pactos" nas localidades em nome dos "direitos dos povos" e das soberanias locais.

Os trabalhos inspirados na seara aberta por François-Xavier Guerra ${ }^{40}$, também voltados ao estudo do fenômeno das Independências hispano-americanas, apontam para uma outra direção. Tomando como paradigma o movimento revolucionário francês, essa perspectiva aponta para a coexistência de universos mentais distintos nos setecentos, por causa da ascensão de valores modernos de uma concepção individualista em meio à prevalência do modus vivendi do Antigo Regime ${ }^{41}$. A partir de então, o jusnaturalismo estaria afeito ao antigo modelo corporativo de sociedade, baseado no chamado “constitucionalismo histórico", o qual teria sido contestado pela idéia moderna de nação "una e indivisível" composta por indivíduos, a qual se atribui um caráter eminentemente liberal $^{42}$. Nestes termos, a novidade a informar o processo independentista na América espanhola seria marcada por ambigüidades pautadas, da mesma forma que na Península, pela herança da existência dos antigos Reinos, que funcionavam quase como unidades

\footnotetext{
39 "Fundamentos iusnaturalistas de los movimientos de independencia" in Boletín del Instituto de Historia Argentina y Americana “Dr.E.Ravignani”, Tercera serie, n 22, $2^{\circ}$ sem. 2000.

${ }^{40}$ Modernidad e independencias. Ensayos sobre las revoluciones hispânicas, México, FCE/Editorial Mapfre, 1992; e do mesmo autor em colaboração com Annick Lemperière na organização, Los espacios públicos en Iberoamerica.

${ }^{41}$ François-Xavier Guerra, “A nação moderna: nova legitimidade e velhas identidades”, István Jancsó (org.)., op.cit., pp. 33-60.

${ }^{42}$ Nesse sentido ver a análise feita por Geneviève Verdo para o caso do Rio da Prata, Les "ProvincesDesunis" de le Río de La Plata: souveraineté et représentation politique de la indépendance argentina (18081821), Thèse de Doctorad, Université Paris I, 1998. Para ela, nos primeiros anos da revolução em Buenos Aires, os que defendem os chamados "direitos dos povos" (num ideal corporativo de sociedade) devem ser considerados como mais moderados, em contraposição aos radicais identificados com o ideário revolucionário francês, liderados, entre outros, por Mariano Moreno.
} 
autônomas, e que já no século XVIII dificultaram em muito o trabalho dos Bourbouns em direção a uma unificação político-administrativa do seu Império ${ }^{43}$.

Ambas as formas de análise fazem parte de uma renovação dos estudos sobre a história ibero-americana do período e não se apresentam como necessariamente excludentes. Concordam que no período está em curso uma mudança significativa no plano político, mesmo divergindo quanto aos conceitos e ênfases de sua transformação. Sem deixar de lado o termo jusnaturalismo - qualificando-o, como faz António Manuel Hespanha, em uma vertente "individualista" surgida no século XVIII, e não apenas entendendo-o como doutrina relativa à visão corporativa dos antigos reinos seiscentistas ${ }^{44}-$ deve-se ter em mente sua coexistência com valores pautados pelos primórdios do liberalismo; ao longo dos oitocentos, os liberais negarão completamente a concepção do "pacto" entre partes, seguindo a recusa que o historicismo alemão fará ao "direito das gentes" por acusá-lo de "abstrato" e pregador de normas imutáveis e "a-históricas"45.

O Império Português conheceria uma primeira forma de interpretação pactista de tipo racionalista na Ilustração. Foi a teoria política que deu base ao pombalismo a responsável pela sua incorporação oficial no universo lusitano, prevalecendo uma dimensão moderada do direito natural que fortalecia a figura do monarca como central e "soberana" em relação as outras esferas sociais, além de manter um forte respaldo deísta ${ }^{46}$. Sua primeira manifestação literária está na conhecida Dedução cronológica e analítica, escrita por José de Seabra da Silva sob as vistas do Marquês de Pombal ${ }^{47}$. Nela seu autor, interessado em defender a autonomia do monarca português em relação ao papado, e em

\footnotetext{
${ }^{43}$ Ainda que o trabalho de José Maria Portillo Valdés, Monarquia y gobierno provincial. Poder y constitucion en las Provincias Vascas (1760-1808), Madri, Centro de Estudios Constitucionales, 1991, trate apenas do caso espanhol na Península, ele analisa o peso que as constituições provinciais, e, portanto, os antigos reinos, tiveram quando se tentou implantar um modelo distinto na relação entre as partes da monarquia em meados do século XVIII.

${ }^{44}$ Panorama histórico..., apresenta várias das vertentes para o jusnaturalismo no século XVIII.

${ }^{45}$ Ver também as suas várias definições ao longo da Época Moderna, além de seu declínio no século XIX, em Norberto Bobbio (et. alli.), Dicionário de Política, 5 ed., São Paulo, UnB/Imprensa Oficial, 2004.

${ }^{46}$ José Reinaldo de Lima Lopes, "Iluminismo e jusnaturalismo no ideário dos juristas da primeira metade do século XIX”, István Jancsó (org.), Brasil. Formação do Estado e da nação, pp. 195-218, fala de um "jusnaturalismo domesticado" para o mundo português que os juristas brasileiros herdaram no século XIX; ver também José S. da Silva Dias, "Pombalismo e teoria política", Cultura - História e Filosofia, Lisboa, 1982, v.1, pp.45-70.

47 Deducção chronologica e analytica na qual se manifesta o que sucessivamente passou nas differentes epocas da Igreja sobre a censura, proibição e impressão dos livros..., Lisboa, Offina de Miguel Manescal da Costa, 1767, 2v. Ver análise de Zília Osório de Castro, Constitucionalismo vintista. Antecedentes e pressupostos. Lisboa, Centro de História da Cultura da Universidade Nova de Lisboa, 1986, p.28.
} 
atacar as ações da Companhia de Jesus, apresenta a tese da soberania do rei "ungido de Deus Todo-Poderoso", ao mesmo tempo em que constrói, no plano constitucional, uma interpretação anticorporativa da sociedade ${ }^{48}$. Sustenta que teria havido um "pacto originário global" na fundação da monarquia portuguesa quando D. Afonso Henriques (considerado o primeiro rei de Portugal) foi aclamado "soberano" depois de vencer, por guerra justa, a Batalha de Ourique em 1139. Desde seu início, tratar-se-ia de uma "monarquia pura", em que a soberania estaria única e exclusivamente centrada no rei, e na qual as Cortes seriam organismos meramente consultivos que o monarca convocaria apenas para conhecimento das necessidades do seu reino.

O Tratado de direito natural de Tomás Antonio Gonzaga é outro exemplo dessa mesma vertente ${ }^{49}$. Ainda que diferindo de algumas questões intrínsecas à Dedução de Seabra da Silva, a obra do poeta mineiro também se desenvolve no quadro político do absolutismo, ao manter como axioma a unidade e indivisibilidade da soberania, residente única e exclusivamente na realeza ${ }^{50}$. De caráter extremamente moderado (influenciado, sobretudo, por Hugo Grócio e Samuel Pufendorf), o direito natural de Gonzaga era o "direito da ordem" em que a vontade do legislador estava inicialmente colocada em Deus e incidia, na face da Terra, no monarca ${ }^{51}$. E a despeito do pacto realizado, as características do sumo imperante não teriam origem popular, sendo esse, ao mesmo tempo, superior às leis e autônomo em relação a qualquer outra autoridade temporal. Em ambos os autores, a identificação com o ideário que o regime tentara construir era evidente.

Mas foram, sobretudo, as reformas na área jurídica que, levadas a cabo nas épocas pombalina e mariana, serviram de plataforma para transformação radical da concepção de poderes que servia de base ao sistema monárquico. Foram elas: a publicação da Lei da Boa Razão (1769) e a reforma dos Estudos Jurídicos da Universidade de Coimbra (1772); o projeto do Novo Código para sistematização do direito legislativo (1786); e a reforma da organização judiciária senhorial (entre 1790 e 1792). Todas tinham a intenção de favorecer a centralidade do direito nacional, identificado com a vontade do soberano como única

\footnotetext{
${ }^{48}$ António Manuel Hespanha e Ângela Barreto Xavier, op.cit.

${ }^{49}$ Originalmente obra de sua dissertação de licença na Universidade de Coimbra (1768) a qual foi dedicada pelo autor ao Marquês de Pombal. Rio de Janeiro, Ministério da Educação e Cultura/Inst. Nacional do Livro, 1957.

${ }^{50}$ José S. da Silva Dias, op.cit..

${ }^{51}$ José Reinaldo de Lima Lopes, op.cit.
} 
fonte legítima de emanação da "lei", contra o "costume" e a tradição de autogoverno das corporações que, na tradição do Antigo Regime, detinham o privilégio de efetuar a justiça $^{52}$. Não era à toa que, nas décadas 1770 e 1780, os temas constitucionais ligados à unidade do poder estavam na ordem do dia.

As duas primeiras medidas, em especial, tiveram como justificativa a "modernização" do ensino e das práticas jurídicas no caminho das "nações polidas" e da "boa razão", além de formar um quadro de profissionais que pudessem atender às novas necessidades do Estado $^{53}$. Especificamente nesse campo, tratava-se de retirar o ranço medievalista da formação e atuação dos juristas, com a diminuição do peso excessivo dado à retórica e aos cânones (a intensiva leitura dos glosadores e comentadores, a escolástica "bartolista"), em contrapartida à valorização do direito positivo e ênfase na sua prática de ação cotidiana ${ }^{54}$. Com isso deu-se a exaltação do direito natural (ou das gentes), e do chamado "direito pátrio", entendido como a positivação do primeiro aplicado a um determinado contexto histórico. Um dos espaços privilegiados de sua divulgação foi a Universidade de Coimbra que, como grande centro de ensino da época, seria também responsável pela formação de grande parte dos primeiros legisladores do Império do Brasil $^{55}$.

Nesse sentido, os novos Estatutos coimbrãos para as ciências jurídicas previam a elaboração de programas e métodos que inexistiam, sobretudo em matéria de história do “direito pátrio português”. Foi Pascoal José de Mello Freire dos Reis que, na condição de lente da Universidade e divulgador incansável do Iluminismo português, tornou-se seu executor compendiário mais abnegado ${ }^{56}$. Além dele, também Francisco Coelho de Souza

52 Ana Cristina Araújo (coord.), O Marquês de Pombal e a Universidade. Coimbra, Imprensa da Universidade, 2002; Luis Reis Torgal, "Universidade e sociedade nos primórdios do liberalismo português". Portugal. Da Revolução Francesa ao Liberalismo. Universidade do Minho, Actas do Colóqio, 04-05 de dezembro de 1986; António Manuel Hespanha, A história do direito na história social, Lisboa, Horizonte, s/d.

53 Desta forma, havia uma intrínseca ligação entre a reforma e os ideais dos políticos reformistas ilustrados portugueses como já tem sido notado pela historiografia.

${ }_{54}$ Mario Júlio de Almeida Costa e Rui de Figueiredo Marcos, "Reforma pombalina dos estudos jurídicos" in Ana Cristina Araújo (coord.), op.cit.; Paulo Merêa, "Lance de olhos sobre o ensino do direito desde 1772 até 1804”, Boletim da Faculdade de Direito, Coimbra. V. XXXIII, 1958.

55 Segundo Lúcia Maria Bastos Pereira das Neves, Corcundas, constitucionais e pés-de-chumbo: a cultura política da Independência. 1820-1822, São Paulo, USP, Tese de Doutorado, 1992, quase a metade dos deputados eleitos para a Assembléia Constituinte de 1823 teria passado pela Universidade de Coimbra.

56 Nessa universidade regeu a disciplina desde a data em que se inaugurou a cadeira (1774) até 1783, e escreveu uma história (Historia Iuris Civilis Lusitani) para a mesma que, cinco anos depois, viria a receber 
Sampaio $^{57}$ e Ricardo Raimundo Nogueira ${ }^{58}$ - este último como substituto da cadeira escreveriam importantes compêndios para a mesma disciplina. Ao valorizarem o Direito Público, tais autores elaborariam teorias que, partindo da discussão das "leis fundamentais" e de formação do pacto original da monarquia portuguesa, conceberiam o poder de "fazer leis" como primeira prerrogativa do soberano ${ }^{59}$. Todos seus compêndios trazem, dessa forma, um histórico da formação de Portugal, com o intuito de comprovarem a sua independência do Reino de Leão desde o século XII, bem como a existência das Cortes de Lamego como pacto fundador da monarquia.

Nesse sentido, Mello Freire argumenta, retomando a interpretação lançada na Dedução de Seabra da Silva, que D. Afonso Henriques teria recebido o título de rei após vencer a Batalha de Ourique, e herdado a soberania de seus pais (o Conde D. Henriques de Borgonha e D. Teresa) sobre o dote do Condado Portucalense. Defende que a forma de governo de Portugal seria uma "monarquia pura", onde todos os "direitos de soberania

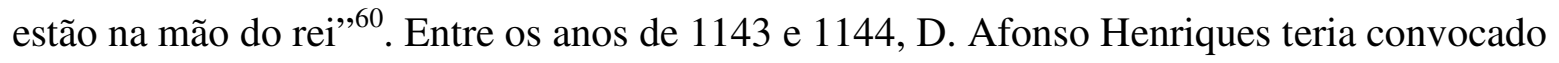
as Cortes de Lamego, "onde foi coroado, e tomou mais solenemente o título de rei de que já usava, e com o consentimento das três ordens do Estado, isto é, do clero, nobreza e povo, se estabeleceram as Leis Fundamentais do nosso Reino" ${ }^{61}$. Para Mello Freire, são:

consagração oficial para o ensino. Em 1805, seria a vez de outra obra sua, sobre as instituições do direito civil e criminal português (Institutiones juris civlis lusitani, cum publici tum privati e Institutiones juris criminalis lusitani), ser adotada para a mesma cadeira, a qual serviria de base ao ensino de direito nacional ao longo de muitos anos. Seus quatro livros foram traduzidos em partes e publicados no Boletim do Ministério da Justiça, entre os anos de 1966-7, a partir do número 161. Ver Paulo Merêa, "Notas sobre alguns lentes de direito pátrio no período de 1772-1804", Boletim da Faculdade de Direito, Coimbra, vol. XXXVI, pp. 5-13. Biblioteca Nacional de Lisboa (BNL), Seção de Reservados (manuscritos), História do Direito Português (Códice 118); "História da Legislação Portuguesa" (Códice 8527). Sobre a atuação jurídica de Melo Freire, ver Paulo Ferreira da Cunha, Faces da Justiça, Coimbra, Almedina, 2002.

${ }^{57}$ Preleções de Direito Pátrio Público, e Particular, oferecidas ao Sereníssimo Senhor D. João, Coimbra, Real Imprensa da Universidade, 1793.

${ }^{58}$ Biblioteca Nacional de Lisboa, Seção de Reservados (manuscritos), Direito Publico de Portugal de Ricardo Raimundo Nogueira, Lente Substituto de Ley, presidindo a Cadeira de Direito Pátrio no anno de 1788 (Códice 9347) e "Preleções de Direito Público de Portugal [com outra letra] compostas pelo Dr. Ricardo Raymundo Nogueira. Lente de Leis na Universidade. Tiradas de seus próprios originais por diligência do Dr. Antonio Ribeiro dos Santos seu amigo, e colega" (Códice 1715). Um outro estudo de direito pátrio foi escrito, na mesma época, por Luiz Joaquim Corrêa da Silva, "Preleções de Direito Pátrio", Biblioteca Geral da Universidade de Coimbra, Seção de Manuscritos, Códice 1460.

${ }^{59}$ António Manuel Hespanha e Ângela Barreto Xavier, op.cit., p.168-172.

${ }^{60}$ BNL, Códice 8527, p. 6.

${ }^{61}$ Idem, Direito Público de Portugal, Parte Primeira, p. 51. 
"as Leis Fundamentais de qualquer Estado verdadeiramente os pactos, e condições que dão forma ao novo Império, e com os quais os Vassalos se sujeitam ao Sumo Imperante, que os deve governar; é claro que estas Leis não podem ter lugar em um Estado já formado, em que os súditos reconhecem um Soberano, e estão sujeitos a sua autoridade; porque a mesma natureza da Sociedade Civil repugna um novo Pacto entre os vassalos e o Soberano a respeito do Supremo Império". ${ }^{2}$

Assim, o jurista nega qualquer participação ativa do "povo" na translação do poder para os reis, pondo por terra a possibilidade do "direito de resistência" por parte dos vassalos que pretendessem refazer o pacto. Frisa que o "direito de fazer leis era desde o princípio privativo dos Reis", e "que as mesmas Cortes nunca exercitaram algum dos direitos da soberania, nem o seu voto foi decisivo para o estabelecimento das Leis, ou imposição de tributos"63; que teria sido apenas a "benignidade do Senhor D. Afonso Henriques" que, "cheio de amor para seus vassalos", "quis que as Leis que estabeleciam fossem a contento de todos, e permitiu-lhes que dessem um testemunho expresso da sua aprovação, e obediência em as aceitar, ${ }^{\circ 4}$.

Francisco Coelho de Souza Sampaio partilha de elaboração muito semelhante a respeito das bases da monarquia portuguesa. Para ele, no princípio dos vários direitos privativos dos monarcas - dentre os quais os de legislar e o de julgar - subsiste fortemente uma vertente religiosa segundo a qual "os direitos majestáticos, ou poder supremo, têm o seu princípio constitutivo na mesma lei natural, e que este Império Deus o quis, Deus o constituiu, como necessário para conservação, e segurança dos direitos do homem, e que a pessoa designada, ou eleita pelos mesmos homens para Imperante, é quem o poder supremo radica primária, direta e imediatamente" ${ }^{\natural 5}$. Embora aí esteja, em primeiro plano, a

\footnotetext{
${ }^{62}$ Idem, p.50. Admite que apenas no caso de vacatura do rei o poder retorna ao "povo" para que se decida a escolha de nova dinastia.

${ }^{63}$ Idem, Parte Segunda, p.93-4.

${ }^{64}$ Idem, p.95.

${ }^{65}$ Preleções de Direito Pátrio Público, e Particular...., p. VI-VII. Nas "Observações às Preleções de Direito Pátrio Público, e Particular, oferecidas ao Sereníssimo Senhor D. João" (Lisboa, Imprensa Régia, 1805), Sampaio critica os princípios dos revolucionários franceses, e acusa a concepção de que a Soberania seria fornecida aos monarcas pelos "povos": "o estabelecimento da Sociedade Civil, e do Sumo Imperante, não depende do mero arbítrio dos homens, ou do livre uso dos seus direitos facultativos, mas de sua vontade, ou de um livre arbítrio obrigado, ou regulado pelos preceitos da Lei Natural"; donde se deduziria que "os pactos, e convenções não foram a causa imediata do estabelecimento da Sociedade, e da Constituição dos Imperantes,
} 
justificativa divina da instituição das sociedades, seu autor não deixa de notar também a importância do "pacto" no estabelecimento das "Leis Fundamentais" que, no Império português, teriam sido estabelecidas nas Cortes de Lamego. A partir de então, nem o próprio rei poderia alterá-las, pois forneciam a "natureza de pacto, e convenção entre os reis e vassalos"66. E por se tratar de um sistema de "monarquia plena e pura", argumenta - na mesma linha de raciocínio de Mello Freire - que a convocação das Cortes "dependeram sempre do arbítrio dos príncipes", e que elas nunca tiveram "voto algum decisivo".

Quanto à formação do regime em Portugal, os compêndios elaborados por Ricardo Raimundo Nogueira seguem, de modo ainda mais evidente, os passos da obra de Mello Freire. Nogueira também parte da idéia de uma "monarquia pura e independente", cujas bases teriam sido lançadas nas Cortes de Lamego, valendo-se de argumentos semelhantes aos do seu predecessor ${ }^{67}$. Com ele compartilha da mesma concepção segundo a qual as Cortes antigas apenas tinham o "direito de propor o que julgavam conveniente", e que cabia "ao príncipe [dar] providências oportunas sobre aquela matéria", o que era condizente com o sistema de "monarquia pura" ${ }^{\text {68 }}$. Atribui o fato de os reis ouvirem as Cortes, ou os povos, à sua "benignidade", à "bondade e indulgência dos nossos soberanos em quererem ouvir o seu povo", pois que "estes Congressos Nacionais" jamais teriam exercido "algum dos direitos supremos da majestade" $" 69$.

Nesse panorama setecentista de produção intelectual acerca da fundação e do caráter da monarquia portuguesa, elaborada pelos juristas em Coimbra, foi António Ribeiro dos Santos quem questionou o paradigma herdado do pombalismo ${ }^{70}$. Escrevendo desde finais da década de 1780, sua reflexão sobre o tema expressava o tom de mudança operado no universo político português de fins do século XVIII que, fortemente marcado pelos acontecimentos revolucionários ocidentais, promoveria, no campo do Direito Natural, a ascensão de elementos jusnaturalistas de vertentes mais liberais (em especial, as de Jean

mas unicamente o meio de preencher a vontade de Deus, que por uma necessidade moral obrigou os homens a unir-se em Sociedade Civil".

${ }^{66}$ Preleções de Direito Pátrio Público, e Particular...., p.32.

${ }^{67}$ Direito Publico de Portugal de Ricardo Raimundo Nogueira, p.32v.

${ }^{68}$ Idem, p.52v.

${ }^{69}$ Idem, p.54v.

${ }^{70}$ Filho de comerciante, ele ingressou desde cedo na carreira eclesiástica e nesta ascendeu, lecionando na Universidade de Coimbra desde 1778, ocupando vários cargos e funções importantes na esfera pública, e produzindo uma vasta obra acerca de questões do direito e da religião. Para uma análise da trajetória 
Jacques Burlamaqui e Emmerich van Vattel). Sem pôr em causa a estrutura do regime absoluto, Ribeiro dos Santos procurava apresentar um conceito de "Leis Fundamentais" que desse garantia a duas realidades jurídicas: "o direito do soberano em reinar e os direitos dos povos em garantir o bem comum nos aspectos particulares que este envolvia"71.

Em oposição aos seus predecessores, que na história do direito pátrio não consideravam a participação dos súditos como fator ativo na gênese do pacto monárquico, Ribeiro dos Santos defende que a "nação" teria tido um papel fundamental desde o momento das Cortes de Lamego, e que dotada de "vontade" também poderia, junto com o rei, transformar o mesmo pacto $^{72}$. Nas suas palavras:

"Pelo que respeita a sua forma, elas [as "Leis Fundamentais"] foram estabelecidas por mútuo consentimento de Nação e do Príncipe, que é o que forma o pacto e convenção fundamental, ficando por isso mesmo Leis não meramente Civis e dependentes da vontade do Príncipe, mas leis públicas fundamentais, inalteráveis, e dependentes para a sua advogação, ou mudança do concurso das vontades do Povo e do Rei que é o que constitui o Direito Publico Fundamental ou Constitucional. Em verdade estas Leis foram feitas por este concurso, e autoridade do Rei e do Povo, se vê claramente das cláusulas das mesmas Cortes."73

Além da abertura para enxergar um papel ativo dos "povos" no estabelecimento e transformação do pacto, uma outra preocupação de Ribeiro dos Santos é a da criação de meios para tornar efetivos os limites morais que colocassem um freio no exercício do poder

individual e intelectual de Ribeiro dos Santos, ver José Esteves Pereira, O pensamento político em Portugal no século XVIII. António Ribeiro dos Santos. Lisboa, Imprensa Nacional/ Casa da Moeda, 1983.

${ }^{71}$ Zília Osório de Castro, op.cit., p. 29. Um dos exemplos da novidade trazida pelo pensamento de Ribeiro dos Santos pode ser visto na polêmica que se deu em 1788, quando no papel de deputado da Junta de Revisão e Censura do Novo Código Civil elaborado por Pascoal de Mello Freire, teceu duras críticas à obra do colega. Essas iam no sentido de entender o Código como um fiel produto do projeto pombalino que, além de ser ultrapassado, desconsiderava a participação da sociedade no quadro institucional das ordens, ou seja, não tocava no problema da reinserção da nação no contexto do Estado. Ribeiro dos Santos propunha então a convocação de Cortes em nome dos antigos "direitos dos povos", enquanto Mello Freire atentava para o perigo de subversão do regime que isso poderia ocasionar, acusando o clérigo de "monarcómono" e propagador de doutrinas sediciosas. O debate foi longo, e vários foram os pontos de discordância entre ambos; no final, o censor acabou por sofrer um processo no qual seria absolvido, sendo então nomeado desembargador (1790) da Casa da Suplicação.

${ }^{72}$ António Manuel Hespanha e Ângela Barreto Xavier, op.cit., p. 172.

${ }^{73}$ BNL, Seção de Reservados (manuscritos), Códice 4677, p.25. 
do monarca. Afirma que Portugal, sendo uma monarquia, era, contudo, uma monarquia temperada, a qual teria "Leis Fundamentais e de Direito que são essenciais a toda e qualquer monarquia", além das "Leis Fundamentais positivas". Argumenta que "estas duas ordens de Leis Fundamentais obrigam os nossos príncipes": umas "os obrigam pelo mesmo título de sua soberania, porque são obrigações e condições naturais e inseparáveis dela; outras os obrigam pela força das promessas e direito inviolável de convenções que se fizeram entre eles e o povo"74. Desta forma, as mesmas "Leis Fundamentais" não permitiriam o exercício arbitrário do poder em função da conjugação do poder soberano do monarca e da vontade do povo em garantir a realização dos objetivos do pacto social ${ }^{75}$. Veja-se, a título de exemplo, a justificação que faz para o direito do príncipe de impor tributos: apesar de afirmar que o soberano poderia fazê-lo "em ordem à conservação do Estado todas as vezes que a necessidade publica assim pede", enuncia restrições, já que ela deveria acontecer apenas quando fosse a única alternativa, sempre proporcional às possibilidades $^{76}$.

A consideração de Ribeiro dos Santos quanto aos "direitos tradicionais dos povos" assinala uma diferença significativa em relação ao discurso oficial, além de um programa de ajuste do regime aos novos tempos. Ao preservar a soberania absoluta do monarca, sua obra põe a nu as contradições presentes no cerne do regime lusitano, o qual lutava para se manter afeito aos ideais políticos construídos ao longo dos setecentos mesmo diante do conturbado quadro vivido pelos regimes monárquicos no mundo inteiro. Dessa forma, por mais que ele colocasse ainda mais em evidência a esfera dos direitos individuais, continuava-se a privilegiar o campo do Direito Público, bem como a figura do soberano como "grande protetor dos povos".

Embora o próprio Ribeiro dos Santos, na expectativa da conservação da ordem e estabilidade monárquica em fins do século XVIII, tenha chegado a defender a convocação de Cortes, quando essas de fato foram abertas como desdobramento da Revolução de 1820, já não se tratava mais de reforma, mas de revolução. Isso porque a mudança de paradigma proposta nesse momento implodiria as bases do regime vigente, o qual já era alvo de grandes descontentamentos tanto em Portugal como no Brasil. As teses liberais radicais da

\footnotetext{
${ }^{74}$ BNL, Seção de Reservados (manuscritos), Códice 4670, p.32-32v.

${ }^{75}$ BNL, Seção de Reservados (manuscritos), Códice 4668, Sobre a origem do poder do Príncipe, p.165-165v.

${ }^{76}$ BNL, Seção de Reservados (manuscritos), Códice 4677, p. 68v.-9.
} 
necessidade da garantia da "soberania da nação", dos "direitos dos cidadãos" e da separação e do controle dos poderes políticos iam de encontro à política joanina, a partir de então identificada com o passado "absolutista"77. Apesar da predominância desse ideal, distintas eram as posições quanto à natureza do novo sistema de "monarquia constitucional", as quais puderam ser momentaneamente amalgamadas pela crença numa "regeneração portuguesa".

Algumas das concepções políticas que estavam na base das transformações provocadas pelas reformas setecentistas em relação ao Antigo Regime adquiriam na boca dos revolucionários vintistas um verdadeiro sentido de ruptura. A difusão de um ideal de racionalidade, presente na concepção de um pacto fundador que informasse a estruturação dos poderes e funções do Estado, assim como a própria unidade no Legislativo, que para os ilustrados serviria à defesa de uma centralização na figura do monarca, foram revalorizadas do ponto de vista de uma nova "sociedade de indivíduos" soberana: a "nação". Subsidiária a esta, estava uma idéia moderna de representação política que, desconhecida no universo da sociedade corporativa strictu sensu, baseava-se na eleição de representantes que adquiriam legitimidade para agir individualmente perante as decisões do governo. Como entidade agregadora da vontade pública ou geral, a nação representaria a síntese de uma nova ordem que implodia com o substrato político vigente no Império português, anos depois das pioneiras experiências de ruptura dessa monta no mundo ocidental.

O movimento revolucionário de Pernambuco já havia colocado, em 1817, sinais contundentes na mesma direção, seguindo proposições ainda mais radicais. Ele foi uma tentativa de criação de um governo independente na região em reação ao encaminhamento da política do Rio de Janeiro, vinda de uma das Províncias mais ricas do Império e que crescera significativamente seu volume de negócios, sobretudo pelo aumento na exportação do algodão desde fins do século anterior ${ }^{78}$. Seu projeto era a implantação de uma República que chegou a durar três meses com um Governo Provisório; este revogou tributos criados por D. João VI, enviou emissários para províncias vizinhas visando sua expansão, aprovou um regulamento para seu funcionamento no qual enunciava que em breve seria convocada

\footnotetext{
${ }^{77}$ Zília Osório de Castro, op. cit.

${ }^{78}$ Carlos Guilherme Mota, Nordeste 1817: estruturas e argumentos, São Paulo, Perspectiva, 1972; Denis Beranrdes, "O processo de independência, a formação do Estado Nacional e a questão regional no Brasil: o caso do Nordeste (1808-1824)", Texto apresentado no VII Congresso da AHILA, Florença, 1985; Amaro Quintas, A revolução de 1817, 2aed., Recife, FUNDARPE, 1985.
} 
uma Assembléia Constituinte para confecção do novo "pacto social". Esse regulamento era informado pelo princípio revolucionário da "soberania do povo" e afirmava que se, no espaço de três anos, não se achasse convocada uma Assembléia, ficaria "cessado de fato o dito Governo, e entra[ria] o povo no exercício da soberania para o delegar a quem melhor cumpra os fins da sua delegação" ${ }^{\text {79. }}$.

A radicalidade e abrangência que tomaram os acontecimentos de Pernambuco com a mobilização de amplos setores sociais fizeram que slogans da experiência francesa de 1789, como o de "patriota" (codinome que os revolucionários adotaram para si) e da "perfeita igualdade" entre os homens, difundissem-se com extrema rapidez. É isso que explica o fracasso do movimento, para além da repressão das forças imperiais, diante do temor que se rompesse o status quo da sociedade que, vale lembrar, era profundamente hierarquizada e escravista $^{80}$. Nestes termos, o movimento esteve diante de um impasse: se era necessário negar a herança monárquica portuguesa para criação de uma nova ordem (observe-se que a palavra "nação" quase não aparece nas proclamas de 1817), ao mesmo tempo era preemente a manutenção dos vínculos que ligavam os brancos proprietários e comerciantes a esse passado como forma de diferenciá-los dos demais. A ruptura total com a "nação portuguesa" se mostrara, no mínimo, problemática por parte dos envolvidos que tinham bens a perder.

Em Portugal, em 1820, o caráter da ruptura foi distinto, e inicialmente fez-se em nome do passado (a "regeneração") tendo que se haver com a reconfiguração da monarquia em um regime constitucional. É fato que, se tomarmos os princípios liberais que a embasavam, ela poderia significar uma ameaça à desestabilização da ordem social aos moldes do "perigo" dos pernambucanos de $1817^{81}$. Mas a preservação do monarca também pôde funcionar como anteparo em nome da moderação, caminho, aliás, que seria trilhado em ambos os hemisférios nos anos imediatamente seguintes ${ }^{82}$. Na rasteira da difusão do movimento vintista por todo o Império, a redefinição do papel de cada parte na nova

\footnotetext{
${ }^{79}$ Documentos Históricos. Revolução de 1817, Rio de Janeiro, Biblioteca Nacional/Divisão de Obras raras e publicações, 1954, v. CIV, Regulamento para o Governo Provisório.

${ }^{80}$ István Jancsó e João Paulo Pimenta, op.cit..

${ }^{81}$ Veja-se como os princípios políticos divulgados pelos revolucionários vintistas embasaram a resistência dos chamados "tapuios" (índios destribalizados) no Pará contra as autoridades da Província em 1821. André Roberto de A. Machado, A quebra da mola real das sociedades. A crise política do Antigo Regime português na Província do Grão-Pará (1821-25), São Paulo, Tese de Doutorado, FFLCH-USP, 2006, capítulo três.
} 
unidade punha a nu a urgência com que se deveriam estabelecer as novas bases do pacto de união da "nação portuguesa" 83 . Nestes termos, a crescente polarização que se deu entre deputados de Portugal e do Brasil no tocante à divisão e funcionamento dos poderes políticos imperiais foi a pedra de toque da discussão que, a partir de 1822, tomou conta do cenário constituinte e legislativo português.

Foi com o projeto apresentado pelos deputados de São Paulo nas Cortes de Lisboa concebido como defesa da condição de Reino alcançada pela América desde 1815 e que se ancorava na permanência do Príncipe Regente D. Pedro no Brasil e na manutenção de um centro de poder Executivo no Rio de Janeiro (em desobediência aos decretos ali aprovados em 1821) - que as posições divergentes claramente se enunciaram ${ }^{84}$. Na sua discussão, enquanto parte dos representantes de Portugal evocava o nome da "nação" como elo entre ambos os hemisférios - no sentido revolucionário adquirido pelo vocábulo para defender uma totalidade soberana em detrimento da concepção corporativa de reinos ou partes -, alguns deputados do Brasil construiriam uma distinta $\operatorname{argumentação~}{ }^{85}$. Operando na mesma chave interpretativa, os que apoiaram o citado projeto defenderiam que, após os acontecimentos de 1820-21, a "nação" estaria ainda para se formar já que a identidade portuguesa não garantia os termos do novo pacto entre as partes, baseado em valores constitucionais. Entre eles, o padre Diogo Antônio Feijó, eleito deputado por São Paulo ${ }^{86}$, seria explícito:

"Nós ainda não somos Deputados da Nação, a qual cessou de existir desde o momento que rompeu o antigo pacto social. Não somos Deputados do Brasil, de

\footnotetext{
${ }^{82}$ Manuel Felipe Cruz Canavieira, Liberais moderados e constitucionalismo moderado (1814-1852), Lisboa, Instituto Nacional de Investigação Científica, 1988.

${ }^{83}$ Valentim Alexandre, op.cit..

84 Márcia Berbel, op.cit:; Antonio Penalves Rocha, "A economia política na desagregação do Império português", José Luis Cardoso (coord.), A economia política e os dilemas do Império luso-brasileiro, Lisboa, Comissão Nacional para as Comemorações dos Descobrimentos portugueses, 2001, pp.149-197.

${ }^{85}$ Os discursos foram pesquisados no Banco de Dados "Vocabulário político dos deputados do Brasil nas Cortes de Lisboa (1821-22)", elaborado por bolsistas de Iniciação Científica sob a orientação da Prof. Márcia Berbel, Departamento de História/USP.

${ }^{86}$ Diogo Antônio Feijó (1784-1843) era natural de São Paulo, onde, voltando-se para a vida eclesiástica, dedicou-se à educação nas vilas de Itu e Campinas. Sua carreira política começou em 1821, justamente quando foi eleito para ocupar uma cadeira nas Cortes de Lisboa. Posteriormente, seria deputado nas duas primeiras legislaturas do Império do Brasil (a primeira iniciada em 1826 e a segunda em 1830), estando à frente da pasta do Ministério da Justiça entre os anos de 1831-32. Em seguida, foi indicado senador pelo Rio de Janeiro e, como é sabido, Regente entre os anos de 1835-37, durante a menoridade do Imperador.
} 
quem em outro tempo fazíamos parte imediata; porque cada província se governa hoje independente. Cada um é somente Deputado da província que o elegeu, e que o enviou" $"$.

Nestes termos, o paulista Antônio Carlos de Andrada e Silva ${ }^{88}$, um dos mais eloqüentes defensores do projeto do "Reino do Brasil", negava as acusações feitas pelos europeus de que ao expor os "direitos" do Brasil ele apoiaria a separação dos hemisférios. Afirmava que não se podia dizer tal coisa "quando as diversas partes de uma Nação est[avam] como independentes, e trata[va]m de formar o pacto, que as un[isse] com conhecimento de causa" ${ }^{\prime 9}$. O debate então girava em torno do decreto aprovado por D. Pedro no Rio de Janeiro para convocação de Cortes para a América, que o mesmo Antônio Carlos defendera em nome da "soberania" como "coleção de todas as vontades individuais dos cidadãos de uma nação"90. No dia anterior, ele já havia aventado a hipótese de o Brasil ser uma "nação separada" no tocante ao Legislativo, mantendo uma união com Portugal apenas no poder Executivo, ou seja, pela dinastia ${ }^{91}$.

\footnotetext{
${ }^{87}$ Discurso proferido em 25/abril/1822.

${ }^{88}$ Antônio Carlos Ribeiro de Andrada Machado e Silva (1773-1845), era natural de Santos (São Paulo). Diplomou-se em Leis e Filosofia pela Universidade de Coimbra, onde obteve o título de Doutor em 1797. De volta ao Brasil, ocupou vários cargos públicos. Na função de ouvidor e corregedor em Olinda (desde 1815), foi acusado de participar da Revolução em Pernambuco em 1817, o que lhe valeu a prisão. Depois de solto, foi indicado para desembargador da Relação da Bahia, posto que não assumiu por ter sido eleito deputado pela Província de São Paulo para as Cortes de Lisboa, em 1821. Entrou na Casa legislativa no ano seguinte e, depois de intensa participação nos debates, abandonou-a em outubro. Após a Independência, atuou como deputado na Constituinte de 1823, também por São Paulo. Depois de sua dissolução, ficou quase cinco anos exilado na Europa. Em 1832, recusou a nomeação de ministro plenipotenciário do Brasil junto à corte de Londres. Foi novamente deputado na 4 legislatura (1838-1841), e atuou como ministro do Império de 18401842. No ano de sua morte, foi nomeado senador pela Província de Pernambuco.

${ }^{89}$ Discurso proferido em 30/agosto/1822.

${ }^{90}$ Idem.

${ }^{91}$ Discurso do dia 29/agosto/1822.
} 
O baiano Cipriano Barata ${ }^{92}$ também sustentou incisivamente o mesmo. Dizia que tendo ficado os "dois os hemisférios independentes de direito e de fato" após a revolução constitucional, "cada um como uma nação independente da outra", o Brasil recobrara "parte da soberania que lhe tocava" e "podia usar dela, como bem quisesse segundo seu bom

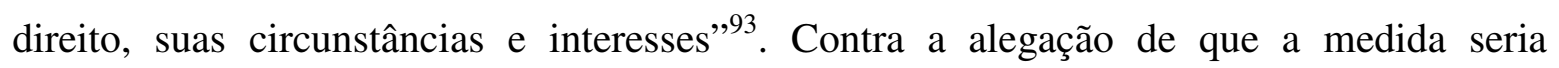
inválida, argumentava que ela se fundaria na "legítima autoridade do povo transferida a S.A.R. pela nova revolução" conforme o "direito natural, público e das gentes que lhes assist[ia]"94. Arrematava que os "povos do Brasil" teriam os mesmos direitos que os de Portugal e que esse era o momento de reivindicá-los, ou seja, quando o "pacto social" entre ambos estava em construção.

Obviamente, no bojo da questão residia uma série de interesses políticos e econômicos que não conseguiriam encontrar um consenso viável para que o Império permanecesse unido ${ }^{95}$, o que permitiu a aproximação de deputados que futuramente encampariam projetos díspares para o Brasil independente. Daí o abandono coletivo que alguns representantes americanos fizeram das Cortes, em protesto contra a falta de entendimento estabelecida ${ }^{96}$. $\mathrm{O}$ fato é que uma alternativa de Independência pudera ser gestada para a América portuguesa que, a partir do Centro-Sul, teria de enfrentar o mesmo problema da construção de uma unidade política interna. Nessa, a centralidade do problema

92 Cipriano José Barata de Almeida (1762-1838) era natural de Salvador. Bacharel em Filosofia pela Universidade de Coimbra, em 1790, teve uma atuação política intensa nos primeiros anos do Império, sobretudo na imprensa, onde ficou conhecido pela publicação de seu combativo jornal Sentinela da Liberdade. Consta que participou da Conjuração baiana de 1798, e anos depois, seu nome estava entre os envolvidos na Revolução de Pernambuco de 1817 como articulador do movimento na Bahia. Em 1821, eleito deputado pela Bahia para as Cortes de Lisboa, tomou posse na Casa Legislativa, a qual abandonou no ano seguinte. De volta ao Brasil, iniciou a publicação do citado jornal em 1823, no Recife; no mesmo ano, recusou tomar assento na Assembléia Constituinte instalada no Rio de Janeiro. Foi preso em 1824 por estar envolvido na Confederação de Pernambuco, sendo finalmente libertado em 1830. Voltou à Bahia, mas no ano seguinte foi novamente encarcerado, depois de ter sido remetido ao Rio de Janeiro, sendo solto em 1834. Mesmo na prisão continuava a publicação, ainda que intermitente, de seu Sentinela. Morreu em Natal para onde se mudara com a família. Uma recente e completa biografia de Barata é o livro de Marco Morel, Cipriano Barata na Sentinela da Liberdade. Salvador, Academia de Letras da Bahia/Assembléia Legislativa do Estado da Bahia, 2001.

${ }^{93}$ Discurso proferido em 19/setembro/1822.

${ }^{94}$ Idem.

${ }^{95}$ Antonio Penalves Rocha, op.cit.

${ }^{96}$ Foram eles Antônio Carlos Andrada Machado, José Ricardo da Costa Aguiar, Cipriano Barata, Francisco Agostinho Gomes, José Lino Coutinho, Antônio Manuel da Silva Bueno e Diogo Antônio Feijó que, abandonando Lisboa de forma irregular, buscaram refúgio na Inglaterra de onde escreveram Manifestos justificando a decisão de abandono das Cortes em outubro de 1822. Ambos os textos foram publicados, na época, pelo Correio Braziliense ou Armazém Literário, vol. XXIX, n.173, novembro/1822, p. 530-539. 
da "nação" e, em decorrência, do "pacto" que deveria se estabelecer de forma soberana, continuaria fortemente presente.

Como vimos, desde fins dos setecentos, as discussões sobre as "Leis Fundamentais" e sobre o "direito pátrio" já apontavam para a urgência na redefinição das bases políticas da unidade portuguesa. Se de início ela pôde ser concebida em termos da manutenção da soberania do monarca, com ênfase na formulação de um Direito Público, a Revolução implantou um distinto paradigma, com a idéia de defesa da supremacia do Legislativo e sobrevalorização dos direitos individuais. No entanto, vale notar que o caráter regalista da leitura oficial do jusnaturalismo racionalista no mundo português teria peso na derrota dos vintistas em 1823, assim como nos primórdios do Império do Brasil. Neste último, os desdobramentos da estratégia usada pela Corte de cruzar os mares, para ao contrário do que acontecera com o vizinho espanhol nunca estar ausente, teria efeitos não só na viabilização da Independência como nos tons de moderação que o regime político brasileiro assumiria desde seu início.

\subsection{O impacto da Revolução do Porto no Brasil, a Independência e a instalação da Assembléia Constituinte de 1823}

Se a eclosão revolucionária em terras portuguesas deve ser entendida como desdobramento da crise do Antigo Regime, os antecedentes mais imediatos desse processo remontam a 1808 com a vinda da Família Real para o Rio de Janeiro. Fato inédito na história da colonização ocidental, a instalação da Corte européia gerou tanto uma revalorização do Brasil no contexto imperial quanto descontentamentos internos das mais diversas ordens. Ao longo da década de 1810, como é sabido, os domínios portugueses no novo continente passaram a desfrutar da condição de Reino (assim elevado em 1815) e o andamento da política joanina não apontava perspectivas de volta da Corte para Lisboa: haja vista que o motivo imediato da partida, Napoleão Bonaparte, já se encontrava derrotado desde 1814 e a Europa num período de relativa paz ${ }^{97}$.

\footnotetext{
${ }^{97}$ Maria de Lourdes Vianna Lyra, A utopia do poderoso Império-Portugal e Brasil: bastidores da política 1798-1822, Rio de Janeiro, Sette Letras, 1994; Maria Odila Dias, op.cit., e Andréa Slemian, op.cit. .
} 
A violência e a radicalidade dos acontecimentos de 1817 em Pernambuco demonstram o nível de tensão interna existente no mundo português ${ }^{98}$. No mesmo ano, uma abortada conspiração militar contra a regência inglesa em Lisboa, supostamente liderada pelo general Gomes Freire Andrade, assustou as autoridades e foi duramente combatida com punição exemplar para os acusados ${ }^{99}$. Sabe-se que por essa época, em Portugal, iniciaram-se articulações políticas com o objetivo de reverter o quadro dos efeitos negativos da viagem da Família bragantina aos trópicos, as quais tiveram um pólo importante na associação fundada no Porto, em janeiro de 1818, conhecida por Sinédrio. Com o intuito de observar a marcha dos acontecimentos, seus membros se reuniam periodicamente para pensar alternativas à crise vivida no Reino e, após a vitória liberal na Espanha em 1820, começaram a agir operacionalmente ${ }^{100}$.

Foi assim que, em agosto daquele ano, às margens do Douro, um movimento encabeçado inicialmente por militares logo obteve apoio de vários segmentos sociais contra o governo joanino no Rio de Janeiro ${ }^{101}$. A defesa da implantação de uma ordem constitucional moderna, realizada em nome de uma "regeneração" da monarquia, afrontava diretamente o sistema vigente e adquiriu, desde seu início, um caráter revolucionário. Com sua rápida difusão pelo território português, e após a solução de algumas dissidências internas, deu-se a instalação da Junta Provisional de Governo em Lisboa, em outubro, a qual procedeu à nomeação de diversas comissões para reforma da administração. Em finais de 1820, esse governo restabelecia a segurança pública interna, regulava a forma das eleições, e elaborava esboços de um texto constitucional que substituísse a Constituição espanhola de Cádiz (1812), então provisoriamente adotada.

As "Cortes Constituintes da Nação Portuguesa" abriram seus trabalhos em janeiro de 1821 e passaram a centralizar as decisões políticas a despeito do governo bragantino do Rio de Janeiro. Tinham por tarefa primordial a elaboração de uma Constituição liberal e já enunciavam uma proposta radical de submissão da autoridade Executiva (monarca) à Legislativa (assembléia). Em março, as Cortes aprovaram o documento das "Bases da

\footnotetext{
${ }^{98}$ István Jancsó e João Paulo Pimenta, op.cit. .

99 Isabel Nobre Vargues, "O processo de formação do primeiro movimento liberal: a Revolução de 1820”, José Mattoso (dir.), História de Portugal. O Liberalismo, Lisboa, Estampa, 1996; Iara Lis Souza, op.cit..

${ }^{100}$ Isabel Nobre Vargues, op.cit..
} 
Constituição Política da Monarquia Portuguesa"102 que, como diretriz dos preceitos que deviam nortear o novo regime, afirmava ser aceito pelos portugueses residentes na Europa e extensíveis aos americanos à medida que estes declarassem sua vontade de adesão.

Em Portugal, mantinha-se a expectativa em relação à aceitação do movimento na América, o qual acabaria por encontrar terreno muito fértil. A primeira Província a aderir foi a do Pará ${ }^{103}$, em $1^{\circ}$ de janeiro de 1821, com a formação de uma Junta Provisória em Belém aos moldes daquelas eleitas na Península e a adoção provisória da Constituição espanhola. No dia 10 do mês seguinte foi a vez da Bahia, atitude que impulsionou sua aceitação por todo o Norte e Nordeste ${ }^{104}$. Com isso, o governo de D. João VI recebia um duro golpe, e viu-se constrangido a ceder diante da resposta que esses acontecimentos suscitaram no Rio de Janeiro. Lá, na madrugada do dia 26 de fevereiro, uma grande agitação das tropas, comerciantes e pequenos proprietários no Largo do Rocio exigiu a submissão do monarca às Cortes, a eleição dos representantes fluminenses para as mesmas, a nomeação de um novo ministério e a partida imediata da Família Real para Lisboa ${ }^{105}$. Cedendo às pressões, o monarca jurou colocar o texto de Cádiz enquanto uma Constituição portuguesa não estivesse pronta.

${ }^{101}$ Sobre o tema ver: Zília Osório de Castro, op.cit.; Valentim Alexandre, op.cit.; Miriam Halpern Pereira (et. alli.), O liberalismo na península ibérica na primeira metade do século XIX. Lisboa, Sá da Costa, 1982, 2 vols.

102 José Joaquim Gomes Canotilho, "As Constituições”, in; José Mattoso (org.), op.cit.. O documento das "Bases" pode ser encontrado na internet no site: www.arqnet.pt/portal/portugal/liberalismo/bases821.html

${ }^{103}$ Geraldo Mártires Coelho, Anarquistas, demagogos e dissidentes. A imprensa liberal no Pará de 1822, Belém, CEJUP, 1993; André Machado, op.cit.

${ }^{104}$ Luis H. Dias Tavares, A independência do Brasil na Bahia, Rio da Janeiro, Civilização Brasileira, Brasília, INL, 1977; e Thomas Wisiak, A nação partida ao meio: tendências políticas na Bahia na crise do Império Luso-brasileiro, São Paulo, Universidade de São Paulo/FFLCH, Dissertação de Mestrado, 2001. Veja-se também: Denis Bernardes, O patriotismo constitucional: Pernambuco, 1820-1822. São Paulo, Universidade de São Paulo/ FFLCH, Tese de Doutoramento, 2002; Argemiro Ribeiro de Souza Filho, A guerra de Independência na Bahia: manifestações políticas e violência na formação do Estado nacional (Rio de Contas e Caetité), Salvador, Universidade Federal da Bahia, Dissertação de Mestrado, 2003.

${ }^{105}$ Os novos ministros nomeados foram: Ignácio da Costa Quintela para a pasta dos Negócios do Reino; Joaquim José Monteiro Torres para a pasta da Marinha e Domínios Ultramarinos; Silvestre Pinheiro Ferreira para a pasta dos Negócios Estrangeiros e da Guerra. Além desses, foram substituídos o presidente do Real Erário e o da Mesa de Consciência, funcionários do mesmo Erário, o Intendente Geral da Polícia, o Comandante do Corpo da Polícia, o general de Armas, o Bispo Capelão Mór, o Inspector Geral dos Estabelecimentos Literários, o diretor do Banco do Brasil, e o presidente da Junta do Comércio. Francisco Adolfo de Varnhagen, História da independência do Brasil, $10^{\circ}$ ed., Belo Horizonte, Itatiaia/São Paulo, Edusp, 1981. 
Com a amplificação das adesões na América, Juntas de Governo ${ }^{106}$ foram eleitas nas várias capitais das Províncias entre os anos de 1821 e 1822 que, mesmo sem a prévia existência de uma regulamentação para seu governo, colocaram-se submissas à nova Casa legislativa instalada em Lisboa. Ficavam funcionando, em terras brasileiras, duas autoridades irreconciliáveis do ponto de vista das Cortes: de um lado as Juntas, que passaram a representar um novo canal de representação política dos interesses da Província; de outro, a Corte bragantina que, com a volta do rei a Lisboa em abril, ficara sob a Regência de D. Pedro sem nenhum regimento que controlasse suas ações. Daí, surgiria um foco de tensão no equacionamento dos poderes que o pacto constitucional em construção teria de resolver.

A eclosão do constitucionalismo na América portuguesa abriria um amplo espaço de instabilidade política ao criar possibilidades e expectativas de transformação da ordem política, e mesmo social, marcado por violenta disputa de poder nas localidades onde os agentes foram incitados a, cada vez mais, tomarem parte ativa na cena pública. Esse era o quadro em todo o território português e, já há uma década, no hispano-americano. A formação das Juntas foi, dessa maneira, um processo permeado de tensões das mais diversas ordens, sendo comum que vilas se negassem à sua autoridade ${ }^{107}$, além das tentativas de formação de outras que não fossem nas denominadas capitais ${ }^{108}$. O pano de fundo desses conflitos era a rearticulação dos espaços de poder que, tendo em vista o modelo de um Estado liberal, investia nas esferas provinciais em detrimento das Câmaras.

Nas Cortes, a chegada de deputados das Províncias do Brasil foi, pouco a pouco, pondo a nu a dificuldade da reformulação da unidade portuguesa num contexto constitucional, conforme anunciamos anteriormente. Por trás das desavenças, estavam interesses bem concretos de negociantes de grosso trato, daqueles ligados ao comércio de cabotagem e abastecimento do Centro-Sul, de produtores e de servidores e funcionários ligados à Corte do Rio de Janeiro, os quais haviam se beneficiado com a proximidade do

\footnotetext{
106 Também chamadas à época de "Juntas Provisórias", “Governos Temporários Administrativos” ou "Juntas Provisionais".

107 Vejam-se vários casos relatados na correspondência das Juntas; (Arquivo Nacional) As Juntas Governativas e a Independência, Rio de Janeiro, Arquivo Nacional, Conselho Federal, 1973, 3v.

108 Argemiro Ribeiro de Souza Filho, op.cit., cita o caso de uma Junta instalada no Rio das Contas no sertão da Bahia, em 1822, a despeito do Conselho Interino instalado em Cachoeira em nome da Província. Em Itapicuru, no Maranhão, ocorreu formação semelhante em 1824. ANRJ, Negócios de Províncias, I JJ 553.
} 
monarca após 1808 , e que defendiam a permanência de D. Pedro ${ }^{109}$. Foram eles que, primeiramente, apoiaram a desobediência do Regente às Cortes, quando do "Fico" em janeiro de 1822, dando forma a um discurso que imputava às Cortes um "projeto recolonizador" do Brasil ${ }^{110}$. E embora estivesse subjacente à defesa da continuidade da América como Reino Unido a manutenção da posição privilegiada do Centro-Sul, representantes de outras Províncias do continente puderam vê-la com bons olhos à medida que os portugueses da Europa mantinham-se reticentes aos posicionamentos mais autonomistas de algumas de suas bancadas, sobretudo a da Bahia.

$\mathrm{Na}$ busca de uma solução para essa crescente tensão, o herdeiro dos Braganças aprovou, em 16 de fevereiro, por ação do ministro José Bonifácio de Andrada e Silva, a convocação de um Conselho de Procuradores das Províncias na cidade carioca, o qual teria por intuito avaliar a Constituição que se fazia em Lisboa segundo condições e interesses americanos. A medida foi alvo de grande controvérsia e o cenário de acirrada disputa política existente no Rio de Janeiro fez que ela fosse substituída, em 3 de junho de 1822, por um outro decreto prevendo a instalação de uma Assembléia Legislativa, vulgarmente chamada de "Cortes do Brasil"111. Ainda se acreditava que a formação de um braço legislativo na América pudesse reforçar uma unidade de propósitos constitucionais com seu congênere lisboeta. No entanto, essa unidade já estava posta em xeque, e até os Governos Provisórios provinciais demonstravam posicionamentos variados tanto em relação às decisões tomadas na urbe fluminense, quanto à sua própria regulamentação definida pela Assembléia lisboeta.

Em 10 de junho de 1822, a Junta instalada no Maranhão escrevia ao ministro Bonifácio afirmando não poder cumprir o decreto de 16 de fevereiro para eleição de um procurador na Província "sem ordens das Cortes, a cujas Soberanas Autoridades" ela havia jurado "fidelidade e obediência"112. No dia seguinte, era a vez do Governo do Pará fazer o mesmo, sob justificativa de que não reconhecia "outro centro de Poder Legislativo, e

\footnotetext{
${ }^{109}$ Alcir Lenharo, op.cit.; Cecília Helena de Salles Oliveira, A astúcia liberal. Relações de mercado e projetos políticos no Rio de Janeiro (1820-1824), Bragança Paulista, Edusp/Ícone, 1999.

${ }^{110}$ Márcia R. Berbel, "A retórica da recolonização", in: István Jancsó (org.), Independência: história e historiografia, pp. 791-808.

${ }^{111}$ É sabido que enquanto alguns setores da sociedade política carioca, reconhecidos pela historiografia como "liberais", defendiam a instalação de uma Assembléia Legislativa no Brasil, José Bonifácio e grupos mais conservadores apostavam na formação de um Conselho de Procuradores como forma de representação das Províncias. Sobre isso ver: Cecília Helena de Salles Oliveira, op.cit..
} 
Executivo que não seja o residente no Soberano Congresso Nacional em Portugal" "113. Ambas as Juntas mantinham solidariedade também com a do Piauí, como ficou documentado na correspondência que trocaram entre si em que reiteravam a fidelidade a um único centro comum: Lisboa. A da Bahia, em agosto, também negava obediência aos decretos vindos do Rio, mesmo sem contato direto com as Juntas do Norte. Como se sabe, após a formalização da Independência entre setembro e outubro, esses Governos se manteriam fiéis a Portugal e só seriam vencidos mediante a utilização de força militar arregimentada pelo Imperador. Com a iminência de uma guerra, os piauienses, em janeiro de 1823, enviavam um ofício ao Rio em que pediam que não lhes enviassem tropas pela opção política que faziam em nome dos "direitos dos povos". Justificavam que "a situação natural desta Província (e das duas mais que lhe ficam no Setentrião) lhe promet[ia]m maiores vantagens da sua união com a Corte de Portugal, que com a do Rio de Janeiro", sendo a "sua correspondência" "muito mais fácil com a primeira, por intermédio do Maranhão, que com a segunda, pelo da Bahia". Além disso, afirmavam que "suas produções sem consumo, e de dificílima exportação para o Rio de Janeiro, e vice-versa, lhe torna[va]m ainda mais difícil a comunicação com a Corte, e mais ociosa a união com a mesma" 114 .

Com os conflitos que se abriram nas localidades a partir da adesão ao movimento vintista, a necessidade de maior regulamentação dos poderes das Juntas era imediata ${ }^{115}$. A lei que as criara, aprovada em Lisboa em 29 de setembro de 1821, acabou por gerar adaptações e críticas à forma de seu funcionamento. A principal delas estava na divisão das atribuições com o governo lisboeta, e tomou corpo após a decisão de D. Pedro de permanecer no Rio explicando-se, em parte, pelo anseio de que sua estada se desdobrasse em uma maior autonomia das Províncias do Brasil perante Portugal. Em ofício datado de 18 de março de 1822, a Junta de Pernambuco acusava o citado decreto das Cortes de querer

\footnotetext{
${ }^{112}$ As Juntas Governativas e a Independência, pp.59-60.

${ }^{113}$ Idem, p.5.

${ }^{114}$ As Juntas Governativas e a Independência, p.212.

115 Idem. Várias Juntas escreveram ao governo do Rio de Janeiro para que se deliberasse, o mais rápido possível, sobre a forma dos seus governos. Ver exemplos na correspondência do Ceará e do Pará que eram as mais incisivas acerca da questão. Essa última, em janeiro de 1823, escreveu para o governo do Maranhão comunicando a decisão de pedir ao "Soberano Congresso, que se estabele[cesse] provisoriamente em qualquer das referidas Províncias uma Delegação do Poder Executivo legislada pela Constituição da Monarquia, por ser este o meio mais próprio, e único talvez de acalmar a agitação dos Povos" (p.21) (grifo meu).
} 
tirar "toda a força, e energia da província" e promover o "divide et imperas" ao propor "um Governo de Armas, uma Junta da Fazenda, um Comandante de Marinha, uma Administração de Justiça com Chefes nomeados pelo Governo Executivo independente do Governo da Província"116. A reclamação era para que as autoridades das Províncias tivessem um papel ativo nessas instâncias.

O mesmo Governo pernambucano, quatro meses depois, escrevia um outro ofício ao Rio de Janeiro defendendo que a Junta da Fazenda deveria "considerar-se subordinada em todos os respeitos à Junta do Governo da Província”, e que "um dos membros desta [fosse] Presidente daquela". Afirmava que tinha encaminhado pedido semelhante a D. João VI, do que reclamava ter recebido um "ignominioso desprezo". A negociação era explícita: reconhecia-se a "necessidade de união das Províncias do Brasil entre si para melhor sustentarem seus direitos", ou seja, apoiava-se D.Pedro, mas reivindicava-se um controle interno dos assuntos da Província ${ }^{117}$.

A Junta de Minas Gerais se pronunciara de forma ainda mais incisiva em abril de 1822. Ao escrever para o ministro José Bonifácio, ponderava os "graves inconvenientes, que resultariam dos novos Governos com diferentes poderes, e independentes", e afirmava já manter uma "liga" com a província de São Paulo no sentido da "suspensão dos mencionados decretos" lisboetas e de "verificar-se o centro da união das Províncias em S.A.R [D.Pedro], e o poder executivo das mesmas"118. A mesma Junta mostrava assim estar afinada com as proposições do Rio de Janeiro na defesa do Príncipe no Brasil, e sua justificativa - do temor que os povos vissem na medida "ameaças de receber de novo os ferros do anterior despotismo dos Governadores e Capitães Generais" - afinava-se perfeitamente com o discurso da "recolonização" já amplamente ventilado no Rio de Janeiro.

Ainda assim, no mesmo ofício, o Governo mineiro criticava o decreto de 16 de fevereiro para convocação de um Conselho de Procuradores Gerais por acreditar que nele os "Poderes Legislativo e Executivo se un[ia]m, e [se] confund[ia]m contra as Bases da Constituição", fornecendo faculdades ilimitadas aos citados cargos. Ao final, fazia um

\footnotetext{
${ }^{116}$ As Juntas Governativas e a Independência, p.661.

${ }^{117}$ Idem, pp.671-72.

118 "Correspondência oficial do Governo Provisório de Minas (1821-1824)", 22/março/1822, Revista do Archivo Publico Mineiro, pp. 615-620. Sobre a mesma crítica ver As Juntas Governativas e a Independência, correspondência de 22 de março de 1822 (Minas Gerais, pp.41-2).
} 
longo questionamento acerca do que estaria no rol de suas atribuições e, partindo da premissa de que à Província "compet[iria] a autoridade, e jurisdição na parte Civil, Econômica, Administrativa e de Polícia”, conforme o artigo $6^{\text {o. }}$ do referido decreto de regulamentação, pedia esclarecimentos sobre sua esfera de ação ${ }^{119}$.

Nas Cortes, deputados de Províncias do Brasil mostravam estar atentos a essas reivindicações. Cipriano Barata, no momento em que defendia "Cortes no Brasil", reproduzia idêntica reclamação que se fazia na América em relação à instituição das Juntas: "os povos do Brasil, escrevem, queixando-se daqueles decretos, como os que tem desorganizado as Províncias; eles clamam que tirar das Juntas administrativas a autoridade sobre o Governo das Armas, e Junta da Fazenda, é a origem primária de todas as desordens"

A questão da jurisdição sobre a Fazenda - até então delegada às respectivas Juntas criadas em fins dos setecentos como forma de racionalizar os ganhos da coroa e, por isso, subordinadas ao Real Erário - era, sem dúvida, um dos pontos sobre os quais os novos governos locais almejavam ter controle. Nesse sentido, é sintomático que logo no início de seus trabalhos legislativos, em junho de 1821, o Governo Provisório de São Paulo tenha determinado que se exigisse "com a possível brevidade o Balanço exato e circunstanciado do estado atual dos Cofres" que a Junta deveria continuar a fornecer "todos os meses ao Governo" 121 . Decidia também que "todas as Portarias do Erário do Rio de Janeiro não [fossem] cumpridas pela Junta da Fazenda sem que primeiro se lhes seja posto o cumpra-se por este Governo" "122. Sabe-se também que, após a Independência, alguns Governos Provisórios deliberaram que um dos seus membros fosse presidir a Junta da Fazenda, conforme ocorrido na Paraíba e no Ceará, com o argumento de ser "antipolítica" a separação entre ambos oriunda do "desorganizador sistema das Cortes de Portugal",

Outro ponto que incomodou profundamente as Juntas dizia respeito à autoridade do Comandante de Armas que, declarada independente dos governos provinciais, já suscitara a crítica de representantes do Brasil na Casa legislativa. A indisposição com a medida era

\footnotetext{
${ }^{119}$ Idem.

120 Diário das Cortes Gerais e Extraordinárias da Nação Portuguesa, disponíveis na Internet: Www.debates.parlamento.pt, discurso proferido em 19/setembro/1822.

${ }^{121}$ Actas do Governo Provisório de 1821 a 1822, São Paulo, Archivo do Estado de S. Paulo/ Typographia da Companhia Industrial de São Paulo, 1894, pp. 10-11.

${ }^{122}$ Idem, p.11.
} 
reforçada pelo temor do envio de tropas portuguesas ao Brasil com o intuito de sufocar dissidências, como de fato chegou a acontecer no Norte. Várias foram as manifestações das Juntas contrárias a ela, cuja intensidade da crítica variou de acordo com os conflitos desencadeados em cada localidade. Na Paraíba, em outubro de 1822, em razão do nível de tensão que punha em descrédito a autoridade da Junta, seus membros afirmavam ser os Governos Provisórios "inermes" e a força armada estar "cometida a uma outra Autoridade independente": "sendo todo o Povo da Província Tropa ou da primeira, ou da segunda, ou da terceira Linha; e sendo todas três imediatamente sujeitas aos Governos das Armas independentes, quem resta[va] à obediência, e subordinação dos Provisórios?" ${ }^{\text {"124 }}$.

Desta forma, pode-se afirmar que muitas das Províncias realmente viam com bons olhos um alinhamento com a Corte do Rio de Janeiro que, ao longo do ano de 1822, constituiu-se numa das oposições ao projeto predominante nas Cortes lisboetas. Que isso poderia interessar aos grupos hegemônicos locais, à medida que significasse maior autonomia no controle de seus negócios internos, era certo. Partindo da premissa que a Independência, declarada em 1822 por D. Pedro, surgiu do impasse que se instaurou quando tiveram de ser repensados os vínculos político-institucionais entre Brasil e Portugal numa ordem política constitucional, a adesão das Províncias ao Rio de Janeiro no mesmo ano tanto ajudou no malogro da unidade portuguesa como lançou ao novo Império um manancial multifacetado de expectativas quanto ao novo Estado e seu funcionamento. Muitas das fichas foram jogadas no trabalho das "Cortes" na América, das quais, como afirmavam os membros da Junta do Rio Grande do Norte, esperava-se "em silêncio o remédio" dos males que a afligiam "logo que se instalasse a Assembléia Geral Constituinte e Legislativa do Brasil"125.

A Assembléia Legislativa e Constituinte do Império do Brasil iniciou seus trabalhos em 3 de maio de 1823, em cumprimento à palavra de D. Pedro de que manteria a sua convocação após a Independência. Na época, Bahia, Pará, Maranhão e a Província

\footnotetext{
${ }^{123}$ As Juntas Governativas e a Independência, ofício de 17/abril/1823.

${ }^{124}$ Idem, 14/outubro/1823, p.593.

${ }^{125}$ Idem, 25/junho/1823, p.500.
} 
Cisplatina encontravam-se em guerra entre forças que almejavam a continuidade da união com Portugal e aquelas que defendiam a adesão ao governo do Rio de Janeiro. Os deputados foram eleitos de acordo com Instruções elaboradas pelo ministro do Império, José Bonifácio de Andrada e Silva que, valendo-se das informações do Censo levantado em $1819^{126}$, aumentou o número de representantes por Província em relação às Cortes de Lisboa. Bonifácio defendeu que os deputados não poderiam ser, ao todo, menos de 100. Mesmo assim, a Casa foi aberta com pouco mais da metade do número dos deputados esperados, já que muitos representantes chegariam nos meses seguintes, enquanto alguns nem tiveram tempo para tomar parte dela (ver tabela Tabela) ${ }^{127}$. Para sua abertura, valeu o princípio da maioria mais um, embora o mesmo viesse a ser questionado posteriormente.

Tabela: Número de deputados por Província na Assembléia Legislativa e Constituinte de 1823

\begin{tabular}{l|llll} 
Províncias & $\begin{array}{l}\text { Cadeiras } \\
\text { Propostas }\end{array}$ & $\begin{array}{l}\text { Cadeiras } \\
\text { Ocupadas }\end{array}$ & Suplentes & $\begin{array}{l}\text { Deputados não } \\
\text { substituídos }\end{array}$ \\
\hline Alagoas & 5 & 4 & - & 1 \\
Bahia & 13 & 11 & 3 & - \\
Ceará & 8 & 7 & - & 1 \\
Cisplatina & 2 & - & - & - \\
Espírito Santo & 1 & 1 & - & - \\
Goiás & 2 & 1 & - & - \\
Maranhão & 4 & - & - & - \\
Mato Grosso & 1 & 1 & - & - \\
Minas Gerais & 20 & 20 & 4 & - \\
Pará & 3 & - & - & - \\
Paraíba & 5 & 4 & - & 1 \\
Pernambuco & 13 & 12 & 2 & 1 \\
Piauí & 1 & - & - & - \\
Rio de Janeiro & 8 & 8 & 2 & - \\
Rio Grande do Norte & 1 & 1 & 1 & - \\
Rio Grande do Sul & 3 & 4 & - & - \\
Santa Catarina & 1 & 1 & - & - \\
São Paulo & 9 & 9 & 3 & -
\end{tabular}

\footnotetext{
${ }^{126}$ Censo levantado pelo desembargador Antônio Rodrigues Veloso de Oliveira encontrado nos Annaes Fluminenses de Sciencia (1822), Revista do Instituto Histórico e Geográfico Brasileiro, Rio de Janeiro, n.29, parte 1, pp. 159-9. As Instruções de José Bonifácio datam de 19 de junho de 1822, e foram transcritas por José Honório Rodrigues, A Assembléia Constituinte de 1823, Petrópolis, Vozes, 1974, pp. 292-9.

${ }^{127}$ Segundo José Honório Rodrigues, op.cit., a média de comparecimento dos deputados em plenário é de: 50 para os meses de maio e junho; de 50 a 60 no mês de julho; de 60 a 70 em agosto; e de 70 para os meses de setembro, outubro e novembro.
} 
\begin{tabular}{l|lrrr}
100 & 84 & 15 & 5
\end{tabular}

Fonte: Inventário analítico do Arquivo da Assembléia Geral Constituinte e Legislativa do Império do Brasil - 1823. Brasília, Câmara dos Deputados/Coordenação de Publicações, 1987, p.43.

Antes de iniciados os trabalhos regulares, existiram cinco sessões preparatórias em que regras e formalidades sobre o funcionamento da Assembléia começaram a ser discutidas. Foi quando se nomeou uma Comissão para elaboração de um regimento provisório, cuja discussão se desdobraria em várias sessões ao longo do ano, não havendo tempo suficiente para que fosse completamente aprovado. Apesar de a Assembléia ter sido abortada, o trabalho legislativo por ela produzido não pode ser ignorado. Sem contar o regimento e o Projeto de Constituição, cuja discussão iniciou-se em 15 de setembro, foram apresentados 38 Projetos de Lei, além de centenas de propostas, indicações e pareceres das Comissões instaladas. Os que chegaram a ser aprovados como leis foram seis: um sobre a vigência da legislação que regia o Brasil até abril de 1821, outro sobre a revogação do decreto de 16 de fevereiro de 1822 que criara o Conselho de Procuradores, o seguinte para estabelecimento da forma como deveria ser observada a promulgação dos decretos da Assembléia, outro acerca da proibição aos deputados de exercerem qualquer outro emprego durante sua deputação (ou aceitassem qualquer graça), outro para revogação do alvará de 30 de março de 1818 que proibia o funcionamento das Sociedades Secretas, e um último para criação de uma nova forma para o governo das Províncias ${ }^{128}$. Alguns outros que tiveram intenso debate por tocarem em matérias caras à época não chegaram a alcançar o status de lei. Entre estes se destacam o projeto para naturalização dos portugueses apresentado pelo pernambucano Francisco Muniz Tavares em 22 de maio, o da liberdade de imprensa (temática amplamente discutida em muitos momentos), a proposta para criação de uma universidade de autoria de José Feliciano Fernandes Pinheiro, e também a Indicação de José Resende Costa sobre a arrematação da fazenda dos defuntos e ausentes apresentada em 4 de julho. Além disso, o trabalho das Comissões que funcionaram ativamente ao longo de todo o ano (sendo as mais importantes as de colonização, comércio, eclesiástica, estatística e diplomacia, fazenda, guerra, poderes, política, interna, saúde pública, redação do Diário e das leis), contemplou uma imensa variedade de assuntos.

\footnotetext{
128 Todos aprovados como leis em 20 de outubro de 1823. Ver: Coleção das Leis do Império do Brasil de 1823, Rio de Janeiro, Imprensa Nacional, 1887. Também disponível na Internet no site: www2.camara.gov.br/legislacao/
} 
Uma novidade que tomou forma no espaço da Assembléia foi a exposição de um amplo relatório da situação da Fazenda, feita pelo então ministro e também deputado Manuel Jacinto Nogueira da Gama ${ }^{129}$ (inicialmente proposta para ser apresentada em sessão secreta, foi logo aprovada sua leitura pública), em 6 de outubro. A questão da falta de numerário já era antiga, sendo que, logo após a Independência, D. Pedro nomeara uma Comissão para sindicar o estado do Tesouro e dar seu parecer ${ }^{130}$. Novamente se apontava o problema das "sobras" das Províncias que não chegavam à Corte, já que a renda imperial era praticamente limitada às receitas do Rio de Janeiro. Na Fala do Trono que abriu os trabalhos constituintes, o Imperador colocou a questão em tons dramáticos, afirmando que "as circunstâncias do Tesouro público eram as piores possíveis", para o que pedia urgentes medidas legislativas ${ }^{131}$. Situação essa que justificaria a contratação de um empréstimo financeiro com os ingleses. No citado relatório, o ministro confirmara os problemas e se referia também à imensa dificuldade em se tratar da matéria em razão da quase inexistência de dados organizados nas próprias Províncias. A Casa legislativa faria esforços para essa sistematização não apenas no que toca à Fazenda, mas em várias áreas, expedindo recorrentes solicitações de informações aos governos locais. Por causa da interrupção dos trabalhos da Casa no mês seguinte, e da atenção aos trabalhos de discussão do Projeto de Constituição, pouco se discutiria a seu respeito.

Portanto, tensões das mais diversas ordens foram inerentes aos trabalhos da Assembléia Constituinte em função do nível dos problemas que pretendia resolver. Mas foi, sobretudo, a partir de julho que elas se intensificaram em função do acirramento das disputas internas presentes entre a Casa e o governo. Em 16 de julho, deu-se a renúncia de José Bonifácio e Martim Francisco de Andrada dos Ministérios do Império e da Fazenda, respectivamente, os quais passaram a fazer oposição ao novo gabinete, na imprensa e também na condição de deputados eleitos juntamente com seu outro irmão, Antônio Carlos.

\footnotetext{
${ }^{129}$ Nascido em São João d’El Rei (1765), Nogueira da Gama ligou-se pelo casamento a duas famílias ricas e importantes na política: sua mulher era filha de Braz Carneiro Leão e de Ana Francisca Maciel da Costa. Doutorou-se em Matemática e Filosofia pela Universidade de Coimbra, tendo sido temporariamente lente da Real Academia de Marinha de Lisboa. Foi eleito deputado à Constituinte pelo Rio de Janeiro, e nomeado para Ministro da Fazenda em três ocasiões distintas: 1823, 1826 e 1831. Em 1826 foi indicado senador por Minas Gerais, e chegou a ser presidente do Senado. Recebeu vários títulos, entre eles, o de Marquês de Baependi.

${ }^{130}$ Ver a transcrição do relatório em Liberato de Castro Carreira, op.cit., pp. 100 e seg.

${ }^{131}$ Fala do Trono de 3 de maio de 1823. Todas as discussões aqui reproduzidas foram consultadas pelo Diário da Assembléia Geral, Constituinte e Legislativa do Império do Brasil- 1823 [DAG] (edição fac-
} 
No dia seguinte, o Imperador escolheu os também deputados José Joaquim Carneiro de Campos para a pasta do Império ${ }^{132}$, e Manuel Jacinto Nogueira da Gama para a da Fazenda ${ }^{133}$. Ainda em julho, começaram a adentrar a Casa os deputados baianos que, após a "pacificação" da região, vinham ocupar suas vagas ${ }^{134}$. A postura crítica que alguns desses trariam na bagagem intensificaria ainda mais o debate, haja vista que estava em pauta exatamente o projeto para regulamentação dos Governos das Províncias.

Sabe-se que na antevéspera da decisão pelo fechamento da Casa, dia 10 de novembro, sua situação interna chegou às raias de incontrolável. Antes de se iniciar a ordem do dia, os deputados aprovaram que o "povo" que não cabia mais nas galerias poderia adentrar a sala e permanecer no recinto atrás das cadeiras dos representantes. Essa foi a proposta do padre José Martiniano Alencar ${ }^{135}$, que venceu não sem os enfáticos protestos de José da Silva Lisboa. Assim, a sala ficou repleta. Um tempo depois, foi anunciado pelo ministro da Marinha, Luis da Cunha Moreira, que quatro de seus colegas haviam pedido demissão e que D. Pedro já os substituira ${ }^{136}$. Em razão da intensa

similar), Brasília, Senado Federal, 1973, 3v., também disponíveis na internet no endereço: Www.camara.gov.br

$\overline{132}$ José Joaquim Carneiro de Campos (1768-1836) era natural da Bahia, filho de negociante baiano, formouse em Teologia e Direito pela Universidade de Coimbra. Voltou para o Brasil em 1807, sendo nomeado oficial maior do secretário dos Negócios do Reino. Em 1818 passou a pertencer ao conselho de D. João VI. Depois da Independência, elegeu-se deputado pela província do Rio de Janeiro como suplente de Gonçalves Ledo, sendo Ministro nos anos de 1823, 1826 e 1829. Integrou o Conselho de Estado. Quando D. Pedro renunciou, ocupou o cargo de regente do Império. Alcançou vários títulos, entre os quais o de Marquês de Caravelas.

133 Os outros integrantes do gabinete de 17 de julho de 1823 continuaram os mesmos: no Ministério da Marinha, Luis da Cunha Moreira, depois Marquês do Cabo-Frio; no da Guerra, João Vieira de Carvalho, depois Marquês de Lages; e no da Justiça, Caetano Pinto de Miranda Montenegro, depois Marquês da VilaReal da Praia Grande.

${ }^{134}$ Vale lembrar que esses haviam sido eleitos sob ordem do governo de Cachoeira porque Salvador, até meados de 1823, esteve sob o domínio de grupos que queriam permanecer unidos à Portugal.

135 José Martiniano Alencar (1798-1860) era natural do Crato, Ceará. Como padre, participara ativamente da Revolução de Pernambuco de 1817. Em 1821, foi eleito deputado suplente pelo Ceará para as Cortes de Lisboa, e como o titular José Inácio Gomes Parente não compareceu por motivos de saúde, Alencar foi chamado à Casa legislativa, onde adentrou em 1822. Após a Independência, foi eleito representante pela mesma Província para a Assembléia Constituinte de 1823. Foi novamente eleito deputado, agora pela Província de Minas Gerais, para a $2^{\mathrm{a}}$. legistura que se iniciou em 1830. Permaneceu no cargo até o ano seguinte quando foi escolhido, pelo Ceará, para senador do Império. Foi por duas vezes Presidente da sua Província natal, entre os anos de 1834-37 e 1840-41.

${ }^{136}$ Os novos ministros eram Francisco Villela Barbosa para o Império e Estrangeiros, Clemente Ferreira França para a Justiça, Sebastião Luiz Tinoco da Silva para a Fazenda, e José de Oliveira Barbosa para a Guerra. 
manifestação da platéia que lotava a sala ${ }^{137}$, o então presidente da sessão, Severiano Maciel da Costa $^{138}$, suspendeu os trabalhos daquele dia.

No dia seguinte, o número de deputados caiu de 75 para 64, numa prova evidente do receio que predominava entre eles. Antônio Carlos de Andrada, sob a alegação de que "o Mundo nos vê; a Nação nos escuta"139, ${ }^{\circ}$ logo fez uma Indicação para que eles se declarassem em "sessão permanente" até que obtivessem de S.M.I. os motivos de "tão extraordinário movimento de tropas" com que a cidade amanhecera. A partir de então, o clima de tensão chegava ao seu limite. Após a leitura de um ofício em que o ministro do Império explicava o posicionamento das tropas em decorrência aos rumores que atacavam "a honra particular de S.M.I.", a maioria dos deputados votou pela nomeação de uma Comissão especial para avaliar o caso em função da urgência da matéria. Esta aprovou a continuidade da sessão permanente até que mais esclarecimentos fossem dados.

Os mesmos chegariam à uma hora da manhã, quando S.M.I. responderia existir "uma crise" na capital, acusando os periódicos atribuídos aos irmãos Andradas de serem seus grandes fomentadores. A Comissão tentou remediar o clima nervoso propondo que se suspendesse, num primeiro momento, a discussão do Projeto de Constituição para se concluir a lei sobre a liberdade de imprensa, já que o governo a via como uma questão tão danosa. No dia seguinte, 12 de novembro, logo pela manhã, o ministro Francisco Villela Barbosa foi submetido a uma verdadeira sabatina na Casa, o que não contribuiu para acalmar os ânimos. Em seguida, chegou a notícia de que o herdeiro dos Braganças, por decreto, mandara suspender os trabalhos constituintes. Como "Imperador e Defensor Perpétuo do Brasil", afirmava que tanto tivera "o direito" de convocá-la como agora de "dissolver e convocar já uma outra na forma das instruções feitas", a qual "ser[ia] duplicadamente mais liberal do que a extinta". Justificava sua atitude pela "conhecida

\footnotetext{
${ }^{137}$ Nesse dia, esteve em discussão o controverso caso de espancamento do boticário David Pamplona, que o periódico $O$ Tamoyo então noticiava ter sido obra de "portugueses" contra os "do Brasil", assim contribuindo para intensificar os ânimos no Rio de Janeiro após a Independência.

138 João Severaino Maciel da Costa (1769-1833) era natural de Mariana, Minas Gerais. Foi formado em Coimbra, e depois exerceu a função de Desembargador do Paço do Rio de Janeiro. Entre os anos de 1809-10, ocupou o cargo de governador da Guiana Francesa. Acompanhou D. João VI a Portugal em 1821, e depois retornou ao Brasil sendo eleito deputado para a Assembléia Constituinte de 1823 por Minas Gerais. Ocupous duas vezes o lugar de Ministro, em 1824 (Império), e 1826 (Fazenda e Estrangeiros). Em 1826, foi indicado senador pela Província da Paraíba. Integrou o Conselho de Estado na qualidade de conselheiro efetivo desde 1824. Ocupou o cargo de presidente da Província da Bahia em 1825. Ligou-se por casamento à família Werneck, cujos membros eram fazendeiros importantes radicados em Vassouras, região cafeicultora carioca.

${ }^{139}$ DAG, sessão de 11/novembro, p. 395.
} 
facção que dominava aquele Congresso" e necessidade de fazer a "justa distinção entre os beneméritos que sempre tiveram em vista o bem do Brasil, e os facciosos que anelavam

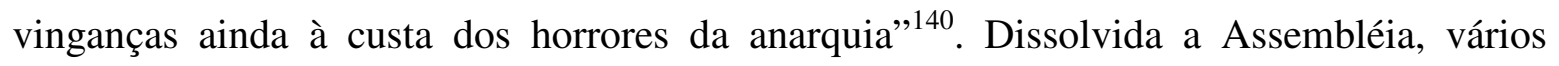
deputados foram presos, inclusive os três Andradas que logo partiram para a França em exílio.

O desfecho dos trabalhos da Assembléia, que pode ser acompanhado em detalhes nos Diários, bem como os enfáticos posicionamentos de Antônio Carlos contra as acusações feitas a ele e a seus irmãos, foram responsáveis pela sobrevalorização, que se fez desde à época, do papel dos Andradas no fechamento da Casa ${ }^{141}$. No entanto, a ênfase na participação individual dos mesmos foi sendo criticada por análises que, também desde o século XIX, recuperaram a importância da obra constituinte de $1823^{142}$. Trabalhos específicos sobre a Constituinte só vieram a ser novamente escritos entre os anos 1960 e

${ }^{140}$ Respectivamente, decretos de 12 e 13 de novembro de 1823; Coleção das Leis do Império do Brasil de 1823, Rio de Janeiro, Imprensa Nacional, 1887.

${ }^{141}$ A idéia de que teriam sido os Andradas (Antônio Carlos, José Bonifácio e Martim Francisco) os principais responsáveis pelas polarizações das discussões e, no limite, pelo fechamento da Casa legislativa ${ }^{141}$, já pode ser vista na obra do contemporâneo inglês John Armitage, História do Brasil, Belo Horizonte, Itatiaia/ São Paulo/Edusp, 1981, que escreveu poucos anos depois do seu fechamento. Como forma de defesa pessoal, os próprios Andradas fomentaram essa interpretação, justificando que sua ascendência positiva entre o "povo", que os "apelidava de Pais da Pátria", teria sido o motivo do golpe mobilizado por seus inimigos (conforme afirmou José Bonifácio, "A dissolução da Assembléia foi mais que um crime....", Miriam Dolhnikoff (org.), José Bonifácio de Andrada e Silva, Projetos para o Brasil, São Paulo, Companhia das Letras, 1998, p. 212). Francisco de Adolfo Varnhagen, História da independência do Brasil. Belo Horizonte, Itatiaia; São Paulo, Edusp, 1981, segue caminho semelhante reforçando a oposição que os mesmos teriam desempenhado após a deposição de Bonifácio e Martim Francisco do ministério. Outros autores, vinculados a uma historiografia mais tradicional, levaram avante esta idéia, como Pedro Calmon, História do Brasil, Rio de Janeiro, José Olympio, 1959 e Hélio Vianna, História do Brasil, São Paulo, Melhoramentos, 1961-2.

${ }^{142}$ Um dos pioneiros na recuperação do valor da Assembléia foi Francisco Inácio Marcondes Homem de Mello (Barão Homem de Mello), A Constituinte perante a história (1863), Brasília, Senado Federal, 1996, que se insere na crítica à "versão saquarema" da história feita pelos liberais desde a década de 1860, valorizando o trabalho dos primeiros constituintes em detrimento da figura do Imperador e da monarquia. Criticando duramente $o$ ato da dissolução, ele lançou a tese de que a principal oposição na Casa teria se dado entre os parlamentares e D. Pedro, o qual não estaria habituado a aceitar interferências no seu governo. Vale notar que quando essa obra veio a lume, o conhecido José de Alencar, um conservador afeiçoado a defender a causa do trono, tivera uma polêmica com seu autor no Jornal do Commercio. Esse último sairia em defesa da atuação de D. Pedro no momento da dissolução, sob o argumento de que a Assembléia Constituinte exorbitara, abusando de seus poderes. Ver análise sob os vários julgamentos da Constituinte em Paulo Bonavides e Paes de Andrade, História Constitucional do Brasil, $3^{\mathrm{a}}$ ed., Rio de Janeiro, Paz e Terra, 1991. Num outro contexto, e na rasteira da valorização do passado ibérico realizado por Oliveira Lima, vale destaque a interpretação positiva da experiência da Assembléia feita por João Camilo de Oliveira Torres, $A$ democracia coroada (teoria política do Império do Brasil), Rio de Janeiro, Typ. Jornal do Comércio, 1957. Escrita na década de 1950, seu autor enaltecia o legado da monarquia na construção política-institucional do Império, a qual afirmava ter formado uma verdadeira democracia debaixo do bem pensado equilíbrio de poderes estabelecido desde a Carta de 1824. Sobre a historiografia, ver Wilma Peres Costa, "A Independência 
1970, e não foram portadores de interpretações genuinamente originais ${ }^{143}$, haja vista a aura de continuidade conservadora que a historiografia, de cepa mais crítica, então atribuía ao processo de emancipação ${ }^{144}$. Com a renovação dos estudos do "político" no campo da historiografia em nível mundial desde os anos 1980, a temática vem cada vez mais sendo revisitada no Brasil, informando novas abordagens sobre a matéria.

Desta forma, o que se sabe hoje acerca das relações políticas no âmbito da Assembléia nos permite dizer ser impossível reduzi-las a uma luta encabeçada pelos irmãos Andradas, ou mesmo entre D. Pedro de um lado e os parlamentares de outro, que teria levado o primeiro a encerrar, de forma "despótica", os trabalhos constituintes. Interpretações recentes lançam novas luzes sobre o problema. Maria de Lourdes Vianna Lyra distingue duas posições centrais, não excludentes, entre as quais os representantes de 1823 teriam gravitado: de um lado, aqueles que apoiavam o Imperador e a centralização política com a união de todos os territórios americanos de colonização portuguesa, com a supremacia do poder Executivo; de outro, os representantes de grupos "minoritários" desvinculados da Corte, especialmente os regionais (mas não apenas), que lutavam pela adoção de um sistema representativo pleno, com a preponderância do poder Legislativo num maior controle da autoridade do Imperador e seus ministros, bem como no estabelecimento de um sistema de autonomia provincial ${ }^{145}$.

Lúcia Maria Bastos Neves aponta uma distinção entre duas tendências de pensamento e ação que muito se assemelha à de Lyra, a partir de uma análise prosopográfica dos que tomaram assento na Assembléia. Segundo ela, haveria, por um lado, um grupo que intitula de "luso-brasileiros" em que predominavam os indivíduos

na historiografia brasileira”, István Jancsó (org.), Independência: História e historiografia, São Paulo, Hucitec/Fapesp, 2005, pp.53-118.

${ }^{143}$ Ver José Honório Rodrigues, op.cit., que faz uma descrição detalhada dos feitos da Assembléia e de alguns debates defendendo o papel importante da Assembléia no tocante às suas contribuições "ideológicas e doutrinárias" para o Império, apesar do efeito de "contemporização" que ela produziu em relação à política e a sociedade. Da mesma época, ver Dylva Araújo Moliterno, A Constituinte de 1823: uma interpretação, Niterói/ Univ. Federal Fluminense, Dissertação de Mestrado, 1974, que sustenta que não teria existido nenhuma consistência partidária entre os deputados, que teriam agido sozinhos, desarticulados de interesses políticos locais.

${ }^{144}$ Refiro-me aqui especialmente à análise de Emília Viotti da Costa, "Introdução ao estudo da emancipação política do Brasil", que ao analisar o processo de Independência como absolutamente conservador da ordem vigente, vê o processo constitucional como um reprodutor das desigualdades já vigentes, cujas inovações liberais não teriam repercussão na prática. Numa outra chave interpretativa, o estudo quase contemporâneo de Maria Odila Dias, op.cit., reforça a idéia de uma notável continuidade política que marcaria todo o processo de emancipação e construção do Império do Brasil. 
graduados na Universidade de Coimbra e que tinham servido ao governo português, imbuídos de um ideal ilustrado reformador que, na esteira do projeto de um Império lusobrasileiro, defendiam a centralidade da monarquia e buscavam transformações políticas moderadas. Por outro lado, os que chama de "brasilienses" constituído exclusivamente pelos nascidos no Brasil que, identificados com médios e pequenos produtores e comerciantes, eram mais abertos às novas idéias e posturas mais radicais ${ }^{146}$.

Já Evaldo Cabral de Mello chegou a defender a existência de uma antagonização entre grupos e interesses das províncias do Sul, que apoiariam uma monarquia constitucional centrada na figura de D. Pedro, e os do Norte-Nordeste, que sustentariam um projeto federalista para o Brasil que iria contra a tentativa de unificação proposta pelos grupos ligados à Corte ${ }^{147}$. $\mathrm{O}$ mesmo autor, um ano depois ${ }^{148}$, matizaria essa posição ao estudar o que chama de "federalismo pernambucano". Aqui, Mello permite entrever como na própria Província existiam forças em constante disputa quanto à defesa da adesão ao Rio de Janeiro (uma postura que chama de "centralista") ou a uma maior autonomia local, nem sempre excludente em relação à anterior, e que também teria marcado o posicionamento dos deputados de 1823.

A despeito de suas diferenças, essas abordagens possuem aproximações entre si ao revelarem, mesmo que por oposição, a dificuldade em se falar em bancadas "provinciais" com projetos homogêneos, já que a marca da distinção entre as tendências apontadas estava também pautada por um afinamento ou negação em relação a um projeto de adesão ao Rio de Janeiro ${ }^{149}$. Por mais que existissem posicionamentos comuns entre os vários representantes das localidades, o problema era que a "Província", como canal de representação e unidade política de convergência de regiões a integrarem-na, ainda estava em construção. Por seu lado, o ambiente de luta política travada na própria Corte nos anos que cercam à Independência, conforme demonstra Cecília Helena de Salles Oliveira ${ }^{150}$, coloca-nos a impossibilidade de se vislumbrar um projeto único e coeso para o Império do Brasil, mesmo no seu pretendido centro.

\footnotetext{
${ }^{145}$ Maria de Lourdes Vianna Lyra, op.cit..

${ }^{146}$ Lúcia Maria Bastos Neves, op.cit.

147 “O Jogo da Independência”, Caderno Mais, Folha de S. Paulo, 23/março/2003, p.10-1.

${ }^{148}$ A outra independência. O federalismo pernambucano de 1817 a 1824, São Paulo, Editora 34, 2004.

149 Andréa Slemian e João Paulo Pimenta, $O$ "nascimento político" do Brasil: origens do Estado e da nação (1808-1825), Rio de Janeiro, DP\&A, 2003.
} 
No entanto, como a criação do plano normativo constitucional não deve ser entendida simplesmente como reflexo dos embates políticos, sendo também a produção de um ordenamento jurídico que dialoga com o substrato mental de uma sociedade calcado na expectativa de sua realização, não há nunca sinonímia perfeita - ainda que sempre exista alguma - entre ações dos grupos políticos e decisões no tocante à lei fundamental. $\mathrm{O}$ que, no caso do Brasil, era reforçado pela extrema fluidez inerente ao processo de formação das bases do novo Império. Dessa forma, além das Assembléias serem um locus de disputa, elas também eram - como o são até hoje -, espaços de construção de consensos possíveis. Assim se passou em 1823, quando esteve em andamento a aprovação do Projeto de Constituição que, mesmo com discordâncias, pôde ser votado e emendado sob a égide da legitimidade adquirida em nome dos "representantes da nação". Daí não ter sido apenas a falta de entendimento entre os parlamentares a responsável pelo fechamento da Assembléia, mas sua inserção na correção de forças existentes no ambiente político da época.

Nestes termos, se a dissolução da Casa explica-se por meio de tensões polarizadas em momentos específicos, dentro e fora do seu espaço, sua produção constitucional teria longevidade, servindo de base fundamental para a Carta Constitucional elaborada no ano seguinte. A análise da produção do novo pacto permite que se compreenda os termos da construção de uma alternativa política que já se relevava, nessa época, minimamente consensual. Assim, vejamos seus termos desde o início dos trabalhos constituintes.

\subsubsection{A construção de um novo pacto político e a legitimidade da Assembléia}

A primeira polêmica que ocorreu no âmbito da Assembléia se deu já nas sessões preparatórias, iniciadas em 17 de abril de 1823, quando da discussão de um regimento provisório para os trabalhos da Casa, elaborado por uma Comissão previamente eleita. Duas questões, aparentemente de mera formalidade, mobilizaram os deputados: na sala legislativa, a cadeira do presidente dos trabalhos ficaria no mesmo nível que a do Imperador? E deveria o representante da monarquia, todas as vezes que lá adentrasse, estar coberto com a coroa, manto e cetro imperial ${ }^{151}$. Quanto à primeira, é José Custódio

\footnotetext{
${ }^{150}$ Cecília Helena Salles de Oliveira, op.cit. .

${ }^{151}$ DAG, v.1, sessão de 30/abril.
} 
$\operatorname{Dias}^{152}$, deputado por Minas Gerais, quem advogou que ambas as cadeiras ficassem no mesmo nível, pois que se deveria "respeitar a nação legitimamente representada" na figura do seu presidente, "só da qual deriva toda a autoridade que pelo pacto social se lhe vai a conferir" 153 . O paulista Antônio Carlos de Andrada Machado rebateu, marcando a diferença entre o monarca e o representante que presidia a Assembléia "pela glória, esplendor e aparato" que forneceria respeito ao primeiro. Votou-se e venceu a distinção com o trono no topo, seguido pelo presidente no primeiro degrau, quando o Imperador estivesse na sala; nas sessões ordinárias, a cadeira do presidente ficaria defronte o mesmo trono.

No tocante à segunda questão, posto que a proposta de regimento fosse a de que D. Pedro entraria "descoberto" na sala, o deputado Joaquim José Carneiro de Campos, eleito pelo Rio de Janeiro, logo se manifestou contrário. Afirmava ser na condição de "Chefe da Nação" que o Imperador viria a instalar a Assembléia, o que lhe daria um lugar privilegiado em relação aos representantes eleitos e o direito de utilizar seus símbolos, posto que "a Coroa é sua insígnia assim como o Manto e o Cetro" ${ }^{154}$. Agora era Antônio Carlos que votava contra os ornamentos de distinção, argumentando que sendo ambos, Imperador e Assembléia, "poderes constitucionais" distintos, deveriam estar lado a lado. Depois de breve argumentação, assim se decidiu, e o Imperador entrou, na sessão inaugural em 3 de maio, despojado de seus símbolos, que foram conduzidos separadamente por um de seus Oficiais. Porém, no mês seguinte, o mesmo Carneiro de Campos voltou a colocar a questão em pauta, discordando novamente da decisão ${ }^{155}$. Vários deputados argumentaram que o Imperador deveria manter os símbolos da realeza, e João Antônio Rodrigues de Carvalho ${ }^{156}$ questionou abertamente: por que "só o Imperador, na função mais solene da nação, há de

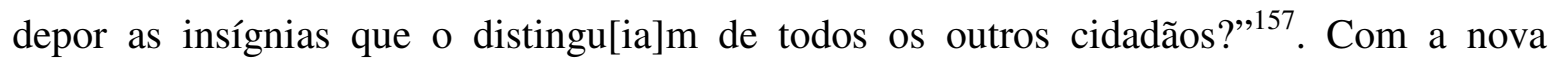
votação, decidiu-se que D. Pedro voltaria a entrar, no recinto da Assembléia, com o cetro e coroa.

\footnotetext{
152 José Custódio Dias (?-1838), era sacerdote em Minas Gerais. Ocupou a cadeira de deputado, pela sua Província natal, na Assembléia Constituinte de 1823, e posteriormente nas três primeiras legislaturas, entre os anos de 1826-1835. Neste último ano, foi nomeado senador.

${ }^{153}$ DAG, v.1, sessão de 30/abril , p.5.

${ }^{154}$ Idem, p. 7.

${ }^{155}$ DAG, v.1, sessão de 11/junho.

156 João Antônio Rodrigues de Carvalho (?-1840) era natural do Ceará. Foi eleito deputado por sua Província natal para a Assembléia Constituinte. Ocupou o cargo de Presidente da Província de Santa Catarina entre os anos de 1824-5, e em 1826 foi escolhido senador.

${ }^{157}$ DAG, v.1, sessão de 12/junho, p.207.
} 
Ambas as questões traziam subjacentes uma expressa necessidade da resolução do lugar dos poderes em construção, monarquia e Assembléia, ou, para sermos mais precisos, Executivo e Legislativo, na criação de um governo constitucional. Ponto de tensão típico dos processos de formação dos Estados nacionais à época, seus desdobramentos informaram o cotidiano dos trabalhos legislativos marcados, no Brasil, pela urgência no enquadramento da monarquia em moldes liberais. Desta forma, a perquirição dos distintos sentidos da qualidade do novo pacto político da unidade soberana que se pretendia gestar, bem como da legitimidade da Casa legislativa, permite-nos adentrar ao complexo universo mental dessa sociedade que vivia tão intensamente uma experiência de ruptura política. Afinal, conforme afirmou Pedro de Araújo Lima ${ }^{158}$, representante da província de Pernambuco e, anos depois, regente do Império, "estas matérias Constitucionais são novas entre nós; [e] os povos ainda não conhecem bem estes direitos"159.

A perspectiva contratualista voluntarista da Constituição como expressão de um pacto feito pelas vontades, individuais ou coletivas, que fundariam a nação, fazia-se fortemente presente. Foi exatamente nestes termos que se expressou o padre Venâncio Henriques de Resende ${ }^{160}$, representante por Pernambuco, ao afirmar que "uma nação só se constitui quando organiza o seu pacto social; no qual marca as condições debaixo das quais os homens cedem dos seus originários direitos, e pelas quais se conhece as vantagens que eles tiram dessa cessão"161. Para ser membro de uma sociedade, fazia-se "necessário o

\footnotetext{
158 Pedro de Araújo Lima (1793-1870) era natural de Serinhaém (Pernambuco). Tonou-se bacharel em Cânones pela Universidade de Coimbra (1817), onde galgou o grau de doutor em 1819. No ano seguinte, foi nomeado ouvidor da Comarca de Paracatu em Minas Gerais, cargou que não chegou a ocupar. Foi eleito deputado para as Cortes de Lisboa pela sua Província natal, e com a Independência, foi escolhido representante para a Constituinte pelo Rio de Janeiro. Na condição de deputado, esteve presente nas $2^{\mathrm{a}}$. e $3^{\mathrm{a}}$. legislaturas (de 1830-3 e 1834-7), e foi escolhido senador em 1837. Teve importantes cargos executivos no governo, sendo varias vezes nomeado Ministro do Império, ocupando também a pasta da Justiça, da Fazenda e dos Negócios Estrangeiros. Foi conselheiro de Estado e regente do Império, sendo agraciado com o título de Marquês de Olinda.

${ }^{159}$ DAG, v.1, p.64.

${ }^{160}$ Venâncio Henriques de Resende (1784-1866) era natural de Serinhaém, Pernambuco. Era sacerdote e assim aderiu à Revolta Pernambucana de 1817, sendo preso e levado para a Bahia. Anistiado, retornou à sua Província natal em 1821 para reassumir a função de padre. Acusado de conspiração por ocasião da tentativa de assassinato do governador de Pernambuco (Luiz do Rego), foi novamente preso e levado para Lisboa, ganhando a liberdade em 1822. Neste ano, retornou ao Brasil e foi eleito deputado constituinte. Em 1824, aderiu à Confederação do Equador e, debelada a revolta, fugiu para os Estados Unidos da América de onde retornou em 1829. Elegeu-se deputado para a Assembléia Geral por várias legislaturas: a $2^{\mathrm{a}}(1830-33)$, a $3^{\mathrm{a}}$ (1834-37), a $4^{\mathrm{a}}$ (1838-41), a $5^{\mathrm{a}}$ como suplente (ocupando assento entre 1843-44), e a $8^{\mathrm{a}}$ (que ocupou de 185052). Em 1848, como pároco da Igreja de Santo Antônio no Recife, foi nomeado Vice-Presidente da Província. Em 1853, foi diretor do Liceu Pernambucano e da Instrução Pública. Morreu no Recife.

${ }^{161}$ DAG, v.1, sessão de 22/maio, p. 102.
} 
expresso consentimento daquele que a ela se quer ligar", e ninguém teria o direito de exigir a "proteção que aquela sociedade lhes dá" se não se "sujeita" a suas obrigações ${ }^{162}$.

O posicionamento de Antônio Carlos de Andrada expunha claramente tanto a concepção individualista desse novo pacto como a necessidade da "sujeição"163.

“Três são, a meu ver, os degraus da organização social; $1^{\circ}$ indivíduos dispersos, se é que jamais os houve, ou ao menos, famílias separadas, por amor de sua conservação e, talvez, principalmente arrastados por necessidade intelectual e moral, reúnem-se, para que a força coletiva escude a fraqueza individual; para este primeiro pacto é mister unanimidade; só é parte da nova sociedade quem quer. Dado este primeiro passo, segue-se o segundo, isto é, estabelecer a forma de regimento da sociedade já formada; e neste degrau basta a pluralidade não de um Corpo, mas da Nação inteira. Por fim, estabelecida a forma de Governo, o Corpo ou indivíduo, que é a razão social, faz atos, são obrigatórios para a Nação toda, quando são os atos resultados da pluralidade, não da Nação inteira, mas do só corpo que legisla"164.

Sendo assim, depois de estabelecida a forma de governo os indivíduos não só seriam obrigados a se submeterem a ele, como a depositar no "corpo" que legisla a legitimidade das ações do governo. No entanto, concepções distintas entrariam em choque no ambiente da Assembléia como expressão de projetos mais conservadores ou mais radicais em torno da unidade política em gestação. No tocante à existência ou não do pacto antes da Constituição, a discordância entre os deputados se fez presente de forma clara.

Na mesma linha, Antônio Carlos argumentaria que o pacto em questão já estava formado, devido ao fato de D. Pedro estar "reconhecido Imperador pela mesma nação que nos fez deputados; e antes que fôssemos deputados já estava aclamado Imperador por esta mesma nação"165. Igualar o Imperador aos representantes seria, portanto, uma "anarquia".

\footnotetext{
${ }^{162}$ DAG, v.1, sessão de 25/junho, fala de Pedro de Araújo Lima, p. 289.

163 José Carlos Chiaramonte, Ciudades, provincias, Estados: orígenes de la Nación Argentina (1800-1846). Buenos Aires, Ariel, 1997, chama de "pacto de sujeição" uma das leituras da sociedade representativa que se opunha à concepção mais radical de representação direta, proposta por Jean-Jaques Rousseau no $O$ Contrato Social, e pela qual o indivíduo se dispunha a obedecer ao governo depois de ocorrido seu estabelecimento.

${ }^{164}$ DAG, v.1, sessão de 22/maio, p. 107.

${ }^{165}$ DAG, v.1, 11/junho, n.24, p.202.
} 
Seu irmão Martim Francisco Ribeiro de Andrada ${ }^{166}$, também eleito por São Paulo e ainda ministro do Império, corroborava a tese de que o Imperador era já o "chefe da nação" independentemente da Constituição que estava em elaboração ${ }^{167}$. Posição semelhante conduzia com os interesses daqueles entre os deputados que defendiam de antemão a união das Províncias, até então portuguesas, e a centralidade da Corte no arranjo político do novo Império, independentemente da guerra de posições que grassava no Norte e Nordeste.

Os críticos à noção de uma unidade preexistente não foram poucos. Quando da volta da discussão acerca dos protocolos que a assembléia deveria dispor em seu regimento interno, José Antônio da Silva Maia ${ }^{168}$, deputado por Minas Gerais, argumentava que o presidente e o Imperador, quando juntos na Casa, deveriam se sentar em cadeiras no mesmo nível, sem distinção de degrau, pois que "se está tratando do pacto social [e] quando o presidente fala neste lugar ao Imperador, parece-me que nada mais é do que um homem falando a outro homem". Admitia que seria diverso seu parecer "quando o Imperador tiver aceitado a Constituição: então cumpre tratá-lo como Imperante e chefe reconhecido da nação" ${ }^{\text {169 }}$. Com esse raciocínio, Maia destituía provisoriamente D. Pedro do título, sob a condição de que ele deveria aceitar o pacto, ou seja, a autoridade legislativa, para ter direito a ser chamado de Imperador.

166 Martim Francisco Ribeiro de Andrada (1775-1844), era natural de Santos. Tornou-se bacharel em Matemática pela Universidade de Coimbra. Junto com seu irmão José Bonifácio, participou do Governo Provisório da Província de São Paulo em 1821 e foi escolhido por D. Pedro para ocupar o Ministério no ano seguinte (compondo o que ficaria conhecido como "ministério dos Andradas"). A ele, coube a Pasta da Fazenda, na qual permaneceu até julho de 1823. Nessa condição, foi eleito deputado constituinte por sua Província natal. Dissolvida a Assembléia, foi exilado na França juntamente com seus irmãos José Bonifácio e Antônio Carlos. Voltou ao Brasil em 1828. Ocupou a cadeira de deputado por Minas Gerais na $2^{\mathrm{a}}$ legislatura da Assembléia Geral (1830-33), como suplente na $3^{\mathrm{a}}$ (1836-37), e por São Paulo na $5^{\mathrm{a}}$ (1838-41). Foi novamente ministro da Fazenda com a Maioridade (1840-41).

${ }^{167}$ DAG, v.1, 11/junho, n.24, p.202.

168 José Antônio da Silva Maia (1789-1853) era natural do Porto, Portugal. Foi Procurador da Coroa e Conselheiro de Estado. Ocupou a cadeira de deputado por Minas Geras na Constituinte de 1823, e na Assembléia Geral por duas vezes: na $1^{\text {a }}$ legislatura (1826-29), e na $2^{\text {a }}$ durante o ano de 1830 . Nesse ano, foi nomeado ministro do Império. Posteriormente, seria ministro da Justiça e da Fazenda (1840), e novamente do Império (1843-44). Foi escolhido senador em 1843.

${ }^{169}$ DAG, v.1, 11/junho, n.24, p.201. 
O baiano Francisco Gê Acaiaba Montezuma ${ }^{170}$, seguindo raciocínio semelhante, ia mais longe ao defender a não obrigatoriedade de aceitação do pacto, pois se "a Constituição que vamos a fazer não me agradar por me não convencer de sua bondade, não a aceito nem assino, e despedir-me-ei da minha pátria" ${ }^{\text {171 }}$. O mesmo valeria para as Províncias, pois se um indivíduo tinha o "direito para se desnaturalizar, se a Constituição do Império for tal que não lhe agrade, como negá-lo a uma Província ou Províncias? Como negarei a um povo a faculdade de procurar os meios de sua felicidade, sendo este seu mais sagrado dever?"172. Embora o mesmo deputado posteriormente afinasse seu entendimento com grupos políticos da Corte, nesse momento a posição de que as Províncias não seriam obrigadas a aceitar o contrato constitucional afrontava aqueles que nem sequer colocavam isso em pauta.

Duas posições distintas saltavam aos olhos: a daqueles que valorizavam o papel dos representantes e da Assembléia (Legislativo) na elaboração do pacto, pois não o consideravam ainda constituído; e a dos que reconheciam a autoridade do Imperador de antemão, pois que assim já teria sido reconhecido pela "nação", com a preservação da soberania da monarquia e na esteira da tradição ilustrada setecentista portuguesa. A tensão entre essas duas concepções se desdobrava amplamente nas polêmicas que envolveram a definição de soberania e de nação, conceitos-chaves na construção das bases do novo Estado.

\footnotetext{
${ }^{170}$ Francisco Gomes Brandão (1794-1870) era natural da Bahia, filho de família modesta. Cursou a Escola Médico-Cirúrgica em Salvador e, mais tarde, Direito na Universidade de Coimbra. Em 1821, regressou à Bahia e, no ano seguinte, seguiu para a Vila de Cachoeira onde ajudou na criação do Governo Provisório contra o domínio "português" na Província. No ano de 1822, prestou juramento "à causa do Brasil" e trocou seu nome paterno Gomes Brandão por "Gê Acayaba de Montezuma" (sendo Gê a designação de uma tribo, Acayaba o nome de uma árvore, acaiá ou cajazeira, e Montezuma o Imperador asteca morto pelos espanhóis, numa clara referência à América). Foi eleito deputado pela Bahia para a Assembléia Constituinte de 1823 que, por causa da guerra na região, só lhe permitiu tomar posse em julho. Com o fechamento da Casa legislativa, Montezuma foi preso e deportado para a França junto com os irmãos Andrada com os quais tinha se aliado. Voltou ao Brasil apenas em 1831, quando sua atuação política será identificada com os "restauradores" ou "caramurus". Atuou como deputado, novamente pela Bahia, em 1831 como suplente de Miguel Calmon du Pin e Almeida (posteriormente Marquês de Abrantes). Em 1834, publicou "A Liberdade das Repúblicas", panfleto em defesa das instituições existentes no Brasil e contra a propaganda federalista. Durante o último gabinete de Feijó (1837), ocupou as pastas da Justiça e dos Estrangeiros. Novamente foi deputado pela Bahia na $4^{\text {a }}$ legislatura (de 1838-41), sendo reeleito para a seguinte. Apoiou a Maioridade em 1840, e foi escolhido senador pela sua Província natal em 1851. Três anos depois, foi agraciado com o título de Visconde de Jequitinhonha.

${ }^{171}$ DAG, v.1, 11/junho, n.24, p.201.

${ }^{172}$ DAG, v.3, 18/setembro, p.55.
} 
Trazida pelos tempos revolucionários, a concepção de soberania "una" e "indivisível" e que residiria na "nação"173, aos moldes do discurso predominante em Portugal após 1820, gerou confrontos entre os deputados de 1823 devido ao fato do projeto de Independência ter sido levado a cabo pelo herdeiro dos Bragança, em oposição às Cortes lisboetas. A princípio, percebe-se um consenso na sua formulação geral. Pedro de Araújo Lima, por exemplo, defendia a "soberania" no Império com a reunião de todas as Províncias e de todos os poderes, incluindo o do Imperador. Afirmava ser verdade "que nenhum dos poderes em que se divide a soberania faz soberania"; e que não era "inútil; [mas] necessário que se explique que a soberania está na nação toda inteira, e não em parte dela" ${ }^{\prime 17}$. No entanto, essa ampla definição escondia discordâncias fundamentais a respeito de quem a exercia ou a delegava.

Aqueles que se assumiam claramente como contrários à "soberania popular" recuperavam o papel central do "chefe da nação" e criticavam a falta de limites a essa força, nos moldes das teses moderadas de Benjamin Constant escritas anos antes ${ }^{175}$. Nestes termos, José Joaquim Carneiro de Campos criticava os "desvarios" que se têm produzido pela "má inteligência" da "idéia de soberania do povo", que só poderia ser verdadeira se tomado "o povo pela nação" com a inclusão do monarca ${ }^{176}$. Em outro momento, afirmava que apesar desta "augusta Assembléia estar revestida da plenitude do exercício da soberania nacional", "nela não se achavam concentrados todos os poderes soberanos", pois da mesma forma tinha de se preservar a "preeminência essencial e inalienável da Suprema Dignidade do Chefe da nação" "177. No mesmo sentido, Antônio Carlos de Andrada era taxativo ao defender que "soberania" não se confundia com "povo", e nem estava centrada apenas na Casa legislativa, pois “ela não se compõe de um só dos poderes políticos, mas da reunião de todos" ${ }^{\prime 178}$.

\footnotetext{
${ }^{173}$ Sobre o sentido de soberania ver: François-Xavier Guerra, "De la política antigua a la política moderna. La revolución de la soberania", Los espacios públicos en Iberoamerica. Ambiguidades y problemas, México, Fondo de Cultura Economica, 1998.

${ }^{174}$ DAG, v.3, 17 de setembro, p. 33.

${ }^{175}$ Escritos de política, São Paulo, Martins Fontes, 2005, capítulo I.

${ }^{176}$ DAG, v.3, 20/setembro, p. 63.

${ }^{177}$ DAG, v.1, 28/julho, p.470.

${ }^{178}$ Idem, v.1, 20/maio, p.85.
} 
As opiniões divergentes problematizavam a atribuição de soberania ao monarca. Manuel Caetano de Almeida e Albuquerque ${ }^{179}$, para atacar o direito de sanção do Imperador às leis feitas "antes da Constituição", recorreu a um caminho singular. Reconhecia que o direito em questão como "prerrogativa da soberania da nação" não podia "ser exercitado pela nação mesma, [e] necessariamente h[avia] de ser delegada, do mesmo modo que é a faculdade de legislar" ${ }^{\prime 80}$. Por se tratar de uma monarquia constitucional, em que "há uma dignidade eminente", "o chefe da nação é o guarda nato da felicidade geral; é aquele a quem pertence vigiar sobre todos os outros poderes: a ele pertence, pois ver se os atos do poder legislativo são, ou não, conformes à vontade da nação". No entanto, por se tratar de aprovação de uma lei antes do estabelecimento da "Lei Fundamental" não caberia ao monarca esse direito. Nestes termos, sua soberania só seria real depois do pacto.

Custódio Dias foi quem claramente defendeu a posição do Imperador como subordinado à "Nação":

"Representantes como somos de uma Nação livre, que se constitui, não podemos enquanto nos constituímos, tratar o Imperador como superior à mesma Nação, mas sim como secundário à sua Soberania. Não o façamos tão metafísico, que não o vejamos delegado dela exercendo o Poder Executivo cujas metas ainda não marcamos" ${ }^{181}$.

Como se vê, os deputados eleitos teriam papel fundamental como "delegados da nação" para o exercício da "soberania". Montezuma, afinado com esse discurso, explicava que "quando dizemos que o chefe da nação é soberano", isso não significava que exercitasse "o direito da soberania da nação", conforme fazia a Assembléia; ou seja, o monarca seria "superior a todos os indivíduos dessa nação" apenas por ser colocado "por eles no mais alto

\footnotetext{
${ }^{179}$ Manoel Caetano de Almeida e Albuquerque (1780-1844) era natural de Pernambuco. Formou-se em Leis na Universidade de Coimbra em 1806. Iniciou sua carreira na magistratura em 1808 como Juiz de Fora, depois Corregedor, da Ilha da Madeira. Foi desembargador da Relação da Bahia e, em 1821, ocupou o mesmo cargo na Casa de Suplicação da Corte, entre outros postos. Elegeu-se deputado por Pernambuco na Assembléia Constituinte de 1823, e na $1^{\text {a }}$ legislatura (1826-1829) da Assembléia Geral, sendo escolhido senador pela mesma Província em 1828. Neste ano, foi nomeado Ministro do Supremo Tribunal de Justiça, tomando posse do cargo em 1829.

${ }^{180}$ Idem, v.1, 25/junho, p. 295.

${ }^{181}$ DAG, v.1, 11/junho, n.24, p.202.
} 
posto da hierarquia civil""182. Portanto, Imperador e "nação" eram coisas diferentes, o primeiro sendo escolhido pela segunda.

Como se vê, o problema da "soberania" relacionava-se diretamente com o da "nação". À época, dois sentidos não necessariamente excludentes, constituíam parte de seu significado político ${ }^{183}$. Herdada historicamente da tradição moderna, era recorrente sua utilização como uma forma de associação ou "governo" organizado sob certas leis ou costumes, como fruto de um contrato político afeito ao substrato jusnaturalista e já presente, conforme vimos, na tradição ilustrada portuguesa em sua vertente moderada. Ao mesmo tempo, a concepção individualista de "nação", que François-Xavier Guerra chamou de "moderna" e "revolucionária", "una e indivisível", cuja representação centrava-se, sobretudo, nos novos espaços legislativos em construção em todo mundo ocidental ${ }^{184}$. Daí, em nosso caso, a expressão dos "deputados da nação", a "vontade nacional”. A coexistência entre ambos na fala dos deputados da Assembléia de 1823 inviabiliza análises que queiram marcar posicionamentos de grupos políticos por meio de sua distinção.

Essa constatação aponta para um diferencial do caso do Brasil diante da América hispânica quanto à construção de alternativas constitucionais. Nessa última, os acontecimentos de 1807 precipitaram um "vazio de poder" em todo Império ${ }^{185}$. A busca de soluções para a crise acabaria por desencadear um processo revolucionário em ambos os hemisférios, que nos domínios americanos adquiriu caráter independentista, com a formação de governos autônomos que reivindicavam a "volta" da soberania aos "povos", já que o rei estava ausente ${ }^{186}$. Mesmo como fenômeno difuso que variou bastante em cada localidade, ele pôde ser observado já desde a formação das primeiras Juntas de Governo, a partir de 1810, na América. Uma de suas conseqüências foi a valorização do "direito dos

\footnotetext{
${ }^{182}$ DAG, v.2, 29/julho, p. 477.

183 Apesar da polissemia do vocábulo, deve-se evitar o anacronismo de se pensar o sentido político que "nação" veio a possuir na segunda metade do XIX - como produto de laços culturais comuns (língua, costumes, religião, etc.) conforme construíram os expoentes do Romantismo, e posteriormente pelo ideal do "princípio de nacionalidade" no século XX - para a época em questão. Sem essa ressalva, a interpretação pode ser conduzida a graves erros, como atribuir aos coevos uma luta "nacionalista" na construção de novas unidades culturais homogêneas. Essa questão é detidamente discutida por José Carlos Chiaramonte, "Metamorfoses do conceito de nação durante os séculos XVII e XVIII", István Jancsó (org.), op.cit..

184 “A nação moderna: nova legitimidade e velhas identidades”, István Jancsó (org.), op.cit..

${ }^{185}$ Miguel Artola, Antiguo Régimen y revolución liberal, $2^{\text {a }}$ ed., Barcelona, Ariel, 1983; e Josep Fontana, La crisis del antiguo régimen (1808-1833), 4 ed., Barcelona, Grijalbo, 1992.

${ }^{186}$ Para os aspectos jurídico-políticos que deram sustentação a tal alternativa, ver Eduardo Martiré, 1808. Ensayo histórico-jurídico sobre la clave de la emancipación hispanoamericana, Buenos Aires, Instituto de investigaciones de Historia del Derecho, 2001.
} 
povos", em perspectiva corporativa, configurando alternativas que logo seriam legadas aos novos Estados.

Para o caso da América portuguesa, algumas razões explicam a quase inexistência de expressividade dos "direitos dos povos" no sentido encontrado nos territórios de colonização espanhola ${ }^{187}$. Antes de tudo, pela periodização. O movimento revolucionário no mundo luso ocorreu ao menos dez anos depois do espanhol, quando o mundo já vivia uma onda conservadora que, de alguma forma, "domesticara" as proposições radicais francesas que assustaram o mundo em fins do século XVIII ${ }^{188}$. Desta forma, a idéia da "nação soberana" fora adequada a uma perspectiva monárquica constitucional mais moderada, sendo ela uma das manifestações mais concretas da irreversível construção individualista da modernidade. Mais que isso, o Império português não vivera a acefalia da legitimidade dinástica central, pois que a Corte decidira atravessar os mares em 1807, consciente que o contrário poderia implicar a perda do Brasil. Dessa forma, a soberania do monarca, tal qual formulada pelos ilustrados portugueses no momento de crise, manteria por mais tempo sua integridade. Ainda que como explicação mais subliminar, vale notar que os Impérios ibéricos tinham distinta configuração interna, por mais que tivessem sido submetidos a um mesmo esforço de racionalização e centralização, com as reformas setecentistas. Para o hispânico, é possível dizer que a antiga divisão de reinos fortemente presente durante os seiscentos, então subsidiada pelas clássicas teses jusnaturalistas corporativas (refiro-me em especial a Hugo Grocio e, posteriormente, a Samuel Pufendorf), forneceu um substrato ideológico fundamental aos revolucionários americanos que buscaram alternativas de governo nas primeiras décadas do XIX.

\footnotetext{
${ }^{187}$ Nesse sentido, os apontamentos feitos por José Carlos Chiaramonte, "Fundamentos iusnaturalistas de los movimientos de independencia", valem muito mais para a América hispânica do que para o Brasil no momento das Independências. Um exemplo disso, está no trabalho de Genèvieve Verdo, op.cit., que aponta existir em Buenos Aires, nos primeiros anos revolucionários, uma verdadeira oposição entre, ao menos dois grupos: aqueles que defendiam "os direitos dos povos", partidários do constitucionalismo histórico e informados por um ideal corporativo de sociedade, que ela analisa como grupos mais "moderados"; e outros mais próximos ao ideal revolucionário francês de pacto e nação, que apoiavam um poder Executivo forte, concentrado e eficaz, por ela identificados com Mariano Moreno. Ainda que ambos autores tratem do jusnaturalismo de forma distinta, o aparecimento do "direito das gentes" foi um fenômeno mais típico da América espanhola.

188 Jean-Jacques Chevalier, "L'influence des lumières et de la Revolution Française sur l'organisation du pouvoir dans les premières Constitutions de L'Amerique Latine (1811-1828)", El pensamiento constitucional de Latinoamerica 1810-1830. Caracas, Academia Nacional de la Historia, 1962, tomo IV, pp. 223-253, mostra como também na América houve, no início da década de 1810, um primeiro momento constitucional de feição mais radical em relação aos anos 20 daquele século.
} 
No seu conjunto, essas questões valem para pensarmos a própria peculiaridade do processo constitucional nos primórdios do Brasil. No tocante à "nação", é possível identificar, a partir dos sentidos existentes à época, o peso da tradição ilustrada portuguesa no fortalecimento da monarquia como um dos espaços de gravitação de várias das alternativas gestadas. Ela se desdobrava numa concepção de "nação" em que o monarca não apenas faria parte dela como todos os outros "súditos" ou "cidadãos", mas que também preservava "Sua Majestade" por meio da prevalência de sua soberania ${ }^{189}$. Coerente com seu pensamento político, Antônio Carlos de Andrada o traduzia em palavras:

"Nação abrange o Soberano e os Súditos; povo só compreende os Súditos. O Soberano é a razão social, coleção das razões individuais; o povo é o Corpo que obedece à razão. Da confusão destes dois termos de amalgamação in-filosófica da Soberania e povo, tem desmandado absurdos [...] exijo por isso, que se substitua à palavra povo a de Nação todas as vezes que se falar em Soberania",

Mesmo partindo de uma concepção individualista moderna, a nação abrangia o Imperador e os seus "Súditos" numa equação em que ela só existia pela monarquia como sua "razão social". É fato que esse discurso se adequou muito bem à defesa de projetos centralizadores encabeçado pelo Centro-Sul, o que não o impedia de aparecer na boca de representantes de várias localidades unidos pela defesa de uma alternativa moderada de transformação política.

Aqueles dissidentes à concepção de nação como intrinsecamente articulada à monarquia privilegiavam a soberania da Assembléia, e esta como sua representante primordial. Desta forma, "nação" e "Imperador" seriam instâncias distintas, posto que o segundo só teria seu título após o estabelecimento do corpo social e das regras que deveriam reger a sociedade. A antagonização entre ambos apareceu claramente na fala de Francisco Montezuma quando defendeu, por extensão, a inviolabilidade dos deputados:

"A que nomeação devemos nós atender de preferência, a do Chefe do Poder Executivo ou à da Nação? Creio que ninguém duvida que prefere esta segunda.

\footnotetext{
${ }^{189}$ Sem dúvida, esse sentido era também afeito ao ideal das monarquias restauradas na Europa.
} 
Logo a responsabilidade não tem lugar enquanto duram as funções de Deputado, porque não pode por efeitos dela ser punido, nem sair do lugar que a Nação lhe deu, sem se atacar a dignidade dela" ${ }^{, 191}$.

Dias depois o mesmo deputado afirmava: "Todos somos iguais, e até devemos supor-nos no estado de Natureza, revestidos da plenitude de nossos direitos. Ainda não temos pacto de sociabilidade; ainda não somos nação no sentido político e do direito das gentes"192. Argumentações que davam substrato perfeito às expectativas autonomistas existentes no âmbito da Casa.

No entanto, se quisermos atribuir uma feição jusnaturalista ao momento fundante do pacto, como pretende José Carlos Chiaramente, deve-se ter claro que não se tratava de uma versão moderna corporativa vinculada aos antigos "direitos dos povos". No que se refere exclusivamente à questão, a Assembléia de 1823 rompera, pelas razões acima enunciadas, com as bases de sustentação ideológica do Antigo Regime.

No que tocava à construção dos vínculos de tipo nacionais, ou de uma "comunidade política imaginada" nos termos de Benedict Anderson ${ }^{193}$, a discussão sobre a definição de quem seriam os "brasileiros" permite que se analise alguns de seus impasses. Nesse momento, colocou-se o problema da nação como "depositária de uma herança comum a ser preservada" 194 ou, no caso, rompida em função da Independência e da urgência de sua reconstrução em oposição à nação portuguesa. O passado, recente ou longínquo, foi evocado quando se tratou de um projeto do deputado pernambucano Francisco Muniz Tavares ${ }^{195}$, apresentado em maio de 1823 , que visava definir quem, entre os "naturais de Portugal", deveriam ser considerados "cidadãos brasileiros". Segundo ele, todos "aqueles

${ }^{190}$ DAG, v.1, 02/maio, p. 31.

${ }^{191}$ DAG, v.2, 02/setembro, p.706.

${ }^{192}$ DAG, v.3, 18/setembro, p.55.

${ }^{193}$ Nação e consciência nacional, São Paulo, Ática, 1989.

${ }^{194}$ István Jancsó e João Paulo Pimenta, op.cit., p. 160.

${ }^{195}$ O padre Muniz Tavares (1786-1876) era natural do Recife, onde foi ordenado em 1816. No ano seguinte, participou da Revolução de Pernambuco e, preso, permaneceu três anos na Bahia. Em 1821, foi eleito deputado às Cortes de Lisboa pela sua Província natal. De volta ao Brasil após a Independência, foi escolhido representante para a Assembléia Constituinte de 1823. Bacharel e doutor em Teologia pela Univerisdade de Paris (1825), foi também secretário da Legação e encarregado de negócios do Brasil junto à Santa Sé (18261832). Em 1841, exerceu as funções de secretário da presidência da Província de Pernambuco. Atuou novamente como deputado na $6^{\mathrm{a}}$. legislatura (1845-1847), também por Pernambuco. Foi conselheiro de Estado. 
portugueses, que presentemente residissem no Brasil com intenção de permanecerem, e que tivessem dado provas não equívocas de adesão à Sagrada Causa da Independência" seriam elevados à categoria de "brasileiros", ao contrário daqueles "portugueses cuja conduta fo[sse] suspeita" ${ }^{\prime 196}$.

No mês seguinte iniciou-se, de forma acalorada, a discussão do projeto ${ }^{197}$. As principais críticas eram duas: primeiro, a dificuldade em se encontrar critérios exatos para as "provas de adesão à causa do Brasil", correndo-se o risco de se gerar "temor e perseguições"; segundo, a escolha da naturalidade, isto é, local de nascimento, para a separação entre "brasileiros" e "portugueses". Num dos principais ataques à proposta, o deputado Carneiro de Campos afirmava:

"Deixamos de ser Portugueses, e passamos a ser Brasileiros, desde que pela insurreição do Brasil se dissolveu o antigo Pacto Social que nos ligava à Monarquia Portuguesa [...], pois não é o lugar do nascimento por si só o que constitui, a qualquer Cidadão desta ou daquela Nação, porém sim o Pacto Social expresso, tácito ou presumido."198

Acusava o projeto de ser injusto com muitos nascidos em Portugal, e pregava que "os portugueses que ficaram entre nós" fossem a partir de então entendidos como "cidadãos brasileiros" em nome de um passado partilhado comum ${ }^{199}$.

A defesa da proposta de Muniz Tavares, por seu lado, embasava-se na distinção marcada pelo local de naturalidade, entendido como "pátria" e que não poderia ser diluído por uma opção política. Antônio Carlos de Andrada marcava essa diferença ao afirmar que “a simples habitação no Brasil não faz[ia] brasileiro", e que desde setembro de 1822 os "portugueses s[eriam] estrangeiros, e não cidadãos"200. Justificava que seria "quase impossível em regra que um português p[udesse] amar de coração" a Independência do Brasil, o que implicava "a ruína da sua pátria de origem":

\footnotetext{
196 DAG, v.1, 22/maio, p. 100.

${ }^{197}$ DAG, V.1, sessão de 19/junho.

${ }^{198}$ Idem, v.1, 20/junho, p. 260.

${ }^{199}$ Idem, p. 262.

${ }^{200}$ DAG, v.1, 19/junho, p.252.
} 
"O amor dos nossos lares, o aferro ao primeiro berço, onde se gastaram os anos da nossa meninice, a afeição à pátria que nos viu nascer, são sentimentos naturais, que podem sim calar-se à vista de outras considerações, mas que sempre existem cobertos nas almas bem formadas" $" 201$.

A análise da discussão escancara como, à época, não se podia pensar nos vínculos que uniam os indivíduos em sociedade sem referências à "pátria"202. Para além de seu sentido comum como expressão de laços afetivos e sentimentais que ligavam os homens ao seu local de nascimento - sentido esse que a nação viria a ter apenas posteriormente nos oitocentos - ela também trazia consigo um conteúdo cívico e moral ${ }^{203}$. As referências ao "amor à pátria" e "patriotismo", recorrentemente utilizadas pelos deputados de 1823, bem como as de "sacrifício" e de "felicidade" de "servir à Pátria", estavam eivadas dessa carga simbólica. Corporificada pelos revolucionários franceses, a "pátria" como escolha política em nome da "felicidade", como adesão a um pacto estabelecido, também compunha o quadro de sua rica polissemia ${ }^{204}$. Nestes termos, questionava o padre cearense José Martiniano Alencar se não deveriam valorizar o lugar de adoção ao invés do local de nascimento: "qual é a Pátria de um Cidadão Brasileiro ainda que ele tenha nascido em Portugal, se não o Brasil?",205.

Enquanto essa discussão acontecia na sala da Assembléia, vaias e gritos chegaram a ser pronunciados pela platéia. Concomitantemente, nas ruas de muitas cidades do vasto Império rivalidades contra "portugueses" tomavam corpo e se imbricavam com conflitos de distinta natureza, servindo de matéria explosiva para muitos deles. Depois da elevação dos ânimos na Casa, decidiu-se no final do mês que a dita proposta não continuaria a ser discutida, e a resolução da distinção era delegada ao debate sobre o texto constitucional propriamente.

\footnotetext{
${ }^{201}$ DAG, v.1, 19/ julho, p.253.

${ }^{202}$ Pierre Vilar, Hidalgos, amotinados y guerrilleros: pueblo y poderes en la historia de España. Barcelona, Crítica, 1982, que chama a atenção de como a discussão sobre os vocábulos "pátria" e "nação" é fundamental para se pensar a questão nacional.

${ }^{203}$ François-Xavier Guerra, “A nação moderna: nova legitimidade e velhas identidades”, István Jancsó (org.), op.cit., p.43-5.

204 Veja-se nesse sentido a utilização da expressão "patriota" que se fez em Pernambuco quando do movimento de 1817 em Márcia Regina Berbel, "Pátria e patriotas em Pernambuco (1817-1822): nação, identidade e vocabulário político". István Jancsó (org.), Brasil: Formação do Estado e da nação. São Paulo/Ijuí, Fapesp/Hucitec/Unijuí, pp. 345-63.
} 
No mês de setembro, o problema voltou à tona na discussão do capítulo 1 do Projeto de Constituição, que previa serem "brasileiros" "os homens livres habitantes no Brasil e nele nascidos"; bem como "os portugueses residentes no Brasil antes de 12 de outubro de $1822^{\prime 206}$. Após polêmica que resultou na aprovação de que todos os "brasileiros" seriam considerados "cidadãos brasileiros"207, quando se tocou no caso dos "portugueses" novamente a questão da naturalidade ou da adesão ao pacto criou impasse. Dessa vez, os ânimos foram controlados e aprovou-se, por maioria, cláusula semelhante àquela defendida meses antes no projeto de Muniz Tavares. Desta forma, foram considerados "cidadãos brasileiros" todos os "portugueses" que "expressa ou tacitamente se tivessem ligado à sociedade brasileira": ou seja, à "pátria" como terra-mãe fizera diferença, e os nascidos no outro hemisfério tinham de apresentar seu juramento à nova "causa". Assim seria mantido na Carta outorgada no ano seguinte.

Não fora essa a única contribuição das discussões que ficaria contemplada no texto final da lei, a despeito da interrupção dos trabalhos. Todos os debates acerca do caráter do pacto político, tomado pelos protagonistas como um momento fundador mimetizado pela Assembléia, informaram o campo discursivo que forneceu materialidade às disputas pela construção de uma nova unidade, a qual estava longe de ser consensual, dentro e fora do ambiente legislativo. A resolução do papel que caberia à monarquia no peso entre os novos poderes já se mostrava fundamental.

Quando se iniciaram os trabalhos da Assembléia Constituinte, aparentemente estava definida a forma do regime a ser adotado: o de uma monarquia constitucional. No entanto, os deputados construíram diversas leituras sobre seus pressupostos, bem como da relação

\footnotetext{
${ }^{205}$ DAG, v.1, 19/junho, p. 246.

${ }^{206}$ Apresentado na sessão de $1^{\circ}$. de setembro de 1823.

${ }^{207}$ Sobre a questão da cidadania ver Andréa Slemian, “'Seriam todos cidadãos?': os impasses na construção da cidadania nos primórdios do constitucionalismo no Brasil (1823-1824)”. István Jancsó (org.), Independência: história e historiografia. São Paulo, Fapesp/Hucitec, 2005, pp. 829-847; e Kirsten Schultz, "La independencia de Brasil, la ciudadanía y el problema de la esclavitud: A Assembléia Constituinte de 1823”, Jaime Rodríguez (coord.), Revolución, independencia y las nuevas naciones de América, Madri, Mapfre, 2005, pp. 425-429.
} 
dos poderes no seu conjunto, tema tão caro àqueles que buscavam uma forma equilibrada de governo avessa aos solavancos revolucionários.

Um dos pontos fundamentais era a questão da inviolabilidade da figura do monarca. Sob a defesa de que "Sua Majestade" estaria "acima das fraquezas humanas, não [sendo] homem, mas um ente metafísico" ${ }^{208}$, e que se deveria preservar sua "indelével Glória",209, desde logo os mais moderados saíram em sua defesa. Nas sessões preparatórias, no entanto, José Custódio Dias atacou a tese da inviolabilidade como "iliberal", e apoiou que o presidente da sessão deveria responder à fala do Imperador em razão da preeminência do papel legislativo da Assembléia sobre ele. A pronta resposta veio do sempre alerta Antônio Carlos de Andrada, que afirmou ter o Imperador "superioridade" para "influir sobre todos os poderes delegados" como "essência da monarquia constitucional"210.

Aparentemente, predominavam defesas como essa, sobretudo nos primeiros meses de trabalho da Casa, em que se concebia a monarquia constitucional como um regime em que o monarca teria um papel fundamental no Executivo, além de influência sobre as outras instâncias. No entanto, a tensão existente quanto à forma do governo revelava-se não apenas nos discursos, mas também nas votações. Um exemplo disso foi a discussão do projeto sobre a forma de promulgação das leis e decretos da Assembléia Constituinte, elaborado por uma Comissão. Nela, os representantes se detiveram exaustivamente numa polêmica colocada pelo artigo $3^{\circ}$., que afirmava que as leis por eles aprovadas não seriam dependentes de sanção imperial. Imediatamente vieram à tona distintas leituras acerca do papel do monarca na nova ordem.

Entre os que defendiam ferozmente a sanção estava Martim Francisco Ribeiro de Andrada. Sua justificativa fundamental era que o Imperador seria a base da "harmonia" entre os poderes:

"se a Assembléia tem direito de fazer leis anteriores à Constituição, o Monarca tem direito de as sancionar; já disse nesta Assembléia, e torno a repeti-lo, eu não considero livre uma Nação pela simples divisão dos Poderes; estou persuadido que a base principal da liberdade é a harmonia, é uma tal ou qual ingerência de um em

\footnotetext{
${ }^{208}$ DAG, v.1, 26/maio, discurso de Antônio Carlos de Andrada, p.121.

${ }^{209}$ DAG, v.1, 09/junho, discurso de José Antônio Rodrigues de Carvalho, p.187.

${ }^{210}$ Idem, p. 12.
} 
outro Poder, e esta deve conceder-se ao Monarca nas Leis anteriores à Constituição assim como o Poder Legislativo a tem nesta mesma época no Poder Executivo, quando este se desliza dos seus deveres. Se ninguém nega este direito à Assembléia para por termo às aberrações do Executivo, qual será o motivo de não ter este também autoridade de pôr termo às aberrações da Assembléia?"211.

Outros que como ele criticavam o artigo e votavam pela sua supressão, reiteravam a posição de um "Poder Vigilante ou Moderador" do Imperador, que já estaria definido antes mesmo da própria Constituição. José Joaquim Carneiro de Campos argumentava que o "que verdadeiramente caracteriza[va] o Governo Monárquico Representativo, e o distingu[ia] das Repúblicas [era] a grande influência que o Monarca tem no Corpo Legislativo" ${ }^{\text {212. }}$.

Um dos discursos mais eloqüentes a favor do artigo e, portanto, contra a sanção, foi o do padre Henriques de Resende. Delegando à Assembléia o estabelecimento das "regras de conduta dos poderes constitucionais", ele despojava o monarca de qualquer qualidade essencial da monarquia que justificasse sua preeminência:

"Também não posso admitir essa essencialidade da Sanção Imperial: nada é essencial nestas matérias, Senhor Presidente; tudo procede dos interesses dos Povos, e da conveniência que eles acham em tais e tais instituições [...] Mas dizem a Assembléia não é infalível, e sujeita as paixões, e o Imperador é um Anjo, não tem paixões? O Imperador é mais sujeito a essas paixões porque tem para elas mais incentivos; comanda a força, dá os empregos, as honras, e é quem executa as Leis e por isso tem mais interesse em que elas sejam a jeito; nós nada disso temos, e somos temporários, e tornamos para o que de antes éramos. Assembléia não é infalível: e o Imperador é? Nego. É tanto homem como nós; e demais tem maiores entraves; para ver a verdade, mais incentivo de paixões" 213 .

\footnotetext{
${ }^{211}$ DAG, v.1, 25/junho, p. 294.

${ }^{212}$ DAG, v.1, 26/junho, p.300.

${ }^{213}$ DAG, v.1, 26/junho, p. 302-3.
} 
Depois de três sessões em que a matéria esteve em pauta, em votação apertadíssima aprovou-se a supressão do artigo, ficando implícita a necessidade de sanção imperial. No entanto, no mês seguinte, quando da terceira e última discussão da matéria ${ }^{214}$, o resultado se inverteria. Após polêmica sobre os protocolos que deveriam ser seguidos para entrega das leis aprovadas ao Imperador - ao que uns defendiam a "pompa" e "cerimonial" como necessária para o culto da "subordinação legal" à monarquia - a supressão do artigo $3^{\circ}$. foi alvo de nova e ampla discussão. O combativo paraibano Joaquim Manuel Carneiro da Cunha $^{215}$, em enfática fala contra a sanção, chegou a argumentar que sua aprovação seria até mesmo perigosa: "o povo que tem os olhos na Assembléia e que julga ter escolhido homens para fazer a sua felicidade, se visse que o monarca se opunha a uma lei que ele esperava remediaria alguns de seus males, quem sabe a que excessos chegaria!" ${ }^{216}$. Nova votação apertada, só que dessa vez a sanção foi recusada conforme ficou na lei de 20 de outubro de 1823 que, posteriormente aprovada, estabeleceria a forma provisória para promulgação dos decretos da Assembléia Constituinte sem a sanção imperial. Foi, sem dúvida, uma vitória que contrabalançou os poderes do Imperante.

Subjacente a essa discussão estava o debate acerca da divisão e controle entre os poderes, tão caro à época. Por se tratar de um regime de Monarquia Constitucional, a discussão em torno da inviolabilidade do monarca desdobrava-se em polêmicas sobre o exercício de sua função Executiva. Para os que defendiam a majestade da Coroa, era comum o argumento da "irresponsabilidade" de suas ações pelas quais responderiam seus ministros como delegados do Executivo, nos moldes propostos por Benjamin Constant em sua interpretação da Carta Constitucional francesa de $1814^{217}$. A equação tinha por objetivo preservar a figura do rei e a estabilidade da ordem, ao colocar como alternativa, em casos de conflito, a queda do ministério e sua imediata substituição pelo monarca. Daí a permanente discussão acerca da necessidade de se marcar a responsabilidade não apenas dos ministros, mas também dos ocupantes de cargos e instituições que tivessem funções

\footnotetext{
${ }^{214}$ DAG, v.1, iniciada em 28/julho.

215 Joaquim Manuel Carneiro da Cunha era proprietário rural na Paraíba. Foi deputado Constituinte pela mesma Província. Na Assembléia Geral, ocuparia o mesmo posto por quatro vezes: na $2^{a}$ legislatura (1830-3), na $4^{\mathrm{a}}$ (durante os anos de 1839-41), na $5^{\mathrm{a}}$ (durante os anos de 1843-5), e na $8^{\mathrm{a}}$ (durante os anos de 1850-2).

${ }^{216}$ DAG, v.1, 29/julho, p.476.

${ }^{217}$ Escritos Políticos.
} 
executivas, como forma de legitimar, do ponto de vista normativo, a garantia de punição aos abusos praticados.

Nesse sentido, sob o slogan da independência dos poderes, as mais variadas posições tomavam corpo, alimentadas por uma permanente disputa na construção das delimitações dos poderes Executivo e Legislativo. Manuel José de Sousa França ${ }^{218}$ valia-se do "respeito à máxima divisão dos poderes políticos que adotamos por base do sistema constitucional" para atacar a proposta de que o Imperador, ao suspender os conselheiros de Província eleitos, tivesse que prestar conta de suas razões para a Assembléia ${ }^{219}$. Alegava que isso seria "estender às raias da autoridade do corpo Legislativo sobre o Executivo" que "lhe não deve ser subordinada por via de regra", e induzir a ingerência de um "poder" sobre o outro. Com esse discurso, atribuía ao Imperador a possibilidade de controlar os citados conselheiros. Carneiro de Campos concordava com França na proposição, mas justificava a supremacia do Imperador retirando-lhe autoridade executiva. Alegava que sua "suprema autoridade vigilante, ou o poder Moderador, que nas monarquias é inseparável do monarca" estava destinada "a evitar a perturbação da ordem pública e desarranjo da máquina política [...] quando se não oferece outro algum meio ordinário e pacífico de evitar os danos iminentes do Estado"220. Dias depois, resumia em poucas palavras o papel do "Moderador":

"Para conservar a liberdade entre estes dois escolhos é indispensável que o Poder Legislativo e o Monarca sejam armados de uma igual vigilância: o Poder Legislativo sobre os Ministros, que no exercício do Poder Executivo podem favorecer a tirania de um só; e o Monarca sobre o Corpo Legislativo, para que este não possa sair dos seus limites que a Nação lhe tem marcado. Estas considerações deram nascimento ao poder Moderador, que é o baluarte da liberdade pública e a mais firme garantia para a Nação de que nós, que somos os seus legítimos

\footnotetext{
${ }^{218}$ Manoel José de Sousa França (1780-1856) era natural de Santa Catarina. Bacharel em Direito. Ocupou a cadeira de deputado pela Província do Rio de Janeiro na Constituinte de 1823, e na Assembléia Geral por mais três vezes: na $1^{a}$ legislatura (1826-9), na $6^{2}$ (de 1845-7) e na $7^{2}$ (somente em 1848). Em 1831, foi Ministro da Justiça ainda do Primeiro Império (março-abril), e da Justiça e do Império no início da Regência (abriljulho). Ocupou o cargo de Presidente da Província do Rio de Janeiro (1840-1).

${ }_{219}$ DAG, v.1, 23/junho, p. 279.

${ }^{220}$ Idem.
} 
Representantes, e os que nos sucederem em outras Assembléias, jamais nos transformaremos em seus Senhores e Tiranos"

O discurso refletia a urgente necessidade de enquadramento de uma monarquia, pensada em termos moderados, nos moldes constitucionais, traduzida numa equação de equilíbrio entre os poderes. Meses depois, um discurso do deputado por Minas Gerais, Severiano Maciel da Costa, futuro Marquês de Queluz ${ }^{222}$, definiria com clareza o “poder Moderador" que, como se sabe, seria incorporado na Carta de 1824.

As propostas para supremacia do Legislativo como forma de valorização de seu papel perante o Executivo também foram várias vezes evocadas "em nome da nação", tendendo a confundir Corte e monarquia numa tentativa de fortalecimento da autonomia das partes do Império. Por essa razão, criticou-se à emenda de José Bonifácio para que as despesas extraordinárias das Províncias não fossem feitas sem a aprovação de D. Pedro. Henrique de Resende se opôs frontalmente à matéria, e defendeu que as mesmas despesas extraordinárias fossem assunto da Assembléia, e não do Imperador, "porque isto seria deixar uma porta aberta para o poder Executivo meter o seu arbítrio a mão nos cofres da nação; o que [seria] contrário aos princípios Constitucionais" ${ }^{\text {223 }}$. Sua opinião foi apoiada por vários deputados e acabou sendo majoritária.

A tentativa de construção da legitimidade do Legislativo fez-se claramente presente quando se discutiu qual seria a punição da tropa e do governo do Rio Grande do Sul por terem se voltado contra o poder da Assembléia ao apoiar o veto imperial. José Arouche de

\footnotetext{
${ }^{221}$ DAG, v.1, 26/junho, p. 301.

222 Silvana Mota Barbosa, A shinge monárquica: o Poder Moderador e a política imperial, Campinas, Unicamp, Tese de Doutorado, 2001, defende a idéia de que teria sido a atuação de Severiano Maciel da Costa - um dos escolhidos para compor a comissão responsável pela elaboração da Carta de 1824 - decisiva para a introdução do "poder Moderador" no seu texto. Em 22 de setembro, ele o definiu na Assembléia: "Sabemos todos que num Governo Constitucional, o Supremo Chefe, além do Poder Executivo para a simples execução das Leis, tem o Supremo Poder Moderador, em virtude do qual ele vigia como d'atalaia sobre todo o Império; é a Sentinela permanente, que não dorme, não descansa; é o Argos Político, que com cem olhos tudo vigia, tudo observa, e não só vigia, e observa, mas tudo toca, tudo move, tudo dirige, tudo conserta, tudo compõe, fazendo aquilo que a Nação faria, se pudesse, mas sendo preciso cometê-lo a alguém, tem mostrado a razão, e a experiência, que vale mais cometê-lo a uma pessoa física, que a uma pessoa moral, isto é, uma Corporação./Ora se o Supremo Moderador tudo deve ver, e tudo tocar, é preciso que tenha olhos, e braços por todo o Império. Esses olhos, esses braços, são as Autoridades Provinciais, que vêem, e tocam por ele, e com ele estão em contínuo e imediato contato; relações estas que não quadram aos Membros do Poder Judiciário, que deve ele mesmo ser vigiado, sobreroldado. E essas Autoridades Provinciais devem abranger uma grande extensão do território, pois que sua multiplicação sem urgente necessidade, além de grandes despesas, só serviria de complicar, e entorpecer a marcha do Governo em suas operações." (DAG, v.3, p.88).
} 
Toledo Rendon ${ }^{224}$, representante por São Paulo, argumentava que se tratava de um "crime de lesa nação" e que se deveria implantar uma devassa determinada pela Casa e não pelo Executivo $^{225}$. Apesar de posicionamentos discordantes que defendiam caber apenas ao governo decidir sobre a matéria, novamente Henriques de Resende apontou a gravidade do delito, por "atentar contra as autoridades constituídas":

"uma vez instalada esta Assembléia, a ela exclusivamente compete o legislar; que ela é quem deve marcar a divisão dos Poderes e fixar as atribuições, que a cada um deve competir: que ela é quem pode definir as prerrogativas, e regalias do Chefe do Poder Executivo; e que toda, e qualquer mão estranha que nisto se ingerir, comete um crime, um atentado contra o exercício da Soberania Nacional confinada a esta Assembléia"226.

A proposta de Arouche Rendon foi aprovada incluindo a destituição dos envolvidos dos seus cargos para que se mostrasse "todo o rigor" o "desprazer" causado pelos mesmos.

Em muitos momentos os deputados discutiram se as matérias em pauta seriam da competência de um ou de outro poder: do monarca e seus ministros ou da Assembléia. Um outro ponto de tensão era a contínua exigência, por parte dos deputados, de visibilidade das ações realizadas pelos ministérios. Essa demanda cresceu visivelmente depois de julho, resultado do próprio desenvolvimento dos embates internos da Casa. Entre os meses de julho e agosto, o baiano Montezuma chegou a propor três indicações nesse sentido: a primeira para que o governo apresentasse o que havia entre ele e os gabinetes estrangeiros, inclusive o de Portugal $^{227}$; a segunda, para que se exigisse do ministério as informações

${ }^{223}$ DAG, v.2, 14/julho, p. 402.

${ }^{224}$ Nascido em São Paulo (1756-1834), formou-se em Leis na Universidade de Coimbra (1779). De volta à sua capitania natal, dedicou-se à advocacia. Em 1789, iniciou carreira militar e ocupou vários cargos públicos. Subindo rapidamente de patente, organizou, em 1817, corpos de milícia que se destinavam ao sul do Brasil. Em 1822 foi promovido à marechal de campo. No mesmo ano, ocupou o cargo de Governador de Armas da Província de São Paulo, pela qual foi eleito deputado para a Assembléia de 1823. Posteriormente, seria membro do Conselho de Governo paulista, provedor da Santa Casa de Misericórdia e diretor da Faculdade de Direito de São Paulo (de 1828-1833). Deixaria escritas ao menos duas memórias: uma sobre a agricultura e outra sobre as aldeias de índios, ambas para São Paulo. Ver: José Arouche de Toledo Rendon, Obras, São Paulo, Governo do Estado de São Paulo, 1978.

${ }^{225}$ DAG, v.2, 26/julho, p. 459.

${ }^{226}$ Idem , p. 461.

${ }^{227}$ DAG, v.2, 29/julho, p. 479. 
respectivas do estado atual do Império em suas diferentes repartições ${ }^{228}$; e a terceira para que o governo informasse com detalhes os balanços da Intendência, pois argumentava que estes vinham sendo feitos de forma muito geral e "o público te[ria] direito de saber com individuação em que se gastam as rendas da nação" 229 . Todas foram discutidas e, por motivos diversos, negadas.

Em setembro, no entanto, o mesmo deputado propôs outra indicação para que se pedissem esclarecimentos ao governo acerca do balanço de despesas do Tesouro em julho de $1823^{230}$. Diferentemente das anteriores, esta foi aprovada, junto com uma outra que denunciava as várias gratificações que possuiria o atual Inspetor do Arsenal do Exército, caso que foi encaminhado à Comissão de Guerra ${ }^{231}$. No início de outubro, aprovou-se um pedido de leitura pública e impressão de um ofício do ministro da Fazenda sobre a situação em que se encontravam as operações de crédito e os modos pelos quais se poderia contrair um empréstimo ${ }^{232}$. Em 11 de outubro, Joaquim Manuel Carneiro da Cunha propôs que se investigasse uma portaria do ministro da Guerra, de 2 de agosto, que mandava a Junta da Bahia remeter ao Rio de Janeiro os prisioneiros de Guerra - então chamados "portugueses" - para que estes tomassem praça nesta cidade. Cunha atacou com a medida e, diretamente, também o ministro:

"Senhor Presidente, não pode ser senão erro do Ministro da Guerra; é contra ele que eu falo; e sempre quando eu falo contra o Governo, me dirijo só aos Ministros; nunca contra aquele que nenhuma responsabilidade tem, que a mesma Constituição faz impecável (Apoiado, Apoiado). Respondam, pois, os Ministros pelo que fazem, aliás, não há Constituição, nem segurança, nem sei como poderemos consolidar a nossa obra" 233 .

\footnotetext{
${ }^{228}$ DAG, v.2, 18/agosto, 607-610.

${ }^{229}$ DAG, v.2, 23/agosto, p. 631.

${ }^{230}$ DAG, v.3, 18/setembro, p.59.

${ }^{231}$ DAG, v.1, 22/setembro, p. 81.

${ }^{232}$ DAG, v.3, 06/outubro.

${ }^{233}$ DAG, v.3, 11/outubro, p. 227.
} 
Após discussão, aprovou-se que os esclarecimentos deveriam ser prestados. Era óbvio que a idéia do controle dos poderes dos ministros abria espaço para ataques e acusações das mais variadas ordens.

Três dias depois, Antônio Carlos, então já identificado como opositor ao novo ministério de D. Pedro, propôs duas indicações, ambas aprovadas com urgência: uma para que o governo informasse sobre a fuga da Corveta Liberal e levantamento do bloqueio de Montevidéu ${ }^{234}$; outra para que se pedisse as razões da nomeação de um membro do governo da Bahia, Felisberto Caldeira Brant Pontes - que acabara de assumir seu lugar como deputado - para Comandante das Armas. Argumentava que "esta nomeação tend[ia] a concentrar poderes, que por sua natureza devem estar separados", e ia "de encontro aos princípios constitucionais que nos regem"235.

É fato que o número de pedidos de esclarecimento e transparência feitos pelos deputados aumentaram muito no segundo semestre dos trabalhos da Casa, pari passu à tensão crescente entre os próprios representantes. No dia 11 de novembro, véspera do decreto da dissolução da Assembléia, os deputados ainda reivindicavam esclarecimentos do governo. No entanto, a contínua discussão sobre os papéis do Executivo e o do Legislativo na ordem constitucional era potencializada também pelo acirramento da luta política no âmbito da Corte. Por isso, deve-se entender que os protagonistas dessa história igualmente instrumentalizaram a discussão de modo a criarem uma incompatibilidade entre o regime de D. Pedro e a Assembléia como poderes antagônicos, o que poucas vezes se verificou claramente por duas razões: primeiro, porque governo e Imperador não eras sinônimos; e segundo, porque muitos deputados também atuavam como ministros, ou seja, nas duas instâncias de poderes em construção. $O$ fato é que ambas ainda necessitavam confeccionar sua legitimidade pública na nova ordem.

\subsubsection{A criação dos Governos Provisórios das Províncias}

No começo do ano de 1823, Diogo Antonio Feijó redigiu, no Recife, um Manifesto tratando longamente de justificar seu rompimento com as Cortes de Lisboa perante aqueles que o haviam elegido deputado pela Província, isto é, os paulistas. Depois de acusar os

\footnotetext{
${ }^{234}$ DAG, v.3, 14/outubro, p. 245.
} 
"portugueses da Europa" do maior desprezo e injustiça com a "causa do Brasil", discorria sobre a urgência na organização do governo. Elogiava que na feitura da Constituição Portuguesa se tivessem criado Juntas de Governo, mas criticava o silêncio relativo à sua jurisdição institucional:

“enfim, falta generalizar-se o sistema representativo, estendendo-se a todas as partes da Nação à sua imagem, o seu encanto, e energia; em uma palavra, naquela Constituição se encontra um vazio imenso, e irreparável relativamente ao Governo das Províncias, ficando estas em muito pior estado que o antigo pela inteira divisão das Autoridades, e sua eterna colisão, atenta a distância do último anel, que as prende",236.

Com discurso afinado com o das Juntas no que tocava à reclamação da "divisão de Autoridades", Feijó lançava para os "novos representantes" a tarefa de realizar uma equação favorável ao Brasil, onde as "Províncias extensas e inabitadas" sofriam com a falta de leis e a impossibilidade de fazê-las. Em setembro do mesmo ano, quando se iniciava na Assembléia a discussão do Projeto de Constituição, João Soares Lisboa publicava o texto de Feijó no seu combativo periódico Correio do Rio de Janeiro, sob a alegação que ele não circulara na Corte a despeito de seu apropriadíssimo conteúdo ${ }^{237}$.

Reivindicação semelhante para o governo das Províncias foi feita pelas próprias Juntas de Governo já existentes. Em 4 de maio de 1823, o governo de Sergipe escrevia ao ministro José Bonifácio expondo a necessidade que tinham de medidas para regulamentação de seus trabalhos: "sem leis, sem instruções entramos às cegas no

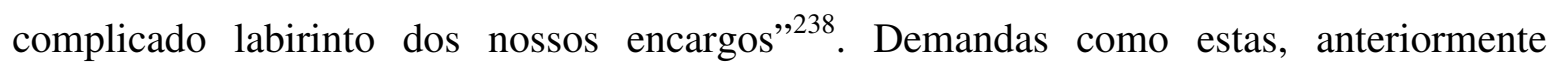
dirigidas a Lisboa, desde as vésperas da Independência eram freqüentemente dirigidas à Corte do Rio de Janeiro, pedindo urgência no esclarecimento de suas funções. Desta forma, as expectativas que se voltaram à Assembléia Constituinte quando de sua abertura em 1823

\footnotetext{
${ }^{235}$ Idem.

${ }^{236} \mathrm{BN}$, Correio do Rio de Janeiro, 16-17/setembro/1823.

${ }^{237}$ Idem.

${ }^{238}$ As Juntas Governativas e a Independência, v.2, p. 736.
} 
eram enormes tanto no que dizia respeito a aspectos administrativos quanto na definição das Províncias como espaços políticos de "representação dos povos".

Não foi à toa que, logo no início das sessões da Assembléia, três propostas para regularização, ainda que provisória, dos Governos Provinciais surgiram entre os primeiros projetos de lei. Em 7 de maio, foi lido o de José de Sousa Mello ${ }^{239}$, deputado por Alagoas, seguido dois dias depois pelos de Antônio Carlos de Andrada e de Antônio Gonçalves Gomide $^{240}$, por Minas Gerais ${ }^{241}$. Mesmo que todos concordassem com a extinção das Juntas de Governo e com a escolha de um presidente de Província pelo Imperador, mantinham diferenças importantes entre si. O primeiro projeto, de Sousa Mello, frisava que o Comandante de Armas seria subordinado ao Presidente, ambos nomeados pelo Imperador. Além disso, quatro dos dez artigos que o compunham tratavam da instituição de um "juiz do povo" eleito na paróquia para "desafogo e liberdade dos povos" que, como pessoas de "conhecimento, luzes, e prudência", assumiriam as questões da justiça tão judiadas pela falta de magistrados letrados locais. O projeto de Antônio Carlos se diferenciava em dois pontos fundamentais: primeiro, pela concepção de que o governo das forças armadas seria independente do presidente da Província (com exceção das ordenanças e do recrutamento) e vinculado diretamente ao Imperador, o que asseguraria ao poder central um papel importante no controle dos distúrbios regionais; e segundo, pela idéia de que, apesar da administração da justiça ser independente do presidente e dos seus conselheiros, estes poderiam suspender os magistrados. Além disso, o Conselho eletivo para auxiliar o presidente não seria permanente. Sem maiores detalhamentos, o projeto de Gomide deixava entender que o comandante de armas seria também escolhido pelo "poder Executivo", e por ele amovível, sem especificar a quem responderia diretamente por suas ações.

Em 26 de maio, os projetos para o governo das Províncias eram anunciados à “ordem do dia”. Foi quando o Padre José Martiniano de Alencar fez uma indicação, no mínimo, polêmica: que se reservasse a deliberação final da matéria para quando estivessem presentes “todos os Srs. Deputados, ou ao menos os da Bahia, que [era] uma Província de

\footnotetext{
239 José de Sousa Mello era natural de Alagoas, e pela mesma Província seria novamente eleito deputado para a 1 legislatura da Assembléia Geral (1826-9).

${ }^{240}$ Antônio Gonçalves Gomide (1770-1835) era natural de Minas Gerais. Médico, foi eleito deputado para a Constituinte pela sua Província natal, e nomeado senador em 1826.

${ }^{241}$ DAG, v. 1, 7/maio, pp. 40-5.
} 
primeira ordem" ${ }^{242}$. Alegava que problema semelhante teria se passado nas Cortes em Portugal, quando a proposta dos representantes de São Paulo em 1822 fora criticada por ir contra aos decretos aprovados anteriormente por representantes de outras bancadas, já ingressos na Casa. Muito embora Alencar não anunciasse diretamente, isso significava questionar a ação dos presentes como legítima para deliberar, pois que nem todas as partes do Império estavam contempladas com poder de decisão. Portanto, o problema era de quem decidia pela "nação" e, no limite, quem a representava.

Outro padre, o pernambucano Francisco Muniz Tavares, colocou-se contra a indicação de Alencar, em nome da "desgraça a que est[aria] reduzida a administração das Províncias", sendo necessárias medidas urgentes que pudessem "obstar a torrente dos males"243. Mas foi Antônio Carlos que tocou no cerne da questão, ao argumentar que a antiga "monarquia portuguesa" era composta de "duas partes distintas, e até inimigas" [Portugal e Brasil], mas que agora o novo Império seria "um todo homogêneo" "244. Punha definitivamente por terra qualquer representação de tipo corporativa das partes (Províncias) posto que os deputados, como "indivíduos" eleitos, deveriam falar em nome da "nação". As outras falas que se seguiram nem discutiram a questão. $O$ único que se pronunciou a favor do padre cearense, foi Joaquim Manuel Carneiro da Cunha, em tom provocativo: alegava que urgente era resolver a desarmonia entre o governo civil e o das armas, e não o projeto em pauta.

A indicação de Alencar foi rejeitada e, na mesma hora, seu autor propôs que todas as representações das Juntas Provisórias recebidas pelo governo fossem encaminhadas à Assembléia, para que todos pudessem conhecer as reivindicações e os abusos praticados nas localidades. Depois de certo impasse, a medida foi aprovada; também ficou decidido que seria o texto de Antônio Carlos a base para o debate da matéria, muito provavelmente pelo seu maior detalhamento e pela influência que, naquele momento, seu autor gozava no ambiente da Casa.

Logo na primeira discussão (que deveria apenas aprovar se o Projeto teria validade ou não), a questão da extinção das Juntas de Governo tomou a cena. Ao fazer a defesa do seu projeto, Antônio Carlos atacou as Juntas a despeito do "entusiasmo geral" que teriam

\footnotetext{
${ }^{242}$ DAG, v.1, 26/maio, p. 122.

${ }^{243}$ Idem, pp.122-3.

${ }^{244}$ Idem, p. 123.
} 
inicialmente causado nas localidades. Afirmava que elas teriam sido fruto do "erro" de querer juntar as atividades executivas, deliberativas e de "juízo", e, com o intuito de separálas, defendeu a criação do cargo de presidente. Em relação ao comandante de Armas, atacou sua subordinação às autoridades locais, exatamente o contrário do que defendera anteriormente nas Cortes de Lisboa quando da regulamentação dos órgãos para o Brasil. De opinião semelhante foi Francisco Muniz Tavares, que relegou à instituição o papel de "pomo fatal da discórdia" pela divisão de poderes que ela implantara nas Províncias, aos moldes de críticas feitas desde o ano anterior. Moderadíssimo, defendia que a função de presidente era contrária a sua escolha por eleições populares.

As posições daqueles que não apoiavam a continuidade da discussão do projeto variaram em dois extremos. De um lado, os que defendiam as Juntas contra as acusações que, nas Províncias, elas seriam instâncias fomentadoras de desordens, como fizeram Carneiro da Cunha e o Padre Alencar. Ambos rechaçaram o texto no que tocava à independência das armas, mesmo que o primeiro tenha concordado sobre a necessidade de uma autoridade executiva confiada a um Presidente ${ }^{245}$. De outro, aqueles que, numa posição conservadora, mostravam ser mais cautelosos em função da existência de "partidos opostos" que poderiam reagir à nova lei. Nesse sentido, José Joaquim Carneiro de Campos apoiava a aprovação simples de instruções para o funcionamento dos governos já instituídos, e Manuel Jacinto Nogueira da Gama propunha que se remetesse a questão para a Comissão de Constituição, onde poderia ser tratada com menos alarde ${ }^{246}$. Mesmo assim, como já despontara desde o início, o andamento da matéria foi aprovado (36 votos a 19).

Em junho de 1823 se iniciou a segunda discussão do projeto de autoria de Antônio Carlos, agora artigo por artigo, sendo somente concluída em 11 de outubro. A questão da extinção das Juntas Provisórias, matéria do primeiro artigo, imediatamente reinstaurou a polêmica. O deputado da Paraíba, Augusto Xavier de Carvalho, foi o primeiro a se posicionar contra sua substituição por presidentes escolhidos:

"Não sou nem serei nunca de parecer que desde já se declarem abolidas as Juntas de Governo: é uma instituição que os Povos esperaram, que receberam com gosto, e que tanto tem respeitado que ainda quando na desordem têm insurgido contra

\footnotetext{
${ }^{245}$ Idem, pp.127-8.
} 
algumas Juntas, é para as substituírem por outras ainda temporárias, mas nunca por um só indivíduo [...] Portanto ordenem-se ajustadas providências; mas não se arranque de repente pela raiz uma Instituição que os Povos consideram como seu Paladio; pois pode levar a crimes que, no meu pensar, cumpre antes prevenir que ter de castigar." 247

Uniram-se à argumentação os mesmos Carneiro da Cunha e padre Alencar. Este atacou Antônio Carlos por querer centralizar as decisões no Rio de Janeiro, afirmando que isso seria visto pelas Províncias como um ato "despótico". No entanto, uma outra voz eleita na região Norte, a do pernambucano Henriques de Resende, apoiou a extinção das Juntas. Na terceira discussão do projeto $^{248}$, alguns deputados voltariam a se posicionar contra a matéria, alegando que muitos males e desordens ocorreriam nas Províncias se essas instituições fossem abolidas. Mas, ainda assim, venceu sua extinção.

Quando se tratou do segundo artigo - que estabelecia ser o governo provisoriamente conferido a um presidente e a um Conselho - as discordâncias vieram novamente à tona. $\mathrm{O}$ autor do projeto voltou a atacar as Juntas que, "formadas por eleição popular, cuidaram que tinham em si o poder da nação, supuseram-se uns pequenos Soberanos, e julgaram que tudo lhes era permitido, e d'aqui procederam as desordens e os erros que têm feito os povos desgraçados" 249 . Carneiro da Cunha dessa vez rechaçou completamente o artigo, enquanto Henriques de Resende, seguido por Muniz Tavares e Belchior Pinheiro de Oliveira, defenderam-no. $\mathrm{O}$ artigo foi aprovado.

$\mathrm{Na}$ discussão do terceiro artigo - que estipulava que o presidente seria o executor e administrador, nomeado e demitido pelo Imperador - foi o padre Luís Inácio de Andrade Lima, eleito por Pernambuco, que desta vez protestou:

"Eu olho, senhor Presidente, tão somente a utilidade dos Povos, é esta a mira da minha Política. Os Povos deste vasto Império há longo tempo, calcados pelo despotismo dos delegados dos Monarcas, olham com horror para tudo quanto seja

\footnotetext{
${ }^{246}$ DAG, v.1, 27/maio, p. 133-7.

${ }^{247}$ DAG, v.1, 16/junho, p. 218.

${ }^{248}$ DAG, v.1, 3/julho, p. 343.

${ }^{249}$ DAG, v.1, 04/julho, p. 349.
} 
fabricado ao segredo dos Gabinetes. Eles vêm nesse Projeto uma organização de Governo, que se diz de forma Constitucional em epílogo; mas cujas Autoridades, que mais podem, são da nomeação do Imperador; e um Conselho de nomeação popular, mas que nada mais pode senão dar conselhos, e fantasiar melhoramentos. ${ }^{250}$.

José Joaquim Carneiro de Campos propôs uma emenda para que a junta eleitoral de cada província mandasse uma lista para o Imperador escolher o presidente, na qual foi apoiado por Custódio Dias que defendeu, também, que o mesmo fosse "amovível" quando "se mostrar que cometeu erro que o mereça" ${ }^{251}$. Henriques de Resende propôs emenda conciliatória para que o Imperador indicasse os presidentes entre os homens da Província, mas defendeu sua escolha pessoal e poder de demissão, pois o cargo era:

"um lugar de feitorização; é um lugar que o Imperador devia encher pessoalmente; como porém isso não é praticável nomeia seus agentes para em seu nome governarem as Províncias. Já se disse que o movimento do Poder Executivo deve ser rápido e vigoroso; se o Imperador não pudesse ad nutum remover um homem, que não é senão seu Feitor, quando visse que era mal servido, o andamento do Poder Executivo ficaria paralisado" 252 .

Apesar das distintas emendas conciliatórias, a discussão girou em torno da questão: caberia ao Imperador escolher o presidente e, caso sim, deveria ser ele um homem da Província?

$\mathrm{Na}$ terceira e última discussão do mesmo artigo, enveredou-se por um caminho distinto. Entre discursos contrários e favoráveis à matéria, foi Manuel José de Sousa França quem corajosamente defendeu que "o meio da nomeação dos mesmos Povos" nem sempre era "eficaz para se obter o melhor governo". Completou que tanto importava "para a liberdade dos Povos que o presidente seja de nomeação absoluta do governo, como que nisso intervenha o voto e proposta dos mesmos Povos: o que importa[va] [era] ter olho largo sobre estes Empregados: removê-los, e castigá-los quando declinarem dos seus

\footnotetext{
${ }^{250}$ DAG, v.1, 17/junho, p. 229.

${ }^{251}$ Idem, p. 233.

${ }^{252}$ Idem, p. 233.
} 
deveres" 253 . Desviada assim do problema inicial, venceu a proposta para que o Imperador escolhesse o presidente independentemente das províncias, mas que se marcasse sua responsabilidade de acordo com a emenda então aprovada.

A questão da presença do Conselho nos despachos do presidente (art. $6^{0}$.) e sua periodicidade (art. $9^{\circ}$.) também foram pontos de atrito na discussão, por tocarem na limitação da autoridade executiva por meio do órgão eletivo. Cândido José de Araújo Viana $^{254}$, de Minas Gerais, propôs emenda para que o presidente decidisse sozinho apenas nos negócios de pura execução ${ }^{255}$. Porém, José Bonifácio sustentou a matéria do jeito que estava, ou seja, para que o presidente despachasse por si mesmo sem exigir a presença do Conselho, pois que o mesmo não seria um "capitão general", mas "muito menos do que isso; um homem que há de executar as ordens que receber, e as Leis; e que só delibera em casos extraordinários e repentinos"256. Portanto, argumentava não haver precisão "desse Conselho permanente, transformando assim o Governo de uma Província em Assembléia deliberativa"; por fim, perguntava: "que utilidade resultaria de tal Conselho" além "de levarem os negócios tanto tempo"? Após sua fala, uma clara defesa do poder de ação dos presidentes, nenhum outro deputado se colocou contra a medida, e novamente venceu o artigo como fora redigido.

Dois dias depois, Martim Francisco propôs uma emenda - ao artigo $8^{\circ}$, que estipulava o número de conselheiros, eleitos da mesma forma que os deputados - para que todos os membros do Conselho também fossem escolhidos pelo Imperador por lista tríplice, aumentando ainda mais o poder centralizador do governo imperial. Dessa vez foi o próprio autor do projeto, seu irmão Antônio Carlos de Andrada, que rechaçou a matéria. Defendeu que os Conselhos fossem "de eleição popular, pois em rigor de princípios [seria] preciso que o povo t[ivesse] parte no que é administração, porque é muito interessado nela" ${ }^{257}$,

\footnotetext{
${ }^{253}$ Idem, p.358.

${ }^{254}$ Cândido José de Araújo Viana (1793-1875) era natural de Sabará, Minas Gerais. Formou-se em Direito pela Universidade de Coimbra. Exerceu o cargo de juiz em Mariana e de desembargador em Pernambuco, na Bahia e no Rio de Janeiro. Foi eleito representante, pela sua Província natal, para a Assembléia Constituinte de 1823, para a $1^{\mathrm{a}}$ legislatura da Câmara dos Deputados (que ocupou de 1826-8), a $2^{\mathrm{a}}$ (1830-1833), a $3^{\mathrm{a}}$ legislatura (1834-1837), e a $4^{\mathrm{a}}$ legislatura (que ocupou de 1838-9). Foi Presidente da Província de Alagoas (1828-9) e do Maranhão (1829-32). Exerceu a função de Ministro da Fazenda entre os anos de 1832-4, do Império em 1841, e do Supremo Tribunal de Justiça em 1849. Em 1838, foi escolhido senador, sendo posteriormente também Conselheiro do Estado. Obteve o título de Marquês do Sapucaí.

${ }^{255}$ DAG, v.1, 7 de julho, p. 362.

${ }^{256}$ Idem.

${ }^{257}$ DAG, v.1, 9 de julho, p.377.
} 
num modo de valorizar a divisão entre as distintas formas de representação, a popular e a monárquica.

O mesmo Antônio Carlos, no entanto, defendeu em seguida - na discussão do artigo $9^{\circ}$., sobre a periodicidade de reunião do Conselho - que o órgão eletivo não fosse permanente, polemizando com Henriques de Resende que assim o queria em nome de uma representação popular constante ao lado do presidente ${ }^{258}$. Venceu a posição do padre pernambucano, com a proposição de que, não estando o Conselho reunido, o presidente decidiria sobre a matéria e a comunicaria aos conselheiros o mais rápido possível, numa tentativa de evitar os excessos que poderia cometer ${ }^{259}$. O que comprova que, apesar da série de vitórias que alcançavam os artigos originais do projeto do Andrada, algumas modificações foram nele introduzidas.

Esse foi o caso do artigo 16 que estipulava ser o comandante militar independente do presidente da Província e vinculado diretamente ao governo central. Mesmo que Antônio Carlos, em conseqüência da pressão dos deputados, o tenha reformulado - para que o governador de armas não pudesse empregar força armada contra inimigos externos sem a requisição das autoridades civis, e nem colocar em marcha a $2^{\mathrm{a}}$. linha fora da província sem ordem do Executivo - não houve acordo. O padre Henriques de Resende foi o primeiro a se manifestar contrário, afirmando que ainda estaria "muito fresco na memória de todos um dos principais agravos de que nos queixávamos das Cortes Portuguesas: a independência dos governadores de armas"260. Rogava que afastassem "a mais leve suspeita de má-fé e duplicidade" que estaria presente se fizessem "o mesmo que de[ram] em culpa aos portugueses" em Lisboa.

Em sua crítica à matéria, o padre foi seguido por Carneiro da Cunha, Muniz Tavares e pelo cearense José Mariano de Albuquerque Cavalcanti ${ }^{261}$ na sua crítica à matéria. $\mathrm{O}$ último foi radical ao propor que o comandante de armas fosse independente do governo e subordinado apenas ao Conselho provincial eleito nas localidades. Andrada Machado

\footnotetext{
${ }^{258}$ DAG, v.2, 10/julho, p. 383-5.

${ }^{259}$ DAG, v.2, 16/julho, p.414.

${ }^{260}$ DAG, v.1, 20/junho, p. 259.

261 José Mariano de Albuquerque Cavalcanti (1772-1844) era natural de Sant’Ana, Ceará. Participou do movimento revolucionário de Pernambuco em 1817 e, com a sua derrota, foi recolhido às prisões do Recife e enviado à Bahia. Foi eleito deputado para a Assembléia Constituinte de 1823, para a terceira legislatura (1834-1837), e também para a seguinte (1838-1841), sempre pela mesma Província. Exerceu o cargo de
} 
rechaçou completamente essa proposta, criticando "a necessidade da mediação do Conselho em tudo" o que tomava por sinônimo, no seu discurso, de cada Província possuir um centro independente: isto seria, a seu ver, querer "manter pequenas Republicazinhas com seus presidentes" 262 .

$\mathrm{Na}$ continuação da discussão, Henriques de Resende e Carneiro da Cunha novamente falaram contra a matéria. O segundo recorria à memória imediata dos acontecimentos:

“Todos sabem quais foram as conseqüências que resultaram da independência do Chefe da Força Armada nos Governos que nos mandaram as Cortes de Portugal [...] Igualmente não se pode dizer que esta disposição se firme na opinião geral dos Povos, pois creio que não há uma só Província que tenha louvado semelhante separação de poder; antes foi ela um dos poderosos motivos que determinaram os Povos para a independência do Brasil, como S.M.I. o declarou no seu Manifesto"263.

Predominantemente foram os deputados do Norte que negaram a independência das forças armadas nas Províncias pela real possibilidade de intervenção no âmbito local do governo imperial sediado no Rio de Janeiro. Além disso, a recentíssima lembrança da política do envio de tropas promovido pelas Cortes para a região ainda deixava marcas muito profundas em todos eles.

Também havia os problemas que as Juntas de Governo encontravam com relação à administração da força militar. Em novembro de 1822, o ministro da Guerra recebia um ofício do governo do Ceará em que seus membros justificavam a "urgência" de terem alterado a lei para inclusão do comandante de armas como membro permanente da mesma Junta $^{264}$. Alegavam que, para segurança da mesma, "era da primeira necessidade a reunião da autoridade militar suprema e civil da Província", tendo-se formado "um Conselho de

Presidente do Ceará (de 1831 a 1833), de Santa Catarina (1835-6) e de Sergipe (1837). Faleceu em Magé, no Rio de Janeiro.

${ }^{262}$ DAG, v.1, 21/junho, p. 268.

${ }^{263}$ DAG, v.2, 17/julho, p. 419.

${ }^{264}$ As Juntas Governativas e a Independência, v.1, p.320. 
oficiais escolhidos para serem ouvidos nos negócios militares de maior monta"265. A medida era uma clara tentativa de submissão da força militar ao governo civil da Província, pois se as tensões entre ambos já eram recorrentes desde a colônia, as mesmas seriam agravadas com a instalação das Juntas e a necessidade de definição estrita de suas atribuições. Era isso que pregava o radical Cipriano Barata, na sua Sentinella da Liberdade de agosto de 1823, quando defendia que o governador de armas deveria ser eleito pelo governo civil das Províncias, e só poderia comandar as tropas de $1^{\text {a }}$ Linha para "conservar a disciplina militar"266.

Em outubro, quando da terceira e última discussão acerca da matéria, a pressão dos deputados opositores ao artigo centralizador proposto por Antônio Carlos conseguiram reverter o quadro. Nessa ocasião, foi primeiramente o paulista Nicolau Pereira de Campos Vergueiro $^{267}$ que se colocou contra a questão da independência das forças armadas nas Províncias, ao argumentar que elas teriam de ser apenas executoras "daquilo que se lhe manda[va]m"268. Montezuma e Luís José de Carvalho e Melo, ambos eleitos pela Bahia, concordaram, e defenderam que se marcasse claramente que o comandante de armas ficasse dependente do governo da Província. Na votação final, venceu-se a supressão da matéria, e retirou-se a independência da citada autoridade.

Mudança semelhante de posições se passou quando da discussão do artigo 17, que previa a autonomia da administração da justiça, mas concedia ao presidente o direito de suspender o magistrado desde que este logo desse parte à Corte. Na segunda discussão, o tom da crítica era que a medida traria consigo "uma implícita invasão do poder Executivo nas atribuições, e exercício do poder Judiciário, cuja independência deve ser, quanto possível for, tão respeitada e sustentada por todas as Leis regulamentares que se houverem

\footnotetext{
265 Idem.

266 Sentinella da Liberdade na guarita de Pernambuco, 2 de agosto de 1823, n. 35.

${ }^{267}$ Nicolau Pereira de Campos Vergueiro (1778-1859) era natural de Bragança, Portugal, doutorou-se em Leis na Universidade de Coimbra em 1801 e em seguida partiu para o Brasil, fixando-se em São Paulo onde exerceu a advocacia. Lá ocupou vários cargos públicos, sendo também proprietário e comerciante. Em 1821, participou do Governo Provisório dessa Província, sendo eleito deputado para as Cortes de Lisboa. De volta ao Brasil, em 1823, elegeu-se deputado para a Constituinte e, posteriormente, para a 1 a legislatura instalada em 1826, sempre por São Paulo. Em 1828, foi escolhido senador pela Província de Minas Gerais. Fez parte da primeira Regência Trina provisória (1831), e ocupou várias pastas ministeriais entre os anos de 1832-33 e 1847. Exerceu as funções de diretor do curso jurídico de São Paulo (1837-1842), além de ter-se notabilizado como proprietário rural em São Paulo.

${ }^{268}$ DAG, v.3, 11/outubro, p. 221.
} 
de fazer"269, e que não haveria "liberdade pública enquanto o poder judicial não for absolutamente independente" 270 . Antônio Carlos reformulou o artigo para que se deixasse claro que o presidente só poderia suspender o magistrado em caso de revoltas e motins, e assim se aprovou.

Mas foi em finais de julho, na terceira discussão do $\operatorname{artigo~}^{271}$, que a pressão oposicionista ao projeto conseguiu aprovar uma diminuição no poder de ação do presidente: decidiu-se que a administração da justiça seria mesmo independente, e que o "delegado do Imperador", apenas em Conselho e de comum acordo com o chanceler, poderia suspender o magistrado em casos de revolta e motim. Também o artigo 19, que dava poder ao Imperador de suspender os conselheiros (como o defendera Antônio Carlos na primeira discussão) foi suprimido. Na mesma época, deu-se a inserção de uma emenda de Henrique de Resende que propunha ser o Conselho responsável pelo exame das contas da Província. Todas essas medidas delegavam às Províncias uma possibilidade de pressão diante das ordens do governo central que, mesmo pequena, atendiam a expectativas existentes na Casa, e provindas não apenas dos deputados do Norte.

Um dos poucos consensos alcançados no tocante ao projeto, deu-se na questão da fazenda. O artigo 18, que estipulava que a administração e arrecadação nas Províncias continuariam a ser feitas pelas suas respectivas Juntas, da mesma forma como as presidiam os antigos governadores de acordo com os regimentos existentes, foi um dos poucos pontos aprovados sem nenhuma discussão. A partir de agora, seriam os presidentes responsáveis por elas sem ingerência direta do governo central, conforme se criticara no funcionamento dos Governos Provisórios aprovado nas Cortes de Lisboa. Talvez por essa razão na Assembléia de 1823 ninguém tenha discordado da matéria, que acabou por sofrer apenas emendas de forma do próprio Antônio Carlos.

A tensão presente no penúltimo mês de funcionamento da Casa ficou evidente no discurso do baiano Antônio Ferreira França ${ }^{272}$ contra a escolha dos presidentes pelo Imperador, mesmo depois do artigo já ter sido aprovado nas três discussões:

\footnotetext{
${ }^{269}$ DAG, v.1, 21/junho, discurso do deputado pelo Rio de Janeiro, Manuel José de Sousa França, p. 271.

${ }^{270}$ DAG, v.1, 23/junho, discurso do deputado pelo Rio Grande do Sul, José Feliciano Fernandes Pinheiro, p. 277.

${ }^{271}$ DAG, v.2, 28/julho, p. 467-9

272 Antônio Ferreira França (1771-1848), era natural de Salvador. Estudou Matemática, Filosofia e Medicina na Universidade de Coimbra. De volta à Bahia, ingressou no magistério, sendo em 1815 nomeado para a
} 
"Nós aclamamos um Imperador para nos reger, e com os seus competentes direitos; mas os Povos não declararam de maneira alguma que aqueles direitos que eles pudessem conservar se lhes tirassem; eles estavam na posse de eleger os seus Governos Provinciais [...] e parece-me haver injustiça em se lhe tirar a eleição destes Governos (à ordem, à ordem) [...] Eu estava dizendo que havia absurdo na Lei, segundo o meu modo de pensar; as Províncias, por exemplo, a da Bahia e a de Pernambuco, porventura não têm filhos capazes de governar a Província, eleitos pelo Povo que os pode conhecer, e que tem direito de os eleger? Pergunto não seria mais útil que um filho da Província a governasse, do que mandar governá-la por um filho de outra? Quem é que pode governar uma casa melhor, o filho dela, ou o de outra, bem que seja parente? [...] Não digo que seja inteiramente da eleição do povo; mas que o povo os proponha para deles escolher o Governo."273

Sua fala, pronunciada em outubro, quando uma série de opositores já se calava sobre o assunto, exaltou os ânimos na Assembléia e assim foi chamado “à ordem”. Nesse momento, venceu o que já havia sido revogado pela Casa que, mesmo sem representação de todas as Províncias, arrogava a si mesma legitimidade para falar em nome da "nação".

A partir dessa discussão seria aprovada uma das leis que se manteria em vigor até 1834: a de 20 de outubro de 1823 que dava forma provisória aos Governos Provinciais ${ }^{274}$. Por ela, extinguiam-se as Juntas de Governo e estabeleciam-se um presidente e um secretário, escolhidos pelo Imperador, bem como um Conselho privativo à primeira autoridade, eleito da mesma forma que os deputados. A autoridade presidencial poderia despachar por si só, pois os Conselhos não seriam permanentes, mas no caso da suspensão de magistrados e do comandante militar era necessário o aval dos conselheiros. Nas Províncias, valia também a dependência do comandante militar em relação à autoridade civil, pois o mesmo deveria consultar o presidente em Conselho no caso do uso de forças "contra os inimigos internos", diminuindo a ingerência direta do poder central. No caso da

cátedra de um recém-criado curso de Cirurgia. Em 1822 era vereador, e foi também membro do Conselho de Governo da Província. Ocupou a cadeira de deputado, sempre pela sua Província natal, na Assembléia Constituinte de 1823 e nas três primeiras legislaturas, durante os anos de 1826-37.

${ }^{273}$ DAG, v.3, 11/outubro, p.226.

${ }^{274}$ Coleção das Leis do Império do Brasil de 1823, Rio de Janeiro, Imprensa Nacional, 1887. 
justiça, o magistrado seria independente e, nos casos de motins e revoltas, o "delegado do Imperador" poderia suspendê-lo, apenas em Conselho e de acordo com o chanceler (onde houvesse relação). No geral, marcavam-se várias atribuições para os mesmos presidentes, responsáveis pelo fomento da agricultura, educação, estabelecimento de câmaras, proposição de obras, censos, fiscalização das contas e receitas das comarcas, decisão sobre os conflitos de jurisdição nos distritos, vigia sobre a infração das leis, cuidados com os escravos, determinação de receitas extraordinárias, sendo também responsáveis pelas Juntas da Fazenda pública.

Apesar da interpretação de que a lei teria ressuscitado os "antigos governadores coloniais", conforme palavras de Cipriano Barata ${ }^{275}$, e da crítica que se difundiu contra a extinção das Juntas como autoridades eletivas, ela significou, do ponto de vista da construção normativa de um arranjo político liberal, um passo importante na valorização das Províncias como espaços convergentes de poder político ${ }^{276}$. Mesmo que seus governos continuassem, durante anos, profundamente marcados por conflitos entre autoridades civis e militares (como se verá no capítulo seguinte), as bases para reivindicação de uma nova legitimidade já haviam sido dadas. Desenhava-se um esboço de separação de poderes da unidade política que, confirmado pela Carta do ano seguinte, serviria de base às transformações futuras.

Na discussão do artigo $2^{\circ}$. do Projeto de Constituição, outra polêmica revelaria as incompatibilidades existentes no âmbito da Assembléia no tocante à relação política entre as partes do novo Estado. De título Do território do Império do Brasil, o artigo afirmava serem as Províncias componentes da unidade o "Pará, Rio Negro, Maranhão, Piauí, Ceará, Rio Grande do Norte, Paraíba, Pernambuco, Alagoas, Sergipe d’El-Rei, Bahia, Espírito Santo, Rio de Janeiro, São Paulo, Santa Catarina, Rio Grande do Sul, Minas Gerais, Goiás, Mato Grosso, as Ilhas Fernando de Noronha e Trindade, e outras adjacentes; e por federação o Estado Cisplatino" ${ }^{277}$. Depois de resolvido que não se tocaria na questão da

\footnotetext{
275 Sentinella da Liberdade na guarita de Pernambuco, 5/novembro/1823.

${ }^{276}$ Parte da historiografia reproduz a idéia de Cipriano Barata de que a lei teria como propósito reestabelecer a ordem colonial agora capitaneada pelo Rio de Janeiro, como R. Barman, op.cit., Evaldo C. de Mello, op.c cit.. Porém, vale notar que ela estava alicerçada em pressupostos institucionais distintos em relação ao funcionamento dos domínios do Império português, em que a tentativa de divisão de poderes aos moldes constitucionais é evidente.

277 “Projeto de Constituição", DAG, v.2, 1/setembro.
} 
Cisplatina por falta de informações ${ }^{278}$, o deputado da Bahia, Antônio Ferreira França, fez um aditamento para que o parágrafo do artigo começasse por dizer que o território compreenderia "confederalmente as Províncias",279. Seu colega de bancada, Francisco Montezuma, mostrou-se favorável e argumentou que o princípio não abalava a indivisibilidade do Império, a qual já havia sido aprovada no artigo $1^{\circ}$., e granjearia "maior conceito, e pública confiança"280.

O primeiro a se pronunciar contrário à idéia foi Manuel José de Sousa França, ao tratá-la como incompatível com a Monarquia e com a "Constituição", além de considerá-la prenúncio de uma desunião interna:

"O que nos cumpre averiguar é, se, rebus sic stantibus, podemos admitir na Constituição do Império essa federação? De certo que não; porque quando os Povos do Brasil se deram as mãos, e proclamaram a sua Independência, foi com a pronunciação de um Governo Monárquico, que se estendesse à todas as partes do Império; e não se restringiram a haver Constituições parciais, e internas em cada uma das Províncias; sobre as quais se estabelecesse depois a Constituição geral de Federação de Estados, que em tal caso devia seguir-se. Por isto somente, e não por outra razão de incongruência, é que voto contra a emenda. Nós, como Representantes da Nação devemos seguir na obra da Constituição, que fazemos, não os arbítrios que melhor nos parecem, se não a norma, que está pronunciada pela mesma Nação; a qual não foi, nem é de certo, a de um sistema de Federação das Províncias." 281

Para ele, portanto, "federação" seria um sistema que privilegiaria a autonomia das partes em detrimento dos pressupostos monárquicos que elas teriam adotado.

\footnotetext{
${ }^{278}$ Neste momento, a Província Cisplatina vivia um ambiente político de divisão e conflito por conta da resistência de importantes setores locais a "trocar" a lealdade jurada às Cortes lisboetas por uma ainda incerta lealdade ao Império do Brasil, que, no entanto, podia ser vislumbrada como a continuação lógica à "incorporação ao Reino do Brasil" que sustentara a própria criação da Província, em julho de 1821. A retirada das tropas leais a Portugal e a adesão ao Império, em 14 de fevereiro de 1824, não resolveriam definitivamente a questão, que se desdobraria ainda na guerra de 1825-1828 (João Paulo G. Pimenta - Estado e nação no fim dos impérios ibéricos no Prata, 1808-1828. São Paulo, Hucitec/Fapesp, 2002).

${ }^{279}$ DAG, v.3, 17/setembro, p. 34.

${ }^{280}$ Idem, p.35.

${ }^{281}$ Idem.
} 
Apesar de também pertencer à bancada da Bahia, Luís José de Carvalho e Melo foi veementemente contrário à proposta de seu conterrâneo, seguindo os mesmos argumentos utilizados por França. Perguntava: “Que quer dizer Império indivisível? Não existe já uma monarquia constitucional pelos próprios povos proclamada?"282. Respondia que uma monarquia seria "um todo composto de todas as partes dirigidas ao fim único da prosperidade geral erguida sobre a base de uma Constituição, que se compõe de Leis fundamentais unidas com as regulamentares, estabelecidas com o mesmo fim". Argumentava que isso não se afinava com federação e que, portanto, eles não poderiam subverter o sistema depois de os "povos" terem já manifestado "a sua vontade", decretada "pela unânime voz da nação".

Foi o mesmo Joaquim Manuel Carneiro da Cunha que, já tendo sido contrário ao projeto para o governo das Províncias, saiu em defesa do aditamento. Argumentava que além da federação não ser incompatível com a monarquia, também seria quase que o caminho natural do Brasil no futuro, em razão de sua diversidade e grandeza. Seu discurso causou grande excitação, sendo chamado "à ordem”:

"Não se pode argumentar com o exemplo de outros Estados a respeito do Brasil; a sua vastidão, e mesmo a grandeza de cada uma de suas províncias, que aumentando progressivamente, brevemente cada uma se tornará uma Potência, não pode fugir das vistas daqueles, que fazendo a Constituição de tão rico Império, não atendem somente ao que convém do presente, porém desejam prevenir males para o futuro; e por isso talvez, que o honrado Membro se lembrasse d'uma federação, que, em nada se opondo ao sistema adotado, fosse o vínculo mais forte da união eterna das Províncias com o todo do Império; atendamos às três Províncias do Rio Negro, Pará e Maranhão, que ficando tão destacadas, e em uma longitude imensa, como poderão sem grandes inconvenientes recorrer sempre ao Rio de Janeiro? (à ordem). Estou na ordem. Ora se esta federação não se opõe a Monarquia Constitucional, como há exemplos tanto na história antiga, como na moderna, e mesmo na Europa, porque a não admitimos, com aqueles limites, que permitir a nossa forma de Governo; podendo haver em cada uma das Províncias uma primeira Assembléia Provincial,

\footnotetext{
${ }^{282}$ Idem, 36.
} 
que tenha a iniciativa das Leis regulamentares, e que informando com mais conhecimentos à Assembléia dos Representantes da Nação tudo quanto for mister para promover a sua prosperidade, consiga-se desta sorte o bem, que todos desejamos?",283

O padre Alencar concordou, e falou da eficácia que existiria na idéia de federação se as províncias do Norte, "que não entraram no nosso pacto social”, viessem a formar uma unidade à parte. Montezuma reiterou que assim mostrariam “à nação, que serão respeitados os inalienáveis direitos de cada uma das Províncias; aqueles sem os quais elas jamais poderão conseguir verdadeira prosperidade que está implícita no gozo de uma salutar, e bem entendida Liberdade: não serão independentes; mas só serão dependentes naquilo que necessário for para a manutenção da forma monárquico-representativa, pela nação adotada." 284

Nesse sentido, aqueles que operavam na lógica da "federação" defendiam claramente uma maior autonomia para as Províncias. A princípio se poderia argumentar, como o fez Evaldo Cabral de Mello $^{285}$, que eram os deputados das regiões do Norte que encamparam essa bandeira contra os do Centro-Sul na Assembléia. No entanto, ainda que tenham sido eles os responsáveis por levantar a questão, estavam longe de articular discursos e programas homogêneos em suas bancadas. Veja-se que Carvalho e Mello foi radicalmente contra o projeto, assim como o padre Henriques de Resende, que dizia ser a federação "um pouco inconsistente com o que vai vencido, e com o sistema adotado pela nação"286. Também Pedro José da Costa Barros ${ }^{287}$, deputado pelo Ceará, foi contrário à "esta palavra" que "admitida nesta Assembléia seria o mesmo que se disséssemos às

\footnotetext{
${ }^{283}$ Idem.

${ }^{284}$ Idem, p.38.

285 Ver do autor o já citado "O Jogo da Independência”.

${ }^{286}$ Idem.

${ }^{287}$ Pedro José da Costa Barros (1779-1839) era natural do Aracati, Ceará. Mesmo tendo freqüentado aulas de Retórica e Antiguidades na Universidade de Coimbra (1797-1801), dedicou-se à carreira militar e, em 1803, iniciou no Regimento de Artilharia do exército português. De volta ao Ceará, ascendeu de posto e, em 1821, foi eleito deputado pela mesma Província para as Cortes de Lisboa, cadeira que nunca ocupou, por causa de funções que desempenhava no Rio de Janeiro. Na Independência, serviu na Brigada Real de Artilharia e, em 1823, foi eleito deputado para a Constituinte. No mesmo ano, foi nomeado Ministro da Marinha, mas não ocupou o cargo, do qual foi demitido três dias depois. Foi Presidente de Província do Ceará (1824) e do Maranhão (1825-1828). Em 1827 foi escolhido senador, cargo que ocupou até sua morte, sendo também conselheiro imperial (1829). Ver: Zília Osório de Castro, op.cit., v.1, pp. 218-9.
} 
Províncias, governai-vos por leis próprias: escolhei cada uma de vós o governo que muito quiserdes: Criai sobre vós a Autoridade que vos parecer: sois livres e independentes"

A posição de Caetano Maria Lopes Gama ${ }^{289}$ que, deputado por Alagoas, criticou longamente a idéia de uma federação para o Brasil, só reforça a idéia de que não havia um projeto coeso de federação defendido pelos do Norte. Nas suas palavras:

"Pela palavra - federação - exprimem todos os publicistas, que eu tenho podido ler, uma convenção, pela qual corpos políticos consentem em se tornarem cidadãos de um melhor Estado para melhor obterem uma comum segurança; e para que um sistema federativo seja perfeito, e durável, devem os Estados confederados ter uma forma de Governo homogênea. Passemos a fazer aplicação deste sistema ao estado do Brasil. Esta grande porção da América, conquanto seja favorecida pela Natureza, não apresenta mais do que uma população de 3,8 milhões de homens [...] Sendo incontestável que o Brasil é uma Nação pequena, e em sua infância, o que será cada uma das Províncias que o compõe? Algumas não têm mesmo os elementos para ser Províncias; como então já serão Estados? [...] Para que cada Província do Brasil seja um Estado não basta ter muitas léguas, é preciso ter mais força relativa à sua grandeza, e os meios de existir por si."290

O mesmo deputado considerava "injúria" supor que os "Brasileiros do Pará e Maranhão" não quisessem unir-se com eles como "porção integrante do nosso Império" ${ }^{291}$. Nessa direção, José da Silva Lisboa proclamava que Província alguma poderia "ter agora a liberdade de querer, ou não, aderir à Causa comum, nem pactuar condições de federação. Do contrário, estaria no arbítrio de cada uma, destruir e impossibilitar os efeitos do esforço político, para sustentar a Independência e Integridade do Império"292.

\footnotetext{
${ }^{288}$ DAG, v.3, 18/setembro, p. 49.

289 Caetano Maria Lopes Gama (1795-1864) era natural de Pernambuco. Bacharel em Direito pela Universidade de Coimbra. Foi deputado por Alagoas na Constituinte, por Pernambuco na $1^{a}$ legislatura da Assembléia Geral (1826-9), e por Goiás na $2^{\mathrm{a}}$ (1830-34). Exerceu o cargo de Presidente das Províncias de Goiás (1824-7), do Rio Grande de São Pedro (1829-31), e de Alagoas (1844-5). Por várias vezes ocupou o cargo de ministro, entre os anos de 1840-62. Foi nomeado senador em 1839. Também conselheiro de Estado, obteve o título de Visconde de Maranguape.

${ }^{290}$ DAG, v.3, 18/setembro, p.50.

${ }^{291}$ Idem.

${ }^{292}$ Idem, p. 52.
} 
Contrariando a argumentação da associação entre os do Norte e a "federação", também esteve Nicolau Vergueiro entre os defensores do aditamento de Ferreira França. Ele, que desempenharia um papel fundamental nas reformas do Primeiro Reinado, propôs um outro entendimento para o termo. "Rejeitando, pois toda espécie de federação que se refira a Estados independentes", advogou em nome do que chamou "uma outra espécie de federalismo, que podemos chamar interno ou doméstico, o qual dando uma certa independência, às diferentes sessões, conserva, todavia, a utilidade do todo" ${ }^{293}$. Partindo do princípio de que "cada Cidadão é independente para tratar dos seus interesses, salvo as relações que o unem à Sociedade", argumentava que o mesmo valeria para os Municípios e Províncias. Desta forma, "os negócios, que pertencem a todos" seriam "dirigidos por todos, mas os que pertencem à parte" seriam "dirigidos por essa parte: e assim a Província diri[giria] os seus, do mesmo modo o Município e a Povoação, cada família, e cada indivíduo" ${ }^{294}$.

Na sua esteira, o médico baiano autor do polêmico aditamento, teria dito - segundo o taquígrafo que não conseguiu transcrever literalmente - "que as Províncias s[eriam] ajuntamentos de homens com iguais direitos. Que neste exercício de direitos iguais e maneiras de maior utilidade se funda[ria] a união federal de Homens, Casas, Vilas, Cidades, Províncias e Reinos, sujeitando-se todos ao Império de um, a quem tributam mantença e honra para salvação certa de todos"295. Aqui fica claro como os defensores de uma autonomia maior das províncias não o faziam embasados numa teoria que privilegiasse o "direitos dos povos" num sentido corporativo, mas, ao contrário, numa clara identificação com uma concepção individualista de sociedade.

Apesar da derrota da proposta de Antônio Ferreira França na votação final, as distintas leituras sobre a "federação" marcavam o início de uma polêmica que se desdobraria Império adentro: a dos poderes políticos que separavam e uniam suas distintas partes. No mesmo universo de problemas esteve a questão sobre os governos das Províncias que, como espaços em construção marcados por lutas intestinas, inviabilizavam a existência, no âmbito da Assembléia, de bancadas locais homogêneas. A adesão ao Imperador, bem como a forma como ela deveria se dar, dividia grupos por todo o Brasil,

\footnotetext{
${ }^{293}$ DAG, v.3, 18 de setembro, p.48.

${ }^{294}$ Idem.

${ }^{295}$ Idem.
} 
inclusive na Corte. Daí ser equivocada a caracterização de um único projeto "centralizador" sediado no Rio de Janeiro, como fica evidente pela disputa que se desdobrou no âmbito da própria Casa legislativa, por mais que alguns posicionamentos propusessem $\mathrm{o}$ fortalecimento da esfera do Executivo. A equação interna que o arranjo políticoinstitucional imperial deveria ter era, de fato, uma questão muito mais complexa e em aberto do que a divisão entre "centralizadores" e "autonomistas" poderia sugerir. A Carta Constitucional outorgada no ano seguinte proporia soluções nesse sentido, e as legislaturas instaladas desde 1826 ofereciam condições para cumpri-las.

\subsection{A Carta Constitucional de $\mathbf{1 8 2 4}$}

Após o fechamento da Assembléia, D. Pedro nomeou um Conselho para redigir um novo Projeto de Constituição. Ele foi composto por dez homens que na época the inspiravam confiança: João Severino Maciel da Costa, Luiz José de Carvalho e Mello, José Egídio Álvares de Almeida (Barão de Santo Amaro), Antonio Luiz Pereira da Cunha, Manoel Jacinto Nogueira da Gama, José Joaquim Carneiro de Campos, Clemente Ferreira França, Marianno José Pereira da Fonseca, João Gomes da Silveira Mendonça e Francisco Villela Barboza. Os seis primeiros tinham sido deputados da extinta Casa legislativa quatro pelo Rio de Janeiro, um por Minas Gerais e um pela Bahia - e são conhecidos pelas suas posturas conservadoras do ponto de vista político. Não há dúvida que o texto elaborado foi devedor dos trabalhos constituintes da Assembléia de 1823, de cujo Projeto de Constituição apenas 24, dos 272 artigos, chegaram a ser discutidos e votados.

Desde setembro de 1822, pelo menos um esboço de Constituição para o Brasil - o de autoria de Hipólito José da Costa, publicado no seu Correio Brazilienze $e^{296}$-, circulava no Rio de Janeiro. O regime de monarquia constitucional que o periodista propunha tinha feições bem moderadas e batia de frente com aquelas adotadas pelas Cortes de Lisboa, contra as quais seu autor se colocara ${ }^{297}$. No preâmbulo que escreveu ao texto, chamou de

\footnotetext{
${ }^{296}$ Correio Braziliense, ou Armazém Literário, setembro/1822, v. 29, no. 172, pp. 371-384.

${ }^{297}$ Deve-se notar que Hipólito da Costa adotara, nos idos de 1822, o discurso de que as Cortes de Lisboa tinham intenção de "recolonizar", afeito aos grupos que no Rio de Janeiro encamparam a viabilização da Independência. Ver István Jancsó e Andréa Slemian, "Um caso de patriotismo imperial", Correio Braziliense, ou Armazém Literário, vol. XXX/ Hypólito José da Costa. São Paulo/Brasília, Imprensa Oficial do Estado/ Correio Braziliense, 2002, Tomo I, p.605-667.
} 
"monstruosa a Constituição de Portugal" de 1822, e, defendeu veementemente a existência de uma segunda câmara para o poder Legislativo. Nesse sentido, usava como exemplo a Inglaterra e os Estados Unidos, onde a instituição fora introduzida como "fruto de meditação e de princípios". Partindo da divisão em três poderes - Executivo, Legislativo e Judiciário - Hipólito da Costa propunha que o rei e um Conselho de Estado dividissem a atividade legislativa com os representantes eleitos. Esse Conselho, como segunda câmara, teria o poder de aprovar ou rejeitar as leis, da mesma forma que o monarca, além de auxiliar este último na assinatura de tratados e na declaração de guerra e paz. Ao menos a iniciativa das leis seria dada aos deputados, sendo estes invioláveis quando no exercício de sua função. Um Conselho de ministros, que compartilharia atribuições executivas com o mesmo monarca, também o aconselharia quanto às questões externas e na aprovação de leis. Como autoridades responsáveis, os ministros seriam julgados pelo Conselho de Estado em caso de infração da Constituição ou de não execução das leis. Para o governo das Províncias, propunha a manutenção das Juntas (compostas de representantes eleitos), mas criava também o cargo de Presidente, nomeado pelo Imperador. Os municípios ficariam subordinados a essa autoridade provincial.

Como se vê, a proposta era uma resposta bem moderada às expectativas que existiam na época no tocante à construção de uma Constituição para o nascente Império, as quais se acentuariam no ano de 1823 após a apresentação do Projeto da Comissão na Constituinte. E esta veio a público em $1^{\circ}$ de setembro de 1823 e, mesmo tendo sido obra coletiva, foi muito devedor da elaboração de Antônio Carlos de Andrada Machado ${ }^{298}$. Nele se faz clara a concepção, defendida por este, de que os "representantes da nação" seriam o Imperador e a Assembléia, sendo o primeiro também portador de soberania ${ }^{299}$. Definia-se o

${ }^{298}$ O Projeto foi elaborado por uma comissão de deputados composta de: Antônio Carlos Ribeiro de Andrada
Machado e Silva, José Bonifácio de Andrada e Silva, Antônio Luiz Pereira da Cunha, Manoel Ferreira da
Câmara Bittencourt e Sá, Pedro de Araújo Lima (que assinou "com restrições"), José Ricardo da Costa Aguiar
de Andrada e Francisco Muniz Tavares. Sendo apresentado em $1^{\text {o. }}$ de setembro, sua discussão iniciou-se no
dia 15 do mesmo mês.
${ }_{299}$ Desde a época, a comparação entre esse texto e a Carta de 1824 é recorrente. Um dos primeiros a fazê-la
foi Armitage, op.cit., que elogia a Carta outorgada afirmando "em princípios gerais a Constituição é tão
satisfatória como a projetada pela última Assembléia: e em conformidade com a promessa do Imperador
muitas das suas disposições são ainda mais liberais" (p. 80). Segundo o autor, a Carta teria sido inspirada
muito mais na Constituição portuguesa de 1822 do que no projeto elaborado pelos deputados "brasileiros" em
1823 , e produzira avanços em relação ao processo liberal no Brasil. Para Varnhagen, op.cit., o Projeto
elaborado pela Assembléia "era na essência vazada no molde da de Portugal", e à medida que conferia muitos
direitos aos cidadãos "deixava ampla porta à revolução, com a impunidade legalizada na própria
Constituição" (p.197). Segundo o mesmo autor, embora a Constituição outorgada não diferisse muito deste 
"Império do Brasil" como "uno e indivisível", garantia as liberdades individuais e direitos civis a todos os "brasileiros" (incluindo os libertos), com a marcação das restrições aos direitos políticos e dos critérios de distinção para eleitores (que num primeiro círculo deveriam ter renda anual de "250 alqueires de farinha de mandioca") e elegíveis aos cargos públicos.

O regime de monarquia constitucional proposto era dividido em três poderes: Legislativo, Executivo e Judiciário. O primeiro seria "delegado à Assembléia Geral e ao Imperador conjuntamente", num sistema bicameral composto da Câmara dos deputados (eletiva) e do Senado vitalício (também eletivo, mas com lista tríplice para escolha do Imperador quando uma cadeira ficasse disponível). A adoção da segunda Câmara, cuja função seria frear os abusos e radicalismos que poderiam estar presentes entre os deputados, já que as medidas legislativas tinham de passar por ambas as instâncias, marcava o caminho da moderação da proposta. Ambas as funções de deputado e senador não eram consideradas incompatíveis com a de ministros e conselheiros privados (art. 68), o que significava que os legisladores poderiam ocupar, concomitantemente, um cargo executivo. A proposta espelhava uma verdadeira tentativa de controle e equilíbrio entre os poderes políticos. No âmbito do Legislativo, ao Imperador caberia uma sanção apenas suspensiva às leis que, no caso de veto, poderiam retornar ao plenário e serem posteriormente aprovadas, desde que nas duas Casas representativas. À Câmara dos Deputados competia, além de várias funções como o poder de acusação sobre ministros e conselheiros, duas medidas fundamentais de controle do Executivo: o poder de requerer ao

projeto, ela formaria um "código mais harmônico e homogêneo" do que aquele que a Assembléia, no seu "parto informe de paixões", conseguiria realizar. Homem de Mello, op.cit., ao contrário, valorizando o papel da Assembléia, afirmava que o Projeto teria servido de base para a Constituição como um "monumento dos princípios puros e liberais", e que a Carta só lhe foi superior na "forma e estilo" (pois que o primeiro apresentaria grandes defeitos de redação), contendo poucas disposições novas. Aurelino Leal, História Constitucional do Brasil, Rio de Janeiro, Imprensa Nacional, 1915, manteria a análise da aproximação entre os textos, evitando julgar negativamente o trabalho dos constituintes de 1823. Caio Prado Jr, Evolução política do Brasil, $20^{2}$ ed., São Paulo, Brasiliense, 1993, pp. 53-6, como um dos responsáveis pela inauguração de uma historiografia crítica no Brasil, analisaria com detalhes o Projeto de 1823 reconhecendo-o como um "retrato do liberalismo burguês" e, por isso, absolutamente negativo e "ideológico". Para ele, a Carta manteria sua linha geral com a "única inovação de vulto" centrada no "Moderador". José Honório Rodrigues, op.cit., foi um dos que, na década de 1970, reiterou o o caráter positivo dos trabalhos da Assembléia e do Projeto na elaboração da Constituição de 1824. Mais recentemente, Maria de Lourdes Viana Lyra, O Império em construção: Primeiro Reinado e Regências, São Paulo, Atual, 2000, e Silvana Mota Barbosa, op.cit., apontam que uma das distinções entre os dois documentos constitucionais estava num maior fortalecimento do Executivo na Carta de 1824, então corporificado pelo Imperador junto ao Moderador. Ver também o balanço que Paulo Bonavides e Paes de Andrade, op.cit., fazem da historiografia acerca da questão. 
Imperador a demissão dos ministros de Estado que parecessem nocivos ao bem público (ainda que o Imperador pudesse negá-la), como constante no parágrafo $2^{\circ}$, do artigo 91; e o exercício de fiscalização da arrecadação e emprego das rendas públicas, bem como de tomar conta aos empregados respectivos, conforme parágrafo $3^{\circ}$ do mesmo artigo. Também era privativa aos mesmos deputados a iniciativa de leis sobre impostos, recrutamentos e escolha da nova dinastia, no caso de extinção da reinante. Ao Senado, por sua vez, para além das funções de discussão das leis, caberia exclusivamente o conhecimento dos delitos individuais cometidos pela família imperial, ministros, "conselheiros privados", senadores e deputados (destes apenas enquanto estivessem na função), além dos crimes de responsabilidade também previstos na Constituição. Para todos, a instituição poderia se converter em "grande jurado" das matérias, podendo, em caso de cassação, até consultar os membros do tribunal supremo de Justiça que não teriam direito a voto. Desta forma, os senadores teriam garantida sua parcela de controle sobre o Executivo.

O Executivo seria delegado ao Imperador que, como pessoa "inviolável e sagrada", governaria por meio de seus ministros "responsáveis", os quais referendariam seus atos. Dessa forma, seguia-se o modelo das monarquias restauradas de preservação da legitimidade dinástica. Entre as atribuições do monarca estavam declarar guerra e paz e fazer tratados de aliança (com o conhecimento do Legislativo), conceder honras e distinções, nomear ministros e conselheiros privados, fazer executar as leis, convocar, prorrogar e adiar a Assembléia. Não se previa, porém, que ele pudesse fechar a Câmara dos Deputados. Haveria também um "Conselho privado" nomeado pelo Imperador e, tanto quanto os ministros, igualmente responsável pelas suas opiniões. Ambas as funções não eram incompatíveis com as de deputado.

Para o Judiciário estavam previstos juízes e jurados. Os juízes de direito letrados seriam "inamovíveis" e não poderiam ser privados do seu cargo sem sentença proferida em razão de delito, o que garantiria sua independência em relação aos outros. Ao "sistema de jurados", concebido como um dos direitos dos cidadãos, pois que previa a participação de indivíduos sem magistratura na esfera da justiça, previa-se que uma lei posterior regulamentaria suas atividades. No tocante ao governo das Províncias, o Projeto desenhava uma forma muito genérica. Propunha que se tomassem as comarcas, subdivididas em distritos e freguesias, com a designação de um presidente, um "subpresidente" e um 
"conselho presidial eletivo" para cada localidade. Neles residiriam todo o governo econômico e municipal por meio de um "administrador e executor" alcunhado "decurião" (nome inspirado no cargo administrativo existente na Roma antiga). No item sobre a Fazenda Nacional, dizia-se apenas que as contas de cada comarca deveriam ser objeto de um capítulo separado no orçamento geral.

O Projeto começou a ser discutido, não sem que antes existissem alguns pontos de atrito sobre a forma de como se deveria fazê-lo. Depois que se fixou o dia 15 de setembro para seu início, Antônio Carlos colocou o problema da ordem da discussão, que se decidiu remeter a uma Comissão ${ }^{300}$. O mesmo deputado fez uma indicação para que, por meio de uma deputação, se mandasse um exemplar do texto ao Imperador. A proposta foi rechaçada sob a argumentação de que se tratava de um texto de "quatro membros" que não representava ainda a "vontade da nação expressa por seus Representantes", e que poderia ser muito modificado, e até negado pela Assembléia ${ }^{301}$. Ficou decidido que o Imperador o receberia por meio da secretaria conforme acontecia com os papéis corriqueiros.

A Comissão decidiu que o Projeto passaria apenas por uma discussão (e não por três, como ocorria com as leis regulamentares), o que gerou polêmica. O mesmo Antônio Carlos defendeu a proposta em nome da "necessidade de rapidez" para não se "molestar a paciência dos povos", argumentando que as Constituições recebiam a "perfeição" apenas do "decurso dos tempos e da experiência"302. Os que a atacaram colocaram na pauta uma questão fundamental: a necessidade de se ouvir a opinião dos “os povos do Brasil”, ou seja, de haver tempo para que o submetessem às várias Províncias e à “opinião pública”, como professaram, novamente unidos, Joaquim Manuel Carneiro da Cunha e o Padre Alencar ${ }^{303}$. No dia seguinte, aprovou-se uma emenda conciliatória entre ambas as posições, proposta por João Antônio Rodrigues de Carvalho, para existirem duas discussões em que cada deputado poderia falar duas vezes por artigo ${ }^{304}$, o que nem houve tempo para entrar em prática.

O último ponto a ser resolvido era quanto ao número mínimo de deputados que aprovariam as decisões. Pouco antes de se entrar na matéria do Projeto, Nicolau Vergueiro

\footnotetext{
${ }^{300}$ DAG, v.2, 09/setembro, v.2, p. 740-1.

${ }^{301}$ DAG, v.2, 10/setembro, discursos de Henriques de Resende e Nicolau Vergueiro.

${ }^{302}$ DAG, v.2, 12/setembro, p. 766.

${ }^{303}$ Idem, pp.767-8.

${ }^{304}$ DAG, v.2, 13/setembro.
} 
fez indicação para que as aprovações só se dessem com base nos dois terços do número total de deputados, e não da maioria mais um, conforme proposto pela Comissão ${ }^{305}$. O subsídio de sua defesa era a ampliação do consenso em torno das decisões, evitando que alguns grupos pudessem controlá-las, no que concordaram Carneiro da Cunha e José Mariano de Albuquerque Cavalcanti. No entanto, perdeu-se a parada e ficou decidido que a metade mais um seria considerado número suficiente.

Dos artigos que chegaram a ser discutidos em plenário, alguns foram aprovados sem discussão, enquanto outros geraram intenso debate. Os que despertariam polêmica foram, no Título I, o já citado artigo $2^{\text {o. }}$, que propôs a união do Império por "confederação" (que não foi aprovada), e o $4^{\mathrm{o}}$, que falava em uma divisão do território em comarcas, distritos e termos, sendo modificado para que se mantivesse a "divisão atual” baseada nas Províncias e Câmaras. No Título II, foi o capítulo sobre a definição dos "membros da sociedade" que sofreu a reformulação mais significativa do ponto de vista de seu conteúdo original: na votação, venceu que todos os chamados "brasileiros" seriam incluídos na categoria de "cidadãos", inclusive os libertos (art. 6 $6^{\text {.) }}$ (sem marcar a distinção de seu local de nascimento) $)^{306}$. Quanto aos "portugueses" que seriam alçados à condição de "brasileiros" $\left(\operatorname{art} .2^{\circ}\right)$, venceu que se deveria exigir “expressa ou tacitamente" a adesão destes ao Império, conforme discutido mais acima. No mesmo item, os critérios para se obter "carta de naturalização" também geraram debate, e ao final foi introduzido um adendo que marcava os que deixariam, fosse por opção ou sentença, de ser "cidadãos brasileiros". A questão dos "direitos individuais" (art. $7^{\text {o. }}$ ) mereceu discussão no que tocava, em especial, à liberdade religiosa e à liberdade de culto (arts. 14-16).

Logo que o Projeto começou a ser discutido entre os deputados, João Soares Lisboa publicou no seu Correio do Rio de Janeiro um parecer crítico, de próprio punho, convidando seus leitores a fazerem o mesmo ${ }^{307}$. Então dissertou sobre a "soberania" como "una, indivisível e inalienável", residente apenas na "nação", para defender que era em nome desta que se deveria escrever o preâmbulo, e não se "invocar os auxílios da Sabedoria Divina" como a Comissão havia proposto. Dizendo ter recebido de seus correspondentes um outro projeto de Constituição que considerava mais adequado “às peculiares

\footnotetext{
${ }^{305}$ DAG, v.3, 15/setembro, p.1.

${ }^{306}$ Andréa Slemian, op.cit. .

${ }^{307}$ Correio do Rio de Janeiro, n.41, 19/setembro/1823.
} 
circunstâncias do Brasil" e que muito o agradou, Soares Lisboa passaria a transcrevê-lo nos quatro números seguintes do seu periódico. De fato, tratava-se de uma proposta bem mais radical, cuja ênfase estava no fortalecimento do poder Legislativo em nome "nação"308. Iniciava-se pela defesa dos direitos individuais e inalienáveis, numa apresentação que lembrava a Declaração francesa de 1789; mas ao tratar do território, já deixava claro um diferencial: preferia não enumerar todas as Províncias que se sujeitariam àquela Constituição pela situação indefinida dos limites do Brasil, em posição oposta aos que, na Assembléia, advogavam que o Império já estaria formado. E antes de entrar propriamente nas atribuições dos poderes, marcava que seria considerada uma "abdicação" se o Imperador violasse claramente algum de seus artigos, ou se recusasse a obedecê-los.

Segundo a proposta de Soares Lisboa, o Legislativo estaria centrado em uma só Câmara de representantes eleitos pelos "povos", e os critérios de sua votação não faziam menção a restrições sócio-econômicas. Seu autor até aceitava a possibilidade de existirem duas Câmaras - embora argumentasse que isso era típico da Europa e não caberia no Brasil -, mas desde que ambas fossem eletivas e temporárias. Entre as atribuições do dito congresso estaria escolher, por lista tríplice, os membros do Tribunal Superior, e fazer efetiva a responsabilidade de seus membros no caso de injustiça (tinha poder para julgálos), confirmar as declarações de paz e guerra, além dos tratados de aliança feitos pelo Imperador. Por sua vez, ao Tribunal Superior caberia julgar ministros, embaixadores e mais agentes do governo. Do que se pode apreender que o Executivo, nessa concepção normativa, era o poder que mais demandava controle.

No tocante à organização das Províncias, a proposta de Soares Lisboa expunha um detalhamento maior do que o Projeto da Comissão constituinte. Previa que em cada localidade existiria um governador (nomeado pelo Imperador) e uma Assembléia provincial, composta de 31 a 51 membros, que poderia fazer leis municipais (somente no tocante ao âmbito de sua jurisdição), além de caber-lhe a iniciativa de enviar ao Congresso Geral leis que dissessem respeito à localidade. À essa Assembléia caberia fiscalizar a conduta das autoridades e fazer efetiva a responsabilidade do governador: se este violasse a Constituição, ela poderia declará-lo culpado e enviar um pedido ao Supremo Tribunal para ser julgado. Existiriam também um comandante de armas e uma Junta da Fazenda, ambos

\footnotetext{
${ }^{308}$ Idem, números 42-45, 20, 22-24 de setembro de 1823. O Projeto era datado de 20 de janeiro de 1823 e seu
} 
sujeitos à tutela provincial. Os impostos ou as "sobras" só poderiam ser entregues ao governo central ou à vista de decreto do Congresso Geral, ou por ordem do governador devido à determinação da Assembléia local. Assim, tanto o papel do órgão eletivo local seria prevalente ao Executivo, como estava prevista uma autonomia local no gerenciamento dos seus negócios internos.

O contraste com a proposta da Assembléia era notável, e seria escancarado quando, a partir de outubro, Soares Lisboa passou a fazer críticas diretas a ela ${ }^{309}$. Sob a alegação de que cumpriria observar se o Projeto apresentava de "maneira satisfatória a representação nacional, e se marca[va] os limites de cada um dos poderes”, o publicista enumerava vários pontos "problemáticos". Detinha-se nas falhas no tocante à atribuição de poderes, no critério sócio-econômico e "incertíssimo" da "mandioca" para os eleitores, na vitaliciedade do Senado como inaceitável, e, em especial, no ataque à valorização da divisão em “comarcas". Defendeu peremptoriamente a Província como locus da política - pois que a manutenção das antigas comarcas seria contribuir para o fracionamento e enfraquecimento das partes -, cobrando a separação das esferas eletivas locais da ação do Executivo como forma de fortalecer a "representação" em todo o Império.

Crítica semelhante, mas muito mais incisiva, foi feita à época por Cipriano Barata, mesmo longe da Corte ${ }^{310}$. No início de outubro, Barata referiu-se aos "absurdos" e aos "erros de política" que o "Projeto suspirado da nossa liberal Constituição" conteria" ${ }^{311}$ Para além do forte ataque que fez ao que chamou de tentativa de construção de uma "aristocracia" no Brasil, o combativo periodista tocava diretamente na questão da falta de governos representativos para as Províncias, defendendo sua "liberdade" e "união confederal em forma imperial". Nos números seguintes, falaria abertamente em um "Império Federativo" para o Brasil, o que significava dizer que as Províncias deveriam ter autonomia para tratar de suas "leis particulares" e negócios internos pelos seus "naturais e seus governos", o que, ademais, justificar-se-ia pela dificuldade de comunicação entre todas $\operatorname{as~partes~}^{312}$.

\footnotetext{
autor assinava com o codnome de "Seu Constante Leitor".

${ }^{309}$ Idem, no. 68, 21 de outubro de 1823.

${ }^{310}$ Marco Morel, op.cit. Vale notar que tanto João Soares Lisboa como Cipriano Barata chegariam a ser presos por suas opiniões radicais.

${ }_{311}$ Sentinella da Liberdade na guarita de Pernambuco, n. 54, 08/outubro/1823, pp. 233-4.

${ }^{312}$ Idem, n. 55, 11/outubro/1823, p. 237.
} 
Dessa maneira, a ênfase na urgente construção dos Governos das Províncias como amplos e efetivos canais de representação política unia os críticos. Lisboa e Barata operavam na lógica de que o controle interno dos poderes passava pelo seu fortalecimento como esferas locais que pudessem fazer frente ao Executivo central e que, ao mesmo tempo, uma maior parcela da população fosse alçada à condição de partícipe do jogo político. Obviamente, para eles, a dissolução da Assembléia Constituinte em novembro de 1823 colocaria em xeque qualquer possibilidade de acordo interno viável. Mas essa não seria a reação imediata das Províncias e Câmaras, a despeito de alguns posicionamentos contundentes $^{313}$. A rapidez com que se forjou a tentativa de legitimar o fechamento do Legislativo teve efeito, para o que contribuiu o intenso trabalho da Comissão na elaboração de um novo texto constitucional.

O novo "Projeto" sabiamente marcaria a Província como esfera de poder local, ainda que de forma um tanto lacônica na definição de suas atribuições. Valendo-se da experiência do Projeto de 1823, do qual incorporaram artigos e concepções, em menos de um mês de trabalho ${ }^{314}$ os nomeados conselheiros redigiram a Carta de $1824^{315}$. Mas haveria uma alteração na dinâmica de controle de poderes do edifício político em relação ao anterior, cuja introdução de um "quarto poder", o Moderador, é um dos seus pilares. Mas não o único, como se verá. Antes de tudo, o texto confirmava a opção por um Império unitário como "nação livre" que "não admitia com qualquer outra laço algum de união ou federação", além de manter a divisão das Províncias em que já se achava subdividido. Para

${ }^{313}$ O ocorrido em Pernambuco, em 1824, com a deflagração da Confederação do Equador, foi o mais contundente de todos eles ao propor a separação das Províncias do Norte do Sul do Brasil. No entanto, também no Maranhão existiram distúrbios e tentativas de anulação do juramento da Constituição (ANRJ, Negócios de Províncias, I JJ ${ }^{9}$ 553-4); e igualmente em Salvador logo que se soube da notícia da dissolução da Constituinte (BN, Seção de Manuscritos, Ofício de João Severiano da Costa, 05/janeiro/1824). Sobre esses conflitos, ver Iara Lis Souza, op.cit..

${ }^{314}$ O Conselho iniciou seus trabalhos logo após a dissolução da Assembléia e quase diariamente reunia-se sob a presidência do Imperador. Em 20 de dezembro de 1823, saía dos prelos da Tipografia Nacional o novo Projeto de Constituição por ela elaborada, o qual seria então submetido às Câmaras Municipais de todas as Províncias. Paulo Bonavides e Paes de Andrade, op.cit.

${ }^{315}$ A Carta Constitucional de 1824 tem sido objeto de análises específicas acerca de seu conteúdo intrínseco desde o Império. Para o século XIX, ver: José Antônio Pimenta Bueno (Marquês de São Vicente) (1857), Direito público brasileiro e análise da Constituição do Império, Brasília, Senado Federal, 1978; José Carlos Rodrigues, Constituição política do Império do Brasil, seguida do Ato Adicional", Rio de Janeiro, Eduardo \& Henrique Laemmert, 1863; J. M. Corrêa de Sá e Benevides, Analyse da Constituição política do Império do Brasil, São Paulo, Typographia King, 1890. Posteriormente, seriam nas "histórias constitucionais" que a Carta passava a ser objeto de análise; ver: Aurelino Leal, História constitucional do Brasil, Rio de Janeiro, Imprensa Nacional, 1915; Waldemar Martins Ferreira, História do direito constitucional brasileiro. São 
além da garantia dos direitos individuais e invioláveis (fixados no título $8^{\mathrm{o}}$ ), é digna de nota a incorporação de todos os brasileiros à condição de "cidadãos", como havia sido aprovado na votação do Projeto, com a manutenção da necessidade de adesão "tácita e expressa" dos portugueses “à causa da Independência”. Quanto aos direitos políticos, valeria o critério sócio-econômico para votação (que previa uma renda mínima anual de cem mil réis para participação no primeiro círculo), uma distinção bastante inclusiva para a época ${ }^{316}$. Por mais que se questione a eficácia da prática desses artigos, ninguém duvida de seu caráter eminentemente liberal.

A expressão de que o poder Legislativo seria "delegado à Assembléia Geral com a sanção do Imperador" (art. 13) deixava claro que ambos o exerciam como representantes da "nação" e que a autoridade do último teria certa prevalência às medidas da primeira. Para a Assembléia, mantinha-se o sistema bicameral sendo a segunda Câmara (ou "Senado"), vitalícia, e a Câmara de Deputados eletiva. Ao monarca, mantinha-se a prerrogativa do veto suspensivo sobre as leis aprovadas nessas duas instâncias. Nas atribuições dos deputados, o texto detalhava amplamente suas funções: no tocante às iniciativas privativas da Casa, apesar de manter os poderes que tinham de principiar "o exame da administração passada, e reformada dos abusos nela introduzidos" (art.37), e de "acusação dos ministros de Estado, e conselheiros" (art. 38), retirava-se um item que lhes dava o direito de fiscalizar a arrecadação e emprego das rendas públicas, ou seja, um controle mais direito sobre as atividades do governo. No que vale aos senadores, mantinham-se suas atribuições exclusivas, para além da aprovação das leis, de conhecimento de delitos individuais da Família Real, dos ministros, dos conselheiros, dos senadores, e dos delitos dos deputados no momento da legislatura, mas retirava-se a expressão de conversão da Casa em "grande jurado" (previsto no art. 105 do Projeto). Os deputados e senadores podiam acumular os cargos de ministros e conselheiros também já previsto no documento de 1823 , sendo que os representantes eleitos deixariam seus cargos no Legislativo, mas os segundos exerceriam ambas as funções.

Paulo, Max Limonad, 1954; Paulo Bonavides e Paes de Andrade, op.cit.. Mais recentemente, ver interpretação de José Reinaldo de Lima Lopes, op.cit., p. 202-4.

${ }^{316} \mathrm{O}$ conservador José Antônio Pimenta Bueno, op.cit., afirmaria na década de 1850, que o modo de eleição previsto para o primeiro círculo praticamente estabelecia "o voto universal", pois que seria preciso "ser quase mendigo para não possuir tal rendimento" (p.191-2). 
O Imperador passava a ser considerado "chefe do Executivo", diferentemente do Projeto que estipulara ser esse poder delegado a ele, pondo por terra uma sutil diferença que apontava que sua função seria proveniente da "nação". Ele exercia o governo por meio de seus ministros, que continuavam sendo pensados como "responsáveis". O mesmo "chefe" atuaria como "Moderador" numa leitura peculiar da proposta de Benjamin Constant. Diferentemente da doutrina do pensador, em que o monarca exerceria apenas o pouvoir neutre enquanto seus ministros o Executivo, os formuladores da Carta de 1824 fizeram que ele acumulasse ambas as funções ${ }^{317}$. Daí a tradução livre que se fez de clef do francês (literalmente "fecho", no sentido de "fecho da abóbada") para a "chave de toda a organização política", conforme se definiria o Moderador no artigo 98, num reforço no papel do poder do monarca em função dos outros ${ }^{318}$. A discussão se ao "Moderador" caberia um papel mais interventor e impositivo ou de simples mediação e manutenção do equilíbrio do jogo político, daria origem a um estimulante e fecundo debate político durante os oitocentos ${ }^{319}$.

Segundo a Carta, o Imperador também seria assistido privativamente por um Conselho de Estado (cap. VII) composto de conselheiros vitalícios por ele nomeados e a ser ouvido em todos os negócios graves e medidas gerais de administração, inclusive naquelas que cabiam às atribuições do Moderador. Em vários sentidos, o novo Projeto de Constituição alterava, no plano normativo, o equilíbrio entre os poderes previstos na ordem constitucional em relação ao abortado na Assembléia. Entre as novidades, destaca-se a ingerência do Imperador sobre o Legislativo por seu direito de, se necessário, poder suspender a Câmara dos Deputados (art. 101). Some-se a isso que, no tocante ao Judiciário, agora o Imperador poderia suspender magistrados nos casos de queixas contra eles, desde que precedesse uma audiência com os mesmos juízes e ouvisse seu Conselho de Estado.

No que toca às Províncias, a proposta da Carta respondeu melhor às demandas por uma autonomia maior das localidades do que o Projeto da Comissão da Assembléia,

\footnotetext{
${ }^{317}$ Silvana Mota Barbosa, op.cit.

318 Afonso Arinos de Melo Franco, O constitucionalismo de D. Pedro I no Brasil e em Portugal, Rio de Janeiro, Ministério da Justiça/Arquivo Nacional, 1972.

${ }^{319}$ Ver a interpretação de José Antônio Pimenta Bueno (Marquês de São Vicente) (1857), op.cit.; debatida por Zacarias de Góes e Vasconcelos, Da natureza e limites do poder Moderador (1860), Brasília, Senado Federal, 1978; e também por Braz Florentino Henriques de Souza, Do poder Moderador (1864), Brasília, Senado Federal, 1978. Sobre o debate na época ver análise de Silvana Mota Barbosa, op.cit.; e de Diego Rafael
} 
mesmo que se deixassem as medidas regulares para serem resolvidas nos regimentos posteriores. Assim, além do Presidente nomeado pelo Imperador, criavam-se Conselhos Provinciais em cada capital com membros eleitos localmente, o qual tinha como principal objetivo propor, discutir e deliberar sobre "os negócios mais interessantes das suas Províncias" (art. 81) (lembrar que os Conselhos criados pela lei de 20 de outubro de 1823 não eram permanentes e serviriam apenas para auxiliar a autoridade executiva da Província). Todas as suas resoluções teriam de ser remetidas diretamente ao presidente, que as encaminharia à Assembléia Geral quando esta estivesse reunida; do contrário, o Imperador teria o poder de, interinamente, aprová-las e suspendê-las. Sob a restrição que o mesmo órgão não poderia legislar sobre os interesses da "nação" e de outras Províncias, restava uma definição geral ampla de suas atribuições (sua interpretação seria um ponto de divergência entre os deputados quando do início dos trabalhos legislativos em 1826). Quanto à confirmação da Província como principal locus de poder não restava nenhuma dúvida, e as Câmaras municipais ficavam obrigadas a encaminhar seus "negócios" para o Conselho Provincial para ali serem discutidos e encaminhados às autoridades superiores.

Vê-se, portanto, que em comparação com a proposta constitucional que publicara o redator do Correio do Rio de Janeiro, a Carta de 1824, em termos normativos, estava muito próxima do Projeto elaborado pela Assembléia de 1823. No entanto, o equilíbrio interno entre ambos os Projetos resolvia-se com ênfases distintas: enquanto o texto da Comissão de Constituição, sob a influência de Antônio Carlos de Andrada, primava pela construção de uma equação entre os poderes que, apesar da preservação da majestade do monarca, tendia a criar maiores mecanismos de autocontrole mútuo entre os poderes, a Constituição de 1824 transferia ao Imperador um papel-chave (fosse de ativo interventor ou de simples mediador na cena política, de acordo as posteriores interpretações divergentes) no ordenamento político. Trata-se de duas tendências que, não de todo divergentes, propunham uma ação distinta para as instituições no centro do governo. O Projeto de 1823 apontava na direção de uma preocupação - que fora cara aos norte-americanos ${ }^{320}$ - por uma maior autonomia

Ambrosini, Do poder moderador: uma análise da organização do poder na construção do Estado imperial brasileiro, São Paulo, Dissertação de Mestrado, FFLCH/USP, 2004.

${ }^{320}$ Refiro-me aqui ao sistema de cheks and balances citado na Introdução e, ao mesmo tempo, à necessidade que os federalistas americanos viam de controlar o Legislativo (como poder eminentemente popular), fornecendo maior força ao Executivo, e sobretudo ao Judiciário, por eles considerado o "mais fraco dos poderes". 
(note-se no caso do Judiciário) e ao mesmo tempo certa ingerência entre os poderes para sua neutralização mútua (veja-se a intervenção prevista dos deputados e dos senadores no Executivo). A mesma preocupação não estaria totalmente ausente da Carta - cuja linha de força central situa-se na ação dos braços do Executivo em relação aos outros poderes - mas encontra nela uma relevância menor.

Por um aparente contra-senso, a Carta de 1824 colocaria em pauta a possibilidade de maior autonomia na ação política das Províncias, ao definir suas atribuições de forma ampla. Reconhecia, como extensão dos direitos individuais, a garantia do cidadão em intervir "nos negócios da sua Província" "imediatamente relativos a seus interesses" (art. 71), mesmo confirmando a criação do cargo de presidente da Província. Também passível de interpretações diversas, a construção dos canais institucionais para representação dos interesses locais era outro legado deixado em aberto pela Carta. Nesse sentido, é revelador que, muitos anos depois, em sessão da Câmara dos Deputados, o mesmo Antônio Carlos de Andrada acusasse "os senhores conselheiros de Estado" de terem feito a Constituição "às carreiras", copiando "seu projeto" com a inserção do "poder moderador", do elemento federativo" e "alguns artigos diferentemente",321.

No seu conteúdo geral, é notável como a Carta se afastava de algumas das premissas gerais da Constituição portuguesa de 1822. Ainda que, como argumenta Jorge Miranda, o Projeto discutido na Assembléia em 1823 tenha sido influenciado por algumas formulações específicas do constitucionalismo vintista - como nas garantias individuais dos cidadãos, na questão eclesiástica, nas normas sobre instrução pública e estabelecimentos de caridade, e em parte no Judiciário - era distinta a forma geral de organização dos poderes, a despeito dela se fazer sob a égide de uma monarquia constitucional ${ }^{322}$. A começar pela definição da própria "nação" dos vintistas que, como "união de todos os Portugueses de ambos os hemisférios", não fazia menção à monarquia e adotava uma concepção mais próxima àquela revolucionária de fins dos setecentos. Nesse sentido, era já no Título I que se marcava detalhadamente a garantia dos direitos e deveres individuais dos portugueses.

Para a Constituição portuguesa de 1822, a divisão de poderes se dava na clássica tripartição, sendo o Legislativo unicameral, de duração de apenas dois anos e com critérios

\footnotetext{
${ }^{321}$ Discurso de 12 de junho de 1841, apud Aurelino Leal, op.cit..

322 Jorge Miranda, O Constitucionalismo liberal luso-brasiliero, Lisboa, Comissão Nacional para as Comemorações dos Descobrimentos Portugueses, p. 26.
} 
de votação que dispensavam os econômicos. As atribuições das Cortes, marcadas no artigo 103, para as quais não haveria sanção executiva, favoreciam a centralização de decisões relativas a tratados externos, fiscalização das rendas, dos impostos e despesas públicas, repartição das contribuições das Juntas, e verificação dos secretários de Estado e demais empregados. Também não dependeriam de veto quaisquer medidas tomadas em sessões extraordinárias e constituintes. As demais teriam sanção suspensiva. $\mathrm{Na}$ enunciação do Executivo, já se afirmava que a "autoridade do rei" provinha "da nação" e que a ele não cabia opor-se à reunião das Cortes (nem prorrogá-las nem dissolvê-las), impor tributos, suspender magistrados e comandar força armada. Criava-se um Conselho de Estado que auxiliaria o Rei nos "negócios graves”, na sanção de leis e nas declarações de guerra e paz, e que seria escolhido por esse após eleição e formação, nas Cortes, de listas dos candidatos. No caso da força militar, confirmava-se o papel central da Casa legislativa para permissão de seu emprego no território de Portugal e Algarve, e quase o mesmo se passava em relação à Fazenda pública. Pregava-se a independência do Judiciário em relação aos outros dois poderes, já que seria atribuição do Supremo Tribunal conhecer os delitos dos agentes do Executivo, sendo os cargos dos juízes letrados vitalícios. No entanto, qualquer cidadão poderia acusar os magistrados os quais, depois de uma possível suspensão pelo rei mediante a apresentação de provas e consulta ao Conselho, seriam submetidos a juízo. No tocante ao governo das partes (que se dividia em distritos e câmaras), o texto português de 1822 deixava a questão para ser resolvida posteriormente, fixando apenas que existiriam Juntas administrativas. É fato que mesmo para Portugal essa Constituição teria vida curta, pois já em 1823 D. João VI voltava ao poder com a derrocada liberal. Três anos depois, com sua morte e início da regência de D. Isabel (filha de D. Pedro), o Imperador do Brasil enviaria, para governo do Reino, a mesma Carta que outorgara para o Brasil com modificações feitas de próprio punho ${ }^{323}$. Lá ela também teria vida longa ${ }^{324}$.

Distanciando-se de alguns dos princípios mais radicais expressos pela revolução em Portugal, na Carta de 1824, mais ainda do que no Projeto de 1823, predominara uma aproximação com o espírito das monarquias restauradas européias. No entanto, seria um

\footnotetext{
${ }^{323}$ Essa ficou conhecida como a Carta de abril de 1826. Afonso Arinos de Melo Franco, op.cit., reproduziu os fax-símiles anotados pelo Imperador e seu secretário na alteração da Carta de 1824 para adaptá-la a Portugal. Ver também a análise de Silvana Mota Barbosa, op.cit.

${ }^{324}$ Manuel Felipe Cruz Canavieira, op.cit..
} 
exagero afirmar que o constitucionalismo no Brasil, e mesmo no mundo luso, não passava de uma mera repetição do francês contra-revolucionário ${ }^{325}$, haja vista as soluções específicas criadas para cada um dos contextos para além da preservação da legitimidade monárquica. Tomando como parâmetro a Carta Francesa de 1814, que na época se tornou um modelo constitucional para os regimes moderados ${ }^{326}$, vemos como suas premissas apontavam para um regime ainda mais centralizador na figura do monarca do que aquele forjado no Brasil, mesmo sem a explícita criação de um "quarto poder". Dessa forma, o texto francês iniciava-se, após uma breve introdução aos direitos dos indivíduos, pela definição das atribuições do Executivo. Afirmava que apenas ao rei "sozinho", como pessoa "inviolável e sagrada", pertencia a ação desse poder, que delegava aos seus ministros como responsáveis. Ao monarca era permitido propor leis, com exceção das relativas aos impostos, bem como sancioná-las e promulgá-las. O Legislativo seria "exercido coletivamente" pelo rei e pelas duas Câmaras: a dos "Pares" e a dos Deputados. A primeira seria convocada pelo monarca, composta em número ilimitado por ele mesmo, e teria o precedente para fazer deliberações secretas. Somente em caso de crime, seus membros poderiam ser julgados, ainda assim na mesma Câmara. Os deputados, por sua vez, seriam eleitos obedecendo a critérios, sobretudo, sócio-econômicos. A Câmara de Representantes poderia ser dissolvida pelo rei, mas tinha o direito de ao menos acusar os ministros que, então, seriam julgados pelos Pares. A Justiça era também concebida como uma emanação do monarca e os juízes seriam por ele nomeados e concebidos como inamovíveis.

Em não mais de 76 artigos, a Carta francesa foi de fato a primeira tentativa de criação de um regime constitucional em meio ao ambiente fortemente conservador criado pela Santa Aliança na Europa. Sua vida seria curta em função de um impasse que, segundo Pierre Rosanvallon, marcaria o tenso momento de sua elaboração: o da manutenção da

\footnotetext{
${ }^{325}$ Conforme pretendeu, por exemplo, Afonso Arinos de Melo Franco, op.cit..

326 A Carta francesa foi outorgada após a abdicação de Napoleão em 1814 mediante a volta da monarquia bourbônica encabeçada por Luís XVIII. Nos conturbados meses que se seguiram, instalou-se um governo, depois denomidado dos "Cem Dias", que intentou, em face das arbitrariedades do novo monarca, a volta do governo napoleônico. Vale notar que depois de pronta a Carta, e na véspera da sua apresentação, deixaram Paris o Imperador da Rússia e o da Aústria com suas tropas, o que significava que estavam estes, baluartes da Santa Aliança, satisfeitos com o regime constitucional limitado que se implantava. Pierre Rosanvallon, $L a$ monarchie impossible. Les chartes de 1814 et de 1830, Paris, Fayard, 1994., p.51. A Carta Constitucional de 1814, e outros constitucionais, também podem ser encontrados em Maurice Duverger, Constitutions et Documents politiques, Paris, PUF.
} 
tradição monárquica com a preservação, ao mesmo tempo, dos princípios liberais trazidos pela revolução, ou seja, a necessidade de contemplar duplamente as principais conquistas dos revolucionários e também as do Império ${ }^{327}$. No Brasil, as tensões tinham origem diversa. Eram fruto dos embates sobre a forma do novo pacto alimentado, por um lado, pelas expectativas provindas do processo de politização vivido nas diversas localidades e níveis sociais após a revolução vintista e, por outro, pela necessidade de manutenção de uma ordem interna por meio da monarquia. Desta forma, por mais que o Executivo tivesse força na Carta de 1824, ele não acumulara tantos poderes quanto os presentes no documento francês, pois que seus artífices tiveram de fazer concessões, por mínimas que fossem, as expectativas então existentes. Em comum, foi uma questão de vida ou morte para ambos os regimes monárquicos, o francês e o brasileiro, a construção da sua legitimidade constitucional, o que os obrigou a evocar, e ao mesmo tempo a negar, o peso de suas tradições.

Por essa razão, o envio, em 1824, do Projeto de Constituição às Câmaras municipais do Brasil como forma de submetê-lo à apreciação dos "povos" foi ato, desde à época, controverso $^{328}$. Mesmo que ele tenha significado a negação da soberania da Assembléia como nova instância de representação política, em função da valorização das municipalidades como formas tradicionais do Antigo Regime ${ }^{329}$, eram elas que de fato ainda funcionavam como portadoras de legitimidade política num momento em que a novidade constitucional ainda não sedimentara suas próprias bases ${ }^{330}$. Ao final,

\footnotetext{
${ }^{327}$ Para o autor, esta dubiedade também estaria presente na interpretação coeva que se fez do texto da lei, quando os liberais franceses pregavam que ela representaria um "pacto" entre o rei e a sociedade - pois que o soberano jurava obedecê-la - e os "ultra", ou conservadores partidários do Antigo Regime, que ela era uma concessão do rei para seus súditos.

328 Veja-se como Frei Caneca, no primeiro número do seu Typhis Pernambucano (25/dezembro/1823), criticava a concepção de que as Câmaras municipais seriam os órgãos legítimos de representação da "nação". Frei Joaquim do Amor Divino Caneca, Evaldo Cabral de Mello (org.), São Paulo, Editora 34, 2001, p.341.

${ }^{329}$ José Reinaldo Lopes Lima, op.cit., p.195.

${ }^{330}$ Veja-se como ao menos duas das Juntas de Governo Provisório propuseram uma consulta semelhante ao "voto geral da Província por meio das Câmaras" sobre a medida de convocação de uma Assembléia Legislativa por D. Pedro, em junho de 1822 (Arquivo Nacional. As Juntas Governativas e a Independência). A Junta da Paraíba convocou um "Grande Conselho" na capital, e o mesmo se fez em várias localidades por sua ordem (na Vila do Pilar, na Vila Nova da Rainha, na Vila da Bahia de São Miguel, de Mamanguape, além do Senado da Capital), do que atestou os "Votos Unânimes, e espontâneos da maior parte dos Povos" à instalação de Cortes em terras americanas (v.2, ofícios de 30 de julho, 14 e 29 de agosto de 1822, pp.565589). No Ceará, a Junta informou, em ofício de 9 de agosto de 1822, que "bem crente nos patrióticos sentimentos dos Cidadãos Constitucionais da Província", ordenara que "na presença das Câmaras, pelo modo que parecer mais sensato, exprimissem a sua vontade geral" (v.2, p.215) acerca da medida. No entanto, no ofício seguinte informou que tendo designado o dia para ajuntamento dos "Povos nos Passos do Conselho", a
} 
praticamente sem nenhuma alteração significativa, o texto foi outorgado pelo Imperador, em 25 de março de 1824.

Ainda que as adesões ao Projeto verificadas em muitas Câmaras tenham ratificado a proposta - não sem a ocorrência de conflitos conforme apontou Iara Lis Souza -, as "Reflexões" feitas pela Câmara de Itu sobre o Projeto tiveram um papel emblemático ${ }^{331}$. O texto, datado de $1^{\text {o. }}$ de fevereiro de 1824 , tinha um tom cuidadoso. Deixava claro, em seu preâmbulo, que os vereadores apenas se puseram a refletir sobre o Projeto por possuírem um "Imperador que mil vezes tem reconhecido os direitos imprescritíveis dos seus súditos", e, sem pretender "singularizar-se" na sua atitude, sujeitar-se-iam à "maioria dos votos da nação". Então, passavam às críticas e sugestões. O primeiro ponto tratado era o da organização da "representação nacional", que se alegava não ser "acompanhada de uma só garantia que firma[sse] sua existência" e que a colocasse "a salvo da invasão do poder Executivo". Defendiam que, para seu fortalecimento, fossem acrescentadas duas outras atribuições à Câmara dos Deputados: o poder de fixar as despesas públicas e de repartir a contribuição direta, além de marcar anualmente as informações sobre as forças de mar e terra (Título IV, capítulo $1^{\mathrm{o}}$ ). Propunham também que fosse reduzido o critério sócioeconômico para a função de senador (sob a alegação que o fixado era muito alto para algumas Províncias), e que também se diminuísse o mesmo critério para ser deputado e eleitor em qualquer nível, visando uma inclusão maior no exercício dos direitos políticos. Na mesma linha, criticavam o artigo 96 que previa que os cidadãos brasileiros poderiam ser eleitos representantes em qualquer localidade, independentemente de terem nela nascido ou serem domiciliados, numa valorização dos vínculos locais de deputados e senadores.

No que tocava aos Conselhos Provinciais, duas medidas eram igualmente reivindicadas para aumentar seu poder de ação: que as propostas sobre "imposições" (determinações) pertencessem igualmente a eles como forma de auxiliarem o trabalho na Câmara, ou seja, que tivessem também a iniciativa das leis; e o direito de cobrar a

fim de exprimirem "livremente os seus sentimentos sobre a justa convocação de uma Assembléia Legislativa e Constituinte neste Reino do Brasil", o mesmo não pôde ocorrer em virtude da ameaça de que "indivíduos mal intencionados [...] tramavam certa confederação sediciosa para naquele dia" deporem o governo (ofício de 13 de setembro de 1822, p. 316). A Junta se justificava dizendo procurar "todos os modos razoáveis de satisfazer os Povos, consultando a vontade geral", em razão de uma "conspiração" contra ela iniciada nas vilas de Icó, Lavras e Crato. Tudo indica que a consulta malograra apesar dos esforços da Junta. 
“execução da lei” da competente autoridade da Província (diga-se, seu presidente). Do Moderador, criticavam abertamente tanto a possibilidade de dissolução da Assembléia pelo Imperador, do que resultariam sempre "grandes inconvenientes", como o direito de perdão às penas de ministros e conselheiros que o monarca poderia aprovar. Sendo "crimes contra a Pátria", nem o "Chefe da nação" poderia absolvê-los. Entre outras medidas, pediam também que a Constituição marcasse os limites para concessão de títulos por D. Pedro, e a imediata criação dos cargos de juiz de paz.

Desta forma, era claro que, aceitando os princípios gerais estabelecidos pelo Projeto, as reformulações dos ituenses visavam aumentar as atribuições do Legislativo e dos Conselhos, bem como ampliar os critérios de participação política. Suas propostas nem chegaram a ser discutidas, o que demonstra que, se as municipalidades eram identificadas como esferas legitimadoras para referendar o Projeto, isso não significava o reconhecimento do seu poder de emissão de opinião política sobre assunto tão importante. Revela também que, naquele momento, o governo de D. Pedro ainda conseguia aglutinar expectativas diversas no tocante ao regime a ser implantado que, mal ou bem, ganhava materialidade com uma Constituição.

A manifestação mais radical provocada pelo Projeto veio, sem dúvida, da Câmara de Recife, onde se decidiu, num contexto de iminente ruptura com o Rio de Janeiro, pela sua não aceitação. Lá, no "voto sobre o juramento do Projeto de Constituição" 332, Frei Joaquim do Amor Divino Caneca atacou o texto do Projeto da Comissão nomeada pelo Imperador, além da "dissolução arbitrária e despótica da soberana Assembléia Constituinte" como atentados à "nação" e à criação de um "pacto social". Do ponto de vista da Constituição, criticou sua ênfase no Executivo, a criação do Moderador, o bicameralismo com o Senado vitalício, a incompatibilidade das funções de ministros e representantes, e tratou como a objetivação mais candente de um projeto centralizador para enfraquecimento político das Províncias. Estava-se à beira da deflagração da “Confederação do Equador”, movimento revolucionário que tomou forma em Pernambuco em 1824 pela autonomia da região em oposição à legitimidade pretendida pela Corte do Rio

\footnotetext{
${ }^{331}$ Paulo Bonavides e Roberto Amaral, Textos políticos da História do Brasil. $3^{\mathrm{a}}$ ed., Brasília, Senado Federal, 2002, v.1, doc. 68.6 (disponível no site: www.cebela.org.br ). Entre os que a assinaram estava Diogo Antônio Feijó.

${ }^{332}$ Proferido em sessão de 6 de junho de 1824, publicado em Frei Joaquim do Amor Divino Caneca, Evaldo Cabral de Mello (org.), pp. 557-66.
} 
de Janeiro. O próprio Caneca chegaria a publicar o radical "Projeto da lei orgânica que deveria reger provisoriamente a República pernambucana", escrito em março de 1817 para regulamentar o Governo Provisório que então se instaurou, como exemplo de quais princípios deveriam ser seguidos ${ }^{333}$. Novamente o governo imperial, agora sob a batuta do herdeiro legítimo dos Braganças, reprimiria duramente o movimento. No entanto, sua marca ficaria indelével na memória da oposição à dissolução da Assembléia e à atuação do Imperador nesses primeiros anos do Império.

Tal leitura que qualificou a atuação política de D. Pedro como "despótica" e "absolutista", seria posteriormente reiterada por análises críticas que caracterizaram a Constituição de 1824 e o próprio regime imperial como "flagrante contradição entre estatuto legal e realidade, ${ }^{, 334}$. Nestes termos, a Carta outorgada, a despeito da incorporação de inovações da época, teria servido para confirmar os interesses das classes dos grandes proprietários e negociantes ao criar uma estrutura que nunca poderia se instituir de fato em terras luso-americanas ${ }^{335}$. O que dava margem também para acentuar o caráter supostamente "postiço" do liberalismo no Brasil, já que a prática política cotidiana impediria que o mesmo se realizasse plenamente ${ }^{336}$.

No entanto, pelo que se viu até aqui, a construção de uma ordem constitucional mostrava-se, à época, como uma necessidade. Da mesma forma a adoção de um paradigma liberal, cujos artífices da complexa engenharia normativa do período mostravam ser, mais do que ninguém, conhecedores. Era assim que os problemas da formação de uma nova

\footnotetext{
${ }^{333}$ Idem, Typhis Pernambucano, n. XVIII, 13 de maio de 1824, pp. 441-445.

${ }^{334}$ Emília Viotti da Costa, op.cit.

${ }^{335}$ Essa idéia já estava presente em Caio Prado Jr., op.cit., que, mesmo considerando a Carta um produto essencialmente liberal, afirmaria que as "boas intenções de D.Pedro ficariam contudo nas promessas", não saindo do papel. Antes dele, Aurelino Leal, op.cit., em perspectiva diversa, colocara o problema de que se era "possível ter feito uma Constituição liberal, não era fácil completá-la, desdobrando-a nos seus complementos" devido às "próprias abstrações teóricas, ainda inconsistentes e prenhes de um um idealismo, não raro impraticável" que a compunha. Ver também Sérgio Buarque de Holanda, "A letra e o espírito do regime" in Sérgio Buarque de Holanda, História Geral da Civilização Brasileira, São Paulo, Difusão Européia do Livro, 1968, tomo II, $5^{\circ}$ volume, ao afirmar que apesar do caráter liberal da Constituição, ela teria permanecido como "letra-morta" além de ter criado no Império uma dicotomia entre teoria e prática política.

${ }^{336} \mathrm{Um}$ dos que melhor sintetizou essa idéia foi Roberto Schwarz, "As idéias fora do lugar", Ao vencedor as Batatas. Forma literária e processo social nos inícios do romance brasileiro, São Paulo, Duas Cidades, 1992, p.13-28. A despeito de todas as críticas que essa interpreteção já recebeu (tendo sido a de Maria Sylvia de Carvalho Franco, "As idéias estão no lugar", Cadernos de Debate, no 1, São Paulo, Brasiliense, 1976, uma das primeiras), ainda hoje encontramos análises que pretendem denominar o tipo de liberalismo que aqui se desenvolveu como "importado", como a de Alberto Vivar Flores, "El liberalismo constitucional en la fundación del Imperio Brasileño", Revista Electrónica de Historia Constitucional, n. 6, set./2005 (disponível no endereço: hc.rediris.es).
} 
unidade política, mesmo que mantendo a legitimidade dinástica, passavam pela resolução dos problemas que envolviam um Estado nacional independente, entre os quais, a formação de um centro político-administrativo e de uma estrutura que o unisse em torno de suas mais diversas partes; ademais, a criação de laços comuns, fossem reais ou simbólicos, ideológicos ou discursivos, que pudessem fornecer os vínculos de imaginação a essa comunidade. Foi assim que os próprios coevos tiveram clareza de que não deveria existir uma fissura entre a teoria e a realidade, e tentaram resolvê-la por meio não só da criação, mas da sobrevalorização da implementação de um sistema de medidas positivas. Dessa forma, seria significativo que, em 1825, numa correspondência trivial do presidente de Pernambuco ao Rio de Janeiro, depois de elogiar a Carta de 1824, ele completasse: "não temos, porém, uma Legislação que se diga propriamente pátria e adaptada às nossas circunstâncias. Eis o grande e majestoso objeto em que nos achamos empenhados"337. A prática da Lei Fundamental era o imediato desafio a ser enfrentado.

${ }^{337}$ ANRJ, ANRJ, Negócios de Províncias, I JJ 248 , ofício de 26/maio/1825. 


\section{Capítulo 2}

\section{Desenhando as instituições para um novo Império}

Em junho de 1831, o Conselho do Governo do Ceará escrevia para a Câmara Geral da Vila de Santo Antônio do Jardim demonstrando extrema preocupação em relação ao clima de guerra civil que ali, e em toda Província, havia se instaurado desde a Abdicação. Dizia que eles deviam evitar "com o maior zelo" todos os conflitos e "fazer conhecer com muita clareza ao povo rude, e quase supersticioso pelos direitos da realeza, que a saída do ex-Imperador nada influiu de mudança ou alteração no essencial das nossas instituições constitucionais". Reforçava que era "necessário fazer conhecer também a esse povo, que a Abdicação voluntária do ex-Imperador no seu Augusto Filho não só concorreu para que se não derramasse o sangue Brasileiro" como ainda prometia "vantajosos melhoramentos na administração pública, que se acha[va] confiada a beneméritos cidadãos". É digno de nota que junto à correspondência seguiam alguns números do Semanário Constitucional por conterem ordens recebidas do "ministério" e "as doutrinas de moderação, que constantemente aconselhavam todos os periódicos". Comunicava que os mesmos conselheiros haviam decidido chamar para a capital o coronel Joaquim Pinto Madeira, acusado de ser mentor de "desconfianças e intrigas" como defensor do "absolutismo", além de enviar a pessoa do comandante de armas para "acalmar os ânimos, e harmonizá-los" 1 .

Nesse momento, a situação era de difícil controle nas vilas do Crato, Icó e Lavras, de onde se tinham notícias da deposição de empregados públicos por grupos armados que amedrontavam as autoridades ${ }^{2}$. Mas o recado dado no ofício era claro: mais do que nunca era hora de fazer valer o papel das "instituições" imperiais como instrumento de manutenção da estabilidade do regime, difundindo perante o "povo rude" uma imagem de sua força mesmo sem a presença do monarca. A afirmativa seria um simples ornamento de retórica se não estivesse em jogo a construção de um Estado, cuja ênfase estava colocada

\footnotetext{
${ }^{1}$ ANRJ, Negócios de Províncias, IJJ ${ }^{9} 173$.

${ }^{2}$ Idem, correspondência do vice-presidente José de Castro Silva ao Rio de Janeiro, 22/julho/1831. No mesmo livro encontram-se várias correspondências trocadas entre as Câmaras e o Conselho sobre as desordens e seus envolvidos.
} 
nas instituições jurídicas desde o início dos trabalhos legislativos em 1826. Após a outorga da Constituição em 1824, a aposta era que a implementação de reformas na máquina pública pudesse vir a garantir tanto seu funcionamento como a legitimidade necessária para consecução de uma nova unidade, até então apenas alinhavada. Não era à toa que, quando da Abdicação, essa imagem fosse evocada como forma de trazer os "rebeldes", "pacificamente", à ordem instituída.

O fato de os primórdios de nossa produção legislativa ter privilegiado essa perspectiva fez que alguns temas fossem pontos de constante debate pelos oitocentos adentro. Um deles, talvez o que mais tenha mobilizado energias, estava na discussão acerca da centralização/descentralização dos poderes entre a Corte e as diversas regiões do Império, o que passava pela definição do grau de autonomia das províncias. Se essa questão foi relevante nas disputas que se travaram na Assembléia em 1823 e durante todo o período do Primeiro Reinado, desdobrando-se na imprensa da época, ela foi central quando se iniciaram os debates acerca da reforma da Constituição que culminaria, em 1834, no Ato Adicional. Desde então, a temática ocuparia, com sua contrapartida institucional, um espaço permanente de discussão nos círculos políticos e públicos, fossem eles mais liberais ou mais conservadores.

Exemplo disso ocorreu nos anos 1860 quando, em virtude de mudanças sócioeconômicas vividas desde a década anterior que demandaram novas medidas políticas ${ }^{3}$, pode-se falar num verdadeiro debate de posições sintetizado pelas conhecidas publicações do Visconde do Uruguai rebatidas, anos depois, pelo liberal alagoano Tavares Bastos ${ }^{4}$. O primeiro, como típico representante da elite política imperial e um dos responsáveis diretos pelo Regresso a partir de 1840, criticava o excessivo poder dado, desde 1834, às Assembléias Legislativas provinciais, já que as defendia como simples "esferas administrativas" em nome da centralidade política da Corte imperial. Tavares Bastos, por sua vez, sob a bandeira dos liberais, defendeu um amplo programa de reformas no sentido de construção de um "federalismo monárquico", com a valorização da Província como

\footnotetext{
${ }^{3}$ Paula Beiguelman, Formação política do Brasil, São Paulo, Pioneira, 1976.

${ }^{4}$ Paulino José Soares de Souza (Visconde do Uruguai), Ensaio sobre o direito administrativo, Rio de Janeiro, Typographia Nacional, 1862, 2 t.; Estudos práticos sobre a administração das Províncias no Brasil. Rio de Janeiro, Garnier, 1865; A Província: estudo sobre a descentralização no Brasil (1870), São Paulo/Brasília, Cia. Editora Nacional/INL, 1975; ver análise do debate em Gabriela Nunes Ferreira, Centralização e
} 
unidade política “autônoma”. É notório como suas diferenças estavam, sobretudo, nas estratégias de organização do Estado perante os desafios concretos então vividos; no entanto, as distintas soluções buscadas por ambos os aproximavam ao elegerem o âmbito do espaço político-administrativo como capaz de consolidar a unidade.

A recente historiografia soube valorizar a importância dessas questões desde os primórdios do Império, conforme demonstram trabalhos de José Murillo de Carvalho ${ }^{5}$, Ilmar Rohllof de Mattos ${ }^{6}$, Roderick Barman ${ }^{7}$, Miriam Dolhnikoff ${ }^{8}$, e Maria de Fátima

descentralização no Império. O debate entre Tavares Bastos e Visconde do Uruguai, São Paulo, Editora 34/Departamento de Ciência Política da USP, 1999.

${ }^{5}$ Em A construção da ordem. A elite política imperial, Brasília, UnB, 1981, Carvalho procura compreender a formação da unidade no Brasil pós-Independência, a qual teria ocorrido, na sua opinião, de forma atípica em relação ao resto da América. Para ele, a resposta para essa distinção deve ser buscada na constituição de uma elite imperial homogênea, cuja origem remonta a fins do século XVIII, a qual acabaria por controlar politicamente o Estado imperial em construção, manejando-o de acordo com seus interesses e fornecendo-lhe feições extremamente centralizadoras e conservadoras.

${ }^{6}$ Em O tempo saquarema. A formação do Estado imperial, Rio de Janeiro, Access Editora, 1999, o autor defende a idéia de que o processo de constituição do Estado imperial no Brasil se deu pari passu ao da construção de uma classe senhorial, entendida esta como um conjunto de elementos dos mais distintos segmentos sociais, unificados pela adesão aos princípios de "ordem" e "civilização". Em crítica aberta à idéia de uma elite homogênea e de um Estado quase "monolítico", ele demonstra como havia diferentes projetos e práticas entre os blocos conservadores e liberais predominantes, ou seja, entre "saquaremas" e "luzias". A disputa entre esses dois grupos, internamente heterogêneos, foi acirrada, mas o projeto dos primeiros se tornaria mais factível: por mais que os liberais optassem pela defesa de um projeto político descentralizado, com ênfase nos poderes locais como aposta para garantia de liberdade (como se veria nos primeiros anos da Regência), eles seriam impotentes para resistir à ação dos seus opositores que vislumbraram na centralização um poderoso elemento de controle interno. Assim, ao longo do Segundo Reinado, teria se confirmado a associação entre a "monarquia" e a "ordem", com a vitória de um governo centralizador, sediado no Rio de Janeiro.

${ }^{7}$ Brazil. The forging of a nation 1798-1852, Stanford, Stanford University Press, 1994. Para o autor, a monarquia encabeçada por D. Pedro teria sido centralizadora e geraria discordâncias cuja estaria no conflito de distribuição e de controle do poder entre as várias instâncias locais e o governo central. Tendo sido a Regência um momento de "experimentação política" levada à frente pelos liberais, partilha de posição semelhante a de Ilmar Mattos, ao afirmar que um dos principais problemas desses anos foi a incapacidade, ou mesmo ausência, de um plano do governo central para lidar com a acirrada luta entre as facções que ganharam força nas Províncias e mobilizavam as camadas populares. Ainda assim, um dos ganhos desses anos teria sido o Ato Adicional de 1834, com a criação da esfera dos governos provinciais largamente independentes, ao que atribui um certo traço de "federalismo". O controle fluído dos liberais prepararia uma reação por parte dos conservadores que, a partir de 1837, adquiriram grande força política e conduziram à efetivação de um governo monárquico centralizado na figura de D. Pedro II.

${ }^{8}$ O pacto imperial Origens do federalismo no Brasil, São Paulo, Globo, 2005. Dolhnikoff, ao estudar o papel das elites regionais na construção do Estado nacional, defende que as reformas promovidas ao longo do Primeiro Reinado e no início da Regência teriam sido responsáveis pela formação de um ordenamento jurídico e institucional que fortaleceu uma estrutura descentralizada de governo imperial. Segundo ela, apesar da reação de 1840-1842, foi esse arranjo "federativo" que permaneceu como predominante na política ao nível nacional nos oitocentos, o qual teria sido plenamente compatível com o regime de monarquia. Só assim a unidade teria sido possível, ou seja, na medida em que essas elites conseguiram empreender o atendimento de suas demandas pela consolidação de espaços locais de poder. 
Gouvêa ${ }^{9}$, ainda que eles não se detenham especificamente sobre o Primeiro Reinado e início da Regência. Apesar de diferenças e antagonizações, todos apontam como a construção de um arranjo político-institucional foi um dos principais palcos de conflito na consolidação do regime político imperial. Nesse sentido, vejamos a seguir como, no âmbito da criação dos poderes das Províncias, resolveu-se o impasse da organização de sua administração.

\subsection{Os Governos das Províncias}

Após a outorga da Carta de 1824, as adesões a ela ocorreram em todas as capitais das Províncias que eram pretendidas ao novo pacto político, ainda que forçada em algumas localidades pela violência por parte do governo de D. Pedro I. Como se sabe, isso não foi sinônimo do fim de tensões regionais que, endêmicas ao desenrolar do próprio processo de desintegração do Império português na América, cada vez mais necessitavam ser administradas por parte das autoridades. O nível de conflitos foi realmente incontrolável para o caso da Cisplatina, onde a defesa incondicional de sua incorporação ao Brasil desembocou numa guerra com as Províncias Unidos do Rio da Prata em 1825, que muito contribuiu para o desgaste da imagem do Imperador ${ }^{10}$. Nesse mesmo ano, porém, a Independência seria reconhecida pela Inglaterra e, logo depois por Portugal, o que garantiria a existência de um novo Estado do ponto de vista das suas relações externas. Também se iniciaram as eleições para os representantes que deveriam compor a Assembléia Geral que, como promessa da Constituição, deveria se instalar no Rio de Janeiro. Os adeptos da causa imperial assim propagandeavam que a "nação" começaria a "ter partilha na administração pública", pois que seu "voto" passaria a "ser ouvido na

\footnotetext{
9 "Dinâmica provincial na formação da monarquia constitucional brasileira, 1820-1850" (impresso), texto apresentado no Seminário Internacional Brasil: de um Império a outro, realizado no Departamento de História/USP, São Paulo, em setembro/2005; e, no prelo, O Império das Províncias - Rio de Janeiro, 18221889, Rio de Janeiro, Faperj, 2006. Gouvêa analisa, a partir do caso do Rio de Janeiro, como a circunscrição da esfera provincial teve fundamental importância política no arranjo institucional que iria vigorar na estrutura do Império. Tomando as Assembléias provinciais enquanto importante espaço de representação de interesses locais e de luta política, evidencia uma descontinuidade em relação ao período colonial, quando o foco das disputas se concentrara essencialmente nas Câmaras. Mostra como a Assembléia constituiu-se num exemplar espaço de negociação entre grupos locais, sem deixar de lado sua dinâmica em relação ao governo imperial.

10 João Paulo G. Pimenta, "O Brasil e a 'experiência cisplatina' (1817-1828)", István Jancsó (org.), Independência: história e historiografia. São Paulo, Fapesp/Hucitec, 2005, pp.755-89.
} 
organização das leis" pela escolha dos seus deputados para promoção de sua "conservação e melhoramento"11.

Dessa forma, em maio de 1826, quando se iniciaram os trabalhos regulares do Parlamento, composto pela Câmara dos Deputados e a dos Senadores, o clima era de grande expectativa. Logo nas sessões preparatórias da primeira Casa, uma das questões que se discutiu era a validade, para seus trabalhos internos, do regimento elaborado pela extinta Assembléia Legislativa e Constituinte de 1823. A imperiosidade na regulamentação do exercício de suas funções era um dos pilares da construção da eficácia da instituição parlamentar por meio da normalização e controle de seu funcionamento cotidiano ${ }^{12}$. Logo em seguida, era apresentado pelo deputado José Antônio da Silva Maia ${ }^{13}$, por Minas Gerais, um projeto para sua feitura, para o qual se aprovou imediata urgência ${ }^{14}$.

O tema da regulamentação do governo das Províncias também foi levantado nos primeiros dias após a instalação da Assembléia, por Raimundo José da Cunha Mattos ${ }^{15}$, eleito pela província de Goiás ${ }^{16}$. O deputado fez uma indicação para que se organizasse um regimento que marcasse a ação dos seus presidentes, pois da lei de 20 de outubro de 1823 (a qual, vale lembrar, estabelecera uma forma provisória para os governos provinciais) não teria se retirado, até o momento, "nenhum fruto positivo". A questão ficaria para segunda leitura.

Dias depois, o mesmo deputado apresentou um projeto para regimento dos presidentes, no qual se detalhavam suas atribuições como "administradores e executores" do Imperador ${ }^{17}$. Entre elas, prover empregos, proceder aos recrutamentos, presidir as Juntas de Justiça, de expediente dos negócios e da Fazenda, decidir as tensões de jurisdição entre

\footnotetext{
${ }^{11} \mathrm{BN}$, Abelha do Itaculumy, n. 67, 14/junho/1824.

${ }^{12}$ Fernanda Paula Sousa Maia, O discurso parlamentar português e as relações Portugal-Brasil. A Câmara dos Deputados (1826-1852), Lisboa, Fundação Calouste Gulbenkian/Min. da Ciência e Tecn., 2002, estabelece como a questão era base do nascimento do Parlamento moderno.

${ }^{13} \mathrm{O}$ deputado já havia tomado assento na Assembléia Constituinte de 1823 pela mesma Província.

${ }^{14}$ Annaes do Parlamento Brasileiro. Câmara dos Deputados. Sessão de 1826, Rio de Janeiro, Typographia do Imperial Instituto Artístico, 1874 [APB-CD (1826)], t. 1, sessão de 17/maio, p.63.

${ }^{15}$ Cunha Mattos (1776-1839) era natural de Faro, Portugal. Desde cedo, iniciou carreira militar no Reino, participando de campanhas na América. Foi no Rio de Janeiro que galgou os mais altos postos da hierarquia militar, sendo nomeado governador de armas de Goiás por D. Pedro I. Em 1823, chegou a essa Província que o elegeu deputado para a $1{ }^{\text {a }}$ legislatura (1826-1833). Participou das campanhas militares no Rio Grande do Sul (1826) e posteriormente foi nomeado Marechal de Campo (1835). Ao fim da vida, dedicou-se à atividades intelectuais, sendo um dos sócios fundadores do Instituto Histórico e Geográfico Brasileiro.

${ }^{16}$ APB-CD (1826), t. 1, sessão de 11/maio, p.41.

${ }^{17}$ Idem, sessão de 17/maio, p.71-3.
} 
as autoridades (se ele estivesse envolvido em alguma, o mesmo caberia à Relação ou ao Conselho do Governo) e mandar legalmente conhecer seus abusos, o que se adequava bem à concepção de que os conflitos deveriam ser resolvidos na esfera da administração. Serlhe-iam vedados, no entanto, suspender os magistrados e os comandantes de armas, bem como se envolver nas questões de justiça e de organização interna das tropas. Criar-se-ia um Conselho privativo, apenas consultivo, para auxiliá-lo, cujos membros seriam responsáveis "ao governo e à nação pela falta de zelo", e também por comunicar ao Executivo quando os presidentes cometessem quaisquer irregularidades ${ }^{18}$.

Na sua segunda leitura, o projeto gerou polêmica acerca de seu encaminhamento ${ }^{19}$. Alguns deputados defenderam que ele seguisse para uma comissão, enquanto outros argumentaram que, por sua importância, deveria ser discutido ali mesmo. Seu autor, afirmando tê-lo apresentado "por conhecer as calamidades que os povos têm sofrido, e as desordens que se têm suscitado entre os presidentes das Províncias, e os governadores das armas", e em nome da "felicidade geral da nação", disse pouco se importar sobre como seria encaminhado. No entanto, após ser aprovado que deveria seguir à comissão das leis regulamentares, o projeto não voltou a aparecer no plenário. Preocupado, Cunha Mattos apresentou, nesse mesmo dia, um outro projeto, agora para que se marcassem as atribuições dos chamados governadores (ou comandantes) de $\operatorname{armas}^{20}$. A partir do detalhamento de suas funções, seu autor propunha que eles não poderiam intervir na "conservação ou no restabelecimento da tranqüilidade dos povos" sem ordem do presidente; a única exceção seria no caso de autoridades civis estarem envolvidas nos motins. Após segunda leitura ${ }^{21}$, também esse projeto desapareceu de cena.

Após o juramento da Carta de 1824, o Imperador passara a nomear os presidentes de Província $^{22}$, os quais governariam com um Conselho privativo não permanente estabelecido pela lei de 20 de outubro de 1823. Conforme vimos, a função desses conselheiros era

\footnotetext{
18 Vale notar que a proposta do deputado era que esse Conselho fosse composto por um "prelado", o magistrado de "maior graduação", o "comandante de forças", um "negociante de grosso trato eleito pelos homens bons do povo da capital", e de um "agricultor de melhor nota" escolhido da mesma maneira, deixando evidente uma composição corporativa de sociedade e a necessidade de manifestação de seus distintos interesses.

${ }^{19}$ APB-CD (1826), t.1, sessão de 22/maio, pp.113-5.

${ }^{20}$ Idem, pp.123-125.

${ }^{21}$ Idem, t.1, sessão de 09/junho, p.53.

${ }^{22}$ Uma listagem com o nome e período de governo de todos os presidentes nomeados no Império encontra-se em Vicente Tapajós, Organização política e administrativa do Império, Brasília, FUNCEF, 1984, pp.249s.
} 
auxiliar a ação executiva dos presidentes e, por mais que o clima de instabilidade política em algumas capitais inviabilizasse seu pleno funcionamento, foram implementados ${ }^{23}$. A Constituição criaria um outro Conselho eletivo para agir no âmbito local (capítulo V), intitulado "Geral de Província", cuja ação era, a princípio, mais propositiva para indicar ações e projetos adequados às condições de cada região ${ }^{24}$. Sua justificativa era a garantia aos cidadãos do "direito de intervir" nos "negócios da sua Província". No entanto, o "método" para seus trabalhos ficava condicionado a um regimento que deveria ser elaborado pela Assembléia Geral (Art.89), e eles não haviam ainda sido instalados.

Cunha Mattos, ao tratar da regulamentação do governo provincial, não citava o Conselho Geral da Província, e propunha como solução às desordens existentes nas várias localidades o controle das autoridades executivas dos presidentes e comandantes. Mas antes mesmo de suas propostas serem submetidas a uma segunda leitura, o deputado pelo Ceará Manoel José de Albuquerque ${ }^{25}$ propôs uma outra indicação, para que a comissão de Regimento regulasse os trabalhos dos citados Conselhos Gerais das Províncias ${ }^{26}$. Defendia que existiria uma "analogia" entre esses órgãos e a Câmara dos Deputados, e pedia urgência por ser "mui necessário que se conheçam as necessidades dos povos" das quais os Conselhos seriam "veículos". Na hora, a despeito da informação de que os senadores estariam elaborando um Projeto sobre o tema, a urgência foi aprovada. Estava claro, para aqueles ocupados na normalização do aparato estatal do novo Império, que a regulamentação das instituições provinciais, cujo funcionamento significava a possibilidade de estabilidade interna a cada uma delas, era premente. Mesmo que as atribuições e urgências que teriam cada órgão ou função fossem objeto de permanente disputa, esses legisladores acabariam por construir um padrão para sua implementação.

\footnotetext{
${ }^{23}$ Veja-se em especial o caso do Pará onde, em 1824, o presidente José de Araújo Rozo relatava ao ministério que seu Conselho tanto se recusava a obedecê-lo como se recusara a dar posse ao comandante de armas recém chegado à capital. Domingos Antônio Raiol, Motins políticos (ou história dos principais acontecimentos políticos da Província do Pará desde o ano de 1821 até 1835) (1865-8). Belém, Universidade Federal do Pará, 1970, $1^{\circ}$ volume, pp.104-5 (agradeço essa indicação a André Machado).

${ }^{24}$ É importante notar que o fato dos dois Conselhos serem eletivos, além dos conselheiros poderem ocupar simultaneamente cadeiras em ambos - até 1831, quando uma lei passou a impedi-los de assim o fazerem -, pode gerar uma certa confusão. Deve-se frisar que o primeiro deles (criado em 1823) costumava ser referido como "Conselho da Presidência" ou mesmo "Conselho do Governo", para diferenciá-lo do "Geral da Província" que, como veremos, só seria implantado mais tarde.

${ }^{25}$ Manoel José de Albuquerque (?-1858) era natural da Bahia. Professor e funcionário público, ele ocupou por três vezes a cadeira de deputado pela Província do Ceará na Assembléia Geral: na 1ªgislatura (1826-29), na $5^{\mathrm{a}}$ (1843-44), e na $9^{\mathrm{a}}$, agora como suplente (1853-54).

${ }^{26}$ APB-CD (1826), t.1, sessão de 18/maio, p.81-2.
} 
É fato que a segunda Casa, a dos senadores, estava realmente elaborando um Projeto para os Conselhos Gerais, o qual foi lido para no plenário da Câmara em sessão de 11 de julho de 1826 , com emendas já sugeridas por uma comissão ${ }^{27}$. O texto regulamentava o funcionamento cotidiano da instituição, a forma de se constituir as sessões, suas discussões, as propostas, as comissões, as votações, as pessoas empregadas e seu poder de polícia. À medida que a leitura seguia, os representantes sugeriam alterações; a primeira delas confirmou uma emenda sugerida segundo a qual os conselheiros que os comporiam não seriam "responsáveis" no exercício de suas funções ${ }^{28}$. O que significava dizer que os mesmos não poderiam ser julgados pelas suas opiniões já que as sessões seriam públicas e era recomendável que suas atas se publicassem em forma de Diário nos moldes da Assembléia Geral.

Seguindo a leitura, uma polêmica mobilizou intensamente os deputados: a votação nos ditos Conselhos deveria ser secreta, conforme proposto pelos senadores, ou "aberta" de acordo com emenda assinada por Francisco de Paula Souza e Mello ${ }^{29}$, representante por São Paulo ${ }^{30}$ ? O baiano Lino Coutinho ${ }^{31}$ foi o primeiro que saiu em defesa da emenda, argumentando longamente que todo "cidadão deve[ria] votar em público sem constrangimento" contra qualquer segredo que se pudesse fazer das matérias de governo. Como ele, o também paulista José Ricardo da Costa Aguiar ${ }^{32}$ seria incisivo ao defender que nada se fizesse "às escondidas". No entanto, em nome das "circunstâncias" que existiam nas Províncias, e dos "inconvenientes" que isso poderia gerar em nome da "liberdade do

\footnotetext{
${ }^{27}$ APB-CD (1826), t.3, sessão de 11/julho, pp. 112-126.

${ }^{28}$ Idem, pp.116-7.

${ }^{29}$ Francisco de Paula e Souza e Melo (1791-1851), era natural de Itu, São Paulo. Escolhido deputado pela sua Província natal para as Cortes de Lisboa, alegou doença e foi dispensado. Após a Independência, foi novamente deputado na Constituinte de 1823, e também nas duas primeiras legislaturas (1826-1833), sempre por São Paulo. Em 1833 foi escolhido senador. Foi ministro do Império (1847) e da Fazenda (1848).

${ }_{30}^{30}$ APB-CD (1826), t.3, sessão de 11/julho, pp. 118-122.

${ }^{31}$ Natural da Bahia, José Lino Coutinho (1784-1836) era formado em medicina pela Universidade de Coimbra. Fez parte da primeira Junta Provisória de Governo que se instituiu na Bahia em 1821, após a deposição do governador Conde de Palma, e foi eleito deputado para as Cortes de Lisboa (a qual abandonou em 1822 junto com outros deputados das Províncias do Brasil). Foi eleito deputado para as duas primeiras legislaturas, e ministro do Império entre julho de 1831 a janeiro de 1832. Em 1828, como deputado, apresentou um projeto de reforma do Ensino Médico.

32 José Ricardo da Costa Aguiar de Andrada (1787-1846) era natural de Santos, São Paulo. Bacharel em Leis pela Universidade de Coimbra (1810), foi desembargador da Relação da Bahia em 1819. Foi deputado eleito para as Cortes de Lisboa, pela sua província natal. Com a Independência, ocupou novamente a cadeira de deputado na Constituinte de 1823. No mesmo ano, saiu sua nomeação para desembargador da Casa da Suplicação; e, em 1828, assumiu a presidência do recém criado Supremo Tribunal de Justiça. Além de deputado à $1^{a}$ legislatura, foi suplente de deputado no ano de 1841 (4 legislatura).
} 
votante", o discurso contrário angariaria adeptos ${ }^{33}$. Isso significava uma forma de preservar os próprios conselheiros em meio à luta política travada nas localidades, já que muitos dos então deputados acabariam por ser eleitos para essa função. A questão dos ordenados para os membros do dito Conselho foi também especialmente debatida; mas acabou-se por votar que a matéria fosse remetida à comissão da Fazenda ${ }^{34}$. Assim, aprovava-se o projeto que agora deveria voltar ao Senado, conforme prescrevia a Constituição, para que as emendas fossem aprovadas antes de seguir para a sanção do Imperador.

No exato mesmo dia em que esse Projeto veio ao plenário, Diogo Antônio Feijó, então deputado por São Paulo, apresentaria um outro sobre "administração e economia das Províncias" 35 . O padre, que já havia se pronunciado publicamente sobre a importância de se regulamentarem o governo provincial desde sua volta de Lisboa em 1822, agora desenhava uma ampla proposta para seu ordenamento. Nela se estabeleciam regimentos para as autoridades já existentes dos presidentes, para novo funcionamento das Câmaras municipais, também para criação dos Conselhos Gerais - aos quais se atribuíam alguns poderes específicos não citados pelo texto dos senadores - e do cargo dos juízes de paz. No que tocava ao "delegado do Imperador", caber-lhe-ia o papel de "inspetor" sobre todas as outras funções e órgãos da Província, no sentido do cumprimento das leis sem nenhum poder de intromissão na jurisdição de cada um. Seria dever do presidente dar parte ao governo central das infrações e abusos cometidos, assim como enviar anualmente um balanço da receita e despesa depois de por ele devidamente fiscalizada.

O projeto de Feijó propunha também um controle da mesma autoridade presidencial: que os Conselhos Gerais tivessem poderes para, sempre que necessário, pedirem esclarecimentos sobre deliberações feitas pelo representante do Executivo, além de responder a todos os "funcionários públicos de qualquer natureza e graduação" que se queixassem dos mesmos. Os Conselhos também deveriam rever as posturas municipais, aprovando-as ou rejeitando-as, além de fiscalizar sua prestação de contas financeira. No texto, confirmava-se a submissão das Câmaras à autoridade eletiva da Província, a qual caberia também estabelecer normas para suas eleições e sessões, bem como para ação dos

\footnotetext{
${ }^{33}$ Essa foi a posição de Manoel José de Souza França, eleito pelo Rio de Janeiro, que falou longamente sobre a matéria. O deputado, desde a Assembléia Constituinte de 1823, na qual foi representante pela mesma Província, destacava-se freqüentemente pelas suas posições moderadas.

${ }^{34}$ APB-CD (1826), t.3, sessão de 12/julho, pp.134-9.

${ }^{35}$ Idem, sessão de 11/julho, pp. 127-131.
} 
juízes de paz. Dessa forma, Feijó valorizava o âmbito dos Conselhos e, portanto, do espaço de representação popular como força política fundamental em contraposição aos presidentes, e que por isso deveriam ser colocados em funcionamento o mais breve possível.

Dessa maneira, o regulamento efetivo das Províncias ainda estava em aberto quando se iniciaram os trabalhos legislativos, o que ocasionava o descontentamento esporádico de alguns deputados. Nicolau Pereira de Campos Vergueiro ${ }^{36}$ chegou a se pronunciar mais de uma vez acerca do "despotismo dos presidentes" a que os habitantes das localidades estariam sujeitos $^{37}$, e do desprezo com que se tratavam de suas matérias que "em parte nenhuma são tão mal administrados como na Corte", onde "tratam-se como coisas mui insignificantes" ${ }^{38}$.

O projeto de Feijó foi remetido à comissão de leis regulamentares e voltou ao plenário no início do ano legislativo seguinte, 1827, quando sua discussão foi momentaneamente abortada ${ }^{39}$. Nesse momento, Bernardo Pereira de Vasconcellos ${ }^{40}$, deputado pelas Minas Gerais, deixou claro como existiam discordâncias sobre a prioridade das questões. Em função de o projeto ser muito extenso, argumentou que se deveria tratar "dos juízes de paz e das Câmaras, porque estas autoridades são as que por ora são mais essenciais", e que:

"A respeito dos presidentes nós temos uma lei que foi feita pela assembléia constituinte [de 20 de outubro de 1823]: esta lei não é má, e ainda acresce outra razão, e é que não temos conselhos gerais de províncias, porque esta lei está dependente de aprovação de um regimento comum [da Câmara e do Senado]: por conseqüência acho que não é próprio o reformar o regimento de presidentes de

\footnotetext{
${ }^{36}$ Nicolau Vergueiro já havia ocupado uma cadeira de deputado na Assembléia Constituinte de 1823 pela sua Província natal, São Paulo.

${ }^{37}$ APB-CD (1826), t.3, sessão de 08/agosto, p.71.

${ }^{38}$ Annaes do Parlamento Brasileiro. Câmara dos Deputados. Sessão de 1827, Rio de Janeiro, Typographia do Imperial Instituto Artístico, 1875 [APB-CD (1827)], t. 1, sessão de 16/maio, p.105.

${ }^{39}$ APB-CD (1827), t. 1, sessão de 17 de maio, p.117-8.

40 Bernardo Pereira de Vasconcelos (1795-1850), era natural de Ouro Preto. Formou-se em Direito na Universidade de Coimbra. Iniciou sua carreira pública como juiz de fora da Vila de Guaratinguetá. Foi eleito deputado para a Assembléia Geral, sempre pela sua Província natal, para as quatro primeiras legislaturas, ocupando o cargo de 1826 até 1838, quando foi nomeado senador. Foi ministro da Fazenda do primeiro gabinete da Regência Trina Permanente (1831-32), do Império e da Justiça também na Regência (1837-39). Foi vice-presidente da Província de Minas (1833-35), e um dos principais defensores do "Regresso".
} 
província, porque se ele não tem produzido os melhores efeitos, é por motivos bem notórios, é porque se não tem observado a lei" ${ }^{41}$.

José Clemente Pereira ${ }^{42}$, deputado pelo Rio de Janeiro, fez uma emenda no mesmo sentido, para que se discutisse primeiramente os regimentos para as Câmaras e dos juízes de paz como assunto mais urgente; assim foi aprovado.

Quanto ao projeto vindo do Senado acerca dos Conselhos Gerais de Província, uma incompatibilidade entre a opinião das duas Câmaras prorrogou sua aprovação (vale lembrar que todos os projetos de lei tinham de ser aprovados por ambas as Casas, sendo que as emendas feitas por uma deveriam ser aprovadas pela outra). Após ter sido discutido e reenviado aos senadores, Vasconcellos propôs uma indicação, no mesmo ano de 1826, para que eles deputados retirassem as emendas que foram acrescentadas ao texto original ${ }^{43}$. Falava em nome da urgência na instalação e imediato funcionamento dos órgãos, e argumentava que os senadores estavam irredutíveis em marcar a inviolabilidade dos conselheiros de Província, conforme aprovado pelos deputados. Evocava os "danos que est[ariam] sofrendo os povos das Províncias por essa falta, estando, como est[ariam], privados de um direito, que a constituição lhes confere, e que ninguém lhes pode tirar sem manifesto atentado à lei constitucional" ${ }^{, 44}$. Apesar de reconhecer que a imunidade de seus membros seria essencial para emissão de suas opiniões, pedia que se abrisse mão dela para que o canal de acesso de representação provincial pudesse funcionar.

A proposta foi enviada à comissão de Constituição, que emitiu um parecer favorável $^{45}$. No entanto, na sua discussão, alguns deputados colocaram-se veementemente contrários a voltar atrás na emenda, e defenderam a inviolabilidade como ponto

\footnotetext{
${ }^{41}$ APB-CD (1827), t. 1, sessão de 17 de maio, p.117 (grifos do próprio texto).

${ }^{42}$ José Clemente Pereira (1787-1854) era natural de Trancoso (Portugal), estudou Direito na Universidade de Coimbra, e, como negociante, emigrara para a Corte do Rio de Janeiro. Lá, ligou-se ao grupo de José Gonçalves Ledo e do Padre Januário, que na década de 20 aglutinou uma série de interesses de comerciantes e proprietários quando da eclosão revolucionária constitucional, consagrados na historiografia como "liberais" (então opositores políticos de José Bonifácio e seus irmãos). Construiria uma sólida carreira como magistrado e servidor público, ocupando cargos de Juiz de Fora, presidente do Senado e de presidente do Tribunal do Comércio. Foi deputado eleito nas duas primeiras legislaturas (de 1826 a 1833), e também nos anos de 1838 a 1841. Ocupou várias pastas como ministro, tanto no primeiro como no Segundo Reinado. Foi escolhido senador em 1842, e também desempenhou a função de conselheiro de Estado.

${ }^{43}$ APB-CD (1826), t. 4, sessão de 18/agosto, p.191-2.

${ }^{44}$ Idem, p. 192.

${ }^{45}$ Idem, sessão de 26/agosto, pp. 269-270.
} 
fundamental para o funcionamento dos Conselhos. O mais incisivo nessa crítica foi o baiano Antônio Ferreira França ${ }^{46}$ :

“esta emenda meus senhores, importa toda a lei (apoiado). Sem ela os conselhos são nulos (apoiado). Não valem nada, e talvez servirão somente para comprometer os homens de bem, que há nessas províncias (apoiado, apoiado). Em segundo lugar aqui mesmo logo que alguém oferece uma emenda, e esta é apoiada, já não a pode retirar só pela sua vontade: é preciso que nisso convenha a câmara. Não é isto o que se observa nesta casa? Creio que todos sabem disto" ${ }^{\text {"47. }}$.

Dessa forma, apesar da justificativa pela retirada da inviolabilidade em nome do funcionamento imediato da instituição, a indicação foi reprovada ${ }^{48}$. Venceu que se esperasse por uma reunião entre as duas Casas - conforme fórmula marcada pela Constituição para quando houvesse discordância - para se resolver a questão.

O fato é que vão se passar dois anos sem a existência de previsão sobre uma reunião entre Senado e Câmara dos Deputados e, portanto, sem que os mesmos Conselhos Gerais pudessem ser implementados nas Províncias. Assim foi que Manoel Caetano de Almeida e Albuquerque $^{49}$, deputado por Pernambuco, em maio de 1828 propôs uma resolução com idêntico teor ao apresentado anteriormente por Vasconcellos, para que o regimento fosse aprovado sem as emendas propostas por eles. Dessa vez foi o padre mineiro José Custódio $\operatorname{Dias}^{50}$ que, já tendo sido contra a matéria dois anos antes por considerar que ela ia contra a Constituição, saiu novamente ao seu ataque pela necessidade de se preservarem os conselheiros:

“Qual será o conselheiro de província que se atreverá a arrostar a prepotência dos presidentes, herdeiros e fiéis imitadores dos capitães generais, vendo que hoje ou amanhã pode ser preso pelas mesmas opiniões que emitira? Se um representante da

\footnotetext{
${ }^{46} \mathrm{O}$ deputado já ocupara uma cadeira como representante pela sua Província natal na Assembléia de 1823.

${ }^{47}$ APB-CD (1826), t. 4, sessão de 26/agosto, p.270.

${ }^{48}$ Idem, sessão de 01/setembro, p.336-7.

${ }^{49}$ Manoel Caetano de Almeida e Albuquerque já havia ocupado a cadeira de deputado por Pernambuco na Assembléia Constituinte de 1823.
} 
nação, tendo mui expressamente garantida na constituição a inviolabilidade, é atacado com impropérios, e até ameaçado, como se viu na ministerial gazeta, só faltando realizar-se as ameaças (porque por ora não podem); será mais respeitado o conselheiro da província, sem uma lei que lhe afiance imunidade? Claro é que esta medida nenhum bem vai produzir, ${ }^{, 51}$.

Instava, por fim, que a Câmara não cedesse ao "emperramento do Senado", e que ela deveria recorrer a um meio de "sanar a divergência".

A questão gerou polêmica. $\mathrm{O}$ autor da resolução, Manoel Caetano de Almeida e Albuquerque, justificou longamente a medida alegando que, sem ela, as "Províncias est[ariam] privadas de um remédio indispensável" para seu governo. Afirmava que a Constituição não poderia estar em andamento "em algumas províncias do Norte" pois eles não tinham como saber das "necessidades daquele povo", e que apenas no Sul se gozaria dos benefícios do regime constitucional, no que foi apoiado pelos colegas. O embate de opiniões era claro: ou se alterava a forma de aprovação das leis com a retirada das emendas, em nome da agilidade de instalação dos órgãos eletivos, ou se mantinha a decisão dos deputados pela imunidade dos conselheiros diante das disputas políticas locais.

Antônio Ferreira França, que anteriormente fora incisivo na crítica à retirada das emendas, agora mudara de opinião. Sua justificativa era que, em primeiro lugar, um regimento devia regular os trabalhos internos e externos, e não tratar de "direitos", como seria o caso da inviolabilidade; além disso, afirmava ser preciso que os mesmos Conselhos funcionassem e que eles não podiam "privar as Províncias desse benefício", com exceção do Rio de Janeiro, que já tinha a Assembléia Geral ${ }^{52}$. Do mesmo discurso se valeu Manoel José de Souza França ${ }^{53}$, aludindo ao direito que a Constituição garantia aos cidadãos "de intervir nos negócios das suas Províncias" por meio dos Conselhos:

\footnotetext{
${ }^{50}$ O padre Custódio Dias já havia ocupado a cadeira de deputado por Minas na Assembléia Constituinte de 1823.

${ }_{52}^{51}$ [APB-CD (1828)], t.1, sessão de 10/maio, p. 38.

${ }^{52}$ Idem, p.40.

${ }^{53}$ O deputado já havia participado da Assembléia Constituinte de 1823, em ambas como representante pelo Rio de Janeiro.
} 
“Conseqüentemente sem conselhos gerais de província não podemos dizer verdadeiramente que tenhamos constituição paras as províncias, senão para o Rio de Janeiro somente (apoiados); que as outras províncias estão isoladas, status in statu. Logo a necessidade de se estabelecerem os conselhos gerais de província é urgente",54.

O deputado Holanda Cavalcanti de Albuquerque ${ }^{55}$, eleito por Pernambuco, seria ainda mais incisivo, alegando que "o primeiro fim" a que eles se deveriam dedicar era a "execução da Constituição e a união das Províncias do Império", o que significaria colocar os Conselhos Gerais em prática ${ }^{56}$. Da mesma forma que seus companheiros, também se referiria à desvantagem que, nesse aspecto, estaria submetido o Norte em relação ao Sul do país.

A despeito dos pronunciamentos contrários à resolução, que atacaram também a "regra constitucional", a proposta foi aprovada quando Luiz Paulo de Araújo Bastos ${ }^{57}$, deputado pela Bahia, propôs uma emenda para que a Câmara tomasse a iniciativa de propor um projeto próprio que contemplasse a questão ${ }^{58}$. A resolução privilegiava a implementação das instituições previstas na Carta de 1824, deixando momentaneamente de lado a inviolabilidade dos conselheiros que, em função da forma como se processava a administração, não ficariam resguardados de serem incriminados pelas suas ações.

Em 27 de agosto de 1828, o Imperador dava sanção legal ao regimento para os Conselhos Gerais de Província da forma como ele havia sido proposto pelo Senado em $1826^{59}$. A partir daí, eles passariam a ser criados nas capitais e funcionariam concomitantemente aos da Presidência, ainda que em períodos ou em dias separados por

\footnotetext{
${ }^{54}$ APB-CD (1828), t.1, sessão de 10/maio, p. 40.

${ }^{55}$ Antônio Francisco de Paula e Holanda Cavalcanti de Albuquerque (1797-1863) era natural de Pernambuco, filho de grande proprietário rural. Assentou praça no Exército, e em 1816 partiu para o Rio de Janeiro de onde seguiu para a África na condição de ajudante de ordens do governador de Moçambique. Regressou à Corte em 1819, alcançou promoção na carreira e partiu para Macau no mesmo ano. Voltou a Pernambuco apenas em 1824, quando se aliou às forças realistas de Francisco Paes Barreto no momento da Confederação do Equador. Nesse ano, passou a servir no Estado maior do Exército, chegando a tenente-coronel em 1827. Foi eleito deputado pela sua Província natal para as três primeiras legislaturas da Assembléia Geral, de 1826 a 1837 . Em 1838, foi nomeado senador. Ocupou, por inúmeras vezes, a pasta do ministério do Império, entre os anos de 1830 a 1863. Foi também conselheiro de Estado. Obteve o título de Visconde de Albuquerque.

${ }_{57}$ APB-CD (1828), t.1, sessão de 10/maio, p.42.

${ }^{57}$ Luiz Paulo de Araújo Bastos (1797-1863) era natural da Bahia. Bacharel em Direito Canônico, foi deputado à Assembléia Geral pela sua Província natal na 1ª legislatura (1826-9). Também exerceu a presidência da mesma entre os anos de 1830-1. Obteve o título de $1^{\circ}$ Barão de Fiais.

${ }^{58}$ APB-CD (1828), t.1, sessão de 10/maio, p.43.
} 
existirem conselheiros eleitos para ambos ${ }^{60}$. Nos seus cento e quinze artigos, ele marcava todas as etapas de funcionamento da instituição, desde as reuniões preparatórias, as atribuições do presidente e do secretário, a ordem das sessões no que tocava às propostas, discussões, instalação das comissões e modo de votar, estipulava as pessoas empregadas no seu serviço e também sua ação de polícia. Realmente não se estabeleciam direitos, como a inviolabilidade, a nenhum dos cargos envolvidos.

Como projeto alternativo para os Conselhos Gerais, retornava ao plenário outra parte (título V) daquele apresentado por Diogo Antônio Feijó em 1826, e que se encontrava há dois anos na mesa dos trabalhos ${ }^{61}$. Logo que entrou em discussão o artigo $1^{\circ}$., que marcava que os presidentes de Província deveriam prestar aos Conselhos os esclarecimentos necessários sobre objetos de suas deliberações, a matéria foi aprovada sem discussão. Também foi aprovado o artigo $2^{\circ}$., que estipulava que os mesmos órgãos fariam responder aos funcionários públicos de qualquer gradação sobre queixas contra eles, com ressalva de Lino Coutinho para que essas matérias fossem enviadas ao governo central pelos respectivos presidentes, o que ficou estabelecido ser matéria de um regimento interno. Ambas as matérias caracterizam, definitivamente, os Conselhos Gerais como esferas de poder perante a autoridade executiva dos presidentes, e o consenso em torno da questão demonstra como essa foi uma preocupação geral na primeira legislatura.

No tocante aos artigos três e quatro - que tratavam da atribuição dos Conselhos Gerais em rever as posturas das Câmaras e de fiscalizar sua receita e despesa - foi seu próprio autor, Feijó, que indicou que a matéria fosse suprimida por estar em trâmite a regularização das municipalidades; assim ficou decidido. Voltava-se, portanto, à questão da inviolabilidade dos conselheiros que, segundo o projeto, deveria valer para os mesmos no exercício de suas funções, incluindo que não poderiam ser presos salvo em flagrante ou por

${ }^{59}$ Coleção das Leis do Império do Brasil de 1828, Rio de Janeiro, Imprensa Nacional, 1887, parte I.

${ }^{60}$ É importante dizer que os Conselhos de Presidência, também chamados do Governo, funcionavam de acordo com a lei de 20 de outubro de 1823 que previa que eles não seriam permanentes, e que se reuniriam uma vez ao ano "no tempo que aprouver ao mesmo Conselho, à vista das circunstâncias locais". Marcava apenas que a primeira reunião fosse imediata à eleição dos conselheiros (em número de seis), a qual se fazia da mesma forma como se elegiam os Deputados para a Assembléia. Sua sessão ordinária não duraria mais de dois meses, mas que poderia ser convocado extraordinariamente sempre que o presidente assim solicitasse. No caso dos Conselhos Gerais de Províncias, era a Carta de 1824 (capítulo V) que marcava que as sessões durariam dois meses podendo ser prorrogadas, se necessário; seus trabalhos se iniciariam no dia 01 de dezembro de cada ano (art.80). Seus membros (em número de 21 para as Províncias mais populosas e 13 para as menos) também seriam eleitos da mesma forma que os "representantes da Nação".

${ }^{61}$ APB-CD (1828), t. 2, sessão de 03/junho, p.16. 
ordem expressa da Câmara dos Deputados ${ }^{62}$. A questão novamente gerou polêmica. Bernardo Pereira de Vasconcellos, em defesa da matéria e em nome da oposição que ela encontrava, propôs emenda para que a Assembléia Geral pudesse marcar a responsabilidade dos mesmos ${ }^{63}$. Vários deputados o apoiaram, entre eles Lino Coutinho e José Custódio Dias, que sempre se posicionaram a favor da inviolabilidade para defesa dos conselheiros diante das arbitrariedades das autoridades e das disputas políticas existentes em cada localidade. Apesar do questionamento de que não cabia marcar responsabilidade a cargos meramente consultivos como esses, a matéria foi aprovada com a citada emenda.

Aprovou-se também o direito dos conselheiros receberem um "módico" subsídio quando seu soldo ou ordenado fosse notadamente pequeno, e de se chamar o suplente mais próximo na falta do proprietário do cargo. Vale dizer que aqueles eleitos que tivessem emprego ficariam suspensos do seu exercício quando o mesmo fosse incompatível com a atividade. Antes de seguir para os senadores, o projeto passaria por uma terceira discussão regulamentar, quando ao menos uma nova atribuição dos Conselhos foi acrescida $^{64}$. Tratava-se da inclusão proposta por Francisco de Paula Souza e Mello de que os Conselhos Gerais fiscalizassem a receita e despesa provincial e enviassem anualmente um parecer diretamente à Assembléia Geral. Tal atribuição também estava no rol de competências do presidente da Província, de acordo com a lei de 20 de outubro de 1823, e entregá-la também aos ditos Conselhos significava aumentar a esfera de controle financeiro dos órgãos eletivos nas localidades e, portanto, seu papel político.

O deputado cearense, Manoel do Nascimento Castro e Silva ${ }^{65}$, atacou diretamente a medida, argumentando que ela excederia as atribuições dadas pela Constituição aos Conselhos Gerais de Província:

"porque o ato de tomar conta como ele quer, é um ato meramente administrativo; quando pela Constituição, como já fiz ver, só compete aos conselhos gerais propor,

\footnotetext{
${ }^{62}$ APB-CD (1828), t. 2, sessão de 03/junho, p. 17 e seguintes.

${ }^{63}$ Idem, pp.20-1.

${ }^{64}$ APB-CD (1828), t. 2, sessões de 14 e 16/junho.

65 Manoel do Nascimento Castro e Silva (1788-1846) era natural do Aracati, Ceará. Era advogado provisionado, não tendo cursado curso superior, e começou sua carreira como escrivão no Crato e em Aracati. Foi deputado pelo Ceará às Cortes de Lisboa (1822), e, sempre pela mesma Província, ocupou a cadeira de representante nas quatro primeiras legislaturas da Assembléia Geral (1826-41). Foi presidente da Província do
} 
discutir e deliberar e não administrar, ato que pela lei de 20 de outubro de 1823 compete ao conselho de governo, que decerto preenche os mesmos fins que deseja o ilustre deputado" 66 .

Desta forma, ele estabelecia uma distinção nas atribuições entre ambos os Conselhos: ao do Governo (ou da Presidência) competia tratar da "administração" para a execução das leis, mas ao Geral de Província cabia "propor, discutir, e deliberar sobre os negócios mais interessantes da Província”, como o mesmo deputado citou do artigo 81 da Constituição.

No entanto, Paula Souza, autor da proposta, questionou: se os conselheiros eram mesmo "obrigados a promover o bem de suas Províncias", como não poderiam "fiscalizar as rendas"’ ${ }^{67}$ A observação atenta da retórica do representante permite que se chegue ao cerne da questão: creditava também aos Conselhos Gerais uma ação administrativa por meio do controle das rendas provinciais, retirando seu monopólio da tutela do presidente. Com o mesmo intuito, José Custódio Dias chegou a fazer um aditamento para que os conselheiros também fiscalizassem as diferentes contas especificadas pelos vários empregados públicos ${ }^{68}$. Embora esta última não tenha sido aprovada, a emenda do paulista assim o foi por maioria, sendo acrescida ao texto original de Feijó, que agora seguia aos senadores. A maioria dos deputados se mostrava, portanto, resoluta na necessidade de aumento de poder do novo órgão como forma de controlar a ação presidencial.

Com a instalação dos vários Conselhos Gerais de Província a partir da lei de 1828, logo se colocaria em plenário um novo problema: como discutir as propostas por eles encaminhadas à Assembléia Geral? Já no ano anterior, quando o governo enviara aos deputados várias atas do Conselho da Presidência do Rio Grande do Norte em que se pedia deliberação sobre uma série de medidas legislativas (lembrar que os Conselhos Gerais ainda não estavam instalados), a dúvida de como se deveria proceder ficara no $\mathrm{ar}^{69}$. Um parecer propunha que se remetesse parte do material para várias comissões e parte para o governo como forma de deliberação. Vários representantes falaram em nome da impressão

Rio Grande do Norte (1825-27), e várias vezes ministro da Regência entre os anos 1834-37. Em 1841, foi escolhido senador.

${ }^{66}$ APB-CD (1828), t. 2, sessões de 14/junho, p.121.

${ }^{67}$ Idem, sessão de 16/junho, p. 123.

${ }^{68}$ Idem, sessão de 14/junho, p.121.

${ }^{69}$ APB-CD (1827), t.1, sessão de 08/maio, p.47-8. 
de tudo como forma de valorizar as representações das localidades e analisá-las no plenário, mas essa proposta foi derrotada, e aprovado o parecer.

A questão mereceu nova discussão quando começaram a chegar as propostas enviadas pelos Conselhos Gerais. As primeiras a entrarem na Casa foram encaminhadas pelo órgão de Minas Gerais, em abril de 1829, e, em número de quinze, versavam sobre variados assuntos ${ }^{70}$. Foi então que o deputado José Carlos Pereira de Almeida Torres ${ }^{71}$ sugeriu que se formasse uma comissão ad hoc para se marcar a direção que as propostas teriam, haja vista suas resoluções serem novidade entre eles. Depois de breve discussão sobre como deveriam agir, Vasconcellos propôs que fossem distribuídas às comissões às quais dissessem respeito. Assim foi aprovado.

No entanto, o incômodo em relação a essa deliberação fez que, dias depois, o deputado Caetano Xavier Pereira de Brito ${ }^{72}$, eleito por São Pedro do Rio Grande do Sul e então secretário em exercício dos trabalhos da Casa, questionasse se não deveriam mandar imprimir algumas das várias propostas dos Conselhos Gerais de Província ${ }^{73}$. A polêmica, em torno de estarem ou não sendo realmente discutidas as propostas nas comissões, logo desembocou para a natureza das resoluções provindas das localidades. Francisco de Paula Cavalcanti de Albuquerque ${ }^{74}$, de Pernambuco, argumentou que o material deveria ser impresso para entrar em discussão como qualquer outro projeto apresentado na Câmara,

\footnotetext{
${ }^{70}$ Annaes do Parlamento Brasileiro. Câmara dos Deputados. Sessão de 1829, Rio de Janeiro, Typographia do Imperial Instituto Artístico, 1876 [APB-CD (1829)], t.1, sessão de 25/abril, p. 47-8. As propostas versavam sobre: 1. a prorrogação do prazo de abolição do tráfico de escravos; 2 o imposto da carne verde; 3 . o voto do presidente da Junta da Justiça; 4. o abuso dos oficiais da provedoria dos ausentes; 5. os impedimentos dos juizes de fora e ordinários; 6 . uniformes dos milicianos; 7 . a demora dos julgamentos dos conselhos de guerra; 8. o exame das contas da Junta da Fazenda; 9. os oficiais das Intendências do Ouro; 10. a extinção da Junta da Fazenda; 11. o perdão dos desertores milicianos; 12. a cobrança dos dízimos; 13. a redução dos emolumentos dos empregados no foro secular e eclesiástico; 14. a abolição dos ofícios de tabelião de notas; 15. a revista dois milicianos e licenças para saírem de seus distritos.

${ }^{71}$ José Carlos Pereira de Almeida Torres estudou Direito na Universidade de Coimbra, desempenhando papel de advogado e magistrado. Ocupou vários cargos públicos. Foi deputado da Assembléia Geral por Minas Gerais na $1^{\mathrm{a}}$ legislatura (1826-9) e pela Bahia na $2^{\mathrm{a}}$ (1830-3). Exerceu o cargo de presidente da Província de São Paulo (1829-1831) e também do Rio Grande de São Pedro (1831). Ocupou a função de ministro do Império e da Justiça (interino), além de ter sido conselheiro de Estado. Em 1843, foi eleito senador; foi agraciado com o título de Visconde de Macaé.

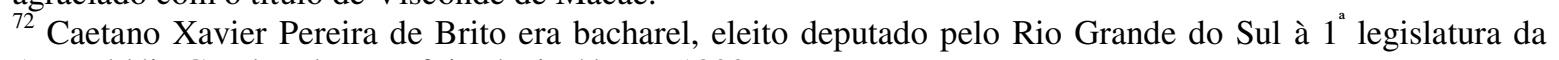
Assembléia Geral. Faleceu e foi substituído em 1829.

${ }_{74}^{73}$ APB-CD (1829), t.2, sessão de 14/maio, p.69.

${ }^{74}$ Francisco de Paula Cavalcanti e Albuquerque (1793-1880) era natural de Jaboatão, Pernambuco. Era proprietário rural e fez carreira militar. Participou como deputado do último ano da $1^{\mathrm{a}}$ legislatura da Assembléia Geral (1829) como suplente do pernambucano Manoel Caetano de Almeida e Albuquerque, o qual fora nomeado senador. Exerceu o cargo de presidente da Província de Pernambuco (1835-7) e também de ministro da Guerra. Foi escolhido senador em 1840, e agraciado com o título de Visconde de Suassuna.
} 
pois que os ditos Conselhos seriam como "câmaras parciais, que pode[riam] apresentar propostas sobre objetos do interesse de sua Província"75. Dessa forma, o deputado atribuía a esses órgãos um poder que, segundo a Constituição, cabia apenas ao Legislativo por meio da proposição das matérias para aprovação de leis, ou seja, sua iniciativa.

Imediatamente, a questão passou a informar opiniões divergentes. Lino Coutinho, antes de tudo, marcou uma distinção entre o que seriam "representações" e o que seriam "projetos" enviados das Províncias. Ainda assim, defendeu que ambos deveriam ser encaminhados diretamente para uma comissão que emitiria pareceres sobre eles. Advogava, em nome da Constituição, que aos mesmos Conselhos somente caberiam propor medidas de âmbito local:

"Daqui, pois, se conclui que não é das atribuições dos conselhos provinciais projetar sobre impostos, etc, etc. Todo o trabalho de tais conselhos é sobre medidas parciais, se convém ou não convém tais posturas etc., e nunca podem tratar de objetos gerais que pertencem à assembléia"76.

O representante baiano tocava num ponto que seria dos mais controversos no processo de construção dos governos provinciais do Império do Brasil: o da divisão entre questões "locais" e "gerais". Pela solução que propunha, Lino Coutinho criticava as medidas enviadas por Minas, e pretendia assegurar que as Comissões pudessem frear aquelas resoluções que "exorbitassem" a esfera de ação dos Conselhos.

O deputado Araújo Bastos seria igualmente incisivo ao criticar a aproximação entre esses Conselhos e a "câmara legislativa", como teria dado a entender Francisco de Paula Cavalcanti de Albuquerque ${ }^{77}$. A despeito dos "dois privilégios" que acreditava ter as propostas vindas das Províncias - a de poderem ser apresentadas como "projetos de lei" e de sofrerem uma única discussão - reforçava que teriam de ser encaminhadas para uma comissão que as "emendaria se necessário". No mesmo sentido, Manoel José de Souza França questionava como a Assembléia poderia “obrar" sem ouvir o parecer da comissão, ainda mais para questões de "interesse geral".

\footnotetext{
${ }^{75}$ APB-CD (1829), t.2, sessão de 14/maio, p.69.

${ }^{76}$ Idem.

${ }^{77}$ Idem, p.70.
} 
A defesa mais enfática de que as propostas dos Conselhos teriam que ir direto ao plenário veio de Antônio Paulino Limpo de Abreu ${ }^{78}$, deputado por Minas Gerais. Segundo ele, assim estaria na Carta de 1824 que não falava em comissão para os negócios das Províncias:

“A razão é bem óbvia: é porque a constituição queria dar aos conselhos gerais todos os direitos que pudessem ter a respeito dos interesses peculiares de suas províncias" $^{, 79}$.

Tal argumentação não mobilizou muito mais adeptos e, quando da votação, acabou por vencer que se remetesse tudo para uma comissão de questões provinciais, o que serviria de norma para o futuro.

A despeito disso, é evidente a tendência existente entre os deputados nos primeiros anos dos trabalhos legislativos em querer transformar os Conselhos Gerais de Província em espaços de poder local efetivo, bem como um esforço para colocá-los em funcionamento o mais rápido possível. Daí ter sido possível sair vitoriosa a indicação para retirada das emendas feitas ao projeto enviado pelo Senado, em nome da criação efetiva dos órgãos. A segunda legislatura, iniciada no ano de 1830, não apenas confirmaria, como reforçaria, essa tendência. Desta forma, ainda que quase nada se avançasse em relação a um regimento para os presidentes de Província, a tentativa de fortalecimento dessa instituição eletiva foi vista, senão como um cerceamento, ao menos como um equilíbrio em relação a eventuais atitudes despóticas por parte dos "delegados do Imperador". Vejamos como essa intenção, que se deve inserir dentro do quadro de reformas liberais do período, desdobrou-se no desenrolar das discussões acerca das autoridades provinciais em ações normativas por parte da

\footnotetext{
${ }^{78}$ Antônio Paulino Limpo de Abreu (1798-1883) era natural de Lisboa. Ainda criança, veio com a mãe para o Rio de Janeiro, sendo que posteriormente retornou à Portugal para estudar Direito na Universidade de Coimbra. Regressou ao Brasil em 1820, iniciando sua carreira na magistratura como Juiz de Fora da vila de São João d'El-Rei. Ocuparia outros cargos públicos, entre eles, o de Desembargador da Relação da Bahia. Foi eleito deputado para a Assembléia Geral para a $1^{\mathrm{a}}$ legislatura (1826-9), a $2^{\mathrm{a}}(1830-3)$, a $3^{\mathrm{a}}(1834-7)$, a $4^{\mathrm{a}}(1838-$ 41) e a $6^{a}$ (que ocupou de 1846-8), em todas representando Minas Gerais. Exerceu a função de presidente da mesma Província (1833-5). Em 1842, foi deportado para Portugal em consequiência da sua participação nos pronunciamentos armados das províncias de São Paulo e Minas Gerais, tendo regressado no ano seguinte. Ocupou várias vezes o cargo de ministro (do Império, da Justiça, dos Estrangeiros e da Marinha), sendo também ministro do Supremo Tribunal de Justiça (1846-8). Foi escolhido senador em 1847. Obteve o título de Visconde de Abaeté.

${ }^{79}$ APB-CD (1829), t.2, sessão de 14/maio, p.70.
} 
Assembléia; entre outras questões, a polêmica acerca da forma como se deveriam discutir as propostas dos Conselhos Gerais voltaria a campo.

Logo após a abertura da Câmara dos Deputados em 1830, Feijó, reeleito por São Paulo, voltaria a colocar a importância de um regimento para os presidentes de Províncias, reapresentando, com modificações, a parte do seu projeto elaborado em 1826 que tratava da matéria ${ }^{80}$. Seu pedido de urgência foi aprovado, e o projeto entrou em discussão. $\mathrm{O}$ novo texto mantinha quase todas as atribuições anteriormente conferidas ao cargo, propondo ainda a revogação da lei provisória de 20 de outubro de 1823, ou seja, retirando de sua alçada a presidência das Juntas da Fazenda e da Justiça (marcada pela citada lei nos artigos 35 e 36) e extinguindo o Conselho que lhe era particular (o do Governo) por considerar suas atribuições idênticas aos Gerais de Província. A estes últimos, fornecia a possibilidade de indicar os indivíduos que poderiam substituir temporariamente os presidentes, inclusive o lugar de vice-presidente, ambos os quais não deveriam entrar em exercício sem antes prestar juramento "de bem servir" ao órgão. Desta forma, sob a argumentação de que os presidentes eram "verdadeiramente absolutos" e que eles, deputados, em cinco anos, não haviam feito nada para contê-los, retirava-lhes o papel estratégico que desempenhavam na condução das Finanças e Justiça das Províncias (lembrar que a lei de 1823 o permitia suspender magistrados) e equacionava seu papel em relação ao dos conselheiros locais. No entanto, assegurava-lhe o lugar de "primeira autoridade" e regulamentava seu dever de "dispor de força a bem da segurança e tranqüilidade da Província" sem prévia consulta a nenhuma outra instância.

O projeto de Feijó e sua urgência foram criticados. O pernambucano Luiz Francisco de Paula Cavalcanti e Albuquerque ${ }^{81}$ acusou-o de "anticonstitucional" por se referir aos presidentes como "delegados do chefe da nação", quando na verdade não passariam de seus "administradores", que deveriam se reportar aos ministros e não ao Imperador $^{82}$. O combativo paraibano Joaquim Manoel Carneiro da Cunha ${ }^{83}$ reclamou da urgência e atacou

\footnotetext{
${ }^{80}$ Annaes do Parlamento Brasileiro. Câmara dos Deputados. Sessão de 1830. Rio de Janeiro, Typographia do Imperial Instituto Artístico, 1878 [APB-CD (1830)], t. 1, sessão de 26/maio, p. 235-6.

${ }^{81}$ Luiz Francisco de Paula Cavalcanti de Albuquerque (1753-1844) era natural de Pernambuco. Magistrado, ocupou a cadeira de deputado, sempre por sua Província natal, na Assembléia geral durante a $1^{a}$ legislatura (1826-29), a $2^{\mathrm{a}}$ (1830-33) e a $3^{\mathrm{a}}$ (1834-37). (Seu nome aparece referido nos Anais por Luiz Cavalcanti mas, por vezes, também por Paula Cavalcanti).

${ }^{82}$ APB-CD (1830), t. 1, sessão de 26/maio, p. 237.

${ }^{83} \mathrm{O}$ deputado ocupara cadeira na extinta Assembléia Legislativa de 1823, também por sua Província natal.
} 
a proposta de aumento dos ordenados dos presidentes, que preteria outras prioridades imediatas, como a "instrução pública" e os pagamentos dos seus professores.

Lino Coutinho, reeleito pela Bahia, foi quem mais enfaticamente apoiou a proposta de Feijó, por conta dos presidentes terem "até hoje obrado segundo seu arbítrio sem conservar lei alguma" "84; além disso, acusava-os de fazer "a desgraça de todas as Províncias [...] não se querendo curvar à lei nenhuma". Tal argumento encontraria respaldo entre os deputados, vencendo a urgência do projeto com a nomeação de uma comissão especial para tratar da matéria. No entanto, há que se notar que a matéria não voltou mais ao plenário antes de 1834, quando um regimento diferente da proposta do então representante paulista seria, finalmente, aprovado.

Imediatamente após o final dessa discussão, retomou-se o projeto que marcava as atribuições dos Conselhos Gerais de Províncias ${ }^{85}$ o qual, aprovado pelos deputados em 1828 a partir de texto do mesmo Feijó, havia sido encaminhado aos senadores, conforme vimos acima; no ano seguinte (1829), ele voltara da segunda Câmara com emendas que se mandaram imprimir (e que não foram transcritas) $)^{86}$, as quais apenas agora (1830) entravam em discussão. Em geral, vários representantes se opuseram às emendas, sob justificativa de que os senadores tentavam resguardar a autoridade dos presidentes de Província evitando que ele fosse submetido à ação dos mesmos Conselhos, visivelmente fortalecidos pela proposta. Nesses termos, falou Martim Francisco Ribeiro de Andrada ${ }^{87}$ contra todas as alterações sugeridas pelos representantes vitalícios:

“As atribuições dos conselhos de província versam sobre tudo que for de utilidade provincial. Será de utilidade provincial conhecer da violação da lei perpetrada pelo presidente da província? Indubitavelmente. Se [for] uma atribuição do conselho da província, cuidar do que é útil, como o conselho da província não pode tomar disso conhecimento, ouvindo as autoridades contra quem se reclama? Como não se quer que se ouça o presidente?",88.

\footnotetext{
${ }^{84}$ APB-CD (1830), t. 1, sessão de 26/maio, p. 236.

${ }^{85}$ Idem, pp. 237-240.

${ }^{86}$ APB-CD (1829), t. 5, sessão de 29/agosto, p.81.

${ }^{87} \mathrm{O}$ deputado, que havia sido eleito pelo Rio de Janeiro para a Assembléia Legislativa de 1823, quando era ministro junto com seu irmão José Bonifácio de Andrada e Silva, agora era representante por Minas Gerais.

${ }^{88}$ APB-CD (1830), t. 1, sessão de 26/maio, p. 237-8.
} 
Com justificativas semelhantes, foi predominante a posição de que os presidentes de Província deveriam dar esclarecimentos aos Conselhos, conforme já haviam aprovado os deputados. Assim falou novamente Lino Coutinho, pela necessidade de se transformarem os presidentes em "homens constitucionais", deixando de ser "capitães-general"89. Na mesma linha pronunciou-se Augusto Xavier de Carvalho ${ }^{90}$, reeleito pela Paraíba, ao afirmar que os Conselhos deveriam ser "obrigados a receber as queixas contra os presidentes",91. Igualmente Francisco de Paula Souza - que na legislatura anterior incluíra no Projeto a emenda para que esses conselheiros tivessem inclusive poder para fiscalizar as rendas das Províncias - defendeu que os mesmos Conselhos ficariam prejudicados na representação dos interesses das localidades se não tivessem direito a obterem explicações das autoridades executivas $^{92}$. O advogado baiano Antônio Pereira Rebouças ${ }^{93}$, estreante no âmbito legislativo, seria enfático nesse sentido:

"Ora, de que servirão as queixas dirigidas ao governo ou ao corpo legislativo, se elas não vierem competentemente motivadas, se o conselho não empregar todas as medidas conducentes a alcançar os esclarecimentos necessários para dirigir representações dignas de serem atendidas, obrando com mais conhecimento e mais prudência?",94.

Ainda que timidamente, alguns deputados se colocaram contrários à opinião geral; com o argumento de que os Conselhos não teriam autoridade para tomar esclarecimentos ao presidente, o que competiria apenas ao tribunal de justiça. No entanto, quando da votação,

\footnotetext{
${ }^{89}$ Idem, p.238.

${ }^{90}$ Augusto Xavier de Carvalho foi deputado pela Paraíba por três vezes: na Constituinte de 1823, e na Assembléia Geral nas duas primeiras legislaturas (1826-9 e 1830-3).

${ }_{91}^{91}$ APB-CD (1830), t. 1, sessão de 26/maio, p. 238.

${ }^{92}$ Idem.

93 Antônio Pereira Rebouças (1798-1880) era natural de Maragojipe, Bahia. De família humilde, foi autodidata nas Ciências Jurídicas quando era escrevente de um cartório judicial. Tornou-se advogado em 1821 sem jamais ter cursado qualquer faculdade, recebendo o direito de exercer a profissão após aprovação nos exames oficiais. Participou ativamente da luta de independência na sua Província natal. Foi membro do Conselho Geral da Bahia (1828), e elegeu-se deputado para a Assembléia Geral nas $2^{\mathrm{a}}(1830-33)$ e $3^{\mathrm{a}}$ legislaturas (1834-37). Posteriormente seria novamente representante da Bahia (1843-4) e de Alagoas (18457) na Câmara, e também deputado provincial.

${ }^{94}$ APB-CD (1830), t. 1, sessão de 26/maio, p.239.
} 
todas as emendas feitas pela segunda Casa foram negadas, inclusive a que vetava aos deputados e senadores o acúmulo da função de conselheiros. A vitória tranqüila do projeto nos moldes como havia sido votado em 1828 indicava o fortalecimento da tentativa de se consolidar os Conselhos Gerais como verdadeiros órgãos de poderes locais, a partir do que havia sido enunciado de forma muito geral pela Constituição de 1824. Mantida a incompatibilidade de opiniões entre as duas Casas legislativas, o projeto não voltaria mais à cena; isso também ocorreu porque, já no ano seguinte, entraria em discussão a possibilidade de uma reforma da Constituição que tocaria, entre outras, na questão dos governos provinciais.

Mas antes disso, no mesmo ano de 1830, uma outra decisão favorável ao fortalecimento político dos Conselhos Gerais de Província tomaria forma. Trata-se da aprovação, depois de longuíssimo debate, de que as propostas encaminhadas pelos mesmos Conselhos à Câmara dos Deputados, desde que tivessem forma de projeto, não poderiam sofrer emendas e seriam submetidas à apenas uma discussão, que as aprovaria ou rejeitaria na sua totalidade. $\mathrm{O}$ que significava que, no caso de aprovação, a iniciativa da lei teria partido da localidade. Sobretudo por essa razão, iniciou-se uma polêmica da matéria quando esteve em pauta uma proposta do Conselho da Bahia acerca das moedas de cobre falso que há anos preocupavam as autoridades na região, e alguns deputados demonstraram dúvidas sobre como propor modificações ao seu texto original ${ }^{95}$. Nesse momento, o deputado José Antônio da Silva Maia ${ }^{96}$ questionou o tratamento dado aos projetos oriundos das Províncias, sugerindo ser conveniente que, para além de uma discussão geral, houvesse uma outra, em que se pudesse tratar de cada um dos artigos em particular. Lembrava que a Constituição (artigo 85) marcava que os projetos encaminhados pelos Conselhos Gerais deveriam passar por apenas uma discussão. Ainda assim, o encaminhamento que se daria à presente proposta gerou discordâncias.

Em meio às argumentações sobre o número das discussões, o pernambucano Luiz Francisco de Paula Cavalcanti e Albuquerque defendeu que os deputados não poderiam emendar nenhuma das propostas vindas dos Conselhos Gerais, por dois motivos: por uma questão de economia de tempo na Câmara - pois que as matérias já teriam sido discutidas

\footnotetext{
${ }^{95}$ APB-CD (1830), t. 1, sessão de 17/maio, p.158.

96 Deputado que já havia sido eleito pela mesma província de Minas Gerais para cadeira na Assembléia Legislativa de 1823, e para a primeira legislatura da Câmara dos Deputados.
} 
no âmbito de suas localidades -; e porque esses órgãos tratavam de "coisas cíveis e peculiares da sua Província, não de coisas políticas”, bastando rejeitá-las ou aprová-las ${ }^{97}$. No mesmo sentido, Lino Coutinho foi taxativo ao enfatizar que eles não poderiam alterar o teor dos projetos enviados, bastando rejeitá-los no caso dos mesmos transcenderem a esfera provincial. Além disso, afirmava que o trabalho dos Conselhos apresentava muita similaridade com o do Legislativo:

“Se, pois, a proposta não envolve nenhuma das matérias de que falo [de negócios gerais], a câmara não faz mais do que aprovar, porque a constituição mandou que aquela espécie de pequeno corpo legislativo legislasse sobre os interesses particulares da província, e nós apenas somos censores; por isso que a constituição diz que devem as propostas ser aprovadas com uma única discussão" ${ }^{\text {98 }}$.

Deve-se notar que por trás de uma aparente formalidade estava em jogo a possibilidade de, no caso de serem aprovadas as propostas sem modificações, os Conselhos Gerais de Província acabarem por exercer papel importante na proposição e determinação das leis. O mesmo Luiz Cavalcanti chegou a defender que os projetos elaborados nessas instâncias deveriam ser remetidos por esses mesmos órgãos, valorizando-os como esferas de representação e em detrimento de alguns entre seus colegas que, em nome de sua localidade, os apresentavam pessoalmente em plenário.

No entanto, a dúvida sobre a matéria fez que um requerimento feito por Holanda Cavalcanti de Albuquerque - para que se encaminhasse a decisão sobre a melhor forma de se discutirem as propostas à comissão de Constituição - fosse aprovado ${ }^{99}$. Sob o discurso da prudência, Bernardo Pereira de Vasconcellos também a defendeu, colocando como crítica à posição de Cavalcanti o inconveniente de se rejeitarem questões importantes por causa de um ou outro artigo ruim. O deputado Aureliano de Souza e Oliveira Coutinho ${ }^{100}$

\footnotetext{
${ }_{97}$ APB-CD (1830), t. 1, sessão de 17/maio, p.158.

${ }^{98}$ Idem, p. 159.

${ }^{99}$ Idem, p. 158.

100 Aureliano de Souza e Oliveira Coutinho (1800-1855) era natural do Rio de Janeiro. Bacharel em Direito pela Universidade de Coimbra, desempenhou, após sua volta ao Brasil, seus primeiros cargos públicos nas Minas Gerais. Ocupou por duas vezes a cadeira de deputado na Assembléia Geral: na $2^{\text {a }}$ legislatura (1830-33), por Minas Gerais, e na 4 legislatura (1838-41), pelo Rio de Janeiro. Foi escolhido senador, pela Província de
} 
foi o único que se pronunciou pela necessidade de discussão imediata da matéria, mas não angariou adeptos; afinal, seguir o caminho da moderação mostrava-se fundamental para revestir de legitimidade os atos da Assembléia.

Dias depois, a comissão emitiu um parecer assinado por Feijó e por José Martiniano de Alencar ${ }^{101}$ para que as propostas dos Conselhos Gerais fossem discutidas como os demais projetos apresentados na Casa, e que sua única discussão correspondesse à terceira prescrita no Regimento interno (em que era lícito falar tanto sobre seus aspectos gerais como sobre cada artigo em particular) ${ }^{102}$. Vale notar que o baiano Antônio Ferreira França, também membro da comissão, votou em separado; para ele, a discussão de tais propostas deveria apenas versar sobre sua vantagem ou inconveniente, ou seja, ser aprovada ou rejeitada, sem emendas. A partir daí teve início uma intensa polêmica.

Luiz Cavalcanti mantinha sua posição de que não caberiam emendas às propostas das localidades, em nome da Assembléia ser "fiscal dos atos dos Conselhos Gerais" apenas quando esses exorbitassem de sua esfera, não devendo "intrometer-se em emendar resoluções provinciais"103. Argumentava que o mesmo deveria fazer o Senado que, no caso de discordância, esperaria até a reunião de ambas as Casas. Agora, o primeiro a apoiá-lo seria seu companheiro de bancada, Holanda Cavalcanti de Albuquerque, num longo discurso em que valorizava os Conselhos como instâncias de representação dos negócios provinciais:

\footnotetext{
"se a constituição não quisesse que aos conselhos gerais se reservassem a legislação sobre negócios peculiares de suas províncias, não diria que eles pudessem propor resoluções, porque nisto não supõe privilégio neste caso, porque todo o cidadão pode propor qualquer projeto à assembléia geral e esta tomá-lo em consideração e passar pelo processo do nosso regimento [...] a instituição dos conselhos é uma das melhores disposições da constituição, e aqueles que lhe intentam tirar estas iniciativas querem perder uma das melhores instituições que temos"104.
}

\footnotetext{
Alagoas, em 1843, e presidente da Província de São Paulo (1831) e do Rio de Janeiro (1844-8). Entre 1833 e 1841, esteve à frente de vários Ministérios. Obteve o título de Visconde de Sepetiba.

${ }^{101}$ Alencar já estivera presente na Assembléia Constituinte de 1823, também eleito pela província do Ceará.

${ }^{102}$ APB-CD (1830), t. 1, sessão de 28/maio, p.257.

${ }^{103}$ APB-CD (1830), t. 1, sessão de 28/maio, p. 257.

${ }^{104}$ Idem, pp.257-8.
} 
Desta forma, defendia não apenas que os órgãos tivessem ingerência "legislativa", mas também "iniciativa" na proposição das leis. Ajuntava ainda que fazer emendas aos seus projetos seria uma verdadeira "invasão da Câmara dos deputados em um direito privativo das Províncias", sendo que a rejeição das mesmas poderia causar menos males.

Seguiram-no Lino Coutinho e Ernesto Ferreira França ${ }^{105}$, este eleito por Pernambuco, que afirmavam terem os Conselhos Gerais verdadeiros poderes para legislarem. O segundo afirmava categoricamente ter sido a Constituição que reconhecera o "direito e a necessidade desse pequeno corpo legislativo" para "promover o bem particular das Províncias, sem se ingerir nos negócios gerais da nação" ${ }^{106}$. Tais posições expressavam a tentativa de se valorizar as decisões tomadas localmente perante as ações dos deputados e senadores, e em especial os Conselhos como um canal direto de representação provincial. A reação a ela tendeu a reforçar a concepção de que era a Câmara a instância máxima no julgamento das prioridades e necessidades da "nação", já que seus representantes estariam capacitados para agirem em seu nome.

Assim falou Feijó, a despeito da sua posição anterior (desde 1826) em favor do funcionamento dos Conselhos Gerais como esfera de poder fazendo frente à dos presidentes de Província. A base de seu pronunciamento era a defesa do papel da Assembléia como instituição primordial no direcionamento dos caminhos a serem trilhados pelo Império, onde estariam reunidos aqueles mais capazes de legislar não para uma, mas para todas as Províncias:

"Se qualquer projeto de lei apresentado nesta câmara, que geralmente é composta de 100 membros, ainda mesmo tendo que ir para o senado sofre aqui emendas, como devem ficar aqui isentas delas os projetos de um conselho geral, composto de 12 a

\footnotetext{
${ }^{105}$ Ernesto Ferreira França (1804-1872), era natural da Bahia (filho de Antônio Ferreira França que, em 1830, também ocupava uma cadeira como representante da Bahia). Em 1819, iniciou a Faculdade de Leis na Universidade de Coimbra onde recebeu o grau de bacharel. De volta ao Brasil foi nomeado, em 1824, Juiz de Fora da Comarca de São Paulo e, no ano seguinte, Provedor da Fazenda dos Defuntos e Ausentes. Foi Ouvidor da Comarca do Recife e desembargador da Relação do Maranhão. Exerceu, em várias ocasiões, a função de deputado: por Pernambuco, na $2^{\mathrm{a}}$ legislatura (1830-1833); pela Bahia, na $3^{\mathrm{a}}(1834-1837)$; e na $5^{\mathrm{a}}$ (1843-1844) e na $6^{\mathrm{a}}(1845-1847)$ como suplente. Exerceu a função de ministro nos Estados Unidos da América do Norte (1838-9) e, posteriormente, à frente da pasta dos Negócios Estrangeiros (1844). Em 1857, foi nomeado ministro do Supremo Tribunal de Justiça.

${ }^{106}$ APB-CD (1830), t. 1, sessão de 28/maio, p.261.
} 
13 membros? Era embaraçarmos, e em lugar de fazermos benefício aos conselhos gerais fazíamos um grande mal" ${ }^{107}$.

Dessa forma, defendia o parecer, ou seja, que os projetos enviados pelas localidades fossem considerados da mesma forma que os outros da Casa (e assim pudessem receber emendas), sem maiores privilégios além de serem submetidos a uma única discussão.

$\mathrm{Na}$ mesma direção, o deputado cearense Alencar argumentou serem os deputados responsáveis por "legislar não só para toda a nação em geral, como peculiarmente para cada uma das províncias", e que aos Conselhos caberia apenas "propor projetos peculiares" a suas respectivas localidades ${ }^{108}$. Por essa razão, nunca as resoluções dos Conselhos poderiam ser "mais" do que os correntes projetos de lei, e deveriam sofrer emendas como esses últimos. Vasconcellos, que igualmente já demonstrara ser favorável à atribuição de poderes aos mesmos Conselhos, também advogou a favor do parecer que previa uma separação entre "iniciativa direta e indireta" na proposição das leis, sendo a primeira única e exclusivamente de atribuição da Câmara que assim teria direito de modificar o que fosse proveniente de todas as partes do Brasil.

A votação do parecer assinado por Feijó e Alencar reprovou-o em ambas as partes: na primeira, por ampla maioria, negou-se que os projetos das Províncias fossem tratados da mesma forma que os demais; na segunda, por uma apertadíssima vitória de 38 a 37 votos, recusou-se a aceitação de emendas aos seus artigos ${ }^{109}$. Logo após, Holanda Cavalcanti de Albuquerque fez um requerimento para que as propostas dos Conselhos Gerais fossem discutidas para obter simples aprovação ou reprovação, sem admitir emendas. No entanto, a divisão de opiniões que predominava na Casa em relação à matéria fez que se aprovasse nova remessa da questão à comissão.

A polêmica voltou à cena quase um mês depois ${ }^{110}$ quando para resolução do impasse foi apresentado um novo parecer. Dessa vez, Joaquim Manoel Carneiro da Cunha introduziu uma nova variável no argumento contrário à feitura de emendas aos projetos

\footnotetext{
${ }^{107}$ Idem, p, 257.

${ }^{108}$ Idem, pp. 258-9.

${ }^{109}$ Idem, p.262.

${ }^{110}$ Idem, sessão de 23/junho, p.474.
} 
provinciais que residia num desejo de maior autonomia na gestão das questões locais pelos Conselhos, traduzido na defesa da "confederação":

“Alguns Srs. deputados disseram que isto era um sistema de confederação; mas já se respondeu que se o é, a constituição é que os determina e não é esse artigo da nossa constituição o mais liberal, o mais franco? Quando li a constituição oferecida, olhando para os seus artigos, logo que li este ${ }^{111}$ dei o meu voto: dele hão de emanar todos os bens que nos hão de resultar, demos, pois, a estes conselhos as suas atribuições, não lhas roubamos, não queiramos que fiquem no mesmo estado ou pior ainda que um particular, e demais os conselhos vendo que suas propostas são sujeitas às discussões minuciosas e sofrendo emendas não terão vontade de trabalhar" $" 112$.

O deputado citava o exemplo dos Estados Unidos da América onde, segundo ele, eram "pequenas assembléias nas Províncias" que tratavam de seus interesses específicos, cujos conteúdos não deveriam ser nunca do conhecimento dos legisladores da Assembléia Geral.

Holanda Cavalcanti de Albuquerque, mantendo sua opinião contrária às emendas às propostas provinciais, fez uma longa fala no sentido de frisar a distinção entre as matérias de interesse geral, das quais eles deputados não se deveriam "desviar", e as de interesse peculiares das Províncias, no que não caberia se "intrometer" por causa do volume e importância dos trabalhos "da nação"113. Também Lino Coutinho aproveitou-se do argumento da "confederação" para defender a não ingerência dos representantes nos projetos dos Conselhos: sendo o Brasil um “império heterogêneo", em que "cada Província diversifica em costume, em climas, e em terrenos", de nada valeria um "sistema de concentração, de se querer fazer tudo pela Corte" já que a Constituição permitiria que "cada Província form[ass]e as suas leis peculiares"114.

\footnotetext{
${ }^{111}$ Refere-se ao artigo 81 que afirmava que os Conselhos Gerais poderiam "propor, discutir e deliberar sobre os negócios mais interessantes de suas Províncias; formando projetos peculiares, e acomodados às suas localidades, e urgências".

${ }^{112}$ APB-CD (1830), t. 1, sessão de 23/junho, p.475.

${ }^{113}$ Idem, p.476.

${ }^{114}$ Idem, p. 477.
} 
No entanto, a divisão de posições se mantinha no ambiente da Casa. Nesse momento, Evaristo Ferreira da Veiga ${ }^{115}$ fez uma longa fala em defesa de estar a Assembléia "expressamente autorizada para discutir as propostas dos Conselhos" e, portanto, de "corrigir essas propostas"116. Não obstante, sustentou que os deputados não deveriam ter receio de falar em "federação", desde que o fizessem conforme os termos da Constituição, pois que a importância e "força" dos Conselhos Gerais estaria nela assegurada e, por conseqüência, uma "maior liberdade para o Brasil". Como se vê, o deputado, como outros dos seus companheiros que apoiavam a interferência da Câmara nos projetos vindos das localidades, não colocava a questão em termos de "centralização" ou "descentralização" mas no papel do Legislativo sobre os órgãos provinciais. Novamente, votou-se o adiamento da questão.

A resolução final só seria votada no mês seguinte, quando de novo ficaria evidente a existência de divisão de opiniões entre os deputados ${ }^{117}$. Por 40 contra 32 votos, foi aprovado que não se admitiriam emendas aos projetos dos Conselhos Gerais; por 39 a 33 , passou também que haveria uma única discussão para aprovar ou reprovar os mesmos. Aprovou-se ainda que se deixaria aos senadores a decisão sobre como procederiam. Dessa forma, a decisão representava uma vitória dos poderes dos Conselhos no que tocava à ingerência do Legislativo, pois, por mais que à Assembléia ficasse assegurado o poder de vetar suas propostas, o fato de não se fazer emendas evitava a alteração de seus conteúdos. Há que se notar que os deputados pernambucanos, junto com o baiano Lino Coutinho e o paraibano Carneiro da Cunha, destacaram-se na defesa incisiva da questão, rivalizando sobretudo com Feijó e Vasconcellos, que estavam empenhados em preservar a superioridade legislativa da Câmara.

A decisão, informada pelo tom reformista presente entre os deputados, era especialmente relevante à medida que aos presidentes das Províncias não cabia nenhum poder de sanção, mesmo que temporária, sobre os projetos aprovados nos Conselhos Gerais. Um parecer emitido pela comissão encarregada do exame das propostas desses

\footnotetext{
115 Evaristo Ferreira da Veiga (1799-1837) era natural do Rio de Janeiro. Foi editor do periódico constitucional moderado A Aurora Fluminense, impresso no Rio de Janeiro entre os anos de 1827-35. Tradutor e poeta, foi deputado eleito para a Assembléia Geral durante a $2^{a}$ e a $3^{a}$ legislaturas (1830-6), em ambas por Minas Gerais.

${ }_{116}$ APB-CD (1830), t. 1, sessão de 25/junho, p.486-88.

${ }^{117}$ Idem, t.2, sessão de 10/julho, p.95.
} 
Conselhos, dado em meio ao debate sobre sua forma de discussão, demonstra como aos representantes era muito caro, nesse momento, preservar o poder dos mesmos órgãos ${ }^{118}$. Trata-se de um ofício enviado pelos conselheiros da Paraíba em que relatavam terem aprovado a suspensão da execução de algumas posturas feitas pela Câmara da Vila do Pilar em função do "gravame" que alegavam sofrer seus moradores. O Conselho, alegando não ter condições de aprovar tudo como a "lei lhe incumbe", narrava ter enviado a questão para que o presidente ordenasse à Câmara sua suspensão, ao que este se negou. Remetia então o problema para a Assembléia, pedindo sua interferência para resolução da contenda. A comissão, no entanto, declarou não haver necessidade de intervenção do presidente: o secretário do Conselho deveria comunicar sua decisão diretamente à Câmara do Pilar a qual, por sua vez, caberia obedecer. O texto do parecer, que foi aprovado sem discussão pelos deputados, argumentava que por não se tratar de matéria que demandasse "execução" da autoridade presidencial, era de atribuição "privativa" do Conselho Geral decidir o caso. Obviamente que se tratava de uma interpretação da lei imbuída do espírito que predominava na Casa, ou seja, de fortalecimento dos poderes do órgão eletivo perante a autoridade do presidente de Província.

Essa tendência de atribuição de maiores poderes às instâncias representativas seria reforçada na Câmara com a Abdicação. Não há dúvida de que após a saída de cena do Imperador inaugurou-se um momento de grande movimentação política que, com a participação de amplos setores sociais, alimentou-se da possibilidade real de uma transformação radical do regime ${ }^{119}$ (como se verá no capítulo seguinte). Para o caso dos governos das Províncias, antes de entrarem na pauta da discussão da reforma, uma outra medida de resguardo da autoridade do órgão eletivo dos Conselhos em contraposição à ação dos “delegados do Imperador” seria aprovada. Assim, vejamos.

Com a instalação da Regência, entrou em discussão na Câmara um projeto de lei que deveria marcar as atribuições do novo governo ${ }^{120}$, o qual tocou novamente na relação

\footnotetext{
${ }^{118}$ Idem, t.1, sessão de 22/junho, p.466.

119 Ilmar Rohloff de Mattos, "La experiencia del Imperio del Brasil”, Antonio Annino (et. alli), De los imperios a las naciones: Iberoamerica, Ibercaja/Obra Cultural, 1994.

${ }^{120}$ O Projeto para regulamentação da Regência foi apresentado na sessão de 09 de maio de 1831 , redigido por uma comissão formada por José da Costa Carvalho, deputado pela Bahia (posteriormente Marquês de Monte Alegre), Francisco de Paula Souza e Mello, deputado por São Paulo, e Honório Hermeto Carneiro Leão, deputado por Minas Gerais (posteriormente Marquês do Paraná). Annaes do Parlamento Brasileiro. Câmara dos Deputados. Sessão de 1831. Rio de Janeiro, Typographia do Imperial Instituto Artístico, 1878 [APB-CD
} 
entre os poderes dos presidentes e dos Conselhos Gerais de Província ${ }^{121}$. Isso se deu especialmente na discussão do artigo $6^{\circ}$., que fornecia cumulativamente à Regência e aos presidentes de Província, estes reunidos com seus conselheiros privativos, a atribuição de "aprovar e suspender interinamente as resoluções dos Conselhos", com exceção de questões que não fossem da competência dos mesmos. A proposição era uma clara tentativa da comissão que redigira o texto do projeto em criar algum mecanismo de cerceamento à ação dos mesmos Conselhos por meio da autoridade executiva provincial.

Paula Souza justificou a medida, como um de seus redatores, embora lamentasse que ela não traria grande vantagem por ser necessário “organizar de outra forma os Conselhos Gerais, dando-lhes maior número de membros, e dando aos chefes das Províncias ingerência na fatura das leis"122. A posição do deputado paulista, que no ano anterior defendera o papel fiscalizador da instituição perante as outras autoridades, agora mostrava ser igualmente imprescindível manter certa entrada do presidente nos seus negócios como forma de equilibrar todos os poderes na Província à imagem da arquitetura pensada para o governo central. Isto é, fazer que os mesmos presidentes desempenhassem um papel semelhante ao do Imperador na sanção, ainda que temporária, das leis produzidas na Assembléia.

Imediatamente outros representantes se colocaram contra a medida, sendo Antônio Rebouças o primeiro a falar. Este a desaprovou completamente por não achar justo que os "Conselhos de Presidência fossem considerados superiores aos Conselhos Gerais de Província”, e que os “delegados do poder executivo" fizessem um papel que cabia, em última instância, ao Moderador ${ }^{123}$. Antônio Ferreira França também sustentou a emenda supressiva ao ponderar não estar estabelecido em nenhuma lei qual autoridade deveria sancionar as decisões das Províncias. Por meio da defesa da reforma, o segundo afirmou ser “necessário, não só para isto como para outras coisas”, uma resolução para que a

(1831)], t.1. A lei daí originada, que marcaria as atribuições da Regência, foi sancionada por referenda ministerial em 14 de junho de 1831, e privava os Regentes das principais atribuições do Poder Moderador: o direito de dissolver a Câmara dos Deputados; o de conceder anistia em caso urgente (que ficava competindo à Assembléia com sanção da Regência); o de perdoar ministros e conselheiros de Estado; o de conceder títulos, honras, ordens militares e distinções; o de nomear conselheiros de Estado. Sobre isso ver Silvana Mota Barbosa, A shinge monárquica: o Poder Moderador e a política imperial, Campinas, Unicamp, Tese de Doutorado, 2001, pp. 172 seg.

${ }_{121}^{121}$ APB-CD (1831), t.1, sessão de 21/maio.

${ }^{122}$ Idem, p.76.

${ }^{123}$ Idem, p.73. 
Assembléia recebesse "do povo os poderes necessários para fazer na Constituição aquelas mudanças que o tempo pede que se façam"124.

Francisco de Paula Araújo e Almeida ${ }^{125}$, deputado pela Bahia, foi favorável ao artigo que fornecia à autoridade executiva provincial o direito de aprovar ou suspender as resoluções dos Conselhos Gerais com argumentos semelhantes aos de Paula Souza ${ }^{126}$. Com isso defendia que parte das funções que exercia o Imperador no governo central fosse repassada para os presidentes, como seus "delegados", dada a necessidade de se afrouxarem os "laços muito apertados" pelos quais se uniam as Províncias e a Corte ${ }^{127}$. Por maior contra-senso que sua opinião pudesse aparentar, em função da defesa do fortalecimento da autoridade executiva, e ao mesmo tempo, por uma maior autonomia provincial, o deputado respondia a Feijó, que atacara o artigo sob outro argumento: por considerá-lo um "primeiro passo para a independência das Províncias", pois permitira que elas aprovassem suas próprias leis $^{128}$. O futuro Regente então ponderou que a presente lei deveria se limitar a marcar os limites do novo governo, e não conceder atribuições aos presidentes.

Carneiro da Cunha e o Padre Alencar falaram contra o aumento do poder presidencial que viria a ocorrer caso as medidas dos Conselhos fossem a ele submetidas ${ }^{129}$. O segundo mostrou inclusive ser simpático a que se afrouxasse "certa dependência em que esta[riam] as Províncias da capital”, mas que temia propor uma reforma da Constituição no momento em que se discutia uma lei para a Regência. A questão da autonomia continuava a ser cara a Lino Coutinho, o qual não se colocou totalmente contrário à matéria desde que após a negativa da sanção por parte dos presidentes os Conselhos tivessem o direito de aprová-la interinamente, conforme funcionava com a Assembléia Geral. Continuava, assim, a defender que os Conselhos fossem dotados de poder legislativo:

“Atendam bem à posição geográfica das províncias do Brasil; é mais fácil ir da Inglaterra à Jamaica, e do Pará a Portugal, do que vir do Pará ao Rio de Janeiro; e

\footnotetext{
${ }^{124}$ Idem, p.74.

${ }^{125}$ Francisco de Paula Araújo e Almeida (1799-1844), era natural da Bahia. Era médico e bacharel em Letras. Foi deputado eleito pela sua Província natal para a Assembléia Geral na $2^{\text {a }}$ (1830-33) e na $3^{\text {a }}$ legislaturas (1834-37).

${ }^{126}$ APB-CD (1831), t.1, sessão de 21/maio, p.74.

${ }^{127}$ Idem, p. 75.

${ }^{128}$ Idem, 74.

${ }^{129}$ Idem, respectivamente pp. 76 e 78.
} 
havemos de negar a províncias tão distantes e de tão difícil comunicação o que a Inglaterra concede à Jamaica cuja navegação para a metrópole é tão fácil? Eu não sei como pode ver-se tanto ao longe, que se julgue que esta medida virá a produzir a separação das províncias; e quando assim fosse, era a constituição que tinha marcado o princípio da separação, art. 72, determinando que os conselhos gerais legislem como corpo legislativo, e estabelecendo em cada província estes corpos legislativos, embora as suas atribuições sejam limitadas" ${ }^{\prime 130}$.

Como se vê, as posições dos deputados em relação à matéria eram impossíveis de serem reduzidas a simples opiniões antagônicas. A questão que novamente articulava todos os discursos, mesmo no que parecia ser um caso banal de sanção suspensiva por parte dos presidentes e da Regência, era a da estruturação normativa dos poderes nas Províncias e, por conseqüência, seu grau de autonomia institucional em relação à Corte. Nestes termos, foi sintomático que o pernambucano Rego $\operatorname{Barros}^{131}$ declarasse que, se não passasse a matéria, faria uma emenda à Constituição para que os presidentes fossem escolhidos pela Regência a partir de uma lista tríplice elaborada pelo "povo". O assunto, que sequer estava em pauta, fazia parte das alternativas pensadas pelos deputados num ambiente em que já se enunciava a possibilidade de uma reforma da Constituição.

$\mathrm{Na} \operatorname{votação~}^{132}$, foi aprovada a supressão do artigo da Lei da Regência, o que significava o rechaço da interferência, ainda que indireta, do presidente de Província nas decisões dos Conselhos. Nesse sentido, e apesar das visíveis discordâncias existentes entre os deputados que apoiaram a supressão, era evidente a tendência, entre a maioria da Assembléia, de trabalhar para fortalecimento das ações dos Conselhos Gerais como órgãos políticos em relação à autoridade executiva provincial.

Um projeto que entrou em discussão no mês seguinte, junho de $1831^{133}$, também tocava na regulamentação das instâncias provinciais. Tratava-se da interdição aos membros

\footnotetext{
${ }^{130}$ Idem, p. 75.

${ }^{131}$ Nos Diários, o discurso é equivocadamente atribuído a "Rego Barreto", nome que não existia entre os deputados. Deduzimos que se tratava de "Rego Barros" que, por sua vez, poderiam ser dois: Sebastião ou Francisco, irmãos eleitos por Pernambuco (o segundo seria posteriormente senador do Império e condecorado com o título de Conde da Boa-Vista). Não há nenhum indício para afirmar com certeza aqui qual dos dois teria feito essa fala. Nas seguintes também atribuídas a "Rego Barros", o problema persiste.

${ }_{132}$ APB-CD (1831), t.1, sessão de 21/maio, p.78.

${ }^{133}$ Idem, sessão de 03/junho, p. 123.
} 
eleitos para comporem os Conselhos Gerais das Províncias, bem como aos vereadores das Câmaras municipais de ocuparem concomitantemente uma cadeira no Conselho do Governo, ou seja, no órgão privativo de decisão do presidente. Era comum conselheiros eleitos para ambos, inclusive com acúmulo de cargo de deputado, haja vista que em geral as duas instituições não se reuniam ao mesmo tempo. Marcar a incompatibilidade dos cargos estava, na época, na base de discussão da separação e controle dos poderes políticos em governos constitucionais; no caso do Parlamento brasileiro, tal discussão se apoiava no fato de estar previsto uma atuação administrativa à autoridade executiva do Conselho da Presidência (conforme estipulava a lei de 20 de outubro de 1823), e ao Geral da Província a proposição e deliberação dos assuntos interessantes às localidades. Como veremos, na prática, nem sempre essas funções eram tão claramente delimitadas. Num outro sentido, evitar que um mesmo conselheiro ocupasse as duas cadeiras era também uma forma de ampliar a participação dos homens da Província no âmbito decisório.

A proposta de interdição à ocupação simultânea dos cargos foi imediatamente refutada por José Bento Leite Ferreira de Mello ${ }^{134}$, deputado por Minas Gerais, que alegou tanto que não havia nas localidades pessoas "capazes" suficientes para ocuparem os cargos, como que a compatibilidade de funções se mostrava útil para o bom desempenho da administração pública. De opinião contrária, os pernambucanos Carneiro da Cunha e Rego Barros falaram em seguida, defendendo a medida. O primeiro argumentou que a permissão para se acumularem cargos era extremamente nociva, raciocinando em função da necessidade de separação de funções como forma de garantir um mútuo controle no exercício das mesmas funções. Também em sua defesa, Rego Barros saudou o fato de que o projeto poderia "preparar as Províncias para uma federação" - o que, segundo ele, viria a acontecer "mais cedo ou mais tarde" - já que permitiria a ampliação da participação da população no governo $^{135}$.

Vários outros se posicionaram a favor da matéria, mas Rebouças e Vasconcellos, representantes pela Bahia e por Minas Gerais respectivamente, foram quem mais longamente falaram contra ela. O deputado baiano considerou-a anticonstitucional,

\footnotetext{
134 José Bento Leite Ferreira de Mello (1785-1844) era natural de Campanha, Minas Gerais. Sacerdote e proprietário rural, foi membro da primeira Junta de Governo Provisório em Minas, e posteriormente também do Conselho Geral da Província. Ocupou a cadeira de deputado à Assembléia Geral nas três primeiras legislaturas (1826-34), sempre pelo seu rincão natal. Deixou a Câmara quando nomeado senador em 1834.

${ }^{135}$ APB-CD (1831), t.1, sessão de 03/junho, p.123.
} 
argumentando que embora grande parte das Constituições conhecidas, monárquicas ou republicanas, não concebesse o acúmulo de cargos públicos e eletivos, a brasileira de 1824, aceitava que empregados públicos pudessem ser eleitos senadores e deputados para não "restringir os direitos políticos"136. Da mesma forma, Vasconcellos - que já havia desempenhado a função de conselheiro em Minas Gerais -, defendeu não haver incompatibilidade no exercício de ambos os empregos, mas, ao contrário, facilidade na deliberação dos negócios públicos. No entanto, tais pronunciamentos seriam exceções, sendo, na mesma sessão, aprovada a proibição aos conselheiros acumularem os cargos ${ }^{137}$.

A vitória da medida confirmava, com a visível predominância da posição pelo fortalecimento dos Conselhos Gerais, a preocupação dos deputados não apenas com a implementação dos órgãos provinciais, mas também com uma maior abertura nos canais de participação política na Província. Do que se conclui que, desde o início da primeira legislatura (1826), trabalhou-se para dar forma administrativa à Constituição no que tocava ao arranjo político-institucional provincial, e que definir os poderes e sua forma de controle nas várias localidades significava, concomitantemente, construir o próprio papel de um centro político na nova unidade. Não era á toa que as discussões travadas em torno do tema acabassem invariavelmente esbarrando em questões como a da autonomia e a da "federação".

Ao passo que tomava forma o clamor pela reforma constitucional, o projeto de regimento para os Conselhos Gerais de Província - aprovado pelos deputados em 1830 e doravante nas mãos dos senadores -, bem como as propostas para regulamentação da autoridade dos presidentes, não voltariam mais à cena. Mesmo assim, começaria a se sedimentar o discurso que apostava na criação normativa como primeiro e decisivo passo para o funcionamento administrativo do Império, e, portanto, de sua estabilidade. Nesses fervilhantes anos legislativos, a Câmara dos Deputados reservava para si um papel fundamental na nova "nação". E, como veremos a seguir, esse se revela nas falas, ações e decisões dos seus representantes.

\footnotetext{
${ }^{136}$ Idem, p. 124. É fato que a Carta de 1824 marcava, no artigo 29, que os senadores e deputados poderiam ser nomeados para o cargo de ministro ou conselheiro de Estado, com a diferença que os senadores continuavam a ter assento no Senado, e o deputado deixaria vago seu lugar na Câmara, mas poderia ser reeleito se houvesse nova eleição.

${ }^{137}$ Foi sancionada como decreto em 12/agosto/1831, Coleção das Leis do Império do Brasil.
} 
No início do ano legislativo de 1827, o deputado mineiro José Custódio Dias propunha em plenário que os deputados dessem uma resposta mais incisiva à "Fala do Trono", tradicionalmente feita pelo Imperador quando da abertura dos trabalhos, do que aquela que uma comissão eleita propusera ${ }^{138}$. Argumentou que deveriam apontar as irregularidades que a Constituição vinha sofrendo nos últimos tempos, ao que outros propuseram que se criticasse a continuidade da guerra na Cisplatina, levada adiante pelo governo a despeito das significativas opiniões contrárias. Seus companheiros acabaram por rejeitar sua proposta, após manifestações segundo as quais seria o caso de mera formalidade, cabendo um tom "geral" e "respeitoso" em relação à "Fala" do Imperador. Nesse momento, Cunha Mattos acabaria por sintetizar uma base política das mais caras à Assembléia, ao sustentar um discurso de oposição à colocação de José Custódio Dias:

"A câmara de deputados do Brasil, Sr. presidente, há de servir de modelo às câmaras dos deputados de todas as nações constitucionais do universo [...] O sistema constitucional é o sistema da natureza, Sr. presidente, o mais é sistema fictício, é enganador, é falso. O sistema constitucional representativo há de vir a reger todo o mundo" ${ }^{, 139}$.

Falava ele em nome da "prudência, circunspecção e sabedoria" que deveria animá-los a tratar dos assuntos ali existentes. No entanto, na Casa, os princípios enunciados por Custódio Dias eram também amplamente evocados, não apenas para apoiar a defesa de posições moderadas, mas também para exigir tomadas de posições contra "injustiças" e “arbitrariedades", seja de que ordem fosse, reafirmando a supremacia do Parlamento como poder de representação nacional. Afinal, assim constava da Carta de 1824 que, em seu artigo 15, parágrafo 9, atribuía à Câmara dos Deputados a função de "velar na guarda da Constituição, e promover o bem geral da nação".

Assim, os pedidos de transparência em ações governamentais eram instrumentos freqüentemente utilizados na Câmara de acordo com as defesas encampadas pelos

${ }^{138}$ APB-CD (1827), t.1, sessão de 11/maio, p. 60. 
representantes. Mesmo recurso já estivera presente nos trabalhos da Constituinte de 1823, e agora aparecia consolidado pela Carta outorgada, que marcava ser de atribuição exclusiva dos deputados a acusação de ministros e conselheiros de Estado. No entanto, a necessidade de se demandar esclarecimento aos agentes do governo era, geralmente, ponto de tensão entre os poderes.

Já em 1826, no segundo mês de funcionamento da Casa, um parecer elaborado pela comissão de Constituição pedia ao ministro do Império que enviasse informação circunstanciada do estado geral dos negócios de sua repartição, ao que o mesmo se negou afirmando não se tratar de seu dever ${ }^{140}$. O fato gerou polêmica, pois alguns deputados argumentaram que uma prestação de contas das ações ministeriais não estava prevista constitucionalmente, ao que outros retrucaram que ela se entendia do "espírito" da Lei Fundamental. Um destes foi Bernardo Pereira de Vasconcellos, que defendeu a criação de uma lei que obrigasse todos os ministros a dar contas de seus atos a ambas as Câmaras, para tanto, evocou a condição dos como:

"guardas da constituição, podemos a todo tempo advertir o ministério de seus erros, e mesmo castigá-lo; podem porém ocorrer circunstâncias tão poderosas que seja muito arriscado ao corpo legislativo o entrar neste exame, e fazer as reformas: pode haver circunstâncias tais, que obriguem o corpo legislativo a sancionar medidas mesmo anticonstitucionais" 141 .

$\mathrm{O}$ argumento de que era a "letra da Constituição" que os deveria guiar mostrou-se convincente sendo aprovado que o ministro não seria obrigado a dar informações detalhadas de suas ações. No entanto, dois dias depois, entrou em discussão uma indicação de Vergueiro para que o mesmo ministro do Império prestasse esclarecimentos acerca de treze itens que enunciava ${ }^{142}$; depois de um adiamento, aprovou-se que uma comissão decidiria sobre quais artigos caberiam nos ditos "esclarecimentos"143.

\footnotetext{
${ }^{139}$ Idem, p. 61.

${ }^{140}$ APB-CD (1826), t.2, sessão de 12/junho, p.105.

${ }^{141}$ Idem, p. 107.

${ }^{142}$ APB-CD (1826), t.2, sessão de 14/junho, p.130.

${ }^{143}$ APB-CD (1826), t.2, sessão de 17/junho, p.187-193.
} 
Deve-se notar que, na mesma sessão, havia se iniciado a discussão de um projeto de lei sobre as responsabilidades do ministério. No mundo ocidental, essa questão ganhara uma importância fundamental no desdobrar da experiência revolucionária constitucional, em especial a partir da França, atrelada à idéia de transparência e controle político que a sociedade deveria exigir dos governos: os empregados públicos deveriam responder pelos seus atos e, desse modo, terem responsabilidade marcada sobre eles. $\mathrm{O}$ que valia, sobretudo, no tocante às atribuições dos vários níveis do Executivo. Na Constituição brasileira de 1824, essa responsabilidade estava prevista para ministros (art. 133) e conselheiros de Estado (art. 143), tendo se moldado à dinâmica administrativa em funcionamento desde os primórdios do Império. Dessa maneira, a concepção da responsabilidade funcionava como complemento ao discurso da "eficácia legislativa", pois garantiria que os agentes executores da lei poderiam ser punidos pelos seus atos no caso de abuso de autoridade.

Foi o incansável José Lino Coutinho que primeiro falou da urgência em se fazer uma lei de responsabilidade dos ministros, em maio de $1826^{144}$. A indicação ficou para segunda leitura, mas a discussão que se seguiu, sobre uma proposta do pernambucano Almeida e Albuquerque para que se sondasse os motivos da imensa mortandade entre os recrutas que vinham do Ceará para a Corte, recolocou-a imediatamente em pauta. Os pronunciamentos dos deputados foram feitos para esclarecer a quem caberia a culpa por tal mortandade. Vasconcellos a atribuiu aos ministros. Lino Coutinho considerou-a de responsabilidade das autoridades que executavam as leis, cujos limites de ação também deveriam ser marcados. Venceu uma emenda de Vergueiro para que se pedissem informações ao governo, ficando no ar a necessidade de providências no tocante às responsabilidades $^{145}$.

Dias depois, parte da comissão de leis regulamentares apresentava um projeto de lei, assinado por Vasconcellos, Vergueiro e José Ricardo da Costa Aguiar (este com restrições), sobre a responsabilidade dos empregados públicos, categoria que incluía ministros e conselheiros de Estado ${ }^{146}$. Na sessão seguinte, outros deputados da mesma comissão apresentaram um projeto divergente, esse assinado por Lino Coutinho, Almeida e

\footnotetext{
${ }^{144}$ APB-CD (1826), t.1, sessão de 11/maio, p.42.

${ }^{145}$ Idem, p.48.

${ }^{146}$ Idem, sessão de 29/maio, p.168-175.
} 
Albuquerque e novamente por Costa Aguiar, também com restrições ${ }^{147}$, que atribuía a responsabilidade apenas para ministros e secretários de Estado. Aprovada a urgência do tema, entrou em discussão qual dos dois projetos seria o mais apropriado.

O primeiro a falar foi Manoel Caetano de Almeida e Albuquerque, que assinava o segundo projeto; argumentava que a responsabilidade dos ministros e secretários era "particularíssima”, portanto caberia uma lei especial para ela ${ }^{148}$. Lino Coutinho seguiu seu colega pernambucano e, com ironia, questionou se seria "o desembargador" quem faria "tratados de paz e, declara[va] a guerra" ou os "oficiais" que entregavam "forças navais e de terra", desmembravam Províncias e davam conselhos de segurança ao Estado. Assim, deixava claro que, pela abrangência de suas decisões, os atos dos agentes diretos do Executivo seriam dotados de maior responsabilidade. Os que defendiam que todos fossem igualados à condição de empregados públicos falavam da inexistência de distinção quando se tratava de um delito contra a "nação", e desse modo acabavam por defender uma ampla institucionalização da responsabilidade em toda a administração como forma de controle. Por causa da inexistência de um consenso, pediu-se a impressão dos projetos para melhor análise dos deputados.

Dias depois, quando a questão voltou ao plenário, a longa discussão sobre a matéria atestaria a divisão de posições existentes na Casa ${ }^{149}$. Não é irrelevante notar que o ponto central que norteou a polêmica era a existência ou não de formas para se controlar, a partir da administração, a ação da imensa quantidade de funcionários espalhados pelo território do Império para o que as autoridades judiciais espalhadas pelo território se revelavam ineficazes. Vários deputados defenderam que marcar sua responsabilidade seria uma solução para o problema, e assim apoiaram o projeto que incluía todos os empregados. Para esses, era "princípio inquestionável que no sistema constitucional todos os funcionários públicos de qualquer hierarquia [fossem] responsáveis pelos abusos que cometerem no exercício de suas funções" ${ }^{\text {"150 }}$, e Vasconcellos citou exemplos de como magistrados e juízes locais acabavam por se tornar "invioláveis", dada a ausência de uma lei que pudesse marcar os limites de sua ação.

\footnotetext{
${ }^{147}$ Idem, sessão de 30/maio, p.176-179.

${ }^{148}$ Idem, p. 180.

${ }^{149}$ Idem, sessão de 16/junho, pp. 163-174.

${ }^{150}$ Idem, discurso de José Cesário de Miranda Ribeiro, deputado por Minas Gerais, depois Visconde de Uberaba.
} 
Não há dúvida que, sob a égide dos novos tempos, o controle dos abusos de autoridade era questão de primeira ordem no andamento da administração, como veremos adiante para o caso do governo das Províncias. É sintomático que a solução apresentada fosse a de criação de uma nova lei que fixasse crimes e penas, as quais poderiam ser aplicadas a partir de denúncias apresentadas a deputados e senadores, governo, presidentes de Província, ou autoridades judiciais às quais competisse o caso. Em face da ponderação de que o "mal" seria geral e que a cada dia as "prevaricações dos funcionários" aumentariam, José Custódio Dias se juntou aos que defendiam a responsabilidade de todos, mediante a constatação que:

“Todos os empregados da nação, desde o mais pequeno até o supremo, necessitam reforma: não há quem o duvide. A metade, ou duas terças partes da nação, está litigando e clamam contra os magistrados, contra seus abusos e excessos; não há quem não murmure" ${ }^{\prime 151}$.

Mediante o argumento de que para se enquadrar os abusos de autoridade existiam "muitos

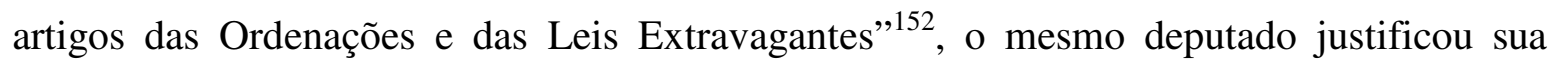
inviabilidade pelos numerosos "embaraços" que causavam essas antigas compilações.

Apesar do esforço de alguns em sensibilizarem seus companheiros acerca da necessidade de uma lei de responsabilidade para todos os empregados públicos, aprovou-se a discussão do projeto para que a mesma fosse prevista, por hora, apenas aos ministros e secretários de Estado. $\mathrm{O}$ fato de se julgar que o problema de maior urgência era o controle das altas esferas do Executivo, aliado ao discurso de que o funcionamento e controle da administração poderia ser aprimorado a partir da formação dos regimentos para os cargos, foram decisivos para a tomada da decisão. O citado projeto só seria finalmente sancionado como lei no ano seguinte ${ }^{153}$.

Ainda que não tenha se estendido a todos os empregados públicos, a lei consolidava o papel da Assembléia, entre outras instâncias, no controle da autoridade Executiva, bem

\footnotetext{
${ }^{151}$ Idem, p. 172 .

${ }^{152}$ Idem, discurso de José Bernardino Baptista Pereira, deputado pelo Espírito Santo, p. 173.

${ }^{153}$ Lei de 15 de outubro de 1827, "Da responsabilidade dos ministros e secretários de estado, e da maneira de proceder contra eles", que além de marcar os crimes também sentenciava as penas para os casos.
} 
como reiterava o argumento de serem eles, deputados, os "guardas da Constituição", os quais agiam para que a "lei fundamentada do Império não fosse infringida". Nestes termos pronunciava-se Holanda Cavalcanti de Albuquerque em 1829, quando exigia do governo imediatos esclarecimentos sobre a "suspensão das garantias constitucionais" para sua "pátria", Pernambuco, que dizia correr "perigo iminente" por causa das "irregularidades ministeriais" ${ }^{\prime 154}$. Semanas depois, chegaria a resposta do ministro da Justiça ${ }^{155}$, alegando que a enérgica medida de "suspensão de liberdades individuais" se dera em função da ação de indivíduos armados no Sítio de Afogados, que proclamaram o "sistema republicano, e a abolição da monarquia constitucional jurada e estabelecida no Império, [e] marcharam pelo interior sublevando os povos"156. Por fim, esclarecia que a suspensão acabara já em 27 de abril em função de se achar a Província com a ordem restabelecida.

Em seguida, na mesma sessão ${ }^{157}$, foi lido um ofício do ministro da Guerra ${ }^{158}$ justificando que, pelas mesmas desordens, o Imperador mandara criar uma comissão militar $^{159}$ para julgar os acusados em Pernambuco, a qual foi igualmente extinta em 27 de abril. Nesse momento, os que pediram um perfeito conhecimento das medidas tomadas não se intimidaram em atacar diretamente o ministério, sendo que os dois ministros aqui incriminados (Lúcio de Gouveia e o general Oliveira Álvares) escapariam por pouco de uma acusação formal ${ }^{160}$. Foi quando Diogo Antônio Feijó fez um discurso que se tornou célebre, defendendo tanto a responsabilidade como a acusação nos seguintes termos: "Sr. presidente, é sem dúvida este o primeiro dia constitucional que o Brasil vai presenciar. A nossa Constituição até hoje não tem sido mais que um nome vão, e Constituição sem responsabilidade é uma quimera, ou, antes, um laço que se arma ao cidadão, porque o governo faz o que quer à sombra dela, enquanto os governados se iludem com belas

\footnotetext{
${ }^{154}$ APB-CD (1829), t.1, sessão de 03/abril, p.8.

${ }^{155}$ Então Lucio Soares Teixeira de Gouveia, o qual já havia sido por deputado na Assembléia Constituinte de 1823 por Minas Gerais, e também eleito para assumir o mesmo cargo em 1826.

${ }^{156}$ APB-CD (1829), t.2, sessão de 06/maio, pp. 17-8.

157 Idem, p.20.

${ }^{158}$ Marechal Joaquim de Oliveira Álvares.

${ }^{159}$ Vale notar que a instituição de comissões militares como forma de julgar os acusados de envolvimento em desordens e motins era vista, em tempos constitucionais, com maus olhos, como uma forma antiga e "absolutista" de se proceder judicialmente, já que não previa os direitos "inalienáveis" previstos aos indivíduos nos regimes modernos.

${ }^{160}$ A acusação dos ministros foi votada no mês de julho, e não foi avante na Câmara por uma diferença de 39 a 32 votos; apud Pedro Calmon, História do Brasil, Rio de Janeiro, José Olympio, 1959, v.5, p. 1571-72, que cita o número de votos a partir dos Anais da Câmara de 1829, v. IV, p. 124.
} 
palavras e promessas"161. Como esse, houve outros tantos casos de pedidos de esclarecimento ao governo, como de acusações ou tentativas de acusações aos agentes responsáveis do Executivo, a depender também das tensões políticas existentes na Corte.

Se os deputados tomavam para si a legitimidade de "guardar a Constituição" - que no caso brasileiro fora desde o início pensada como uma atribuição do Legislativo muito mais do que do Judiciário - era também necessário e "legítimo" agir em nome da "nação", como unidade existente para além das particularidades. Essa busca por tal legitimidade seria alçada ao primeiro plano quando, com a Abdicação e início da Regência, o Parlamento atribuiria a si mesmo um papel central na direção dos desígnios da mesma "nação". No espaço da Assembléia, a permanente tensão entre os que falavam em nome de suas "Províncias" e os que enfatizavam que seus interesses deveriam estar acima delas, foi, sem dúvida, um fator a mais de dificuldade que os deputados tiveram que remover.

Foi assim que o ambiente político decorrente do problema da construção nacional tanto informou como impôs especiais dificuldades à criação de medidas e reformas durante o Primeiro Reinado. Essas seriam, por sua vez, responsáveis pela materialidade de um novo Estado, ao passo que confirmavam o espaço legislativo como seu criador e "árbitro". Como se viu, a institucionalização do governo das Províncias fazia parte desse programa, inserida num amplo espectro de reformas que cabe agora, ainda que rapidamente, mapear.

\section{2. Um panorama das "reformas liberais"}

A busca pela eficácia na administração do Império, assim como a incorporação dos recônditos mais longínquos do território à esfera da legalidade, deram forma a uma série de medidas votadas e aprovadas nas duas primeiras legislaturas (a primeira de 1826 a 1829, e a segunda de 1830 a 1833). Entre elas, destacamos aqui duas leis que contribuíram significativamente para a implementação de um novo arranjo entre os poderes nos âmbitos local e nacional: a da criação dos cargos de juizes de paz, de $1827^{162}$, confirmada pelo Código do Processo em 1832; e a de reorganização das Câmaras municipais, de 1828. No mesmo sentido, a nova organização da Fazenda nas Províncias que também contribuiu ao discurso de racionalização e institucionalização das relações entre o "todo" e as "partes".

${ }^{161}$ APB-CD [1829], t.4, sessão de 16/julho, p.124. 
Quanto aos juízes de paz, eles foram claramente concebidos, assim como o sistema de jurados, como uma tentativa de efetivar o poder de ação judiciária por meio do reforço da descentralização do sistema, por meio de eleição de representantes locais. Segundo Thomas Flory, o juiz de paz era uma espécie de magistrado sem formação, eleito para exercer as funções judiciais na paróquia, o qual mantinha independência em relação ao governo central e recebia autoridade para decidir sobre alguns casos civis ${ }^{163}$. Após sua implementação, esses juízes teriam seus poderes aumentados no início da Regência pelo Código Processual, que ampliou sua jurisdição penal e de vigilância, além de instituir definitivamente o sistema de jurados. Este, como um órgão eletivo popular ${ }^{164}$, também significou uma tentativa de relativização do poder dos magistrados formais e, junto aos juízes de paz, teria um papel importante na participação da sociedade civil na estrutura da justiça. Na prática, o funcionamento de ambos geraria tensões as mais diversas, mas, posteriormente, com o Regresso começariam a perder força ${ }^{165}$.

Vale notar que, quando de sua concepção, tanto os juízes de paz como os jurados estavam vinculados ao debate em torno das Constituições modernas, no que tocava à garantia de direitos dos indivíduos por meio do acesso às formas de justiça. Dessa maneira, a Carta brasileira de 1824 deixara previsto, no artigo 162, que haveria juízes de paz, eleitos da mesma forma que os vereadores, bem como um sistema de jurados ${ }^{166}$. Foi assim que em

${ }^{162}$ Lei de 15 de outubro de 1827, ver Coleção de Leis do Império do Brasil.

${ }^{163}$ El juez de paz y el jurado en el Brasil imperial. Control social y estabilidad política del nuevo Estado, México, Fundo de Cultura Economica, 1986. Dessa maneira, a sua criação teria sido uma junção entre o princípio de representação popular aplicado à judicatura e os ideais de autonomia defendidos pelos liberais no momento. Instituído antes da aprovação formal dos primeiros Códigos, ele poderia ser visto como um ataque frontal à elite judicial, pois seus elegíveis não necessitavam ter formação acadêmica, bastando ser eleitores de segundo grau (o que excluía apenas os menores de 25 anos, e os que ganhavam menos de 200 mil réis por ano).

${ }^{164}$ Para ser jurado valiam os mesmos critérios que para juiz de paz, ou seja, ser eleitor segundo grau: maior de 25 anos e com renda superior a 200 mil réis.

${ }^{165}$ Devido as características dos cargos dos juizes de paz e dos jurados, Thomas Flory, op.cit., considera que eles criaram uma contradição insolúvel para os liberais: na prática, sua grande independência local teria debilitado os agentes potencialmente valiosos do Estado ao dividir com eles seus poderes tradicionais e seu prestígio, como no caso dos magistrados e juizes de fora. Na sua ótica, essa tendência - que chama de "descentralizadora" - desdobrou-se em outras esferas e acabou por enfraquecer o poder central, resultando na mobilização dos setores conservadores no momento conhecido como do "Regresso". A síntese de Flory é que os liberais, por meio da ênfase excessiva que teriam dado a instituições como essa, enquanto suporte dos poderes locais, não teriam sido capazes de assegurar a ordem interna que, só a partir da década de 40 , se concretizaria no Brasil. Deve-se notar que apesar do trabalho de Flory oferecer pesquisa preciosa sobre o tema, tal interpretação induz a uma compreensão da instituição como um empecilho para a formação do Estado, o que não parece razoável.

${ }^{166}$ Na Assembléia Constituinte e Legislativa de 1823 houve tempo para discussão do artigo que tratava do tema, e muitos dos deputados se posicionaram a seu favor. Em geral, enfatizavam que esse sistema garantiria 
1827, conforme vimos acima, quando teve início a discussão sobre a administração do Império a partir de dois projetos que, desde o ano anterior, estavam transitando no âmbito da Assembléia - o de Diogo Antônio Feijó para "administração e economia das Províncias" ${ }^{\prime 167}$, e o de Nicolau Vergueiro sobre os municípios ${ }^{168}$ - os deputados decidiram privilegiar as Câmaras e os juízes de paz, por considerarem que estavam sem normalização $^{169}$. Em seguida, votaram que o capítulo sobre os juízes de paz fosse o primeiro a entrar em discussão - tinha-se notícia que os senadores concebiam um projeto sobre os municípios - para a qual se escolheu o texto de Vergueiro (coube a Feijó fazer as emendas que achasse necessárias).

Logo no primeiro artigo - que concebia um juiz de paz para cada distrito ou bairro designado pela Câmara - a polêmica que se instaurou dizia respeito ao papel dos poderes municipais ${ }^{170}$. A divisão de opiniões foi acirrada entre os deputados que apoiavam que as Câmaras pudessem estabelecer os critérios para marcação dos juízes, e os que defendiam a formação de uma medida geral que não passasse pela sua ingerência. Estes, que atacavam a medida, saíram na frente com o discurso de Diogo Feijó para que não se deixasse a decisão para as Câmaras por não saber "o que elas poderão fazer" "171. José Clemente Pereira seria mais incisivo, ao demonstrar a dificuldade de uma ação unificada imperial se a matéria fosse decidida nos municípios:

aos "cidadãos seus direitos", além da necessidade de controle das arbitrariedades cometidas pelos magistrados formais. Os seus opositores argumentavam que o jurado só poderia funcionar depois da aprovação de códigos que regulassem as leis civis e criminais; Diário da Assembléia Geral Constituinte e Legislativa do Império do Brasil 1823, v. 3, sessão de 22/outubro. A justificativa para que ele fosse criado após a aprovação dos Códigos criminais e do processo, pode ser pensada a partir das reflexões de Bartolomé Clavero, Happy Constitution. Cultura y lengua constitucionales, Madri, Trotta, 1997. Para este, enquanto na Inglaterra o sistema de jurado era parte fundamental do regime do Parlamento, tendo como função primordial a defesa dos direitos da Commom Law, e nos Estados Unidos era um dos pilares da Constituição como garantia de liberdade individual, na França ele ocupou um distinto lugar no nascente sistema constitucional. Ali, como a justiça passou a ser entendida como uma "criação legislativa", uma justiça institucionalizada que se reduzia em função da lei, o sistema de jurado seria um cargo circunscrito, um aplicador da legislação que pretendia preservar seu papel histórico na defesa dos direitos individuais. Assim, fazia sentido os deputados brasileiros argumentarem que o Código Criminal seria imprescindível para o funcionamento do sistema, já que no Brasil seguiu-se, sobretudo, o modelo francês.

${ }_{167}$ APB-CD (1826), t.1, sessão de 11/julho, pp. 127-131.

${ }^{168}$ Idem, t.4, sessão de 30/agosto, pp. 312-7.

${ }^{169}$ APB-CD (1827), t.1, sessão de 17/maio, p. 117-8.

${ }^{170}$ Idem, sessão de 18/maio, p. 128.

${ }^{171}$ Idem, p.129. 
"E não convém que deixemos essa divisão ao arbítrio discricionário das Câmaras, sem ser acompanhada de bases, que regule este arbítrio; senão resultarão grandes abusos, por falta de inteligência; e decididamente uma notável falta de unidade no estabelecimento das divisões dos distritos, porque câmaras haverá que dêem um juiz de paz a cada freguesia, outras mais, e outras menos"172.

Pereira defendeu uma divisão bem "ordenada e distribuída" em função da quantidade de paroquianos das freguesias, frisando ser "indispensável às circunstâncias do Brasil que o número deles se multiplique" para trazer as "vantagens" que dizia estar "intimamente convencido" existirem em relação a esse sistema de juízes.

O que estava na base de ambas as falas era a crítica à autonomia das Câmaras para decidirem os critérios de divisão dos juízes de paz nas localidades. Outros deputados chegaram a argumentar que os municípios eram "compostos de homens poucos instruídos, e por isso pouco próprios para entrarem no verdadeiro espírito, que os deve dirigir quando marcarem os distritos" ${ }^{\prime 13}$. O sentido de minimização dos poderes das Câmaras era tão difundido na Assembléia que José Ricardo da Costa Aguiar chegou a propor que os juízes de paz fossem escolhidos pelos Conselhos Gerais de Província, que por seu turno deveriam ser compostos "de pessoas mais esclarecidas, com os precisos conhecimentos locais da província" ${ }^{\prime 174}$. O fato de os Conselhos ainda não estarem em funcionamento inviabilizou sua proposta.

Os que apoiaram o artigo, favoráveis a ação das Câmaras na matéria, falaram em nome do conhecimento das circunstâncias particulares que teriam os vereadores, os quais mesmo sem "saber ler, nem escrever, hão de ter o senso comum necessário para o que se pretende""175, sendo as Câmaras "os corpos, que melhor conhecimento te[riam] do território" 176 . Vasconcellos defendeu a matéria pelo fato do estabelecimento das mesmas Câmaras "de acordo com a Constituição" estar prestes a ocorrer, o que iria reformular seus poderes e aumentar sua autoridade ${ }^{177}$. Apesar da votação apertada, essa posição que

\footnotetext{
${ }^{172}$ Idem.

${ }^{173}$ Idem, discurso de José Bernardino Baptista Pereira, deputado pelo Espírito Santo, p.130.

${ }^{174}$ Idem, sessão de 19 de maio, p.134.

${ }^{175}$ Idem, discurso de Manoel Caetano de Almeida e Albuquerque, p. 137.

${ }^{176}$ Idem, p. 134.

${ }^{177}$ Idem, p.136.
} 
deixava aos municípios o arbítrio para marcar os juízes foi vitoriosa num primeiro momento.

Num segundo, essa medida seria alterada, ficando definido que haveria em cada distrito (conforme designado por uma comissão) um juiz. Novamente seria reformulada pelos senadores nas suas emendas ao projeto, que propuseram existir um juiz em cada freguesia (ou capelas curadas), confirmando a não intervenção das Câmaras na sua designação, mas diminuindo seu número em relação ao que aprovaram os deputados (visto os distritos serem em maior número do que as freguesias) ${ }^{178}$. Os deputados então sentiramse forçados a aprovar a emenda, sob a argumentação de que ficaria a "perder de vista" uma reunião entre ambas as Casas para se chegar a uma solução, e que a aprovação da lei naquele momento, era, dos males, o menor.

Essa foi a única alteração de fundo que fizeram os senadores ao Projeto aprovado na Câmara. Note-se que o outro ponto de discussão da matéria, que tratava das atribuições dos juízes de paz, foi a ampla gama de funções que lhe conceberam os deputados. Originalmente, o texto de Vergueiro previa que os juízes pudessem conciliar e julgar pequenas contendas, prevenir e indagar a existência de delitos, aplicar punições correcionais, prender os criminosos, dando parte de suas ações às autoridades competentes ${ }^{179}$. Desde o início, houve debate entre aqueles favoráveis a reduzi-los a meros agentes de conciliação entre as partes, sem autoridade para julgar nenhuma contenda, e outros que defendiam que, sem maiores atribuições, a instituição não seria proveitosa para sanar a quase inexistência de "justiça" que imperava no Brasil ${ }^{180}$.

Na segunda discussão do projeto acrescentaram-se algumas atribuições ao mesmo cargo: o poder de usar força armada em caso de desordem, de fazer corpo de delito, de impor penas à violação das posturas policiais das Câmaras, de vigiar a conservação das matas e florestas, entre outras menores ${ }^{181}$. O seu direito de julgar ficou circunscrito a "pequenas demandas" que não ultrapassassem determinado valor, e caía por terra sua ação correcional. Ficava decidido que para ser juiz de paz valiam as mesmas atribuições que

\footnotetext{
178 Idem, t.4, sessão 28/agosto, p. 256-9. O deputado paraibano Augusto Xavier de Carvalho chegou a argumentar que havia Províncias onde as freguesias "dista[va]m uma das outras 30 ou 40 léguas" e que possuírem apenas um único juiz seria completamente inviável.

${ }_{179}$ APB-CD (1826), t.4, sessão de 30/agosto, pp. 314.

${ }^{180}$ A discussão sobre esse item encontra-se nas sessões dos dias 19 e 21 de maio, e 28 e 30 de junho de 1827.

${ }^{181}$ APB-CD (1827), t.3, 09/julho
} 
para ser eleitor - que pela Constituição, no artigo 94, significava ter renda anual acima de duzentos mil réis, com exceção dos libertos -, sendo aprovado também o recebimento de um ordenado e tornar um escrivão disponível para cada juiz. O amplo espectro de sua atuação, em detrimento dos antigos cargos de juízes municipais ${ }^{182}$, confirmava uma tentativa de diminuição do poder judiciário que tradicionalmente detinham as Câmaras nas várias localidades do país, além de apostar na autonomia dos agentes como forma possível de fortalecimento da ação do Estado.

No entanto, era intenso o fluxo com que chegavam à Câmara dos Deputados requerimentos que pediam a aprovação de regulamentos mais específicos para ação e controle das mesmas autoridades. Era assim que em 1829, o Conselho Geral da Província de Minas Gerais afirmava ser de "absoluta necessidade" que se marcasse a "responsabilidade dos juízes de paz", bem como os "meios de punição" e "garantias" para que os mesmos não ficassem sujeitos a "acusações judiciais temerárias"183. Desta forma, apresentava uma proposta para que as Câmaras municipais tivessem uma maior ingerência na "observância" e execução da lei por parte dos indivíduos que ocupassem tal cargo. Não obstante, no mesmo ano, também adentrara à Casa legislativa um requerimento do Conselho Geral do Rio Grande de São Pedro em que se propunha que os juízes de paz desempenhassem algumas das atribuições dos juízes criminais como, por exemplo, inquirir testemunhas ${ }^{184}$. O que mostra que a necessidade de uma maior regulamentação para o cargo estava intrinsecamente articulada à defesa de uma agilização nas medidas judiciais.

Nesse sentido, a aprovação da lei de criação dos juízes de paz esteve inserida num ambiente legislativo onde existia um sentimento comum em relação à necessidade de reordenamento da estrutura judicial do nascente Império. Não à toa, tão logo nas primeiras sessões de 1826, José Antônio da Silva Maia fez uma indicação para que se convidasse a comissão de Legislação a tomar as medidas necessárias, concomitantemente, para a organização de códigos civis e criminais (já marcada pela Carta de 1824 no artigo 179,

\footnotetext{
${ }^{182}$ A criação dos cargos de juizes de paz foi negativa para os conselhos municipais, pois os deixou sem poderes judiciais e dependentes de pequenas multas impostas pelos mesmos juizes; ver Thomas Flory, op.cit.

${ }^{183}$ CEDI-CD, ano/localização: 1829, PDID 87 N. No mesmo ano, o Conselho do Governo de Minas Gerais deferia várias representações acerca de problemas na observância da lei de 15/outubro/1827, e também dos conflitos de jurisdição entre os juizes de paz e outras autoridades na Província. Ver: Actas das sessões do Conselho do Governo da Província de Minas Gerais de 1829 [ACG-MG (1828)], Ouro Preto, Typographia do Silva, 1829, p.78.

${ }^{184}$ APB-CD (1827), t. 3, sessão de 02/junho, p. 39 s.
} 
parágrafo XVIII), e observar se a Constituição estava sendo cumprida ${ }^{185}$. Também não foi à toa que o primeiro projeto codificador que apareceu na Casa fosse para marcar os princípios de um Código Penal, do deputado José Clemente Pereira ${ }^{186}$, então vislumbrado como prioridade em razão da falta de parâmetros constitucionais para julgamento do andamento e julgamento dos processos. Meses depois, Bernardo Pereira de Vasconcellos assinava um outro Projeto para o estabelecimento de um Supremo Tribunal de Justiça ${ }^{187}$. A lei que regulamentou a criação deste último foi aprovada dois anos depois, em 1828, subsidiando a criação do Código Penal, em 1830, e do Código do Processo Criminal ${ }^{188}$, em 1832.

Conforme já vimos anteriormente, o fato de se ter privilegiado a codificação judicial correspondia à preocupação central dos primeiros legisladores brasileiros com a administração da vida pública. Se isso significou, no caso dos juízes de paz, o reforço de uma autoridade eletiva local, o esvaziamento jurídico dos antigos corpos camarários reforçou, em contrapartida, a esfera da Província como locus de poder.

Uma das maiores inovações institucionais que veio na esteira do movimento revolucionário português e se confirmou nas bases do Império do Brasil foi o estabelecimento da Província como uma unidade política-administrativa ${ }^{189}$. Nesse sentido, o esvaziamento do poder político das Câmaras através de sua dependência à autoridade provincial surgia como uma necessidade quando se iniciaram os trabalhos legislativos de 1826. Mesmo que pautado pela Carta de 1824 (capítulo V), a implementação de tal arranjo de poderes ainda sofria com a falta de uma legislação específica ${ }^{190}$.

Era assim que logo após a instalação da Câmara dos Deputados, para ela foram encaminhados requerimentos como o do Conselho de Governo de Minas Gerais, que

\footnotetext{
${ }^{185}$ APB-CD (1826), t. 1, sessão de 12/maio, p.59.

${ }^{186}$ Idem, t. 2, sessão de 03/junho, pp.16-8.

${ }^{187}$ Idem, t.4, sessão de 07/agosto, pp. 57-8.

${ }^{188}$ O Código Processual de 1832 sofreria uma reforma em 1841 em que o aumento dos poderes dados aos juizes de paz, bem como sua perspectiva "descentralizadora" do processo judicial, seria revisto.

${ }^{189}$ Sobre isso ver o trabalho de Maria de Fátima Gouvêa, op.cit.; Miriam Dolnikhoff, op.cit.; Márcio Eurélio R. de Carvalho, Afirmação de uma esfera pública de poder em Minas Gerais (1821-1851), Belo Horizonte, UFMG, 2003.

190 Márcio Eurélio R. de Carvalho, op.cit., trata da dificuldade de implementação da esfera provincial para Minas Gerais.
} 
criticava o uso que os oficiais faziam das rendas municipais e pedia providências ${ }^{191}$. Relatavam os conselheiros que haviam feito o exame das "contas de receita, e despesa das Câmaras desta Imperial Cidade, da de Mariana, das Vilas de São João, de São José, do Príncipe, e Minas Novas", pois haviam sido estas as únicas a enviarem seus relatórios. Criticavam o "abuso com que os oficiais das ditas Câmaras/ exceto as da Vila do Príncipe/ continuam a deduzir e receber propinas anuais, e a prestar-se a vários dispêndios em festividades", pois a arrecadação jamais chegava para as despesas ordinárias. Solicitavam também a verificação de um plano anexo para criação de rendas para os municípios, já que a lei de 20 de outubro de 1823 (que criara os ditos Conselhos de Governo) não era explícita sobre como deveriam proceder.

Da mesma Província, escreveu a Câmara de Ouro Preto, em 9 de julho de 1828, um ofício aos "Senhores Representantes da Nação Brasileira" em que "respeitosamente de novo implora[va]" que estes se dignassem a ultimar as "sábias leis já projetadas, e outras urgentes de que o Brasil, e em particular, a rica e vasta Província Mineira tanto carec[ia]"192. De todas as leis que reivindicavam conclusão, as primeiras eram as que diziam respeito ao exercício dos Conselhos Gerais de Províncias e à criação das "Câmaras Constitucionais". Apesar da cordialidade do requerimento, o tom geral era de cobrança, com clara associação entre a existência de uma base legal constitucional e a "felicidade dos seus industriosos e fiéis Habitantes".

Se para a Província havia uma lei, ainda que provisória, com seus parâmetros gerais, para as Câmaras inexistia qualquer legislação nova. Foi assim que quando da discussão sobre a administração das Províncias em 1827 - a partir do já citado Projeto de Diogo Antônio Feijó do ano anterior - preferiu-se tratar de medidas que reformulassem a esfera municipal; e, apenas pelo fato de os senadores terem tomado a dianteira na proposição de um projeto para o tema, que a questão dos juízes de paz veio antes a plenário. O tal projeto da segunda Casa sobre os municípios chegou ao plenário em junho de 1828, já aprovado por uma comissão interna dos deputados ${ }^{193}$. Não houve debate na discussão de grande parte

${ }^{191}$ Centro de Documentação e Informação, Câmara dos Deputado, Brasília (CEDI-CD), ano/localização: 1826, lata 22, maço 19 , pasta 1.

${ }_{192}$ CEDI-CD, ano/localização: 1828, Lata 1, PD/3, doc. 2.

${ }^{193}$ APB-CD (1828), t.2, sessão de 18/junho, p.146. 
dos seus artigos, predominando certo consenso, sobretudo, no que tocava às "funções municipais".

Dessa forma, quando foi lido o artigo que afirmava serem as Câmaras "corporações meramente administrativas" sem "jurisdição alguma contenciosa", a matéria foi rapidamente aprovada. Praticamente só houve discussão no que tocava ao direito que elas teriam ou não de impor taxas. Neste momento, o argumento de Augusto Xavier de Carvalho, deputado pela Paraíba do Norte, foi decisivo para negação de tal direito:

“a Câmara hoje não é senão administrativa, nenhuma autoridade tem judiciária ou executiva: ela deve dar providências no caso de consternação geral; mas nunca pôr taxas" 194 .

Além disso, a obrigação de os vereadores enviarem informações e solicitações às autoridades da Província foi confirmada em vários artigos. Seu resultado está no texto da lei de $1^{\circ}$. de outubro de 1828, que estabeleceu que as Câmaras deveriam encaminhar aos Conselhos Gerais, para serem aprovados, os provimentos e posturas que convinham aos interesses do município (art. 39); igualmente deveriam fazê-lo para execução de obras de grande porte (art. 47), e para autorização de venda, aforamento ou troca de bens imóveis que só poderiam ocorrer por decisão do "presidente de Província em Conselho, enquanto não se instalarem os Conselhos Gerais" e, na Corte por ordem do ministro do Império" (art. 42). Ficava também estabelecido que as Câmaras forneceriam anualmente o balanço de sua receita financeira aos Conselhos Gerais, tornando-a pública pela imprensa (onde ela existisse; art. 46); do mesmo modo, ficavam obrigadas a dar parte das infrações da Constituição, das negligências de todos os empregados, e dos maus tratamentos e atos de crueldade que se fizeram com os escravos (artigos 58-9). Quanto à questão crucial das rendas, ficava estabelecido que as Câmaras teriam de propor aos Conselhos de Províncias os meios de aumentá-las desde que explicitada sua necessidade, bem como no caso de despesas extraordinárias.

Num ponto a proposta vinda do Senado suscitou posicionamentos claramente antagônicos: o dos critérios para os elegíveis à função de vereador. O projeto afirmava, no

\footnotetext{
${ }^{194}$ Idem, sessão de 21/junho, p. 169.
} 
seu artigo $4^{\circ}$., que poderiam exercer tal função todos os que tivessem votos nas Assembléias Paróquias - o que significa dizer, pelo artigo 92 da Constituição, os maiores de 25 anos com renda anual acima de cem mil réis, com exceção dos "criados de servir" desde que com dois anos de permanência no respectivo termo. Logo de início ${ }^{195}$, o mineiro Silva Maia foi contrário à medida, argumentando que os vereadores não deveriam "ter menos consideração para serem escolhidos do que os juízes de paz”, para cuja eleição somente era exigida uma renda mínima de duzentos mil réis; o argumento era que os critérios para a ocupação do cargo fossem mais restritivos, atribuindo-se-lhe um caráter de distinção.

Dois posicionamentos em defesa à fala de Silva Maia trataram da importância de se acentuar as restrições econômicas nos critérios de escolha dos vereadores. O cearense Manoel do Nascimento Castro e Silva argumentou que não se poderia confiar o cargo "a quaisquer, só porque tem cem mil réis"196; José da Cruz Ferreira ${ }^{197}$, eleito pelo Rio de Janeiro, associou a riqueza à qualidade da representação e defendeu os chamados "homens bons":

\begin{abstract}
"As nossas leis antigas eram mui sábias neste ponto, mandava-se escolher sempre os melhores homens, os mais abastados. [...] as Câmaras eram compostas de homens os mais ricos, os melhores que lá havia; é preciso que se saiba que estes homens pela maior parte têm tido boa educação" 198 .
\end{abstract}

Augusto Xavier de Carvalho de pronto contestou o argumento, e falou em nome de uma maior abertura política aos elegíveis ao cargo:

"Eu não faço consentir a representação na riqueza dos homens, eu vejo muitos com grandes riquezas que não prestam para nada; porventura os que podem votar nas assembléias paroquiais, só por não ter uma renda determinada não podem formar parte de uma boa representação nacional? Eu creio que sim; aquele que tiver mais

\footnotetext{
${ }^{195}$ Idem, p. 146.

${ }^{196}$ Idem , p. 147.

197 José da Cruz Ferreira era natural do Rio de Janeiro e magistrado. Foi eleito deputado por sua Província natal para a $1^{\text {a }}$ legislatura (1826-9) da Assembléia Geral.

198 APB-CD (1828), t.2, sessão de 18/junho, p.147.
} 
votos é que há de fazer melhor a administração do seu município do que aquele que tem rendas, ele está muito unido com o seu município" ${ }^{199}$.

Diogo Antônio Feijó, que também apoiou a abertura do critério, foi inclusive de opinião favorável a que os libertos pudessem ser eleitos vereadores, pois que, sendo "capazes para entrar em todos os empregos civis e militares", assim se poderia "remediar uma espécie de injustiça que há para com eles" ${ }^{200}$. Seu colega paulista, José Ricardo da Costa Aguiar, reiterou a idéia contra o que poderia ser chamado de uma "nova espécie de aristocracia de classes", em defesa do "merecimento" como critério que deveria imperar.

$\mathrm{Na}$ votação final, foi aprovado o artigo tal qual concebido pela comissão, e assim permaneceu na lei de outubro de 1828. Vencia uma maior abertura dos limites de participação da população nas Câmaras sob a égide da mais liberal das concepções, que exaltava as "virtudes pessoais" como qualidade fundamental para participação política. Embora significativo, esse discurso não se constituía em incomum novidade ${ }^{201}$; o que de fato representava uma mudança residia na alteração do critério de eleição para os municípios concomitante à perda de autonomia política que os mesmos sofriam do ponto de vista de sua normalização. A medida ia contra a tradicional distinção dos "homens bons" que nas Câmaras, entendidas como "corporações", encontraram espaço de ascensão política durante praticamente todo o período colonial $^{202}$. A maioria desses legisladores mostrava então não ter dúvida que a nova esfera de poder deveria ser a Província.

$*$

As primeiras legislaturas brasileiras também tiveram diante de si um outro desafio: a questão financeira e a sustentação do novo Império. Sabe-se que as difíceis condições econômicas pós-Independência agravaram-se significativamente no início do ano de 1829, quando um grande déficit nas contas públicas anunciou o deplorável estado das finanças na

\footnotetext{
${ }^{199}$ Idem.

${ }^{200}$ Idem, p. 148.

${ }^{201}$ Sobre o cruzamento entre discurso liberal e critérios de participação política, ver Andréa Slemian, "Seriam todos cidadãos?: os impasses na construção da cidadania nos primórdios do constitucionalismo no Brasil (1823-1824)", István Jancsó (org.), op. cit., pp. 829-847.

202 Maria Fernanda Bicalho, "As câmaras ultramarinas e o governo do Império", O Antigo Regime nos trópicos: a dinâmica imperial portuguesa (séculos XVI-XVIII), Rio de Janeiro, Civilização Brasileira, 2001.
} 
Corte $^{203}$. No começo de abril, o Imperador convocou extraordinariamente o Parlamento para iniciar seus trabalhos desse ano um mês antes do previsto, sob a justificativa do "desastroso futuro" que aguardava a "nação" se os "negócios da Fazenda" continuassem sem "medidas eficazes e salutares"204.

No ano seguinte, 1830, novamente foi convocada uma sessão extraordinária, a partir de setembro, tendo como um de seus intuitos a votação de um orçamento geral para o Império, tentativa que malograra ao final dos quatro anos da primeira legislatura ${ }^{205}$. A sua realização, de fundamental importância no ideário da racionalização e estabilidade segundo a receita dos novos Estados liberais, estava prevista na Constituição (artigos 171 e 172), que firmou o princípio de prestação de contas pelo ministro da Fazenda e o da físcalização orçamentária pelo Legislativo $^{206}$. O fato era que, para além da dívida pública e passiva que arrochava a situação financeira desde finais da década de 1820, a Corte nem recebia recursos e nem dispunha de mecanismos eficazes para exercer um monitoramento sobre as contas das Províncias. O orçamento era um dos instrumentos pensados para reverter esse quadro, o que contribuiria para formação de um centro efetivo do ponto de vista administrativo moderno.

Nas próprias Províncias, era comum os presidentes reclamarem do funcionamento das Juntas de Fazenda, sobre as quais não recaía nenhuma forma de controle para além da sua autoridade executiva. Em 1828, chegava à Câmara um ofício do presidente da Bahia, datado do ano anterior, pedindo ao ministro providências para que a Junta remetesse as "sobras" que cabiam para ao Conselho do Governo segundo a lei de 20 de outubro de 1823 (que no seu artigo 25 marcava que os mesmos Conselhos teriam direito à oitava parte das respectivas sobras das Províncias) ${ }^{207}$. Alegava que tanto para o ano de 1824 como para o de 1825, a Junta justificara não existirem sobras, graças aos gastos com tropas armadas para a região, mas que agora o balanço das contas de 1826 desmentia essa afirmação. Por isso, o

\footnotetext{
${ }^{203}$ Liberato de Castro Carreira, História financeira e orçamentária do Império do Brasil (1889), Brasília/Rio de Janeiro, Senado Federal/Fundação Casa Rui Barbosa, 1980, t.1, p. 175 seg..

${ }^{204}$ APB-CD (1829), t.1, sessão de 02/abril (abertura), "Fala do Trono".

${ }^{205}$ De 1826 a 1829 só tinham sido aprovados orçamentos parciais e, na prorrogação de 1830, aprovou-se o Orçamento geral do Império, sancionado na forma de lei em 15 dezembro do mesmo ano. Esta lei estabelecia que a proposta de Orçamento para o exercício do ano seguinte fosse sempre apresentada à Câmara dos Deputados até maio.

${ }^{206}$ Sobre a questão orçamentária nos primeiros anos do Império ver o trabalho de Adalton Francioso Diniz, Centralização política e apropriação de riqueza: análise das finanças do Império brasileiro (1821-1889), São Paulo, Universidade de São Paulo, Tese de Doutoramento, 2002.
} 
Conselho do Governo deliberou a requisição da quantia que lhe cabia das "sobras", o que não foi obedecido pela Junta sob a alegação de que o montante que restava não chegava sequer para pagar as dívidas ativas e passivas, persistindo um déficit. Presidente e conselheiros não se conformavam com essa resolução, contra-argumentando que por "sobras" se deveria entender a "diferença da receita à despesa" sem contar as dívidas.

No ano anterior, 1827, já havia dado entrada na Casa dos Deputados algumas cópias das atas do mesmo Conselho de Governo da Bahia, encaminhadas pelo seu vice-presidente, uma das quais tratava da "inutilidade" de se dispor da citada lei, que punha "à disposição do Conselho a oitava parte das sobras das rendas públicas da Província”, por ser dependente do arbítrio da Junta Administrativa da Fazenda"208. O que estava em discussão era um plano para iluminação da cidade de Salvador, mas chegava-se no mesmo problema do descontrole que o governo da Província teria em relação às "sobras" que lhe caberiam.

Caso semelhante de falta de entendimento entre as duas ocorreu na reunião do Conselho de Governo de Pernambuco em 1830, quando um dos conselheiros observou que até então não se havia cumprido o artigo da citada lei de 20 de outubro de 1823, referente às "sobras" para as despesas ordinárias do governo provincial ${ }^{209}$. Requereu que se exigisse da Junta da Fazenda um balanço do último ano para que se tomasse conhecimento do montante que caberia ao Conselho, o que foi prontamente aprovado. Em Minas Gerais, idêntica reivindicação era feita pelo também Conselho de Governo em 1828, quando se pedia a declaração anual da arrecadação dos impostos para efetivação das ditas "sobras",210. O que significava dizer que não era comum o recebimento, por parte dos governos provinciais, de informações sobre as contas públicas prestadas pelas mesmas Juntas.

\footnotetext{
${ }^{207}$ CEDI-CD, ano/localização: 1828, PDID 461.

${ }^{208}$ Idem, ano/localização: 1827, PDID 766.

209 Atas do Conselho do Governo de Pernambuco (1821-1834), Recife, Assembléia Legislativa de Pernambuco/Arquivo Público Estadual, 1997, v.1, p. 87.

${ }^{210}$ Actas das sessões do Conselho do Governo da Província de Minas Gerais de 1828 (ACG-MG 1828), Ouro Preto, Typographia do Silva, 1828, sessão de 17/janeiro, p. 11-2. Na sessão do ano seguinte, em 14 de março de 1829, o Conselho de Governo de Minas Gerais aprovou um requerimento para o Rio de Janeiro, no qual acusava a Junta da Fazenda de fazer despesas extraordinárias na Província a despeito de suas ordens contrárias. Cobrava, portanto, a obediência da Junta ao mesmo Conselho e presidente. Também se tem notícias de reclamação das "sobras" no Rio Grande de São Pedro, quando em 1831, o Conselho Geral de Província escrevia sobre a necessidade dessas para a execução de obras públicas (CEDI-CD, ano/localização: 1832, maço 42, pasta 16).
} 
Uma lei para resolução desse problema foi aprovada em outubro de 1831, organizando o Tesouro Público Nacional e as Tesourarias nas Províncias ${ }^{211}$. Tal lei, prevista na Carta de 1824 (art. 170), extinguiu o antigo Erário Régio, o Conselho de Fazenda e as Juntas provinciais, sendo medida fundamental para implementação de um sistema de controle financeiro que se pretendia eficaz. Para isso criava um Tribunal do Tesouro no Rio de Janeiro, responsável tanto pela direção e fiscalização da receita e despesa nacional, quanto pela distribuição e contabilidade de todas as rendas públicas. Ao mesmo Tribunal caberia propor as condições dos empréstimos, examinar o estado da legislação sobre a Fazenda, e um "instituir rigoroso exame do estado da atual arrecadação", podendo inclusive demitir ou aposentar todos seus funcionários. Seu presidente seria o ministro da Fazenda, e várias novas seções dariam conta de sua implementação.

A lei de 4 de outubro criava também (título $3^{\circ}$ ), uma Tesouraria para cada uma das Províncias, as quais estariam todas subordinadas ao Tribunal do Tesouro. Nelas, a autoridade principal era delegada a um Inspetor, a quem competia a fiscalização de todas as rendas provinciais para além da execução das deliberações emanadas da instância central. No entanto, toda a correspondência entre ambos os órgãos seria feita pelo presidente da Província (art. 85), o qual receberia dos mesmos Inspetores o balanço anual da Receita e Despesa para enviar ao Tribunal depois de emitir seu parecer, dado juntamente com os conselheiros. Ao presidente caberia também - sempre em Conselho - a aprovação das arrematações dos contratos (art. 56), das despesas extraordinárias (art. 48), e o conhecimento das arbitrariedades praticadas por qualquer um de seus empregados. Mantinha-se, assim, a centralidade do "delegado do Imperador" como dono da última palavra na administração da Fazenda na Província, função que já desempenhara em relação às antigas Juntas. Uma novidade era que aos Conselhos Gerais de Província, da mesma forma que à Câmara dos Deputados, era dado o direito de anualmente convocar uma comissão encarregada de avaliar a legalidade do desempenho dos órgãos da Fazenda, numa clara tentativa de atribuir a este órgão um controle sobre a ação executiva.

Nos seus 118 artigos, a lei indicava minuciosamente o número de empregados e seus vencimentos, a organização e a regulamentação do Tesouro, tanto na Corte como nas Províncias. A circunscrição da esfera de poder de cada uma das autoridades fazia parte da

\footnotetext{
${ }^{211}$ Lei de 04 de outubro de 1831, Coleção de Leis do Império do Brasil.
} 
lógica de racionalização administrativa exatamente de acordo com a tendência, existente nos trabalhos dos deputados, de implementação de um arranjo que amalgamasse, por meio de instituições de tipo constitucionais, a unidade do Império. Em 1832, já se achavam em exercício para controle da Fazenda Pública - que valia "chamar-se, com razão, a mola Real de todos os Governos",212 - as Tesourarias de São Paulo, Minas Gerais, Rio Grande do Sul, Santa Catarina, Bahia, Pernambuco, Alagoas e Rio Grande do Norte (em grande parte das outras, já estavam em fase de organização) ${ }^{213}$.

Nesse sentido, a lei do orçamento votada no ano de $1832^{214}$ instituiu o princípio legal que dividia a receita e a despesa pública em "geral" e "provincial", o que significava dizer que as rendas de cada qual, tanto as já existentes como as que pudessem vir a ser criadas, deveriam, a partir de então, respeitar sua circunscrição. A definição dos limites que deveriam nortear essa separação seria um dos pontos permanentes de tensão entre as Províncias e a Corte, e se desdobraria das formas as mais variadas e violentas no alvorecer do Império. A consolidação da medida, inclusive no que dizia aos conflitos, viria com o Ato Adicional de 1834, que circunscreveria às Assembléias provinciais a competência de legislação sobre a fixação de despesas internas (incluindo aqueles no plano do município).

Do que se conclui que, no que tocava à administração das finanças, a criação do Tribunal do Tesouro e a aprovação da lei de Orçamento dotaram o Império do Brasil das bases normativas de uma estrutura típica de Estados modernos ${ }^{215}$. Por mais que estejamos tratando de um momento evidentemente tenso e instável como foi o início da Regência, o funcionamento dessa estrutura logo pode ser sentido na Corte. Em 1833, o relatório do ministro da Fazenda ${ }^{216}$, o ex-deputado Cândido José de Araújo Vianna, informava já existir no Rio de Janeiro uma melhor fiscalização das rendas públicas, o que coincidia com uma

\footnotetext{
${ }^{212}$ ANRJ, Negócios de Províncias, I JJ ${ }^{9}$ 439, fala do presidente na abertura dos trabalhos do Conselho Geral da Província (Santa Catarina), 1 \% dezembro/1830.

${ }^{213}$ Liberato de Castro Carreira, op.cit., p. 221-2.

${ }^{214}$ Sancionada em 24 de outubro de 1832.

${ }^{215}$ Ver o impacto da lei da Fazenda Pública e dos Orçamentos nas Províncias em sessão de 27 de fevereiro de 1833 do Conselho de Governo de São Paulo, quando um parecer apontava os vários inconvenientes vividos pela localidade em relação aos déficits geral. ACP-SP, v.16, pp. 135.

${ }^{216}$ Apud Liberato de Castro Carreira, op.cit., p. 226-7.
} 
maior participação das "sobras" das Províncias na renda nacional, conforme comprova a análise dos balanços das receitas feitos a partir de $1830^{217}$.

Na ação legislativa, ficava patente a criação de novos instrumentos de extração de recursos $^{218}$, numa clara tentativa de extinção, por parte do Rio de Janeiro, da antiga autonomia econômica das Províncias quanto à arrecadação e distribuição das suas rendas $^{219}$. Ou seja, a idéia que movia esses homens era a de criação de um arranjo institucional no qual a Corte desempenharia papel central na garantia da existência financeira de todo o Império, a despeito das disputas e distúrbios regionais. O fato de essa estrutura ter efetivamente entrado em funcionamento não asseguraria uma perene centralização por parte da mesma Corte, mas sim a possibilidade de que a sempre tensa relação entre o "centro" e suas "partes" fosse institucionalizada também sob um campo essencialmente conflitivo ${ }^{220}$.

\subsection{A prática legislativa e a execução das leis na esfera da administração}

Em 1827, a secretaria dos deputados acusava o recebimento de uma Memória, datada de 12 de junho, em que seu autor, José Maria Cambraia, afirmava ter "ânimo a levar à presença desta Augusta Câmara" no sentido de apontar "os males que ameaça[va]m o

\footnotetext{
${ }^{217}$ Dados sistematizados por Adalton Francioso Diniz, op.cit.. O autor mostra que a partir da década de 1830, as Províncias com maior participação no envio das "sobras" para a Corte são Bahia e Pernambuco, seguidas do Maranhão e do Rio Grande do Sul.

${ }^{218}$ Márcia Eckert Miranda, "Fronteira, guerra e tributos: o Rio de Grande de São Pedro do Sul (1750-1836)", (impresso), texto apresentado no Seminário Internacional Brasil: de um Império a outro, realizado no Departamento de História/USP, São Paulo, em setembro/2005. A autora analisa como, para o Rio Grande do Sul, as transformações institucionais colocadas em prática desde fins do Primeiro Reinado, especialmente no que tocava à criação de um novo sistema fiscal, geraram agudas tensões entre a elite provincial e a Corte, pela paulatina abolição dos contratos régios. Mostra como a concessão desses contratos, em especial o do couro e do municio das tropas, foi a base de uma ação cooperativa entre setores regionais e a Corte durante anos, o que garantia uma certa estabilidade nessa região fronteiriça fortemente militarizada. Dessa forma, afirma que a tentativa de construção de um novo aparato administrativo moderno para o Estado gerou violentas resistências contra o projeto que tentara instituir o Rio de Janeiro como centro.

${ }^{219}$ Adalton Francioso Diniz, op.cit., defende que o processo de consolidação da unidade nacional no Brasil foi sinônimo da construção de uma estrutura de apropriação de riqueza que, produzida nas Províncias, era em grande parte escoada para e usufruída pela Corte no Rio de Janeiro. Assim, para o autor, constituiu-se um sistema de centralização tanto financeira como política, à medida que o centro absorvia e redistribuía os recursos tendo em vista seus interesses. Para uma posição diametralmente oposta, ver Miriam Dolnikhoff, op.cit..

${ }^{220}$ Veja-se como o Visconde do Uruguai, anos depois, no segundo tomo do seu Ensaio sobre o direito administrativo, Rio de Janeiro, Typographia Nacional, 1862, relata uma série de casos de tensão entre as Assembléias Legislativas provinciais e a Corte devido à interpretação sobre qual era a jurisdição de cada uma no tocante às finanças locais, especialmente no caso de criação de novos impostos.
} 
Império" pela "relaxação" que via no "respeito a Deus e a lei"221. Entre várias medidas que pedia fossem urgentemente tomadas - sobretudo no que dizia respeito ao âmbito de ação da justiça, com a revogação ou criação de novas leis - apontava que se devia cuidar sobretudo da "observância" das leis; o que, "junto com o respeito à Religião" e o "castigo aos maus", declarava serem as "colunas que sustentam os reinos e impérios" e sem as quais se viveria uma "anarquia, de que se seguem imensas desgraças" 222 . Em seguida, passava a narrar uma série de arbitrariedades cometidas nos mais variados níveis da vida pública, deixando explícito que o respeito à "lei" deveria ser, sobretudo, controlado na esfera da administração. Isso significava dizer que o governo deveria ter um papel fundamental no controle da eficácia reguladora da sociedade, idéia igualmente cara aos primeiros legisladores no Brasil que, conforme vimos, concebiam uma ênfase ao papel do Estado na construção da ordem interna.

Nesse sentido, a Câmara dos Deputados tinha uma importância tanto na feitura das leis como de "guardiã" contra as injustiças que pudessem ser praticadas, e os atritos causados por sua ação ficavam relegados ao seu limite de interferência perante a esfera de atuação do governo. Logo no ano de sua instalação, em 1826, era recorrente aparecerem em plenário pedidos para que fosse efetivada a "observância das leis", como os requerimentos que, por mais de uma vez, tratavam do caso dos recrutamentos. Em maio, Cunha Mattos oferecia uma indicação para que se exigisse do ministério uma rigorosa aplicação da legislação no que dizia respeito a eles, por causa de uma série de arbitrariedades que estariam sendo cometidas ${ }^{223}$. Imediatamente, alguns de seus companheiros argumentaram que à Assembléia não caberia "recomendar" nem "exigir" nada do governo, ao que Manoel José de Souza França complementou que, se o fizessem, estariam se "metendo" com o que não lhes "competia". A proposta foi negada.

Dias depois, o mesmo deputado voltou com quase idêntica indicação: que se notificasse o governo a exigir o cumprimento das leis para o recrutamento, enquanto não se organizasse nova regulamentação ${ }^{224}$. Culpava, sobretudo, os capitães de ordenança e os

\footnotetext{
${ }^{221}$ CEDI-CD, ano/localização: 1827, PDID 888Z.

${ }^{222}$ Idem, fl. 11v.-12v.

${ }^{223}$ APB-CD (1826), t.1, sessão de 12/maio, p. 53.

${ }^{224}$ Idem, sessão de 26/maio, p.138.
} 
comandantes de distrito pelos abusos que se sabiam cometidos. Marcos Antônio Bricio ${ }^{225}$, deputado pelo Ceará, defendeu estar fora da alçada da Câmara "tomar conhecimento do procedimento desarrazoado das autoridades que não executa[va]m as instruções e as ordens do governo" 226 . Tal opinião foi predominante, sendo aprovada não a exigência, mas a pergunta ao governo se as mesmas leis estavam sendo cumpridas; diferença significativa de postura dos deputados no tocante a sua esfera de ação.

Mesmo assim, tanto aqueles que defenderam uma postura mais incisiva da Câmara em relação às exigências que se deveria fazer ao Executivo, como seus opositores, falaram em nome da necessidade da "execução das leis" como única fonte segura da "felicidade dos povos", conforme argumentou o citado Souza França, autor da proposta aprovada. José Custódio Dias também foi taxativo, ao observar que seriam os "governos que faz[ia]m a boa, ou má ventura das nações", pois que as leis seriam como "teias de aranha, que apanham moscas, e deixam passar aves grandes de rapina, quando não [fossem] escrupulosamente observadas",227. O saldo da votação era que a "observância" proposta à Assembléia não deveria ser confundida com pressão ostensiva sobre o ministério, mas ficar circunscrita à vigilância sobre suas ações (como já se apontou, cabia aos deputados a acusação de ministros e conselheiros). Reiterava-se que era ao governo que cabia assegurar, cotidianamente, a "boa administração das leis".

Pela mesma época, o mineiro Silva Maia propôs que fossem pedidos ao Executivo esclarecimentos sobre o cumprimento das leis relativas aos Governos Provisórios ${ }^{228}$. Especificamente o que estava em jogo eram os problemas causados pelos conflitos entre autoridades civis e os "governadores de armas", além do funcionamento das comissões militares para alguns casos. Questões pungentes, e a indicação foi aprovada sob a justificativa de se tratarem de esclarecimentos, e de a Câmara ser "a sentinela e guarda das garantias individuais". Dias depois, a Casa recebia um ofício do ministro José Feliciano Fernandes Pinheiro reconhecendo a existência de acúmulos de cargos civis e militares nas

\footnotetext{
${ }^{225}$ Marcos Antônio Bricio (1800-1871), era natural do Maranhão. Oficial do Exército, chegou ao posto de tenente-coronel. Ocupou, por duas vezes, a cadeira de deputado na Assembléia Geral: na 1' legislatura (182629) pelo Ceará, e na $6^{a}$ (1845-47) pelo Pará. Foi condecorado com o título de Barão de Jaguarari.

${ }^{226}$ APB-CD (1826), t.1, sessão de 26/maio, p.138.

${ }^{227}$ Idem.

${ }^{228}$ Idem, sessão de 22/maio, p.116-9.
} 
Províncias, em desrespeito, portanto, à lei de 20 de outubro de $1823^{229}$. Após breve discussão, decidiu-se encaminhar a matéria à comissão de leis regulamentares para que solucionasse o problema.

Portanto, se a tarefa da Câmara de controlar as arbitrariedades que pudessem ser cometidas na prática da legislação tinha limites de intervenção que esbarravam na ação do governo, a ela caberia indubitavelmente a palavra final sobre a normalização da ordem política pois que, como já vimos, a concepção era de que a lei criaria o direito, e não o contrário. Nesse sentido, era comum o encaminhamento de requerimentos que pediam à Câmara esclarecimentos sobre a forma de interpretar as leis, e mesmo solicitações para aprovação ou revogação de medidas. No conjunto, tais requerimentos apontavam problemas na administração pública, mas reiteravam a importância do Parlamento como agente de sua resolução por meio da legislação. Vejamos o caso de um ofício enviado aos deputados pela Câmara de Salvador, datado de agosto de 1829, em que os vereadores pediam esclarecimentos sobre a lei de $1^{\text {o. }}$ de outubro de 1828 que estabelecia a nova forma de organização dos municípios ${ }^{230}$. Entre outras, as dúvidas versavam sobre a compatibilidade entre o cargo de vereador e outros, o destino dos antigos cargos existentes nas Câmaras, a gratificação do Procurador, e sobre como proceder para obrigar os vereadores a comparecerem às sessões. Apesar da data, o ofício só foi para comissão no ano de 1833, e não se tem notícia de seu encaminhamento posterior.

Também era praxe o envio, para conhecimento dos deputados, de decisões tomadas pelo governo ou órgãos administrativos e em princípio não previstas na lei. Era assim que a secretaria de estado dos Negócios da Guerra remetia à Assembléia em 1828 uma consulta do Conselho Supremo Militar, no Rio de Janeiro, sobre representação da Junta de Justiça da Bahia $^{231}$. Esta última encaminhara dúvidas ao órgão supremo sobre a lei que a mandara $\operatorname{criar}^{232}$, para as quais pedia a aprovação de soluções, de caráter provisório, feitas por seus membros no ano anterior. O Conselho Militar assim o fez e mandou notificar os deputados.

Os pedidos aos deputados de intervenção contra injustiças eram muitos, mas sua ação revelava-se quase sempre muito cautelosa. Para o ano de 1826, dois casos

\footnotetext{
${ }^{229}$ Idem, sessão de 31/maio, p. 194-5.

${ }^{230}$ CEDI-CD, ano/localização: 1833 , maço 14 , pasta 1 , fl.2.

${ }^{231}$ CEDI-CD, ano/localização: 1828, PDID 439.

${ }^{232}$ Lei de 13 de outubro de 1827.
} 
exemplificam essa postura. Um foi o requerimento de uma tal Candida Joaquina de Jesus que, sendo condenada ao degredo, afirmava que não lhe haviam sido concedido os dez dias marcados por lei para a colocação de embargos à pena ${ }^{233}$. Em face do fato de a requerente afirmar que deveria partir no dia seguinte, um imediato parecer da comissão de justiça e legislação apontou que a queixa não tinha fundamento; após discussão, assim foi aprovado. No entanto, dois dias depois, novo parecer sobre o caso vinha à tona sob a alegação da existência de uma certidão que dava à condenada direito ao pedido ${ }^{234}$. Então o caso voltou à discussão.

Os deputados contrários ao pedido argumentaram que a lei para o caso já teria sido cumprida, não havendo nada mais a considerar. Os que propugnavam um efetivo papel da Câmara na defesa dos "interesses da sociedade", sustentaram que eles teriam poder para passar por cima das normas existentes, se assim lhes parecesse. Assim falou Lino Coutinho, sublinhando que "encolhia os ombros" para as leis existentes quando o que estava em jogo era a "liberdade de um cidadão". Semelhante posição seria a de Custódio José Dias ${ }^{235}$ :

"Eu estou persuadido que as leis foram feitas para os homens e não os homens para as leis. Esta câmara tem o direito de ouvir os desgraçados. Todos os presos têm direito de clamar contra um abuso tão antigo, e que nós devemos destruir para o bem público, pois essa lei é muito bárbara. [...] Eu sou procurador de todos os infelizes e para isso é que vim aqui. Risquemos esta lei antiga, esta lei bárbara"236.

Mesmo assim tal posição foi derrotada, vencendo uma proposta mais "moderada" para que se pedissem informações ao governo por meio do envio de um requerimento ao ministério. Desfecho semelhante teria, dias depois, um outro caso de prisão em que os envolvidos alegavam estar sem culpa formada ${ }^{237}$; a despeito da enfática defesa da Casa como "sustentáculo das garantias" do cidadão, novamente feita por Lino Coutinho, o parecer aprovado ordenava que tudo fosse também remetido ao Executivo.

\footnotetext{
${ }^{233}$ APB-CD (1826), t.1, sessão de 20/maio, p.111.

${ }^{234}$ Idem, sessão de 24/maio, p. 129.

235 Não confundir com José Custódio Dias. Custódio José Dias era capitão-mor, eleito representante por Minas Gerais para as $1^{a}$ e $2^{a}$ legislaturas da Assembléia Geral, cargo que ocupou de 1826 a 1832.

${ }^{236}$ APB-CD (1826), t.1, sessão de 24/maio, p. 129.

${ }^{237}$ APB-CD (1826), t.2, sessão de 06/junho, p. 50.
} 
Seria a mesma cautela que predominaria no plenário quando, em junho de 1831, houve a discussão de um ofício da Câmara da Vila do Brejo da Areia, na Paraíba do Norte, no qual seus vereadores pediam aos "representantes da nação" a demissão do presidente da Província. Alegavam que este, “combinando-se com algumas pessoas más”, teria promovido uma "sedição" além de ser "motor de tantos outros atentados cometidos" contrários à "lei, e que revoltam a corporações verdadeiramente constitucionais". Argumentaram também que, em vez de lançar mãos de medidas criminosas, preferiram entregar sua "representação concebida em ignorantes e mal traçados rabiscos à consideração da Augustíssima Assembléia, onde existe a fonte dos remédios para os males da pátria" ${ }^{238}$. O que mostra o apelo à esfera do legislativo como forma de preservar o direito de representação contra as arbitrariedades era recorrente, independentemente do encaminhamento que os deputados dessem.

No entanto, se não temos notícias sobre a ação dos deputados no caso da denúncia da Vila do Brejo da Areia, são conhecidos dois pareceres discordantes emitidos por uma comissão, dois anos depois, que ilustram bem as tensões internas que costumavam predominar na Assembléia diante de conflitos de legitimidade como esse. Em representação de 13 de abril de 1833, os vereadores da Câmara de Belém do Pará faziam uma ampla exposição dos motivos que tiveram para "desobedecer ao governo do Império" não dando posse ao presidente nomeado para aquela Província, José Mariani, conservando no cargo o atual, Joaquim Machado de Oliveira. A representação vinha assinada com "3\% dos nomes dos Cidadãos de todas as classes", além de documentada com vários papéis que atestariam que a chegada do novo presidente fizera pôr em movimento aqueles do "partido restaurador" 239 .

Um primeiro parecer acerca da matéria condenava diretamente a ação dos paraenses, recordando vários casos de insubordinação que já teriam ocorrido na mesma Província, e afirmando que somente da "observância das leis lhes poderia resultar a paz, a tranqüilidade e a felicidade" 240 . Argumentavam os deputados que haviam elaborado o texto que o "pretexto da salvação pública" não poderia servir para acobertar tais atos, e que não se deveria "salvar um povo calcando aos pés a Constituição, as leis, e a justiça, habituando

\footnotetext{
${ }^{238}$ CEDI-CD, ano/localização: 1833, maço 31, parta 4, fl.15v.-20v.

${ }^{239}$ CEDI-CD, ano/localização: 1833, maço 20, pasta 4.

${ }^{240}$ Ambos pareceres foram lidos na sessão de 17 de julho de 1833.
} 
os homens ao desprezo de tudo". Assim, desaprovava semelhante procedimento, mandando remeter tudo ao governo, a quem "compet[ia] fazer executar as leis" e as "medidas de justiça". Só que houve um outro parecer, escrito como voto separado de dois membros da comissão $^{241}$, que pedia um "maduro exame" da situação para que a "Justiça de mãos dadas com a prudência" olhasse para a "melancólica crise em que se acha[va] a Província do Pará". Lembrava que os "ânimos dos paraenses" já estariam irritados pelo "choque de partido" e "criminoso abandono" daquela "desgraçada" localidade desde a "horrorosa catástrofe do Palhaço" 242 . Com essa consideração também defendia que fosse a matéria encaminhada ao governo, mas desde que houvesse uma decisão mais ostensiva tomada pela Casa. Assim, o espectro de ação que ia desde uma defesa incondicional da "lei" até um afrouxamento da mesma em função de uma situação peculiar - no caso, de ser sabido que o Pará estava submerso em conflito internos - era a marca permanente do embate que se travava no Legislativo quando o ponto em questão dizia respeito a possíveis injustiças.

Essa questão desdobrava-se nos discursos de combate às arbitrariedades por meio da tensão entre duas formas de solução para os problemas: ou pela via da legislação ou pela efetivação de sua prática. Nestes termos, em 1827 tomou corpo em plenário a discussão de um parecer da comissão de Constituição que tratava de uma queixa dirigida ao Conselho de Presidência de Goiás, por um de seus membros, contra o vice-presidente ${ }^{243}$. A justificativa era que o acusado teria "excedido os limites da ordem" pelas "injúrias" com que atacara o conselheiro. Imediatamente os deputados Souza França e Holanda Cavalcanti de Albuquerque argumentaram que se tratava de matéria do governo, que teria "a seu alcance [os] meios para fazer os presidentes das Províncias e seus Conselhos cumprirem com suas obrigações e manterem a ordem em suas conferências" 244 .

Em sentido contrário, Cunha Mattos foi um dos que, junto com Lucio Soares Teixeira de Gouveia, defendeu a criação de um regimento para funcionamento dos Conselhos de Governo (para além daquele que estava sendo discutido para os Conselhos

\footnotetext{
${ }^{241}$ O primeiro, assinado por Manoel Alves Branco e Honorato José de Barros Paim, deputados pela Bahia, e por Francisco de Souza Paraíso, deputado pela Paraíba do Norte; e o segundo por Antônio Pedro da Costa Ferreira, deputado pelo Maranhão e Francisco de Paula Almeida Albuquerque, deputado por Pernambuco.

${ }^{242}$ Verdadeiro massacre ocorrido na cidade de Belém, em outubro de 1823, quando morreram mais de 250 homens que estavam detidos no brigue chamado "Palhaço". Ver Domingos Antônio Raiol, pp. 45-52. Uma análise da questão está em André Machado, A quebra da mola real das sociedades. A crise política do Antigo Regime português na Província do Grão-Pará (1821-25), São Paulo, Tese de Doutorado, FFLCH-USP, 2006. ${ }^{243}$ APB-CD (1827), t.2, sessão de 18/junho, p. 90-2.
} 
Gerais, e que ainda não havia sido aprovado). Justificava que assim se poderia coibir comportamentos inadequados, pois que a lei de 20 de outubro de 1823 seria "manca" nesse quesito. A discussão subseqüente não chegou a nenhum consenso: não foi aprovada a criação de um regimento, tampouco que se remetesse tudo ao governo (conforme emenda proposta por Francisco de Paula Cavalcanti de Albuquerque). Ficou decidido que a votação não estava concluída e, embora ela tenha ficado para a ordem do dia, não voltaria mais ao plenário.

Não obstante a falta de resolução do caso, ele expressava uma dualidade de posições que, em meio ao processo de separação entre as esferas do Legislativo e do Executivo, seria fartamente manipulada pelos deputados na busca de resoluções para conflitos de várias ordens. Desta forma, por mais que à Câmara dos Deputados não coubesse um papel de intervenção direta na ação do governo - em se tratando de um regime constitucional moderado como o que se instituía no Brasil - a esfera da administração não podia mais ser pensada sem o aval daqueles encarregados de falarem "em nome da nação". Mesmo sendo o governo entendido como peça fundamental para execução e controle direito da observância das leis, ele tinha que necessariamente agir no espaço agora pretendido como de "legalidade". Foi assim que, normalização e administração passariam muito rapidamente a serem entendidas, no Brasil, no âmbito do Legislativo, como dois pilares fundamentais e indissociáveis na ênfase que caberia ao poder público na organização do corpo social.

\section{3.1. A administração política das Províncias}

Conforme vimos anteriormente, logo que foi instaurada a Assembléia Constituinte de 1823, uma de suas principais tarefas recaía na instauração de um governo constitucional para as Províncias. Nas discussões então travadas, à função almejada de que esses governos servissem de "canais de representação dos povos" articulava-se à necessidade de delimitação de suas atribuições no âmbito administrativo. Nestes termos, é que foi aprovada a lei de 20 de outubro de 1823. No ano seguinte, a Carta Constitucional criaria - ao menos no papel - um órgão concebido como responsável pela expressão direta dos "interesses das Províncias", que eram os Conselhos Gerais das Províncias; isso significava a concepção de

\footnotetext{
${ }^{244}$ Idem, p.90.
} 
um espaço político com especial papel propositivo perante a autoridade do presidente e de seu Conselho. Como também vimos, os embates pelo equacionamento dos poderes de cada qual durante o Primeiro Reinado foram sintomáticos do quão importante se tornava zelar pela sua implementação.

Em princípio, o presidente de Província e seu Conselho privativo (também chamado “do Governo" ou "Administrativo") seriam entendidos como responsáveis pela execução das leis e administração da vida local; o que não impedia que entre as atribuições do primeiro estivesse a proposição de medidas para melhoramento público. Afinal, o representante do Executivo na Província era entendido como pivô central do governo, ou seja, o "privativo protetor dos Povos, e, mormente contra os abusos e vexames das autoridades", conforme palavras registradas em ata do Conselho de São Paulo em $1825^{245}$. Por sua vez, a ação dos Conselhos Gerais de Província, existentes apenas depois de 1829, estaria centrada na formação de propostas e projetos a partir das necessidades da população, bem como no controle das Câmaras municipais. Na prática, essa delimitação criaria, de fato, uma separação no funcionamento de ambos os órgãos, mas, sobretudo pelo fato do Conselho de Presidência ser entendido numa concepção de administração que delegava aos protagonistas do Executivo um grande poder de ação ${ }^{246}$, não era incomum que suas jurisdições se misturassem.

Quanto aos Conselhos de Presidência, os próprios coevos demonstravam dúvidas acerca da continuidade de sua existência, já que a lei que os instituíra era provisória e o texto da Constituição não os citava para o governo das Províncias. Um ofício do presidente de Pernambuco, José Carlos Mayrink Ferrão, datado de 4 de fevereiro de 1826, demonstra claramente essa incerteza. Depois de noticiar a instalação de tal Conselho na cidade do Recife em janeiro, dava conta do "embaraço" que o mesmo se encontrava no exercício de suas funções, pois as despesas necessárias não teriam como ser supridas pelo "estado atual dos cofres da Província" e pelo desconhecimento das "sobras" das rendas. Ferrão dizia acreditar que quando "reunida a Assembléia" (marcada para iniciar seus trabalhos em

\footnotetext{
${ }^{245}$ Atas do Conselho da Presidência da Província de São Paulo (anos de 1824-1829) (ACP-SP). Documentos Interessantes. São Paulo, Arquivo do Estado de São Paulo/Secretaria de Educação, 1961, vol.86, sessão de 10/novembro/1825, p.90.

${ }^{246}$ Esse foi um ponto de grande debate na Assembléia Constituinte de 1823 quando muitos deputados se opuseram à extinção das Juntas de Governo e à instituição de um presidente escolhido pelo Imperador. No
} 
maio), tal embaraço seria dissolvido, "entrando em exercício o Conselho Geral da Província". Mesmo frisando que, de sua parte, "lhe dava toda a importância", afirmava que o Conselho de Presidência não trazia "grandes vantagens" para a administração pública, mesmo com os "bons desejos dos Membros que o compõe". Ao final, pedia esclarecimentos de como deveria contar seus dias úteis, já que os conselheiros faltavam em dias sucessivos ${ }^{247}$.

A despeito da posição pessoal de Mayrink Ferrão, é notável como, pela análise das sessões do Conselho de Recife registradas em suas Atas, o volume de trabalho e de suas sessões tiveram um aumento significativo, sobretudo a partir dos anos de 1831 e $1832^{248}$. Caso semelhante observa-se para o Conselho de Presidência de Minas Gerais que, em 1831, aprovou a necessidade de se criar uma outra secretaria para auxiliar o presidente por causa da "extensão e variedade de incumbências administrativas que [se] tem acrescido à presidência, e seu Conselho com o progresso da legislação"249. Dessa forma, é certo que a instalação do seu congênere Geral da Província não extinguiu, sequer inibiu o funcionamento do órgão privativo do presidente. Além disso, era prática comum os conselheiros do Governo decidirem pelo encaminhamento de matérias ao novo órgão, como se vê numa exemplar atitude dos próprios pernambucanos que, em sessão de 1833, junto com o presidente respondiam à Câmara de Serinháem que as posturas desta deveriam ser encaminhadas ao Conselho Geral da Província ${ }^{250}$.

Como órgãos auxiliares da atividade dos presidentes, era natural que as tensões vividas em cada uma das Províncias, nesse momento de profunda instabilidade política que foi o do Primeiro Reinado, estivessem presentes no funcionamento cotidiano dos Conselhos de Governo. Até porque o amplo espectro de sua atuação, previsto pela lei de 20 de outubro de 1823, e dado o precedente de que os mesmos presidentes poderiam convocá-los quando assim julgassem conveniente, faria que, cada vez mais, sua implementação fosse vista como fundamental para efetivação do controle e observância das leis, princípios tão caros àqueles que forjavam a unidade do novo Império. No tocante à estrutura dos Conselhos, é

entanto, também as antigas Juntas, mesmo que provisórias, tinham sido concebidas com um amplo leque de ação administrativa, com a diferença que seus membros eram eleitos localmente.

${ }^{247}$ ANRJ, Negócios de Províncias, IJJ 247.

${ }^{248}$ Atas do Conselho do Governo de Pernambuco (1821-1834) (ACG-PE), v.2.

249 Actas das sessões do Conselho Geral da Província de Minas Gerais de 1831 [ACGP-MG (1831)], sessão de 01/dezembro, p.12. 
significativo que um outro presidente de província de Pernambuco, posterior a Mayrink Ferrão, também fizesse críticas incisivas. Tratava-se de Manoel Zeferino dos Santos que afirmava, em agosto de 1833, estar o mesmo Conselho sem se reunir há mais de um mês devido ao não comparecimento de seus membros; entre as razões para o descaso dos conselheiros, dizia acreditar estarem baixas as gratificações. Alegava que a situação causava "grande retardação na execução dos negócios públicos" pois imensa era a "generalidade" de matérias que deveriam ser deliberadas pelo presidente em Conselho (art. 24), o que transformava o "governo das Províncias numa verdadeira oligarquia" que impedia a "pronta solução" para negócios urgentes ${ }^{251}$.

Poder-se-ia argumentar que Zeferino dos Santos repugnasse a instituição do Conselho de Governo por impedi-lo de tomar decisões a seu bel-prazer; mas não se deve supor que seus conselheiros privativos fossem, realmente, "freios" à ação presidencial. Não era à toa que os deputados que, desde 1826, apoiaram a formação de um poder local que rivalizasse com os dos presidentes, apostassem não no fortalecimento dos Conselhos de Presidência, mas nos Gerais de Província. O próprio João Carlos Mayrink Ferrão quando, de posse da função Executiva central em Pernambuco, confessara que abrira mão de convocar seu Conselho privativo quando a mesma Província vivia um clima tenso devido a boatos de insurreição nos idos de $1827^{252}$. No ofício endereçado ao Rio de Janeiro, alegara que naquelas "circunstâncias bast[ou] chamar para junto de si o vice-presidente", de quem dizia "ter muito boa opinião", sendo que ele continuava a ajudá-lo no expediente sem mesmo a presença dos conselheiros. $\mathrm{O}$ que equivale dizer que se os mesmos conselheiros podiam colocar inconvenientes à ação presidencial, os presidentes também tinham formas de evitá-lo.

Na sua prática cotidiana, também o Conselho de Presidência se permitia contestar ordens que viessem da Corte, como se passou na Província de Rio Grande de São Pedro durante a guerra da Província Cisplatina ${ }^{253}$. Em ofício enviado ao Rio de Janeiro, o presidente informou da convocação extraordinária de seu Conselho quando teve conhecimento da ordem de Sua Majestade Imperial que mandava aos proprietários

\footnotetext{
${ }^{250}$ ACG-PE, v.2, sessão de 20/setembro/1833, p. 266.

251 ANRJ, Negócios de Províncias, IJJ 251.

${ }^{252}$ ANRJ, Negócios de Províncias, IJJ ${ }^{9}$ 247, ofício de 30/junho/1827.

${ }^{253}$ ANRJ, Negócios de Províncias, IJJ ${ }^{9} 450$, ofícios de fevereiro/1826.
} 
fronteiriços que recolhessem ao interior seus "gados e cavalhadas" por motivos de segurança. O texto da decisão unânime do Conselho explicitou que a ordem era "arrebatada" e nada prudente em seus resultados", além de "impolítica" à medida que "parecia anunciar aos povos a pouca confiança que o governo da Província tinha na força [militar] que com tanto empenho" fora mandada ao Sul pelo Imperador. Assim, dada à "circunspecta erudição" e os "elevados talentos" das autoridades imperiais, o presidente rogava-lhes a compreensão. Não se tem notícia de que o mesmo presidente, José Egídio Gordilho de Barbuda e seus conselheiros, tenham sido reprimidos pelo ato.

Vale esclarecer que, segundo o previsto por lei, os Conselhos de Governo não eram permanentes e se reuniam em sessão ordinária uma vez por ano durante dois meses, período esse que poderia ser prorrogado quando necessário. A época para sua instalação deveria ser a mais adequada às condições locais - desde que a primeira reunião fosse imediatamente posterior à eleição dos conselheiros - e o presidente poderia convocá-lo, extraordinariamente, no momento que julgasse adequado aos negócios públicos ${ }^{254}$. Isso fazia que as datas de seu funcionamento ordinário variassem, o que também era ocasionado pelo nível de conflitos vividos em cada Província ${ }^{255}$. No entanto, havia uma tendência para que ele ocorresse em período mais ou menos próximo ao do Conselho Geral da Província, pois, até 1831, valeu o princípio da compatibilidade entre as funções dos seus membros, que assim podiam ser eleitos para ambos simultaneamente. Logo que a normalização do funcionamento dos Conselhos Gerais foi aprovada, alguns conselheiros privativos do presidente colocaram em pauta a fixação dos dias da semana em que cada órgão se reuniria, para não haver choque com as atividades da Junta da Fazenda (posteriormente extinta) ${ }^{256}$.

O presidente e seu Conselho de Governo ocupariam, no Primeiro Reinado e início da Regência, um papel central na condução da administração das Províncias e de sua vinculação institucional com a Corte. Para tanto, eles tinham poder para deliberar sobre as mais variadas matérias que tratassem, na esfera provincial, da execução das leis e controle

\footnotetext{
${ }^{254}$ Quando da abertura dos trabalhos do Conselho do Governo, era comum o presidente fazer uma exposição da situação da Província, aos moldes do que fazia o Imperador com a solenidade da "Fala do Trono".

${ }^{255}$ Veja-se como presidente de Pernambuco noticiava, em 1829, que as sessões do Conselho de Governo da Província, que já deveriam ter começado, foram adiadas devido ao funcionamento de Conselho Militar que ocasionara a suspensão das "formalidades que garantem a liberdade do cidadão". ANRJ, Negócios de Província, $\mathrm{IJJ}^{9} 249$.

${ }^{256}$ Ver exemplos nas Atas: ACP-SP, v.86, sessão de 08/novembro/1828; CPG-MG (1829), sessão de 03/janeiro/1829; e ACG-PE, v.2, sessão de 08/agosto/1829.
} 
da máquina pública ${ }^{257}$. Por essa razão, era comum que ao órgão fossem remetidas representações e pedidos que, quando aprovados, poderiam ser colocados em prática no momento em que o presidente enviava seu pedido de aprovação ao governo imperial ${ }^{258}$. Para além da obrigação de discutir e implementar leis, os Conselhos tinham também por dever a manutenção da ordem política nas localidades. É visível que, nos momentos de maior instabilidade, os conselheiros se reuniam com seu presidente, geralmente de forma extraordinária $^{259}$.

Manuel da Costa Pinto, autoridade presidencial do Maranhão em 1828, rapidamente convocou seu Conselho a partir da denúncia feita por um particular que alegava ter manuseado uma mala cheia de cartas em que havia "maços de papéis incendiários". O presidente imediatamente mandou recolher tais papéis sob a justificativa de que conhecia, por meio de "notícias do Sertão", a existência de indivíduos que defendiam a causa da "república". Na sessão, a polêmica girou em torno do direito que os conselheiros teriam de violar a correspondência alheia - o que era concebido como um comportamento "anticonstitucional" - para apurar a veracidade dos fatos. Após ouvir o Conselho, o presidente ordenou que assim se procedesse; ao encontrarem somente "papéis enxovalhados", concluíram que os mesmos poderiam ter "sido trocados de propósito por se acharem [os culpados] já prevenidos" ${ }^{, 260}$. Independentemente do fatídico desfecho, cabe sublinhar que, em nome da segurança na Província, o órgão autorizou a infração de um direito garantido pela Constituição.

No entanto, grande parte das sessões dos Conselhos de Governo era dedicada à resolução de conflitos e tensões presentes no cotidiano da administração pública. Afinal o presidente, reunido com seus conselheiros, era responsável, segundo a lei de 20 de outubro de 1823, por "dar parte ao governo dos abusos", "dar parte à Assembléia das infrações das leis", e de "decidir temporariamente os conflitos de jurisdição entre as autoridades", desde

\footnotetext{
${ }^{257}$ Os Conselhos de Governo também analisavam a prestação de contas das Câmaras municipais já que, pela lei que os criara, eram eles responsáveis pelo exame das "contas de receita e despesa dos Conselhos, depois de fiscalizadas pelo Corregedor da respectiva comarca” (lei de 20/outubro/1823, artigo 24, parágrafo 11). Posteriormente, com a promulgação da lei de $1^{\circ}$ de outubro de 1828 que instituiu uma reformulação dos municípios, caberia aos Conselhos Gerais de Província a fiscalização das receitas das Câmaras (na prática, ambos os órgãos o faziam).

${ }^{258}$ Cabe salientar que, embora não seja objeto desse trabalho, a implementação de medidas que visavam a instrução pública era um tema de preocupação constante do órgão.

259 Vale destacar como, para o ano de 1831, as reuniões extraordinárias dos Conselhos de Governo aumentaram absurdamente; o mesmo vale para o período de guerra no Rio Grande de São Pedro do Sul.
} 
que suas resoluções fossem endereçadas à Corte. Na prática, isso permitia que o mesmo órgão arbitrasse e solucionasse problemas a ele encaminhados, o que não deixava de estar previsto na lei. Vejamos alguns destes casos.

Em agosto de 1826, o presidente de São Paulo convocava uma sessão do seu Conselho para tratar de uma queixa contra as "violências e arbitrariedades" praticadas pelo ouvidor da comarca de Itu, Antônio de Almeida Silva Freire da Fonseca ${ }^{261}$. Meses antes, outra denúncia contra o mesmo ouvidor adentrara na Casa, acusando-o de ter prendido despropositadamente vários cidadãos, quando fora aprovado que ele deveria ir pessoalmente ao Conselho responder pelas acusações ${ }^{262}$. O não cumprimento dessa solicitação era agora agravado pelas novas denúncias, o que fez que os conselheiros considerassem as ações do ouvidor realmente "despóticas", responsáveis por "flagelar" e "pôr em desesperação os povos" da citada localidade, decidindo remeter tudo ao conhecimento do Imperador. Além disso, frisavam que "poderosos e verídicos motivos" obrigavam o presidente a pedir à Sua Majestade que se "Dign[asse] mandar recolher o dito ouvidor". Aprovaram também que fosse colocado em liberdade um alferes da vila de Sorocaba que acusava o mesmo Freire da Fonseca de colocá-lo na cadeia sem culpa formada. Dessa forma, o Conselho deliberava não apenas um encaminhamento para a matéria como também indicava um veredicto para o problema, sem que o mesmo fosse encaminhado a uma outra esfera da Justiça.

Esse tido de ação esteve presente também nos anos que se seguiram ao funcionamento do Conselho privativo do presidente. No ano de 1829, o órgão em Minas Gerais dava seu parecer sobre a realização de uma devassa para na Vila de Paracatu, solicitada por autoridades locais após uma série de distúrbios envolvendo militares e a suspeita de ataques ao seu novo comandante ${ }^{263}$. Quando da exposição dos fatos, o Conselho havia determinado que o ouvidor mandasse proceder a um "corpo de delito" dos acusados, bem como à inquirição de testemunhas; com a chegada dos seus resultados, apresentados pelo respectivo juiz ordinário, os conselheiros decidiram pela completa "nulidade" a que estaria fadada a devassa: do "tumultuoso ajuntamento", as testemunhas escolhidas só

\footnotetext{
${ }^{260}$ ANRJ, Negócios de Províncias, IJJ $^{9}$ 555, sessão de 22/maio/1828.

${ }^{261}$ ACP-SP, v.86, sessão de 08/agosto/1826, pp.137-8.

${ }^{262}$ Idem, sessão de 02/março/1825, pp.41-2.

${ }^{263}$ ACG-MG (1829), sessão de 17/março, pp.94-100.
} 
chegaram a indicar seis nomes - número que então se considerou insuficiente para caracterizar uma "assuada" - e não comprovariam que as desordens teriam sido motivadas pelas razões alegadas. Assim, foi aprovado um "perpétuo silêncio" sobre o caso.

As tensões causadas pela ação das autoridades judiciais são matéria constante nas deliberações dos presidentes em Conselho. Em sessão de junho de 1832, os conselheiros de Pernambuco aprovaram um pedido de informações ao juiz de paz da Freguesia do Recife, sobre o processo que envolvia um indivíduo que ferira mortalmente outro e que, por sua ordem, saíra da prisão ${ }^{264}$. Dias depois, tendo chegado à Casa as explicações do dito juiz, foi elaborado um parecer que o acusava de ter "dormitado sobre a execução dos seus deveres", mas que o eximia de culpa em função de doença que o mesmo alegara ${ }^{265}$; por fim, ordenava que se procedesse a "corpo de delito" e se formalizasse o "processo criminal" (como já deveria ter feito o dito juiz).

Para além da acusação de descaso no cumprimento de seus deveres ${ }^{266}$, eram comuns denúncias de que oficiais da Justiça teriam procedido a prisões sem culpa ${ }^{267}$, cometido todo tipo de excessos no exercício de suas funções ${ }^{268}$, e mesmo recebido insultos ${ }^{269}$. A incidência de conflitos de jurisdição também era constante, como se vê num ofício encaminhado ao Conselho de Governo de Pernambuco, em 1828, pelo ouvidor da comarca, Ernesto Ferreira França (posteriormente eleito deputado à segunda legislatura), pedindo-lhe a intervenção para sanar um atrito com a Mesa do Desembargo do Paço da Província ${ }^{270}$ : o ouvidor se recusara a fazer a apuração dos juízes de paz, alegando tratar-se de competência da dita Mesa; esta, por seu lado, decidiu que cumpria a Ferreira França fazê-la, o que lhe ordenou em duas provisões. Por fim, o Conselho decidiu que não havia nenhum conflito de jurisdição, e que ao ouvidor cumpria obedecer à ordem; mesmo tomando seu arbitramento

\footnotetext{
${ }^{264}$ ACG-PE, v.2, sessão de 03/julho/1832, p.184.

${ }^{265}$ Idem, sessão de 10/julho/1832, p.187.

${ }^{266}$ Como também demonstra a acusação feita contra o Juiz de Paz da Vila de Mogi das Cruzes (São Paulo), que não teria comparecido para realização de corpo de delito a um homicídio, e cuja suspensão o Conselho aprovara. CGP-SP, v.16, sessão de 05/outubro/1832, p.51.

267 Por exemplo, o caso do Juiz de Jundiaí (São Paulo), que mantivera, nessa condição, indivíduos esclarecidos. CGP-SP, v.15, sessão de 10/outubro/1830, p.178-9.

${ }^{268}$ Em 1829, a Câmara de Jacuí, em Minas Gerais, relatava ao Conselho os excessos que teriam sido cometidos pelo Ouvidor da Comarca. ACG-MG (1829), sessão de 09/junho.

${ }^{269}$ Veja-se a queixa que fez o Juiz Almotacel da Câmara de Minas dos insultos que teria recebido do Capitão da Cavalaria. ACG-MG, sessão de 15/outubro/1828.

${ }^{270}$ ACG-PE, v.2, sessão de 04/agosto/1828, p.56.
} 
como provisório - pois que ainda poderia ser contestado no Rio de Janeiro - pedia que fosse logo obedecido.

Dessa forma, ficava evidente como as decisões do Conselho poderiam ter ingerência no funcionamento interno de outras instituições. Note-se como em 1827, o vice-presidente em exercício de Minas Gerais enviava um ofício ao Rio de Janeiro em que informava os abusos cometidos na administração da Casa de Misericórdia de Ouro Preto, avaliados por uma comissão de conselheiros ${ }^{271}$. No mesmo sentido, o destaque dado às acusações de arbitrariedades praticadas pelos órgãos da Fazenda não era acidental, haja vista o caráter urgente da organização das finanças públicas. Era assim que em sessão do Conselho do Governo de Minas, em 1829, a Junta da Fazenda era acusada de decidir pela realização de despesas extraordinárias a despeito da opinião do órgão presidencial ${ }^{272}$. Alegava-se que, pela lei de 20 de outubro de 1823, era função do presidente e conselheiros decidirem pelas despesas extraordinárias, as quais só poderiam ser postas em prática com a prévia aprovação do Imperador. Com unanimidade, o Conselho aprovou o encaminhamento ao governo imperial de um requerimento de acusação da Junta.

Da mesma forma, em 1832 o Conselho de Governo de Pernambuco acusava a Junta da Fazenda de tomar a arbitrária deliberação de receber em moeda de prata metade dos impostos que pagavam os agricultores de açúcar e algodão, sendo que os mesmos eram medidos em moeda de cobre com menor valor, aumentando o ônus sobre os produtores ${ }^{273}$. Um parecer emitido por um dos conselheiros defendia que os impostos fossem pagos na mesma moeda em que se procedia à avaliação, e requeria que, depois de ouvida a Junta, tal abuso fosse comunicado ao governo. Assim se decidiu. Anos antes, o mesmo Conselho aprovara que a Junta de Fazenda desse esclarecimentos sobre uma queixa de injustiça encaminhada ao órgão por um particular acerca dos lugares de negócios no Trapiche da Alfândega ${ }^{274}$.

Nessa direção, o ministério dos Negócios do Império lançara uma portaria, datada de 15 de julho de 1825, ordenando aos presidentes de Província reunidos em seus

\footnotetext{
${ }^{271}$ CEDI-CD, ano/localização: 1827, PDID 416 A.

272 ACG-MG (1829), sessão de 14/março, p.77.

273 ACG-PE, v.2, sessão de 09/fevereiro/1832, pp.149-150.

${ }^{274}$ Idem, sessão de 04/julho/1829, p.70-1. No ano seguinte (sessão de 15/julho, pp.106-7), uma resolução do Conselho ordenava à Câmara Municipal de Recife que respondesse, em oito dias, a um requerimento de um particular.
} 
Conselhos o envio de informações a respeito de abusos existentes na administração na Fazenda Pública, bem como o apontamento de meios para lhes aumentar o rendimento. Há informações de que o Conselho de São Paulo, em sessão extraordinária, prontamente respondeu à matéria, enviando uma nota ao Rio de Janeiro em que se comprometia a tratar do assunto logo que iniciados seus trabalhos ordinários ${ }^{275}$. O mesmo ocorreu em Pernambuco no ano seguinte, quando os conselheiros ficaram de discutir qual seria a melhor forma de colocar a medida em prática ${ }^{276}$. Portanto, investir na autoridade dos presidentes, e de seu Conselho era, por conseguinte, uma das formas concebidas pelo governo da Corte para implementação de um aparato político-institucional que viabilizasse a unidade do novo Império e o controle sobre seu território.

Concepção semelhante informou a instalação dos Conselhos Gerais de Província, conforme já se discutiu na primeira parte desse capítulo. Como órgãos eletivos entendidos como responsáveis pela representação dos interesses dos cidadãos nas várias localidades, era norma sua reunião durante dois meses, uma vez por ano, período que poderia ser prorrogado por mais um mês caso fosse julgado necessário. Pela Carta de 1824, as sessões deveriam iniciar-se no primeiro dia de dezembro ${ }^{277}$ (como se sabe, esses Conselhos só começariam a funcionar a partir de 1828), sendo que o presidente da Província só estaria presente na solene abertura dos seus trabalhos.

O esforço do governo para que as reuniões dos Conselhos Gerais efetivamente fossem cumpridas pode ser notado desde seu início. Isso porque um dos problemas que marcou seus primeiros anos foi o da falta de comparecimento dos conselheiros que, muitas vezes, encontravam-se em regiões distantes e pouco conectadas com a capital da Província, situação agravada pela ausência de gratificação a eles (ao contrário do que acontecia para os que compunham o Conselho da Presidência). Nesse sentido, o ocorrido no Conselho Geral da Bahia seria exemplar. Logo na primeira representação por ele encaminhada ao Rio de Janeiro, colocava o problema da inexistência de formas de repressão aos membros que não tomassem assento, e pedia medidas contra os faltantes ${ }^{278}$. Afirmava para aquela sessão

\footnotetext{
275 ACP-SP, v.86, sessão de 18/agosto/1825, pp.49-50.

${ }^{276}$ ACG-PE, v.2, sessão de 02/fevreiro/1826, pp.13-4.

${ }^{277} \mathrm{O}$ que implicava que uma mesma sessão tinha início num ano e término no seguinte.

${ }^{278}$ Apud Renato Berbert de Castro, História do Conselho Geral da Província da Bahia 1824-1834, Salvador, Assembléia Legislativa do Estado da Bahia, 1984, p.50. Pela Constituição (art. 73), os Conselhos Gerais das
} 
(de 1828-29), maiores tinham sido os dias sem sessão do que o contrário, ficando "paralisado o serviço que a Constituição, no artigo 71, reconhec[ia] ter todo Cidadão de intervir nos negócios de sua Província"279.

No início da segunda sessão, marcada para começar em 30 de setembro de 1829, os conselheiros baianos reunidos em número menor do que o necessário mandaram convocar os demais ${ }^{280}$. Com a recusa destes em comparecerem, tomaram os presentes a liberdade de lavrar uma Ata que simplesmente suspendia seus dois meses de trabalho para aquele ano. A decisão foi encaminhada ao presidente da Província que, em Conselho, corroborou-a, mandando um ofício à Corte. A resposta vinda do Rio de Janeiro foi explícita: em aviso, datado de 29 de dezembro, o ministro José Joaquim Carneiro de Campos (Marquês de Caravelas), criticou duramente a medida e acusou os conselheiros de terem infringido a Constituição no seu artigo 77, que prescrevia que o mesmo Conselho deveria se reunir todos os anos. Ordenava que os Conselhos imediatamente chamassem por uma "sessão preparatória" e que nela permanecessem até o comparecimento do número mínimo para seu início ordinário. Assim se procedeu, mas foi somente a partir de 28 de fevereiro do ano seguinte que a sessão pôde funcionar com regularidade.

O mesmo problema afetava outras localidades. Ainda em 1829, um requerimento encaminhado pelo presidente e secretário do Conselho Geral do Ceará ao ministro José Clemente Pereira, pedia que fossem tomadas providências para sanar a falta de conselheiros na sessão. Noticiava que, dos 21 eleitos (mais quatro suplentes), na abertura dos trabalhos haviam comparecido 11, o mínimo para que o mesmo funcionasse. Observava que em se tratando de uma Província "pobre”, marcada pela "peste, seca, e revoluções nos anos próximos passados", os citados conselheiros enfrentavam muitas "dificuldades" e "despesas" para virem à capital, além do abandono de "seus interesses particulares"281. O documento chegou à Câmara dos Deputados, bem como um outro escrito exatamente um ano depois, de idêntico teor, descrevendo em palavras e expressões semelhantes as difíceis condições locais, e novamente clamando pela tomada de medidas legislativas ${ }^{282}$.

Províncias mais populosas seriam formados por 21 membros, e os das menos por 13 (art.73). Para que houvesse reunião, era necessária a metade de seus membros mais 1 (art. 78).

${ }^{279}$ Idem.

${ }^{280}$ Idem, p.57.

${ }^{281}$ ANRJ, Negócios de Províncias, IJJ $^{9}$ 172, ofício de 02/dezembro/1829.

${ }^{282}$ Idem, ofício de 02/dezembro/1830. 
Nas Atas das reuniões do Conselho Geral do Ceará, na cidade de Fortaleza, o problema do não comparecimento de seus membros ficou registrado tanto para o ano de 1830, como para o de $1831^{283}$. Neste último, os conselheiros propuseram um projeto que visava sanar esse problema, com a mudança da instalação da sessão para o começo de agosto e uma punição monetária para os faltantes por mais de um ano. No mesmo período, Comissões da Câmara dos Deputados alegavam ter recebido ofícios de Sergipe e do Espírito Santo apontando o mesmo problema, tratado na Casa como "falta de patriotismo", dada a conseqüente "paralisação" dos trabalhos provinciais e o não cumprimento da Constituição $0^{284}$.

Diversas razões poderiam ser alegadas para explicar a dificuldade na implementação dos Conselhos Gerais de Província, entre elas, a inexistência de articulações internas que assegurassem a existência efetiva de unidades provinciais (inclusive no que tocava à definição de suas áreas limites), a falta de gratificação dos seus membros, ou mesmo uma pouca adesão inicial ao seu papel essencialmente propositivo (e não legislativo) de "representação" dos interesses, enquanto seu congênere, o Conselho do Governo, mantinha um caráter deliberativo na execução das leis (semelhante ao anteriormente exercido pelas Câmaras municipais). Mas deve-se notar que o problema da falta de comparecimento dos conselheiros, além de não ser extensivo a todas as Províncias, tendeu a diminuir a partir dos anos $1832^{285}$, quando já vigorava na Câmara dos Deputados a regra interna que impedia a execução de emendas aos projetos apresentados pelos Conselhos Gerais.

$\mathrm{Se}$, como vimos, seu funcionamento foi especialmente caro aos primeiros legisladores ${ }^{286}$, também o foi para o governo no Rio de Janeiro à medida que representava a viabilização de um arranjo político que fornecia materialidade a um regime de monarquia

\footnotetext{
${ }^{283}$ Atas do Conselho Geral da Província do Ceará (1829-1835) (ACGP-CE), Fortaleza, INESP, 1997, pp. $167 \mathrm{e} 178$.

${ }^{284}$ CEDI-CD, ano/localização: 1831, maço 17, pasta 1.

${ }^{285}$ Embora as reclamações a respeito diminuíssem, isso não quer dizer que os Conselhos tenham passado a funcionar com número completo. Um levantamento do comparecimento dos conselheiros nas sessões da Bahia, feito por Renato Berbert de Castro, op. cit., mostra que apesar dele ter subido para o ano de 1830-31, em 1831-32 seu número máximo não passou de 19, em 1832-22 de 17, e na última de 1833-34 de 16.

286 Como demonstração disso, vale notar como o deputado pernambucano Holanda Cavalcanti de Albuquerque, em sessão da Câmara dos Deputados de 25/abril/1829, criticava ostensivamente o atraso na instalação do Conselho Geral devido ao funcionamento de uma comissão militar que vigorou em sua Província. Suas palavras eram significativas: "Os Conselhos Gerais de Província são uma das medidas mais salutares, e que mais esperança dá ao Brasil para o progresso da marcha constitucional". APB-CD (1829), t.1, p.16-7.
} 
representativa que se pretendia construir. Daí a preocupação constante com sua institucionalização que, entendida como um poderoso instrumento de estabilidade da ordem interna, também encontrava respaldo entre as autoridades locais.

Era em função dessa crença que, no Ceará, o Conselho Geral aprovou em 1830 uma proposta para divisão da Província em duas, com a criação de uma nova a partir da Comarca do $\mathrm{Crato}^{287}$. A responsável por essa proposta foi uma comissão especial encarregada de transformar em projetos as matérias contidas no discurso de abertura da sessão, feito pelo presidente de Província e no qual ele apontava o crescimento dos "facinorosos do Cariri", na comarca do Crato, como principal problema então vivido 288 . Aos olhos das autoridades, tratavam-se de "desordeiros" e "criminosos" que não se subjugavam a nenhuma lei e se valiam do "banditismo" como forma de sua ação. A justificativa para a medida era a necessidade de controle público sobre a região. No ano seguinte, uma representação da Vila de Lavras ao ministro do Império expunha a mesma expectativa ao reivindicar a instalação de uma "força" que pudesse "obrar livremente o bem dos súditos, e patrícios que, como emergidos no esquecimento, vivem quase a dois contos de anos entregue às fúrias dos capitães-mores, e dos baixos ouvidores" ${ }^{\text {,289 }}$. Afirmava que a implementação de um novo governo provincial seria a "única providência que pode[ria] minorar os males de seus habitantes" pelo seu poder de arbitramento das irregularidades e de uso da força militar ${ }^{290}$.

Por mais que sua estrutura pudesse gerar controvérsias, é fato que a instalação dos Conselhos foi uma tentativa de construção de um canal direto de representação política das localidades, haja vista ser esta uma das demandas que tomou força desde o início do movimento constitucional. Sua principal atribuição era a formulação de propostas, a ela somada o controle sobre as atividades das Câmaras a partir da lei que as reformulou em 1828. Nesse sentido, cabia aos Conselhos avaliar as posturas municipais e propor o que conviesse aos seus interesses, aprovar a execução de obras de grande porte, receber o balanço das contas das Câmaras, bem como a notícia de "infrações da Constituição, e das

\footnotetext{
${ }^{287}$ ACGP-CE, p. 163-4.

${ }^{288}$ Idem, pp.162-3.

${ }^{289}$ CEDI-CD, ano/localização: 1831, maço 31, pasta 4, fl. 3v.

${ }^{290} \mathrm{Na}$ época, era também comum aparecerem demandas para organização interna dos Governos Provinciais; há notícia de pelo menos dois projetos que propunham a reformulação das Secretarias dos Governos do
} 
prevaricações, ou negligências de todos os empregados" (que também poderiam ser encaminhadas ao Conselho de Governo). Vale notar que grande parte de suas discussões era dedicada aos pareceres sobre as municipalidades, para as quais elegia-se geralmente uma comissão interna que trabalhava no atendimento de suas demandas.

Mesmo não sendo função principal dos Conselhos Gerais tratar de conflitos de administração, há indícios de que o governo incentivou seu poder de fiscalização sobre os negócios das Províncias. Era assim que, em 1831, o Conselho Geral de Minas Gerais acusava o recebimento de uma resolução da Câmara dos Deputados para que lhe fossem encaminhadas quaisquer informações sobre arbitrariedades cometidas na esfera administrativa provincial $^{291}$. Para isso, os conselheiros aprovaram a instalação de uma comissão especial e decidiram que se enviaria o mesmo ofício às Câmaras para que estas estivessem cientes da importância da matéria. A resolução dos deputados foi respondida pelo Conselho Geral de Mato Grosso em fevereiro de 1834, encaminhando ao governo uma lista com uma série de irregularidades que teriam sido cometidas pelas autoridades provinciais $^{292}$. Assim, ainda que o projeto de regimento dos Conselhos aprovado pelos deputados em 1830 - o qual atribuía um papel importante de controle sobre a ação do presidente e seu Conselho de Governo - não tenha sido aprovado, duas decisões tomadas em 1833 aumentavam seu poder de ação: a primeira obrigava os presidentes de Províncias a entregar-lhes os documentos solicitados para desempenho de suas funções ${ }^{293}$; a segunda inscrevia no rol de competência dos Conselhos Gerais o poder de suspender magistrados tal qual previsto aos mesmos presidentes ${ }^{294}$.

Dessa forma, era também comum que o órgão arbitrasse sobre conflitos na vida pública, ainda que as soluções por ele emitidas tivessem sempre caráter indicativo. Novamente, os exemplos são inúmeros. Um deles é encontrado na sessão do Conselho Geral de Minas Gerais, de janeiro de 1831, quando se discutiu uma longa acusação feita pela Câmara da Vila de Pitangui contra uma arbitrariedade que teria praticado seu juiz de

Maranhão (CEDI-CD, ano/localização: 1831, maço 31, pasta 5, ofício de 11/julho) e do Pará (CEDI-CD, ano/localização: 1833 , maço 13, pasta 1 , ofício de 04/julho).

${ }^{291}$ ACGP-MG (1831), sessão de 07/dezembro, pp.21-2.

${ }^{292}$ CEDI-CD, ano/localização: 1834, maço 15, pasta 1.

${ }^{293}$ Decisão de 07/junho/1833, Coleção de Leis do Império.

${ }^{294}$ Decisão de $17 /$ julho/1833, idem. 
fora $^{295}$. Após a descrição de seus atos, os conselheiros julgaram inquestionável a necessidade de remoção do juiz, votando que a matéria fosse urgentemente encaminhada aos deputados e ao Executivo. Procedimento muito semelhante ocorreu no Conselho Geral do Ceará, ainda em 1831, quando um particular reclamou ao órgão a injustiça de uma multa que lhe havia sido imposta pela Mesa Paroquial de Vila Nova ${ }^{296}$. Após a exposição do problema, o parecer do Conselho indicava que se oficiasse ao presidente da Província para fazer constar àquela Câmara a resolução do queixoso, pois a multa por ele sofrida havia sido "imposta ilegalmente". Era dessa forma que também esses Conselhos emitiam regularmente opiniões sobre a jurisdição administrativa ${ }^{297}$, mesmo que elas ainda tivessem que passar pelo crivo da máxima autoridade Executiva da Província e, no limite, também do governo imperial.

Propostas e medidas para melhoramento nas localidades eram constantes em todos os Conselhos Gerais. No ano de 1830, após a instalação de grande parte dos mesmos, a Câmara dos Deputados acusava o recebimento de uma considerável quantidade de suas representações, encaminhadas pelos ministérios. Para lembrar que essa era a prática a ser seguida - isto é, um primeiro encaminhamento ao Executivo central - o ministro Carneiro de Campos achou conveniente expedir circular para todos os Conselhos, já que alguns haviam equivocadamente remetido material de suas sessões diretamente à Assembléia ${ }^{298}$. Assim estabelecia a Constituição no seu parágrafo $4^{\circ}$., artigo 83, sem deixar dúvida de que cabia aos ministérios (e também, em casos de contencioso administrativo, ao Conselho de Estado) o papel central de distribuição dos casos.

As resoluções dos Conselhos tratavam de uma grande diversidade de assuntos ${ }^{299}$, como: impostos (diminuição ou criação), rendas públicas, favorecimento de lavouras e

\footnotetext{
295 ACGP-MG (1830), sessão de 24/janeiro/1831, p.129-130.

${ }^{296}$ ACGP-CE, sessão de 13/dezembro/1831, p. 179.

${ }^{297}$ Vários outros exemplos ainda poderiam ser citados para o caso de Minas Gerais: os que envolveram o juiz de paz e o ouvidor da Vila de Paracatu (ACGP-MG, sessão de 11/dezembro/1830); um sobre mudança de estrada na Vila de Pitangui (CGP-MG, sessão de 16/dezembro/1830); outros sobre arbitrariedades ocorridas na Vila de Paracatu (CGP-MG, sessão de 16/dezembro/1831) e de Caeté (CGP-MG, sessão de 19/dezembro/1832).

${ }^{298}$ CEDI-CD, ano/localização: 1830, maço 17 , pasta 1.

${ }^{299}$ Cabe esclarecer que no para o Rio de Janeiro não havia governo de Província, todas as suas resoluções eram encaminhadas diretamente à Corte. Por vezes, as representações eram diretamente endereçadas à Assembléia, como no caso da Vila de Cantagalo, que em 1832 enviou aos deputados um ofício em que marcava providências necessárias para o município (CEDI-CD, ano/localização: 1831, maço 11, pasta 2, ofício de 21/agosto/1832 equivocadamente colocada na pasta do ano de 1831).
} 
lavradores, corpos militares, instrução pública, criação de vilas e freguesias, ação dos juízes de paz e outras instâncias da Justiçaa ${ }^{300}$, "civilização" dos índios, administração da Fazenda Pública, iluminação de cidades e povoação de áreas, abertura de estradas, e, conforme já referido, aprovação de posturas e solicitações municipais ${ }^{301}$. Os Conselhos também faziam uma separação entre "projetos" e "representações", sendo que, na Câmara dos Deputados, os primeiros seriam aprovados ou reprovados, e as segundas seguiriam à comissão mais indicada.

Os Conselhos Gerais também representavam um espaço de reivindicação contra medidas aprovadas pelo governo imperial. Assim fica evidente em alguns dos posicionamentos tomados pelos conselheiros de Minas Gerais em 1831. No primeiro, foi aprovado o envio de requerimento ao Rio de Janeiro pedindo a manutenção da cobrança dos impostos de entrada de produtos de outras Províncias apenas nas Minas Gerais, abolida pela lei do Orçamento para o ano financeiro de $1832-33^{302}$. A justificativa era que daí vinha

\footnotetext{
${ }^{300}$ Uma reivindicação constante era a do estabelecimento de um Tribunal da Relação nas Províncias que não o possuíssem. Esse foi o caso do Ceará (ACGP-CE, sessão de 07/janeiro/1830, p. 160), do Rio Grande de São Pedro (CEDI-CD, ano/localização: 1831, maço 21, pasta 1, ofício de 12/maio), de Minas Gerais (GP-MG [1831], sessão de 17/dezembro), e também de São Paulo, mesmo antes do funcionamento do Conselho Geral da Província (conforme constante das Atas do Conselho de Governo, ACG-SP, sessão de 20/dezembro/1824). ${ }^{301}$ Do material encaminhado para a Assembléia, várias representações e propostas das Províncias se encontram no Arquivo da Câmara dos Deputados (CEDI-CD); nem todas, no entanto, entraram no trâmite e foram citadas nos Anais, até porque seu conteúdo poderia ser diluído nas propostas das Comissões. Para o ano de 1830, existem resoluções chegadas do Maranhão, que tratavam da diminuição de impostos sobre o algodão e a aguardente, dos lavradores penhorados em dívidas, da redução dos corpos de milícias (maço 17, pasta 1, ofício de 21/junho), de medidas para os vadios, da Casa da Misericórdia, da impressão de leis e de um Jardim Botânico (maço 21, pasta 1); do Pará, que tratavam de estrangeiros, do estabelecimento de uma imprensa, da isenção e vencimentos dos conselheiros, da ação dos juizes de paz, da Fazenda Pública, da cobrança de dízimos, entre vários outros (maço 21, pasta 1, ofício de 27/fevereiro); também de Minas Gerais, Goiás, São Paulo, Piauí, Santa Catarina, Sergipe d’El Rei, Alagoas, Pernambuco e Ceará, sobre vários assuntos (maço 21, pasta 1, ofícios de 27/fevereiro e de 18/maio); e vários do Rio Grande de São Pedro (maço 21, pasta 1, ofício de 12/maio). Para o ano de 1831, foram recebidas representações do Conselho da Bahia, sobre instrução pública, ordenados de oficiais, elevação de Vilas, entre outras (maço 31, pasta 4, ofícios de 15/junho e 22/junho); e várias de Minas Gerais, Santa Catarina, Alagoas e Espírito Santo (maço 31, pasta 4, ofício de 06/junho). Para o ano de 1832, dos Conselhos do Maranhão, Ceará, São Paulo, Minas Gerais, Santa Catarina, Bahia, e várias do Rio Grande de São Pedro sobre expostos, cobrança de impostos, moeda circulante, dispensa de milicianos, entre outros (maço 11, pasta 1 e maço 10, pasta 1). Para o ano de 1833, as resoluções e projetos dos Conselhos Gerais batem o recorde em quantidade: há notícias de resoluções de Minas Gerais, São Paulo, Espírito Santo e Alagoas (maço 14, pasta 1, ofício de 18/abril); várias da Paraíba, entre outras, pelo estabelecimento de um banco provincial, instrução pública, questões de terra da Santa Casa da Misericórdia (maço 13, pasta 1, ofício de 03/junho); várias de Pernambuco, Bahia, Mato Grosso, Piauí, Goiás, Alagoas, Minas Gerais, São Paulo, Maranhão e Espírito Santo (maço 13, pasta 1, ofício de 17/setembro). Não é apenas o número de leis que foram aprovados a partir dessas propostas (em muito menor número, obviamente) que conta para qualificarmos sua importância e mesmo repercussão nos trabalhos internos da Câmara, mas o fato deste se tratar do principal canal de representação das necessidades das Províncias.

${ }^{302}$ ACGP-MG (1831), sessão de 09/janeiro, p. 187.
} 
grande parte das divisas provinciais, e que essa exceção ao território mineiro deveria valer somente até a aprovação, pelo Legislativo, de uma nova proposta para arrecadação dos dízimos e do ouro em pó.

Em outro momento, contestou-se a aprovação e pediu-se a revogação do decreto que impedia aos membros do Conselho Geral da Província e vereadores o exercício da função de conselheiros privativos do presidente no Conselho de Governo ${ }^{303}$. A razão dada para que os cargos fossem compatíveis, para além da existência de vários indivíduos que os acumulavam, era que a prática corrente ajudava na ação administrativa. Não se tem notícia de desdobramentos da questão. No ano anterior de 1830, o mesmo Conselho de Minas chegou a sustentar uma acusação feita pela Câmara de Caeté ao ministro do Império, José Clemente Pereira, de que ele teria infringido a lei de 01 de outubro de $1828^{304}$. O parecer aprovado pelo órgão dizia que Caeté mereceria "elogios [...] por erguer sua voz contra uma portaria que a despeito de novas leis constitucionais quis ressuscitar o império das portuguesas, e restituir aos ouvidores das comarcas a já perdida posse de expedirem ordens aos corpos municipais, que nenhuma sujeição lhes deve" ${ }^{305}$. Encaminhada ao ministério, também desta se desconhece desdobramentos.

Um espaço de permanente tensão no cotidiano dos Conselhos Gerais se fazia no trato com as Câmaras, haja vista que do ponto de vista institucional elas passaram a ser-lhes subordinadas. Era comum os próprios Conselhos do Governo citarem o descaso dos municípios em lhe prestarem informações, como aconteceu em Pernambuco em 1826, quando se decidiu por enviar uma circular a todos para que apresentassem o mais brevemente suas contas ${ }^{306}$. Anos depois, o mesmo Conselho reclamava que a Câmara da cidade do Recife se negava a lhe apresentar suas contas e prestar obediência ${ }^{307}$. Passados alguns dias, o Conselho multou a Câmara, sob a alegação de que ela não havia cumprido com seus deveres, mandando proceder contra seu presidente e vereadores ${ }^{308}$. O conflito continuaria nas sessões seguintes.

\footnotetext{
${ }^{303}$ Idem, sessão de 14/janeiro, pp.231-2. O citado decreto é de 12/agosto/1831.

${ }^{304}$ ACGP-MG (1830), sessão de 07/janeiro, pp.63-4.

${ }^{305}$ Idem, p. 64.

${ }^{306}$ ACG-PE, v.2, sessão de 27/janeiro/1826, p.11.

${ }^{307}$ Idem, sessão de 26/abril/1833, p.234-5.

${ }^{308}$ Idem, sessão de 10/maio/1833, p.238-9.
} 
Outros Conselhos Gerais teriam reclamações semelhantes. Em 1830, o do Ceará acusava as Câmaras da Província de completo desleixo na prestação das suas contas que, desde o ano de 1825 , não tinham sido entregue por muitas delas ${ }^{309}$. No ano seguinte, o presidente, em nome de seu Conselho privativo, enviava essa solicitação para o ministério, pedindo que "Sua Majestade Imperial resolvesse sobre o objeto como julgasse ser de justiça” ${ }^{\text {310 }}$. Foi num parecer emitido pelo Conselho Geral de Minas Gerais acerca de um ofício da Câmara de Mariana que as tensões se revelaram mais explicitamente. Argumentaram os conselheiros que além do não cumprimento de suas ordens sobre as contas municipais, um vereador da dita Câmara taxara a resolução do Conselho de "injuriosa, injusta e degradante" por se esperar um "servilismo" da antiga corporação. Segundo o texto, no cúmulo do "desvario", o homem teria dito que a Câmara não devia “inteira subordinação ao presidente da Província”. Terminava sustentando que cabia ao Conselho formar as "leis para os respectivos municípios" e que era "incompreensível” que alguém ainda pudesse pregar a "independência da Câmara à vista da lei de $1^{\circ}$ de outubro"311.

$\mathrm{Na}$ correspondência de ambos os Conselhos com as autoridades imperiais eram freqüentes as referências a casos de arbitrariedades municipais. Em sessão de 1829, o Conselho de Santa Catarina e seu presidente encaminharam ao ministério um ofício em que acusavam a Câmara de Lages de não dar posse ao vereador mais votado sob a alegação do mesmo "ser pobre"312. Afirmavam que dessa forma a lei era infringida, e ordenavam que o citado vereador fosse imediatamente empossado, inclusive como presidente da Câmara. Remetiam tudo para aprovação do Imperador.

Dois outros casos também exemplificam esse controle por parte dos Conselhos. Em 1830, o presidente do Sergipe enviava ao Rio de Janeiro um ofício documentado acerca de supostas irregularidades cometidas pela Vila de Santo Amaro das Brotas ${ }^{313}$. Alegando que seus vereadores não apenas mostravam "negligência" quanto ao serviço público, deixando de comparecer às reuniões sem justa causa, como executavam uma série de procedimentos de teor duvidoso quanto à prática da lei. Em especial, contestava a decisão da Câmara de

\footnotetext{
${ }^{309}$ ACGP-CE, sessão de 04/dezembro/1830, p. 167.

${ }^{310}$ ANRJ, Negócios de Províncias, IJJ $^{9}$ 173, ofício de 26/janeiro/1831.

311 ACGP-MG (1831), sessão de 03/fevereiro, pp.363-4.

312 ANRJ, Negócios de Províncias, IJJ ${ }^{9} 439$, ofício de 21/março/1829.

${ }^{313}$ CEDI-CD, ano/localização: 1830 , maço 21 , pasta 1 , ofício de $05 /$ maio.
} 
tornar nulas duas sessões de setembro sob a justificativa de terem sido feitas sem a presença do presidente da Casa e com a "exclusão positiva e escandalosa não só dos efetivos, como de suplentes" com maior número de votos. O Conselho presidencial decidira enviar o assunto ao governo do Império, ressaltando que já havia noticiado à vila a necessidade de normalizarem seus trabalhos regulares mesmo que para isso precisasse colocar seus membros "omissos" na inteira observância da lei (de outubro de 1828).

O outro dizia respeito aos abusos que vinham sendo cometidos no contrato de venda de "aguardentes da terra" que, segundo o Conselho Geral da Província do Espírito Santo, instituía um "verdadeiro monopólio contra o pobre lavrador nas condições com que os

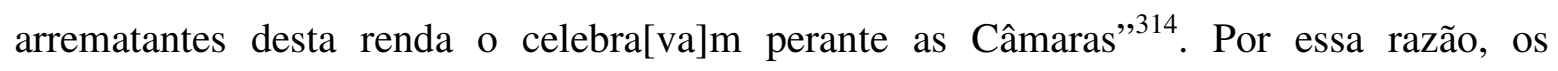
conselheiros alegavam ter enviado um requerimento aos vereadores da cidade de Vitória pedindo esclarecimentos sem obterem resposta. Dessa forma, encaminhavam ao ministério um pedido de orientação de como deveriam proceder na questão, bem como um projeto aprovado no seu âmbito que extinguia o dito contrato como "oposto à Constituição que felizmente" os regeria. Não deixavam também de criticar a postura da Câmara que, além de proceder "inconstitucionalmente negando ao Conselho esclarecimentos", "embaraçavam" o exercício que lhe competia com vistas ao melhoramento dos serviços públicos.

É bem verdade que a ação dos Conselhos nas Províncias - tanto do Geral como do Presidencial - não se constituía o único canal de representação dos municípios, que continuavam a se dirigir diretamente também ao governo imperial ${ }^{315}$, tampouco extinguira as redes de poder nas localidades que, muito provavelmente, iam sendo reconfiguradas à medida que se impunha um novo padrão institucional ao conjunto do Império. O que a ação dos Conselhos procurava era o fortalecimento da esfera provincial como espaço "constitucional" de "apontamento" das necessidades locais e de "observância" da execução das leis. Até que ponto isso foi bem sucedido só é possível inferir avaliando o impacto de tal ação em cada uma das localidades.

\footnotetext{
${ }^{314}$ Idem, ano/localização: 1833, maço 14, pasta 1, ofício de 28/janeiro/1830.

315 Tome-se como exemplo o caso da Câmara de Porto Alegre que, em 1830, recorria aos "Representantes da Nação" para contestar a decisão do Conselho Geral da Província que não aprovara as soluções propostas por ela para sanar a necessidade de aumento de suas rendas. Solicitavam os vereadores que sua proposta, que
} 
Desde a instalação das Juntas de Governo nas Províncias, criadas pelas Cortes de Lisboa em 1821, a proposta de separação das esferas de ação entre as autoridades civil e militar sob uma ordem constitucional vinha causando inúmeros conflitos de jurisdição. Com a aprovação da lei de 20 de outubro de 1823 , a situação só tendeu a agravar-se, haja vista que os comandantes de armas deveriam estar subjugados aos presidentes das Províncias. Mesmo antes da chegada desses às localidades, a partir de 1824, vários confrontos tomavam corpo entre as autoridades, informados pela profunda instabilidade e violência que marcava o período, e que empurrava, cada vez mais, protagonistas de diversas categorias à cena política.

Esse era o caso no Maranhão, cujo governo em 1824 noticiava ao Rio de Janeiro as atitudes arbitrárias que teria praticado o responsável pelas armas que, tendo sido eleito para também compor a Junta, arrogava "não só a autoridade civil, como a militar, prendendo despoticamente a inumeráveis cidadãos". Por essa razão, a Junta justificava sua decisão de extinguir temporariamente o cargo de comandante - assumindo o "governo civil e igualmente o governo das armas" - como uma forma de evitar os males "aos povos" 316. Tudo indica que esse arranjo durou pouco, pois três meses depois, nova correspondência noticiava que um outro governador de armas, José Pereira de Burgos, estava novamente em conflito com a Junta ${ }^{317}$. Burgos era então acusado de infringir a lei de 20 de outubro de 1823, pois teria cometido uma série de atos "sem acordo do governo, e em matérias, que não tem por objeto o serviço militar". Ele defendeu-se das acusações do órgão civil, alegando que "não há[veria] um só artigo, nem ultimamente nos do regimento dado para o Excelentíssimo Senhor presidente, pelo qual sejam Vossas Excelências autorizadas a governar a força armada de primeira e segunda linhas da Província, quando se acha[va]m

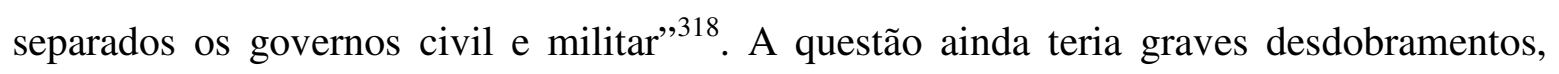
pautados pelas disputas locais de poder que, não apenas no Maranhão, encontravam na

incidia, sobretudo, no aumento de impostos, fosse reconsiderada à luz da urgência da matéria (CEDI-CD, ano/localização: 1833 , maço 33, pasta 1 , ofício de 30/março/1830).

316 (Arquivo Nacional) As Juntas Governativas e a Independência, Rio de Janeiro, Arquivo Nacional, Conselho Federal, 1973, v.1, ofício de 28/fevereiro/1824, p. 140-7.

${ }^{317}$ Idem, ofício de $19 /$ maio/1824, p. 162-3. A dimensão do conflito pode ser mais bem mapeada na correspondência da Junta não editada nessa publicação e constante no ANRJ, Negócios de Províncias, IJJ ${ }^{9}$ 553.

${ }^{318}$ Idem, ofício de 12/maio/1824, p.165. 
definição dos espaços institucionais de jurisdição uma das esferas privilegiadas de sua materialização ${ }^{319}$.

Como se viu acima, desde a instalação da Assembléia Geral em 1826, os deputados colocavam em pauta a necessidade de medidas que pudessem conter a autoridade dos presidentes de Províncias, bem como dos comandantes de armas. Naquele ano, o cearense José Gervásio de Queiróz Carreira ${ }^{320}$ fazia uma indicação sobre a necessidade de se marcar muito claramente as atribuições dos dois cargos para se evitarem os "muitos males e excessos de jurisdição" que estariam ocorrendo ${ }^{321}$. Dois anos depois, o mesmo deputado voltaria a tratar da temática quando se discutia quais autoridades deveriam ser estabelecidas no Rio Negro pelo projeto que o elevaria à condição de Província. Diante de uma emenda proposta por Feijó para que não houvesse nem comandante de armas nem Conselho de Governo, Queiróz Carreira voltaria a argumentar que o problema era a inexistência de leis para as autoridades civis e militares, sendo seus conflitos a "mola de todas as desordens". Alguns deputados então atribuíram a culpa dos conflitos nas Províncias aos comandantes, enquanto outros levantaram os excessos dos presidentes. Os pernambucanos Holanda Cavalcanti de Albuquerque e Manoel Caetano de Almeida e Albuquerque discorreram sobre as arbitrariedades dos "verdadeiros herdeiros dos capitães-generais", ou seja, os comandantes, que lutariam para manter a antiga "preponderância e a principal ingerência na administração pública" que os militares tinham no "antigo governo". José Custódio Dias, por seu lado, incriminou os presidentes dos "maiores despotismos" e de "absolutismo" 322. A emenda não foi aprovada, mas o problema ficava no ar.

Ainda em 1826, chegava aos deputados um ofício do presidente da Província da Bahia acusando o recebimento de uma resposta do ministério a uma consulta feita pelo seu Conselho de Governo. Nesta teria se confirmado uma forma de entendimento da lei de 20

\footnotetext{
${ }^{319}$ Um outro exemplo pode ser visto num ofício encaminhado pela Junta Provisória do Ceará, no ano de 1822, em que seus membros informavam que haviam alterado a lei de 20 de outubro de 1823 para incluir o comandante de armas como membro da mesma Junta. A crise política então vivida na Província justificava a "urgência" com que tinha sido tomada a decisão, cuja envio ao ministério sempre ficavam "à dependência de morosas requisições". As Juntas Governativas e a Independência, ofício de 21/novembro/1822, p. 320. Também para Santa Catarina, sua Junta acusava o Comandante de Armas de tomar medidas sem consultar o Governo em ofício ao governo em 30 de dezembro de 1823 (ANRJ, Negócios de Províncias, IJJ $^{9} 439$ )

${ }^{320}$ José Gervásio de Queiróz Carreira era natural do Ceará, oficial do Exército (major). Tomou assento como deputado na Assembléia Geral durante a $1^{a}$ legislatura (1826-29) como suplente do deputado Pedro José da Costa Barros, o qual havia sido nomeado senador (abril/1826).

${ }^{321}$ APB-CD (1826), t. 1, sessão de 20/maio, p.104-5.

${ }^{322}$ Idem (1828), t.2, sessão de 02/junho, pp.10-15.
} 
de outubro: o presidente seria a "autoridade governante nas Províncias", e o comandante de armas seu subordinado ${ }^{323}$. Por avaliar que ainda faltava um regimento que delimitasse os limites de ação do segundo, o mesmo presidente - na ocasião João Severiano Maciel da Costa, o Marquês de Queluz - sugeria a adoção provisória da "Carta Régia e Instruções dirigidas a D. Fernando José de Portugal”, quando este governara a Província em 1799 (junto seguia uma transcrição do documento). Por mais que a petição não fosse aceita, ela deixava claro o entendimento da normalização como forma de controle das arbitrariedades cometidas.

Outra constante era os ataques aos abusos de autoridade por parte dos comandantes de armas, também típicos do conturbado jogo político vivido nas Províncias. Em 1827, era a vez do presidente de Santa Catarina, Francisco de Albuquerque Melo, acusar aquele que exercia o cargo militar na Província de "julgar-se absolutamente independente" de suas ordens. Julgava-o "incapaz" para o desempenho da função pelos "miseráveis raciocínios, e a hermenêutica de suas interpretações acerca da responsabilidade das ordens que recebe", desprezando-as junto com as leis. Dois anos antes, no Ceará, a falta de entendimento entre as autoridades civil e militar na Província teria feito que o comandante mandasse reunir a tropa como forma de pressão sobre o presidente ${ }^{324}$. Este, Antônio Sales Nunes Belfort, escrevia ao Rio de Janeiro que o primeiro também teria tentado "desanimar os conselheiros a fim de se não prestarem à reunião do Conselho", "interrompendo o livre exercício da administração pública confiada ao chefe da Província"325. Essa era a mostra mais cabal do perigo que se corria nas localidades se seus comandante decidissem se valer das tropas sob seu comando.

Presidentes e comandantes discordavam muitas vezes no tocante ao método de ação com a força militar. Um exemplo revelador dessa tensão ocorreu no Rio Grande de São Pedro, em plena guerra pela Província Cisplatina. Foi quando Francisco de Paula Rozado, à frente das forças militares, propôs que se elegessem alguns "homens de confiança" para reunir "os pardos e pretos livres" na formação de batalhões, e que se convidasse os fazendeiros a "libertarem seus escravos" que tomassem praça ${ }^{326}$. A resposta do presidente

\footnotetext{
${ }^{323}$ CEDI-CE, ano/localização: 1826, lata 26, maço 33, pasta 1, PDID 514, ofício de 28/janeiro/1826.

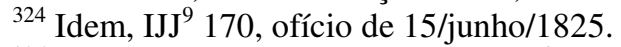

${ }^{325}$ ANRJ, Negócios de Províncias, IJJ ${ }^{9} 439$, ofício de 17/dezembro/1827.

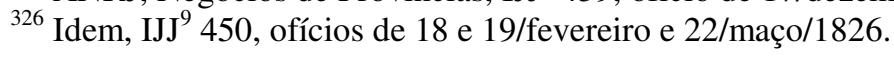


José Egídio Gordilho de Barbuda veio logo no dia seguinte e era contundente: afirmava que inexistia "caráter de urgência" na situação - pois que tropas mandadas pelo Imperador estavam a caminho da fronteira - não havendo, portanto, motivos para "medidas aterradoras", cujas conseqüências "queira os Céus" não viessem a experimentar. Logo depois, encaminhou um ofício ao ministério em que acusava o comandante de armas de propor "doutrina perigosíssima e punível", além de querer "seduzir as Tropas" para voltálas contra o Governo da Província.

Diante de uma ameaça de "projetada revolução" por parte da tropa estacionada na cidade do Recife em 1827, a falta de entendimento entre presidentes e comandantes se faria novamente presente ${ }^{327}$. Procedeu-se a um Conselho de Investigação sobre o caso, e o comandante de armas decidiu pela feitura de um Conselho de Guerra. Enquanto isso, o ouvidor do crime foi noticiado para que realizasse uma devassa para o caso. Diante da "perplexidade" deste último, que considerava deverem optar por um dos procedimentos citados, o comandante respondera que manteria o dito Conselho já convocado, e que o faria com a maior brevidade possível. Assim foi decidido. No entanto, dias depois era a vez de José Carlos Mayrink Ferrão, como autoridade presidencial, noticiar ao Rio de Janeiro que o Conselho de Guerra decidira que o negócio não pertencia ao "foro militar", mas nem por isso os papéis da investigação haviam sido remetidos ao ouvidor; acusava-se o comandante dessa omissão, o qual dizia estar à espera de "ulteriores determinações de Sua Majestade Imperial".

Como vimos, o papel central que desempenhavam os presidentes na administração das Províncias, extensível também aos seus Conselhos privativos, fazia que sua autoridade, de alguma forma, fosse envolvida nos turbilhões dos conflitos locais ${ }^{328}$. A própria normalização de sua função permitia que eles pudessem deliberar sobre assuntos urgentes para depois encaminhá-los à aprovação das instâncias imperiais no Rio de Janeiro. Um exemplo de como isso fazia que, na prática, eles extrapolassem seus espaços de jurisdição pode ser visto em 1827, quando da discussão na Câmara dos Deputados acerca das ações do

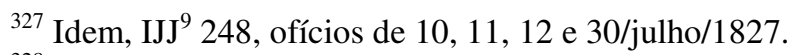

328 Daí serem comuns as acusações de "despotismo" e "arbitrariedades" recorrentemente feitas aos presidentes; caso de uma devassa feita em São Luís do Maranhão, no ano de 1826, contra "facciosos" que teriam por intenção depor o presidente Pedro José da Costa Barros. Nela, foram encontrados pasquins que atacavam diretamente sua autoridade, comparando-o a "Nero" e, ao mesmo tempo, dando vivas "à Constituição e ao Imperador”. ANRJ, Negócios de Províncias, IJJ ${ }^{9}$ 556, 29/maio/1826.
} 
presidente da Província do Mato Grosso ${ }^{329}$. Um parecer desaprovava a conduta deste que, em nome de premente necessidade, criara um Arsenal da Marinha em Cuiabá, definido seu regulamento e oficiais; mesmo assim, e em razão de vantagens que daí poderiam resultar, o parecer também propunha que se tomasse uma "resolução legislativa para conservação e regime" do dito Arsenal. O texto foi aprovado, o que significava dizer que, por mais arbitrária que fosse a atitude, a ação do presidente acabaria por se transformar em lei.

A prática se repetiria em muitos outros casos, encontrando-se dentro dos parâmetros daquilo que então era previsto como "constitucional”. Isso equivale dizer que a valorização da esfera administrativa na garantia das necessidades locais e na luta contra as arbitrariedades, como temos visto, foi uma das vertentes mais importantes na prática dos valores da nova ordem. Deve-se afirmar, portanto, que os novos governos provinciais puderam ser implementados porque permitiram a existência de uma esfera de atuação deliberativa das várias autoridades locais.

Um caso ocorrido nas Alagoas no ano de 1827 é lapidar nesse sentido ${ }^{330}$. No início daquele ano, o vice-presidente em exercício, Tertuliano de Almeida Lins, decidiu pelo “emprazamento" (convocação) do ouvidor da Província, Rodrigo de Souza da Silva Pontes, por considerar que o mesmo sempre "relutara" no cumprimento das ordens que expedia. Diante da negativa do ouvidor em comparecer diante de sua autoridade, justificada pela incumbência de dirigir independentemente a justiça, Almeida Lins aprovou sua prisão e envio ao Rio de Janeiro, por "desobediência ao Imperador". A situação entrou em um impasse, e tudo indica que o comandante de armas tenha se alinhado com o ouvidor contra o vice-presidente. Depois de três sessões extraordinárias do Conselho do Governo, decidiuse "colocar em perpétuo silêncio os acontecimentos" com a retirada da ordem de prisão sobre Silva Pontes, sob a alegação que o fato poderia gerar "revoltas, partidos e tumultos populares". Devido ao caso, a Câmara da Província também chegou a enviar um ofício ao ministério, solicitando como primeira providência um "presidente ilustrado e uma clarificação da independência da Justiça". Dessa forma, o caso ficou resolvido na própria esfera da administração, ao mesmo tempo em que se apelava à normalização como contrapartida da nova legitimidade institucional. Não foi à toa que os vários ofícios sobre a questão foram parar na Câmara dos Deputados.

${ }^{329}$ APB-CD (1827), t. 2, sessão de 09/junho, 88-9. 
Não há dúvida de que um dos saldos da atuação das duas primeiras legislaturas brasileiras foi a definição de um arranjo político-constitucional para a criação e viabilização dos governos das Províncias e de sua relação com a Corte; um arranjo que, a duras penas, foi efetivamente implementado nesses anos. Também não há duvida de que o mesmo arranjo esteve, em suas origens, marcado por um caráter, do ponto de vista da configuração de suas instituições políticas, eminentemente liberal, e que a própria monarquia teve então que ser recriada em novos moldes.

As discussões parlamentares aqui analisadas evidenciaram que a tendência de fortalecimento das esferas locais de poder foi uma das soluções encontradas para que as "partes" pudessem ser formalmente integradas ao "todo" do novo Império. Isso significa dizer que, em vista da desarticulação interna dos espaços americanos que predominara nos séculos de colonização portuguesa, o estabelecimento de novos vínculos de uma unidade, agora pensada, pelos primeiros legisladores brasileiros, tendeu a investir na autonomia dos agentes e órgãos como forma possível de fortalecimento da ação do Estado. Essa era a aposta.

Nesse sentido, a prática da Constituição e os valores constitucionais nos diversos contextos locais concentraram-se na consolidação dos governos provinciais como verdadeiros guardiões da garantia dos “direitos dos cidadãos”, à medida que eles passariam a atuar como esferas de representação de seus interesses. Como se pôde analisar, a partir do breve mapeamento do funcionamento dos dois Conselhos provinciais aqui observados, a ampla jurisdição que ambos exerciam no âmbito da administração lhes fornecia um espaço de jurisdição e deliberação de conflitos que, comum no funcionamento típico colonial, serviram de experiência na construção dos caminhos modernos a serem trilhados pelo Império do Brasil. Talvez por essa razão a idéia de que a estabilidade vinha das instituições coube tão bem na boca de muitos dos protagonistas da época.

${ }^{330}$ CEDI-CD, ano/localização: 1827, lata 9, PDID 825, vários ofícios. 


\section{Capítulo 3}

\section{A reforma da Constituição e a afirmação definitiva da Província}

Em junho de 1830, Joaquim José Pinheiro de Vasconcellos, então presidente da Província de Pernambuco, informava ao ministro José Joaquim Carneiro de Campos (Marquês de Caravelas) que recebera, no dia anterior, a informação de que alguns indivíduos na Vila de Goiana haviam "queimado a Constituição, na ocasião em que faziam

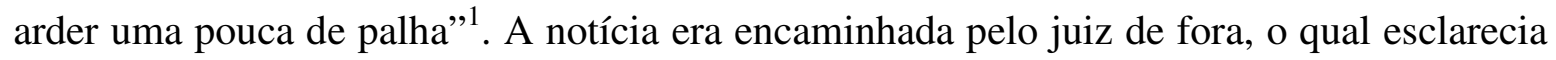
as condições do acontecido e fornecia uma lista com o nome de todos os envolvidos. Segundo ele, tratava-se de "uns poucos Europeus, acompanhados de outros, que ao todo excediam de vinte, pela maior parte taverneiros caixeiros" que, mesmo tendo incitado uma desordem, prontamente obedeceram a suas ordens de se calarem e se recolherem a suas casas $^{2}$. Tendo aberto devassa para o caso, afirmava o juiz que os acusados estavam foragidos e que, apesar do acontecido, "em nada $\mathrm{t}$ [inha] sido alterada a tranqüilidade pública”. O presidente de Província, no mesmo dia em que relatava o fato em correspondência ao Rio de Janeiro, também escrevia ao juiz de fora para que tomasse "o maior cuidado em providenciar para que essa tranqüilidade continu[asse] sem alteração”. E completava:

“E posso asseverar a V. S. ${ }^{\text {a }}$ que nada interessa mais à Sua Majestade o Imperador, e à Nação, do que a manutenção da tranqüilidade Pública, e a religiosa observância da Constituição, que felizmente nos Rege",3.

O que, de início, chama a atenção é que, mesmo sendo o caso de praticamente nenhuma importância em termos de um princípio de sublevação, o presidente imediatamente enviouo para conhecimento do governo imperial. Parte da explicação, para além do esforço do “delegado do Imperador” em prestar qualquer informação de ameaça à ordem, está no fato

\footnotetext{
${ }^{1}$ Arquivo Nacional (ANRJ), Negócios de Províncias, IJJ ${ }^{9}$ 249, ofício de 26/junho/1830.

${ }^{2}$ Idem, ofício de $15 /$ junho/1830.

${ }^{3}$ Idem, outro ofício de 26/junho/1831.
} 
de os chamados "desordeiros" terem atentado contra a Constituição. Nesse sentido, o acontecido não foi entendido como menor num momento marcado por uma profunda instabilidade política, no qual a "Lei Fundamental" já havia adquirido um status de símbolo, tanto da legitimidade de um regime que se encontrava em um dos seus momentos mais críticos, como enquanto propulsor de mudanças políticas em nome dos direitos dos cidadãos. Era assim que o discurso de defesa do escudo da "sagrada égide da Constituição" ${ }^{\prime 4}$ servia a diversos credos e práticas.

Desde a instalação dos trabalhos parlamentares que a defesa da Constituição era presença constante nos pronunciamentos dos deputados. Nos primeiros dias de funcionamento da Câmara, quando se discutia acerca das Comissões que deveriam ser criadas, propôs-se a instauração de uma que teria como finalidade a "guarda da Constituição",5. Foi José Custódio Dias quem mais enfaticamente defendeu a proposta, sob o argumento de que a Constituição estaria "em pedaços", "quase reduzida a pó", e que a eles caberia defendê-la "antes que ela caí[sse] de todo"”. A idéia foi aprovada e essa comissão, incumbida de avaliar as infrações aos princípios constitucionais, ficaria inclusive isenta de cuidar das leis regulamentares. Passada uma semana, era a vez de José Antonio da Silva Maia fazer uma indicação ${ }^{7}$ para que se cuidasse especificamente do artigo 173 da Carta, o qual marcava que no início das sessões da Assembléia se examinaria se a Constituição vinha sendo bem observada. Essa também foi aprovada e, dessa forma, os representantes reforçavam seu papel de seus primordiais defensores.

E assim foi em 1831, quando a construção de um consenso acerca da reforma da Constituição encobriu posicionamentos muito diferentes em relação à sua contundência. Da mesma forma que a feitura inicial da Constituição, entre os anos de 1823-1824, fora marcada por violentas disputas políticas, o mesmo se passaria neste momento com a diferença que, do ponto de vista do funcionamento institucional, as bases jurídicas para uma ordem em moldes tipicamente modernos já tinham sido aprovadas e, mal ou bem, a depender das localidades, implementadas. Obviamente que a saída de cena do monarca

\footnotetext{
${ }^{4}$ Metáfora utilizada por Francisco de Carvalho Paes de Andrade na proclamação que fez aos pernambucanos quando foi escolhido para reger a Província, após a Abdicação. ANRJ, Negócios de Províncias, IJJ ${ }^{9}$ 250, documento de 12/outubro/1831.

${ }^{5}$ Annaes do Parlamento Brasileiro. Câmara dos Deputados. Sessão de 1826, Rio de Janeiro, Typographia do Imperial Instituto Artístico, 1874 [APB-CD (1826)], t. 1, sessão de 9/maio, p.33.

${ }^{6}$ Idem, p.34.
} 
representava outra diferença brutal, a qual ensejou a possibilidade real de transformação radical do regime, como se observa tanto no posicionamento dos representantes como nos projetos surgidos no âmbito da opinião pública. Deste modo, os anos que se seguiram foram intensos no que toca à discussão sobre o ordenamento político do Império, alimentada pela pressão oriunda da mobilização da população que, em várias localidades, tomaria as ruas em nome de transformações das mais diversas naturezas, ocasionando desordens e motins. Tratava-se, sem dúvida, de uma das faces do conflituoso e violento processo que, no Brasil, marcou a construção de um Estado liberal.

No Império do Brasil, o saldo desse embate do ponto de vista da normalização estatal implicou, em 1834, na criação definitiva de uma esfera provincial - a qual já tinha sido esboçada no Primeiro Reinado - e na supressão do Conselho de Estado. A questão fundamental continuaria a ser, em um esforço de racionalização, manter a tendência de privilegiar o funcionamento dos governos das Províncias concebidos como instâncias reguladoras da estabilidade política e social, além de responsáveis pela administração pública a qual incluía a jurisdição dos "povos”. Daí ter sido sintomático que o discurso da autonomia provincial aparecesse, não poucas vezes, desarticulado em relação à ampliação da participação da população nos canais de representação, mas atrelado à defesa de um autogoverno local.

\subsection{A caminho da reforma constitucional}

Na Câmara, um dos primeiros deputados a defender uma reforma para a Carta de 1824 foi o baiano Antônio Ferreira França ${ }^{8}$, em maio de $1831^{9}$. A discussão girava sobre a necessidade de nomeação de um presidente e de um Conselho Geral para o Rio de Janeiro, quando ele propôs "federar as Províncias", pois que este era "o tempo" que a "fortuna" lhes teria dado para isso. Contrapondo as opiniões de alguns de seus colegas que falavam em nome dos "muitos perigos que poderiam resultar de alterar-se a Constituição" naquele momento, argumentava:

\footnotetext{
${ }^{7}$ Idem, sessão de $17 /$ maio, p. 71.

${ }^{8} \mathrm{O}$ deputado já havia sido deputado pela Bahia na Assembléia Constituinte de 1823 , e também na primeira legislatura (1826-1829).

9 APB-CD (1831), t. 1, sessão de 5/maio, p.11.
} 
"Não deixemos de tocar na constituição por aqueles meios que ela manda. Temos para fazer alterações convenientes um intervalo de 13 anos que parece filho da fortuna do Brasil (deixem-mo assim dizer); bem que eu, Senhor Presidente, não o desejava, a falar a verdade, por meio de tanto perigo. A mim, parece-me que vamos correndo com o impulso de uma tempestade surda, e que se não vê, e por isso mesmo os pilotos da nau do estado devem refletir bem que o perigo é tanto maior quanto os escolhos são encobertos, e não podem ser conhecidos senão depois de cair sobre eles. É preciso, portanto, tocar na constituição para torná-la perfeita, mas pelo modo que ela mesma diz" ${ }^{\prime \prime}$.

O caminho era o da legalidade, ou seja, a mudança deveria ser feita da forma como estava prevista na Carta, mas a proposta era audaciosa, sendo, portanto, alvo de uma salva de "apoiados" por parte de alguns deputados.

No dia seguinte, foi a vez de José Cesário de Miranda Ribeiro, deputado por Minas Gerais $^{11}$, apresentar um requerimento para a nomeação de uma comissão especial incumbida de propor as reformas constitucionais convenientes com os artigos 175, $176 \mathrm{e}$ 177 da Carta de $1824^{12}$. Nestes estava estabelecido que uma reforma só poderia ser aprovada desde que, passados quatro anos do juramento da Constituição, uma proposição por escrito fosse lida e aprovada na Câmara dos Deputados. A partir daí, iniciar-se-ia a discussão de quais artigos da "Lei Fundamental" deveriam ser reformulados; seu resultado seria sancionado na forma de uma lei regulamentar após sua aceitação também por parte dos senadores, aprovando-se, assim, o processo de feitura da reforma. Esta, no entanto, só poderia ser efetivamente discutida no início da legislatura seguinte (vale dizer que cada legislatura era de quatro anos, da mesma forma que os mandatos dos deputados), pois que os representantes seriam eleitos já com “especial faculdade” para a pretendida alteração.

\footnotetext{
${ }^{10}$ Idem.

${ }^{11}$ José Cesário de Miranda Ribeiro (1792-1856) era natural de Ouro Preto. Estudou Direito na Universidade de Coimbra. Foi desembargador e elegeu-se deputado para a Assembléia Geral nas duas primeiras legislaturas (1826-29 e 1830-33), e também na $4^{a}$ (1838-41). Exerceu a função de presidente da Província de São Paulo (1835-6). Também ocupou o cargo de ministro do Supremo Tribunal de Justiça, e de conselheiro de Estado. Foi escolhido senador em 1844 por Minas Gerais. Obteve o título de Visconde de Uberaba.

${ }^{12}$ APB-CD (1831), t. 1, sessão de 6/maio, p.13.
} 
Entre os deputados, os que se mostraram mais temerosos da proposta de Miranda Ribeiro foram Lino Coutinho e Luiz Francisco de Paula Cavalcanti de Albuquerque ${ }^{13}$, que colocaram na pauta o temor de que um projeto de reforma promovesse a desagregação das Províncias. O primeiro declarava que não via possibilidade de se "conservar a Constituição na forma em que se acha[va]m" as "idéias geralmente concebidas em todo o Império"14. O segundo pedia para que se levasse em consideração que a Constituição era "o símbolo da união do Brasil", e que convinha devotar o "maior respeito à lei fundamental" 15 . Mas ambos deixavam explícito que a apoiariam se fossem adotadas as fórmulas da "Lei Fundamental". Nesse momento, o autor do requerimento defendeu que, diante do "espírito público" favorável à mudança, eles mostrariam a seus "constituintes" como estariam dispostos a "introduzir todos os melhoramentos que as circunstâncias exigirem, sem que para isso sejam necessárias desordens”. A matéria foi aprovada, sendo eleitos para a comissão especial o próprio José Cesário de Miranda Ribeiro, Francisco de Paula Souza e Mello $^{16}$ e José da Costa Carvalho ${ }^{17}$.

Dias depois era a vez de Paula Souza fazer um eloqüente discurso a favor da reforma ${ }^{18}$. A justificativa era a possibilidade de entregar, "à posteridade, o Brasil, venturoso e livre", sem passar "pelo pungente dissabor de ver desmanchada uma obra" que tanto thes custara até o momento. Valorizava assim o trabalho dos deputados que, desde a instalação da Câmara em 1826, teriam propiciado a difusão de um "espírito de liberdade" por meio da ação legislativa para a prática da Constituição, a qual seria a fonte de "toda a prosperidade" do Brasil. Chegava a argumentar que a verdadeira "revolução" já teria se dado pelos atos das duas primeiras legislaturas, e que o mesmo valia para a "federação", que já encontraria suas bases lançadas:

\footnotetext{
${ }_{13}^{13}$ Ambos deputados cumprindo seu segundo mandato, o primeiro pela Bahia e o segundo por Pernambuco.

${ }_{15}^{14}$ APB-CD (1831), t. 1, sessão de 6/maio, p.13.

${ }^{15}$ Idem, p. 14.

${ }^{16}$ Deputado por São Paulo, o mesmo já ocupara uma cadeira na primeira legislatura (1826-9). Foi também um dos redatores da Lei da Regência para o ano de 1831.

${ }^{17}$ José da Costa Carvalho (1796-1860) era natural da Bahia. Formou-se em Leis na Universidade de Coimbra e, de volta ao Brasil em 1821, foi nomeado juiz de fora da cidade de São Paulo. Ocupou a cadeira de deputado pela sua Província natal na Assembléia Constituinte de 1823, e na Assembléia Geral na $1^{\mathrm{a}}$ e $2^{\mathrm{a}}$ legislaturas (1826-1831). Foi eleito membro da Regência Trina Permanente, junto com Francisco de Lima e Silva e João Braulio Muniz. Em 1833, era nomeado diretor da Faculdade de Direito de São Paulo. Posteriormente, seria novamente deputado na Assembléia Geral na $4^{\mathrm{a}}$ legislatura, iniciada em 1838, agora pela Província de São Paulo, onde se fixara definitivamente. Em 1839, foi escolhido senador pela Província do Sergipe. Ocupou o cargo de ministro do Império entre os anos de 1848 e 1852. Recebeu o título de Marquês de Monte Alegre.

${ }^{18}$ APB-CD (1831), t. 1, sessão de 14/maio, p.38-9.
} 


\begin{abstract}
"Bastou a lei dos juízes de paz, das câmaras municipais e regimento dos conselhos gerais para preparar os grandes resultados que depois tiveram lugar. O Brasil em virtude dessas leis ficou organizado democrática e federalmente; as câmaras municipais são verdadeiros conselhos federais; os conselhos são verdadeiras federações" $"$.
\end{abstract}

Para ele, a reforma somente completaria essa "obra" para melhor satisfazer as necessidades do Império. Era claramente um discurso de moderação, em que se reiterava o papel primordial do Legislativo e das leis, com repúdio a quaisquer "manifestações mais violentas".

A questão da "federação", ou melhor dizendo, das atribuições que caberiam às Províncias e a Corte estavam, assim como o tema da reforma, na ordem do dia. Isso não era à toa já que, como observamos, a prática legislativa ia no sentido de definir as esferas de atuação dos órgãos provinciais em relação ao governo central, sobrevalorizando as instituições como forma de manter a estabilidade nas várias localidades. Nestes termos, fez Manoel Maria do Amaral $^{20}$ um requerimento para o regimento da cota com que cada Província do Império deveria concorrer para as despesas gerais, haja vista estar em pauta, desde o ano anterior, a discussão sobre o Orçamento $^{21}$. O mesmo deputado afirmava oporse "fortemente ao sistema de centralização de finanças" que, segundo ele, procurava-se introduzir, por parecer-lhe "nocivo tanto às Províncias em particular como ao Império em geral" $^{, 22}$. Propunha, então, que se classificasse as despesas nacionais e as provinciais com a declaração da importância de umas e outras, além da marcação da cota das Províncias ao governo geral. Com pouca discussão, foi aprovado que a matéria era "constitucional e justíssima".

A questão colocada pelo deputado Amaral voltaria à cena e provocaria longa discussão quando teve início o debate do projeto de lei que fixaria a receita e despesa para o

\footnotetext{
${ }^{19}$ Idem.

${ }^{20}$ Manoel Maria do Amaral (1789-1879) era natural da Bahia. Formado em Direito, atuava como professor da área. Ocupou a cadeira de deputado na Assembléia Geral pela sua Província natal por seis legislaturas seguintes, de 1830 a 1851 , com algumas interrupções.

${ }^{21}$ APB-CD (1831), t. 1, sessão de 17/maio, p.47.

${ }^{22}$ Idem.
} 
ano financeiro de $1832-3^{23}$. Logo no artigo $1^{\mathrm{o}}$, o projeto previa que as despesas públicas seriam divididas em "gerais da nação e provinciais", sendo que as primeiras continuariam a ser ordenadas pelo ministro da Fazenda e as segundas passariam a ser reguladas pelos presidentes de Província. O então ministro Bernardo Pereira de Vasconcellos fez parte das sessões que trataram do assunto.

O primeiro a fazer críticas ao artigo foi o padre Venâncio Henriques de Resende ${ }^{24}$, contrário a que se deixasse aos presidentes a regulação das finanças. $\mathrm{O}$ argumento era claro: a medida, além de "impraticável apresentava absurdo" pela inexistência de uma outra "autoridade que orce a receita e fixe a despesa" pois que, pela Constituição, os Conselhos Gerais não poderiam fazê- $10^{25}$. Afirmava que, dessa forma, ficariam "os presidentes em Conselho com as rédeas soltas", sem “inspeção ou físcalização", enquanto os "ministros de Estado estavam sujeitos a ser acusados na Câmara dos Deputados, e debaixo da vigilância dela”. Na sessão seguinte, Resende foi taxativo de que a proposta só seria aceitável com a reforma da Constituição e a atribuição de poder legislativo aos citados Conselhos ${ }^{26}$.

Nestes termos, o deputado pernambucano, propondo o fortalecimento da autoridade do órgão eletivo local perante a do presidente, seguia a mesma lógica que predominara na anterior discussão sobre a regulamentação dos Conselhos Gerais, aproveitando o momento para defender que as Províncias tivessem poder para legislar em função de seus interesses. Foi seguido de perto por Honório Hermeto Carneiro Leão ${ }^{27}$ e Diogo Duarte Silva ${ }^{28}$, eleito por Santa Catarina. Estes atacaram o artigo com o argumento de que ele converteria o

\footnotetext{
${ }^{23}$ Idem, sessão de 28/julho, p. 277.

${ }^{24} \mathrm{O}$ deputado já havia ocupado uma cadeira na Assembléia Constituinte de 1823 pela mesma Província de Pernambuco, sendo reeleito para a legislatura seguinte (iniciada em 1834).

${ }^{25}$ APB (1831), t.1, sessão de 28/julho, p. 277.

${ }^{26}$ Idem, sessão de 29/julho, p. 281.

${ }^{27}$ Honório Hermeto Carneiro Leão (1801-1856) era natural de Jacuí, Minas Gerais. Bacharelou-se em Direito pela Universidade de Coimbra. De volta ao Brasil, em 1826, exerceria vários cargos públicos. Além disso, era proprietário rural. Elegeu-se deputado para a Assembléia Geral, por sua Província natal, em três legislaturas consecutivas (1830-1841). Foi presidente da Província do Rio de Janeiro (1841-3) e de Pernambuco (184950). Em 1843, foi escolhido senador. Exerceu a função de ministro da Justiça e da Fazenda, foi presidente do Conselho de ministros do XII Gabinete do $2^{\circ}$ Império e também Conselheiro de Estado (o que ficou conhecido como "ministério da conciliação"). Em 1851, teve papel destacado nas negociações que se deram entre o Império do Brasil, Uruguai e Paraguai em apoio à queda de Rosas no Rio da Prata. Obteve o título de Marquês do Paraná, depois agraciado com o de Visconde.

${ }^{28}$ Diogo Duarte Silva (1774-1857) era natural de Setúbal, Portugal. Foi inspetor da Tesouraria da Fazenda de Santa Catarina. Por essa Província, ocupou a cadeira de deputado na Constituinte de 1823, e na Assembléia Geral em todas as três primeiras legislaturas (1826-37).
} 
presidente em "sultão ou bachá" 29 , e que se fosse estabelecido cumpriria dar "mais ingerência nas despesas aos Conselhos Gerais, para não ficar a sua determinação arbitrária cometida à autoridade administrativa" ${ }^{, 30}$. Vasconcellos, como ministro, também foi da mesma opinião.

Quanto à divisão das despesas e receitas entre gerais e provinciais, os termos do debate mostram o quão espinhosa era a questão. Não apenas pelo seu princípio, aprovado por muitos dos deputados, mas pela forma como ela deveria ser estabelecida. Nestes termos, foi novamente Maria do Amaral que, sem contestar a divisão, defendeu uma "perfeita igualdade no sistema de imposição, não concorrendo umas Províncias com muito e outras com pouco" ${ }^{31}$. Criticava em especial a posição de São Paulo e Minas que, na sua ótica, teriam papel muito confortável nas suas contribuições ao governo central em relação a Bahia, Pernambuco, Maranhão e Rio de Janeiro que, segundo ele, "sustenta[riam] o Império". Para que se tenha dimensão das implicações do problema, o mesmo deputado afirmaria, duas sessões depois, estar disposto a "concorrer para a desunião" se sua Província estivesse em "estado de aumento e prosperidade" e se isso fosse de acordo com o seu interesse, "porque isto era da natureza das coisas",32. Embora tenha esclarecido que, no momento, não era esse o caso, a mensagem estava dada.

$\mathrm{Na}$ continuação da discussão do artigo, as posições continuaram controversas. Joaquim Manuel Carneiro da Cunha ${ }^{33}$, deputado pela Paraíba, falou contra a matéria, considerando-a injusta com as Províncias menores, já que as maiores seriam “como grandes rios que tinham engrossado suas águas com os riachos afluentes"34. Embora afirmasse ter sido sempre um defensor da "federação", argumentava que agora não seria o momento de lembrá-la. Custódio José Dias ${ }^{35}$, representante de Minas Gerais, e Cândido Batista de Oliveira $^{36}$, do Rio Grande de São Pedro, defenderam posições semelhantes. O primeiro

\footnotetext{
${ }^{29}$ APB (1831), t.1, sessão de 28/julho, p. 277, discurso de Diogo Duarte Silva.

${ }^{30}$ Idem, discurso de Honório Hermeto Carneiro Leão.

${ }^{31}$ Idem, sessão de 29/julho, p. 283.

${ }^{32}$ Idem, t.2, sessão de 02/agosto, p. 13.

33 Carneiro da Cunha já havia ocupado a cadeira de deputado pela mesma Província na Assembléia Constituinte de 1823.

${ }^{34}$ Idem, t.2, sessão de 3/agosto, p. 16.

${ }^{35}$ Custódio Dias havia ocupado a cadeira de deputado na Assembléia Constituinte de 1823, e também na primeira legislatura de 1826-9.

${ }^{36}$ Cândido Batista de Oliveira (1801-1865) era natural de Porto Alegre. Estudara Matemática na Universidade de Engenharia Politécnica e, além de professor e engenheiro, ocuparia vários cargos públicos. Entre eles, foi diplomata, ministro da Fazenda e da Marinha, presidente do Banco do Brasil e conselheiro do Estado. Ocupou
} 
sustentou que a "divisão da receita geral e provincial" iria "produzir grandes inconvenientes e nenhumas vantagens", já que seria "impossível estender uma igualdade entre as Províncias do interior e as marítimas" ${ }^{37}$. O segundo atacou o projeto por considerar que ele deixava "as despesas provinciais, ao arbítrio completo e independente dos presidentes em contradição à lei fundamental"; lei esta que seria "federal", mas não na "administração da Fazenda". O baiano Ernesto Ferreira França ${ }^{38}$, por sua vez, defendeu o artigo em nome do "federalismo" como não só "reconhecido" pela Carta de 1824, mas favorável aos "interesses particulares distintos", e que caberia aos Conselhos Gerais marcar as despesas próprias de cada localidade ${ }^{39}$.

A leitura das exposições deixa clara uma questão: algumas Províncias poderiam ganhar, mas outras poderiam perder muito com a divisão de receitas proposta. $\mathrm{O}$ grande número de posicionamentos contrários, no entanto, não impediu a aprovação da primeira parte do artigo que propunha a divisão, e que, no ano seguinte, 1832, viraria lei; a concepção de que seriam os presidentes os responsáveis pela administração do orçamento local foi, ao contrário, negada. Uma última fala de Vasconcellos confirmou, com todas as letras, a opinião de que a autoridade presidencial só poderia ter esse poder depois de uma verdadeira alteração na Constituição e, portanto, do fortalecimento nas Províncias de uma outra autoridade perante a executiva ${ }^{40}$. Contra essa questão praticamente ninguém se colocou, pois tanto a idéia de reforma tinha maioria como já estava no horizonte imediato dos deputados. Vale dizer que a discussão do orçamento continuaria de forma intensa, sendo a principal causa da prorrogação da sessão daquele ano até outubro.

Uma confirmação de que o clima do plenário estava contagiado pela expectativa de mudança foi a proposta de Antônio Ferreira França, em junho de 1831. Nessa ocasião, o deputado baiano defendeu que o "governo do Brasil fosse vitalício na pessoa do Imperador D. Pedro II e depois temporário na pessoa de um presidente das Províncias confederadas no

\footnotetext{
a cadeira de deputado pela sua Província natal na $2^{a}$ legislatura (1830-3) e também no ano de 1834 . Foi escolhido senador em 1849.

${ }^{37}$ Idem, t.2, sessão de 3/agosto, p. 17.

${ }^{38}$ Ernesto Ferreira França representava, nessa legislatura (1830-3), a Província de Pernambuco. Na legislatura seguinte, a $3^{\mathrm{a}}$ (1834-7), ocuparia a cadeira de deputado pela sua Província natal, a Bahia (dados biográficos no capítulo anterior).

${ }^{39}$ Idem, t.2, sessão de 3/agosto, p. 18.

${ }^{40}$ Idem, pp.19-20.
} 
Brasil" 41 . A argumentação era que, dessa forma, os deputados deixariam livre à "vontade da geração futura" a escolha do governo que "melhor lhes convier", e que, pelo tamanho do Império, era "indispensável” serem as Províncias federadas. A Câmara rejeitou a medida, com a alegação de que não se tratava de objeto de deliberação. Deve-se lembrar que fora o mesmo deputado que, na Assembléia de 1823, propusera constar da Constituição que o Brasil se constituía por meio de uma "confederação", o que também foi, na época, voto vencido.

O discurso da ineficácia dos Conselhos Gerais de Província igualmente servia de base para a defesa da reforma. Assim falava Carneiro da Cunha, ao acusá-los de “composição imperfeita", sem a presença de "homens capazes e instruídos" para tratarem de assuntos específicos como das rendas locais ${ }^{42}$. A solução seria, portanto, fortalecê-los como autoridade legislativa. Em contrapartida, a falta de tempo e a morosidade em desembaraçar as propostas e projetos provinciais - sobretudo a partir de 1830 com o volume de material endereçado pelos mesmos Conselhos para a Câmara à espera de deliberação -, era, de fato, um ponto de agravamento da situação legislativa ${ }^{43}$. O problema fez que, em junho de 1831, fossem destinados os sábados apenas para tratar das questões dos Conselhos Gerais ${ }^{44}$. Mesmo assim, a persistente lentidão na sua aprovação faria que, no ano seguinte, os deputados decidissem aumentar em uma hora as sessões dos sábados, a partir de indicação de Batista Caetano de Almeida ${ }^{45}$ que novamente alegava ser o tempo insuficiente para as questões provinciais.

O projeto de reforma elaborado pela comissão especial, nomeada em maio, veio à luz em julho de $1831^{46}$. No debate que se seguiu, foi a vez do pernambucano Holanda Cavalcanti de Albuquerque ${ }^{47}$ colocar-se contrário à sua execução, sob a alegação de que a

\footnotetext{
${ }^{41}$ Idem, t.1, sessão de 16/junho, p.159.

${ }^{42}$ Idem, t.2, sessão de 2/agosto, p. 17.

${ }^{43}$ Note-se que, já em 1826, José da Costa Carvalho fazia uma Indicação para que os projetos remetidos do Senado tivessem apenas uma discussão entre eles deputados com o intuito de agilizar sua aprovação. APB (1826), t.2, sessão de 30/junho, p. 329. Apesar de a Indicação ser aprovada, ela não voltaria mais ao plenário. ${ }^{44}$ APB (1831), t.1, sessão de 25/julho, p.178.

${ }^{45}$ Batista Caetano de Almeida (1797-1839) era natural de Minas Gerais. Era comerciante. Foi deputado por sua Província natal na Assembléia Geral nas $2^{a}, 3^{a}$ e $4^{a}$ legislaturas, cumprindo essa função de 1830 até seu falecimento.

${ }^{46}$ Idem, sessão de 09/julho, p. 222. O documento foi transcrito nos Annaes do Parlamento Brasileiro. Câmara dos Deputados. Sessão de 1834 [APB-CD (18340] Rio de Janeiro, Typographia de Hypollito José Pinto e \& Cia, 1879, t. 1, Documento A, pp.13-29.

${ }^{47}$ Antonio Francisco de Paula e Holanda Cavalcanti de Albuquerque já havia ocupado a cadeira de deputado pela mesma Província na legislatura anterior (1826-9).
} 
Constituição seria "amada pelos brasileiros", "parecendo mais obra da Providência do que dos homens" 48 . Considerava a medida uma "precipitação" e argumentava que as "leis regulamentares" é que deveriam dar andamento a este "sistema tão bem arranjado". Vários o contestaram, sendo aprovada a leitura do Projeto da forma como estava prevista na Carta de 1824. Duas semanas depois, foi encaminhado para impressão e distribuição entre todos os representantes.

A proposta do texto para reforma era audaciosa e detalhada artigo por artigo. Previa a transformação do Império do Brasil em uma associação de tipo federativo e a supressão do poder Moderador, com a manutenção de um regime monárquico. Também estipulava uma reformulação das atribuições que cabiam ao Legislativo, com a retirada da hereditariedade dos senadores - que passariam a ser eleitos nas Províncias -, um regente único e a supressão do Conselho de Estado. No plano provincial, determinava-se a instalação de Assembléias com poder de legislar sobre questões locais, de fixar anualmente a despesa, de distribuir a renda pelos municípios e de controlar e observar o cumprimento da Constituição. Essas Assembléias seriam compostas de duas Câmaras - ou seja, de deputados e de senadores - a exemplo da que funcionaria no Rio de Janeiro. Pelas suas atribuições, nota-se uma sensível diminuição do poder de ação dos presidentes de Província, ainda que eles continuassem sendo escolhidos pelo Imperador e tivessem direito a sanção, mesmo que provisória, sobre as leis por elas aprovadas. Vale notar que o Conselho de Governo, privativo aos mesmos presidentes, nem era citado. Criava-se um cargo de Intendente para todas as cidades e vilas, ao qual competia "executar e fazer executar" todas as leis gerais do Império.

Dois meses depois da apresentação do projeto da comissão especial, ficou decidido que ele teria a prioridade da discussão (não sem uma longa polêmica entre os deputados) ${ }^{49}$. $\mathrm{Na}$ véspera dessa decisão, o padre Venâncio Henriques de Resende apresentou uma proposta pontual de reforma que previa alteração no Capítulo $5^{\mathrm{o}}$, Título $4^{\mathrm{o}}$ da Constituição, para que os Conselhos Gerais de Províncias fossem investidos de poder legislativo. No dia seguinte, o embate de opiniões também foi iniciado por Resende, que levantou um problema, no mínimo, espinhoso: apesar de concordar com o teor do projeto da comissão, apontava que os deputados não estariam autorizados para indicar de que forma se daria a

\footnotetext{
${ }^{48}$ APB (1831), sessão de 9/julho, p.222.
} 
reforma, mas apenas indicar quais artigos eram reformáveis. Era isso que caberia à Câmara de Deputados de acordo com a Constituição, sendo que depois de aprovada a lei de alteração, pelo Senado e pela Regência, o conteúdo dos artigos somente seria alterado pela legislatura seguinte. O pernambucano votava, assim, pela sua própria proposta, sob o argumento que não haveria tempo para discutir aquela da comissão ${ }^{50}$.

Os contrários à realização da reforma manifestaram-se de forma incisiva. $\mathrm{O}$ primeiro deles foi o baiano Antônio Pereira Rebouças, que acusava de "anticonstitucional" tanto o projeto da comissão como aquele apresentado por Henriques de Resende ${ }^{51}$. Foi seguido de perto nos seus argumentos por Holanda Cavalcanti de Albuquerque que, já tendo se pronunciado contra a reforma, agora fez um longo discurso no sentido de provar que os "males atuais" não vinham da Constituição, a qual já permitia a união "federada" do Brasil $^{52}$. A idéia de que o momento era temeroso para realização de uma reforma perpassava seus discursos, extremamente moderados do ponto de vista das inovações que poderiam ser introduzidas.

No entanto, o clima predominante na Casa indicava "tanto o desejo, como a necessidade da reforma da Constituição", segundo as palavras de Carneiro da Cunha ${ }^{53}$. A expectativa por transformações de maior envergadura também se manifestou na fala de Antônio Castro Alves ${ }^{54}$, deputado pelo Rio de Janeiro, que se mostrou totalmente favorável a uma ampla mudança do texto constitucional, criticou o poder Moderador como "idéia roubada de Benjamin Constant", e indicou ser "absurdo" que o título de "defensor perpétuo" tenha sido dada a um "menino" 55 . Nesse ambiente, o projeto da comissão foi facilmente aprovado, mas muitos foram os pronunciamentos favoráveis a que apenas se indicassem quais artigos deveriam ser alterados para que a próxima legislatura assim o fizesse.

\footnotetext{
${ }^{49}$ Idem, sessão de 9/setembro, p.133-142.

${ }^{50}$ Idem, p. 135.

${ }^{51}$ Idem, pp. 135-6.

${ }^{52}$ Idem, pp.139-141.

${ }^{53}$ Idem, p. 136.

54 Antônio Castro Alves (179?-1833) era natural do Rio de Janeiro. Por essa Província, foi deputado na Assembléia Geral na 2 legislatura (1830-3).

${ }^{55}$ Idem, sessão de 09/setembro, p.138.
} 
Por essa razão, no momento em que o projeto entrou em discussão, em $30 \mathrm{de}$ setembro, foi aprovado um requerimento do cearense Castro e Silva ${ }^{56}$ para que se discutisse primeiro "se a reforma da Constituição deve[ria] ser como propôs a ilustre comissão, emendando-se logo os artigos, ou iniciando-se só os artigos reformáveis" ${ }^{\text {"57 }}$. Na sessão em que se discutiu a questão ${ }^{58}$, o deputado José Cesário de Miranda Ribeiro, um dos membros da comissão que elaborara o texto para a reforma, ofereceu um outro mais sucinto, de sua autoria, em que sintetizava em onze artigos os pontos mais importantes do citado projeto ${ }^{59}$. Seu teor era, portanto, muito semelhante ao outro, sendo denominado de "substitutivo". Logo ele foi preferido e entrou em discussão.

A discussão sobre o texto de Miranda Ribeiro esteve longe de ser polêmica, ocupando não mais de quatro curtas ocasiões nas sessões extraordinárias de outubro. Algumas emendas a ele oferecidas acentuaram a radicalidade da proposta. Esse foi o caso da de Manoel Maria do Amaral, que propôs se dissesse que a Constituição do Império seria reformada no sentido de uma "monarquia federativa", e assim foi aprovado. No entanto, a emenda de Antônio Ferreira França para que cada Província tivesse, além de sua Assembléia, uma Constituição particular, foi longe demais, e não obteve aprovação. Em 12 de outubro, finalizou-se a segunda discussão da nova proposta e, no mesmo dia, fez-se a terceira. Dessa forma, foi aprovado rapidamente um projeto geral de reforma mais conciso do que aquele inicialmente proposto pela comissão, e logo encaminhado para apreciação dos senadores ${ }^{60}$.

O projeto aprovado constava de doze itens que previam: a transformação do governo do Brasil numa "monarquia federativa"; o reconhecimento de apenas três poderes políticos (as atribuições do moderador "que forem conveniente conservar" passariam para o Executivo); o Senado eletivo e temporário; a diminuição do tempo da legislatura para dois anos; a supressão do Conselho de Estado; a conversão dos Conselhos Gerais de Províncias em Assembléias Legislativas; a divisão das rendas públicas em "nacionais e provinciais"; e

\footnotetext{
${ }^{56}$ Pelos Annaes, não se pode esclarecer se "Castro e Silva” refere-se a Manoel do Nascimento Castro e Silva ou Vicente Ferreira de Castro e Silva, ambos eleitos pelo Ceará.

${ }^{57}$ Idem, sessão de 30/setembro, p. 211.

${ }^{58}$ Idem, sessão de 7/outubro, p.222.

${ }^{59} \mathrm{O}$ referido projeto substitutivo pode ser encontrada em: APB-CD (1834), t. 1, Documento B, p. 29-30.

${ }^{60}$ Aprovou-se em 13 de outubro de 1831; seu texto pode ser encontrado em: APB-CD (1834), t.1, Documento C, pp. 30-1.
} 
a exigência para o Executivo apresentar por escrito as razões de uma eventual recusa à sanção de lei aprovada na Assembléia.

A rapidez e tranqüilidade com que foi aprovada uma proposta de reforma da Constituição que expressava, sem dúvida, uma alteração substantiva no caráter do funcionamento institucional do regime monárquico no Brasil, só pôde acontecer porque a composição da Assembléia estava profundamente marcada pelo clima de expectativa que se abrira com a Abdicação de D. Pedro I, em 1831. Foi isso que permitiu aos deputados extrapolarem o previsto pela Constituição e aprovarem o teor das modificações que deveriam ser feitas, em vez de apenas indicar os artigos que necessitavam ser alterados ${ }^{61}$. No entanto, a despeito de uma quase unanimidade pela transformação do regime sem sua sublevação completa, a defesa da Carta de 1824 como caminho da legalidade a ser seguido continuaria a desdobrar-se em posições distintas e contundentes na arena do jogo político.

Uma das consequiências mais imediatas da Abdicação de D. Pedro foi o aprofundamento de uma instabilidade política vivida em diversas localidades, causa e ao mesmo tempo efeito de desordens, insubordinações e tentativas de rebeliões que portavam reivindicações e projetos dentre um amplo espectro de possibilidades ${ }^{62}$. Se isso era fruto de um desejo de mudança em relação à ordem das coisas, era também uma resposta à criação e implementação de uma estrutura política-institucional impulsionada pelo funcionamento da máquina administrativa no Primeiro Reinado. Nesse contexto, a Constituição, entendida

${ }^{61}$ Silvana Mota Barbosa, A shinge monárquica: o Poder Moderador e a política imperial, Campinas, Unicamp, Tese de Doutorado, 2001, p.182.

${ }^{62}$ Marcelo Basile, O Império em Construção: projetos de Brasil e ação política na Corte Regencial, Rio de Janeiro, Universidade Federal do Rio de Janeiro, Tese de Doutorado, 2004; Lima Brandão de Aras, Santa Federação Imperial: Bahia. São Paulo, Universidade de São Paulo, Tese de Doutorado, 1995; Gladys S. Ribeiro, A liberdade em construção. Identidade nacional e conflitos antilusitanos no Primeiro Reinado, Rio de Janeiro, Relume Dumará/Faperj, 2002. Em algumas áreas mais pobres, observa-se o aparecimento de verdadeiras práticas de "banditismo" social, onde a criação de poderes paralelos às instituições públicas foi uma alternativa à busca pela sobrevivência e fim de uma instabilidade que remontava, pelo menos, a 1821-2. A correspondência da Província do Ceará com a Corte, por exemplo, descreve como a localidade foi marcada por fenômenos desse tipo. Ver: ANRJ, Negócios de Província, IJJ $^{9} 170$ A, 171-173. Uma análise do caso para a Bahia no momento da Independência foi feita por Argemiro Ribeiro de Souza Filho, A guerra de Independência na Bahia: manifestações políticas e violência na formação do Estado nacional (Rio de Contas e Caetité). Salvador, Universidade Federal da Bahia, Dissertação de Mestrado, 2003, que analisou sua 
como dimensão central do pacto capaz de gerar estabilidade e "prosperidade" na formação do Império, passara a ser o principal alvo de expressão de diferentes - por vezes, antagônicas - propostas.

É fato que houve, no triênio pós 1831, espaço para o surgimento público de propostas verdadeiramente radicais no que tocava ao sistema político do Brasil. Geralmente associadas pela historiografia aos chamados "exaltados", tais propostas identificavam-se tanto com a defesa de projetos de federação que previam uma efetiva ampliação de direitos e de participação política da sociedade, quanto com a difusão de um ideário republicano de governo $^{63}$. A imprensa serviu como seu principal meio de propaganda, a despeito das perseguições que seus ideólogos sofriam por opiniões que pudessem, segundo o governo, subverter "a ordem imperial". Também é verdade que a abertura de uma real possibilidade de alteração do regime dentro da esfera da legalidade, ou seja, por uma ampla reformulação da Constituição empreendida pela Casa legislativa, fez que alguns indivíduos ou grupos saíssem à cena política e vislumbrassem, por meios constitucionais, uma participação mais efetiva nesse processo. O limite entre esse tipo de ação e o aparecimento de movimentos de contestação direta às autoridades públicas era, no entanto, muito tênue ${ }^{64}$.

Mas a expectativa em relação à possibilidade de restauração da ordem monárquica vigente no Primeiro Reinado também mobilizou na cena política protagonistas bem mais moderados do ponto de vista de suas concepções políticas, sobretudo a partir de 1833, quando a radicalidade até então vivida sofreria uma retração ${ }^{65}$. Esses vulgarmente alcunhados de "caramurus" ou "corcundas", não defendiam propriamente a volta ao poder de D. Pedro, mas faziam parte de um segmento bem diversificado na expressão de seus projetos e ações que apostava na manutenção da legitimidade dinástica do regime ${ }^{66}$. A

ocorrência como desdobramento da crise, de dimensões mais amplas, que então abalava o extinto Império português na América.

${ }^{63}$ Silvia Carla Brito Fonseca, A idéia de República no Império do Brasil: Rio de Janeiro e Pernambuco (1824-1834), Rio de Janeiro, Universidade Federal do Rio de Janeiro, Tese de Doutorado; Marco Morel, Cipriano Barata na Sentinela da Liberdade, Salvador, Academia de Letras da Bahia/Assembléia Legislativa do Estado da Bahia, 2001.

${ }^{64}$ Marcelo Basile, op.cit.., analisa a atuação desses indivíduos ou grupos na Corte do Rio de Janeiro que, também organizados em torno da Sociedade Federal Fluminense, teriam sido responsáveis por movimentos de sublevação entre 1831-2.

${ }^{65}$ Idem; Marco Morel, As transformações dos espaços públicos. Imprensa, atores políticos e sociabilidades na Cidade Imperial (1820-1840), São Paulo, Hucitec, 2005.

${ }^{66}$ Marco Morel, "Restaurar, fracionar e regenerar a nação: o Partido Caramuru nos anos 1830”, István Jancsó (org.), Brasil: formação do Estado e da nação, São Paulo/Ijuí, Fapesp/Hucitec/Unijuí, 2003, pp. 407-430. 
questão é que, com a abertura de possibilidade de transformação do sistema político no Brasil, mesmo a defesa dessa bandeira pôde adquirir, em muitos momentos, prática e caráter subversivos.

Já em 1830, o presidente de Província do Ceará mandara proceder a uma devassa na região do Crato, sob a anuência do governo imperial, contra uma suposta sociedade secreta intitulada "Coluna do Trono Constitucional""67. Os indivíduos nela envolvidos teriam propagado princípios subversivos, pois, segundo algumas testemunhas, defenderiam que o Imperador se sentiria "coacto pela Constituição" e necessitando de apoio para manter-se à frente do regime. Tais elementos teriam falado até em "colocar a Constituição" abaixo como forma de preservação da autoridade monárquica. Depois de uma série de acusações, inclusive contra o próprio presidente e ao Conselho, supostamente favoráveis às idéias "republicanas", o processo acabou sem solução. A mesma região sofreria com o agravamento de sua instabilidade interna a partir de 1831, quando chegavam ao Rio de Janeiro acusações de perturbações cometidas por partidários do Coronel Pinto Madeira e do "absolutismo", bem como em função da ação de indivíduos empenhados na formação de uma "república"68. Em 1832, o Conselho do Governo fornecia carta branca ao mesmo presidente para utilização de "força para prisão dos facinorosos", desde que tudo fosse posteriormente noticiado à Assembléia Legislativa. Dois anos depois, os focos de insubordinação na Província ainda não tinham sido controlados.

Há notícia de uma tentativa de conspiração ocorrida no Mato Groso em 1834, a qual teria sido fomentada pela denominada "Sociedade dos Zelosos da Independência de Cuiabá"69. A correspondência do presidente da Província relatando o fato acusava os envolvidos (em número aproximado de setenta) de terem se reunido no quartel da tropa, onde teriam erigido uma "segunda Regência em Nome de S.M. o Imperador" com a conivência dos empregados da administração da Justiça. Relatava ainda várias barbaridades que os mesmos estariam causando à cidade, e assim justificar as medidas de repressão que tinham sido tomadas para conter o movimento. Sem identificar-se em princípio com projetos radicais ou mesmo "restauradores" da ordem, a conspiração parecia indicar muito

\footnotetext{
${ }^{67}$ CEDI-CD, ano/localização: 1832, maço 28 (Autos de Devassa).

${ }^{68}$ ANRJ, Negócios de Província, IJJ $170 \mathrm{~A}$.

${ }^{69}$ CEDI-CD, ano/localização: 1834 , maço 15 , pasta 1 , documento 8.
} 
mais uma disputa entre as autoridades locais e insatisfações com as ordens emanadas do Rio de Janeiro do que um projeto efetivo de subversão da ordem.

Componentes semelhantes estiveram por trás daquela que, em dimensões bem maiores, ficou conhecida na historiografia como "revolução do ano da fumaça", ocorrida em Ouro Preto em março de $1833^{70}$. O movimento teve início na ausência do presidente da Província Manuel Inácio de Melo e Souza, que se encontrava em Mariana, com uma articulação que impediu que Bernardo Pereira de Vasconcellos (então membro mais votado do Conselho Geral de Província) assumisse seu lugar. Os rebeldes aclamaram presidente Manuel Soares do Couto, comandante das Guardas Nacionais e também membro do Conselho, e mantiveram um governo durante dois meses com o apoio da Câmara da cidade, e também de Mariana e Caeté. O movimento foi sufocado por ordem do governo regencial após um cerco à capital, que impediu a entrada de víveres e a comunicação dos revoltosos com outros pontos da Província.

Em representação à Assembléia Geral, datada de 4 de maio, o "grupo de Ouro Preto" colocava-se como "representante da vontade do povo mineiro e verdadeiro defensor da Constituição e do direito de D. Pedro II". Acusava "os sanguinários" Vasconcellos e Melo e Souza de sacrificarem “ao seu rancor vítimas já por eles designadas”, e de lançarem "mãos de armas sem que em todo este conflito a tropa e o povo se deslizassem um só ápice da vereda da lei". Para seus opositores, os idealizadores do movimento seriam "caramurus", restauradores do governo de Pedro I, além de igualmente contrários à "Constituição e [às] leis" ${ }^{71}$. Dessa forma, os discursos apontavam para verdadeiros contra-sensos.

Estudos posteriores sobre a política na região das Minas revelam que o ponto central da sublevação residiu na disputa entre grupos locais pela liderança provincial, da qual alguns setores se sentiam prejudicados diante da política da Regência ${ }^{72}$. Nesse sentido, é

\footnotetext{
${ }^{70}$ Francisco Iglésias, "Minas Gerais”, História Geral da Civilização Brasileira. O Brasil Monárquico, São Paulo, Difel, 1985, tomo II, v.2; Francisco Eduardo de Andrade, "Poder local e herança colonial em Mariana; faces da revolta do 'Ano da Fumaça' (1833)", Termo de Mariana. História e Documentação, Ouro Preto, Editora da UFOP, 1998; Wlamir Silva, "Liberais e povo”: a construção da hegemonia liberal-moderada na Província de Minas Gerais (1830-1834), Rio de Janeiro, Universidade Federal do Rio de Janeiro, Tese de Doutorado, 2002.

${ }^{71}$ Apud Francisco Eduardo de Andrade, op.cit., p.131.

${ }^{72}$ Wlamir Silva, op.cit., p. 318 seg., defende que o embate de posições se deu sobretudo entre grupos de liberais moderados que buscaram sua hegemonia como liderança na Província, em que a acusação de "caramuru" servia à retórica de ambos os lados. O autor argumenta que o saldo da revolta produziu em Minas Gerais uma conciliação "moderada" na região muito antes do que em qualquer outra Província do Império, o que teria permitido aos mineiros viverem uma certa estabilidade no momento das "revoltas regenciais".
} 
correto afirmar que ela foi uma resposta à reconfiguração de poderes implementada nas Províncias desde o Primeiro Reinado, cujas disputas refletiram a violência com que a acomodação à essa nova estrutura institucional deu vazão ${ }^{73}$. Por essa razão, se uma das facetas da instabilidade política presente nos primeiros anos da Regência deveu-se à publicização de projetos de transformação da ordem vigente, fossem eles conservadores ou radicais, a outra esteve na abertura para que grupos locais acirrassem disputas políticas num momento que se revelaria decisivo na formação da estrutura institucional imperial.

Em meio às desordens vividas desde 1831, uma prova de que a Constituição servia de elemento à moderação política foi a de que sua defesa, em nome de uma necessária inviolabilidade em suas bases, rapidamente foi incorporada ao discurso daqueles favoráveis à sua reforma. Essa fórmula, usada por protagonistas entre um amplo espectro de distintas e até opostas opiniões, evidencia a eficácia social da Carta de 1824, quando o assunto era o de suas bases políticas. Isso fica evidente pelo envio de vários ofícios das Câmaras municipais e dos Conselhos provinciais aos Deputados desde 1831. Nesse ano, os conselheiros de Minas Gerais escreveram um "projeto de felicitação" à Assembléia Geral em que apoiavam a iniciativa de uma "reforma dentro dos quadros da Lei" ${ }^{74}$. Reforçavam que o caminho da legalidade deveria ser impreterivelmente seguido:

"O Conselho não se deixa fascinar supondo que a reforma da Constituição será o termo de toda a nossa felicidade; conhece bem que esta só pode obter-se pelo melhoramento dos costumes, pela vulgaridade da Instrução em todas as Classes, e pela exata observância das Leis" ${ }^{75}$.

Dois meses depois, já em 1832, o mesmo Conselho Geral da Província registrava uma "minuta de ofício" em que afirmava seu repúdio a que a Constituição fosse "violada" ou sofresse "qualquer alteração que não eman[asse] do Poder legítimo"76. A posição não era à toa, pois que a capital mineira tinha notícias das sublevações ocorridas no Rio de Janeiro,

\footnotetext{
${ }^{73}$ Francisco Eduardo de Andrade, op.cit., p.128, aponta como a "revolta da fumaça" relacionava-se diretamente com o processo de nulificação sofrido pelas Câmaras municipais desde fins da década de 20, o qual promoveu a insatisfação de grupos envolvidos em redes locais de poder.

${ }^{74}$ Actas das sessões do Conselho Geral da Província de Minas Gerais de 1831, Ouro Preto, Typographia do Silva, 1831, sessão de 9/dezembro, p.34.

${ }^{75}$ Idem.
} 
onde a disputas de partidos e grupos, para além de manterem um clima de tensão, haviam tomado por mais de uma vez conta das ruas ${ }^{77}$. Nos dias que se seguiram, os conselheiros registravam em ata que lamentavam os acontecimentos da Corte e defendiam novamente a reforma "decretada pelas formas legais". Essa construção discursiva era, portanto, uma maneira de preservar as instituições criadas para o Império sob uma legitimidade constitucional moderna.

No mesmo ano de 1831, as Câmaras de Pau d'Alho e Serinháem, em Pernambuco, mandaram ofício à Assembléia em repúdio a qualquer tentativa de mudança que subvertesse o conteúdo da Constituição. A primeira escrevia que seus habitantes, “obedientes à Lei fundamental do Império", estariam resolutos a "não anuírem que ela sofr[esse] qualquer reforma, que não [fosse] feita pela Assembléia Geral Legislativa". A segunda, por sua vez, declarava existirem "anarquistas nessa praça", "persuadindo os incautos" para reformas que lhes trariam "perigos inevitáveis por ofenderem o Código fundamental". Também defendiam que apenas à Assembléia Legislativa caberia o direito de sua execução, a quem confiavam "a felicidade do Brasil"78. Em 1832, a Província de Goiás informava aos deputados no Rio de Janeiro que se encontrava coligada com Minas Gerais na aceitação apenas das mudanças marcadas pela Constituição e na defesa da Regência, tendo inclusive noticiado sua posição ao Grão-Pará e ao Mato Grosso ${ }^{79}$.

Com a aprovação em plenário do projeto de reforma da Constituição, o qual se aceito pelos senadores alteraria significativamente a estrutura política do regime, a Câmara dos Deputados acusava o recebimento de pelo menos trinta felicitações provindas de municípios, Províncias e Sociedades de várias partes do Império ${ }^{80}$. Para além de simples demonstrações de adesão à reforma e à Regência, houve muitas que expuseram sua opinião sobre o conteúdo da mudança. Uma dessas vinha em ofício da Câmara de Cuiabá, que noticiava sua discordância em relação a uma proposta da "Sociedade Promotora do Bem Público", localizada na Vila do Príncipe em Minas Gerais ${ }^{81}$. A dita proposta era anexada ao documento, e convidava os vereadores goianos a defenderem que o projeto de reforma

\footnotetext{
${ }^{76}$ Idem, sessão de 9/fevereiro/1832, p. 394-6.

${ }^{77}$ Marcelo Basile, op.cit..

${ }^{78}$ ANRJ, Negócios de Províncias, IJJ $^{9}$ 250, ofícios de 23/outubro e 31/outubro de 1831.

${ }^{79}$ CEDI-CD, ano/localização: 1832, maço 42, pasta 6, ofício de 03/abril/1832.

${ }^{80}$ Idem, ano/localização: 1832, lata $81 \mathrm{D}$, maço 46 , pasta 2.

${ }^{81}$ Idem, ano/localização: 1832, maço 42, pasta 6, ofício de 1/abril/1832.
} 
fosse aprovado apenas entre os deputados, sem a participação do Senado. O argumento era "afastar os estorvos" que poderiam "inutilizar as belas garantias" que a Constituição oferecia para "extinguir as instituições européias que se pretendeu enraizar entre nós" 82 . O ataque contra os membros da segunda Casa era claro:

"Este Corpo coletivo esquecendo-se do cumprimento dos seus mais sagrados deveres, ou antes, sendo conseqüente com a sua péssima organização, e influência, que na sua eleição exercitou o despotismo, esmera-se continuamente em excogitar tropeços ao andamento das Instituições, que possuímos, e ao estabelecimento daquelas, de que necessitamos" ${ }^{\prime 83}$.

O ofício da Sociedade afirmava que uma mobilização deveria ser feita antes da próxima reunião da Assembléia, no caso de o projeto já ter sido encaminhado ao Senado e este o ter registrado. No entanto, os cuiabanos recusavam a proposta, acusando-a de ser uma prática "anticonstitucional" que poderia "acarretar muito males, e até a ruína do Brasil"; além disso, enviavam tudo para conhecimento da Assembléia Geral.

A defesa da Sociedade de Vila do Príncipe não era uma exceção ${ }^{84}$. Em ofício de 20 de julho de 1833, a Vila de São Domingos do Araxá, como "fiel intérprete da opinião de seus Constituintes”, pedia a extinção do Senado vitalício da Carta de 1824, instituição que julgava uma "anomalia":

“A nossa Pátria por ventura dos Brasileiros só reconhece a Aristocracia natural, isto é a do mérito do indivíduo; a Aristocracia de instituição tem uma existência quimérica porque não havendo entre nós a Lei de primogenitura, como sustentar Classes privilegiadas? O Senado parece feito para representar a Aristocratas, mas aonde a Constituição dá existência a essa Classe? A Câmara desconhece; o Senado

\footnotetext{
${ }^{82}$ Idem, ofício de 2/fevereiro/1832.

${ }^{83}$ Idem.

${ }^{84}$ Vale notar que no ano seguinte, de 1833, a Câmara da mesma Vila do Príncipe enviava um ofício aos "Senhores Representantes da Nação Brasileira" em que criticava abertamente as práticas do Senado, e o fato de seus membros serem arbitrariamente escolhidos a despeito das justas reclamações das Províncias. Pedia a "extirpação dos abusos", em especial que fosse omitido da Lei do Orçamento o "subsídio" dos senadores, que não tinham relação com a localidade que supostamente representavam. CEDI-CD, ano/localização: 1833, maço 13 , pasta 1 , ofício de 3/setembro/1833.
} 
pode abusar do seu mandato, a Nação não o pode revogar, o número de seus membros é limitado, não tem para isso remédio Constitucional, e neste caso, ou o Brasil há de ser vítima de uma facção do Corpo Legislativo, ou se há de lançar no vórtice d'Anarquia" ${ }^{\prime 85}$.

A crítica estava na ordem do dia, assim como a associação depreciativa da Câmara vitalícia à antiga "aristocracia" e ao "sistema europeu"

Outro ponto em que as representações tocavam era o da defesa da federação. Nesse sentido, a Câmara de Garanhuns encaminhava, em 1832, vários ofícios ao presidente da Província de Pernambuco, em nome de uma "reforma federal"87. Argumentando pela "suma perfeição de tão útil obra", "necessária" e "coerente" com as condições e costumes do Brasil, pedia urgência no envio de sua opinião ao "governo supremo" para que uma lei logo pudesse ser sancionada. A justificativa era a de que qualquer alteração nessa ordem já estaria prevista na própria Constituição. Dois anos depois, a Câmara do Acari, no Rio Grande do Norte, teria posicionamento semelhante: reivindicava que, antes da abertura dos trabalhos legislativos, se tomasse em consideração a "lei da reforma da Constituição em sentido federativo", "para que quanto antes apareçam essas salutares medidas, que não importam menos, do que a segurança, e estabilidade deste Império ${ }^{88}$. Dessa vez, a razão alegada era a de que somente assim se poderia acalmar o fogo das paixões, destruir partidos", além de cortar os feitos de D. Pedro I, esse "pérfido homem”.

Por mais que o vocábulo "federação" carregasse em si variados sentidos, o fato de reivindicações como essas chegarem ao plenário junto a propostas de extinção da segunda Câmara (Senado) - que exercia um importante papel de moderação do regime -, não deve ser minimizado. Seu aparecimento deixava à mostra que a aceleração dos acontecimentos causada pela expectativa de transformações, que em todo o Império podia ser comprovada pela generalização da instabilidade e das contestações abertas, abalou fortemente a

\footnotetext{
${ }^{85}$ Arquivo da Câmara dos Deputados, Centro de Documentação e Informação, localização: ano de 1833, lata 86, maço 14 , pasta 1 .

${ }^{86}$ Silvia Carla Brito Fonseca, op.cit., analisa como na imprensa dessa época, sobretudo "exaltada", construiuse a dicotomia entre "sistema europeu" e "sistema americano", em defesa de projetos de federação, e até mesmo de "república".

${ }^{87}$ ANRJ, Negócios de Província, IJJ $^{9}$ 251, ofícios de setembro/1832.

${ }^{88}$ Idem, ano/localização: lata 97-C, maço 26, pasta 5, ofício de 12/abril/1834.
} 
dinâmica dos trabalhos legislativos. Sua expressão foi notada por Evaristo Ferreira da Veiga, então deputado por Minas Gerais, ao afirmar que:

"notarei que as idéias que têm agora aparecido acerca do dia 7 de abril [de 1831], mesmo dentro desta casa encheriam de assombro os brasileiros se fossem ouvidas há um ano. Porém o tempo correu, as opiniões mudaram, novas sensações apagaram as que eram enérgicas e fortes; os homens se modificaram, e aquilo que então seria um crime só pensar-se é hoje um documento de patriotismo" ${ }^{\text {"89 }}$.

E assim, a despeito da defesa incondicional da legalidade da reforma em 1832, a subversão do regime teria espaço como projeto de ação de alguns deputados, como se verá em seguida.

\subsection{A tentativa de radicalização e a aprovação final do projeto de reforma da} Constituição

O ano legislativo de 1832 iniciou-se entre os deputados de forma, no mínimo, tensa. Logo às primeiras sessões, as várias manifestações ocorridas quando da discussão do "voto de graças" que deveria ser dado à Regência ${ }^{90}$, desembocaram num ponto comum: o caráter do projeto de reforma da Constituição que havia sido aprovado em outubro de 1831 . Um dos primeiros a tocar na questão foi Evaristo Ferreira da Veiga que, num longo discurso, defendeu a Câmara das acusações circuladas na imprensa de que seriam os deputados uns "agitadores e revolucionários" "91. Tomando uma posição de moderação, atacava "alguns espíritos imprudentes" que defendiam "reforma já e já", e argumentava que essa nunca fora a posição predominante na Casa. A despeito da aprovação de uma "reforma federativa", afirmava que os deputados acreditavam na "autoridade de D. Pedro II" como "a fiadora da existência do Estado". Desta forma, embora explicasse o 7 de abril pelo "princípio de

\footnotetext{
${ }^{89}$ Annaes do Parlamento Brasileiro. Câmara dos Srs. Deputados. Sessão de 1832 (Terceiro Ano da Segunda Legislatura), tomo primeiro, Rio de Janeiro, Typographia de H. J. Pinto, 1878 [APB-CD (1832)], sessão de 12/maio, p. 13.

${ }^{90}$ Tradicional resposta dada pela Casa à "Fala do Trono" do Imperador, proferida em todo início de ano legislativo; nesse, era dirigida à Regência.

${ }^{91}$ APB-CD (1832), sessão de 12/maio, pp. 11-5.
} 
resistência dos povos", atribuía à Abdicação causas anteriores, inclusive o fato do exImperador ter percebido que "a nação o não queria" mais. Digno de nota é que Ferreira da Veiga tenha partido da crítica aos mais conservadores no intuito de demonstrar, sobretudo aos mais radicais que esperavam grandes mudanças, que sua posição pessoal não se equiparava com a daqueles.

Martim Francisco Ribeiro de Andrada ${ }^{92}$ falou a seguir, e fez longas críticas ao projeto de reforma que havia sido aprovado 93 . Tratando a proposta "federativa" como uma "idéia subversiva" que só teria tido algum espaço na Câmara no ano de 1831, defendeu sua antinomia com a monarquia, entendida como "um estado compacto e unido, regido por um só chefe". Assim declarou que os deputados haviam excedido as suas atribuições ao admitirem o que seria uma "mudança total no sistema de governo". Revelava sua tendência restauradora ao declarar que a Abdicação estava prevista na "Constituição do Império", e que nunca fora intenção da Casa insultar o "augusto pai" de D. Pedro II. Nesse sentido, Francisco Gê Acaiaba Montezuma ${ }^{94}$ pronunciou, no dia seguinte, uma longa argumentação no intuito de provar que a saída do Imperador estivera longe de ser um ato revolucionário, mas, ao contrário, dotada de ampla legitimidade constitucional ${ }^{95}$.

Com vários outros pronunciamentos, a discussão do "voto de graças" tanto tergiversou pelos temas que estavam na ordem do dia no debate público, como serviu de espaço para que aqueles descontentes com o andar das decisões e com a política da Regência também se pronunciassem. Honório Hermeto Carneiro Leão assim pôde, a despeito de sua defesa do governo, falar contra a necessidade de uma reforma tal qual a aprovada na Câmara, pois que, segundo ele, os "princípios federais" já estariam presentes "em parte na nossa Constituição", bastando desenvolvê-los "dando às Províncias mais alguma independência".

O fato é que o projeto de reforma estava nas mãos dos senadores desde o ano anterior, para que pudessem emendá-lo conforme achassem necessário. Uma demonstração da tensão provocada pela espera esteve na indicação feita pelo maranhense Antônio Pedro

\footnotetext{
${ }^{92} \mathrm{O}$ deputado, que havia sido eleito pelo Rio de Janeiro para a Assembléia Legislativa de 1823, quando era ministro junto com seu irmão José Bonifácio de Andrada e Silva, agora era representante por Minas Gerais. ${ }_{93}^{93}$ APB-CD (1832), t.1, sessão de 12/maio, p. 159-162 (seu discurso foi transcrito ao final do tomo).

${ }^{94}$ Montezuma, que já havia ocupado a cadeira de representante pela Bahia na Assembléia Constituinte de 1823, agora era suplente, pela mesma Província, de Miguel Calmon du Pin e Almeida, posteriormente Marquês de Abrantes.
} 
da Costa Ferreira ${ }^{96}$ que, diante do recebimento de uma representação da Câmara de Jacareí acerca da necessidade das reformas constitucionais, sugeriu que ela fosse diretamente enviada ao Senado como forma de pressioná-lo a aprovar o projeto ${ }^{97}$. O autor da proposta justificava-a pela "perrice" dos membros da segunda Casa, que teriam chegado a fazer um requerimento à Câmara questionando se a matéria realmente passara pelo voto dos deputados e se estava conforme a Constituição. No entanto, vários outros representantes clamaram pela moderação, e a indicação acabou reprovada.

Foi em meio a esse clima, reforçado pela pressão advinda da movimentação política das ruas e pela disputa política interna a Casa - sobretudo pelas discussões acerca da remoção de José Bonifácio de Andrada e Silva da função de tutor de D. Pedro II - que na sessão de 30 de julho de 1832 pareceu possível a aprovação de uma proposta radical para o andamento dos trabalhos da Assembléia ${ }^{98}$. Nesse dia, interromperam-se os trabalhos legislativos para leitura de um pedido formal de demissão dos membros da então Regência trina permanente, Francisco de Lima e Silva, José da Costa Carvalho e João Braúlio Muniz $^{99}$. Estes alegavam, em documento, que os ministros haviam coletivamente solicitado sua saída, e que, portanto, não conseguiriam organizar outro gabinete e "ser mais úteis à pátria". Os deputados rapidamente formaram uma comissão especial para aprovação de uma posição sobre o caso, sob a decisão de se manterem "nos seus assentos" em sessão permanente até sua resolução ${ }^{100}$.

Horas depois, a comissão especial apresentou um parecer com a proposta que "esta augusta câmara se convert[esse] em assembléia nacional, para então tomar as resoluções

\footnotetext{
${ }^{95}$ APB-CD (1832), t.1, sessão de 14/maio, pp. 162-4.

${ }^{96}$ Antônio Pedro da Costa Ferreira (1778-1860) era natural da Vila de Alcântara, no Maranhão. Formou-se em Direito na Universidade de Coimbra, e ocupou os cargos públicos de fiscal e superintendente da Junta da Vila de Alcântara, e de secretário do governo do Maranhão. Era também proprietário rural. Ocupou a cadeira de deputado pela sua Província natal na Assembléia Geral durante a $2^{\mathrm{a}}$ legislatura (1830-3) e a $3^{\mathrm{a}}$ (1834-7). Exerceu a função de presidente do Maranhão (1835-7) e, em 1837, foi escolhido senador. Recebeu o título de Barão de Pindaré.

${ }^{97}$ APB-CD (1832), t.1, sessão de 2/junho, p. 119.

${ }^{98}$ APB-CD (1832), t.2, sessão de 30/julho, p. 122 seg..

${ }^{99}$ Essa que ficou conhecida como "Regência Trina Permanente" havia sido eleita logo que se iniciaram, formalmente em maio, os trabalhos legislativos no ano de 1831. Antes dela, houve uma outra, de caráter provisório, escolhida imediatamente após o 07 de abril por reunião emergencial de deputados e senadores, cujas Casas não se encontravam instaladas nesse mês. Essa era comporta por José Joaquim Carneiro de Campos (Marquês de Caravelas), Nicolau Pereira de Campos Vergueiro e o brigadeiro Francisco de Lima e Silva (que seria reeleito para a seguinte).

${ }^{100}$ Desta fizeram parte os deputados Gabriel Mendes dos Santos, Manuel Odorico Mendes, Gervásio Pires Ferreira, Cândido Batista de Oliveira e Francisco de Paula Araújo.
} 
que requer[ia] a crise atual", além de promover imediatamente uma reforma constitucional $^{101}$. A reação contrária a ela foi imediata, encabeçada pela posição moderada do deputado Honório Hermeto Carneiro Leão em nome da defesa da Constituição como única "tábua de salvação":

“O parecer da comissão pretende que esta câmara se declare assembléia nacional. Eu vejo que é o receio dos partidos extremos, que tem pretendido atacar a ordem de coisas criadas pelo 7 de abril, e o voto a favor das reformas, que é quase geral, que move a comissão a apresentar esta medida; mas ela não pensou bem; nós não temos necessidade de ferir a legalidade e os princípios; podemos fazer as leis justas, que forem necessárias para conter os partidos, e na constituição observada temos meios seguros e legais para darmos à nação o que ela pretende" $" 102$.

Nesse sentido, o futuro Marquês do Paraná, sob a posição de manter o princípio de legalidade, propôs uma emenda ao parecer da comissão especial, para que se convidasse a Regência a permanecer no seu posto em nome da "manutenção da ordem". Defendia também que se convocasse o Senado tanto a acompanhá-los em sessão permanente como a encaminhar, imediatamente, suas mudanças ao projeto de reforma. O mesmo deputado arrematava:

"Donde tem vindo a força que tem tido o governo para sufocar em todas as províncias, inclusivamente na corte, todas as facções que têm aparecido? Esta força

\footnotetext{
${ }^{101}$ APB-CD (1832), t. 1., sessão de 30/julho, p.127. Este episódio ficou conhecido na historiografia como uma tentativa de "golpe de Estado" que teria sido arquitetada por um grupo de deputados encabeçados por Diogo Antônio Feijó, acompanhado de José Custódio Dias, no sentido de derrubar a Regência e instaurar um novo regime baseado em uma Constituição publicada pela imprensa naquele mesmo ano, no Periódico Constitucional, que ficou conhecida como "Constituição de Pouso Alegre". Esta se tratava, no entanto, de um documento também moderado, que se assemelhava em linhas gerais ao projeto de Constituição que começou a ser discutido na Assembléia de 1823 (geralmente atribuído a Antônio Carlos de Andrada Machado). Pregava também a extinção da vitaliciedade dos senadores e a transformação dos Conselhos Gerais de Província em Assembléias Legislativas provinciais. Ver: "Breve notícia histórica", Annaes do Parlamento Brasileiro. Sessão de 1832, Câmara dos Deputados. Rio de Janeiro, Tipografia do Império Instituto Artístico, 1875, tomo segundo; Paulo Pereira Castro, "A experiência republicana", Sérgio Buarque de Holanda, História Geral da Civilização Brasileira, São Paulo, Difusão Européia do Livro, 1967, tomo II; Paulo Bonavides e Paes de Andrade, História Constitucional do Brasil, Rio de Janeiro, Paz e Terra; Silvana Mota Barbosa, op.cit..

${ }^{102}$ APB-CD (1832), t.2, sessão de 30/julho, p.128.
} 
não vem senão da observância da constituição e da legalidade que a maioria desta casa, que nós, aqueles que temos defendido o governo, temos constantemente sustentado" $" 103$.

As falas dos deputados que então se manifestaram deixaram explícita a necessidade da continuidade da discussão em sessão permanente até que se decidisse a questão. Coube ao maranhense Manuel Odorico Mendes ${ }^{104}$, como membro da comissão que elaborara o parecer, a defesa da transformação do caráter da Câmara. Este argumentou que seus "honrados colegas" não teriam entendido a proposta: não se tratava da instituição de uma “Assembléia Constituinte", pois que eles já teriam uma "Constituição", mas de promover imediatamente as "reformas indispensáveis" na Carta existente independentemente do Senado ${ }^{105}$. Reforçava que a "falta destas medidas" desde o 7 de abril" estaria causando grandes males à "nação", e completava reforçando sua adesão à monarquia e à Constituição:

"As palavras - assembléia nacional - têm atemorizado alguns senhores que pretendem ver nelas a proclamação do sistema republicano e os horrores da antiga revolução de França. A comissão quer monarquia (muitos apoiados), mas quer as reformas, e quer por meio de leis fortes completar o glorioso 7 de abril e impor silêncio à facção liberticida. Se houvesse um meio dentro da Constituição para reunir os liberais, a comissão com prazer se serviria dele; mas julga e pensa que, proclamando-se já as reformas, é que se conseguirá aquele fim, além de evitarmos o

\footnotetext{
${ }^{103}$ Idem.

${ }^{104}$ Manoel Odorico Mendes (1799-1864) era natural de São Luís Maranhão, filho de uma das famílias mais tradicionais da região. Na Universidade de Coimbra, completou o curso de Filosofia Natural após cursar também a cadeira de Língua Grega. Em 1824, com o falecimento do pai, retornou ao Brasil, após ter vivenciado de perto os desdobramentos da Revolução do Porto. Em janeiro de 1825, iniciou a publicação do jornal O Argos da Lei. Foi deputado eleito por sua Província natal para as três primeiras legislaturas (182637) da Assembléia Geral. Transferiu-se para a capital carioca em meados de 1830, onde se afirmou como político e jornalista, escrevendo para inúmeros jornais de São Paulo e do Rio de Janeiro, entre eles o Farol Paulistano, Clube Aurora, O Verdadeiro Liberal e o Jornal do Comércio. Novamente elegeu-se deputado para a 6 legislatura, agora pela Província de Minas, cadeira que ocuparia de 1845-47. Nessa data, abandonou a política e mudou-se para a França onde passou a se dedicar exclusivamente à vida literária. Traduziu obras clássicas do grego para o português. Faleceu em Londres.

${ }^{105}$ APB-CD (1832), t.2, sessão de 30/julho, p. 132.
} 
choque das províncias, que estão amolando as armas para obterem por força o que o senado friamente lhes tem negado (muitos apoiados)" ${ }^{, 106}$.

Dessa forma, Odorico Mendes tentava justificar uma proposta que daria somente a eles, deputados, o direito de alterar a Constituição, além da primazia na condução política do Império ${ }^{107}$. O que significava dizer, entre outras coisas, uma real possibilidade de alterações em relação ao funcionamento da segunda Câmara.

Nesse dia, os trabalhos dos deputados foram interrompidos às onze horas da noite, com a sua retomada no dia seguinte pela manhã. Imediatamente foram feitas propostas de emendas ao citado parecer. Antônio Paes de Barros, deputado por São Paulo ${ }^{108}$, e Evaristo Ferreira da Veiga propuseram que se aceitasse a demissão da Regência, com convocação dos senadores para nomeação de uma nova ${ }^{109}$. Antônio João de Lessa, eleito pelo Rio de Janeiro, propunha o contrário, solicitando que a Câmara se esforçasse nos seus "desvelos pela pátria”. Foi então que Francisco de Paula Araújo apresentou um novo parecer da comissão, bem mais moderado: a proposta agora era dirigir uma mensagem à Regência convidando-a a permanecer no cargo; também que se procurasse, "pelos meios legais", fazer passar a reforma em ambas as Casas, que se adotasse o código do processo e as medidas já propostas ao código criminal, que se aprovasse a lei do orçamento, e que se desse à Regência o direito de dissolver a Câmara dos Deputados. Aceitou-se que o primeiro parecer, que propusera a transformação do caráter da Assembléia, fosse retirado, e a possibilidade de sua concretização caiu por terra.

\footnotetext{
106 Idem.

${ }^{107} \mathrm{O}$ deputado, a despeito de sua posição por uma transformação mais profunda do que poderia estar em curso, à frente de seu periódico, o Argos da Lei, no Maranhão sempre propugnara um caminho de moderação. Em 1825, defendia nas suas páginas que a Constituição jurada era como "um meio-termo entre a dura e absoluta vontade de um Rei e o furor e desordens da democracia", e chegara a afirmar que a legitimidade do Imperador era proveniente do princípio de "soberania do povo". Em suas palavras: "Todos sabem que o nosso Imperador honra-se muito com lhe vir o seu poder da nação; e tanto isto é assim, que ele se diz Imperador por Unânime Aclamação dos Povos, e não por Herança de S.M.F. E como não se há de honrar, se o poder vindo da nação é o único legítimo, o único duradouro? Se não houvesse povo, não havia Rei nem Imperador: o ato porque se criou um Chefe para reger os membros da sociedade, mostra que a nação é a soberana". [Argos da Lei 1825 (edição fac-similar), São Luís, Serviço de Imprensa e Obras Gráficas do Estado, 1980, 15/março e 06/maio].

108 Antônio Paes de Barros (1791-1876) era natural de São Paulo, e também proprietário rural. Ocupou a cadeira de deputado na Assembléia Geral apenas na $2^{a}$ legislatura (1830-3). Obteve o título de $1^{\circ}$ Barão de Piracicaba.

${ }^{109}$ APB-CD (1832), t.2, sessão de 30/julho, p. 132.
} 
Nessa hora, a tônica da discussão recaiu sobre a manutenção da Regência, e seus defensores argumentaram dos "males" que poderiam advir de sua saída. Foi então que Antônio Pedro da Costa Ferreira, favorável à demissão da mesma, fez uma longa fala crítica em relação aos senadores, valendo-se do argumento de que estes seriam os que mais atacavam a Constituição por não representarem as queixas das Províncias, sobretudo as do Norte, que clamavam por mudanças:

\begin{abstract}
“Alguns dizem - constituição, constituição - sim, eu digo o mesmo; não é porque a constituição fosse jurada na minha província como o foi nas mais? Para o Maranhão não foi oferecida, foi mandada jurar. Não sei porque fatalidade as queixas e gemidos das províncias do Norte nem aqui têm sido ouvidas; as queixas e reclamações da província do Maranhão se acham nas comissões: nunca se atendeu a elas; e depois quando as Províncias fazem alguma coisa, dizem - não tem razão - são desordeiros, anarquistas! É, pois, necessário que se tomem algumas medidas"110.
\end{abstract}

Embora isso não estivesse exatamente em pauta, o maranhense deixava claro ser favorável a alterações em relação ao Senado. De teor semelhante foi a fala de Cândido Batista de Oliveira que, tendo sido um dos membros da comissão especial elaborara o primeiro parecer, fez uma última tentativa de explicar o sentido da "assembléia nacional" que também creditara não ter sido bem compreendida pelos seus companheiros ${ }^{111}$. Defendeu-a em nome das “circunstâncias atuais", nas quais a Câmara não teria poderes para aceitar ou recusar a decisão da Regência. Somente com a transformação do caráter da Casa, haveria condições de "conservação da ordem e tranqüilidade pública".

O esforço de persuasão de Batista Oliveira não foi contemplado na votação: aprovou-se que os Regentes permaneceriam no cargo e que se encaminharia um ofício aos seus membros com uma solicitação formal para que retirassem o pedido de demissão e nomeassem um novo ministério de sua confiança. Nesse mesmo dia, $1^{\text {o. }}$ de agosto, os deputados redigiram um discurso à Regência no qual asseguravam empregar todos os meios para sua sustentação política e pela ordem pública ${ }^{112}$. Também chegaram à Câmara as

\footnotetext{
${ }^{110}$ APB-CD (1832), t.2, sessão de 30/julho, p.135.

${ }^{111}$ Idem, p. 138 .

${ }^{112}$ Idem, sessão de 1/agosto, p.143.
} 
esperadas emendas feitas pelos senadores ao projeto de reforma aprovado em outubro de 1831, mostrando que um dos efeitos imediatos das tentativas de transformação do caráter da Assembléia foi a mobilização do Senado ${ }^{113}$.

As várias emendas propostas transformavam significativamente o caráter do texto original $^{114}$. Suprimiram-se os parágrafos tidos como mais radicais, e que propunham uma monarquia federativa, o fim do poder moderador, o fim do Senado vitalício, o fim do Conselho de Estado e a necessidade de o Executivo declarar os motivos de uma sanção a qualquer lei vinda da Assembléia. Retirou-se também a emenda que falava de uma Regência una, a da renovação da Câmara a cada dois anos, e a da criação nos municípios de um cargo de intendente. Apenas se indicava quais seriam os artigos reformáveis na Constituição no tocante às atribuições dos Conselhos Gerais de Província e à questão das rendas públicas. Além disso, sobre a reformulação das atribuiçõos do Legislativo, os senadores propunham que eles pudessem agir com independência dos representantes eleitos, no caso da segunda Casa se converter em tribunal de justiça.

Conforme estabelecido na Carta de 1824, agora era a vez dos deputados aprovarem as mudanças apresentadas pela segunda Câmara, antes do envio para sanção final do Executivo. Por causa do clima de disputa predominante no plenário, e também à longa votação do orçamento para o ano seguinte, o projeto emendado entraria em pauta quase um mês depois, por indicação urgente de Henriques de Resende ${ }^{115}$.

Logo no início da discussão sobre as emendas dos senadores ao projeto surgiu a primeira polêmica sobre a vitaliciedade dos senadores. $\mathrm{O}$ ataque que alguns deputados imediatamente dirigiram a ela fez que o presidente da sessão advertisse não se tratar de questão em pauta. Mas Joaquim Manuel Carneiro da Cunha teve tempo de fazer um contundente discurso contra o cargo vitalício que, segundo ele, não teria permitido, quando

\footnotetext{
${ }^{113}$ Uma comissão interna ao Senado já havia elaborado um parecer ao projeto em maio de 1832. Esta composta pelos senadores Nicolau Pereira de Campos Vergueiro, Marquês de Santo Amaro (José Egídio Álvares de Almeida) e Marquês de Caravelas (José Joaquim Carneiro de Campos) - desaprovara o texto sob a justificativa do mesmo prescrever à próxima legislatura o caminho pelo qual as mudanças deveriam ocorrer. Segundo o parecer, caberia à Câmara apenas apontar a necessidade da reforma (segundo a "letra da Constituição" no artigo 174), sem fornecer o "remédio", ou seja, as transformações que deveriam ser feitas. Assim, somente os "procuradores expressamente autorizados" (a serem escolhidos na eleição seguinte), teriam esse direito. Ver o texto em APB-CD (1834), t.1, p. 32, documento D.

${ }^{114}$ APB-CD (1834), t.1, p. 32-3, documento F.

115 APB-CD (1832), t.2, sessão 29/agosto, p. 213.
} 
do 7 de abril, a "independência" necessária aos senadores para restabelecerem o "equilíbrio entre o poder e a Câmara dos deputados". O paraibano completava:

"Vejamos, além disso, Senhor Presidente, qual é a organização do senado no Brasil? A sua organização seria boa para a Europa, e não para o Brasil, onde não há classe aristocrática; como, pois, pode continuar a ser vitalício? Como deixar que os senadores não fiquem sujeitos ao menos a mesma responsabilidade moral que têm os deputados?"116

Não se pode negar que, tomando pela sua maioria, a posição dos deputados era por maiores transformações no regime se comparada à dos senadores. E, como se verá, foi em função da participação destes na aprovação do projeto que alguns pontos mais polêmicos puderam ser suprimidos. Isso se deu porque, também entre os representantes eleitos, imperava uma divisão de posições nada desprezível. Um dos que logo fechou com as emendas propostas pela segunda Casa foi Francisco Gê Acaiaba Montezuma ${ }^{117}$. O deputado baiano, que agora defendia uma posição muito mais moderada do que quando de sua estréia parlamentar em 1823 - o que se atribui à sua aproximação, desde o fechamento da Constituinte, com os irmãos Andrada - argumentou pela legalidade da forma proposta pelos senadores e contra o que chamou de "mudança na forma do governo"118. Em longuíssimos discursos, atacou a supressão do poder Moderador e defendeu a incompatibilidade entre a monarquia e a federação, ao contrário de seus discursos quase dez anos antes; em suas palavras:

"Desde que os conselhos gerais puderem fazer tudo quanto convier ao bem-estar e felicidade de suas respectivas províncias; desde que eles puderem legislar, estabelecer impostos, etc., a forma de governo não pode ser a mesma. Não é possível que se aumentem as atribuições dos Conselhos Gerais, tanto quanto se

\footnotetext{
${ }^{116}$ Idem.

${ }^{117}$ Nesse ano de 1832 e no seguinte, Montezuma ocupava a cadeira de deputado como suplente de José da Costa Carvalho.

${ }^{118}$ APB-CD (1832), t.2, sessão 29/agosto, p. 214-5; e sessão de 31/agosto, p.216-223.
} 
quiser, ou tanto quanto for possível, e a forma do governo monárquicorepresentativo" $" 119$.

Outros dois deputados, também baianos, defenderam de forma incisiva as emendas propostas pelos senadores e expuseram semelhantes pontos de vista aos de seu conterrâneo. O primeiro foi Antônio Pereira Rebouças que, sob o argumento de que elas conteriam as "reformas que a nação em geral e as Províncias peculiarmente exig[ia]m"120 , também votou contra a extinção do Moderador e pela incompatibilidade entre monarquia e federação. Na mesma sessão, Miguel Calmon du Pin de Almeida"121 argumentou que a "federação necessária" era "apenas aquela que consist[ia] em dar aos governos provinciais maiores atribuições para seus negócios locais", o que se encontraria totalmente contemplado nas emendas da segunda Casa sem ferir o regime monárquico de governo ${ }^{122}$.

Não obstante, predominaria um repúdio em relação à maioria das propostas feitas pelo Senado: os deputados rejeitaram doze das quatorze emendas elaboradas e requereram a reunião das duas Casas para deliberarem sobre a questão ${ }^{123}$. Provando a divisão de posições entre os deputados, por 45 a 34 votos foi reprovada a emenda para supressão da monarquia federativa; com números quase idênticos, de 47 a 32 votos, foi aceita a manutenção do poder Moderador, conforme emenda dos senadores. Junto com esta, os deputados apenas concordaram em abrir mão do parágrafo que previa ser a Câmara renovada a cada dois anos.

A reunião entre deputados e senadores ocorreu entre os dias 17 e 28 de setembro de 1832, e o seu saldo foi o prevalecimento da posição mais moderada da segunda Casa. Em

\footnotetext{
${ }^{119}$ Idem, sessão de 29/agosto, p. 214.

${ }^{120} \mathrm{Idem}$, sessão de $1^{\circ} /$ setembro, pp.227-234.

${ }^{121}$ Miguel Calmon du Pin e Almeida (1794-1865) era natural da Vila de Santo Amaro, Bahia. Estudou Direito na Universidade de Coimbra, e retornou à sua Província natal logo após a Revolução do Porto de 1820. Então foi eleito primeiro secretário do Conselho de Governo e, posteriormente, deputado para a Assembléia Constituinte de 1823. Dissolvida esta foi para a Europa onde permaneceu até 1827; novamente eleito deputado, tomou assento na $1^{a}$ legislatura da Assembléia Geral (que ocupou de 1827-9), também para a $2^{a}$ (1830-3), e para a 4 (que ocupou de 1838-1840). Entre 1827-8, ocupou a função de ministro da Fazenda e dos Estrangeiros. Recolheu-se à Bahia entre os anos de 1835-7, na primeira Regência Una, e voltou à cena política do Rio de Janeiro com o regente Pedro de Araújo Lima. Foi escolhido senador em 1840 pela Província do Ceará. Obteve o título de Marquês de Abrantes.

${ }^{122}$ APB-CD (1832), t.2, sessão de $1 \%$ setembro, pp. 234-5. Vale notar que tanto Miguel Calmon du Pin de Almeida como Francisco Montezuma foram típicos representantes de Província que ascenderam politicamente na Corte (ainda que de forma errática), tornando-se senadores depois do "regresso".

${ }^{123}$ Idem, sessão de 3/setembro, p.236.
} 
conjunto, foram aprovadas nove emendas controversas dos senadores (duas apenas em parte), e uma das principais polêmicas girou em torno de um Senado vitalício. Entre os deputados, um dos seus principais defensores foi o mesmo Antônio Rebouças, sob o principal argumento de que, como "juízes" de "objetos que afetam a causa pública”, os senadores deveriam ser realmente "amovíveis e vitalícios", além de irresponsáveis; neste ponto, criticaria como "absolutamente anômalo e pernicioso" tomar os modelo dos Estados Unidos para o caso do Brasil, o qual considerava incompatível com o Império ${ }^{124}$. O também deputado Martim Francisco Ribeiro de Andrada defenderia a vitaliciedade como fundamental "para observância da monarquia representativa". Com a junção das duas Casas, e, portanto, com votação conjunta entre seus membros, o Senado vitalício foi mantido por apenas um voto de diferença, já que 23 deputados votaram a favor de sua manutenção ${ }^{125}$. O que significa dizer que a segunda Câmara esteve muito perto de perder sua condição privilegiada.

Entre os senadores, coube a Felisberto Caldeira Brant Pontes ${ }^{126}$, o Marquês de Barbacena, uma longa defesa do conjunto das emendas da segunda Casa. Nela, foi incisivo em repudiar a designação de "federação" para o regime:

“Tudo quanto as províncias desejam, tudo quanto devemos fazer em seu benefício, se consegue melhorando a organização dos conselhos gerais, e aumentando a sua autoridade para legislar completamente no que for do peculiar interesse local de cada província. Não é, pois, na mudança do título de governo que consiste a prosperidade das províncias, mas sim na mudança da organização e autoridade de

\footnotetext{
${ }^{124}$ Idem, sessão de 21/09, pp.267-71.

125 Idem, sessão de 25/09, p.282. Os senadores Nicolau Vergueiro, Padre José Martiniano Alencar e José Inácio Borges foram os únicos que votaram pelo fim da vitaliciedade.

${ }^{126}$ Felisberto Caldeira Brant Pontes de Oliveira Horta (1772-1842) era natural de Mariana, Minas Gerais. Em 1788 foi para Lisboa para prosseguir sua educação no Colégio dos Nobres e, depois, na Academia de Marinha. Em 1801, foi à Bahia onde ocupou o posto de comandante do Regimento de Linha. Além da carreira militar, também exerceu atividades ligadas ao comércio. Em 1819, foi graduado marechal e nomeado fidalgo cavaleiro. Participou do movimento de adesão às Cortes de Lisboa, na Bahia, em 1821 e, no mesmo ano, foi enviado à Inglaterra com funções diplomáticas. Foi eleito deputado pela Bahia para a Assembléia Constituinte de 1823, e escolhido senador em 1826, pela Província de Alagoas. Atuou na guerra da Cisplatina, encampada por D. Pedro no Primeiro Reinado. Exerceria, por mais de uma vez, a função de ministro da Fazendo e do Império, sendo ministro Plenipotenciário na Regência de Feijó em 1835. Foi agraciado com o título de Marquês de Barbacena.
} 
seus conselhos. A palavra - federativa - nem é portuguesa, será o pomo de discórdia entre nós"127.

Para sua satisfação, a supressão do termo "monarquia federativa" seria de fato vencedora.

Com a união das Casas foi aprovado o texto da lei de 12 de outubro de $1832^{128}$, que fornecia aos deputados a serem eleitos para a legislatura seguinte (1834-7) a faculdade de reformarem alguns artigos da Constituição. Nesta lei imperava um espírito bem diverso daquele do projeto aprovado pelos deputados em 13 de outubro de 1831, e que dera início ao processo da reforma. O novo texto esmerava-se em indicar quais artigos da Carta deveriam ser reformados e, ainda que não tocasse diretamente nas bases do regime, também indicava o caminho a ser seguido; aprovava basicamente mudanças com o intuito: do Senado poder reunir-se independentemente dos deputados (art. 49), de existir um Conselho Geral de Província também na capital do Império (art. 72), dos mesmos Conselhos Gerais poderem ser convertidos em Assembléias Legislativas Provinciais (vários artigos), de a Regência permanente ser unitária (art. 123), e do Conselho de Estado poder ser suprimido (vários artigos). E embora seja evidente que o tom da mudança tenha sido minimizado em relação ao ano anterior, sobretudo para aqueles que esperavam por maiores alterações da estrutura política (mesmo fora da Assembléia), a lei de 12 de outubro de 1832 permitiria reformulações em dois pontos significativos do funcionamento do Estado: o do governo das Províncias e o dos conselheiros na cúpula imperial.

Ficava evidente que o modo para realização da reforma indicada pela Carta de 1824 - a qual previa sua aprovação em ambas as Casas legislativas - acabara por ser responsável também pela diminuição da radicalidade da proposta inicial. Nesse ponto, portanto, comprovava-se, para o Império do Brasil, a eficácia do Senado no papel de "conservador" do regime, anunciando que a defesa do caminho da legalidade - isto é, da Constituição -, na reforma tendia a constituir-se como sinônimo de moderação política.

\footnotetext{
${ }^{127}$ APB-CD (1832), t.2, sessão de $1 \%$ setembro, p. 279.

${ }^{128}$ Coleção de Leis do Império do Brasil (1832).
} 


\subsection{A votação da reforma constitucional}

A partir dos enfoques deste trabalho, é correto afirmar que o período das Regências "pode ser visto como um grande laboratório de formulações e práticas políticas e sociais, como ocorreu em poucos momentos da história do Brasil" ${ }^{129}$. Isso vale, sobretudo, para o momento imediatamente pós-Abdicação quando esteve na agenda uma real possibilidade de transformação geral do regime conforme disseminado nos meios impressos em debate público, ou até mesmo no âmbito da Câmara dos deputados. Neste caso, ficava claro que mudanças significativas poderiam ser feitas em meio à própria esfera da legalidade. No entanto, o reforço do controle sobre a imprensa por parte das autoridades, em especial a partir de 1834 , bem como a aprovação de um projeto mais moderado de mudança quando da reunião das duas Casas legislativas, tiveram um efeito considerável no enfraquecimento da publicização de idéias e projetos mais radicais de transformação do regime. Isso não significou, contudo, seu desaparecimento, mas sim crescentes dificuldades de colocá-los em prática dentro do caminho da legalidade, sobretudo aqueles que propunham uma profunda ampliação nos canais de participação política e medidas de maior abrangência social $^{130}$.

Desta forma, quando da abertura dos trabalhos legislativos em 1834, a expectativa da reforma constitucional, ainda que alta, já se encontrava mais circunscrita à forma do funcionamento político-administrativo do regime. $\mathrm{O}$ que, deve-se frisar, não era de pouca monta numa perspectiva política que privilegiava, para a eficácia do Estado, a ação do governo e das suas instituições. Por essa razão, ainda que fosse sabido que os deputados não iriam subverter a estrutura do Império como clamavam os panfletários "exaltados" até porque o espaço do Parlamento, como se viu, tendeu à sua preservação -, a mudança levada a cabo foi mesmo assim crucial ao sistema.

Logo no início da legislatura, os deputados decidiram por uma medida, no mínimo, polêmica quanto ao encaminhamento da reforma constitucional. Uma comissão especial

\footnotetext{
${ }^{129}$ Marco Morel, O período das Regências (1831-1840), Rio de Janeiro, Zahar, 2003, p.9.

${ }^{130}$ Marcelo Basile, op.cit., em especial a descrição faz dos projetos dos "exaltados"; Silvia Fonseca, op.cit.; Marco Morel, As transformações dos espaços públicos.
} 
eleita para elaborar um projeto final do tema, a partir da lei de 12 de outubro de 1832 , apresentou seu texto em junho de $1834^{131}$. Em trinta artigos, a proposta centrava-se na criação e funcionamento das Assembléias Legislativas Provinciais, juntamente com as novas atribuições dos presidentes, e incluía um artigo prevendo a supressão do Conselho de Estado $^{132}$. Entrando a matéria em discussão, o sempre crítico Ernesto Ferreira França, então deputado pela Bahia, abriu o debate afirmando que eles deveriam partir da própria lei de 1832 e não do novo projeto $^{133}$. Sua indicação trouxe à tona opiniões divergentes de como deveriam proceder na realização da aprovação da reforma propriamente dita.

Aprovou-se um requerimento proposto por Holanda Cavalcanti de Albuquerque ${ }^{134}$ para que se decidisse tanto sobre a competência dos deputados efetuarem a reforma da Constituição como uma regulamentação sobre a forma de sua discussão ${ }^{135}$. Foi quando José Custódio Dias ${ }^{136}$ defendeu que seriam eles, os "representantes da nação", a única autoridade necessária para aprovação da reforma. Com isso, o deputado mineiro propunha que os senadores não tivessem mais participação na sua elaboração e assim, como a Carta de 1824 não especificava se o projeto passaria novamente por ambas as Câmaras, a proposta ganhou defensores. A intenção era clara: evitar que, como havia acontecido em 1832, a Casa vitalícia fizesse emendas que modificassem o conteúdo decidido pelos deputados.

Saíram entre seus defensores Luiz Francisco Cavalcanti de Albuquerque ${ }^{137}$, Ernesto Ferreira França e Francisco de Paula Araújo e Almeida, este membro da comissão especial que elaborara o projeto. Alegavam que o Senado já havia votado a matéria e que eles, deputados, estariam dotados de um especial "poder constituinte", delegado pela "nação" que os elegera. Nesse sentido, Evaristo Ferreira da Veiga ${ }^{138}$, num longo discurso, comparou

\footnotetext{
${ }^{131}$ APB-CD (1834), t.1, sessão de 7/junho/1834, pp.104-6. A comissão era composta por Francisco de Paula Araújo e Almeida (Bahia), Bernardo Pereira de Vasconcellos (Minas Gerais), e Antônio Paulino Limpo de Abreu (Minas Gerais); todos os três deputados já haviam participado de legislaturas anteriores, sendo reeleitos.

${ }^{132} \mathrm{O}$ projeto encontra-se em APB-CD (1834), t.1, sessão de 7/junho, pp. 104-6.

${ }^{133}$ Idem, sessão de 14/junho, p. 130.

${ }^{134} \mathrm{O}$ deputado Antônio Francisco de Paula e Holanda Cavalcanti de Albuquerque havia sido reeleito pela sua Província natal, Pernambuco.

${ }^{135}$ APB-CD (18340, t.1, sessão de 14/junho, p.131.

${ }^{136} \mathrm{O}$ deputado já havia participado da $1^{\mathrm{a}}$ (1826-29) e da $2^{\mathrm{a}}$ legislaturas (1830-33), sempre por Minas Gerais, sendo novamente reeleito pela mesma Província.

${ }^{137} \mathrm{O}$ deputado pernambucano já havia participado das duas legislaturas anteriores, pela sua Província natal.

${ }^{138} \mathrm{O}$ deputado já havia participado, também como representante de Minas Gerais, da $2^{\text {a }}$ legislatura (1830-3).
} 
as instituições brasileiras às "americanas" por partirem de "poderes políticos populares" (à exceção do monarca), e tocou no ponto central da questão: dizia recear que as reformas fossem novamente vetadas pelos senadores e o Brasil entrasse, por essa razão, em uma "guerra civil""139.

Foram muitos os que atacaram a matéria em nome de estar estabelecida, pela Constituição, a obrigação de todas as leis passarem pelas duas Câmaras para seu melhor aprimoramento, e que seria um "golpe de estado" isolarem os senadores da discussão. Assim falaram Francisco de Souza Martins ${ }^{140}$, deputado pelo Piauí, o maranhense Antônio Pedro da Costa Ferreira, Manoel Maria do Amaral, pela Bahia, Antônio Peregrino Maciel Monteiro $^{141}$, por Pernambuco, e o autor do requerimento, Holanda Cavalcanti de Albuquerque, que anunciava que já "não tinha esperanças mui lisonjeiras do bom resultado dessas reformas" ${ }^{142}$. Mas foi D. Romualdo Antônio de Seixas ${ }^{143}$, o arcebispo da Bahia, o responsável por um discurso primoroso em defesa da participação da segunda Casa, em nome da moderação política:

"Farei também o meu protesto: não me oponho às reformas, porque as julgo um meio de prevenir talvez uma revolução: faça-se a reforma; mas com o cunho da legalidade; e se a câmara dos deputados da França procedeu revolucionariamente às reformas, no sentir de um ilustre deputado, nem por isso prescindiu da aprovação da outra câmara, para rodear este seu ato de mais algum prestígio; porque não faremos

${ }^{139}$ APB-CD (18340, t.1, sessão de 14/junho, p.136.

${ }^{140}$ Francisco de Souza Martins (1805-57) era natural de Jaicós, no Piauí. Como magistrado, exerceu as funções de Procurador Fiscal da Tesouraria da Fazenda e de Juiz de Direito, em Oeiras e em Niterói. Ocupou a cadeira de deputado na Assembléia Geral pelo Piauí e, posteriormente, também pelo Ceará. Foi presidente da Província da Bahia (1834-6) e do Ceará (1840). Pertenceu ao Instituto Histórico e Geográfico Brasileiro, sendo autor de diversos trabalhos esparsos publicados na imprensa.

${ }^{141}$ Antônio Peregrino Maciel Monteiro (1804-68) era natural do Recife. Formou-se em Letras, Ciências e Medicina na Universidade de Paris. De regresso ao Brasil, após trabalhar três anos como médico, decidiu ingressar na carreira política e elegeu-se deputado para a $3^{\mathrm{a}}$ legislatura (1834-7) da Assembléia Geral. Foi reeleito sucessivas vezes para a mesma cadeira. Entre 1837-9, foi ministro dos Negócios Estrangeiros, e em 1841, tornou-se Conselheiro de Estado. Ingressou na carreira diplomática em 1853, quando tornou-se ministro plenipotenciário do Brasil em Portugal. Recebeu o título de $2^{\circ}$ Barão de Itamaracá. Morreu em Lisboa.

${ }_{142}$ APB-CD (1834), t.1, sessão de 16/junho, p.142.

${ }^{143}$ Romualdo Antônio de Seixas (1787-1860) era natural de Cametá, Pará. Sacerdote, lecionou latim, retórica e filosofia no Seminário Episcopal. Iniciou carreira política como presidente da Junta Provisória do Pará (1821-3). Em 1826, foi nomeado décimo sétimo arcebispo da Bahia. Ocupou a cadeira de deputado nas $1^{\mathrm{a}}$ e $4^{\mathrm{a}}$ legislaturas (1826-9 e 1838-41) representando o Pará, e nas $3^{\mathrm{a}}$ e $5^{\mathrm{a}}$ (1834-7 e 1842-5) pela Bahia. Presidiu a solenidade de sagração de D. Pedro II (1841). Foi agraciado com o título de Marquês de Santa Cruz. Era sócio do Instituto Histórico e Geográfico Brasileiro. 
nós o mesmo? As reformas devem ser o fruto da experiência, e das luzes de todos os legisladores; a nação nos impõe imensa responsabilidade, e quem sabe se mudando as fórmulas, não deixaremos existir os vícios que arruinam o corpo político? Se não for a educação, os costumes públicos, se não for instruindo o mesmo governo que é a segunda moralidade dos povos, se ele não tiver aquela força moral, para fazer respeitar e observar as leis, de que servirão os nossos esforços?"144.

Durante três sessões o tema esteve em pauta e, apesar do coro pela participação dos senadores, a proposta de Custódio Dias foi aprovada com folga ${ }^{145}$. Ficava decidido, portanto, que os deputados dali em diante aprovariam sozinhos a reforma, o que evidentemente não foi visto com bons olhos pela segunda Câmara ${ }^{146}$. No dia seguinte, votou-se pelo início da discussão do projeto elaborado pela comissão, ficando abolida a primeira leitura regulamentar da matéria por se julgar que ela era de imediata urgência.

Logo que entrou na pauta o primeiro artigo do projeto, o qual simplesmente criava as Assembléias Legislativas em cada Província, diferentes concepções no tocante à sua definição vieram à tona ${ }^{147}$. Quem iniciou a polêmica foi Ernesto Ferreira França, ao oferecer uma emenda para que se deixasse claro que as novas Assembléias substituíam os ainda existentes Conselhos Gerais de Província, além do estabelecimento de uma no Rio de Janeiro que englobasse também a capital do Império. Seu argumento para a primeira proposição era que, de acordo com o artigo 81 da Carta $^{148}$, esses Conselhos teriam maiores atribuições do que se queria agora marcar para as novas Assembléias. Isso porque os órgãos existentes teriam direito de deliberar sobre todas as questões que considerassem necessário para as localidades, sem marcação de qualquer limite. Seguiu-o nessa defesa Francisco Gonçalves Martins ${ }^{149}$, também deputado pela Bahia, que dizia não haver dúvida que se iria

\footnotetext{
${ }_{144}$ APB-CD (1834), t.1, sessão de 16/junho, p.140.

${ }^{145}$ Idem, sessão de 17/junho, p.159-50.

${ }^{146}$ Ver as discussões que aconteceram sobre a matéria no Senado nos dias 5, 7, 8, 20, 22 e 23 de agosto.

${ }^{147}$ APB-CD (1834), t.1, sessão de 23/junho, a discussão se inicia na p.166.

${ }^{148}$ O artigo 81 da Carta de 1824 dizia: "Estes Conselhos[Gerais da Província] terão por principal objeto propor, discutir, e deliberar sobre os negócios mais interessantes das suas Províncias; formando projetos peculiares, e acomodados às suas localidades, e urgências".

149 Francisco Gonçalves Martins (1807-1872) era natural de Santo Amaro, Bahia. Estudou Direito na Universidade de Coimbra. Como magistrado, exerceu a função de juiz de direito. Ocupou a cadeira de deputado na $3^{a}$ legislatura (1834-7) da Assembléia Geral - então como suplente pela Bahia de João Gonçalves Cezimbra - e nas quatro legislaturas seguintes. Exerceu a função de presidente da Bahia por duas vezes (1848-
} 
promover uma restrição da ação política nas localidades e, por conseqüência, de sua autonomia $^{150}$.

Conforme vimos anteriormente, os Conselhos tinham ampla esfera de ação e jurisdição. Mas o que argumentaram aqueles que apoiavam o projeto da comissão era que as novas Assembléias teriam um diferencial qualitativo no seu direito de "legislarem no rigor dessa palavra, isto é, a ser a legislação provincial completamente concluída na Província, independente de sanção do poder central" ${ }^{\prime 151}$. No entanto, esse pretenso diferencial esteve longe de ser aceito como uma vantagem, e Holanda Cavalcanti de Albuquerque, que se colocara desde o começo da legislatura anterior contrário à reforma, afirmava considerar que os Conselhos Gerais e as Assembléias Provinciais que se pretendiam criar eram, essencialmente, "sinônimos"152. Sessões à frente, um outro pernambucano, Antônio Peregrino Maciel Monteiro, protestaria contra o fato de a comissão não mostrar "estar muito penetrada da necessidade de ampliar" as atribuições dos mesmos Conselhos, o que considerava o "princípio fundamental da reforma" $" 153$.

No entanto, a discussão foi mais polêmica no que dizia respeito à criação de um órgão provincial para o Rio de Janeiro. Segundo o projeto, a Assembléia a ser aí instaurada não compreenderia o município onde se encontrava a Corte, que deveria se manter independente. A emenda de Ernesto Ferreira França ia de encontro a essa autonomia, ao propor que a urbe carioca fosse integrada à esfera de poder da Província sob a preocupação de que os "direitos das localidades não fossem excluídos". Francisco de Paula Araújo, como membro da citada comissão, atacou a emenda de forma incisiva. Falou em nome de uma diferenciação entre o governo da "corte" - ou "nacional" - e o da Província, os quais, apesar de complementares, tinham que atender a interesses distintos ${ }^{154}$. No mesmo sentido argumentou Bernardo Pereira de Vasconcellos, ao conceber que uma das intenções da lei em questão era estabelecer uma "demarcação definitiva" no que se tratava de nacional, municipal e provincial 155 . A “capital do Império" deveria, portanto, ser "desligada de todos

52 e 1868-71). Ocupou a função de ministro do Império, desembargador e ministro do Supremo Tribunal de Justiça. Foi escolhido senador em 1851. Recebeu o título de Visconde de São Lourenço.

${ }^{150}$ APB-CD (1834), t.1, sessão de 23/junho, p.167.

${ }^{151}$ Idem, p. 169, discurso de Antônio Joaquim de Melo, deputado por Pernambuco.

${ }^{152}$ Idem, p.170-1.

${ }^{153}$ Idem, sessão de 28/junho, p.194.

${ }^{154}$ APB-CD (1834), t.1, sessão de 23/junho, p. 167.

${ }^{155}$ Idem, p. 170. 
os feixos provinciais", "desviada de quaisquer influências" das localidades, concordava Evaristo Ferreira da Veiga ${ }^{156}$.

Os que se aliaram à proposta de Ernesto Ferreira França defenderam que não houvesse diferenciação para o espaço do município sede do governo central, o qual aventavam ser transferido para outro lugar no caso de conflitos entre o poder provincial e o "nacional"157. Luiz Francisco Cavalcanti de Albuquerque também a defendeu como “consentâneo com a Constituição e com a igualdade" que a Assembléia Legislativa, onde estiver a "Corte, compreenda a cidade capital" ${ }^{158}$. Isso porque, segundo ele, "queria que o Brasil todo fosse [um] lugar nacional" sem privilégio para nenhuma parte. Quando da votação, ambas as emendas do baiano Ferreira França foram rejeitadas, sendo aprovado o artigo tal qual proposto pela comissão ${ }^{159}$.

Nesse início de debate, já se percebe claramente como os deputados que defendiam ambas as emendas opuseram-se, sobretudo, a uma concepção presente no projeto: a da implementação de uma definitiva circunscrição da esfera provincial com suas atribuições e ações devidamente marcadas, em contrapartida à delimitação formal de um centro político que até então não havia sido concebido e normalizado em moldes modernos. Nesse sentido, falar em defesa da ampla jurisdição dos Conselhos era sinônimo vislumbrar nesses órgãos uma maior autonomia das localidades em face do governo imperial, o qual também não deveria ter privilégio de jurisdição. Talvez não fosse à toa que entre aqueles que se manifestaram contrários à medida estivessem representantes da Bahia e de Pernambuco, e até se aventasse a hipótese da própria Corte mudar sua sede física. No fundo, o ponto em questão passava pelas tensões na criação de uma estrutura institucional estatal moderna, conflito este inerente a todas as variações desse processo no mundo ocidental.

A posição a favor do projeto sem emendas ganharia força no correr dos debates. Logo que se passou à discussão do segundo artigo, que estipulava o número de membros das Assembléias Legislativas em cada uma das localidades o qual só poderia ser alterado por lei geral, abriu-se novo espaço para críticas ${ }^{160}$. O deputado Francisco de Brito

\footnotetext{
${ }^{156}$ Idem, p. 168.

${ }^{157}$ Idem, p.167, discurso de Francisco Gonçalves Martins.

${ }^{158}$ Idem, p. 169.

${ }^{159}$ Idem, p. 172.

${ }^{160}$ Idem, sessão de 25/junho, p. 173.
} 
Guerra ${ }^{161}$, eleito pelo Rio Grande do Norte, propôs uma emenda para que este número pudesse ser alterado por lei provincial, a depender das condições existentes. Imediatamente o maranhense Antônio Pedro Costa Ferreira saiu em sua defesa, atacando os responsáveis do projeto de serem coniventes com a "centralização". Contestava que "até agora a arte de governar tem sido de centralizar ou tiranizar, porque centralizar e tiranizar o Brasil, era uma e mesma coisa". Terminava defendendo o direito de as Províncias se autogovernarem:

"Sabe-se muito bem que o exercício da soberania dos povos tem tanta maior amplidão, quanto maior é o número de seus deputados: e para que atalhar que as províncias sejam representadas pelo número de deputados que quiserem? Para que continuar a mania de chamar esses negócios peculiares à assembléia geral, quando ordinariamente se observa que os Srs. deputados não têm dados suficientes para conhecerem dos negócios particulares das províncias?"162.

Ambas as falas encontrariam ampla ressonância no plenário. O padre Venâncio Henriques de Resende, representante de Pernambuco, também discordou que a Assembléia Geral marcasse o número de deputados nas localidades, sob o argumento de que "não se pode[ria] aplicar a uma Província o mesmo que para outra"163. Defendeu, inclusive, um princípio ainda mais radical: para que ficasse a cargo de cada uma delas decidir se queria entrar na reforma da Carta de 1824 ou permanecer como estava até o momento, pois cumpria "não adotar uniformidade para tudo, muito mais quando resulta[riam] inconvenientes"164. Por fim, sustentava que "guardando-se a fisionomia da nossa monarquia, tudo o mais se deveria deixar livre às Províncias", e que ao governo imperial apenas "restava o direito de revogar os atos que forem contrários à Constituição". A "unidade" era o "fim" mas os meios dev[er]iam ser tão diversos, quantas são as circunstâncias da localidade".

\footnotetext{
${ }^{161}$ Francisco Brito Guerra (1777-1845) era natural de Augusto Severo, Rio Grande do Norte. Estudou no Seminário Maior de Olinda onde se tornou padre, também se formando em Direito. Tomou assento como deputado pelo Rio Grande do Norte na $2^{\mathrm{a}}$ legislatura (nos anos de 1831-3) como suplente de José Paulino de Almeida e Albuquerque, e na $3^{\mathrm{a}}$ (1834-7). Foi escolhido senador em 1837.

Deputado Geral - 1831 a 1833

${ }^{162}$ APB-CD (1834), t.1, sessão de 25/junho, p.173.

${ }^{163}$ Idem, p.172-4.

${ }^{164}$ Idem, p. 176.
} 
Brito novamente defenderia sua proposta, sob o argumento de existir um problema generalizado no fato de as Províncias clamarem por "coisas muito particulares" à Assembléia Geral, cujo resultado seria a demora e o não deferimento de muitas das questões provindas das localidades ${ }^{165}$. Apoiaram-na também os deputados Francisco Gonçalves Martins, pela Bahia, Jerônimo Martiniano Figueira de Mello ${ }^{166}$, eleito pelo Ceará, José Maria Veiga Pessoa ${ }^{167}$, pela Paraíba do Norte, e o pernambucano Holanda Cavalcanti de Albuquerque. A longa polêmica que se instaurou - diga-se de passagem, a partir de um artigo aparentemente inofensivo - deixava claro que a questão do caráter da unidade do Império era um dos pontos mais espinhosos e controversos na elaboração da reforma.

Os membros da comissão que elaborara o projeto responderam aos seus opositores propugnando uma outra compreensão das bases que articulariam as partes do Brasil, a partir do princípio de consolidação de um centro político que fornecesse "uniformidade para todas as províncias do Império". Francisco de Paula Araújo argumentou que a reformulação da Constituição só teria o intuito de "afrouxar um pouco os laços minimamente apertados, e tirar os embaraços que se opõem à felicidade das mesmas Províncias”, sem destruir o papel da Corte como ponto de união entre elas ${ }^{168}$. Antônio Paulino Limpo de Abreu condenou que uma lei eleitoral pudesse ficar sob a alçada provincial, pois que era matéria constitucional; também atacou veementemente a proposta de Henriques de Resende de atender o livre-arbítrio das localidades como "princípio muito perigoso para se agitarem as facções, e ser perturbada a paz e a tranqüilidade pública"169.

\footnotetext{
${ }^{165}$ Idem, sessão de 26/junho, p. 183.

166 Jerônimo Martiniano Figueira de Mello (1809-1878) era natural de Sobral, no Ceará. Formou-se em Ciências Jurídicas e Sociais na Faculdade de Olinda, onde recebeu o grau de bacharel em 1832. Iniciou sua carreira na magistratura no ano seguinte como promotor público da Corte. Posteriormente ocuparia vários cargos públicos, entre eles, o de juiz de direito da comarca de Fortaleza (1837-1841), o de desembargador da Relação de Pernambuco (1851) depois transferido para a Relação do Rio de Janeiro (1861), e o de ministro do Supremo Tribunal de Justiça (nomeado em 1873). Foi presidente da Província do Maranhão (1843) e do Rio Grande do Sul (1871-2). Por várias vezes, ocupou a cadeira de deputado na Assembléia Geral, estreando na $3^{\mathrm{a}}$ legislatura (1834-7) representando o Ceará (posteriormente também seria eleito por Pernambuco). Foi nomeado senador em 1870 .

167 José Maria Ildefonso Jácome da Veiga Pessoa era militar, natural da Paraíba. Ocupou a cadeira de deputado por esta Província na Assembléia Geral nas $3^{a}$ e $4^{a}$ legislaturas (1834-41), e depois como suplente em 1843.

168 APB-CD (1834), t.1, sessão de 25/junho, p. 173.

${ }^{169}$ Idem, p. 176.
} 
O deputado Figueira de Mello, favorável à proposta de Brito Guerra, ofereceu uma outra emenda também defendida pelos opositores do projeto: que as Assembléias Legislativas provinciais possuíssem duas Câmaras, ou seja, uma para os deputados e outra para os senadores (sendo estes também eleitos), a exemplo do que funcionava na Corte ${ }^{170}$. Sua justificativa era a conveniência das "leis te[rem] o cunho da sabedoria, e mesmo para evitar os inconvenientes de serem as leis feitas em uma só Câmara”. Em apoio à matéria, o piauiense Francisco de Souza Martins argumentava que o senado serviria "para evitar os perigos que pode[ria]m vir de uma só câmara legislativa",171, por "obstar a todos os excessos que pudessem acarretar esses princípios democráticos; o espírito de facção seria contido, o receio da separação das províncias desapareceria"172. No mesmo sentido, o baiano Gonçalves Martins afirmava tratar-se de uma "garantia a mais" à ordem nas Províncias, sem que isso implicasse aumentar os seus direitos ${ }^{173}$.

Vários foram os pronunciamentos contra as emendas à proposta da comissão. Saturnino de Souza e Oliveira ${ }^{174}$, eleito pelo Rio de Janeiro, afirmava ser "inadmissível” que se deixasse às Províncias o direito de marcar o número de seus deputados, já que estava na Constituição que o "sistema" deveria ser "geral"175. Também atacava a idéia de criação, nas Províncias, de uma segunda Câmara, pois, se havia necessidade de um corretivo para possíveis abusos, este deveria ser estabelecido pela sanção dada aos seus presidentes ${ }^{176}$. Da mesma forma que Limpo de Abreu, condenou a proposta de Henriques de Resende como possível de "pôr em combustão todas as Províncias do Brasil”. João Climaco de Alvarenga Rangel $^{177}$, deputado pelo Espírito Santo, seria ainda mais incisivo na crítica ao poder que se queria dar as Províncias, sob o argumento de que iriam "estabelecer com as reformas estados independentes" sem "satisfazer à vontade de nossos cidadãos que queriam reformas compatíveis com as nossas circunstâncias"178. Arrematava que o exemplo a ser seguido não

\footnotetext{
${ }^{170}$ Idem, p. 174.

${ }^{171}$ Idem, p.178.

172 Idem, sessão de 26 de junho, p.184.

${ }^{173}$ Idem, p. 183.

${ }^{174}$ Saturnino de Souza e Oliveira (?-1848) era advogado. Ocupou a cadeira de deputado na Assembléia Geral pelo Rio de Janeiro. Ocupou interinamente o cargo de ministro da Justiça, em 1847. Nesse mesmo ano, tomou posse como ministro dos Negócios Estrangeiros e também foi escolhido senador.

${ }^{175}$ APB-CD (1834), t.1, sessão de 25/junho, p.175.

${ }^{176}$ Idem, sessão de 26/junho, p.185.

177 João Climaco de Alvarenga Rangel (? -1863), era natural do Espírito Santo. Padre, foi deputado pela sua Província natal na 3 legislatura (1834-7) da Assembléia Geral.

${ }^{178}$ APB-CD (1834), t.1, sessão de 25/junho, p.177.
} 
deveria ser "o dos Estados Unidos da América", pondo por terra o "princípio da federação". Ambos deixavam claras posições extremamente conservadoras no que tocava às mudanças em curso.

Com um discurso mais moderado, Evaristo Ferreira da Veiga também foi contrário a todas as emendas propostas. Afirmando ser um defensor de uma "reforma com prudência", argumentou longamente que o regime do Brasil era, atualmente, um meiotermo entre o sistema dos Estados Unidos e o dos "governos especiais europeus" monárquicos ${ }^{179}$. E não deixava de frisar que o exemplo do primeiro deveria inclusive ser seguido:

"Sigamos nossos mestres, nossos irmãos mais velhos em prudência e circunspecção; os americanos do norte existiam isolados em Províncias separadas: tentaram federar-se, e a este respeito há um abuso de palavra entre nós, que nos induz a gravíssimo erro: chama-se federalista aquele que não é senão democrata, e chama-se unitário aquele que é chamado na América do Norte federalista; federalista é o que quer que as províncias tenham em si aquilo que lhes convém para seu bem, mas que se não desliguem umas das outras" ${ }^{180}$.

Nestes termos, não descartava que no Brasil se instalasse, "pouco a pouco", uma federação desde que esta compreendesse a união de todas as partes em uma instância que administrasse as "tensões e rivalidades" entre elas, ou seja, um centro comum. Daí à crítica a que as Províncias pudessem escolher até mesmo o número de seus deputados. Assim, dizia votar "pela federação, mas não pela sua separação".

Quando da votação do artigo dois, que estipulava o número de membros das Assembléias, ele foi aprovado tal qual proposto pela comissão. No entanto, a emenda que alterava sua segunda parte, contrária a uma "lei geral" que determinasse a quantidade dos membros dos Legislativos locais, não foi aprovada por muito pouco. O que significava que o anseio por maiores atribuiçõos às localidades, e mesmo maior autonomia, nesse momento ainda encontrava amplo respaldo na Casa. Analisando o conteúdo desse debate, duas questões merecem ser destacadas: primeiro, que foram apenas os representantes do Norte

\footnotetext{
${ }^{179}$ Idem, sessão de 26/junho, p. 182.
} 
que discursaram em apoio tanto à emenda para jurisdição local sobre o número dos eleitos das Assembléias Provinciais, como à que previa a criação de duas Câmaras para cada uma delas. Por outra parte, foram predominantemente os deputados do Sul que defenderam o projeto da comissão.

No entanto, antes de se pretender qualquer imagem de um suposto projeto coeso de oposição "do Norte" a uma centralização pretendida pelos deputados sulistas, deve-se frisar que tanto o baiano Francisco de Paula Araújo e Almeida - aliás, um dos subscritores do texto em discussão - como o alagoano Manoel Joaquim Fernandes de Barros ${ }^{181}$ fizeram enfáticas críticas às emendas. $\mathrm{O}$ segundo chegou a afirmar que considerava um "princípio subversivo da ordem" permitir que as Províncias escolhessem se queriam ou não aderir à reforma, além de propor uma emenda conciliatória para fixação do número de deputados provinciais que poderia, posteriormente, ser alterado pelas Assembléias. Dessa forma, se a pressão por um regime com maior autonomia do governo nas localidades e desconsiderando a importância política do Rio de Janeiro como centro, era identificada com representantes provindos de regiões mais longínquas da capital imperial, isso não significava o funcionamento de bancadas provinciais unificadas em torno de programas definidos.

A natureza do proposto pelas emendas ao projeto é um segundo ponto importante a ser destacado. Ao defenderem um Senado que funcionasse de forma a controlar os "perigos" de ações radicais, alguns deputados atuavam como opositores em relação a uma excessiva centralização, já que imaginavam que a intervenção do governo imperial pudesse ser minimizada na produção de suas leis. Porém, mesmo que os cargos de senadores fossem também eletivos numa primeira instância, a ênfase era na proposição de uma maior autonomia das decisões nas Províncias sem a defesa da ampliação da participação popular na esfera da política. Dessa forma, a proposta podia ser inovadora no que tocava na relação das partes com o centro do Império, mas, devido ao papel de moderação que nela caberia à Câmara "alta", era conservadora em relação aos direitos políticos da sociedade ${ }^{182}$. A

\footnotetext{
${ }^{180}$ Idem.

${ }^{181}$ Manoel Joaquim Fernandes de Barros (1802-1840) era natural de Alagoas. Médico e doutor em Ciências Físicas, ocupou a cadeira de deputado por sua Província natal na $3^{\mathrm{a}}$ legislatura entre os anos de $1834-5$, sendo depois substituído por Antônio de Castro Vianna.

${ }^{182}$ Deve-se notar também que grande parte dos deputados que defenderam as emendas contra o projeto da comissão seriam posteriormente escolhidos senadores, mesmo que em momentos distintos.
} 
continuidade da discussão da reforma deixaria claro como a defesa da "federação" não possuía uma ligação direta com essa agenda de transformação político-social.

Quando entrou em discussão se as eleições para as Assembléias Provinciais seriam realizadas da mesma forma que para os "representantes da nação", e de dois em dois anos conforme o artigo terceiro do projeto da comissão, Antônio Pedro da Costa Ferreira propôs que se deixasse livre às Províncias para marcarem o tempo de duração de suas legislaturas ${ }^{183}$. Ao deputado, que anteriormente já havia votado pela autonomia local no estabelecimento do número dos seus deputados, juntavam-se novamente Francisco de Souza Martins e Jerônimo Martiniano Figueira de Mello (o qual propusera na discussão anterior a divisão da Assembléia em duas Câmaras). Este último defendeu novamente os “direitos" das Províncias, em poucas e diretas palavras:

"tudo deve ficar às Assembléias Provinciais: porque o sistema de uniformidade para todas as Províncias é pernicioso, e por isso não pode ele deixar de modificar-se segundo as localidades" ${ }^{184}$.

O mesmo fez Henriques de Resende sob o argumento de que "via negarem-se direitos que o bem das Províncias exigiam, direitos que não prejudicavam os interesses gerais da nação ${ }^{185}$. Nesse sentido, defendeu que cada uma dessas localidades fossem entendidas como "relativamente soberanas".

Dois dos autores do projeto, Francisco de Paula Araújo e Bernardo Pereira de Vasconcellos, saíram novamente em sua defesa. Dessa vez, foi o segundo que longamente falou em nome da atuação de um centro na determinação de medidas que considerava de caráter geral, afirmando ser "conveniente" que se entrasse "nesta estrada de federação com muita cautela, e até com medo ${ }^{186}$. Advogava ser um "sectário do partido do justo meio", pelo qual se regozijava de "não ter deslizado dos princípios desta escola", atacando o que considerava como "opiniões exageradas" de seus opositores. Dessa forma, o deputado mineiro anunciava claramente o liberalismo moderado a que era afeito.

\footnotetext{
${ }^{183}$ APB-CD (1834), t.1, sessão de 28/junho, p. 196.

${ }^{184}$ Idem.

${ }^{185}$ Idem, p. 197.

${ }^{186}$ Idem, 198.
} 
Na votação da matéria, foi novamente o estipulado pela comissão que venceu, ficando decidido que as eleições para as Assembléias Legislativas locais se dariam a cada dois $\operatorname{anos}^{187}$. Igualmente foi aprovado que os deputados seriam invioláveis (cuja votação passou por 80 votos favoráveis e apenas seis contra), e que no caso de infração, praticar-seia o mesmo que a Constituição determinava para os representantes gerais e senadores. A polêmica só voltaria a tomar corpo quando entrou em pauta o artigo que previa que as sessões das citadas Assembléias durariam dois meses, podendo ser prorrogadas, quando se julgasse necessário, pelos presidentes das Províncias ${ }^{188}$.

Nesse ponto, o cearense José Maria Veiga Pessoa fez emenda para que as próprias Assembléias Provinciais - e não seus presidentes - tivessem o direito de determinar a prorrogação das sessões. Sua colocação ia contra a ingerência da autoridade Executiva, nomeada pelo poder central, nos trabalhos legislativos das Províncias. Antes dele, João de Albuquerque Maranhão ${ }^{189}$, deputado eleito pela Paraíba, tinha proposto uma medida mais conciliatória em relação ao projeto da comissão, segundo a qual as sessões durariam três meses e poderiam ser convocadas extraordinariamente se os mesmos presidentes ou dois terços da Assembléia assim o quisessem. Holanda Cavalcanti de Albuquerque também se declarou contra o artigo, sob o argumento de que homens escolhidos pela Corte "não podiam saber mais dos interesses das Províncias do que seus próprios representantes" ${ }^{\prime 190}$. Na sessão seguinte, o mesmo deputado seria ainda mais radical na sua colocação: defenderia a total exclusão dos presidentes da administração provincial (e que ficasse a seu cargo apenas "questões externas" e do "movimento das forças de mar e terra"), pois os acusava de serem como "criaturas do poder" que desempenhavam uma espécie de "quinto poder" local $^{191}$.

Os defensores do artigo argumentaram que a ação dos presidentes de Província deveria se espelhar no papel exercido pelo "Moderador", o qual tinha o poder de prorrogar e dar sanção às leis, segundo afirmou Francisco de Paula Araújo ${ }^{192}$. No mesmo sentido, Evaristo Ferreira da Veiga, falando em nome da ampla jurisdição que caberia aos

\footnotetext{
${ }^{187}$ Idem, p. 199.

${ }^{188}$ APB-CD (1834), t.1, sessão de 30/junho, p.205. Trata-se da discussão do artigo $8^{\circ}$ do projeto da comissão.

${ }^{189} \mathrm{O}$ deputado participou unicamente nessa 3 legislatura (1834-37) da Assembléia, pela Paraíba.

${ }^{190}$ APB-CD (1834), t.1, sessão de 30/junho, p.205-6.

191 APB-CD (1834), t.2, sessão de 1/julho, p.8.

192 APB-CD (1834), t.1, sessão de 30/junho, p.206.
} 
Legislativos provinciais, defendeu que eles tivessem as mesmas atribuições e funcionamento que a Assembléia Geral ${ }^{193}$. Então apoiou a intervenção dos presidentes já que, da mesma forma que o Executivo central, seu veto seria apenas suspensivo, o que não impedia a aprovação das matérias que tivessem o acolhimento de mais de dois terços do plenário. Ambas opiniões expressavam o repúdio a que as Assembléias locais tivessem poderes incontroláveis e, em vez de apoiarem uma segunda Casa que pudesse contê-los conforme proposta aventada anteriormente, preferiram investir no reforço da atuação dos presidentes. Num longo discurso a seu favor, Bernardo Pereira de Vasconcellos inclusive argumentou que eles, deputados, não haviam sido autorizados pela reforma para "tocar" nas funções “do poder Executivo" senão no que respeitava a sua sanção ${ }^{194}$. Lembrava que no Brasil existia um "princípio hereditário" para novamente rechaçar os que defendiam os Estados Unidos como modelo, concluindo que nosso "hábito, costume e estado de civilização" concorriam para algum mínimo de "centralização".

A matéria foi aprovada sem emendas, ficando ao presidente de Província resguardado o direito de prorrogação dos trabalhos legislativos locais. Vários dias se passariam envoltos na intensa discussão do cerne da reforma, ou seja, das atribuições que caberiam às Assembléias Provinciais ${ }^{195}$. Agora, mais do nunca, apareceram as disputas pelo caráter dos novos órgãos e do arranjo institucional para o Império.

Dessa vez, o primeiro a protestar foi Cornélio Ferreira França ${ }^{196}$, deputado pela Bahia, retomando o argumento de que se não deveriam especificar as citadas atribuições das Assembléias. Afirmava que bastava dizer que elas teriam "por principal objeto legislar sobre os negócios mais interessantes de suas Províncias, formando projetos peculiares e acomodados a sua localidade" ${ }^{\prime 197}$, já que seria muito dificultoso marcar todas as suas

\footnotetext{
193 APB-CD (1834), t.2, sessão de 01/julho, p.7.

${ }^{194}$ Idem, pp. 10-2.

195 Idem, sessão de 2/julho, p. 14 e seg. Eram os artigos 10 e 11 do projeto da comissão que marcavam as atribuições das Assembléias, o primeiro em 11 parágrafos e o segundo em 9.

${ }^{196}$ Cornélio Ferreira França (1802-1878) era natural de Salvador (filho do Dr. Antônio Ferreira França, e, portanto, irmão de Ernesto Ferreira França, os quais também ocupavam as cadeiras de representantes da Bahia na Câmara em 1834). Cursou Direito na Universidade de Coimbra. Em 1824, de volta ao Brasil, foi nomeado juiz de fora da cidade de Ouro Preto e provedor da Fazenda dos Defuntos e Ausentes, Resíduos e Capelas da mesma cidade. Passou a ouvidor da referida cidade, em 1826, e do Espírito Santo, em 1829, sendo também provedor. Aos seus vários cargos públicos, junta-se sua nomeação para desembargador da Relação de Pernambuco, em 1832, e para idêntico lugar da Relação da Bahia. Exerceu o mandato como deputado na Assembléia Geral pela Bahia na $3^{\text {a }}$ legislatura (1834-7). Ocupou o cargo de ministro do Supremo Tribunal de Justiça, nomeado em 1849. Faleceu no Rio de Janeiro.
}

197 APB-CD (1834), t.2, sessão de 2/julho, p. 13. 
"minuciosidades". Dessa forma, apesar de defender uma ampliação da ingerência dos órgãos legislativos nas localidades, criticava que os mesmos decidissem sobre os impostos para os quais alegava serem necessárias medidas gerais. Vale dizer que o projeto em discussão marcava, no seu artigo 12, que as Províncias não poderiam legislar sobre os impostos de exportação, e que desde 1832 já imperava uma separação entre os tributos "gerais" e "provinciais" responsável por tensões na Casa.

Num outro pronunciamento, o mesmo Cornélio deixaria ainda mais clara sua posição ${ }^{198}$. Sob o argumento de que os impostos de exportação não poderiam ser considerados "gerais" - já que não existiam em todas as Províncias - pregava que a divisão da tributação entre "nacionais" e "locais" fosse abolida, e que a Assembléia Geral apenas determinasse as despesas totais para depois distribuir pelas partes suas "respectivas quotas". Assim evitar-se-ia o inconveniente de "certas rendas" passarem a ser consideradas "despesas gerais", deixando a cargo das localidades a decisão sobre a "maneira" como iriam pagar sua contribuição tributária. O baiano Francisco Gonçalves Martins concordou plenamente com o companheiro de bancada, e salientou que o imposto de exportação, ao contrário do que se supunha, deveria ser entendido como "local também"199. Dessa forma, este último reiterava a defesa contra a fixação das atribuições dos novos órgãos, em nome de uma ampla jurisdição dos Conselhos que o projeto da comissão pretenderia amputar:

“A comissão, Senhor Presidente, excedeu seus limites, e tirou às Províncias um direito que elas tinham; porquanto podendo elas por intermédio dos Conselhos discutir e deliberar sobre tudo quanto fosse de mais interessante para si, e não sendo reformável esse direito" ${ }^{200}$.

Os demais críticos da atribuição precisa de funções às Assembléias também se mostraram afinados com o discurso, já anteriormente veiculado, de que os Conselhos Gerais de Província teriam maior poder de ação do que os órgãos legislativos que viriam a ser criados no seu lugar. Com esse argumento expressou-se Henriques de Resende ao defender que se deixasse às Províncias "plena liberdade sobre tudo em que a Constituição

\footnotetext{
${ }^{198}$ Idem, sessão de 03/julho, p. 20-1.

199 Idem, p. 25.

${ }^{200}$ Idem.
} 
não lhes veda deliberar"201. Em seguida, fez emenda para que a esfera de atuação das Assembléias fossem as mesmas estabelecidas na Constituição para os citados Conselhos, igualmente ao que propusera Ernesto Ferreira França quando do início da discussão do projeto. Este voltava a se pronunciar contra a matéria, criticando "como anticonstitucional, como anti-reformista, e como antibrasileira toda a idéia de restringir as atribuições dos Conselhos Gerais",202.

A necessidade de uma organização precisa das matérias que caberiam aos interesses "gerais" e aos "provinciais" foi um dos argumentos utilizados na defesa do artigo. Nesse sentido falou Evaristo da Veiga, argumentando que "toda a vez que se discut[ia] qualquer proposta dos Conselhos Gerais" a questão que sempre aparecia era "se a proposta est[ava] dentro de suas atribuições, se versa[va] ou não sobre o interesse geral da nação" ${ }^{203}$. Para ele, a Câmara vinha sendo "arbitrária" nessas decisões, o que considerava gerar os "inconvenientes" que só encontrariam "remédios", também inconvenientes, "no arbítrio das Assembléias" e na "sanção do poder moderador". Seu colega de bancada, Saturnino de Souza e Oliveira foi no mesmo caminho, dizendo-se convencido da imperiosidade do estabelecimento das atribuições dos Legislativos provinciais. Nas palavras de Francisco de Paula Araújo de Almeida, novamente aparecia a tese de que o grande diferencial das Assembléias seria sua capacidade de "legislar":

“Os conselhos gerais apenas propunham, dependendo as suas resoluções de três sanções, e [se] a comissão quer que a lei das assembléias provinciais sejam executadas nas suas províncias, ela não pod[e] deixar de estabelecer as coisas sobre que as assembléias provinciais tenham de legislar, do contrário era pôr em conflito as assembléias provinciais com a assembléia geral"204,

Dessa polêmica, ficava claro que o estabelecimento das matérias que caberiam às Assembléias Provinciais era entendido por parte dos deputados opositores - entre os quais se destacavam novamente os representantes do Norte - como uma circunscrição redutora

\footnotetext{
${ }^{201}$ Idem, sessão de 02/julho, p. 15.

202 Idem, p. 17.

${ }^{203}$ Idem, p. 16.

${ }^{204}$ Idem, p. 22.
} 
do poder provincial. Tratava-se de fato de uma resistência a um projeto de unidade que pretendia instituir, de forma definitiva, o Rio de Janeiro como centro, por mais que se contasse com uma visível ampliação dos direitos das localidades expressa na implementação de um órgão Legislativo em cada uma das capitais. Note-se que a mesma lógica valia para a crítica ao enquadramento dos impostos de exportação às "rendas nacionais", não sendo à toa que a reclamação estivesse na boca dos baianos, cuja Província angariava uma grande parte de receitas a partir desses tributos ${ }^{205}$. Mais à frente, aprovou-se que os novos órgãos provinciais não poderiam realmente deliberar sobre os impostos de exportação (artigo 12 do projeto) como forma de resguardar ao Império uma de suas maiores fontes de arrecadação.

Uma outra polêmica que veio à luz de maneira incisiva quando da discussão das atribuições das Assembléias, foi a questão da federação. Como já vimos, desde a Constituinte de 1823 que a idéia de um "pacto federativo" entre as Províncias esteve presente como uma das alternativas mais controversas para estabelecimento de uma unidade política. Também desde lá, seu significado era polissêmico, com o predomínio de uma falta de consenso de sua aplicação no tocante à relação que se pretendia estabelecer entre o todo e as partes do Brasil. Se logo após a Independência sua utilização no plenário foi motivo de certo constrangimento, sendo logo refutada por partes dos parlamentares que então conceberam um primeiro projeto de Constituição, passados mais de dez anos com uma real possibilidade de radicalização do regime, as referências a ela ainda estavam na ordem do dia. Nesse sentido, mesmo entre os mais moderados da Câmara, era comum encontrarmos defesas de uma "federação" para o Império.

No bojo de tais propostas eram comuns as referências aos americanos do Norte como um exemplo a ser seguido. Assim argumentou Francisco de Souza Martins, quando declarou seu desejo de que sua "pátria chegasse um dia a ter uma forma de governo tão liberal como a dos Estados Unidos", que considerava "como o sistema mais perfeito de governo" 206 . A despeito de ter até então apoiado os que criticavam o projeto da comissão, o deputado piauiense defendeu a marcação das atribuições das Assembléias Provinciais tanto para que não ocorressem conflitos de jurisdição, como pela defesa de uma paulatina

\footnotetext{
${ }^{205}$ Catherine Lugar, The merchant community of Salvador, Bahia 1780-1830, Nova York, Tese de Doutorado, State Univesity of New York, 1980.

${ }^{206}$ APB-CD (1834), t.2, p. 26.
} 
ampliação no seu poder de ação depois de sua instalação. Na sua acepção, as "reformas constitucionais nada mais s[eriam] que dar algumas atribuições legislativas aos Conselhos sem dependência do poder geral", e assim poder-se-ia classificá-las de "federais":

\begin{abstract}
"neste sentido não merece censura a federação, [para] dar a certas autoridades locais certas atribuições, que não podem ser exercitadas comodamente pelo governo central [...] se isto é federação, em toda a latitude da palavra poderemos dizer que a monarquia portuguesa era federativa; na nossa mesma monarquia as municipalidades têm o direito de fazer regulamentos sobre alguns objetos" ${ }^{\text {"207 }}$.
\end{abstract}

Sob a identificação do vocábulo com "aliança, liga, união", Souza Martins enquadrava-o em um arranjo institucional que separava funções entre as partes, resguardando uma instância central que tratasse, sob a égide da monarquia, dos interesses gerais.

O maranhense Antônio Pedro da Costa Ferreira, operando com um significado semelhante para "federação", defendeu uma proposta mais ambiciosa ${ }^{208}$. Sem pudores em afirmar que "era preciso que o Brasil fosse federado" para que as províncias pudessem "ficar livres dessa tutela, dessa centralização, ou para melhor dizer, escravidão", ele pregava uma completa autonomia das partes sem que isso significasse "separação". Assim, explicava que não queria uma "independência" como se acreditava ser o caso no interior dos Estados Unidos e "que tanto medo metia a alguns senhores", mas:

"uma federação sui generis (permitindo-se-lhe a expressão), que reunisse em si todas as vantagens da democracia americana com a força das monarquias, queria que as províncias fossem soberanas e independentes em seus negócios particulares, e que se reserve parte da sua soberania para a Assembléia Geral, enfim uma federação que não desmantele o sistema monárquico" ${ }^{209}$.

Pelo seu discurso, percebe-se que o único elo entre as Províncias seria o da representação nacional como salvaguarda da monarquia. O mesmo deputado chegou a falar na

\footnotetext{
${ }^{207}$ Idem, sessão de 4/julho, p. 29.

${ }^{208}$ Idem, pp. 27-8.

${ }^{209}$ Idem, p. 28.
} 
necessidade de "uma verdadeira reforma" e ameaçar que, se os "senhores centralizadores" teimassem em submeter as Províncias do Norte, alguma "desordem” poderia acontecer. Dessa forma, por mais que pudéssemos argumentar que sua real intenção fosse colocar o princípio monárquico em xeque, o fato é que o deputado serviu, naquele momento, como representante de descontentamentos em relação à ordem que se pretendia implementar. Nesse sentido, suas ameaças foram contundentes.

Os que se posicionaram da maneira mais cautelosa possível em relação à matéria foram José Custódio Dias e Bernardo Pereira de Vasconcellos. O primeiro argumentou que os "brasileiros" nunca quiseram "federar-se" e que "nenhum poder lhe havia sido conferido pela nação" para aprovar uma reforma nesse sentido; sustentou "com afinco esse nexo salutar que une ao centro todas as Províncias do Império" ${ }^{210}$. O segundo, que já concebera anteriormente que o "princípio monárquico" seria um diferencial de nosso sistema, atacou o ideal de "soberanizar" ou de "independentizar" as Províncias como contrário às bases estruturais do Império $^{211}$. Defendeu também que, no estágio atual, os presidentes tivessem poder de sancionar todas as medidas tomadas pelos Legislativos locais, pois que seria "muito perigoso" deixá-los trabalhar independentes de uma ação central. Ao final, novamente rechaçou para o Brasil o modelo dos americanos do Norte. E embora ambos não tenham negado diretamente a federação, ficou claro que temiam, de alguma forma, sua implementação.

Quando da votação da matéria, o primeiro artigo que marcava as atribuições das Assembléias Provinciais foi aprovado com algumas emendas de forma, mas com pequena diferença de votos (48 a favor e 38 contrários) ${ }^{212}$. A discussão do segundo artigo sobre as funções dos novos órgãos legislativos voltou a um tema caro aos legisladores desde a primeira Constituinte: o da ação dos presidentes de Províncias e independência dos magistrados. Ernesto Ferreira França foi o primeiro a atacar a proposta para que o governo local, conjuntamente com a Assembléia local, pudessem agir nos casos de "rebelião e invasão de inimigos" (conforme o parágrafo 35 do art. 179 da Constituição), além de suspender a execução de alguma lei policial, municipal ou provincial quando julgasse necessário. O baiano disse considerar o parágrafo uma “imensa centralização", eivada de

\footnotetext{
${ }^{210}$ Idem, p. 29.

${ }^{211}$ Idem, pp.31-2.

${ }^{212}$ Idem, sessão de 5/julho, p. 34.
} 
"despotismo", pois que a "Constituição" não teria dado "ao poder Executivo a faculdade de suspender leis" 213 .

Jerônimo Martiniano Figueira de Mello não só concordou com o argumento de Ferreira França como criticou um outro parágrafo que permitiria às Assembléias decretarem a suspensão, bem como a demissão do magistrado contra o qual houvesse crime de responsabilidade ${ }^{214}$. O argumento era que tal medida "destrui[ri]a a independência de poderes consagrada na Constituição", e que construi[ri]a um verdadeiro "monstro político" ao fornecer aos órgãos legislativos a capacidade de julgar o que não estava sob sua alçada, segundo palavras de Francisco Souza Martins ${ }^{215}$. Os que apoiavam à medida, por sua vez, defendiam que o direito de punir o funcionário judiciário seria uma providência para “remediar os abusos que poderiam provir" de sua prática ${ }^{216}$, e que uma "total independência de poderes" seria impossível de existir num sistema equilibrado, em que um poder exerceria parte do que "em rigor" se poderia "considerar como pertencente a outro" ${ }^{217}$.

No que tocava aos governos provinciais, em especial ao papel dos presidentes, Francisco Alvares Machado de Vasconcellos ${ }^{218}$, deputado por São Paulo, fez uma emenda bastante ambiciosa: propôs que as Assembléias provinciais pudessem decretar a suspensão dos "delegados do Executivo" denunciados por crimes de responsabilidade. O seu argumento era claro:

"Conservando-se os Presidentes no estado em que eles atualmente se acham, não dando às Províncias senão o direito de representar contra eles, em muito risco ficará a liberdade do Brasil",219.

\footnotetext{
${ }^{213}$ Idem.

${ }^{214}$ Idem, p. 35.

215 Idem.

${ }^{216}$ Idem, sessão de 7/julho, p.38-9, posição de José Custódio Dias e também de Antônio Paulino Limpo de Abreu.

${ }^{217}$ Idem, p. 43, discurso de Bernardo Pereira de Vasconcellos que se refere a sistema de "cheks and balances" norte-americano.

${ }^{218}$ Francisco Álvares Machado de Vasconcellos (1791-1846), era natural de São Paulo. Era médico. Foi deputado pela sua Província natal na Assembléia Geral por três vezes: na $3^{\mathrm{a}}$ legislatura (1834-7), na $4^{\mathrm{a}}$ (183841), e na $6^{\mathrm{a}}$ durante o ano de 1845 (deve-se notar que os Anais da Câmara dos Deputados seu nome aparece, por vezes, equivocadamente grafado como "Alves Machado").

${ }^{219}$ Idem, p.38.
} 
Dessa forma, o deputado propunha a criação de uma esfera de controle sobre os presidentes dentro das próprias Províncias, já que caberia apenas ao Imperador - no momento, apenas à Regência - o poder de demiti-los. Machado de Vasconcellos dizia temer pelo futuro, pois se o momento que viviam era favorável a mudanças nas Províncias, não se podia assegurar o mesmo quando D. Pedro II assumisse o trono e aventasse a possibilidade de reavivar qualquer forma de despotismo. Nessa linha criticou que se falasse tanto dos magistrados e não dos presidentes que "até o ano de 1831 vexaram a maior parte das Províncias"220, e defendeu sua emenda como garantia para a posteridade.

Seu mais feroz crítico foi o deputado pernambucano Antônio Joaquim de Melo ${ }^{221}$ que evocou o direito do monarca de controlar o cargo em função do sistema ser de natureza “monárquico-democrática". Por essa razão, convinha "temperar" estes dois princípios "opostos", de sorte que a "máquina administrativa" desviasse de "sua rotação emperros, choques e desordens", sendo contrário também a uma ingerência de "caráter popular" no concernente ao afastamento do mesmo presidente. Então argumentava:

“Ora, nas Províncias já a maior parte dos empregados e agentes públicos são de produção popular; oficiais, guardas nacionais, juízes de paz, municipais, promotores, câmaras, etc.: e se a conservação e ações do único delegado monárquico nas províncias, que é a muitos respeitos o indicador dos trabalhos, e o observador de todos esses agentes populares subordinados, forem submetidas e dependerem da vontade e supremacia da assembléia legislativa, elemento democrático, parece-me que quase de todo desaparecerá no governo das Províncias o elemento monárquico e a sua indispensável influência tanta quanta deva ter para que seja real a forma de governo que nos rege. E que meios restarão ao governo nacional para manter a união das províncias, meios, digo, fortes e não revoltantes?"222.

\footnotetext{
${ }^{220}$ Idem, p.40.

${ }^{221}$ Antônio Joaquim de Melo (1794-1873) era natural de Pernambuco. Formou-se bacharel em Direito. Foi presidente da Província da Paraíba entre 1833-6. Como suplente, ocupou a cadeira de deputado por Pernambuco na Assembléia Geral por duas vezes: em 1834-35, e em 1845-46. Foi eleito deputado titular pela mesma Província na $8^{\mathrm{a}}$ legislatura, cadeira que ocupou em 1850-52.

${ }^{222}$ APB-CD (1834), t.2, sessão de 7/julho, p.38.
} 
Portanto, permitir à Assembléia agir contra o presidente significaria ferir "mortalmente" a autoridade Executiva central e, no limite, ir contra o princípio monárquico.

Após posicionamentos de vários outros deputados, a matéria foi posta em discussão, e o artigo que admitia a suspensão dos magistrados pelas Assembléias Provinciais foi aprovado com pequena emenda de forma ${ }^{223}$. Vale lembrar que pela lei de 20 de outubro de 1823 (que instituíra os Governos Provisórios), os presidentes em Conselho podiam fazer o mesmo, depois de ouvida a autoridade da justiça e em caso de motins e revoltas em que não se pudesse esperar uma decisão do Imperador. A resolução, a despeito da crítica de “aniquilamento do poder judiciário" então proferida ${ }^{224}$, não ia contra a prática administrativa que predominava na ação dos Conselhos nas Províncias os quais, conforme vimos, acabavam por emitir julgamentos dos conflitos em geral mesmo que sob a obrigação de enviá-los ao Executivo central.

Os opositores a que o governo provincial tivesse, junto com a Assembléia, o direito de abolir a execução de leis quando julgasse indispensável, foram vitoriosos na retirada da matéria do projeto da comissão, ainda que com a manutenção do parágrafo para os casos previstos na Constituição - de "rebeliões ou invasão de inimigos". Mas a emenda proposta por Francisco Alvares Machado de Vasconcellos, para que os novos órgãos Legislativos locais pudessem suspender os presidentes que cometessem delitos de responsabilidade, não teve respaldo entre a maioria dos deputados. No entanto, a tentativa de controlar a ação de sua autoridade executiva na Província, ou mesmo de minimizar o arbítrio da Corte na sua escolha e demissão, continuou a informar posicionamentos discordantes em relação ao projeto da comissão.

Assim vemos quando entrou em discussão a matéria que fornecia aos presidentes o direito de sanção das leis elaboradas nas Assembléias Provinciais ${ }^{225}$; o projeto previa que, no caso de sua negação, a autoridade executiva deveria expor as razões e seria obrigada a sancioná-la quando a mesma fosse a ele reenviada, se por acaso obtivesse nova aprovação de mais de dois terços dos deputados (artigos 13-6). Também estava previsto, mais à frente, que caberia ao presidente nomear seis entre os representantes provinciais para comporem

\footnotetext{
${ }^{223}$ Idem, p.44.

${ }^{224}$ Quando das discussões da citada lei dos Governos Provisórios das Províncias na Assembléia Constituinte de 1823, os opositores da suspensão dos magistrados pelo governo tinham utilizado idêntico argumento, ou seja, o da necessidade de total independência da sua autoridade judiciária.

${ }^{225}$ APB-CD (1834), t.2, sessão de 8/julho, p.48.
} 
seu Conselho privativo, o qual ele deveria consultar na aprovação das leis e nos "negócios graves da administração" (artigo 22).

O maranhense Antônio Pedro da Costa Ferreira, que se destacava como um dos que, até o momento, mantinham-se na oposição ao texto da comissão, mostrou-se permeável à matéria com a emenda para que o presidente somente pudesse sancioná-la mediante aprovação pela maioria de seu Conselho, o qual propunha que fosse eletivo. Afirmava que, na sua Província, o Conselho do Governo tinha "produzido muitos benefícios" obstando que se mandasse "gente presa sem culpa formada". Dessa forma, propunha que o voto apenas consultivo dos conselheiros se tornasse "deliberativo" mas, ao mesmo tempo, que a sanção pudesse funcionar como uma "segunda fieira" para possíveis excessos cometidos pelos deputados (já que não existiria uma segunda Câmara). Sob o protesto de outros representantes à sua fala, o maranhense, que mantivera o tom moderado no anúncio de sua emenda, mostrou a que viera:

“miserável o presidente que não tem confiança em Conselheiros eleitos pelo povo; em quem deve então ter confiança? Em criaturas suas? Não; a nação quer que ele tenha confiança em seus mandatários, e a Câmara não deve atender ao amor próprio e vaidade do Presidente, mas deve fazer o bem geral; a haver Conselho eleito pelo Presidente, melhor é que o não haja"226.

Por fim, Costa Ferreira argumentaria que a "experiência" tinha mostrado que os presidentes eram responsáveis por centralizar o poder nas Províncias, e que eles deputados não poderiam ser coniventes com que se deixasse tudo a seu "bel-prazer".

Evaristo Ferreira da Veiga fez longo discurso em defesa dos presidentes como "expressão da Província" e, igualmente, como "expressão da vontade nacional, enquanto seu delegado", sendo contrário a que os conselheiros tivessem voto deliberativo. Argumentou que ocorreria um "verdadeiro caos" caso eles fornecessem voto a um "número muito diminuto de membros [...] eleitos pelo povo", os quais acabariam por funcionar como uma "segunda Câmara, viciosa em sua organização". Valia-se também da opinião de que os

\footnotetext{
${ }^{226}$ Idem, p.49.
} 
mesmos presidentes iam querer estar "em harmonia com a representação nacional” e não o contrário, pois que "o excesso em negar o seu voto os tornaria ridículos" 227.

Por motivos diferentes, Jerônimo Martiniano Figueira de Mello, que também se destacara pela oposição ao projeto, foi contrário à opinião do maranhense ${ }^{228}$. Votou pela completa extinção de um Conselho privativo e se mostrou totalmente contrário a que os presidentes pudessem escolher seus membros entre os deputados, conforme estabelecido pela comissão. Segundo ele, muito se clamava contra a existência e funcionamento dos mesmos órgãos no sentido dos "delegados do Imperador" serem vistos como homens "muito hábeis", capazes de manipularem as opiniões das localidades. Afirmava que o resultado da medida seria um "desvirtuamento da responsabilidade" que poderia, equivocadamente, deixar de recair sobre eles.

Novamente a matéria foi aprovada tal como proposta no projeto. No entanto, a polêmica sobre a autoridade dos presidentes voltaria à tona de forma incisiva quando entraram em discussão as atribuições que, com a reforma (artigo 22), a eles competiriam ${ }^{229}$. Em sete parágrafos, o texto da comissão estabelecia que, além da nomeação de um Conselho, caberia igualmente aos presidentes nomear delegados para os municípios (incumbidos de aprovar provisoriamente as posturas) e empregados públicos, podendo demiti-los "quando o bem do serviço" assim o exigisse. Além disso, estaria no rol de suas funções convocar a Assembléia, inclusive extraordinariamente, suspender a publicação de leis enquanto não fornecesse a sanção (que já havia sido aprovada pelos deputados), e incumbir os "negócios gerais aos empregados provinciais ou municipais", o que equivalia dizer "dar ordens". Nesse sentido, é notório como o projeto propunha um aumento do poder da primeira autoridade executiva da Província em relação ao especificado na lei de 20 de outubro de 1823 (ainda em vigor) que, aos moldes do que Vasconcellos e Paula Araújo defenderam em sessões anteriores, serviria como contrapeso à ação das novas Assembléias.

O debate foi longo e intenso; não só pelos que se colocaram contra o controle dos presidentes sobre os cargos públicos, mas também por uma emenda de teor inesperado feita por Antônio Fernandes da Silveira ${ }^{230}$, representante do Sergipe, que propunha a escolha do

\footnotetext{
${ }^{227}$ Idem.

${ }^{228}$ Idem, p.50.

${ }^{229}$ Idem, sessão de 9/julho, p. 58.

230 Antônio Fernandes da Silveira era monsenhor, nascido em Estância no Sergipe. Formou-se padre em Salvador, onde exerceu a função de cônego na Catedral da Sé. Obteve transferência para sua terra natal, e
} 
"delegado do Imperador" a partir de uma lista tríplice organizada pelas Assembléias Provinciais $^{231}$. No momento em que a emenda foi anunciada, o deputado que presidia os trabalhos contestou a conveniência da matéria por não estar em discussão o artigo 165 da Constituição, o qual marcava serem os presidentes escolhidos pelo Imperador. Mesmo assim, Ernesto Ferreira França e Francisco de Souza Martins pronunciaram-se a favor da proposta do sergipano, o primeiro inclusive sob a defesa de que talvez "todos os empregados devessem ser nomeados por lista tríplice”, pois que o monarca não tinha como “ter mais conhecimento dos homens mais capazes” do que as próprias Províncias ${ }^{232}$. Feita uma consulta ao plenário, decidiu-se que a emenda deveria entrar em votação a despeito de não estar marcada no projeto de reforma.

O primeiro a atacar a proposta de Fernandes da Silveira foi justamente Antônio Joaquim de Melo, que já havia se colocado contra a tentativa de fazer que as Assembléias provinciais pudessem suspender seus presidentes. Seus argumentos seguiram posição, por ele enunciada anteriormente, em defesa do elemento "monárquico" que estaria, segundo suas palavras, em desvantagem diante dos "princípios populares e democráticos" que imperariam nas Províncias ${ }^{233}$. Partindo da premissa de que a organização provincial deveria ser uma "miniatura do quadro da administração geral em tudo que fosse possível”, defendia de forma lapidar a concepção de que caberia ao governo prover o "melhor" para a sociedade, por mais que suas medidas pudessem ser "amargas":

"não se deve supor que o governo tem interesses opostos aos do povo, nem o povo interesses opostos aos do governo; este foi instituído por aquele para seu bem, para o moderar, e é indo algumas vezes contra os quereres irrefletidos do povo que o governo cumpre o que deve e preenche os fins da sua instituição. Se o governo é um mal, naturalmente falando, ele se converte em remédio profícuo na associação, de onde infiro que não é um ente ilusório" ${ }^{234}$.

\footnotetext{
sabe-se que participou ativamente das disputas políticas na época da Independência. Foi membro do Conselho Geral da Província do Sergipe. Ocupou a cadeira de deputado pela mesma localidade na $3^{\mathrm{a}}$ legislatura (18347) da Assembléia Geral. Em Sergipe, foi também editor de um periódico.

${ }^{231}$ APB-CD (1834), t.2, sessão de 9/julho, p.58.

${ }^{232}$ Idem.

${ }^{233}$ Idem, pp. 58-9.
} 
Seu pronunciamento indicava uma posição extremamente moderada, pois além de defender a ingerência do governo central nas Províncias como elemento capaz de fornecer estabilidade, atribuía ao "povo" a obrigação de respeitá-lo em nome dos interesses coletivos.

Por seu lado, Antônio Pedro da Costa Ferreira foi favorável à emenda do sergipano, reiterando a denúncia contra os presidentes de Províncias feita na sessão anterior ${ }^{235}$. Primeiramente, criticou que se retirasse dos "povos" o "direito" de escolherem os membros do Conselho presidencial, o que muito provavelmente seria visto com maus olhos pelas localidades e engrossaria a camada dos "inimigos da reforma". Voltou a atacar a primeira autoridade executiva provincial, sob a alcunha de "bachá", e também aqueles dentre seus colegas que alimentariam uma centralização ainda maior de seu poder, conforme acreditava expressa pelo projeto da comissão. Nesse sentido, Costa Ferreira operava numa chave explicativa que, contrapondo governo e sociedade, pregava uma maior participação dos órgãos da Província nas decisões provindas do Rio de Janeiro. O próprio Fernandes Silveira, ao defender sua emenda, partilhava de semelhante concepção ao argumentar que se tratava de considerar o "interesse dos povos" contra qualquer "arbítrio" que pudesse vir do Executivo central. No entanto, não se deve esquecer que, a despeito do discurso em favor dos "direitos individuais", o que estava em jogo era, sobretudo, a defesa de autonomia das localidades, nem sempre associada a uma maior participação política da sociedade.

Os itens que marcavam as atribuições dos presidentes também foram de imediato contestados por Francisco Alvares Machado de Vasconcellos - o mesmo que anteriormente tinha proposto que as Assembléias provinciais pudessem decretar a suspensão dos “delegados do Executivo" ${ }^{236}$. Seguiu-o de perto Francisco Souza Martins, que falou tanto contra o funcionamento do Conselho da forma como estava previsto no projeto como contra o direito de nomeação e demissão de empregados dados ao livre-arbítrio da autoridade presidencial. No entanto, as várias colocações feitas pelos deputados se polarizaram entre aqueles que apoiavam as Assembléias provinciais poderem indicar os nomes dos elegíveis à categoria de presidentes, e os que delegavam a escolha tão-somente

\footnotetext{
${ }^{234}$ Idem, p.59.

${ }^{235}$ Idem.

${ }^{236}$ Idem, p.58.
} 
ao Imperador apoiado por seus ministros. Aparentemente banal, esse ponto foi mais do que um estopim para polêmicas por estar vinculado a uma questão fundamental: o fato de os presidentes serem peças importantes na política local, em função do arranjo institucional que funcionava no governo das Províncias. Desta forma, o poder de indicá-los era uma das variáveis fundamentais que interferiam diretamente no quadro das disputas políticas regionais.

Daí a discussão ter rapidamente se tornado uma ampla arena de debate acerca da natureza do regime. Conjuntamente a isso, havia a evidência de que o projeto da comissão saía, até aquele momento, vitorioso na aprovação da reforma, o que colocava aos seus opositores um último suspiro de resistência perante a finalização próxima da matéria. Nesse sentido, o baiano Cornélio Ferreira França, ao defender a emenda de Fernandes da Silveira, alegava que o "direito" das Províncias já estaria em profunda desvantagem em relação à Corte depois que se dera aos presidentes o poder de sanção dos atos das Assembléias legislativas $^{237}$. Sua fala expressou a contundência das posições dos favoráveis a uma autonomia provincial ainda maior do que a proposta:

\begin{abstract}
"Suponha-se que com estas reformas dentro dos limites prescritos, vai-se democratizar as províncias, é algum mal? A nossa Constituição consagra a monarquia, mas também consagra a democracia: a Constituição põe limites à democracia, e não é a democracia que põe limites ao imperador: a base é a democracia, se o fím da lei é democratizar as províncias, democratizem-se"238.
\end{abstract}

Dessa forma, o representante baiano subsidiava sua fala no que considerava uma mediação entre "monarquia" e "democracia", só que numa perspectiva que tendia a valorizar a segunda. Por isso, defendeu que o presidente de Província, como "delegado da nação" e não do Imperador, só deveria ter direito à sanção se a "eleição popular" pesasse conjuntamente na sua escolha.

Um dos principais ataques então feitos à emenda para a escolha dos presidentes por lista tríplice consistiu no argumento de que a realização das mesmas pelas Assembléias seria prática anticonstitucional. Foi dessa forma que Saturnino de Souza e Oliveira falou

\footnotetext{
${ }^{237}$ Idem, sessão de 10/julho, p.61.
} 
contra a matéria, que iria contra a "liberdade de escolha do Imperador". Afirmava, contrapondo-se a Cornélio Ferreira França, ser um equívoco compreender os presidentes como "delegados da nação" pois que, para o regime, eles seriam representantes do próprio Executivo. Exatamente por essa razão, completava, teriam eles o "poder de sancionar as leis". No entanto, sua posição foi moderada, já que desaprovou o aumento das atribuições dos presidentes no que tocava à nomeação de conselheiros e empregados públicos ${ }^{239}$.

Henriques de Resende, a despeito de sua posição a favor da autonomia das Províncias e de crítica geral ao projeto proposto, concordou que a emenda do sergipano era contrária à Constituição por não estar no "rol dos artigos reformáveis" que haviam sido aprovados anteriormente por ambas as Câmaras ${ }^{240}$. No entanto, não deixava de demonstrar seu descontentamento com o rumo que a reforma tomara, "em virtude da lei" que agora impedia os deputados de produzir mudanças mais drásticas dentro da legalidade ${ }^{241}$. Numa longa fala explicitava seu ponto de vista: a existência do poder Moderador no arranjo institucional vigente, ao qual se dizia por princípio contrário, fazia uma "salutar anomalia" o Imperador poder nomear e demitir os presidentes sem consultar seu Conselho ou mesmo o ministério. Nestes termos, sua fala mostrava uma das dimensões da eficácia da Carta de 1824, que servia de argumento para a impossibilidade de se avançar nas mudanças para além do prescrito em termos legais.

A discussão do artigo também deu margem a que propostas mais restritivas quanto ao poder das Assembléias provinciais fossem colocadas em pauta. A mais paradigmática delas foi feita por Antônio Joaquim de Melo, na emenda para que os presidentes também tivessem o direito de dissolver o novo órgão legislativo quando assim lhes parecesse preciso, da mesma forma que cabia ao Imperador em relação à Câmara dos Deputados no Rio de Janeiro ${ }^{242}$. Seu argumento central estava embasado na necessidade de criação de um "corretivo" para seu funcionamento local a exemplo dos mecanismos existentes na Corte onde o sistema bicameral e o moderador poderiam servir como "garantia" aos eventuais radicalismos dos representantes. Defendia ser isso ainda mais importante nas Províncias por causa dos "amplos critérios" de inclusão para eleição de um deputado, o que fazia que

\footnotetext{
${ }^{238}$ Idem.

${ }^{239}$ Idem, p. 59 e 61.

${ }^{240}$ Idem, sessão de 9/julho, p.59.

${ }^{241}$ Idem, sessão de 11/julho, p.69.

${ }^{242}$ Idem, sessão de 10/julho, p.64.
} 
"pessoas de diversos cultos, criminosos pronunciados e libertos" pudessem ser eleitos e permanecessem "invioláveis" em suas opiniões. Nesse sentido, o padrão moderado de "feição e compostura" do centro servia de modelo ao discurso das alternativas de moderação que se colocavam para o Império. Isso porque, novamente, era a Carta de 1824 que fornecia os parâmetros da reforma, já que sua estrutura não havia sido colocada em xeque.

Não faltou quem defendesse a matéria. Bernardo Pereira de Vasconcellos foi um deles, sob o argumento extremamente conservador de que, no Brasil, o aumento das atribuições dos presidentes seria indispensável devido à falta de organização e à "fraqueza" do poder Executivo ${ }^{243}$. Gabriel Mendes dos Santos ${ }^{244}$, deputado por Minas Gerais, seguiu o companheiro de bancada defendendo que o direito de dissolução da Assembléia, outrora tido como "antiliberal", seria, no momento, de "necessidade pública"245. Em seu único pronunciamento em toda a discussão da reforma, Mendes dos Santos também atacou a emenda da lista tríplice e defendeu que os presidentes pudessem nomear os seus empregados imediatos (como se queria em um dos parágrafos do artigo proposto), da mesma forma que caberia ao Imperador sua escolha sem intervenção popular.

A emenda de Joaquim de Melo, acerca do direito de os presidentes dissolverem o novo órgão legislativo, também teve detratores. Um deles foi João Climaco de Alvarenga Rangel, deputado pelo Espírito Santo, o qual criticou que os presidentes pudessem dissolver as Assembléias por considerar arriscado aumentar sua autoridade, já que existiriam outros meios de coarctar os possíveis abusos do novo órgão legislativo ${ }^{246}$. No entanto, ele também atacou o uso de listas tríplices por motivos semelhantes que se baseavam no princípio do "equilíbrio da organização social" e na defesa do papel do monarca na escolha do seu "delegado", mostrando ser dotado de posição bem moderada. O pernambucano Antônio Peregrino Maciel Monteiro foi mais incisivo, sendo extremamente contrário a que se desse qualquer outra atribuição aos presidentes rechaçando tanto a proposta para que ele interviesse nas Assembléias como todos os parágrafos do artigo 22

\footnotetext{
${ }^{243}$ Idem, sessão de 11 e 12/julho, pp. 73 e 77.

${ }^{244}$ Gabriel Mendes dos Santos (? -1873) estudou Direito na Universidade de Coimbra. Além de magistrado e servidor público, foi deputado por Minas Gerais na Assembléia Geral de 1833 (nesse ano como suplente de Custódio José Dias) até 1844, ou seja, por quatro legislaturas seguidas. Em 1851, foi nomeado senador.

${ }^{245}$ APB-CD (1834), t.2, sessão de 12/julho, p.76.

${ }^{246}$ Idem, sessão de $11 /$ julho, p.70.
} 
que lhe forneciam novos poderes ${ }^{247}$. Dizia ir contra a "grande centralização em que se queriam pôr as coisas", fechando assim com a posição de outros seus colegas do Norte.

$\mathrm{Na}$ hora da votação, os parágrafos que previam a existência de um Conselho privativo, escolhido pelo próprio presidente, bem como o poder deste último de nomear e demitir empregados públicos e de gerenciar as ordens relativas aos "negócios gerais" das Províncias, foram suprimidos ${ }^{248}$. Na mesma linha, também foi recusada a proposta de Antônio Joaquim de Melo para que as Assembléias legislativas pudessem ser dissolvidas pela autoridade presidencial. Ainda maior rechaço dos deputados mereceu a emenda de Fernandes da Silveira que, pendendo para o lado oposto à de Melo, previa a diminuição do arbítrio do Imperador e da Regência na escolha do "delegado" do Executivo e, portanto, de sua interferência na política local. Note-se que, a despeito das defesas enfáticas feitas à escolha do presidente por lista tríplice, em nome de uma maior autonomia das Províncias, pouquíssimos representantes votaram a seu favor ${ }^{249}$. Uma das explicações para isso está no peso do argumento de que se tratava de medida inconstitucional, por introduzir um elemento de "eleição popular" na decisão a partir da Assembléia local. Assim foi considerado até mesmo por aqueles que o tempo todo estiveram contra qualquer tipo de centralização.

Com essa votação, o término da discussão já estava no horizonte da Casa, e as últimas matérias que tratavam da eleição de um Regente único tiveram apenas um ponto de polêmica: se a sua escolha deveria ou não ser feita pelos eleitores de todo Império, conforme previa o projeto ${ }^{250}$. Nesse momento, Antônio e Cornélio Ferreira França, respectivamente pai e filho, fizeram emendas para que o Regente fosse eleito pelas Províncias as quais, da mesma forma que os "representantes da nação", teriam um voto cada uma. O primeiro justificou a medida nos seguintes termos:

“as Províncias, quer grandes, quer pequenas, todas são iguais, a Constituição não as considera desiguais; e em elas adquirindo alguma independência, como hão de adquirir pelas reformas, ainda serão consideradas como indivíduos mais do que até

\footnotetext{
${ }^{247}$ Idem, p.71.

${ }^{248}$ Idem, sessão de $12 /$ julho, p.80.

${ }^{249}$ Idem; a votação da emenda foi nominal e perdeu por 11 contra 77 votos. Praticamente todos que votaram pela matéria se pronunciaram no plenário.

${ }^{250}$ Idem, sessão de 15/julho, p.90.
} 
aqui, e que entre as nações é máxima que são todas iguais, e uma por ser [menor] que outra não deixa de ter iguais direitos, e as Províncias devem seguir a mesma máxima, porque elas têm para o Império a mesma relação que algumas nações têm para a humanidade universal, porque do contrário aquela província que tiver 1.300 ou 1.400 eleitores determina tudo, assim como têm determinado muitas coisas; e não se enganem os Srs. Deputados que são de pequenas províncias" ${ }^{251}$.

A defesa da "individualização" e igualdade entre as Províncias na escolha do Regente contrapunha-se ao voto de cada um dos eleitores, sendo claramente uma forma de favorecer as localidades menos integradas ao Centro-Sul que, no caso das mais pobres, também possuiriam menor número de eleitores. Não à toa, foi a emenda igualmente encampada por vários representantes do Norte.

Imediatamente Joaquim Inácio da Costa $\mathrm{Miranda}^{252}$, deputado pelo Ceará, e Francisco Gonçalves Martins, deputado pela Bahia, defenderam a proposta alternativa. O primeiro propôs inclusive que a eleição fosse feita pelas Assembléias provinciais, no que foi seguido pelo segundo sob o argumento de que assim formar-se-ia um "círculo mais esclarecido" de eleitores ${ }^{253}$. O piauiense Francisco de Souza Martins também defendeu a matéria, e reiterou ser positivo que apenas os "indivíduos ilustrados, que tiverem maior conhecimento dos homens estadistas", participassem das eleições ${ }^{254}$. O que prova que o posicionamento favorável à valorização da Província como unidade política vinha articulado, nos níveis superiores de escolha, a uma concepção mais restritiva da participação política da sociedade. Nesse ponto, a posição do alagoano Manoel Joaquim Fernandes de Barros foi paradigmática: falou contra o artigo do projeto porque todas as localidades "quererão aumentar o número de seus eleitores" igualando-o em número ao dos "cidadãos brasileiros", o que seria um "gravíssimo inconveniente" por incluir, numa decisão tão importante, gente de todo tipo ${ }^{255}$.

\footnotetext{
${ }^{251}$ Idem, p.92.

${ }^{252}$ Joaquim Inácio da Costa Miranda foi suplente do deputado José Martiniano Alencar, pelo Ceará, no ano de 1832. Na $3^{\mathrm{a}}$ legislatura (1834-7), elegeu-se titular pela mesma Província. Na $5^{\mathrm{a}}$ legislatura, seria deputado pela Província do Piauí nos anos de 1843-4.

${ }^{253}$ APB-CD (1834), t.2, sessão de 15/julho, p.92.

${ }^{254}$ Idem, sessão de 17/julho, p.107-8.

${ }^{255}$ Idem, p. 110.
} 
A despeito de serem somente representantes das Províncias do Norte os que defenderam a emenda, incluindo alguns que foram sistematicamente críticos ao texto da comissão desde o início da discussão, nem todos os egressos da região setentrional do Império a aprovaram. O maranhense Antônio Pedro Costa Ferreira, por exemplo, votou contra os Ferreira França por admitir que "a população era que formava a grandeza dos Estados" não devendo ser seu voto preterido em função ao saldo da opinião provincial ${ }^{256}$. Esse foi o principal argumento utilizado pelos favoráveis ao projeto, ou seja, que a "representação nacional" não poderia estar "baseada no terreno, mas sim nos indivíduos" como único meio de garantia de sua eficácia ${ }^{257}$, já que "por ora as Províncias não esta[ri]am soberanizadas" 258 .

Partindo dessa premissa, falaram longamente Bernardo Pereira de Vasconcellos e Joaquim José Rodrigues Torres ${ }^{259}$, este deputado pelo Rio de Janeiro, no sentido de marcar os "perigos" que poderiam advir de se deixar tal escolha na mão das Assembléias provinciais, as quais concentrariam, nessa ocasião, "todos os poderes do estado". Ambos argumentaram acerca da importância de uma "nomeação popular" para o poder Executivo ter a "força" e "vigor" necessários para "resistir às invasões do poder Legislativo, e concorrer para a manutenção das garantias das liberdades da nação"260. Dessa forma, advogavam claramente pelo fortalecimento e "independência" do Executivo, conforme os questionamentos de Vasconcellos deixavam claro: “O que será um poder Executivo nomeado pela Assembléia Geral? A sua reeleição dependendo da Assembléia resistirá a qualquer facção que se desenvolva no seu seio?"261. Nesse argumento, o princípio a priori mais inclusivo de votação de todos os eleitores servia à legitimação de uma unidade centralizada que se afirmaria em nome da "nação" e não de suas "partes".

Evaristo Ferreira da Veiga também encampou a crítica à emenda para que a eleição ocorresse nas Assembléias provinciais, e foi ainda mais direto na crítica aos seus efeitos

\footnotetext{
${ }^{256}$ Idem, sessão de 15/julho, p.94.

${ }^{257}$ Idem, p.93, discurso de José Alcibiades Carneiro, deputado por Minas Gerais.

${ }^{258}$ Idem, p.94, discurso de José Custódio Dias.

259 Joaquim José Rodrigues Torres (1802-1872) era natural do Rio de Janeiro. Estudou Ciências Matemáticas na Universidade de Coimbra. Ocupou a cadeira de deputado na Câmara, pela sua Província natal, na $3^{\mathrm{a}}$ legislatura (1834 a 1837), na $4^{\mathrm{a}}$ (1838 a 1841), e no ano de 1843 . Desempenhou o cargo de presidente da mesma Província (1834-6). Foi nomeado senador em 1844. Exerceu por inúmeras vezes o cargo de ministro na Regência e no Segundo Império, além de ter sido presidente do Banco do Brasil e Conselheiro do Estado. Foi condecorado com o título de Visconde de Itaboraí.

${ }^{260}$ APB-CD (1834), t.2, sessão de 16/julho, p.98, discurso de Rodrigues Torres.
} 
$\operatorname{diretos}^{262}$. Sob a justificativa da necessidade de fornecerem "o mais amplo direito aos cidadãos que comp[unha]m a nossa sociedade civil", argumentava que o "principal inconveniente" da medida seria a "injustiça que se fa[ria] aos cidadãos das Províncias grandes, privando-os de seus foros". Atacava diretamente aqueles que, por meio da matéria, defendiam uma maior participação das localidades mais distantes da Corte nas decisões políticas imperiais, e pregava que a "igualdade de direitos" entre elas fosse também uma “igualdade de ônus”. Então, argumentava:

"A individualidade das Províncias deve nos levar a grandes considerações; se cada Província quando se trata dos interesses nacionais, deve valer o mesmo que as outras, grandes e pequenas devem ser medidas pela mesma bitola, e então cumpre que um princípio tão fértil seja estendido a outros resultados; cumpre que os impostos com que as Províncias entram para as despesas gerais, sejam da mesma quota, do mesmo valor; quer pequenas quer grande seja a Província do império, cumpre que quando se trata de recrutar soldados exista a mesma bitola"263.

Dessa forma, Ferreira da Veiga sabia que tocava no cerne da questão, pois conforme vimos anteriormente, nos primeiros anos após a Independência, as Províncias do sul foram responsáveis pela viabilização financeira do Império, quadro esse que se pretendia alterar com as medidas tomadas desde 1830.

Quando da votação, o artigo passou sem as emendas dos Ferreira França, o que significou, mais uma vez, outra vitória do projeto da comissão. O resto das matérias foi rapidamente aprovado, inclusive aquela que previa a extinção do Conselho de Estado, o que mostrou ser realmente um consenso ${ }^{264}$. O texto com as emendas propostas deu origem, como se sabe, ao Ato Adicional à Constituição. No entanto, como se viu, toda a análise de sua discussão permite entrever os vetores da disputa no ambiente do plenário.

Antes de tudo, deve-se notar que a leitura dos debates em torno da reforma explicita como a polêmica sobre o equacionamento dos poderes, tendo a Constituição como

\footnotetext{
${ }^{261}$ Idem, p. 100 .

${ }^{262}$ Idem, p. 102.

${ }^{263}$ Idem, 104.

${ }^{264}$ Idem; em 24 de julho de 1834, o texto da Reforma passava para a $3^{\mathrm{a}}$ e última discussão, a qual não produziria modificações.
} 
paradigma, esteve presente em todas as argumentações utilizadas. Isso foi um visível desdobramento da temática do controle e separação entre essas instâncias que, como base da construção constitucional moderna, era parte desse processo. No Brasil, a recriação do sistema monárquico fazia que esse princípio fosse continuamente evocado, a despeito das tentativas de sua subversão por parte de representantes "exaltados", especialmente após a Abdicação. O fato de a opção reformista ter vingado fez que as próprias mudanças fossem pautadas conforme o previsto na Carta de 1824, a qual propositadamente não deixou de marcar a forma como se deveria fazê-las quando julgadas necessárias. Nesse sentido, a manutenção do caminho da legalidade trouxe consigo uma moderação no que tocava a inovações na estrutura do sistema político que permitiu a conservação de suas bases. Um dos exemplos mais candentes esteve na participação da segunda Câmara na alteração do projeto votado pelos deputados, os quais, quando da possibilidade de uma brecha na legislação, foram pela retirada dos senadores de sua aprovação final.

Tal constatação não nega que significativas transformações no tocante ao arranjo institucional das Províncias tenham sido aprovadas e que as mesmas acabassem por marcar a estrutura política imperial brasileira pelo século dezenove adentro. O que a discussão do projeto evidencia é que, a despeito de não existir um consenso geral sobre suas bases em 1834, um certo acordo foi possível em torno do texto da comissão, o que garantiu sua aprovação sem grandes alterações. E essa opção aparece como uma resposta moderada ${ }^{265}$, olhando em retrospecto os trabalhos da Câmara desde 1831, em relação à tentativa de radicalização do regime que angariava adeptos desde o início da terceira legislatura. Mas essa mesma resposta já se fizera em novas bases, visivelmente articuladas pela expectativa de mudanças, como se nota pela própria incorporação da idéia de "federação" na discussão, vocábulo esse que causava no mínimo constrangimento quando citado em plenário nas sessões do Primeiro Reinado.

A polêmica sobre os artigos da reforma também caminhou no sentido de confirmar uma posição diferenciada da Corte do Rio de Janeiro em relação às Províncias. Não foi à toa que entre os representantes mais críticos ao projeto da comissão estivessem predominantemente aqueles egressos da Bahia e Pernambuco, partes estas que, conjuntamente com o Maranhão, mais contribuíam para as rendas do Império e almejavam 
uma valorização política de seus interesses. Daí o debate em torno da autonomia que, colocada em pauta de forma conflitiva desde as Cortes de Lisboa e novamente na Assembléia Constituinte de 1823, continuava - e continuaria - a pautar as relações entre as partes do Império do Brasil. O diferencial em 1834 era que uma estrutura institucional que desse suporte e se apresentasse viável ao novo Estado estava montada tanto do ponto de vista normativo como, em parte, de sua prática efetiva.

Essa não foi a única especificidade em relação à extinta reunião legislativa de 1823. Se naquela época, a tentativa de elaboração de um novo pacto político sob bases constitucionais fazia a tônica das discussões em torno da questão provincial estar centrada na construção dos canais de representação política de tipo moderno - parcialmente inspirada na experiência das Juntas Provisórias de Governo - agora predominava, sobretudo, a preocupação com a autonomia das instituições locais. Trocando em miúdos, tratava-se da desvalorização da idéia de ampliação da participação da sociedade nas esferas de poder, e de derrota de um projeto de inclusão social ${ }^{266}$, diante da proposta de implementação de uma hegemonia dos grupos das capitais das Províncias sobre sua região. Isso ficou claro especialmente na manifestação de muitos críticos do projeto de reforma que, mesmo fazendo oposição sistemática à matéria, queriam ampla liberdade de decisão em relação ao centro, sem grande transformação de seu status quo de brancos e proprietários. Portanto, estavam longe de um projeto que se poderia chamar, na época, de "exaltado", aproximando-se muito mais de um ideal de moderação que pôde, por vezes, articular-se a propostas ainda mais conservadoras, ou "caramurus", conforme já demonstrou Marco Morel $^{267}$.

\footnotetext{
${ }^{265}$ Falamos aqui em moderado no sentido de um comportamento diante das possibilidades existentes, e não como tendência política que pudesse articular os liberais em torno de um projeto político para o Império.

${ }^{266}$ Questão levantada por Miriam Dolhnikof, O pacto imperial. Origens do federalismo no Brasil, São Paulo, Globo, 2005, p. 19.

${ }^{267}$ Marco Morel, em As transformações dos espaços públicos, pp. 127-147, demonstrou que, na época, os projetos de federação para o Império que previam uma ampla autonomia das regiões, e mesmo de "separatismo", não eram atributos apenas daqueles identificados com os grupos mais radicais ou "exaltados". Ao contrário, representantes de setores conservadores do Norte tomaram também essa bandeira, como cita ter sido o caso do pernambucano Antônio Francisco de Paula e Holanda Cavalcanti. Este, que além de deputado por sua Província natal, ocupou altos cargos públicos no Rio de Janeiro, foi um dos protagonistas de um projeto frustado de separação das Províncias do Norte apresentado, na forma de relatório "confidencial", ao plenipotenciário francês no Rio de Janeiro em 1831, pedindo auxílio de seu país. Morel analisa como o governo da França recusou-se a apoiar o intento, mesmo com a previsão da incorporação francesa do GrãoPará, sob o argumento de que não poderia interferir nas questões internas do Império.
} 
Até 1834 vigorou a lei de 20 de outubro de 1823 que instituía de forma provisória um governo para as Províncias. Sabe-se também que essa foi a única norma que marcava as atribuições dos presidentes das Províncias durante todo o Primeiro Reinado, a despeito das várias tentativas de se promover um regimento para os mesmos. Com a aprovação da reforma, foram agregadas, sem grandes inovações, algumas funções à autoridade presidencial - a de convocar a Assembléia Provincial, de suspender a publicação de leis e de expedir ordens e instruções - mesmo com a derrota da alternativa de aumento de seu poder pessoal de decisão. Além disso, a lei final não confirmou seu Conselho privativo, cujo artigo foi suprimido após contestação dos deputados da Assembléia.

Com a supressão da lei de 1823, no plano provincial, a reforma trouxe consigo a necessidade de demarcação da ação presidencial. Por isso, dias depois do término da sua discussão entre os deputados, os senadores enviaram à Câmara um texto em que propunham um definitivo regimento para os presidentes ${ }^{268}$. Este logo entrou em discussão e foi rapidamente aprovado na sua quase totalidade, em não mais de quatro sessões. Tamanha rapidez tem ao menos duas explicações: o fato de, nos idos de agosto e setembro de 1834, os representantes estarem envolvidos na polêmica acerca do projeto de orçamento para o ano seguinte, o que consumiu tempo e energia de todos; e também a generalizada descrença de que, naquele momento, qualquer alteração de fundo pudesse realmente ser implementada, pois a proposta conjugava-se bem com as bases da reforma já aprovadas. Não à toa, a disputa pelas rendas do Orçamento pôde ser vista como mais importante para os interesses dos grupos que os deputados representavam.

Ainda assim, logo que entrou em pauta o primeiro artigo que afirmava ser o presidente a primeira autoridade da Província ao qual todos se achariam subordinados, novamente voltou à tona a questão de que para sua escolha deveria concorrer, ao lado do monárquico, o "elemento popular". Nessa linha, falaram novamente Antônio e Cornélio Ferreira França, respectivamente pai e filho, mesmo que a questão nem estivesse em discussão ${ }^{269}$. O tema continuava a inspirar polêmica. O maranhense Costa Ferreira fez uma emenda para que ao menos constasse no artigo que o presidente só poderia decidir sozinho o que não fosse de atribuição conjunta com o seu Conselho. Após várias manifestações,

\footnotetext{
${ }^{268}$ APB-CD (1834), t.2, sessão de 4/agosto, pp.186-7.
} 
discursos e posições semelhantes às que se vira ao longo da discussão da reforma, não só a proposta de Costa Ferreira foi negada como aprovada outra, de Francisco de Paula Araújo, que isentava o município da Corte da autoridade do presidente da respectiva Província. Mantinha-se também, nesse regimento, a autonomia administrativa do centro político do Império.

O método de escolha do vice-presidente também gerou pronunciamentos contrários, mas, como em outras questões pontuais, em nada se alterou o texto. No entanto, duas inserções feitas pelos deputados reforçavam o sentido da autoridade presidencial. A primeira, a extinção do Conselho de Presidência; e a segunda, de um parágrafo que atribuía ao mesmo presidente o poder temporário de decidir sobre conflitos de jurisdição, entre as autoridades da Província. Ambas deixavam claro que o "delegado do Imperador" poderia agir individualmente, sem consulta prévia a nenhuma instância, o que incluía a centralização, na sua figura, da mediação das tensões administrativas. Dessa forma, um dos principais papéis de árbitro que anteriormente ele desempenhava em comunhão com seus conselheiros, conforme vimos anteriormente, ficaria restrito, a partir de então, a si mesmo.

O texto foi sancionado como lei em outubro, sob a forma de um regimento para os presidentes $^{270}$. Nela se definiam, para além de suas atribuições, os ordenados e ajudas de custo, a forma de escolha do vice-presidente a partir de lista aprovada pela Assembléia provincial e levada para a escolha do Imperador, a forma do juramento de ambas as autoridades diante da mesma Assembléia. Entre as funções presidenciais estavam: executar e fazer executar as leis, exigir dos empregados públicos as informações devidas, inspecionar todas as repartições, prover os cargos (inclusive provisoriamente aqueles de nomeação do Imperador), levar a efeito a ação de empregados gerais nos negócios provinciais, e também conceder licença aos funcionários. Além disso, seria sua obrigação participar ao governo todos os "embaraços" que encontrasse, e suspender a qualquer empregado por abuso já que ele decidiria, mesmo que momentaneamente, os conflitos de jurisdição. Um dos parágrafos marcava que sua autoridade deveria estar à frente das Tesourarias Provinciais (conforme fixara a lei de sua criação em 1831) sem deixar dúvida sobre o papel fundamental que teriam os presidentes na questão da arrecadação monetária da Província e no envio de recursos ao centro do Império.

\footnotetext{
${ }^{269}$ Idem, p.187-9.
} 
Em relação à lei de outubro de 1823, é visível como o âmbito de ação individual prevista aos presidentes aumentava com o novo regulamento, sobretudo porque os seus Conselhos privativos, ainda que apenas consultivos, foram definitivamente extintos. Nesse sentido, seguiu-se um caminho normativo um pouco distinto ao pretendido durante as legislaturas do Primeiro Reinado, quando predominara uma tendência em aumentar o poder dos então Conselhos Gerais da Província como órgãos que poderiam, inclusive, exercer alguma forma de controle sobre a autoridade presidencial. Conforme vimos no capítulo anterior, tal arranjo acabou não sendo aprovado pelos senadores, e os que o defendiam acabariam apostando, a partir de 1831, na reforma da Carta para implementá-lo. No entanto, após várias propostas de transformação radical na forma de escolha dos presidentes, o saldo de toda a discussão de 1834 foi o fortalecimento de sua autoridade diante da novidade da criação de um espaço legislativo provincial.

Nesse sentido, era aprovado um projeto em que a institucionalização de uma esfera de autonomia provincial pôde ser aceita mediante a concepção de fortalecimento do Executivo local, cujo presidente era então reconhecido como peça fundamental de integração do Império sob a égide monárquica constitucional. Por esse motivo, o fato de ele ser escolhido pelo Imperador muito vezes chegou a ser aceito mesmo entre deputados que lutavam contra qualquer medida que soasse centralizadora por parte do Rio de Janeiro. O embate em torno de ser o presidente homem nascido na Província continuou sendo um ponto de permanente tensão, em que seus defensores falavam num melhor conhecimento dos negócios da Província, e seus detratores na necessidade da sua pessoa manter uma imparcialidade em meio aos conflitos locais. Foi dessa forma que o arranjo políticoinstitucional provincial se consubstanciaria, a partir de 1834, nesses dois principais pilares de autoridade: nos presidentes e nas Assembléias Legislativas locais.

\subsection{O Ato Adicional}

A lei da reforma foi sancionada em 12 de agosto de 1834 na forma de um "Ato Adicional" à Carta Constitucional de 1824. Nela se estabelecia a criação das Assembléias Legislativas provinciais, seu funcionamento (incluindo número de membros em cada

\footnotetext{
${ }^{270}$ Lei de 3 de outubro de 1834; ver: Coleção de Leis do Império.
} 
localidade) e atribuições, em nome da institucionalização definitiva da esfera provincial como espaço de atendimento das demandas e interesses regionais. Definiam-se também os critérios para aprovação das medidas tomadas por esses novos órgãos, a ação dos presidentes de Província, as regras para eleição de um regente único (artigos 26-31) e a extinção do Conselho de Estado (art. 32). Confirmava-se também, logo no primeiro parágrafo, a Corte como espaço de jurisdição própria no que tocava à sua administração, sem dependência do presidente da Província.

De acordo com a Lei, os deputados para as Assembléias provinciais seriam eleitos da mesma forma que para a Geral no Rio de Janeiro, só que com tempo de mandato reduzido para dois anos (art. $4^{\circ}$.). Suas sessões seriam de dois meses anuais, prorrogáveis quando o presidente em exercício julgasse "conveniente". Um artigo deixava estipulado que o poder Legislativo central poderia sancionar a organização de uma segunda Câmara (com senadores), caso alguma localidade assim o solicitasse. Competia às mesmas Assembléias legislar sobre a divisão civil, judiciária e eclesiástica, no que cabe destacar: a instrução pública, a fixação de despesas municipais e provinciais, a criação e supressão de empregos e ordenados, as obras públicas, a organização dos regimentos internos, os empréstimos, a administração de todos os bens provinciais. Juntamente com o governo da Província, promoveriam a organização das estatísticas, catequese e civilização dos indígenas, e as medidas necessárias no caso de motins, invasões e subversões (conforme o parágrafo 35, artigo 179, da Carta de 1824). O órgão também tinha poderes especiais de decretar a suspensão, mesmo que temporária, do magistrado, e de decisão sobre a continuidade de um eventual processo em que estivesse pronunciado o presidente.

No que tocava às Câmaras municipais, a lei, além de confirmar sua subordinação à esfera provincial, criava outras formas de intervenção das Assembléias nas questões locais (parágrafos 4-6, artigo 10, e parágrafo 3, artigo 11). Dessa forma, a fixação, repartição e fiscalização de suas rendas, e também os empregos, a construção de qualquer obra pública e autorização para empréstimos estavam sob a alçada dos deputados do novo órgão. A idéia era concretizar um arranjo de poderes que circunscrevesse os municípios como inferiores às Províncias e estas, por sua vez, em uma relação de subordinação, mas ao mesmo tempo de interdependência, com os poderes centrais. 
Esse segundo círculo, que articularia o centro com as partes, era referido no texto da lei, sobretudo quando se estabeleciam as formas de encaminhamento dos atos dos legislativos locais. Assim, ao presidente foi dado o direito de sancionar todas as leis e resoluções provindas das Assembléias locais, o qual também tinha a função de enviá-las ao Rio de Janeiro para sua aprovação definitiva pelo Imperador (artigo 13). Se o presidente julgasse que deveria negar a sanção, esta seria derrubada se a matéria fosse novamente ao plenário provincial por mais de dois terços dos votos. No caso de o presidente julgar que a medida ofendia os direitos de alguma outra Província, mesmo aprovada pela maioria dos deputados, ela deveria ser encaminhada à Assembléia Geral do Império para que se decidisse o caso (art. 16). É fato que, independentemente da sanção presidencial, todos os atos legislativos provinciais passariam pela instância central do governo, mas poderiam ser postos provisoriamente em execução pelo "delegado do Imperador". Em princípio ficava estabelecido que as medidas tomadas pelos novos órgãos só poderiam tratar de questões provinciais, mas, como se sabe, o limite destas com as gerais foi, ao longo de todo o Império, um dos pontos recorrentes de conflitos entre as localidades e o Rio de Janeiro ${ }^{271}$.

O significado político do Ato Adicional tem dividido opiniões da historiografia mais recente. Geralmente ele é associado com um momento em que teria predominado um direcionamento político de matriz liberal, tendente a favorecer a institucionalização da autonomia como forma de integração das partes à unidade do Estado, o qual fracassara de vez com o Regresso de $1840^{272}$. Outra forma de se entender a questão, é a idéia de que ele teria viabilizado um nível de autonomização que permitiria aos grupos políticos locais o controle sob a máquina pública regional, fazendo-os assim aderir a um projeto de

\footnotetext{
${ }^{271}$ Um exemplo disso estava na recorrente tensão que a aprovação de impostos pelas Assembléias legislativas locais gerava ao serem submetidos à Câmara Geral, a qual deveria controlar para que os mesmos não ultrapassassem sua linha de ação provincial, sempre passível de interpretação. Ver descrição de conflitos nesse nível feita por Paulino José Soares de Sousa, Ensaio sobre o direito administrativo, Rio de Janeiro, Typographia Nacional, 1862, tomo 2.

${ }^{272}$ Nesse sentido, ver a análise de Ilmar Rohllof de Mattos, O tempo saquarema. A formação do Estado imperial, Rio de Janeiro, Access Editora, 1999. Também Roderick Barman, Brazil. The forging of a nation 1798-1852, Stanford, Stanford University Press, 1994, que mesmo partilhando dessa interpretação geral, concebe que o Ato Adicional, em vista das pressões que existiram na época, acabou sendo um documento bastante moderado do ponto de vista das transformações no regime. Thomas Flory, El juez de paz y el jurado en el Brasil imperial. Control social y estabilidad política del nuevo Estado, México, Fundo de Cultura Economica, 1986, que pode também ser enquadrado nessa linha geral de entendimento do período. Flory analisa a Reforma de 1834 sob uma mesma linha de moderação: o Ato Adicional teria sido a primeira expressão do desejo liberal de voltar a centralizar a administração que se encontraria diluída pelas reformas promovidas durante todo o Primeiro Reinado.
} 
integridade imperial que, a partir da reforma, se perpetuaria nos oitocentos ${ }^{273}$. As análises acerca do funcionamento das Assembléias Legislativas provinciais no século XIX evidenciam também o amplo espectro de atuação das mesmas que, na prática, agiam muitas vezes independentemente das decisões do centro, mas também geravam conflitos na sua relação com ele ${ }^{274}$.

Como quer que seja, a riqueza dos problemas levantados sobre o período nos coloca novamente diante da dificuldade em se trabalhar com o binômio centralização/descentralização como categoria explicativa para se entender a criação constitucional imperial, por mais que os coevos constantemente o evocassem como poderosa arma no debate político ${ }^{275}$. Por várias razões, é óbvio que a criação das Assembléias provinciais instituiu definitivamente, na ordem constitucional, um espaço de jurisdição local, com Executivo e Legislativo próprios. Entretanto, mantinha-se também sua vinculação, nos mais variados níveis, com a Corte, haja vista a pretensão de unidade de todos os territórios americanos anteriormente portugueses. Além disso, deve-se notar que a noção de "centro" evocada nesse momento não pode ser confundida, do ponto de vista institucional, com aquela outrora existente no Império português, a despeito dos esforços de racionalização que já haviam sido colocados em prática desde os setecentos.

Em função disso, parece correto afirmar que tanto os laços que forneciam materialidade à nova unidade política, como um centro que articulasse administrativamente suas partes, estavam em construção. Tal processo foi marcado pela violência constitutiva das organizações estatais de tipo moderna, em que os esforços em nome da centralização e da descentralização seriam forças em permanente conflito no discurso daqueles que almejavam a garantia de seus interesses ou de vínculos comuns. Assim, por mais (des)centralizado que possa ser caracterizado o arranjo institucional do Império, ressaltar

\footnotetext{
${ }^{273}$ Miriam Dolhnikoff, O pacto imperial. Origens do federalismo no Brasil, São Paulo, Globo, 2005; e, da mesma autora, "O poder provincial (política e historiografia)", Revista de História, São Paulo, 1990, n.112.

${ }^{274}$ Maria de Fátima Gouvêa, O Império das Províncias - Rio de Janeiro, 1822-1889. Rio de Janeiro, Faperj, 2006; Miriam Dolhnikoff, O pacto imperial.

${ }^{275}$ Pierre Rosanvallon, L'État en France de 1789 à nous jours, Paris, Éditions du Seuil, 1992, propõe outra forma de se olhar para o fenômeno do Estado moderno que, mesmo tratando apenas do caso francês, vai muito além de uma tensão entre centralização/descentralização. Concebe quatro eixos no enquadramento da questão que nos parecem especialmente relevantes na colocação de novos problemas: a construção de sua estrutura interna enquanto uma esfera autônoma, que chama de "Leviatã democrático"; o advento de uma "sociedade de indivíduos", que concebe sob a legenda de "instituição do social"; o Estado como "providência", ou seja, na sua função de mediador e protetor dos povos; e a função de regulador da economia como um sistema integrado à sua esfera de ação.
} 
que, de modo geral, teria predominado ou a autonomia das partes ou uma eficácia centralizadora promovida pela Corte pode vir a prejudicar uma ampla percepção da complexidade das variáveis em jogo nessa estrutura. Ainda mais porque, sobretudo após o Ato Adicional, consolidar-se-ia uma base jurídica que iria colocar em pauta a possibilidade de interpretação da lei de acordo com projetos mais "federalistas" ou mais "centralizadores", contribuindo na formação de um espaço privilegiado para tensões e conflitos.

Isso posto, a questão central que interessa frisar aqui se refere ao caráter que a lei de 1834 confirmava no que tocava à estruturação jurídica do Império. Resumida em seus propósitos de transformação mais radical do regime, a reforma concentrou-se, sobretudo, numa reformulação das formas de administração do Estado sem modificar a base normativa lançada na Carta outorgada de 1824. Nesse sentido, tanto a criação das Assembléias Legislativas provinciais como a supressão do Conselho de Estado, como as duas principais mudanças alteravam o trâmite da ação dos poderes públicos confirmando a ênfase dada na crença da eficácia da máquina administrativa. Anos depois, o Visconde do Uruguai confirmaria essa simbiose, numa obra em que se esmerava em criticar o próprio Ato Adicional:

"Não há talvez país em que a administração esteja mais confundida com a política do que o Brasil, e onde menos tenha feito a legislação para distingui-las e separálas. Tudo é política, principalmente pessoal; tudo ressombra política, e é considerado pelo lado político"276.

A despeito da posição de Uruguai em tentar mostrar os malefícios do poder Legislativo dado às Províncias, ficava evidente, pela evocação que faz da defesa de um aprimoramento da administração, como a questão estava na seara do Direito Público.

Tal ênfase também esteve presente nos debates travados em torno da reforma da Constituição. Comparando este momento com aquele de 1823, é revelador como as vozes dissidentes que então falavam em nome de um incremento nos canais de representação dos "povos" no âmbito da política - conforme reivindicado pelos vereadores da Câmara de

\footnotetext{
${ }^{276}$ Paulino José Soares de Sousa, op.cit., tomo 1, p.24.
} 
Cantagalo em 1821, analisado no início deste trabalho - depois praticamente se calaram. Em 1834, o pomo da discórdia passava pelo fortalecimento dos instrumentos políticos das Províncias perante a consolidação do papel central do Rio de Janeiro. Assim confirmava-se a valorização das instituições que falavam em nome dos "interesses coletivos", pondo uma pá de cal na possibilidade de qualquer alteração de status quo pela via legalista.

Duas razões explicam essa mudança de foco: a primeira, a construção de um consenso para a realização de uma reforma desde que se mantivesse a moderação do regime; a segunda, a visível materialidade de um Estado nascente que, por mais que suas ações não chegassem a todos os rincões do território, já demonstrava sua força tanto pela violência como pelo discurso da sua capacidade de estabilidade. Não foi à toa que as rebeliões regenciais vieram na rasteira do Ato Adicional - a despeito de uma crescente abertura política a partir de 1831 -, quando a estrutura jurídica pôde ser pensada, definitivamente, em nível nacional. Essas rebeliões foram sufocadas pelo governo à medida que o funcionamento da máquina pública consolidava, no nível da administração, uma alternativa de preservação de um espaço de autonomia provincial, e dividia grupos e atores políticos nas localidades. Em contrapartida, as instituições públicas definiam-se, cada vez mais, como representantes dos direitos e interesses dos que ascendiam a elas, com a exclusão de uma imensa população que não foi contemplada na formação da sociedade civil brasileira.

Dessa forma, o arranjo institucional promovido em 1834, ao fornecer os instrumentos políticos para que os envolvidos na defesa de seus interesses reivindicassem legalmente os seus direitos, instituía o conflito básico entre o centro e as Províncias. Interesses que, stricto sensu, de privados adquiriram rapidamente um caráter coletivo. Essa foi uma forte razão da perpetuação, mesmo após a Maioridade em 1840, da estrutura política que se analisou ao longo desse trabalho. A volta do Conselho de Estado (por lei de 23 de novembro de 1841), só confirmaria a validade do que já havia sido forjado logo após a Independência, quando se assegurou que a Constituição e a monarquia seriam os dois "pés" de sustentação do regime. 


\section{Conclusão}

Para concluir, cabe salientar como algumas das evidências desta pesquisa apontam para uma discussão geral acerca do processo de formação político-constitucional do Brasil independente. Duas entre elas despontam, a nosso ver, como fundamentais. Em primeiro lugar, o fato de ter sido a Independência, com a conseqüente necessidade de construção de uma alternativa viável do ponto de vista de uma estrutura interna de poder, um indiscutível marco na formação do que posteriormente viria a ser uma burocracia estatal. Foi dessa forma que a ordem constitucional no novo Império fez-se, desde o início, intrinsecamente ligada à valorização da esfera administrativa e, em especial, à criação de instituições que nasciam amparadas por um discurso acerca de sua capacidade de gerar estabilidade nos mais distantes recônditos do território. A idéia era que o "império das leis" deveria estar "estabelecido com aquela solidez que era para se desejar", conforme afirmavam os conselheiros do Conselho Geral da Província de Minas Gerais diante dos distúrbios ocorridos nos idos de 1831, após a Abdicação ${ }^{1}$.

Deve-se notar, nesse sentido, que o processo de criação institucional desde o Primeiro Reinado ocorreu de forma intensa e gerou uma normalização, sob moldes essencialmente modernos, mesmo antes que uma unidade imperial pudesse sobrepor-se definitivamente às outras alternativas e projetos existentes. Seu início marcaria uma nova fase tanto na prática como na concepção política-administrativa em relação ao que existia anteriormente na América portuguesa, cujos alicerces mostrariam ser capazes de ter vida longa. Por isso, cabe refutar a valorização da continuidade da herança patrimonialista ibérica, como atributo de longuíssima duração na história do Brasil, para explicação da formação de um Estado independente sob os escombros do Antigo Regime, nos moldes do pretendido por importante historiografia há algumas décadas ${ }^{2}$. O que significa dizer que, nesse caso, a expressão da continuidade - que sempre existe quando tratamos de problemas

\footnotetext{
${ }^{1}$ Actas das sessões do Conselho Geral da Província de Minas Gerais de 1831, Ouro Preto, Typographia do Silva, 1831, sessão de 16/dezembro/1831, p.81.

${ }^{2} \mathrm{O}$ principal expoente dessa explicação é Raymundo Faoro, Os donos do poder. Formação do patronato político brasileiro, $9^{a}$ ed, São Paulo, Globo, 1991 (1 ${ }^{a}$ edição de 1957).
} 
da natureza histórica - deve ser compreendida num novo patamar, ditado pela crise de paradigmas políticos que revolucionou o mundo ocidental desde o século XVIII e engendrou uma aceleração do tempo histórico profundamente vivenciada pelos coevos, conforme proposto por Reinhardt Koselleck ${ }^{3}$. Portanto, apenas pela marcação dessa ruptura estrutural é que se poderia enunciar suas permanências. Neste trabalho, um exemplo está na própria valorização do Direito Público na estrutura do Império do Brasil que, mesmo devendo ser relacionada com a dinâmica monárquica portuguesa, adquiriu roupagem própria na conjuntura constitucional moderna.

A segunda evidência digna de nota refere-se ao caráter "liberal" atribuído às instituições brasileiras pós-Independência, entre elas a Constituição. Vale retomar que, a idéia de que o liberalismo no Brasil teria sido um fenômeno de "fachada" por supostamente não ter alterado substantivamente estruturas sociais e práticas políticas coloniais, já foi suficientemente criticada nos últimos vinte anos; no entanto, a leitura de que, a despeito do sentido liberal e moderno da construção normativa concebida após a Independência, tudo se revelaria "letra-morta", é um dos desdobramentos dessa mesma matriz interpretativa que ainda se encontra diluída em vários dos estudos que se debruçam sobre o período. Levada ao extremo, poder-se-ia imaginar que, como as leis não seriam necessariamente cumpridas, os primeiros legisladores não tiveram nenhum problema em assumir o que havia de mais atual do ponto de vista das instituições, como se trabalhassem deslocados de sua realidade política-social.

$\mathrm{Na}$ negação dessa interpretação, a presente pesquisa aponta para duas questões complementares que reforçam o enraizamento de uma fecunda construção liberal no Brasil desde o início do Império. Primeiramente, que a Carta de 1824 teve, sim, uma inegável eficácia tanto no que se refere ao desenvolvimento das instituições políticas como na preservação da moderação do regime, como pôde ser claramente observado no processo da Reforma concluída em 1834. A Constituição cumpria, dessa forma, um essencial papel propositivo que os próprios coevos lhe imputaram quando defrontados com a necessidade de projetar uma unidade para o futuro. Como um dos seus desdobramentos, a recriação da administração das Províncias, cuja prática, por mais que se amoldasse às formas reiteradas das relações políticas locais, seria responsável por uma nova distribuição de poderes no que

\footnotetext{
${ }^{3}$ Futuro Passado. Para una semántica de los tiempos históricos, Barcelona, Paidós, 1993.
} 
tocava à junção dos territórios americanos anteriormente portugueses. Trata-se, portanto, da valorização da prática da lei entendida no seu ambiente de luta política, e não apenas na esfera da sua jurisprudência, perspectiva esta especialmente cara aos juristas.

Outro ponto de negação da idéia de um "falso liberalismo" permite que se traga à tona um dos "cimentos" da organização política que se prolongaria, mesmo com a Abdicação, na história institucional do Brasil. Ela está sustentada numa verdadeira necessidade de construção de um Estado que, para aqueles empenhados na sua normalização desde precisamente 1823, não tinha nada de "artificioso". Muito ao contrário. Em razão da completa impossibilidade de se separar, na época, os limites entre utopia e ideologia liberal, a crença na realização de uma ordem interna estável - em que a lei passava a ser também um instrumento de transformação futura - nascia intrinsecamente ligada à possibilidade de manutenção do status quo herdado da colônia sob o que havia de mais moderno do ponto de vista da sua criação legalista. Nesse sentido, é ainda atual a formulação de Florestan Fernandes, segundo a qual o Estado e a nação foram meios para a "burocratização" da dominação existente e, o que é mais importante, para sua concomitante transformação numa estrutura a mais próxima possível das novidades vividas pelo ocidente ${ }^{4}$.

Por essa razão, uma explícita lacuna no texto da lei coube à escravidão. $\mathrm{O}$ fato de ela ter sido, mesmo que implicitamente, recriada do ponto de vista constitucional como uma das instituições fundamentais do novo Império, fez que ela passasse ao largo do debate legislativo nas duas primeiras décadas do Brasil independente, já que sua completa extinção não estava definitivamente no rol das prioridades. $O$ que mostrava que os primeiros legisladores tiveram um verdadeiro conhecimento do que era viável na ordem que se pretendia construir, pois a manutenção da escravidão esteve, nesse período, longe de gerar conflitos ou mesmo dissidências impossíveis de serem controladas do ponto de vista do governo central. Ao contrário, e por mais contraditório que possa parecer, a linha que demarcava o universo dos livres também contribuiu, a despeito do nível crescente de tensões que cercaram a criação da máquina pública, para a estabilidade e adesão dos

\footnotetext{
${ }^{4}$ A revolução burguesa no Brasil. Ensaio de interpretação sociológica ( $1^{\mathrm{a}}$ edição de 1975), 5 ed., São Paulo, Globo, 2006; ver em especial o capítulo 2 e 3.
} 
mesmos ao regime liberal como forma de sua separação dos cativos com quem compartilhavam o estigma da cor ${ }^{5}$.

Dessa forma, era no ambiente de definição de quem eram os cidadãos que uma nova ordem constitucional teria de ser construída. Esbarrava-se aí num problema que o presente trabalho levanta à alçada de fundamental: o da construção dos canais de representação política. Já desde 1821, como se viu, a pressão pela implementação de novos canais ou ampliação de outros já existentes foi notável e continuaria, no âmbito dos trabalhos da Assembléia brasileira, tanto na boca dos parlamentares como em manifestos a eles dirigidos. O que se observou é que, ao longo desses anos, concomitantemente ao desenvolvimento das instituições surgia também a concepção de que elas poderiam falar em nome dos "povos", ou seja, representá-los pela afirmação prioritária dos "interesses coletivos". Da mesma forma, o poder Legislativo que alicerçava seu surgimento na "representação da nação", apresentava sua vocação no Império do Brasil para também zelar pela administração, numa forma de garantir a eficácia do novo Estado. Daí as tensões entre a ação desse poder e o Executivo terem sido especialmente candentes desde a criação de ambos no Primeiro Reinado.

Por acreditarmos que esse processo foi responsável tanto pelo incentivo ao crescimento das instituições públicas como pelo seu afastamento das demandas provenientes daqueles que nem sequer participavam efetivamente da esfera da sociedade civil, ele não pode passar despercebido numa interpretação que se pretenda geral dos primórdios do Império. Foi o que um dia, em conversa informal, István Jancsó sugeriu-me em termos do déficit democrático de nossa formação (idéia que quiçá um dia ainda desenvolva em publicação científica). Por ora, fica a constatação de que as bases de constituição do novo Estado representaram o primeiro passo para a posterior concretização de semelhante destino.

\footnotetext{
5 Rafael de Bivar Marquese, "Governo dos escravos e ordem nacional: Brasil e Estados Unidos, 1820-1860”, István Jancsó (org.), Brasil: formação do Estado e da nação, São Paulo/Ijuí, Fapesp/Hucitec/Unijuí, 2003, pp. 251-265; Andréa Slemian, “Seriam todos cidadãos?': os impasses na construção da cidadania nos primórdios do constitucionalismo no Brasil (1823-1824)”, István Jancsó (org.), Independência: história e historiografia, São Paulo, Fapesp/Hucitec, 2005, pp. 829-847.
} 


\section{Fontes documentais e bibliografia}

\section{ARQUIVOS}

Arquivo Nacional do Rio de Janeiro (ANRJ)

Biblioteca Geral da Universidade de Coimbra (BGUC)

Biblioteca Nacional de Lisboa (BNL)

Biblioteca Nacional do Rio de Janeiro (BNRJ)

IEB (Instituto de Estudos Brasileiros)

Centro de Documentação e Informação, Câmara dos Deputados, Brasília (CEDI)

\section{DOCUMENTAÇÃO MANUSCRITA}

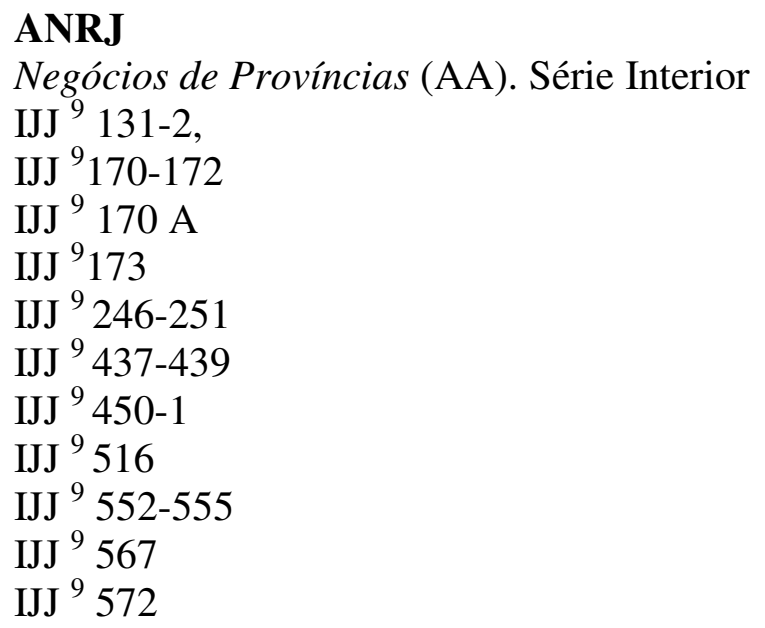

\section{BGUC}

"Preleções de Direito Pátrio", por Luiz Joaquim Corrêa da Silva Seção de Manuscritos, Códice 1460.

\section{BNL}

Seção de Reservados Antonio Ribeiro dos Santos:

- Discursos vários jurídicos (Códice 4677);

- Notas ao Plano do Novo Código de Direito Público de Portugal do Dr. Paschoal José de Mello (Códice 4672) 
Pascoal de Mello Freire:

- História do Direito Português (códice 118);

- História da Legislação Portuguesa (Códices 8527 e 683);

- História do Direito Português (Códice 1711);

- Exposições do Direito Português (Códice 1710)

Ricardo Raimundo Nogueira:

- Direito Publico de Portugal (Códice 9347);

- Preleções de Direito Público de Portugal (Códice 1715).

\section{BNRJ}

Seção de Manuscritos

Ofício de João Severiano da Costa, 05/janeiro/1824. Loc.: II-33,18,10.

\section{CEDI}

1. Arquivo da Assembléia Legislativa e Constituinte do Império do Brasil de 1823 (CEDI- AC 1823)

2. Arquivo da Câmara dos Deputados (CEDI-CD)

Ano de 1826

Lata 22, maço 19, pasta 1 (ofício do Conselho de Governo de Minas Gerais)

Lata 26, maço 33, pasta 1, PDID 514 (ofício do Governo da Bahia)

Ano de 1827

PDID 766 (ofício do Vice-Presidente da Bahia)

PDID 888Z (Memória de José Maria Cambraia)

PDID 416 A (ofícios sobre Províncias)

Lata 9, PDID 825 (consulta da Mesa do Desembargo do Paço)

Ano de 1828

Lata 1, PD/3, doc. 2 (requerimento da Câmara de Ouro Preto)

PDID 461 (ofício do Presidente de Província da Bahia)

PDID 439 (Consulta do Conselho Militar sobre representação da Junta de Justiça da Bahia)

Ano de 1829

PDID 87 N (Representação Conselho Geral de Minas Gerais)

Ano de 1830

Maço 21, Pasta 1 (ofícios sobre Províncias)

Ano de 1831

Maço 11, pasta 2 (petições sobre Províncias e Municípios)

Maço 17, pasta 1 (idem)

Maço 31, pasta 4 (vários ofícios sobre Províncias)

Maço 31, pasta 5 (idem)

Maço 1832 
Maço 42, pasta 6 (ofícios sobre Províncias)

Maço 11, pasta 1 (idem)

Maço 28 (Autos de Devassa)

Lata 81 D, Maço 46, Pasta 2 (felicitações à Câmara dos Deputados)

Ano de 1833

Maço 13, pasta 1 (ofícios sobre Províncias)

Maço 14, pasta 1 (idem)

Maço 20, pasta 4 (Parecer Comissão de Constituição sobre representação da Câmara de Belém do Pará)

Ano de 1834

Maço 15, pasta 1 (ofícios sobre Províncias e Municípios)

Lata $97-\mathrm{C}$, maço 26 , pasta 5

\section{DOCUMENTAÇÃO IMPRESSA}

Arquivo Nacional. As Câmaras Municipais e a Independência. Rio de Janeiro, Arquivo Nacional, Conselho Federal de Cultura, 1973, 2 v.

Arquivo Nacional. As Juntas Governativas e a Independência. Rio de Janeiro, Arquivo Nacional, Conselho Federal, 1973, 3v.

BLAKE, Augusto Vitorino Alves Sacramento. Dicionário bibliográfico brasileiro. Rio de Janeiro, Tipografia Nacional, 1883.

BONAVIDES, Paulo \& AMARAL, Roberto. Textos políticos da História do Brasil. $3^{\mathrm{a}}$ ed., Brasília, Senado Federal, 2002, v.1 (Formação/Império) (disponível no site: www.cebela.org.br)

CARREIRA, Liberato Castro. História Financeira e Orçamentária do Império no Brasil (1889). Brasília/Rio de Janeiro, Senado Federal/Fundação Casa de Rui Barbosa, MEC, 1980, 2 t..

Coleção das leis do Império do Brasil. Rio de Janeiro, Tipografia Nacional, 12 v..

Correspondência oficial do Governo Provisório de Minas (1821-1824). Revista do Archivo Publico Mineiro, ano IX, fac. III e IV, jul./dez. de 1904, pp.588-641.

Documentos para a história da independência. Rio de Janeiro, Oficinas Gráficas da Biblioteca Nacional, 1923.

Documentos Históricos. Revolução de 1817. Rio de Janeiro, Biblioteca Nacional/Divisão de Obras Raras e Publicações, 1954, v. CIV.

Inventário analítico do Arquivo da Assembléia de 1823: descrição do acervo e sinopse de tramitação. Brasília, Câmara dos Deputados/Coordenação de Publicações, 1987. 
RAIOL, Domingos Antônio. Motins políticos (ou história dos principais acontecimentos políticos da Província do Pará desde o ano de 1821 até 1835) (1865-8). Belém, Universidade Federal do Pará, 1970.

SILVA, Antonio de Moraes e. Diccionario da Lingua Portugueza composto pelo Padre D.Rafael Bluteau, reformado, e accrescentado por...Lisboa, Officina de Simão Thaddeo Ferreira, 1789.

- Diccionario da Lingua Portugueza recopilado dos vocabularios impressos até agora, e nesta segunda edição novamente emendado, e muito accrescentado... Lisboa, Typographia Lacerdina, 1813.

. Diccionario da Lingua Portugueza recopilado de todos os impressos até o presente por... Terceira edição... Lisboa, M.P.de Lacerdo, 1823.

. Diccionario da Lingua Portugueza. Quarta edição, Lisboa, Impressão Regia. 1831.

\subsection{Anais, Atas de Assembléias e Constituições}

Actas do Governo Provisório de 1821 a 1822. São Paulo, Archivo do Estado de S. Paulo/ Typographia da Companhia Industrial de São Paulo, 1894.

Actas das sessões do Conselho do Governo da Província de Minas Gerais de 1828. Ouro Preto, Typographia do Silva, 1828.

Actas das sessões do Conselho do Governo da Província de Minas Gerais de 1829. Ouro Preto, Typographia do Silva, 1829.

Anais do Parlamento Brasileiro. Câmara dos Deputados (1826-1834). Rio de Janeiro, Tipografia de Hipolito José Pinho e Cia., 1874-1879. (disponível no site: www.camara.gov.br )

Anais do Senado do Império do Brasil. Rio de Janeiro, Brasília, 1826-1889. (disponível no site: www.senado.gov.br)

Annaes do Parlamento Brazileiro: Assembléia Constituinte de 23. Rio de Janeiro, Hipolito José Pinto, 1876, 6 v.

Atas do Conselho Geral da Província do Ceará (1829-1835). Fortaleza, INESP, 1997 (edição fac-similar).

Atas do Conselho do Governo de Pernambuco (1821-1834). Recife, Assembléia Legislativa de Pernambuco/Arquivo Público Estadual, 1997, 2 v. 
Atas do Conselho da Presidência da Província de São Paulo (anos de 1824-1829). Documentos Interessantes. São Paulo, Arquivo do Estado de São Paulo/Secretaria de Educação, 1961, v.86.

(ano de 1829). Documentos Interessantes. São Paulo, Arquivo do Estado de São Paulo/Secretaria de Educação, 1961, v.15 (Nova Fase).

(anos de 1832-1834). Documentos Interessantes. São Paulo, Arquivo do Estado de São Paulo/Secretaria de Educação, 1961, v. 16 (Nova Fase).

Colleção dos Diarios do Concelho Geral da Província de Minas Gerais. Ouro Preto, Typographia do Universal, 1830 ( $1^{\text {a }}$ sessão, $2^{\text {a }}$ legislatura).

Colleção dos Diarios do Concelho Geral da Província de Minas Gerais. Ouro Preto, Typographia do Universal, 1831 ( $2^{\mathrm{a}}$ sessão, $2^{\mathrm{a}}$ legislatura).

Colleção dos Diarios do Concelho Geral da Província de Minas Gerais. Ouro Preto, Typographia do Universal, 1833 (4 sessão, $2^{a}$ legislatura).

Constituição Política do Império do Brasil (1824), acompanhada pelo Ato Adicional de 1834 e pela Lei de Interpretação de 1840. Brasília, Ministério do Interior/ Fundação Projeto Rondos, 1986.

Constituições do Brasil, acompanhadas das emendas constitucionais e projetos. Rio de Janeiro, Imprensa Nacional, 1948.

Constituições americanas do século XIX (textos disponíveis no site: www.cervantesvirtual.com/portal/constitutciones).

Correio Braziliense, ou Armazém Literário (Londres, 1808-1822) (edição fac-similar). São Paulo/Brasília, Imprensa Oficial/Correio Braziliense, 2000-2, 29 v.

Diario da Assembleia Geral Constituinte e Legislativa do Império do Brasil: 1823. Brasília, Centro Gráfico do Senado Federal, 1973 (3 vols.) (disponível no site: www.camara.gov.br).

Diário da Câmara dos Deputados, A Assembléia-Geral Legislativa do Império do Brasil. Rio de Janeiro, Imprensa Nacional, 1826-1830, 8 v.

Diário das Cortes Geraes da Nação Portuguesa. Lisboa, ano de 1821: 4 tomos, ano de 1822: 3 tomos, ano de 1822-3: 3 tomos. (disponível no site: www.debates.parlamento.pt )

\subsection{Textos políticos e constitucionais (séculos XVIII e XIX)}

AMARAL, Antonio Caetano do. Memórias sobre a forma de governo, e costumes dos povos que habitaram o terreno lusitano, desde os primeiros tempos conhecidos, até o estabelecimento da monarquia portugesa. Lisboa, Academia Real das Ciências de Lisboa, 1792. 
. Memórias. Memória V. Para a História da Legislação e costumes de Portugal. Porto, Livraria Civilização [c.1819].

BENEVIDES, José Maria Correia de Sá e. Analyse da Constituição política do Império do Brasil. São Paulo, Typographia King, 1890.

BENTHAM, Jeremy. Tactique des assemblées législatives, suivie d'un traité des sophismes politiques. Paris, Bossange Frères, 1822.

BASTOS, A.C. Tavares. A Província: estudo sobre a descentralização no Brasil (1870). São Paulo/Brasília, Cia. Editora Nacional/INL, 1975.

BROTERO, José Maria de Avellar. Princípios de Direito Natural. Rio de Janeiro, Typographia Imperial e Nacional, 1829.

BUENO, José Antônio Pimenta Bueno (marquês de São Vicente). Direito público brasileiro e a análise da Constituição do Império. Brasília, Senado Federal, 1978.

BURLAMAQUI, Jean Jacques. Elementos do Direito Natural compostos por João Diogo Burlamaqui, Conselheito de Estado, e Professor de Direito Natural, e Civil; traduzidos em Português, e oferecidos a El Rei Nosso Senhor D. José I por José Caietano de Mesquita, Professor de Retórica, e de Lógica no Colégio Real de Nobres. Lisboa, Officina de Miguel Rodrigues, 1768.

CALDEIRA, Jorge (org.). Diogo Antonio Feijó. São Paulo, Editora 34, 1999 (Coleção Formadores do Brasil).

CARVALHO, José Murilo de (org.). Bernardo Pereira de Vasconcelos. São Paulo. Editora 34, 1999 (Coleção Formadores do Brasil).

COELHO, Fillipe Joseph Nogueira. Direito divino, natural, público universal e das gentes adotados pelas ordenações, leis, decretos e mais disposições do Reino de Portugal. Lisboa, 1773 .

CONSTANT, Benjamin. Principes de Politique (1815). Biblioteca Nacional de Paris (documento eletrônico). (disponível no site: www.bn.fr )

. Escritos de política. São Paulo, Martins Fontes, 2005.

. De la Force du governement actuel dela France et de necessité de s'y rallier... (1796 e 1797). Paris, Flammarion, 1988.

DOLHNIKOFF, Miriam (org.). José Bonifácio de Andrada e Silva. Projetos para o Brasil. São Paulo, Companhia das Letras, 1998.

EGAS, Eugenio (org.). Feijó. Documentos. São Paulo, Typografia Levi, 1912. 
FREITAS, A. Teixeira de. Doutrina das Ações por José Homem Corrêa Telles accomodada ao Foro do Brasil. Rio de Janeiro, Garnier, 1880. . Livro dos Vereadores. Rio de Janeiro, Garnier, 1882.

GONZAGA, Tomás Antonio. Tratado de Direito Natural (1768). Rio de Janeiro, Ministério da Educação e Cultura/ Inst. Nacional do Livro, 1957.

GROCIO, Hugo. Derecho de la guerra y de la paz. Madrid, Reus, 1925, 4 v.

LISBOA, José da Silva (Visconde de Cairu). Leituras de economia política ou direito constitucional conforme a constituição social e garantias da constituição.... Rio de Janeiro, Seignot-Plancher, 1827.

. Constituição moral e deveres do cidadão com exposição da moral pública conforme o espírito da Constituição do Império. Rio de Janeiro, Tipografia Nacional, 1824-1825.

LOCKE, John. Dois tratados sobre o governo (1689). São Paulo, Martins Fontes, 1998.

MADISON, James/HAMILTON, Alexander/JAY, John. Os artigos federalistas. Rio de Janeiro, Nova Fronteira, 1993.

MELLO, Evaldo Cabral de (org.). Frei Joaquim do Amor Divino Caneca. São Paulo, Editora 34, 2001 (Coleção Formadores do Brasil).

MELLO FREIRE, Pascoal José de. Historia Iuris Civilis Lusitani (1788). Tradução para o português: Boletim do Ministério da Justiça, 173, 1968.

. Censura da obra Historae Iuris Civilis Lusitani do ilustre mestre Pascoal José de Mello, por um teólogo erístico, resposta do autor da obra censurada, resposta de Manoel Francisco da Silva e Veiga Magro de Moura, ajudante procurador da Coroa. Lisboa, Imprensa Nacional, 1822.

MONTESQUIEU, Charles Louis de Secondat. Do espírito das leis (1748). $3^{\mathrm{a}}$ ed., São Paulo, Abril Cultural, 1985.

NOGUEIRA, Ricardo Raymundo. Preleções sobre a História de Direito Pátrio. Coimbra, Imprensa da Universidade, 1866.

PAINE, Thomas. Os direitos do homem (1791). Rio de Janeiro, Petrópolis, 1989.

PUFENDORF, Samuel. Droit de la nature et gens ou système general des principes les plus importants de la morale, de la jurisprudence.... Londes, Jean Nours, 1760, $3 \mathrm{v}$.

RODRIGUES, José Carlos. Constituição política do Império do Brasil, seguida do Ato Adicional. Rio de Janeiro, Eduardo \& Henrique Laemmert, 1863. 
ROUSSEAU, Jean-Jacques. O contrato social (1762). $3^{\text {a }}$ ed., São Paulo, Martins Fontes, 1999.

SAMPAIO, Francisco Coelho de Souza e. Preleções de Direito Pátrio Público, e Particular, oferecidas ao Sereníssimo Senhor D. João. Coimbra, Real Imprensa da Universidade, 1793.

- Observações às Preleções de Direito Pátrio Público, e Particular, oferecidas ao Sereníssimo Senhor D. João. Lisboa, Imprensa Régia, 1805.

SILVA, José de Seabra da. Deducção chronologica e analytica na qual se manifesta o que sucessivamente passou nas differentes epocas da Igreja sobre a censura, proibição e impressão dos livros..., Lisboa, Offina de Miguel Manescal da Costa, 1767, 2v.

SOUSA, Paulino José Soares de (Visconde do Uruguai). Ensaio sobre Direito administrativo. Rio de Janeiro, Tipografia nacional, 1862, $2 \mathrm{v}$.

SOUSA, Joaquim Rodrigues da. Análise e comentário da Constituição política do Império do Brasil ou teoria e prática do governo constitucional brasileiro. São Luis do Maranhão, B. de Matos, 1867.

SOUZA, Braz Florentino Henriques de. Do poder moderador: ensaio de direito constitucional contendo a análise do título V, capítulo I, da Constituição política do Brasil. Brasília, Senado Federal, 1978.

TEIXEIRA, Antonio Ribeiro de Liz. Curso de direito civil português ou comentários às instituições do Sr. Paschoal José de Mello Freire. Coimbra, 1848.

SOUZA, Paulino José Soares de (Visconde do Uruguai). Ensaio sobre o direito administrativo. Rio de Janeiro, Typographia Nacional, 1862, 2 t.

. Estudos práticos sobre a administração das Províncias no Brasil. Rio de Janeiro, Garnier, 1865.

VASCONCELOS, Zacarias de Góis. Da natureza e limites do poder moderador (1860-1862). Brasília, Senado Federal, 1978.

VATTEL, E. Von. Le Droit de gens ou Principes de la Loi Naturelle apliqués a la conduite e aux affaires des Nations et des Souverains. Neuchatel, Impr. De la Societa, 1774, 3 v.

\subsection{Periódicos}

Instituto de Estudos Brasileiros (IEB): Sentinella da Liberdad na guarita de Pernambuco

Biblioteca Nacional (BN): Correio do Rio de Janeiro (1821-23)

Abelha do Itaculumy (1824-25)

O Argos da Lei (1825) 


\section{BIBLIOGRAFIA GERAL}

ACKERMAN, Bruce. We, the people. Foundations. Cambridge, Harvard University Press, 1995.

ALENCASTRO, Luiz Felipe. "Vida privada e ordem privada no Império". NOVAIS, Fernando (dir.). História da vida privada no Brasil - Império: a corte e a modernidade nacional. São Paulo, Cia.das Letras, 1997, pp.11-93.

ALEXANDRE, Valentim. Os sentidos do império. Questão nacional e questão colonial na crise do antigo regime português. Porto, Afrontamento, 1993.

ALLAN, T.R.S.. Law, liberty and justice. The legal foundations of British Constitucionalism. Oxford, Clarendon Press, 1994.

ALMEIDA, Nelson. "Da Assembléia Constituinte à Carta Outorgada de 1824". Revista de História. São Paulo, out/dez 1972, v. 92.

AMBROSINI, Diego Rafael. Do poder moderador: uma análise da organização do poder na construção do Estado imperial brasileiro. São Paulo, Dissertação de Mestrado, FFLCH/USP, 2004.

ANDERSON, Benedict. Nação e consciência nacional. São Paulo, Ática, 1989.

ANDRADE, Francisco Eduardo de. "Poder local e herança colonial em Mariana; faces da revolta do 'Ano da Fumaça' (1833)". Termo de Mariana. História e Documentação, Ouro Preto, Editora da UFOP, 1998.

ANDRADE, Manuel Correia de (org.). Confederação do Equador. Recife, Fudação Joaquim Nabuco,/Massangana, 1988.

ANINO, Anonio (et. alli). De los imperios a las naciones: Iberoamérica. Zaragoza, IberCaja, 1994.

Anuário do Museu Imperial. Petrópolis, vol. 34 e 35, 1873/1974; Brasília, Dep. de Documentação e Divulgação, 1977.

ARAS, Lima Brandão de. Santa Federação Imperial: Bahia. São Paulo, FFLCH/USP, Tese de Doutorado, 1995.

ARAÚJO, Ana Cristina Bartolomeu de. "O Reino Unido de Portugal, Brasil e Algarves 1815/1822”. Revista de História das Idéias, n.14, Coimbra, 1992.

(coord.). O Marquês de Pombal e a Universidade. Coimbra, Imprensa da Universidade, 2002.

ARENDT, Hannah. Da revolução. São Paulo/ Ática, Brasília/UnB, 1990. 
ARTOLA, Miguel. Antiguo Régimen y revolución liberal. $2^{\text {a }}$ ed., Barcelona, Ariel, 1983.

AVELAR, Hélio de Alcântara. Administração pombalina. Brasília, UnB/Funcep, 1983 (Col. História Administrativa do Brasil, v.5)

BAILYN, Bernard. Los orígenes ideológicos de la Revolución Norteamericana. Buenos Aires, Paidós, 1972.

BANDECCHI, Brasil. “A primeira análise da Constituição de 1824”. Revista de História, São Paulo, 94, abr./jun. 1973.

BARBOSA, Maria do Socorro Ferraz. Liberais e liberais. São Paulo, FFLCH-USP, Tese de Doutorado, 1992.

BARBOSA, Silvana Mota. A Shinge monárquica: o poder moderador e a política imperial. Campinas, Unicamp, Tese de Doutorado, 2001.

BARMAN, Roderick J.. Brazil: the Forging of a Nation (1798-1852). Stanford, Stanford Univ.Press, 1988.

• "Uma nobreza no Novo Mundo: a função dos títulos no Brasil imperial". Mensário do Arquivo Nacional n.6. Rio de Janeiro, julho/1973.

BARRETO, Vicente. Primórdios do liberalismo: o liberalismo e representação política no período imperial. Rio de Janeiro, Paz e Terra, 1984.

BASTOS, Aurélio. O ensino jurídico no Brasil. Rio de Janeiro, Lúmen Júris, 2000.

BASILE, Marcello Campos. O Império em construção: projetos de Brasil e ação política na Corte Regencial. Rio de Janeiro, Universidade Federal do Rio de Janeiro/IFCS, Tese de Doutorado, 2004.

BEIGUELMAN, Paula. Formação política do Brasil. São Paulo, Pioneira, 1976.

BERBEL, Márcia Regina. A nação como artefato. Deputados do Brasil nas Cortes portuguesas 1821-1822. São Paulo, Hucitec/Fapesp, 1999.

- "Pátria e patriotas em Pernambuco (1817-1822): nação, identidade e vocabulário político". JANCSÓ, István (org.). Brasil: Formação do Estado e da nação. São Paulo/Ijuí, Fapesp/Hucitec/Unijuí, pp. 345-63.

BERNARDES, Denis Antonio de Mendonça. A idéia de pacto social e o constitucionalismo em Frei Caneca. São Paulo, Instituto de Estudos Avançados/USP, 1996 (Coleção Documentos, Série Teoria Política, n. 21) 
. "O processo de independência, a formação do Estado Nacional e a questão regional no Brasil: o caso do Nordeste (1808-1824)". Texto apresentado no VII Congresso da AHILA, Florença, 1985.

. Um império entre as repúblicas: Brasil, século XIX. São Paulo, Global, 1983.

. O papel de frei Caneca na Independência do Brasil. ANDRADE, Manuel Correia de \& outros (orgs.) - Formação histórica da nacionalidade brasileira: Brasil 1701-1824. Recife, Fundação Joaquim Nabuco/Massanganga, 2000, p.197-224.

. O patriotismo constitucional: Pernambuco, 1820-1822. São Paulo, Universidade de São Paulo/ FFLCH, Tese de Doutoramento, 2002.

BICALHO, Maria Fernanda e FERLINI, Vera L. Amaral.(orgs.). Modos de governar: idéias e práticas políticas no Império português. Séculos XVI-XIX. São Paulo, Alameda, 2005.

BIDART CAMPOS, Germán J.. Historia política y constitucional argentina. Buenos Aires, Ediar, $1976.3 \mathrm{v}$.

BONAVIDES, Paulo. Curso de Direito Constitucional. 10 ed., Malheiro Editores, 2000.

\& ANDRADE, Paes de. História Constitucional do Brasil. $3^{\mathrm{a}}$ ed., Rio de Janeiro, Paz e Terra, 1991.

. "O Poder Moderador na Constituição do Império". Revista de Informação Legislativa, Brasília, 41, jan./mar. 1974.

BONIFÁCIO, Maria de Fátima. Seis estudos sobre o liberalismo português. Lisboa, Estampa, 1991.

BORGES, Ricardo. O Pará republicano (1824-1929): ensaio histórico. Belém, Conselho Estadual de Cultura, 1983.

BOXER, Charles R.. A idade de ouro do Brasil (1415-1825). São Paulo, 1963.

. O Império marítimo português 1415-1825. Lisboa, Edições 70, 1969.

BURT, Robert A. Constitución y conflicto. Buenos Aires, Eudeba, 2000.

BUSHNELL, David e MACAULAY, Neil. The Emergence of Latin America in the Nineteenth Century. 2aed. New York, Oxford University Press, 1994.

. El nacimiento de los países latinoamericanos. Madrid, Nerea, 1989.

CAENEGEM, R.V. Van. An historical introduction to western constitucional law. Cambridge, Cambridge University Press, 1995. 
CALMON, Pedro. História do Brasil. Rio de Janeiro, José Olympio, 1959. 7 v.

CANAVIEIRA, Manuel Felipe Cruz. Liberais moderados e constitucionalismo moderado (18141852). Lisboa, Instituto Nacional de Investigação Científica, 1988.

CANOTILHO, José Joaquim Gomes. Direito Constitucional. $4^{\mathrm{a}}$ ed., Coimbra, Almedina, 1986.

. Direito Constitucional e Teoria da Constituição. $3^{\text {a }}$ ed., Coimbra, Almedina, 1995.

CARMAGNANI, Marcello (coord.). Federalismos latinoamericanos: México/Brasil/Argentina. México D.F., Fondo de Cultura Económica, 1993.

CARNEIRO, David. História da guerra cisplatina. Brasília, Ed.UnB, 1983.

CARREIRA, Liberato de Castro. História financeira e orçamentária do Império do Brasil desde a sua fundação, precedida de alguns apontamentos acerca da sua independência. Rio de Janeiro, Imprensa Nacional, 1889.

CARVALHO, José Murilo de. A construção da ordem. A elite política imperial. Brasília, UnB, 1981.

. Teatro de sombras: a política imperial. Rio de Janeiro, IUPERJ/Vértice, 1988.

CARVALHO, Manuel Emílio Gomes de. Os deputados brasileiros nas Cortes gerais de 1821. Brasília, Senado Federal, 1979.

CARVALHO, Márcio Eurélio Rio de. Afirmação de uma esfera pública de poder em Minas Gerais (1821-1851). Belo Horizonte, Universidade Federal de Minas Gerais, Tese de Doutorado, 2003.

CARVALHO, Marcus J.M. de. "Cavalcantis e Cavalgados: a formação das alianças políticas em Pernambuco, 1817-1824”. Revista Brasileira de História, v.18, n.36, 1998, p.331-365.

CASTRO, Renato Berbert de. História do Conselho Geral da Província da Bahia 1824/1834. Salvador, Assembléia Legislativa do Estado da Bahia, 1984.

CASTRO, Zília Osório de (dir.). Dicionário do Vinstismo e do primeiro Cartismo (1821-1823 e 1826-1828), Lisboa/Porto, Assembléia da República/Afrontamento, 2002, 2 v.

. Constitucionalismo vintista: antecedentes e pressupostos. Lisboa, Univ. Nova de Lisboa, 1986.

. "A independência do Brasil na imprensa periódica portuguesa (1822-1823)". Revista de História das Idéias v.15. Coimbra, 1993. P.663-680.

CHACON, Vamireh. Parlamento e parlamentarismo: o Congresso nacional na história do Brasil. Brasília, Centro de Documentação e Informação, Coord. de Publicações, 1982. 
CHEVALIER, Jean-Jacques. "L'influence des lumières et de la Revolution Française sur l'organisation du pouvoir dans les premières Constitutions de L'Amerique Latine (18111828)". El pensamiento constitucional de Latinoamerica 1810-1830. Caracas, Academia Nacional de la Historia, 1962, tomo IV, pp. 223-253.

CHIARAMONTE, José Carlos. "Acerca del orígen del estado en el Río de la Plata". Anuario IEHS, $\mathrm{n}^{\circ} 10$. Tandil, Instituto de Estudios Histórico-Sociales/Universidad Nacional del Centro, 1995.

. "Formas de identidad en el Rio de la Plata luego de 1810". Boletín del Instituto de Historia Argentina y Americana "Dr.E.Ravignani", Tercera serie, nº1, $1^{\circ}$ sem./1989.

. "El problema de los orígenes de los Estados hispanoamericanos en la historiografia reciente y el caso del Río de la Plata". Anos 90 - Revista de Pós-Graduação em História, $\mathrm{n}^{\circ} 1$. Porto Alegre, UFRGS, maio/1993. pp.49-83.

. "El mito de los origenes en la historiografia latinoamericana". Cuadernos del Instituto Ravignani 2. Buenos Aires, s/d.

. "La cuestion regional en el proceso de gestación del Estado nacional argentino. Algunos problemas de interpretacion”. ANSALDI/MORENO (orgs.). Estado y sociedad en el pensamiento nacional: antologia conceptual para el analisis comparado. $2^{\mathrm{a}} \mathrm{ed}$. Buenos Aires, Cántaro, 1996, pp.159-203.

Ciudades, provincias, Estados: orígenes de la Nación Argentina (1800-1846). Buenos Aires, Ariel, 1997.

. "Fundamentos iusnaturalistas de los movimientos de independencia". Boletín del Instituto de Historia Argentina y Americana "Dr.E.Ravignani", Tercera serie, $\mathrm{n}^{\circ} 22,2^{\circ}$ sem./2000.

. "La cuéstión de la soberanía em la génesis y constitución del Estado argentino". Revista Eletrônica de Historia Constitucional, n ${ }^{\text { }}$ 2, junho/2001.

. "Metamorfosis del concepto de nación durante los siglos XVII y XVIII". JANCSÓ, István. Brasil: Formação do Estado e da nação. São Paulo/Ijuí, Fapesp/Hucitec/Unijuí, 2003.

COELHO, Geraldo M. Anarquistas, demagogos e dissidentes. A imprensa liberal no Pará de 1822. Belém, CEJUP, 1993.

CONTIER, Arnaldo Daraya. Ideologia dominante em São Paulo através dos periódicos (18271835): estudo do vocabulário político. São Paulo, FFLCH-USP, Tese de doutoraento, 1972.

Imprensa e ideologia em São Paulo (1822-1842). Petrópolis, Vozes, 1979. 
CORONAS González, Santos M.. "El pensamiento constitucional de Jovellanos". Revista Eletrónica de Historia Constitucional, n.1, junho de 2000.

COSTA, Emília Viotti da. "Introdução ao estudo da emancipação política do Brasil”. MOTA, Carlos Guilherme (org.). Brasil em perspectiva. 19a ed. Rio de Janeiro, Bertrand Brasil, 1990. 1967.

"José Bonifácio: mito e histórias". Anais do Museu Paulista, sep.do t.XXI. São Paulo,

COSTA, Fernando Marques da. "Estruturas sociais e vocabulário social". COSTA, Fernando Marques da \& outros (orgs.) - Do Antigo Regime ao liberalismo 1750-1850. Lisboa, Veja, s.d. p.183-188.

COSTA, Iracema Cunha. Les libéraux français et les liberaux brésiliens en 1830. Paris, Univ. Paris X, 1980 (maîtrise d'Histoire).

COSTA, Jaime Raposo. A teoria da liberdade: período de 1820 a 1823. Coimbra, Instituto de História e Teoria das Idéias/Univ.Coimbra, 1976.

COSTA $\mathrm{F}^{\mathrm{o}}$, Miguel. A imprensa mineira no primeiro reinado: independência política, imperador constitucional e integridade do Império. Rio de Janeiro, s.n., 1955.

COSTA, Wilma Peres. "A economia mercantil escravista nacional e o processo de construção do Estado no Brasil (1808-1850)”. SZMRECSÁNYI, Tamás \& LAPA, José R. do A. (orgs.). História econômica da independência e do império. São Paulo, Hucitec, 1996.

CRUZ, Guilherme Braga da. História do Direito Português. Lições. Coimbra, 1969.

. "Formação histórica do moderno direito português e brasileiro". Scientia Iuridica, 1995.

CUNHA, Paulo Ferreira. Faces da Justiça. Coimbra, Almedina, 2002.

DEBES, Célio. "Estrutura política e legal dos governos paulistas de 1821 a 1834". Revista do Instituto Histórico e Geográfico de São Paulo, São Paulo, 65: 288-313, 1968.

DIAS, José S. da Silva. "Pombalismo e teoria política". Cultura - História e Filosofia, Lisboa, 1982, v.1, p.45-70.

DIAS, Maria Odila L. da Silva. "A interiorização da metrópole”. A interiorização da metrópole e outros estudos. São Paulo, Alameda, 2005, pp. 7-37.

. "Ideologia liberal e construção do Estado do Brasil". Anais do Museu Paulista, São Paulo, XXX: 211-225, 1980-81. 
DIPPEL, Horst. "Constitucionalismo moderno. Introducción a una Historia que necesita ser escrita", Revista Eletrónica de Historia Constitucional, número 6, set./2005, (disponível no site: $\underline{\text { hc.rediris.es/06/articulos/html/08.html) }}$

DOIN, José Evaldo de Mello. Dívida externa do Império. Organização e consolidação do Estado e início do processo de modernização dos instrumentos de exploração, 1824-1864. São Paulo, FFLCH-USP, Tese de Doutorado, 1986. 2 v..

DOLHNIKOFF, Miriam. O pacto imperial. Origens do federalismo no Brasil. São Paulo, Globo, 2005 .

. Construindo o Brasil: unidade nacional e pacto federativo nos projetos das elites (18201842). São Paulo, Universidade de São Paulo, Tese de Doutorado, 2000.

. "O projeto nacional de José Bonifácio". Novos Estudos Cebrap, São Paulo, Cebrap, n.46, novembro de 1996, pp.121-141.

. Caminhos da conciliação: o poder provincial em São Paulo (1835-1850). São Paulo, Universidade de São Paulo, Dissertação de Mestrado, 1993.

. "O poder provincial (política e historiografia)". Revista de História, São Paulo, Departamento de História/USP, n.112, 1990.

DUARTE, Nestor. A ordem privada e a organização política nacional. São Paulo, Nacional, 1939.

Ensaios sobre a constituição dos Estados Unidos. Rio de Janeiro, Forense-Universitária, 1978.

FALCÃO, Joaquim de Arruda. "Os cursos jurídicos e a formação do Estado Nacional (1824)". Os advogados, ensino jurídico e mercado de trabalho, Recife, fundação Joaquim Nabuco/ Editora Massangana.

FALCON, F.J./MATTOS, I.R.. "O processo de independência no Rio de Janeiro". MOTA, Carlos Guilherme (org.). 1822: Dimensões. São Paulo, Perspectiva, 1972. p.292-339.

FAORO, Raymundo. Os donos do poder. Formação do patronato político brasileiro. $9^{\mathrm{a} e d .}$ São Paulo, Globo, 1991. 2 v.

FAVEIRO, Vitor. "Melo Freire e a formação do Direito Público Nacional". Boletim da DireçãoGeral das Contribuições e Impostos, 1968, 109 e 110.

FERNANDES, Florestan. Circuito fechado: quatro ensaios sobre o poder institucional. São Paulo, Hucitec, 1976.

. A revolução burguesa no Brasil. Ensaio de interpretação sociológica. $5^{\mathrm{a}}$ ed., São Paulo, Editora Globo, 2006. 
FERRAZ, Socorro. Liberais e liberais. Guerras civis em Pernambuco no século XIX. Recife, UFPe, 1995.

FERREIRA, Gabriela Nunes. Centralização e descentralização no Império. O debate entre Tavares Bastos e visconde do Uruguai. São Paulo, Editora 34/Departamento de Ciência Política da USP, 1999.

FERREIRA Fº, Manoel. Curso de Direito Constitucional. São Paulo, Saraiva, 1987.

. "Modelo político na constituição do Império". Conferência proferida na Faculdade de Direito de Fortaleza, 1975.

FERREIRA, Pinto. Manual de Direito Constitucional. $2^{\mathrm{a}}$ ed., Rio de Janeiro, Forense, 1990.

FERREIRA, Waldemar Martins. História do direito constitucional brasileiro. São Paulo, Max Limonad, 1954.

FIORAVANTI, Maurizio. Constituición: de la antiguidade a nestros dias. Madri, Trotta, 2001. . Los derechos fundamentales. Apuntes de Historia de las constituciones. Madri, Trotta, 1998.

FLORES, Alberto Vivar. "El liberalismo constitucional en la fundación del Imperio Brasileño". Revista Electrónica de Historia Constitucional, Universidad de Oviedo, n. 6, set./2005 (disponível no endereço: $\underline{\text { hc.rediris.es). }}$

FLORES, Moacyr. Modelo político dos farrapos. $3^{\mathrm{a}}$ ed., Porto Alegre, Mercado Aberto, 1985.

FLORY, Thomas. El juez de paz y el jurado en el Brasil, 1808-1817. Control social y estabilidad política en el nuevo Estado. México, FCE, 1986.

FONSECA, Silvia Carla P. de B. A idéia de República no Império do Brasil: Rio de Janeiro e Pernambuco (1824-1834). Rio de Janeiro, Tese de Doutorado, IFCS/UFRJ, 2004.

FONTANA, Josep. La crisis del antiguo régimen (1808-1833). 4 ed., Barcelona, Grijalbo, 1992.

FORJAZ, Djalma. O senador Vergueiro: sua vida e sua obra. São Paulo, Melhoramentos, 1922.

FRAGOSO, João Luis (et. alli.). O Antigo Regime nos trópicos: a dinâmica imperial portuguesa (séculos XVI-XVIII). Rio de Janeiro, Civilização Brasileira, 2001.

e FLORENTINO, Manolo. O arcaísmo como projeto. Mercado atlântico, sociedade agrária e elite mercantil no Rio de Janeiro (c.1790-1840). Rio de Janeiro, Diadorim, 1993.

FRANCO, Afonso Arinos de Mello. Direito constitucional. Teoria da constituição, as constituições do Brasil. Rio de Janeiro, Forense, 1976. 
. Constitucionalismo de D. Pedro I no Brasil e em Portugal. Rio de Janeiro, Ministério da Justiça/Arquivo Nacional,1972.

. “As idéias políticas da Constituinte”. Revista do IHGB, Rio de Janeiro, 304, 1974.

FRANCO, Maria Sylvia de Carvalho. “As idéias estão no lugar”. Cadernos de Debate, no 1, São Paulo, Brasiliense, 1976.

FURTADO, Celso. Formação econômica do Brasil. 21 ªed. São Paulo, Cia. Editora Nacional, 1986.

GALVÃO, Miguel Arcanjo. Relação dos cidadãos que tomaram parte no governo do Brasil no período de março de 1808 a 15 de novembro de 1889. 2a ed. Rio de Janeiro, Arquivo Nacional, 1969.

GILISEN, John. Introdução histórica ao direito. Lisboa, Calouste Gulbenkian, 1988.

GOUVÊA, Maria de Fátima. O Império das Províncias - Rio de Janeiro, 1822-1889. Rio de Janeiro, Faperj, 2006 (no prelo).

. "Dinâmica provincial na formação da monarquia constitucional brasileira, 1820-1850". Texto apresentado no Seminário Internacional Brasil: de um Império a outro. São Paulo, Departamento de História/USP, setembro/2005.

."Poder político e administração na formação do complexo atlântico português (16451808)". João Fragoso, Maria Fernanda Bicalho e Maria de Fátima Gouvêa (org.). O Antigo Regime nos trópicos: a dinâmica imperial portuguesa (séculos XVI-XVIII). Rio de Janeiro, Civilização Brasileira, 2001, pp. 287-315.

GRAHAM, Richard. Independence in Latin America: A Comparative Approach. New York, Alfred A.Knopf, 1972.

GRIMM, Dieter e MOHNHAUPT, Heinz. Zur Geschichte des Begriffs von der Antike bis zur Gegenwart. Berlin, Duncker \& Humblot, 1995.

. "Verfassung". KOSELLECK, Reinhart/BRUNNER, Otto/ CONZE, Werner (orgs.). Geschichtliche Grundbegriffe. Historisches Lexikon zur politisch-sozialen Sprache in Deutschland. Stuttgart, Klett-Cotta, 1984, v.6, pp. 831-898.

GUERRA, François-Xavier. Modernidad e independencias. Ensayos sobre las revoluciones hispánicas. $2^{\mathrm{a} e d . ~ M e ́ x i c o, ~ F C E, ~} 1993$.

- "A nação na América espanhola: a questão das origens". Revista Maracanan, ano I, n. ${ }^{\circ} 1,1999-2000$, p.09-30.

. “A nação moderna: nova legitimidade e velhas identidades". JANCSÓ, István. Brasil: Formação do Estado e da nação. São Paulo/Ijuí, Fapesp/Hucitec/Unijuí, 2003, p.33-60. 
\& LEMPÉRIÈRE, Annick. Los espacios públicos en Iberoamerica. Ambiguidades y problemas. México, FCE/CEMCA, 1998.

GUIMARÃES, Lúcia Maria Paschoal (org.). O liberalismo no Brasil imperial. Rio de Janeiro, Revan, 2001.

HALPERIN DONGHI, Tulio. Reforma y disolución de los impérios ibéricos 1750-1850. Madrid, Alianza Ed., 1985.

. Revolución y guerra: formación de una élite dirigente en la Argentina criolla. Buenos Aires, Siglo XXI, 1972.

HESPANHA, Antonio Manuel. As vésperas do Leviathan. Instituições e poder político. Portugal - século XVII. Coimbra, Almedina, 1994.

. "Do corporativismo ao liberalismo: redefinindo fronteiras do universo político". Paper apresentado no Seminário Internacional Brasil: Formação do Estado e da nação (c.17701850), São Paulo, Faculdade de História/USP, 03 a 08 de setembro/2001.

. Panorama histórico da cultura jurídica européia. Mem Martins, Publicações EuropaAmérica, 1998.

. "Um autre paradigme d'administration: la Cour en Europe du Sud à l'époque moderne". Die Anfänge der Verwaltung der Europäischen Gemeinschaft (Les débuts de l'administration de la Communauté européene). Baden Baden, Nomos Verlagsgesellschaft, 1992, pp. 271-292.

. "Representación dogmática y proyetos de poder". La gracia del derecho, Madri, Centro de Estudios Constitucionales.

. A história do direito na história social. Lisboa, Horizonte, s/d.(Coleção Movimento, 25).

. "Centro e periferia nas estruturas administrativas de Antigo Regime". Ler História, n.8, 1986.

. "Para uma teoria da história institucional do Antigo Regime". HESPANHA (ed.). Poder e instituições na Europa do Antigo Regime. Lisboa, Fundação Calouste Gulbenkian, s.d.

HOBSBAWM, Eric J.. Nações e nacionalismo desde 1780 - programa, mito e realidade. Rio de Janeiro, Paz e Terra, 1990.

. A era das revoluções 1789-1848. 4ª ed. Rio de Janeiro, Paz e Terra, 1982.

HOLANDA, Sérgio Buarque de. "A herança colonial - sua desagregação". História geral da civilização brasileira. $3^{\mathrm{a}} \mathrm{ed}$. São Paulo, Difel, 1970, t.II, v.1. 
• "A letra e o espírito do regime". História Geral da Civilização Brasileira, São Paulo, Difusão Européia do Livro, 1968, tomo II, $5^{\circ}$ volume, t.II, v.II. CORRIGIR INDICAÇÃO

IGLÉSIAS, Francisco. Trajetória política do Brasil 1500-1964. São Paulo, Cia.das Letras, 1993.

. "Minas Gerais". HOLANDA, Sérgio Buarque de (dir.). História geral da civilização

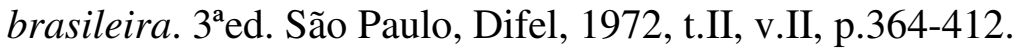

JACQUES, Paulino. "Do relacionamento dos poderes políticos na Constituição do Império". Revista de Informação Legislativa, Brasília, 41, jan./mar. 1974.

JANCSÓ, István. "A construção dos Estados nacionais na América Latina - apontamentos para o estudo do Império como projeto”. SZMRECSÁNYI, Tamás/LAPA, José R. do A. (orgs.). História econômica da independência e do império. São Paulo, Hucitec, 1996.

. Na Bahia, contra o Império: história do ensaio de sedição de 1789. São Paulo, Hucitec/EdUFBA, 1996.

. "A sedução da liberdade: cotidiano e contestação política no final do século XVIII". NOVAIS, Fernando A. (dir.). História da vida privada no Brasil. São Paulo, Cia. das Letras, 1997 (V.I: Cotidiano e vida privada na América portuguesa)

e PIMENTA, João Paulo G.. "Peças de um mosaico (ou apontamentos para o estudo da emergência da identidade nacional brasileira". MOTA, Carlos G. (org.). Viagem incompleta. A experiência brasileira 1500-2000. São Paulo, SENAC, 2000.

e SLEMIAN, Andréa. "Um caso de patriotismo imperial". Correio Braziliense, ou Armazém Literário, vol.XXX/ Hypólito José da Costa. São Paulo/Brasília, Imprensa Oficial do Estado/ Correio Braziliense, 2002, Tomo I, p.605-667.

(org.). Brasil. Formação do Estado e da nação. São Paulo/Ijuí, Hucitec/ Fapesp/Unijuí, 2003.

(org.). Independência do Brasil: história e historiografia. São Paulo, Hucitec/Fapesp, 2005.

KOSELLECK, Reinhart. Crítica e crise. Uma contribuição à patogênese do mundo burguês, Rio de Janeiro, Eduerj/Contraponto, 1999.

Futuro Passado. Para uma semántica de los tiempos históricos, Barcelona, Paidós, 1993.

LACERDA, Regina. A independência em Góias. Góias, Oriente, 1970.

LEAL, Aurelino Araujo. História constitucional do Brasil. Rio de Janeiro, Imprensa Nacional, 1915. 
LEITE, Glacyra Lazzari. Pernambuco 1824: a Confederação do Equador. Recife, Fund. Joaquim Nabuco/Massangana, 1989.

. Pernambuco em 1817: estrutura e comportamentos sociais. Recife, Fund. Joaquim Nabuco/Massangana, 1988.

LEITE, Renato Lopes. Republicanos e libertários: pensadores radicais da independência - Rio de Janeiro (1822). Rio de Janeiro, Civilização Brasiliera, 2001.

LENHARO, Alcir. As tropas da moderação. O abastecimento da Corte na formação política do Brasil: 1808-1842, $2^{a}$ ed., Secr. Mun. de Cultura/Dep. Geral de Doc. e Inf. Cultural, 1992.

LIMA, Manuel de Oliveira. D. João VI no Brasil. Rio de Janeiro, Of.Gráf.do Jornal do Brasil, 1909. (Rio de Janeiro, José Olympio, 1945. 3 v.)

. O movimento da independência (1821-1822). Belo Horizonte/São Paulo, Itatiaia/Edusp, 1989 (1922).

. Império brasileiro: 1822-1889. São Paulo, Melhoramentos.

LIMA SOBRINHO, Barbosa (org.). Antologia do Correio Braziliense. Rio de Janeiro, Cátedra, 1977.

. Pernambuco: da independência à Confederação do Equador. Recife, Secretaria de Educação e Cultura/Conselho Estadual de Cultura, 1979.

LOBO, Eulália Maria Lahmeyer Lobo, Processo administrativo Ibero-Americano (aspectos sócio-econômicos), Rio de Janeiro, Biblioteca do Exército, 1962.

LOPES, José Reinaldo de Lima. O direito na História. Lições introdutórias. São Paulo, Max Limonad, 2000.

- "Iluminismo e jusnaturalismo no ideário dos juristas da primeira metade do século XIX”. JANCSÓ, István (org.). Brasil. Formação do Estado e da nação. São Paulo/Ijuí, Hucite/Fapesp/Unijuí, 2003, p. 195-218.

- As palavras e a lei. Direito, ordem e justiça na história do pensamento jurídico moderno, São Paulo, Edesp/Editora 34, 2004.

LYNCH, John. Las revoluciones hispano-americanas, 1808-1826. Barcelona, Ariel, 1983.

LYRA, Augusto Tavares de. Instituições políticas do Império. Brasília, Senado Federal, 1979.

Organização política e administrativa do Brasil: colônia, império e república. São Paulo, Nacional, 1941. 
LYRA, Maria de Lourdes Viana. A utopia do poderoso império - Portugal e Brasil: bastidores da política 1798-1822. Rio de Janeiro, Sette Letras, 1994.

- Centralisation, système fiscal et autonomie provinciale dans l'Empire brésilien: la province de Pernambuco 1808-1835. Paris, Tese de Doutorado, Univ.Paris X, 1985.

LUGAR, Catherine. The merchant community of Salvador, Bahia 1780-1830. Nova York, Tese de Doutorado, State Univesity of New York, 1980.

MACHADO, André Roberto de A.. A quebra da mola real das sociedades. A crise política do Antigo Regime português na Província do Grão-Pará (1821-25). São Paulo, Tese de Doutorado, FFLCH-USP, 2006.

MACHADO, Alcântara. Ação da bancada paulista "por São Paulo unida” na Assembléia Constituinte. São Paulo, Impressa do Estado, 1935.

MAIA, Fernanda Paula Sousa. O discurso parlamentar português e as relações Portugal-Brasil. A Câmara dos Deputados (1826-1852), Lisboa, Fundação Calouste Gulbenkian/Min. da Ciência e Tecnologia, 2002.

MAIOR, Armando Souto. "A revolução de 1817". ANDRADE, Manuel Correia de \& outros (orgs.) - Formação histórica da nacionalidade brasileira: Brasil 1701-1824. Recife, Fundação Joaquim Nabuco/Massanganga, 2000, p.161-173.

MANIQUIS, Robert (et.all.). La revolución francesa y el mundo ibérico. Madrid, Turner, 1989.

MARQUESE, Rafael de Bivar. "Governo dos escravos e ordem nacional: Brasil e Estados Unidos, 1820-1860”. JANCSÓ, István (org.). Brasil: formação do Estado e da nação. São Paulo/Ijuí, Fapesp/Hucitec/Unijuí, 2003, pp. 251-265.

MARTIRÉ, Eduardo. 1808. Ensayo histórico-jurídico sobre la clave de la emancipación hispanoamericana. Buenos Aires, Instituto de investigaciones de Historia del Derecho, 2001.

MATEUCCI, Nicola. Organización del poder y libertad: historia del constitucionalismo moderno. Madri, Trotta, 1998.

MATTOS, Ilmar Rohloff de. O tempo saquarema. A formação do Estado imperial. Rio de Janeiro, Access Editora, 1999.

e ALBUQUERQUE, Luís Affonso. Independência ou morte. A emancipação política do Brasil. São Paulo, Atual, 1991.

. "La experiencia del Imperio del Brasil". Antonio Annino (et. alli), De los imperios a las naciones: Iberoamerica, Ibercaja/Obra Cultural, 1994.

MATTOSO, José (dir.). História de Portugal. O Liberalismo. Lisboa, Estampa, 1996. 
(dir.). História de Portugal. O Antigo Regime. Rio de Mouro, Lexi Cultural, 2002.

MATTOSO, Kátia M. de Queirós. A Bahia no século XIX - uma província no Império. Rio de Janeiro, Nova Fronteira, 1992.

MAXWELL, Kenneth. "Por que o Brasil foi diferente? O contexto da independência". MOTA, Carlos G. (org.) - Viagem incompleta. A experiência brasileira 1500-2000. São Paulo, SENAC, 2000, p.177-195.

MELLO, Evaldo Cabral de. A outra independência. O federalismo pernambucano de 1817 a 1824. São Paulo, Editora 34, 2004.

. "O Jogo da Independência". Caderno Mais, São Paulo, Folha de S. Paulo, 23/março/2003, p.10-11.

MENEZES, Paulo Braga de. Constituições outorgadas ao Império do Brasil e do Reino de Portugal. Rio de Janeiro, Arquivo Nacional, 1974.

MERÊA, Manuel Paulo. "Projeto da Constituição de 1823". Boletim da Faculdade de Direito de Coimbra, Coimbra, n. 43, 1967, p.133-45.

. "O ensino de Direito em Portugal (1805-1836)". Jurisconsultos portugueses do século XIX. Lisboa, 1947.

. "Direito Romano, Direito Comum e Boa Razão". Boletim da Faculdade de Direito de Coimbra, 1939-40, 16.

MIRANDA, Jorge. Manual de Direito Constitucional. $2^{\mathrm{a}}$ ed., Coimbra, Coimbra Editora, 1982.

. O constitucionalismo liberal luso-brasileiro. Lisboa, Comissão Nacional para as Comemorações dos Descobrimentos Portugueses. Lisboa, 2001.

MIRANDA, Márcia Eckert. "Fronteira, guerra e tributos: o Rio Grande de São Pedro do Sul (1750-1836)". Texto apresentado no Seminário Internacional Brasil: de um Império a outro, São Paulo, Departamento de História/USP, setembro/2005.

MOLITERNO, Dylva Araújo. A Constituinte de 1823: uma interpretação. Rio de Janeiro, UFF, Dissertação de Mestrado, 1974.

MONCADA, Luís Cabral de. "Origens do moderno direito português. Época do individualismo filosófico ou crítico". Estudos de História do Direito, Coimbra, 2, 1949.

. Estudos de História do Direito. Coimbra, 1948-9, 3 v.

MONTEIRO, Nuno Gonçalo Freitas. O crepúsculo dos grandes: a casa e o patrimônio da aristocracia em Portugal (1750-1832). Lisboa, Imprensa Nacional Casa da Moeda, 1998. 
- "Governadores e capitães-mores do Império Atlântico português no século XVIII". BICALHO, Maria Fernanda e FERLINI, Vera (orgs.). Modos de governar: idéias e práticas políticas no Império português. Séculos XVI-XIX, São Paulo, Alameda, 2005, pp. 93-115.

MONTEIRO, Tobias. História do Império. A elaboração da independência. Rio de Janeiro, Briguiet Cia., 1927. 2 vs.

. História do Império. O Primeiro Reinado. São Paulo/ Belo Horizonte, Itatiaia/ Edusp, 1982.

MOREL, Marco. As transformações dos espaços públicos. Imprensa, atores políticos e sociabilidades na Cidade Imperial (1820-1840). São Paulo, Hucitec, 2005.

- "Restaurar, fracionar e regenerar a nação: o Partido Caramuru nos anos 1830". JANCSÓ, István (org.). Brasil: formação do Estado e da nação, São Paulo/Ijuí, Fapesp/Hucitec/Unijuí, 2003, pp. 407-430.

. O período das Regências (1831-1840). Rio de Janeiro, Zahar, 2003.

. Cipriano Barata na Sentinela da Liberdade. Salvador, Academia de Letras da Bahia/ Assembléia Legislativa do Estado da Bahia, 2001.

. Frei Caneca: entre Marília e a pátria. Rio de Janeiro, FGV Editora, 2000.

- La monarchie de Juillet et la fin du Premier Regne bresilien: metamorphoses du liberalisme. Paris, Université de Paris I, 1992 (D.E.A.)

MOTA, Carlos Guilherme. Nordeste 1817: estruturas e argumentos. São Paulo, Perspectiva, 1972.

(org.). Brasil em perspectiva. 19ª ed. Rio de Janeiro, Bertrand, 1990.

(org.). 1822: dimensões. São Paulo, Perspectiva, 1972.

NEVES, Lúcia Maria B. Pereira das. Corcundas, Constitucionais e Pés de Chumbo: a cultura política da independência, 1830-1822. Rio de Janeiro : FAPERJ: Revan, 2003.

- "Leitura e leitores no Brasil, 1820-1822: o esboço frustrado de uma esfera pública de poder". Acervo. Revista do Arquivo Nacional v.8, n.01/02. Rio de Janeiro, 1995. p.123-138.

NOGUEIRA, Octaviano (org.) - Obra política de José Bonifácio. Brasília, Senado Federal, 1973. (org.). A Constituinte de 1823. Brasília, Senado Federal, 1973.

e FIRMO, João Sereno. Parlamentares do Império. Brasília, Senado Federal, 1973, 2 v. 
NOVAIS, Fernando A.. Portugal e Brasil na crise do antigo sistema colonial (1777-1808). $4^{\circ}$ ed. São Paulo, Hucitec, 1986.

. "As dimensões da Independência". MOTA, Carlos Guilherme (org.) - 1822: dimensões, p.15-26.

. "Condições da privacidade na colônia". História da vida privada no Brasil, t.I. São Paulo, Cia. das Letras, 1997, p.13-39.

\& MOTA, Carlos Guilherme. A independência política do Brasil. 2aed. São Paulo, Hucitec, 1996.

OBERACKER JÚNIOR, Carlos - O movimento autonomista no Brasil. A província de São Paulo de 1819 a 1823. Lisboa, Cosmos, 1977.

OLIVEIRA, Cecília Helena L. de Salles. A astúcia liberal. Relações de mercado e projetos políticos no Rio de Janeiro (1820-1824). Bragança Paulista, Edusf/Ícone, 1999.

. Independência e práticas liberais: questões para debate. São Paulo, IEA/USP, 1997 (Coleção Documentos n.37)

. "Política e memória histórica: Gonçalves Ledo e a questão da 'independência"” Jogos da política: imagens, representações e práticas. São Paulo, ANPUH/ Marco Zero, 1992, p.153169.

. "Nação e cidadania: a Constituição de 1824 e suas implicações políticas". Horizontes, n.16. Bragança Paulista, 1998, p.11-38.

PADOIN, Maria Medianeira. Federalismo gaúcho - fronteira platina, direito e revolução. São Paulo, Cia. Editora Nacional, 2001.

PEREIRA, Antonio Manuel. As Constituições políticas portuguesas (além da Carta Constitucional e seus Atos Adicionais, as de 1822, 1838, 1911 e a atual). Porto, 1962.

PEREIRA, José Esteves. "Genealogia das correntes de pensamento do Antigo Regime ao Liberalismo - Perspectivas de síntese". COSTA, Fernando Marques da \& outros (orgs.) Do Antigo Regime ao liberalismo 1750-1850. Lisboa, Veja, s.d. p.47-61.

. Silvestre Pinheiro Ferreira: o seu pensamento político. Coimbra, 1974.

. O pensamento político em Portugal no século XVIII. António Ribeiro dos Santos. Lisboa, Imprensa Nacional/ Casa da Moeda, 1983.

PEREIRA, Miriam Halpern. “A crise do Estado de Antigo Regime: alguns problemas conceituais e de cronologia". Ler História, n.2, 1983. 
(et. alli). O liberalismo na península ibérica na primeira metade do século XIX. Lisboa, Sá da Costa, 1982, 2 v.

PIMENTA, João Paulo G.. Estado e nação no fim dos impérios ibéricos no Prata (1808-1828). São Paulo, Hucitec/Fapesp, 2002.

O Brasil e a América espanhola (1808-1822). São Paulo, Tese de Doutorado, Universidade de São Paulo, 2003.

. “O Brasil e a 'experiência cisplatina' (1817-1828)”. JANCSÓ, István (org.). Independência: história e historiografia. São Paulo, Fapesp/Hucitec, 2005, pp.755-89.

PINHO, Wanderley. "A Bahia, 1808-1856". HOLANDA, Sérgio Buarque de (dir.). História geral da civilização brasileira. 3ªed. São Paulo, Difel, 1972, p.242-311. (t.II, v.II, "Dispersão e unidade").

POCOCK, John. Virtue, Commerce, and History. Essays on Political thought and History, chiefly in the Eighteenth Century. Cambridge, Cambridge University Press, 1985.

O poder legislativo no Brasil - 1823/1973. Brasília, Câmara dos Deputados/Coordenação de Publicações, 1975.

PRADO JÚNIOR, Caio. Formação do Brasil contemporâneo. 21ªed. São Paulo, Brasiliense, 1989.

. Evolução política do Brasil: colônia e império. 20ªed. São Paulo, Brasiliense, 1993.

PROENÇA, Maria Cândida. A independência do Brasil - relações externas portuguesas, 18081825. Lisboa, Horizonte, 1987.

QUINTAS, Amaro. A revolução de 1817.2ª ed., Recife, FUNDARPE, 1985.

- "Nordeste, 1825-1850". HOLANDA, Sérgio Buarque de (dir.). História geral da civilização brasileira. $3^{\text {a }}$ ed. São Paulo, Difel, 1972, p.193-241. (t.II, v.II, "Dispersão e unidade").

REIS, Arthur Cézar Ferreira. "O Grão Pará e o Maranhão". HOLANDA, Sérgio Buarque de (dir.). História geral da civilização brasileira. $3^{\mathrm{a}}$ ed. São Paulo, Difel, 1972, p.71-172. (t.II, v.II, "Dispersão e unidade").

- "Mato Grosso e Goiás". HOLANDA, Sérgio Buarque de (dir.). História geral da civilização brasileira. $3^{\text {a }}$ ed. São Paulo, Difel, 1972, p.173-190. (t.II, v.II, "Dispersão e unidade").

. "O Espírito Santo". HOLANDA, Sérgio Buarque de (dir.). História geral da civilização

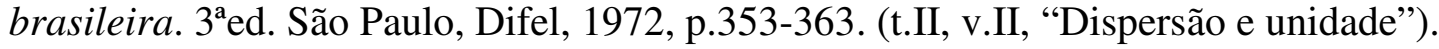


REIS FILHO, Nestor Goulart. Contribuição ao estudo da evolução urbana do Brasil (15001720). São Paulo, Pioneira/EDUSP, 1968.

RENDON, José Arouche de Toledo. Obras. São Paulo, Governo do Estado de São Paulo, 1978.

RIBEIRO, Gladys Sabina. A liberdade em construção. Identidade nacional e conflitos antilusitanos no Primeiro Reinado. Rio de Janeiro, Relume Dumará/Faperj, 2002.

RIBEIRO, Maria Manuela Tavares. "Independência do Brasil e unidade nacional". ANDRADE, Manuel Correia de (e outros orgs.). Formação histórica da nacionalidade brasileira: Brasil 1701-1824. Recife, Fundação Joaquim Nabuco/Massanganga, 2000, p.149-158.

RIZZINI, Carlos. Hipólito da Costa e o Correio Braziliense. São Paulo, Nacional, 1957.

ROCHA, Antônio Penalves. "A economia política na desagregação do Império português". CARDOSO, José Luis (coord.). A economia política e os dilemas do Império lusobrasileiro, Lisboa, Comissão Nacional para as Comemorações dos Descobrimentos portugueses, 2001, p.149-197.

RODRIGUES, José Honório. Independência: revolução e contra-revolução. São Paulo, Perspectiva, 1972. 5 v. . O parlamento a evolução nacional. Brasília, Senado Federal, 1972, 7 v. . A assembléia constituinte de 1823. Petrópolis, Vozes, 1974. . O Conselho de Estado. O quinto poder. Brasília, Senado Federal, 1978.

RODRIGUES, Manuel Augusto. "A Universidade de Coimbra e a elite intelectual brasileira na última fase do período colonial”. Revista de História das Idéias v.12. Coimbra, 1990, p.89110.

RODRÍGUEZ, Jaime E.. La independencia de la America española. Mexico, FCE/Colegio de Mexico, 1996.

ROSANVALLON, Pierre. "Por uma história conceitual do político". Revista Brasileira de História, São Paulo, ANPUH/Contexto, v.15, n.30, 1995, pp. 9-22.

. L'État en France de 1789 à nous jours. Paris, Éditions du Seuil, 1992.

. O liberalismo econômico: história da idéia de mercado. Bauru, EDUSC, 2002.

. La monarchie impossible: les Chartes de 1814 et de 1830. Paris, Fayard, 1994.

RUSSEL-WOOD, A.J.. "Centros e periferias no mundo luso-brasileiro, 1500-1808”. Revista Brasileira de História, v.18, n.36, 1998, p.187-249. 
SALGADO, Graça. Fiscais e meirinhos. A administração no Brasil colonial, 2 ed., Rio de Janeiro, Nova Fronteira, 1985

SANCHEZ AGESTA, Luis. El pensamiento político del despotismo ilustrado. Sevilla, Publicações da Universidade de Sevilha, 1979.

SANTOS, Catarina Madeira dos. Um governo 'polido' para Angola. Reconfigurar dispositivos de domínio (1750-c.1800), Lisboa/Paris, Tese de Doutorado, Universidade Nova de Lisboa/EHESS, 2005.

SARRAILH, Jean. La España ilustrada de la segunda mitad del siglo XVIII. México, Fondo de Cultura Económica, 1957.

SCHULTZ, Kirsten. Tropical Versailles: empire, monarchy, and the portuguese royal court in Rio de Janeiro, 1808-1821. New York, Routledge, 2001.

. "La independencia de Brasil, la ciudadanía y el problema de la esclavitud: A Assembléia Constituinte de 1823". RODRÍGUEZ, Jaime (coord.), Revolución, independencia y las nuevas naciones de América. Madri, Mapfre, 2005, pp. 425-429.

SCHWARZ, Roberto. "As idéias fora do lugar". Ao vencedor as Batatas. Forma literária e processo social nos inícios do romance brasileiro. São Paulo, Duas Cidades, 1992, p.13-28.

SILVA, Luís Antonio Vieira da. História da independência do Maranhão. Tipografia do Progresso, s.d.

SILVA, Leonardo Dantas. "O ideário liberal pernambucano". ANDRADE, Manuel Correia de \& outros (orgs.) - Formação histórica da nacionalidade brasileira: Brasil 1701-1824. Recife, Fundação Joaquim Nabuco/Massanganga, 2000, p.177-194.

SILVA, Maria Beatriz Nizza da. Movimento constitucional e separatismo no Brasil 1821-1823. Lisboa, Horizonte, 1988.

(coord.). O império luso-brasileiro 1750-1822. Porto, Estampa, 1986.

SILVA MARQUES. Elementos de direito público e constitucional, pelo Dr. Silva Marques. $2^{\mathrm{a}}$ ed., Rio de Janeiro, B. de Aguila, 1919.

SKINNER, Quentin. "Language and Social Change”. TULLY, J. (org.) - Meaning and Context. Quentin Skinner and his Critics. Cambridge, Polity Press, 1988.

. As fundações do pensamento político moderno. São Paulo, Companhia das Letras, 1996.

SILVA, Wlamir. Liberais e povo": a construção da hegemonia liberal-moderada na Província de Minas Gerais (1830-1834). Rio de Janeiro, Universidade Federal do Rio de Janeiro, Tese de Doutorado, 2002. 
SLEMIAN, Andréa e PIMENTA, João Paulo G.. O "nascimento político" do Brasil: origens do Estado e da nação (1808-1825). Rio de Janeiro, DP\&A Editora, 2003.

. Vida política em tempo de crise: Rio de Janeiro (1808-1824). São Paulo, Hucitec, 2006.

. “'Seriam todos cidadãos?': os impasses na construção da cidadania nos primórdios do constitucionalismo no Brasil (1823-1824)". JANCSÓ, István (org.). Independência: história e historiografia. São Paulo, Fapesp/Hucitec, 2005, pp. 829-847.

. O difícil aprendizado da política na Corte do Rio de Janeiro (1808-1824). São Paulo, FFLCH-USP, Dissertação de Mestrado, 2000.

(et.all.). Cronologia de história do Brasil colonial (1500-1831). São Paulo, Departamento de História/USP, 1994 (Série Iniciação).

SOBERANES FERNANDEZ, J.L. (ed.). El primer constitucionalismo iberoamericano. Madrid, Marcial Pons, 1992.

SOARES, Gerusa. Cunha Mattos (1776-1839). Rio de Janeiro, Empresa Graphica Editora, 1931.

SOBRAL NETO, Maria Margarida. "A desagregação das estruturas do Antigo Regime: alguns indicadores". COSTA, Fernando Marques da (et. alli) (orgs.). Do Antigo Regime ao liberalismo 1750-1850. Lisboa, Veja, s.d. p.251-258.

SOUZA, Antônio Loureiro de. Baianos ilustres. $3^{\mathrm{a}}$ ed., São Paulo/Brasília, IBRASA/INL, 1979.

SOUZA Filho, Argemiro Ribeiro de. A guerra de Independência na Bahia: manifestações políticas e violência na formação do Estado nacional (Rio de Contas e Caetité). Salvador, Universidade Federal da Bahia, Dissertação de Mestrado, 2003.

SOUZA, Iara Lis Franco Schiavinatto Carvalho. Pátria coroada: o Brasil como corpo político autônomo 1780-1831. São Paulo, EdUnesp, 1999.

SOUZA, M. R.. Direito Constitucional. Introdução à Teoria da Constituição. Braga, 1979.

SOUZA, Otávio Tarquínio de. História dos fundadores do Império. Rio de Janeiro, José Olympio, 1960.

SUBTIL, José. "Forças de segurança e modos de repressão (1760-1823)". COSTA, Fernando Marques da \& outros (orgs.) - Do Antigo Regime ao liberalismo 1750-1850. Lisboa, Veja, s.d. p.32-43.

SZMRECSÁNYI, Tamás/LAPA, José Roberto do Amaral (orgs.). História econômica da Independência e do Império. São Paulo, Hucitec, 1996.

TAPAJÓS, Vicente. Organização política e administrativa do Império. Brasília, FUNCEF, 1984. (Col. História administrativa do Brasil, v. 9). 
TAVARES, Luís Henrique Dias. A independência do Brasil na Bahia. Rio de Janeiro, Instituto Nacional do Livro, 1982.

TENGARRINHA, José. Da liberdade mitificada à liberdade subversiva: uma exploração no interior da repressão à imprensa periódica de 1820 a 1828. Lisboa, Colibri, 1993. 193 p.

. História da imprensa periódica portuguesa. Lisboa, Portugália, 1965.

TILLY, Charles. The Formation of Nation States in Western Europe. Princeton, Princeton University Press, 1974.

TORGAL, Luís Reis. "Tradicionalismo absolutista e contra-revolução (1820-1910)". COSTA, Fernando Marques da \& outros (orgs.) - Do Antigo Regime ao liberalismo 1750-1850. Lisboa, Veja, s.d. p.93-103.

. "Universidade e sociedade nos primórdios do liberalismo português". Portugal. Da Revolução Francesa ao Liberalismo. Universidade do Minho, Actas do Colóqio, 04-05 de dezembro de 1986.

TORRES, João Camilo de Oliveira. A democracia coroada (teoria política do Império do Brasil). Rio de Janeiro, Typ. Jornal do Comércio, 1957.

. Os construtores do Império: ideais e lutas do Partido Conservador Brasileiro. São Paulo, Nacional, 1968.

VARELA SUANZES-CARPEGNA, Joaquín. La teoría del Estado en los orígenes del constitucionalismo hispánico (las Cortes de Cádiz). Madrid, Centro de Estudios Constitucionales, 1983.

VARGUES, Isabel Maria Guerreiro Nobre. A aprendizagem da cidadania: contributo para a definição de cultura política e vintista. Coimbra, Tese de Doutorado, 1993.

VARNHAGEN, Francisco Adolfo de. História da independência do Brasil. Belo Horizonte, Itatiaia; São Paulo, Edusp, 1981. (Notas de Hélio Vianna)

VASCONCELOS, Pedro Carlos da Silva Bacelar. A separação dos poderes na Constituição americana. Alguns problemas recentes. Coimbra, Universidade de Coimbra, Dissertação de Mestrado, 1989.

VERDO, Geneviève. Les "Provinces-Desunis" de le Río de La Plata: souveraineté et représentation politique de la indépendance argentina (1808-1821). Paris, Tese de Doutorado, Université Paris I, 1998.

VIEIRA, Benedicta Maria Duque. O problema político português no tempo das primeiras cortes liberais. Lisboa, Edições João Sá da Costa, 1991. 
VILAR, Pierre. Hidalgos, amotinados y guerrilleros: pueblo y poderes en la historia de España. Barcelona, Crítica, 1982.

VINHOSA, Francisco Luiz Teixeira. Brasil sede da Monarquia. Brasil Reino (2 ${ }^{a}$ parte). Brasília, Funcef, 1984 (Col. História Administrativa do Brasil, v.8).

WEHLING, Arno \& WEHLING, Maria José. Direito e justiça no Brasil colonial. O Tribunal da Relação do Rio de Janeiro (1751-1808), Rio de Janeiro/São Paulo/Recife, Renovar, 2004.

WISIAK, Thomas. A nação partida ao meio: tendências políticas na Bahia na crise do Império Luso-brasileiro. São Paulo, Universidade de São Paulo/FFLCH, Dissertação de Mestrado, 2001. 